\title{
PALEOETHNOBOTANY OF BUENA VISTA: \\ A CASE STUDY OF RITUAL FEASTING \\ IN LATE PRECERAMIC PERU
}

A Dissertation
presented to
the Faculty of the Graduate School
at the University of Missouri-Columbia
In Partial Fulfillment
of the Requirements for the Degree
Doctor of Philosophy
by
DEIL ANDREW DUNCAN


(C) Copyright by Neil Andrew Duncan 2010

All Rights Reserved 
The undersigned, appointed by the Dean of the Graduate School, have examined the dissertation entitled

PALEOETHNOBOTANY OF BUENA VISTA:

\section{A CASE STUDY OF RITUAL FEASTING IN LATE PRECERAMIC PERU}

presented by Neil Andrew Duncan

A candidate for the degree of Doctor of Philosophy,

And hereby certify that in their opinion it is worthy of acceptance.

Professor Deborah M. Pearsall

Professor Robert A. Benfer, Jr.

Professor Lisa Sattenspiel

Professor Christine S. VanPool

Professor Frances M. Hayashida

Professor Michael D. Glascock 


\section{ACKNOWLEDGEMENTS}

Research in archaeology is seldom an individual pursuit and this work is no exception. This dissertation is the culmination of labor and thought from a number of people without whom this work would have been impossible. I owe a great deal of thanks

to those who toiled in the field and in the lab, advised and critiqued me, and supported my efforts to bring this to fruition. First and foremost, I would like to thank Deborah Pearsall who inspired me to pursue paleoethnobotany. My gratitude for her support over the many years it took to complete this dissertation is immeasurable and I have accrued a debt that I can never fully repay. I also especially thank Robert Benfer who first took me to Peru in 1999 and inspired in me a deep love for the people and culture of Peru. I am very grateful to have had the opportunity to provide a small contribution to the Buena Vista Project under his direction.

Many students and volunteers carried out fieldwork for this dissertation research at Buena Vista. I would like to acknowledge the efforts of the participants in the MU Summer Archaeology Field Schools of 2003 and 2004, especially. Also, Victor Hugo Rosas, Miriam Gonzáles, Andrés Ocas Quispe, Miguel Castillo and Omár Ventocilla, were indispensable team members whose experience and camaraderie I greatly appreciate. The most important contribution to the fieldwork, however, came from Bernardino Ojeda, who is without any doubt the most experienced and knowledgeable archaeologist I have known. His contribution to this project was crucial and I, like every archaeologist who has worked on the central coast of Peru, owe him a great deal of thanks. I would also like to 
recognize the contribution of the Centro de Investigaciónes de Zonas Aridas of the Universidad Nacional Agraria - La Molina and particularly Miriam Vallejos for providing laboratory space in Lima and Gloria Villareal for her tireless cataloging of materials. Also, Lucio Laura was invaluable in the field.

At the University of Missouri, I benefitted mightily from the camaraderie of students who have worked or passed through the Paleoethnobotany Laboratory, including Meghann O'Brien, Amanda Logan, Thomas Hart, Jason Fenton, Shawn Collins, Karol Chandler-Ezell, Keith Chan, and Lucia Gudiel. I am thankful for their friendship and individual contributions to my scholarship and personal growth. Also, I would like to acknowledge the work Joel Fecke and Megan Sisk put into sorting many macroremain samples. Joel was also a great help to me by composing figures and phytolith graphs for this dissertation. I would also like to thank Dolores Piperno for her comments on portions of this dissertation and for her consultations on starch and phytolith identifications. Also, Tom Andres was very helpful in assisting me in the identifications of squash seeds for which I am grateful. In addition, I would like to thank my dissertation committee members Frances Hayashida, Christine VanPool, Lisa Sattenspiel, and Michael Glascock for their helpful critiques and thoughtful suggestions.

Lastly, I am fortunate to have enjoyed the love and support of my family throughout this endeavor. I hope only to return the love and support you've given. To my mom and my late father, thank you. And to Eliana, thank you. Secretly, perhaps, you all wished that I had gone to medical school, but outwardly, you always encouraged me to persevere. For this, I am forever grateful. 


\section{TABLE OF CONTENTS}

ACKNOWLEDGEMENTS........................................................................................ii

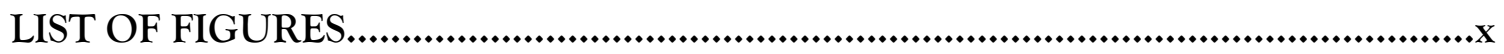

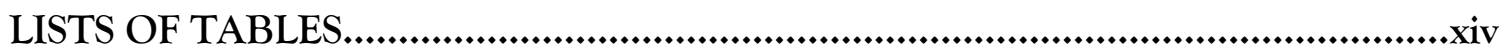

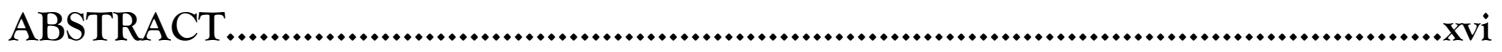

Chapter

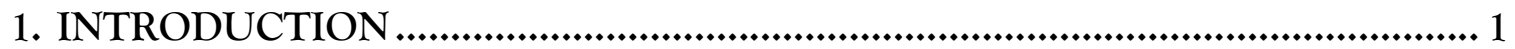

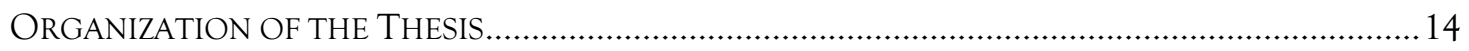

2. RITUAL ARCHITECTURE AND FEASTING AT BUENA VISTA ........................ 17

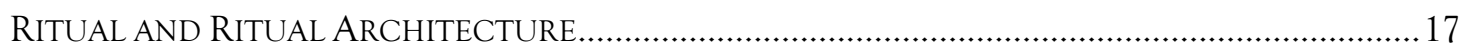

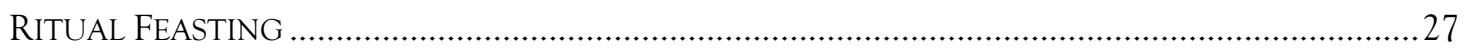

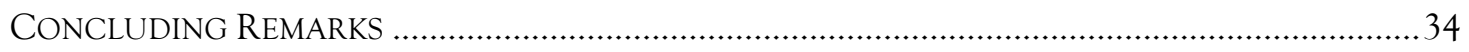

3. ENVIRONMENTAL SETTING OF THE CENTRAL ANDES AND THE

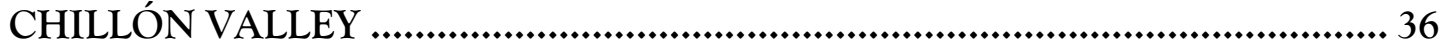

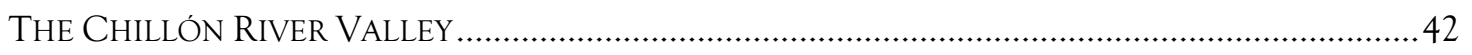

ECOLOGICAL ZONES OF THE CHILLÓN VALLEY ......................................................................45

SOILS AND AGRICULTURE IN THE CHILLÓN ………………………………………………...57

BUENA Vista IN ECOLOGICAL AND ENVIRONMENTAL CONTEXT ..................................................59

4. THE ARCHAEOLOGICAL AND CULTURAL SETTING OF THE



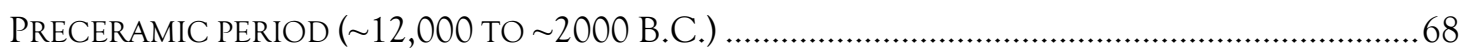




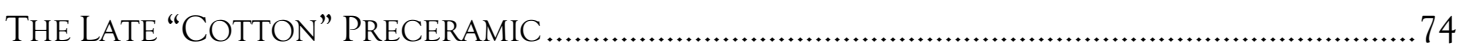

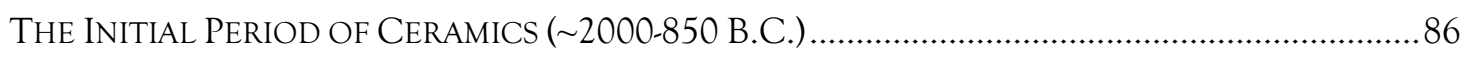

EARly Horizon ( 800 B.C. - A.D. 250) THE EMERGENCE OF CHAVÍN......................................93

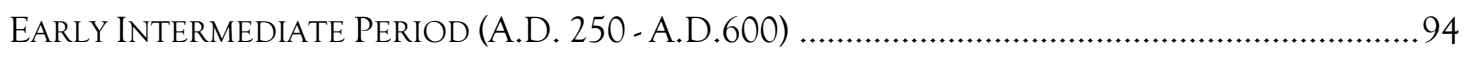

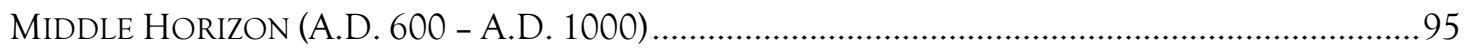

LATE INTERMEDIATE PERIOD AND LATE HORIZON (A.D. 1000 - A.D. 1534) ..............................96

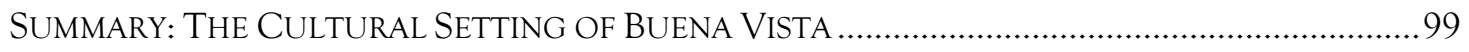

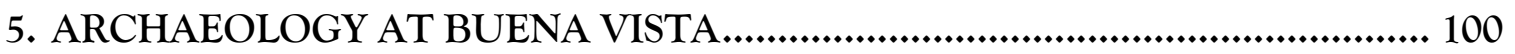

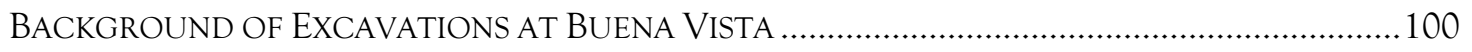

Archaeological Context of Sector B, Unit B-10: The Fox Temple ............................... 108

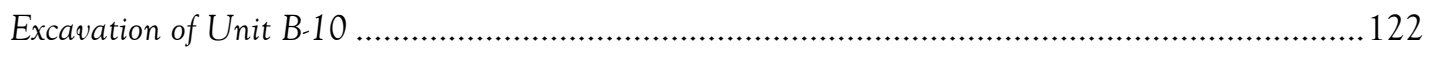

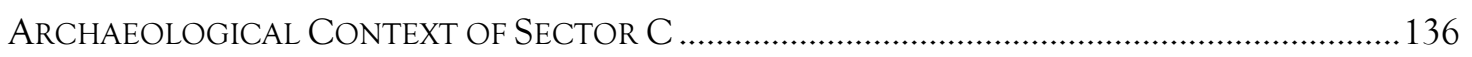

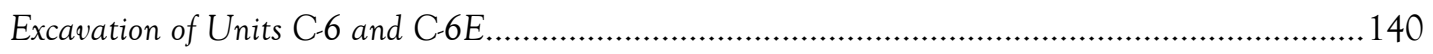

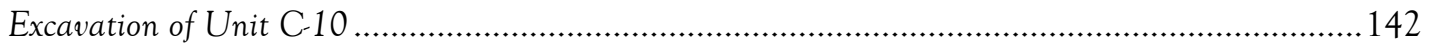

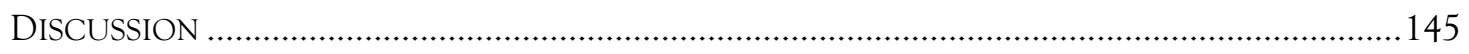

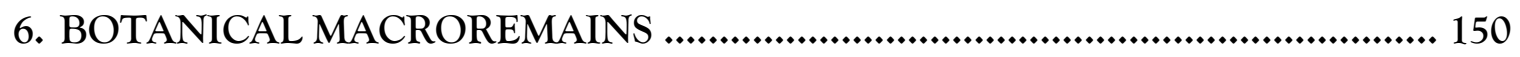

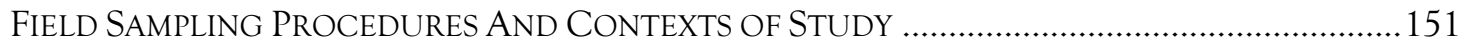

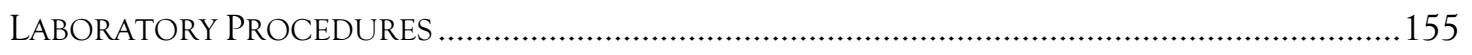

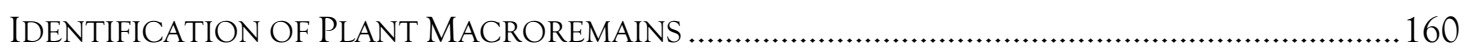

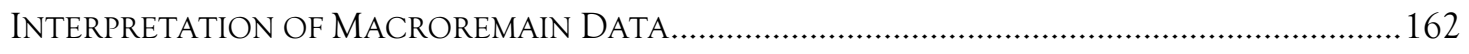

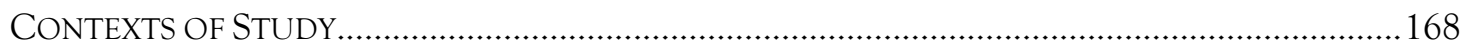

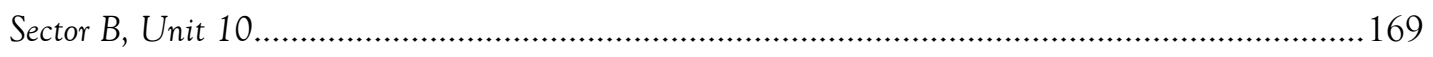

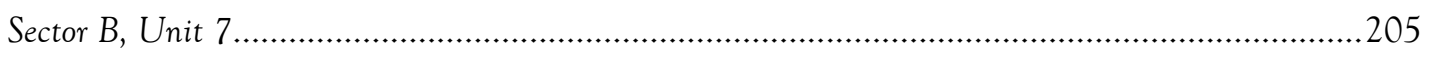


Sector C, Unit 6

Sector C, Unit 10

DisCUSSION OF BOTANICAL MACROREMAINS

219

\section{PHYTOLITHS AND STARCH GRAINS FROM ARCHAEOLOGICAL}

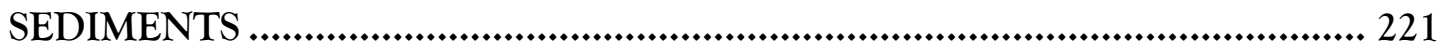

Phytolith AND Starch Research IN PERUVIAn ARCHAEology.........................................22

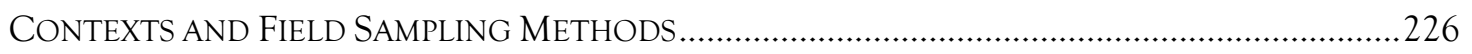

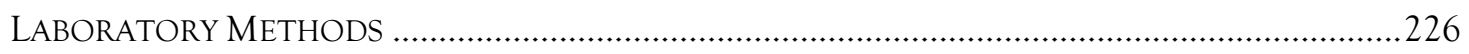

RESULTS OF STARCH AND PHYTOLITHS STUDIED FROM SEDIMENTS .......................................230

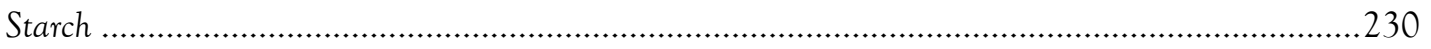

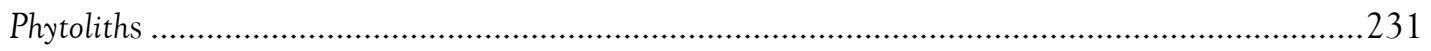

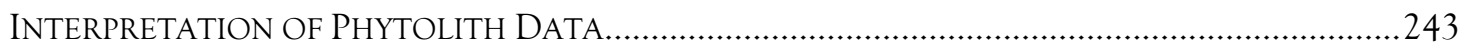

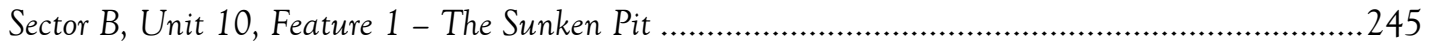

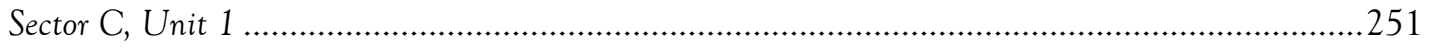

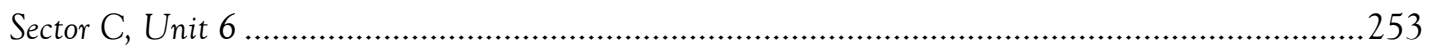

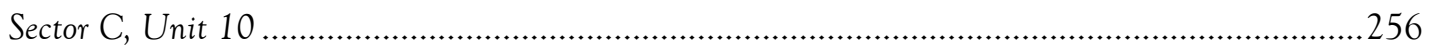

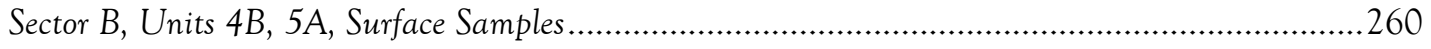

SuMMARY AND DiSCUSSION OF STARCH AND PHYTOLITHS FROM SEDIMENTS .........................260

\section{STARCH AND PHYTOLITHS FROM CUCURBIT ARTIFACTS}

RECOVERED FROM SECTOR B, UNIT 10, FEATURE 1........................... 264

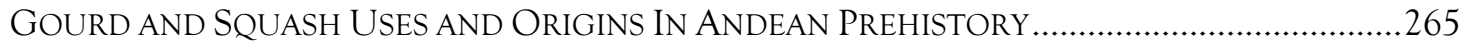

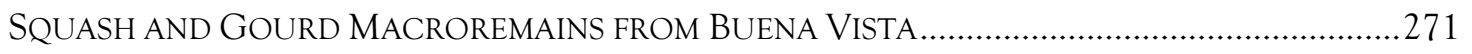

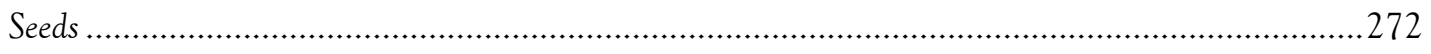

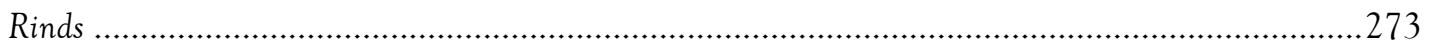




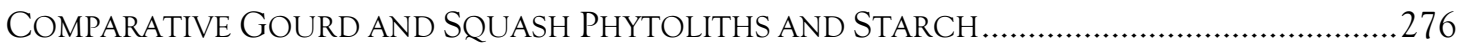

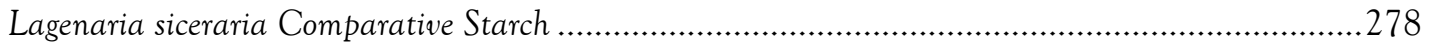

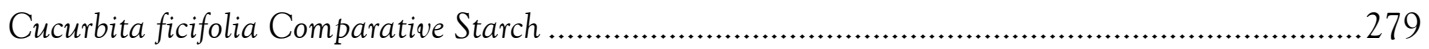

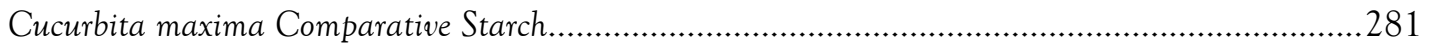

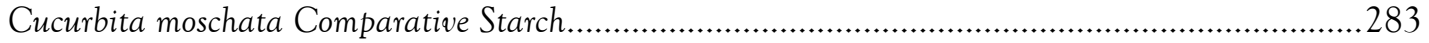

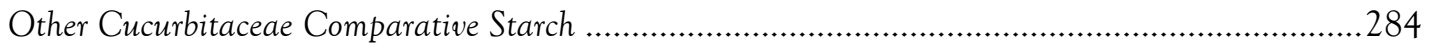

METHOdS For StARCH AND PHYTOLITH EXTRACTION FROM CUCURbIT ARTIFACTS.............287

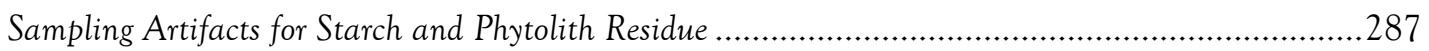

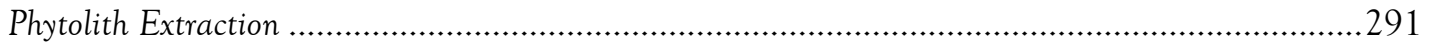

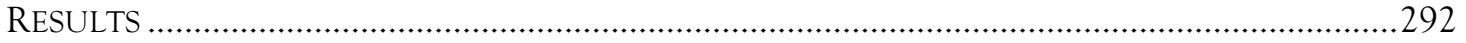

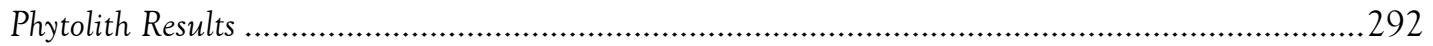

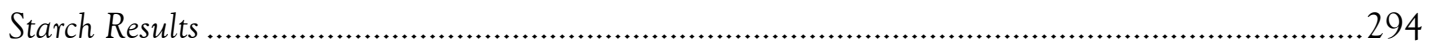

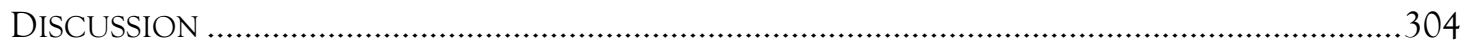

9. DISCUSSION AND CONCLUDING REMARKS...................................................... 306

ARCHAEOlogicAl CONTEXTS of MACROREMAINS, PHYTOLITHS, AND STARCH ......................307

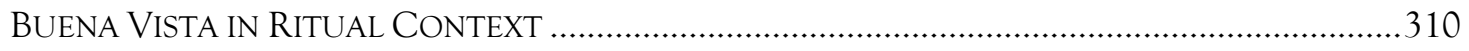

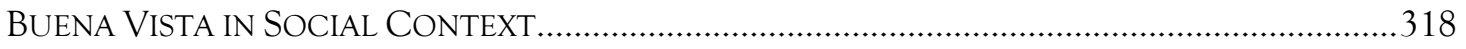

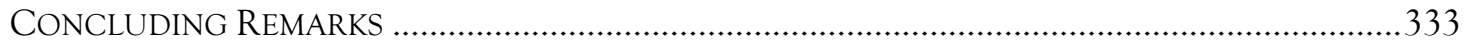

APPENDIX

A. BOTANICAL AND ETHNOBOTANICAL PROFILES OF PLANT TAXA IDENTIFIED AT BUENA VISTA....................................................................... 335

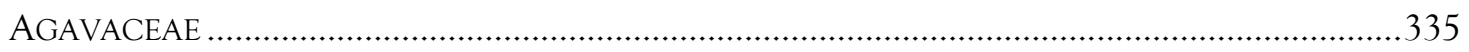

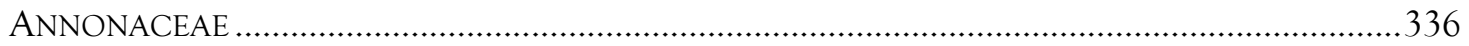




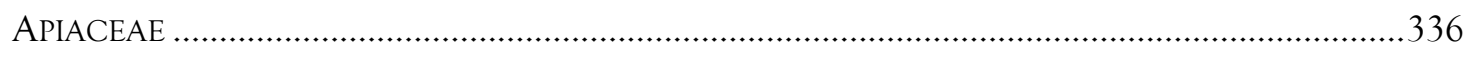

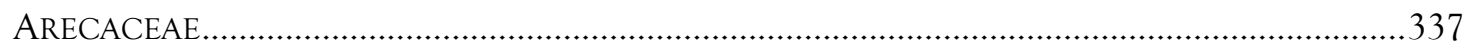

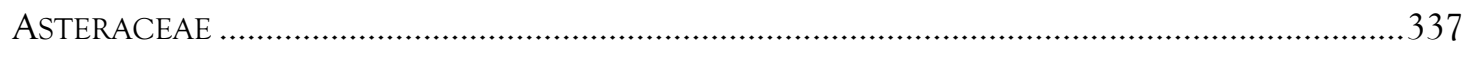

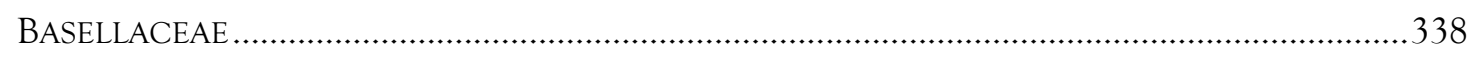

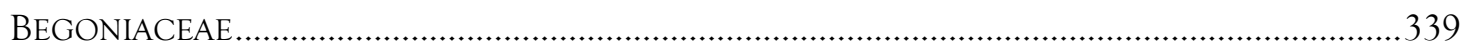

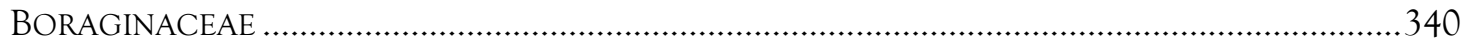

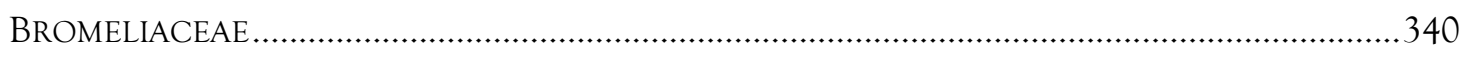

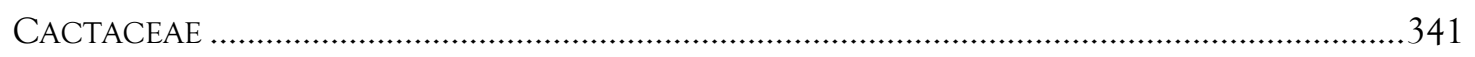

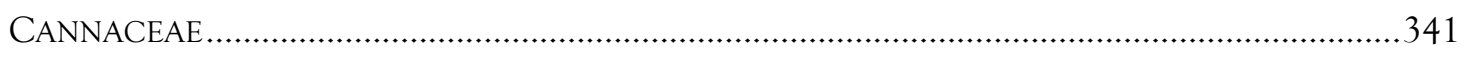

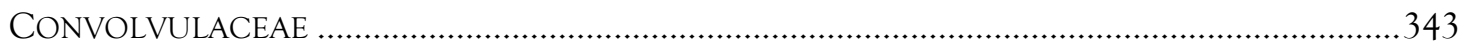

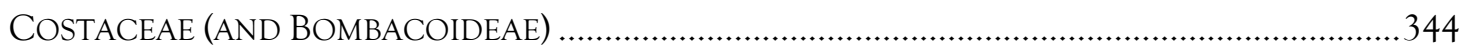

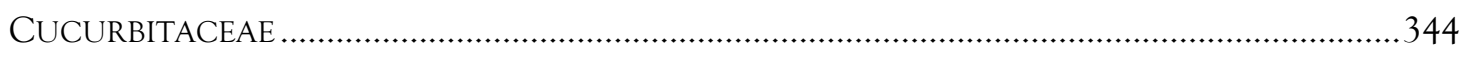

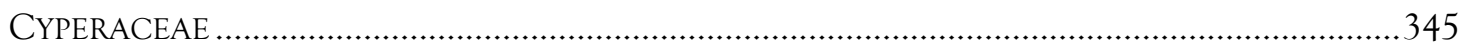

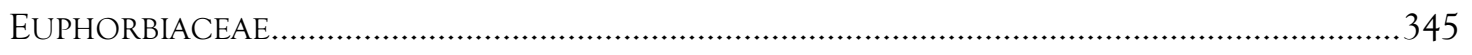

FABACEAE …

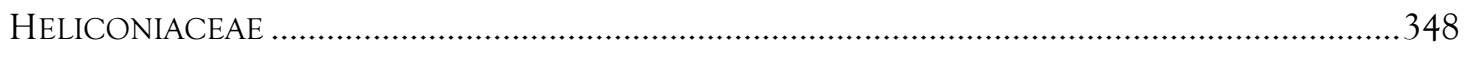

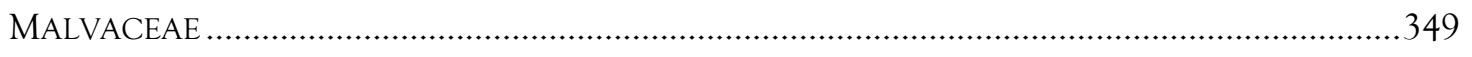

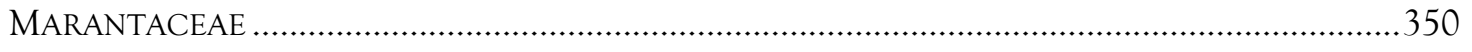

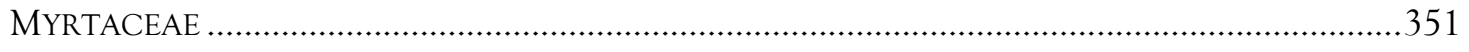

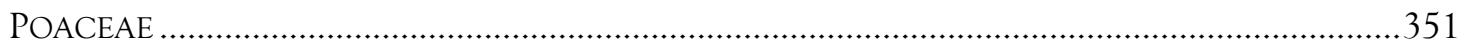

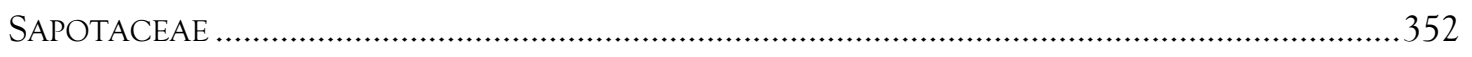

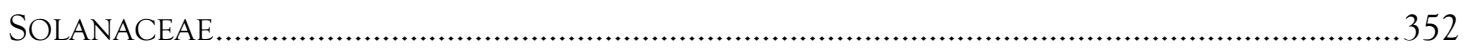




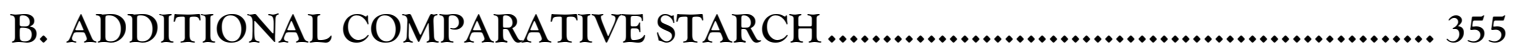

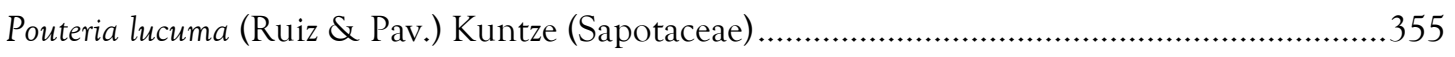

Cyphomandra betacea (Cav.) Sendtn. (=Solanum betaceum Cav.) (Solanaceae) ................................358

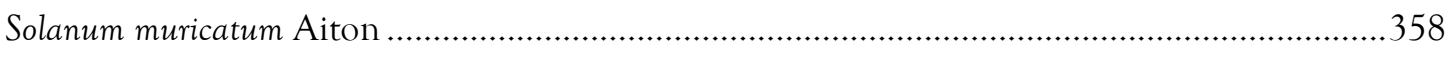

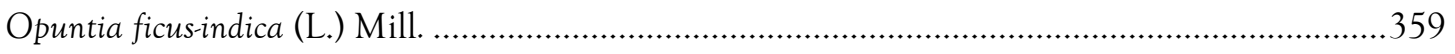

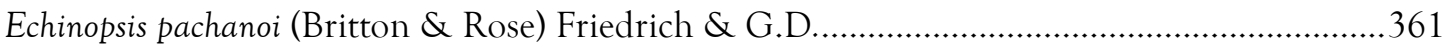

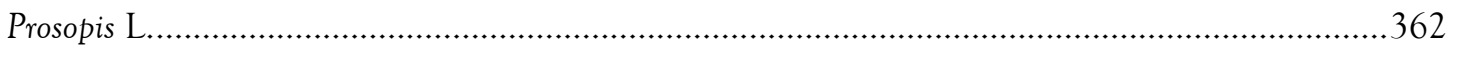

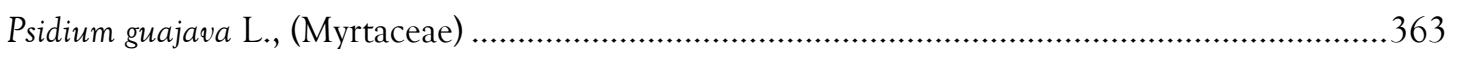

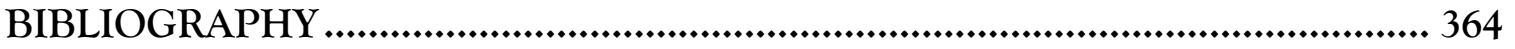

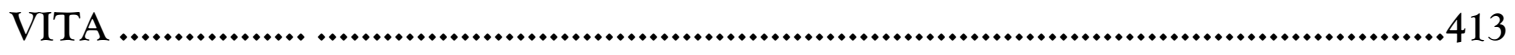




\section{LIST OF FIGURES}

$\begin{array}{ll}\text { Figure } & \text { Page }\end{array}$

1.1 Map of the lower Chillón Valley with location of Buena Vista .................................2

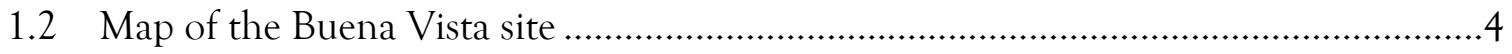

1.3 Photograph of the sculpture of a grimacing discoidal face ........................................5

1.4 The platform and sunken pit in the center of the Gran Sala of the Fox Temple

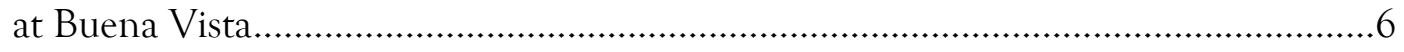

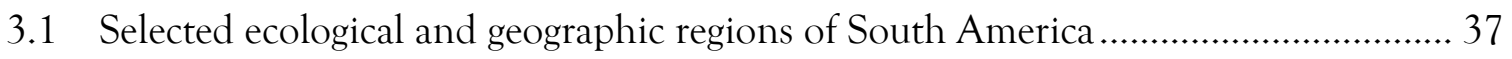

3.2 The thermocline boundary in relationsip with ocean currents and convection during normal (non-ENSO) and ENSO cycles ................................................ 41

3.3 The Chillon Valley showing the location of Buena Vista ....................................... 43

3.4 Longitudinal profile of the Chillón Valley ............................................................ 43

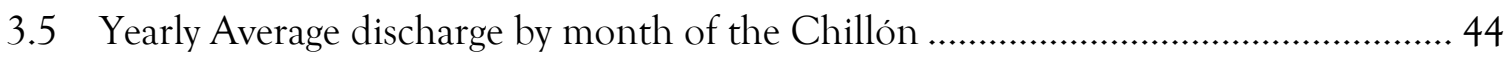

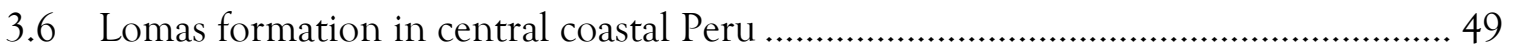

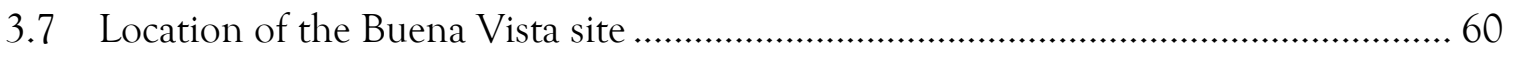

4.1 Map of western Perú showing the location of sites discussed in text ........................ 65

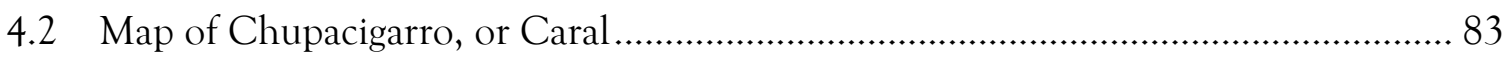

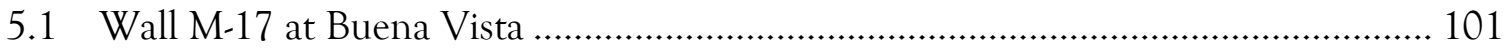

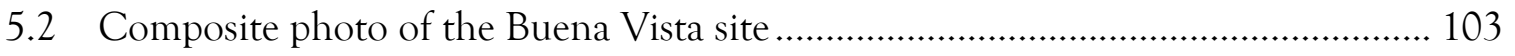

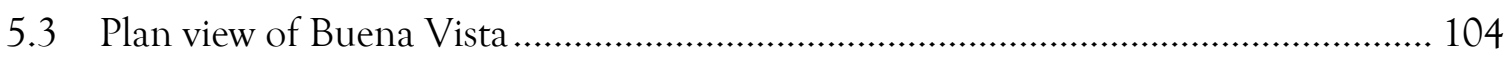

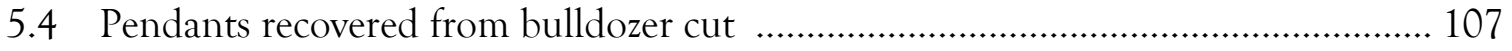


List of Figures, continued

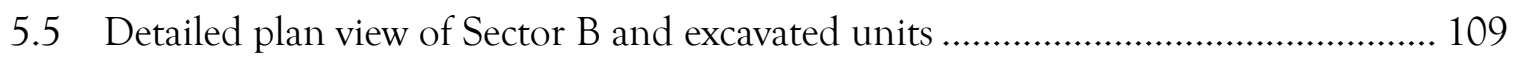

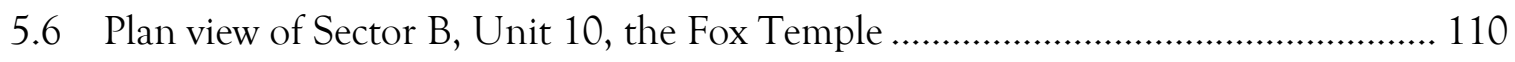

5.7 South-facing profile of Sector B, Unit 10, the Fox Temple................................... 111

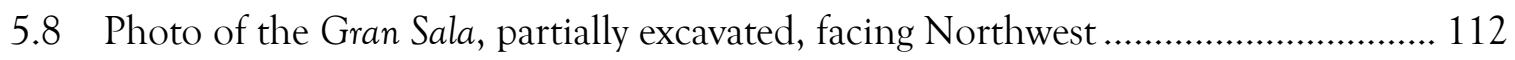

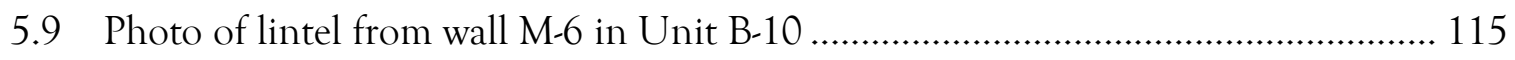

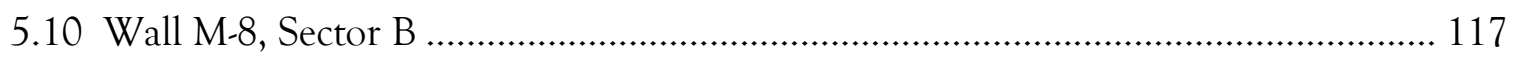

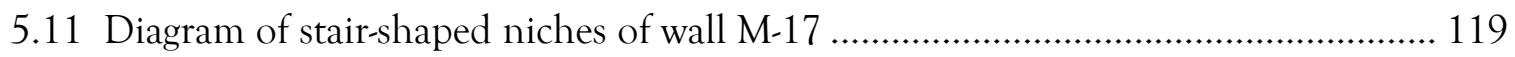

5.12 Photo of Unit B-7 excavated to the floor of Cuarto-3 in Unit B-10........................ 119

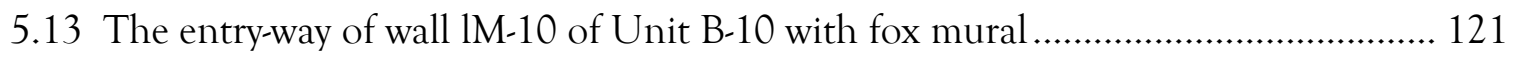

5.14 Photo of Initial Period burial of a woman found in Level 100 fill of

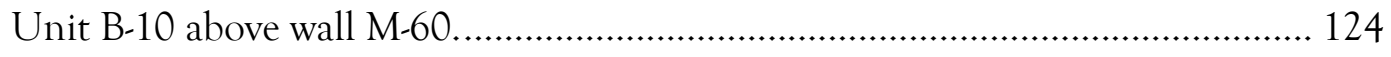

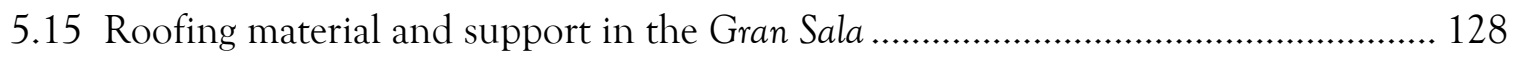

5.16 Photo series of excavation of the sunken pit, Feature 1 of Unit B-10.................... 129

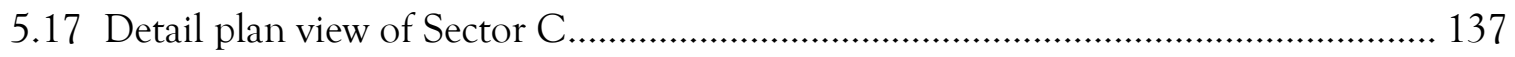

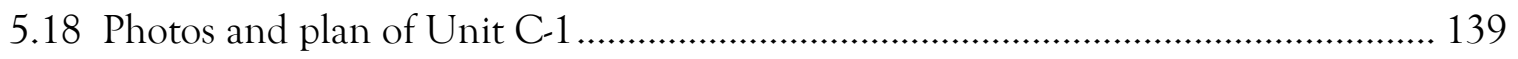

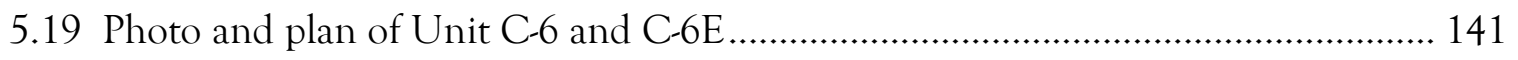

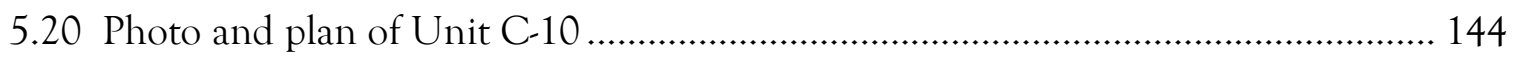

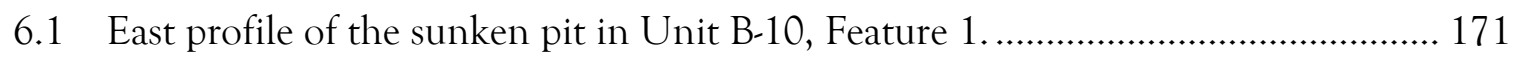

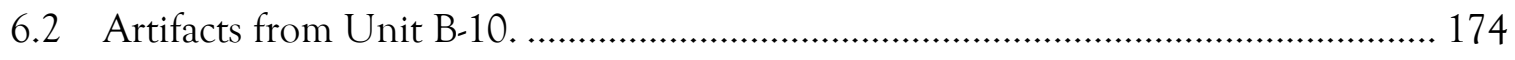

6.3 Unit B-1-, F-1 density of plant remains by stratigraphic level ............................... 183

6.4 Unit B-10, F-1 density of grouped plant remains by stratigraphic level ................. 183 
List of Figures, continued

6.5 Unit B-10, F-1 ratio of food weight to charred wood versus ratio of food weight to uncharred wood by stratigraphic level.

6.6 Unit B-10, F-1 percentage occurence of food types by count.

6.7 Unit B-10, F-1 percentage occurence of food types by weight.

6.8 Unit B-10, F-1 species richness curves for each stratigraphic level.

6.9 Unit B-10, F-1 species richness, diversity, and evenness by stratigraphic level. 197

6.10 Unit B-10, F-1 gourd fragments by stratigraphic level. 204

6.11 Unit C-6 relative proportions of plant macroremains by type and context.

6.12 Unit C-6 relative proportion of food types by context.

7.1 Starch grains recovered from sediments

7.2 Arecaceae spinulose spheres, Type 80ID

7.3 Faceted sphere diagnostic to Cucurbita sp. recovered from archaeological sediments in Unit B-10, Level 200/250, Feature 1. 235

7.4 Spherical phytoliths with stellate projections, Type 80IK 236

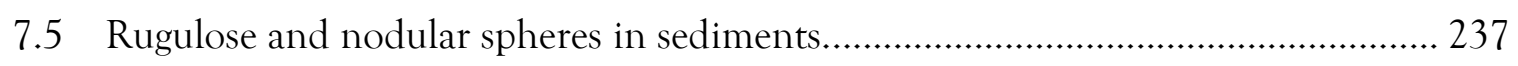

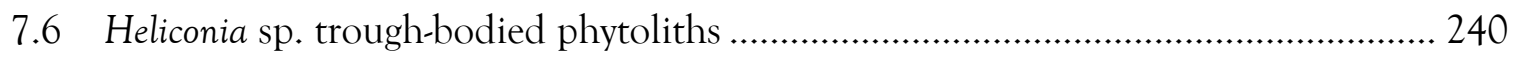

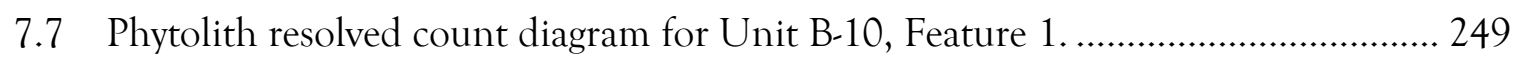

7.8 Pytolith composite count diagram for Unit B-10, Feature 1 ................................. 250

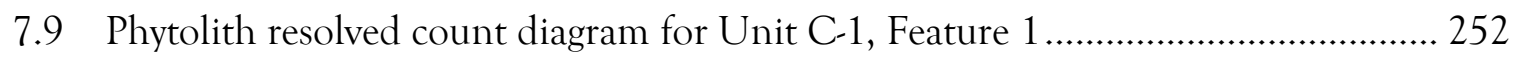

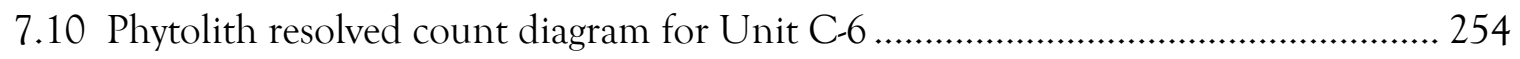

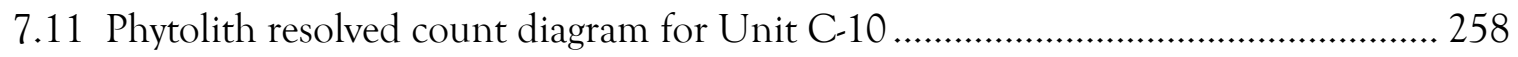

7.12 Phytolith resolved diagram for surface samples at Unit B-4b ............................... 259 
List of Figures, continued

8.1 Archaeological squash seeds from Unit B-10, Feature 1, Level 300....................... 272

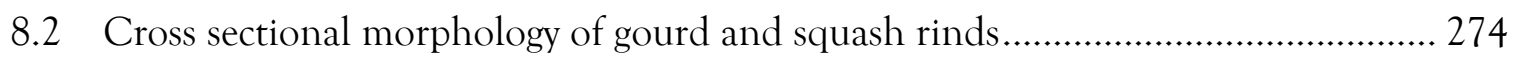

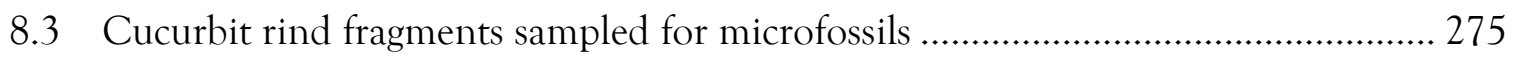

Figure 8.4 Comparative starch grains from Lagenaria siceraria....................................... 277

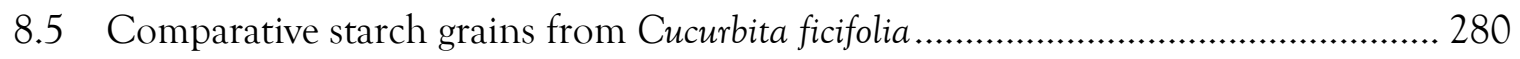

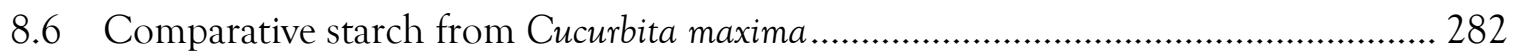

8.7 Comparative starch grains from modern Cucurbita moschata ................................. 284

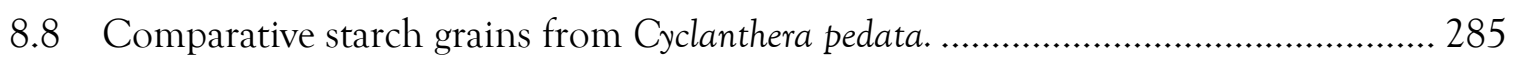

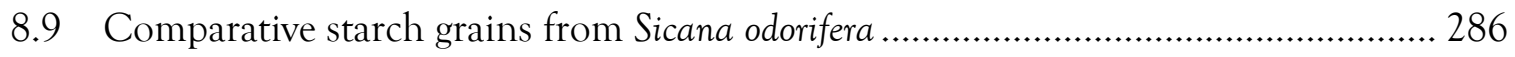

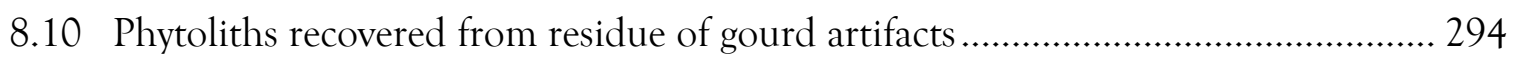

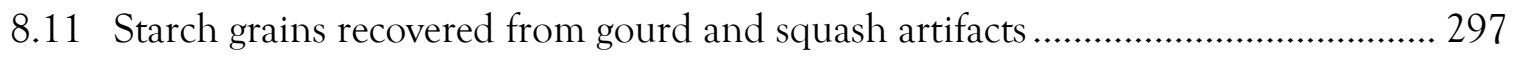

8.12 Unidentified starch grains from cucurbit artifacts. See text for descriptions.......... 303

App. B.1 Starch from the fruit of Pouteria lucuma...................................................... 356

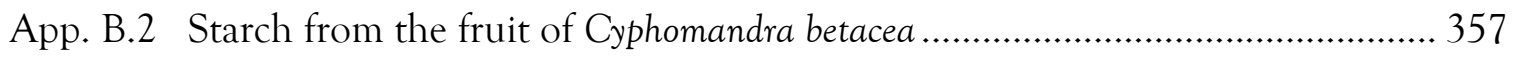

App. B.3 Starch from the fruit of Solanum muricatum ................................................. 359

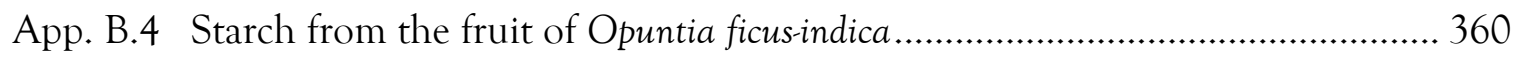

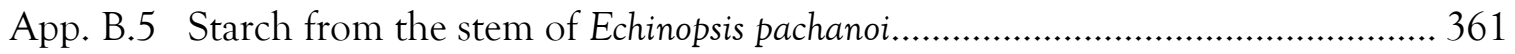

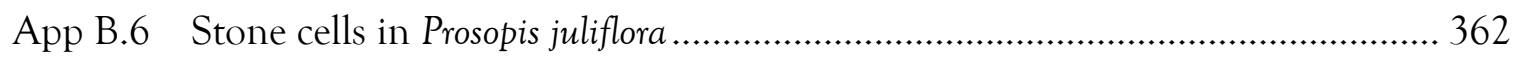




\section{LIST OF TABLES}

Table

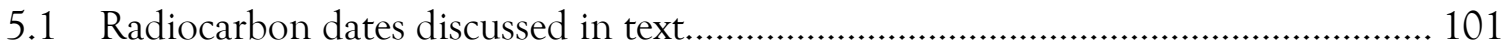

6.1 Contexts sampled and analyzed from Sectors B and C at Buena Vista. ................. 157

6.2 Sector B, Unit 10 macroremains by count and weight....................................... 172

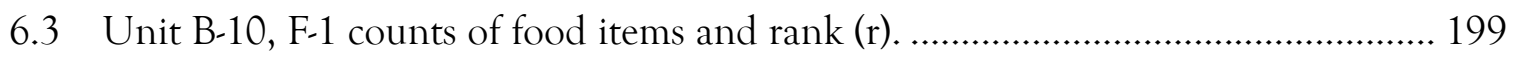

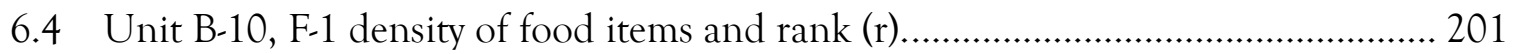

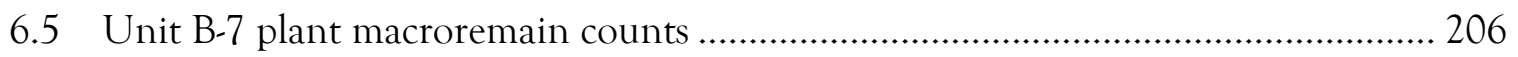

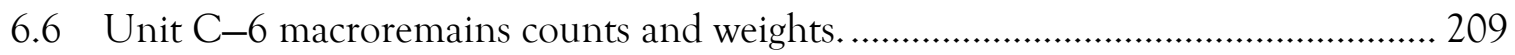

6.7 Unit C-6 density of macroremains weight to sample weight and volume............... 209

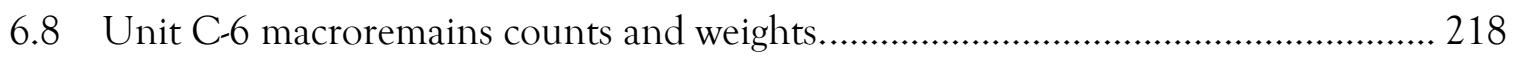

7.1 Contexts of sediments analyzed for macroremains, phytoliths, and starch ............ 226

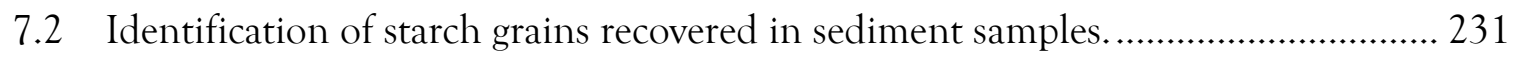

7.3 Phytolith counts from archaeological sediments at Buena Vista............................ 237

7.4 Cross-shaped phytoliths and Variant 1 size determinations................................... 242

8.1 Domesticated Cucurbita spp. in the Americas discussed in the text.......................... 268

8.2 Cucurbit material recovered from macroremain samples at Buena Vista............... 271

8.3 Gourd and squash artifacts and radiocarbon dated contexts at Buena Vista .......... 287

8.4 Phytolith and non-silicified tissues from gourd and squash artifacts ..................... 293 
List of Tables, continued

8.5 Starch grain data from gourd and squash artifacts per sediment sample................ 295

9.1 Cultivated plants from selected Preceramic sites in Perú ........................................ 321 


\title{
PALEOETHNOBOTANY OF BUENA VISTA: A CASE STUDY OF RITUAL FEASTING IN LATE PRECERAMIC PERU
}

\author{
Neil Andrew Duncan
}

Dr. Deborah M. Pearsall, Dissertation Supervisor

\begin{abstract}
This project examines plant macroremains, phytoliths and starch remains recovered from special archaeological and architectural contexts at Buena Vista (11 $43^{\prime} 51.72 " \mathrm{~S}$, $\left.76^{\circ} 58^{\prime} 5.45^{\prime \prime} \mathrm{W}\right)$, an inland site in the lower Chillón Valley of Perú. The primary goal of this work is to evaluate the evidence for feasting at a Late Preceramic site. The identification of feasting activities provides a way of examining the social practices, ritual and political, of the people who built Buena Vista. These results can be compared to other archaeological contexts in the Late Preceramic. Consequentially, this paleoethnobotanical study provides several corollary lines of investigation. The plant remains provide significant information on the agricultural component of subsistence in comparison to coastal sites of the time, as well as evidence for the use of special or specially prepared foods in a ritual context. The materials also add to our knowledge of interregional interaction that linked the coast of Perú to the northern and eastern lowlands.
\end{abstract}




\section{Chapter One - Introduction}

Through multiple paleoethnobotanical approaches, macroremains, phytoliths and starch analyses, this project examines the remains recovered from special archaeological and architectural contexts at Buena Vista, an inland site in the lower Chillón Valley of Perú. The primary goal of this work is to evaluate the evidence for feasting at a Late Preceramic ${ }^{1}$ site. The identification of feasting activities provides a way of examining the social practices, ritual and political, of the people who built Buena Vista. These results can be compared to other archaeological contexts in the Late Preceramic. Consequentially, this paleoethnobotanical study provides several corollary lines of investigation. The plant remains provide significant information on the agricultural component of subsistence in comparison to coastal sites of the time, as well as evidence for the use of special or specially prepared foods in a ritual context. The materials also add to our knowledge of interregional interaction that linked the coast of Perú to the northern and eastern lowlands. Some of the plants being used at the site are significant because they are either not known or very rare at other sites in the region.

The Buena Vista site is located 36 kilometers inland (11 $\left.{ }^{\circ} 43^{\prime} 51.72^{\prime \prime} \mathrm{S}, 76^{\circ} 58^{\prime} 5.45^{\prime \prime} \mathrm{W}\right)$ from the mouth of the Chillón River near the modern town of Trapiche (Figure 1.1). Built

\footnotetext{
${ }^{1}$ I refer to the period between 3000 B.C. to 1800 B.C. as the Late Preceramic (Rowe 1962). This period is also known as the Cotton Preceramic (Engel 1957), and Upper or Late Archaic (Lumbreras 1974).
} 


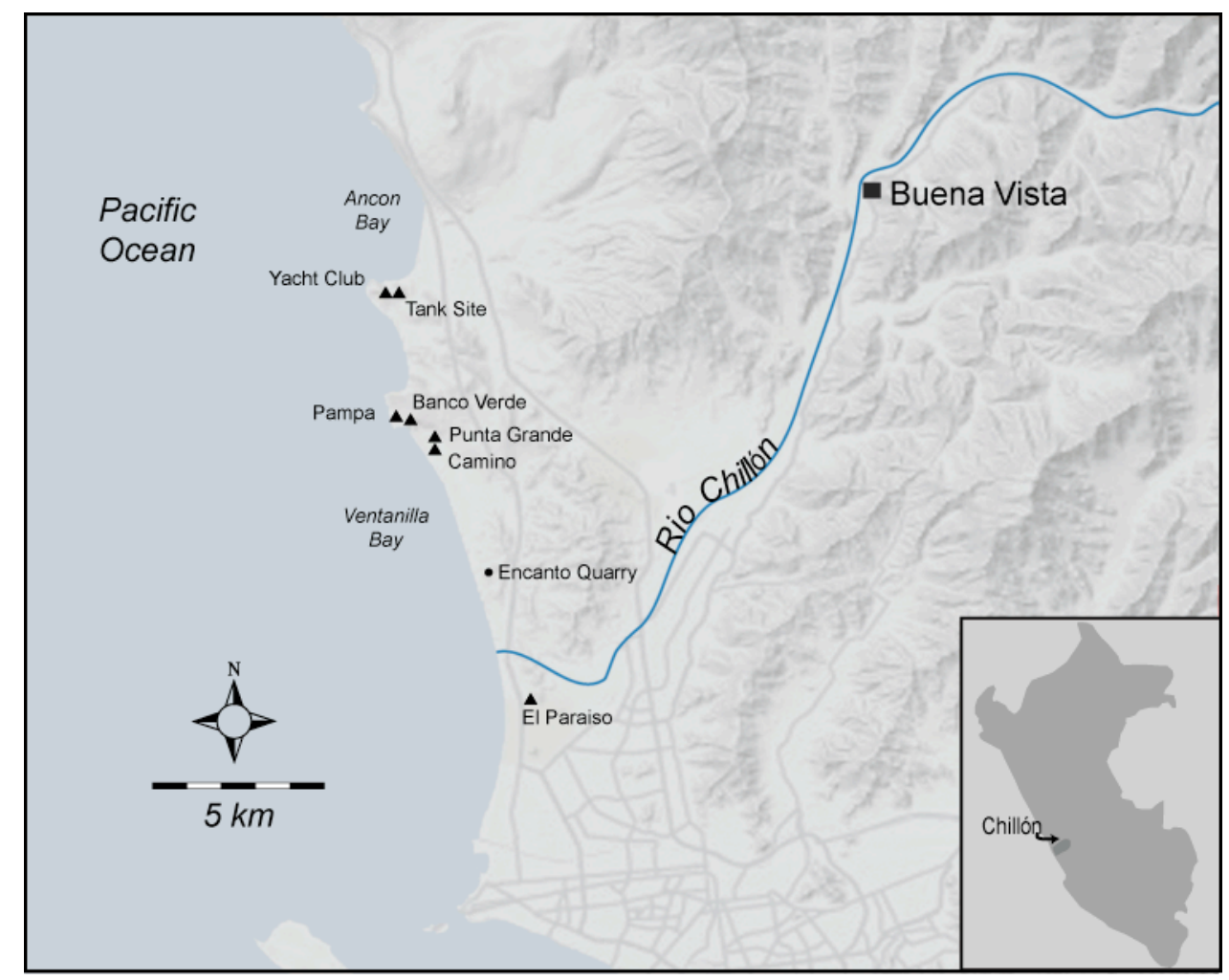

Figure 1.1 Map of the lower Chillón Valley with location of Buena Vista and early sites in the Ancón-Chillón coastal region. Base map from Google - Map data (2010).

on a hillside, Buena Vista's architecture covers nearly six hectares and commands a vantage point thirty-three meters above the valley floor. Frederic Engel (1976:104) first reported the site as dating to the Preceramic Period, and provided a radiocarbon date from grass sampled from plaster as 1500 B.C. (about 1750 cal B.C.), but did not excavate the site. Hugo Ludeña (1975) and Jorge Silva (1996) also noted Buena Vista in their surveys of the region. Robert Benfer of the University of Missouri has conducted fieldwork from 2001 to the present in cooperation with Centro de Investigaciones de Zonas Aridas (CIZA) of Universidad Nacional Agraria de La Molina of Lima, Perú and in conjunction with field schools sponsored by MU and Universidad Nacional Frederico Villareal of Lima in 2003 and 
2004. I served as Field Director of excavations with Bernardino Ojeda from 2001-2005. The dataset for this study was collected from 2001-2004.

Radiocarbon dates of Buena Vista to 2220 cal B.C. confirm the site's Late Preceramic component (see Chapter 5, Table 5.1). This early component is principally comprised of large, ornate monumental architecture. There is a later occupation in the northeastern sector of the site, Sector A, (Figure 1.2) dating to the Late Formative or Early Intermediate Period; however, this occupation is not the focus of this dissertation. An uncalibrated radiocarbon date to $7750+/-100$ B.P. taken from charcoal in a stratum underneath the Late Preceramic architecture hints at another very early occupation. One of the most striking architectural features of the site was uncovered in 2005: a nearly 3.5 meters long plastered sculpture of a grimacing discoidal face flanked by two fox-like animal companions (Figure 1.3). A radiocarbon date of grass in the plaster floor at the base of this sculpture returned $2130 \mathrm{cal}$ B.C. (Benfer et al. 2007). Just to the north, at the top of the stepped pyramid, referred to as the Fox Temple or Templo de los Zorros (Benfer et al. 2007), a large room was discovered in 2004, referred to herein as the Gran Sala. In the center of the room is a platform with a sunken rectangular pit with niched walls (Figure 1.4) similar to Mito-style architecture (Bonnier 1997) and consistent with the Kotosh Religious Tradition (Burger and Salazar-Burger 1980). While the surrounding Gran Sala was almost perfectly clean, except for a tree trunk that may been a roof support, the sunken pit was filled with alternating layers of plant remains and rocks. It was a very rare find, so the contents of this pit became the bulk of my research at Buena Vista. Also, because of the 
unique architectural and ritual context, the remains present a unique opportunity to study ritual during the Late Preceramic.

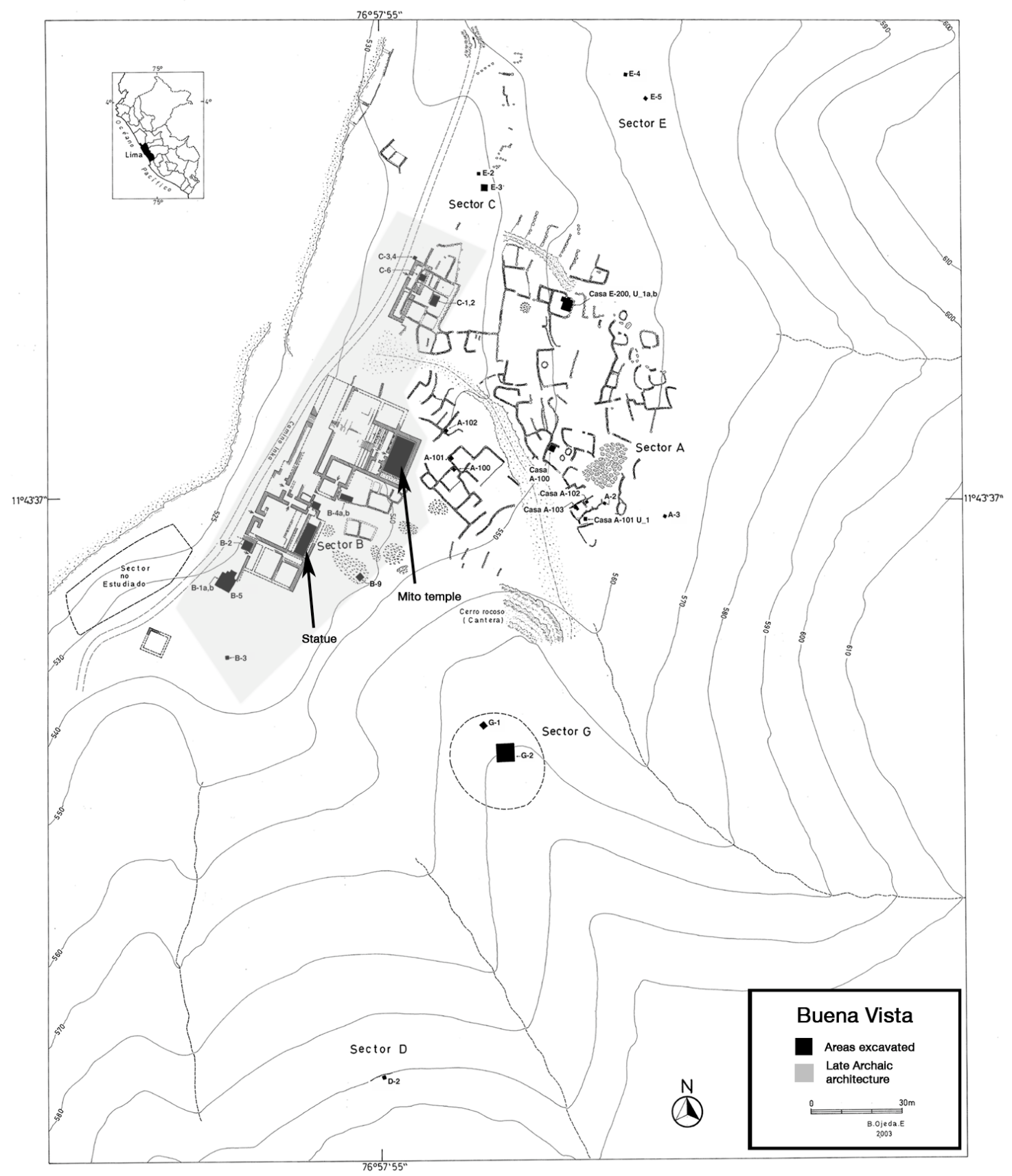

Figure 1.2 Map of the Buena Vista site. Areas excavated are shaded in black. Areas containing Late Preceramic architecture are shaded in gray. Map: Bernardino Ojeda. 


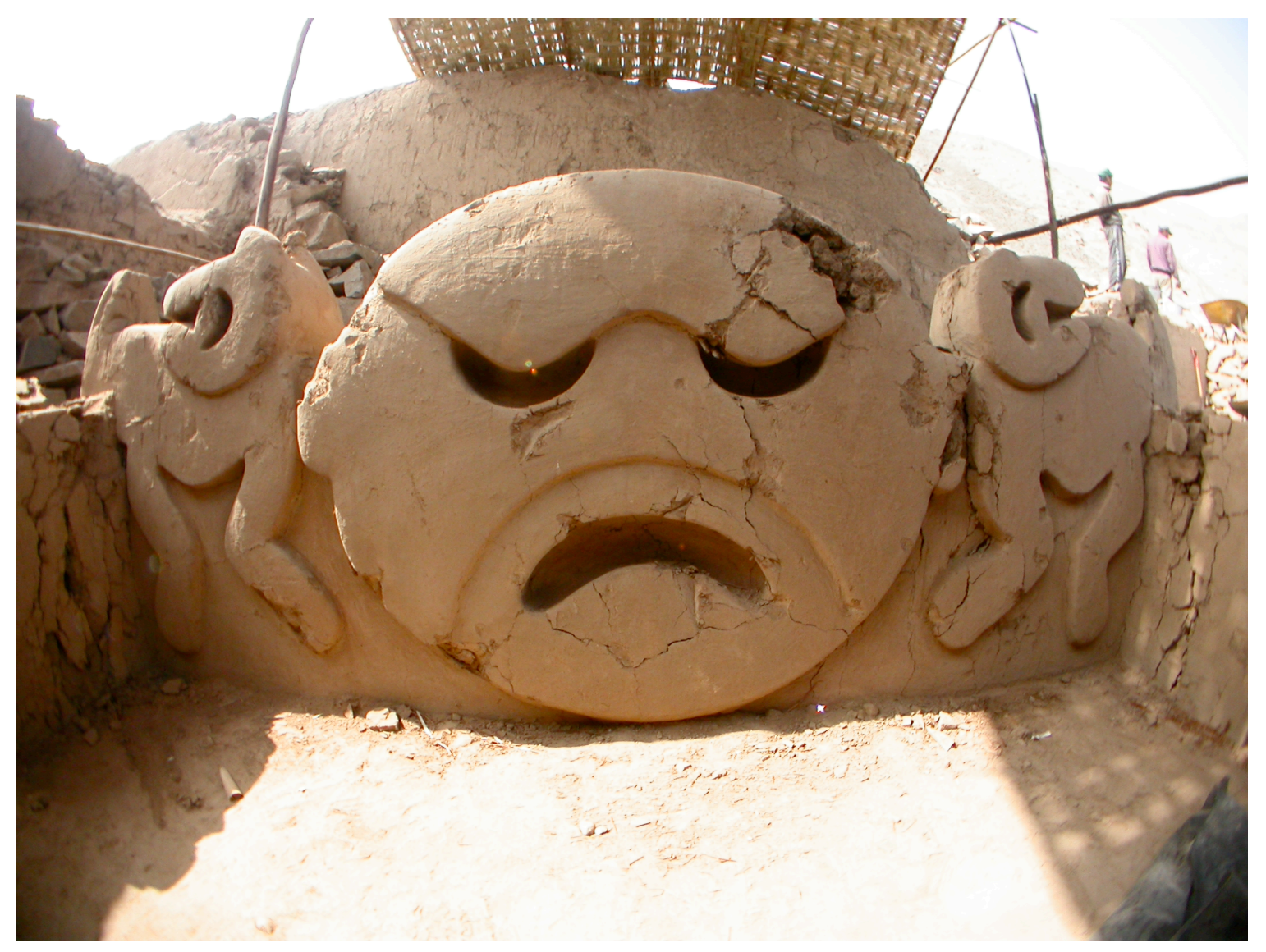

Figure 1.3 Photograph of the sculpture of a grimacing discoidal face flanked by two fox-like animal companions located to the southwest of the Gran Sala in Sector B at Buena Vista. Photo: N. Duncan

A fair question can be asked at this point: What is ritual architecture at Buena

Vista? In studying ritual in the past, I think it is important, as Ian Hodder (1992:223)

points out, to be clear that an interpretation of something as evidence of ritual or religion

should not be led by the fact that one either does not understand or cannot ascribe a

function to what they are observing. Then again, working in the Andean region,

anthropologists have repeatedly shown how the landscape is highly sacralized. Ritual and

religion are inextricable from daily life in most traditional societies, a feature that likely

extends very far back into our human past. Although, we should recognize that ritual can 
have both religious and material justification. As Anthony Wallace (1966) contends, ritual is religion in action, and rituals mobilize supernatural powers to bring about material benefits, such as a successful harvest or sufficient rain. Rituals may have very material reasons for their practice, but simultaneously they may also have religious meaning.

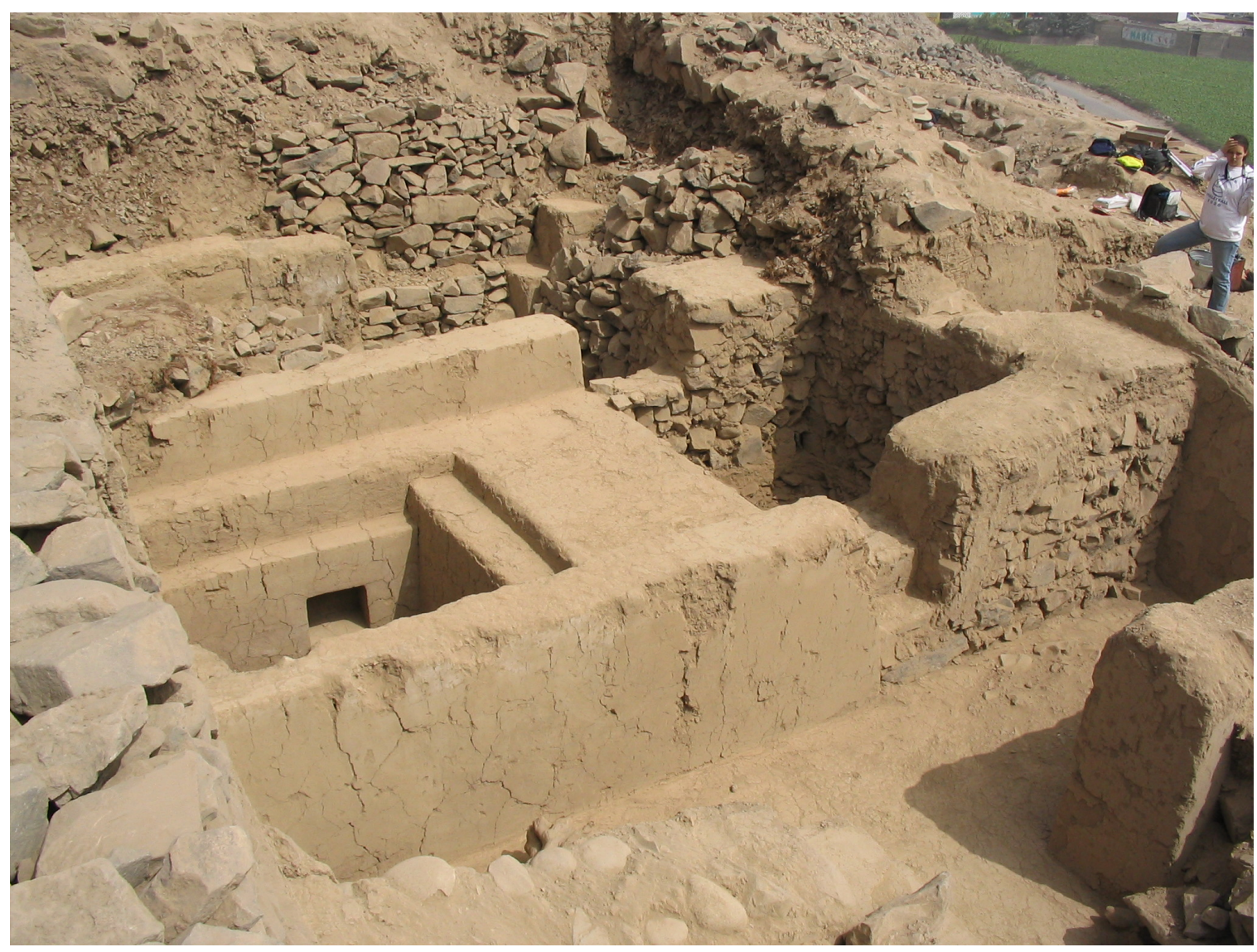

Figure 1.4 The platform and sunken pit with one of the niched walls visible in the center of the Gran Sala of the Fox Temple at Buena Vista, facing southeast. Excavation of the Gran Sala was in progress when this photo was taken. Photo: N. Duncan

The performance of ritual also symbolizes and recreates society into something sacred while bonding individuals as a group (Durkheim 1995[1912]). The performance of ritual, then, is profoundly meaningful as a social act. The participants' shared experience 
reinforces social obligations and collective morality, even if the performers are unaware of the deeper religious meaning underlying the ritual (Rappaport 1999:24-5). For example, for many North Americans, the Thanksgiving holiday is not conceptualized as a religious ritual, rather, many consider it a celebration of family and friends.

As a ritual, feasting may have been practiced in the context of other rituals at Buena Vista, but what were the material consequences of feasting? In the last decade or so, there has been an increased interest in interpreting archaeological evidence of feasting, reflecting a general surge in anthropological interest in feasting from a cross-cultural perspective. Andeanists, however, have long been aware of the integral role that feasting plays in society, particularly the reciprocal role of food and labor among the Inka (Murra 1980, 1967) and among modern groups in mobilizing for community projects (Allen 2002).

Feasting is a communal sharing of food and drink within a special social context or for a special purpose. Feasts, like other rituals can have profound social consequences and, as Brian Hayden $(1995 ; 2001)$ argues, they may have played an integral role in the emergence of social hierarchies as early elites acquired symbolic capital and prestige, as well as accruing debts, through hosting competitive feasts. Feasts also convert food into symbolic capital, and this is a prime component of what Michael Dietler (2001) calls commensal politics, in which hosts make social gains without necessarily exploiting the participants. For instance, a feast may be held in order to mobilize for a harvest to be picked or a canal to be cleaned. Symbolic capital translates into influence on group decisions and actions. Hosting feasts and other public rituals also reiterates and legitimizes 
socially institutionalized relations of power, especially where that power is asymmetrical such as societies with emergent complexity.

In the Late Preceramic, architecture provides the space in which ritual performance takes place. Following Colin Renfrew's (1985) correlates for identifying ritual architecture, Buena Vista's elaborate decoration with niched walls, special locations for ritual practice, with both public and private areas, iconic representations of supernatural forces (Figure 1.3), and the remains of food and drink brought in for consumption all attest to Buena Vista as an example of ritual architecture. Many other Late Preceramic sites in Perú contain ritual architecture that is comparable to Buena Vista, such as those sites in the Kotosh or Mito traditions in the highlands. Although no other contemporary site shares the unique treatment of such a sunken pit that was excavated at Buena Vista. Kotosh or Mito sites have small central hearths, sometimes ventilated, where offerings of food and other goods were burned. In contrast at Buena Vista, the sunken chamber was filled with alternating layers of plant remains and earth. Despite sharing certain architectural forms, the ritual performances conducted at these sites may have been different, for different purposes, and with differing meanings.

The contents of the sunken pit present a unique opportunity to study ritual during the Late Preceramic. The sequence of deposits represents an intentional interment of the $1.5 \mathrm{~m}$ deep pit. First, a layer of grass covered the floor of the pit, atop which were found numerous remains of the non-edible portions of food plants, cotton fiber and seeds, and other plant materials. Charcoal fragments found among the plant remains provided a radiocarbon date of $2220 \mathrm{cal}$ B.C. Atop the plant remains, a layer of round river cobbles 
was mixed with smaller gravel. We found another layer of mixed plant material and a few artifacts such as bone hairpins (Grieder et al. 1988:83-90) and a bone bead as well as a small, commingled assemblage of mussel shells. Charcoal from this layer also dates to 2220 cal B.C., and is contemporaneous to the level below. The layer of plant remains was then covered with small angular rocks, and finally, loose cane bags of rocks, called shicra, buried the pit.

Elsewhere, Benfer et al. (2007) have argued that the stratified layering of the pit is consistent with the definition of ushnu, an Andean concept of sacred place serving, among other functions, as a location for rituals and offerings of food and drink. The layer of round river cobbles in the pit, as an ushnu, would have ritually cleaned liquid offerings of probably fermented beverages; this is consistent with interpretations for other ushnu structures in the more recent past (Pino 2005:146). The pit at Buena Vista is referred to previously as the Cámara de las Ofrendas or the "offering chamber" (Benfer et al. 2007) in which plant remains found are purported to be evidence of such offerings. The results of the present investigation, however, provides strong evidence that the plant remains are refuse, rather than offered foods, but this finding does not necessarily rule out the previous interpretation of the pit's use as an ushnu or the offering of fermented beverages. As will be argued later, the plant remains recovered represent further evidence of rituals conducted in the temple, such as feasting, that would be expected to be concurrent with ritual activities if the feature was used in a similar way to later ushnu platforms (Meddens et al. 2008).

As I will discuss, the deposition of the remains in the pit reflects discard associated with an intensification of activities involving food and a deliberate sequence of burial. 
Above the layer of river cobbles, wood and charcoal density increases while food remains generally increase in density from bottom to top of the pit. The food remains include noneaten parts of food plants, including seeds of chili peppers, guava, lucuma, and squashes, and rind fragments of sweet potato, manioc, and potato, that were recovered with the remains of non-food plants such as many hundreds of cotton seeds, grasses, and partially burnt twigs and charcoal. Faunal remains are much less abundant and limited primarily to mussel shells and small fish vertebrae. Also, the richness and diversity of the foods increases in the upper levels of the pit above the layer of cobbles as does the number of gourd fragments. This suggests an intensification of food activities associated with gourd serving vessels and food containers.

The gourd fragments can also tell us how they may have been used and this is where the study of microfossils comes into play. I tested whether starch and phytoliths could be extracted from gourd and squash rinds to identify their function (Duncan et al. 2009). I selected eight fragments from within the pit and two fragments from the fill material just above the pit and adapted procedures used in the analysis of residues from stone tools and ceramics. Only seven of the artifacts yielded starch, and phytoliths were recovered from only two. Starch grains produced by the artifacts themselves were present, as expected, but non-Cucurbitaceae starch grains were also found that identify foods that were prepared or served using these artifacts. These include root/tuber starch from manioc, arrowroot and potato, fruit starch from chili pepper, and starch from the mesocarp of algarrobo pods, a species of mesquite from with sweet edible pods. Phytolith extraction from the residues of the artifacts was not as successful as for starch. Only two 
fragments yielded phytoliths; these were the two fragments from the fill above the pit. In one fragment, phytoliths of a type produced in Cannaceae or Marantaceae may indicate foods such as achira (Canna indica L.), leren, [Calathea allouia (Aubl.) Lindl.], or arrowroot [Maranta arundinacea (L.)].

The sediments from the pit were also studied for starch and phytoliths to compare to the residue analysis in order to determine if the presence of food starches on the artifacts could be the result of transference of microfossils in the soils to the surfaces of the artifacts. Starch recovery from the sampled sediments produced very low counts and I could make only tentative identifications of two of the starch grains as cf. Cucurbitaceae and cf. Manihot sp. (manioc). No starch grains were recovered from the lower levels of the sunken pit. Phytolith recovery from the sediments from the pit was much more productive. From the results of the sediment analyses, transference of starch and phytoliths from the sediments to the artifacts did not occur.

In general, the pattern of phytolith deposition in the sediments is similar to the patterns observed in the macroremains, with an increase in richness and diversity of herbaceous phytoliths in the upper levels of the pit. This probably relates to intensification of food-related discard in the upper levels. Phytoliths produced by leren and squash are present, as are phytoliths produced in big-leaved plants, Heliconia sp., Marantaceae and/or Cannaceae, and phytoliths from palms. These phytoliths possibly represent foods - leren, arrowroot, achira or palm fruits - but they may also be related to cooking or the transport of foods and other goods. 
Heliconia, Calathea, and palms are not naturally distributed on the central coast of Peru, nor were they found in the macroremains. This leads to an interesting taphonomical question: How did these phytoliths from plants native to coastal Ecuador and the eastern slopes of the Andes or Amazon end up in the pit but the plants weren't identified in the macroremains? It is unlikely that silica bodies from those plant tissues were deposited into the sediments as those plants decayed; the degree of preservation at Buena Vista was exceptionally high. If these plants were used in the preparation of food, the phytoliths could have been released through ashing of the plant tissue during cooking. The big-leaved plants Heliconia, Marantaceae, and Cannaceae, all contain species that produce edible rhizomes. Importantly, each has species with broad flexible leaves used in preparing food, particularly for wrapping foods for cooking or for transport. Each of these plants may have served a dual purpose as food and utility. These plants produce phytoliths in abundance, and if the leaves or rhizomes were burnt in cooking or as waste, they would very likely release silica into the ash. It appears that when the final rituals and feasting had come to an end, the refuse from those activities in the Gran Sala, and other areas of the temple where foods were consumed and prepared, was gathered and deposited into the sunken pit. The phytoliths from exogenous plants would have been deposited, too, with the ash.

The architecture of Buena Vista's temple mound provided the ritualized spatial context within which a feast and other rituals occurred. Also, the remains of consumed foods are disposed of in a special location, in this case the sunken pit. There are significant symbolic differences between refuse and offerings. An offering is like a gift of something personal or valuable to both the giver and the recipient, and the gift is given with a 
sentiment of respect (Firth 1963). The presence of refuse rather than offerings, particularly in the upper levels of the pit may have important underlying meaning; perhaps serving to symbolically cancel the pit after the final rituals were conducted and before the temple was renovated, or maybe the refuse is an indication that the rituals conducted did not have the desired outcome.

In regard to ritual, what function did feasting serve at Buena Vista? One function of feasting is to mobilize labor. Excavations of the temple mound revealed multiple building episodes and repeated sequences of fill and renovation. The extended time over which renovations occurred and the generally small-scale changes to the temple mound did not require massive mobilizations of labor. Small work parties could be mobilized through the hosting of feasts. At Buena Vista, because the timing of the burial of the Gran Sala coincides with the final rituals and feasting that occurred there, those who participated in the constructions were likely the same who participated in the rituals and feasting.

Finally, what do we know about who participated in the construction, rituals, and feasting? This is a more difficult question because we still understand very little about domestic areas near Late Preceramic sites, such as Buena Vista. The refuse in the pit, however, provides a clue based on ethnographic analogy, specifically, the large amount of cotton seeds in the macroremain assemblage. The seeds were not likely offerings because of their association with other refuse. One explanation is that cleaning of cotton seeds, spinning thread, and possibly weaving were being conducted, maybe during idle periods, such as in between ritual events or while cooking. This activity could have a ritualized 
aspect to it, possibly with the participation of men and women or simply cleaning cotton was just something to do as a waiting activity (Goldstein and Shimada 2010).

In summary, there are multiple goals of this dissertation work. From an analysis of plant macroremains, phytoliths, and starches from soils and artifact residue, the first goal is to evaluate the evidence for feasting in the Gran Sala of the temple mound at Buena Vista. This work has already generated a novel technique for the study of food residues from preserved gourd and squash rind serving vessels. Furthermore, this analysis also provides significant data on the use of foods in ritual and provides significant clues to understanding subsistence, the early distribution of economic plants, and evidence of early interregional exchange in the Late Preceramic. We have much to learn about the social practices of the people who built the site. Feasting, as a social event, provides us some insight into how emergent leaders could have mobilized small communities for labor projects or for ritual observance, but feasts would also have served to provide community solidarity and communitas through participation of the feast and other rituals that occurred simultaneously.

\section{ORGANIZATION OF THE THESIS}

In Chapter 2, I outline some of the theoretical approaches to a) identifying ritual architecture and b) identifying feasting. The social and political significance of both ritual architecture and feasting are discussed in more detail.

In Chapter 3, I describe the environmental and ecological setting of the Chillón Valley in the Central Andes. The Andean region displays a fascinating interrelation of weather and geology that dramatically affects plant communities on the coast. I outline the 
geographic and ecological zones of the valley as one ascends inland from the coast to the high cordillera and discuss the hydrology of the river and soil formations compatible with agriculture.

Chapter 4 outlines the pre-Hispanic cultural setting of the Chillón Valley from its first inhabitants through the time of Inka expansion, with special emphasis on the social developments during the Late Preceramic and Initial Period from which I will draw some conclusions for this research in the final chapters.

In Chapter 5, I describe in greater detail the archaeological contexts at Buena Vista that are pertinent to this study. Most of the studied paleoethnobotanical materials were recovered from contexts within the monumental architecture, floors, hearths, and special deposits such as the sunken pit in the room at the top of a temple mound.

Chapter 6 explores the plant macroremain data. I describe the methods used in sampling the archaeological contexts and discuss potential taphonomic issues associated with the plant macroremains. The macroremains are then compared by context to make some preliminary interpretations.

Similarly, in Chapter 7, I explore the phytolith and starch data recovered from soil samples from significant contexts, the methods employed and results. I present some interpretation of the phytolith assemblage across contexts and compare the results to the macroremain assemblage. There are significant differences in the taxa recovered and these are interpreted as issues of deposition associated with human behaviors.

Chapter 8 outlines the investigation of starch and phytolith residues from gourd and squash artifacts. This chapter also provides some background in the archaeology of gourds 
and squashes in the Andes. The results of this experimental technique aimed at identifying the function of gourd and squash artifacts in the serving and preparation of food are important in the interpretation of feasting at the site.

In Chapter 9, I synthesize the macroremain, starch grain, and phytolith results in the interpretation of feasting Buena Vista and attempt to situate the evidence for feasting as it relates to archaeological, ritual, and social contexts. I also compare data from Buena Vista to other sites of the period to explore subsistence, interregional interaction, and the social significance of plant use in the production and consumption of foods in feasting. I also examine several potential future research questions generated by this study's results. 


\section{Chapter Two - Ritual Architecture and Feasting at Buena Vista}

The goal of the chapter is to situate Buena Vista as an example of ritual architecture, where activities within were also ritually formalized. Feasting, as one activity in the ritual context, likely served both practical and symbolic functions. In the discussion that follows, I describe some theoretical approaches to, first, ritual architecture and, second, feasting as a ritual practice. I also explore some of the possibilities and limitations of the study of ritual and feasting in archaeology. I hypothesize that the remains in the sunken rectangular pit in the Gran Sala at the top of the temple mound are the remnants of a ritual feasting event or events that occurred just prior to the temple's entombment. But before evaluating this hypothesis, some discussion of ritual is necessary as is an explanation of the theoretical approach taken in studying ritual in archaeology.

\section{RitUAL AND RITUAL ARCHITECTURE}

In the study of ritual, archaeologists vary not only in their definition of ritual, but also in how they choose to emphasize either ritual as a social practice or as an enactment of religion (Fogelin 2007a). However, these varying approaches have deep roots in the anthropological and sociological study of religion. The primacy of religion in ritual expression was described succinctly by A.F.C. Wallace (1966:102): "The primary phenomenon of religion is ritual. Ritual is religion in action." This is not to say that ritual 
is prescribed by religion, rather, rituals themselves are backed by beliefs and parts of what make up the whole of religion. For Wallace (1966:107), religion is defined as "a set of rituals, rationalized by myth, which mobilizes supernatural powers for the purpose of achieving or preventing transformations of state in man and nature." Rituals, thus, have an underlying belief, but may also serve specific functions that may not be entirely religious. Wallace classified five categories of ritual transformations that moved participants from one perceived state to another: rituals as technology such as subsistence, as therapy or antitherapy aimed at controlling health, as social control aimed at influencing ideology, as salvation, and as revitalization, and these serve both material and nonmaterial purposes. For example, in ritual as technology, rites attempt to control aspects of nature by bringing an end to droughts or in ensuring a bountiful harvest.

For archaeologists, the notion that rituals are expressions of religious beliefs makes interpretation of religion in the archaeological record plausible, especially when ethnographic or ethnohistoric analogies can be applied (Fogelin 2007a:57). Some religious ideals tend to be very stable over time and those associated rituals likewise are unchanging, that is if we consider ritual the very expression of religion. However, interpreting the meaning of religious symbols in the remains of ritual practices in prehistory without applicable ethnohistoric and ethnographic analogies is very difficult (Fogelin 2007b), but not necessarily impossible.

On the other hand, interpreting the function and observing the performance of what Wallace called ritual transformations is the most common approach with archaeological data. We may not necessarily need to know the underlying cosmology or 
pantheon of supernatural beings being exhorted in order to interpret the material, social, and economic manifestations that rituals bring about through their social performance. Neither do we need to assume that all ritual is religious ritual. For example, Durkheim (1995 [1912]) posited that religion and its rituals serve to symbolize and recreate society as something sacred that bonds individuals into a group. Through ritual, the participants' shared experience reinforces social obligations and collective morality. Protocols of behavior, set up through repeated performance, may not have explicit or even implicit religious underpinnings. In this vein, Roy Rappaport (1999:24-5) provides an additional definition of ritual as "the performance of more or less invariant sequences of formal acts and utterances not entirely encoded by the performers." Here, the emphasis placed on the performance of ritual is primary to the underlying meaning or even understanding of the participants.

Recognizing that ritual behaviors have both religious meaning and material effect allows one to approach the study of ritual from a practice perspective (Bell 1997). This perspective recognizes that ritual behaviors may not be religious ones, but still retain similar characteristics as ritual processes: having formal rules or codes, containing elements that are archaic or anachronistic, following strict and/or repetitive patterns, having behaviors governed by a strict code of rules, the use of sacred symbolism, and often having public display of the performance. The underlying meaning of ritual, from a practice perspective, is not what is important. Rather, the goals and the experience of the participants are the focus. However, I do not think that practice oriented approaches negate our potential for understanding the meaning of ritual symbols, be they sacred or 
profane, nor are they any less valid as methods toward understanding culture. For example, borrowing an analogy from John Robb (1998:331), if we understand how people in the past produced food technology without knowing the cultural reasons why they chose those foods, the effort is still a successful demonstration of economic archaeology, even though we have "reduced a complex system of value-laden social relations to a simple faunal inference." In a similar way, examining ritual through a practice perspective might be considered reductionist, but we should not dismiss the notion that all things cultural are also symbolic. As Leslie White wrote in 1940: "All human behavior consists of and is dependent upon, the use of symbols." And in the Andean world, his point is abundantly clear.

Andean archaeologists, many of whom, as Burger and Salazar-Burger (1985:113-114) rightly describe, live in a "desacralized cosmos" and may find it "difficult to accept the profoundly religious nature of Prehispanic societies." The assumption that Prehispanic societies lived in a sacralized cosmos is largely based on traditional Andean society that inhabits what Catherine Allen (2002:33) called "the animated cosmos" where ritual and myth permeates daily life. As the ultimate source of everything one eats, drinks, and wears, "the Earth and the Places watch human consumption jealously and demand their part in it." Based on the ethnographic present and ethnohistoric past, there is significant reason to presume that sacred rituals permeated the daily lives of past peoples as well. If it is reasonable, or rather necessary, to presume that the ritual in the lives of ancient Andeans was equally important as to modern societies, then giving ritual only a marginal role in understanding the past is insufficient (Moore 1996:122). Jerry Moore points out that the 
study of ritual, contrary to being peripheral or non-essential, is crucial to understanding the Andean past even if ritual meanings, cosmological or religious, are not fully understood. In agreement the statements of Allen and Burger and Salazar-Burger above, Moore (1996:122) argues that everything we know about the Andes points to the essential nature of rite. He argues that archaeology of the Andes needs a body of theory in relation to Andean ceremonial architecture in order to understand the material remains of ritual expression. For example, using ethnohistorical descriptions, he compares ancestral shrines to oracular shrines, as they are discernable by their material remains. Ancestor shrines (Doyle 1988), those places where ancestors were buried and where rituals took place to honor them, were often smaller in size and not usually built with permanence in mind. Ancestor shrines are also more common and usually peripheral to the places the descendents lived. In contrast, oracular shrines, such as Pachacamac on the coast, were less common, hosted large numbers of people, and were constructed in a much grander scale to last multiple generations. Usually, these kinds of oracular shrines are built closer to residential areas, but, as was the case at Pachacamac, visitors from great distances would come to consult the oracle.

Moore (1996) contends that despite the limitations of ethnohistorical analogy, identifying archaeological architecture based on social context and ceremonial patterns is still possible, but also, more informative than stylistic or functional categories of architectural types. Interpretation is possible because of the formalized nature of ritual as a communicative event. The thresholds of human perception limit ritual as communication, thus different rituals involve different sets of perception according to the size of the 
audience and the level of detail conveyed in the communication. Architecture, providing the built space for the ritual events, therefore will reflect those different social contexts (Ibid., p. 132). The different social contexts may be more or less obvious; compare the elaborate layout of the Inka capital at Cusco with its complex urban layout to the small built up hillside of Buena Vista, for an example in the extreme. The hypothesis that Moore tests, using examples of large archaeological sites from the Late Preceramic through the Early Horizon, is that these public structures represent political processes, expressed in ritual that involved the public and a differential of power.

Moore's hypothesis rests on the assumption that early Andean architecture functions to communicate, through ritual, social and political differences that would have been understood by the participants. The communicative nature of these constructions allows archaeologists to identify those social and political differences by examining permanence, centrality, ubiquity, scale, and visibility. For instance, during the Late Preceramic, we begin to see the first evidence for permanent, large-scale constructions spanning multiple generations. Many of these sites are centrally located, meaning they are associated with residences, though very few of them are excavated. Moore suggests that these constructions are tightly associated with kin-based belief systems and ancestors or culture heroes were venerated here. The differences between constructions among coastal valleys might be explained by the different kin groups or culture heroes recognized at each site. Small group gatherings in the isolated chambers somehow dovetailed into larger performative rituals in sunken courts and small plazas common in Late Preceramic coastal architecture. The coastal traditions contrast with highland sites that are characterized by small group 
communitas performances in more private spaces (Hastorf 2007:86). Buena Vista is unlike coastal sites typical in the Supe Valley region, such as Caral, containing sunken circular courts, but still contains evidence of both public and private rituals of a similar scale. Overlapping stairways for ritual procession, and observance by those below, led to up to the top of the temple mound where the ritual participants descended into an exclusive and mysterious place where their activities would not have been observable by those outside or at the base of the stairs (see Chapter 5 for a detailed description of the architecture).

Moore's behavioral approach focuses on the function of ritual architecture in the political and social organization of early Andean societies. It is implicit that rituals conducted at these sites had religious and symbolic meaning, but Moore does not attempt to identify those underlying meanings. Citing Edmund Leach (1979 [1966]:233) who posited "no interpretation of ritual sequences in man is possible unless the interpreter has a really detailed knowledge of the cultural matrix which provides the context for the rite under discussion," Moore (1996) argues that meaning, due to its dynamic and polysemous nature, is too difficult to identify archaeologically. Though, I do not think that Moore would take as an extreme position as Christopher Hawkes (1954:56) does, that inference from material remains to spiritual life is near impossible. In fact, Leach's categorical statement above was in reference to late 19th century over generalization of religious meanings in contrast to Victor Turner's careful "thick-description”-like analyses of ritual and ritual meaning: "The gap between Sir James Frazer and Professor Turner is very wide..." (Leach 1979 [1966]:233). Even in archaeology, with careful study of ritual practice, perhaps we can one day better understand meaning associated with those rituals. 
For Andean archaeologists, it may be sufficient to assume that there is some significant part played by religion and cosmology in the performance of ritual in constructed spaces of early Andean monuments. However, we can also apply other criteria to identify specifically those rituals of a religious nature. Colin Renfrew's (1985) pioneering analysis of Bronze Age architecture at the Aegean site of Phylakopi, with the goal of identifying religious ritual in the archaeological record, provides us some points of comparison to apply to the Andean case. Renfrew recognizes the difficulty in separating religious from secular rituals (see also Renfrew 2007), but suggests that religious rites usually take place in a specific, defined place, a liminal area where ritual is focused, and the use of special or well-defined forms or objects not commonly associated with secular contexts are employed for symbolic focus or as offerings (1985:22). Renfrew lists eighteen behavioral correlates that identify religious ritual. These include, but are not limited to:

- Special architecture with attention focusing details such as elaborate decorations and niches.

- Cult images of power and iconic representation, including representations of deities or supernatural beings.

- Special locations for ritual practice, such as altars and benches, pits, and hearths.

- Areas for conspicuous public display and hidden exclusive mysteries.

- Food and drink brought in for consumption or offering.

- Concepts of cleanliness and pollution reflected in the facilities and the maintenance of the sacred area.

- Considerable investment of labor or wealth in procurement of goods and in construction of the structure.

From Renfrew's list, I selected those correlates most applicable specifically to Buena Vista, but these and the other correlates correspond to most, if not all, of the other sites deemed "ritual architecture" in Moore's analysis. 
At Buena Vista the style of the architecture and scale of construction certainly represent a considerable investment in planning. Particular attention was placed on constructing both open areas and isolated exclusive ones. Concepts of cleanliness are apparent in the deposition of materials in the sunken pit in the main temple and pristine condition of the surrounding room. The primary focus in this dissertation, the presence of food and drink brought in for consumption, is discussed at length in the analyses of plant macroremains and microfossils (see Chapters 5 through 8). The menacing disk with two fox attendants excavated in 2005 indicates iconic representation of the supernatural (Chapter 1: Figure 1.2). For Renfrew, the most important, or perhaps the most telling correlate of religious ritual in an archaeological setting is the presence of such symbols representing humans or animals, that is if they can be ruled out as objects or symbols of play or as the simple desire for decoration (Renfrew 1985:21; 2007). Robert Benfer et al. (n.d.) provides an intriguing argument for the antiquity of mythology surrounding the fox in the Andes and Mesoamerica and the significance of the fox constellation in concert with architectural alignments at Buena Vista (see also Benfer et al. 2007). Buena Vista fills the criteria for supernatural representation.

Early monumental architecture, such as that which appears at Buena Vista and other Late Preceramic constructions, is ritual architecture following both Renfrew's and Moore's criteria. The kinds of rituals conducted in these sacred contexts, however, are still poorly understood. Most of our understanding of rituals conducted at sites of this time comes from excavations of highland sites. From evidence gathered at Huaricoto, Kotosh, Shillacoto, and other highland sites. Burger and Salazar-Burger $(1980,1985,1986)$ defined 
the Kotosh Religious Tradition as characterized by small-freestanding buildings with central fire pits, often with ventilated shafts within which small ceremonies were held that included the burning of food offerings and other goods. The burning of chili peppers in some of these features, as suggested by the presence of chili seeds, at La Galgada, for example, is speculated to be ritually significant; chili infused smoke would have caused the participants eyes to water as a symbol of renewal (Grieder and Bueno 1985:97). The Kotosh Religious Tradition is considered an underlying system of religious beliefs that were expressed in ritually similar way at sites with similar architecture. These similar architectural traits are also known as the Mito Tradition (Fung Pineda 1988), but this refers to a more restrictive classification based on the presence of hearths for offerings, niched walls, and split level floors that Elisabeth Bonnier (1997) argued was evidence of cultural interaction, rather than shared religious or political aspects.

On the coast and inland valleys, several sites with architecture similar to that defined in the Kotosh Religious Tradition are known, including several in the Casma Valley (Pozorski and Pozorski 1996), in the Santa Valley (Montoya 2007) and at Caral in the Supe Valley just to the north of the Chillón (Shady and Machacuay 2003). In addition, the sunken pit in the platform in the center of Buena Vista's main temple mound also has Kotosh or Mito characteristics. However, despite sharing certain architectural forms, the ritual performances conducted at these sites may have been different, for different purposes and with differing meanings. At Buena Vista, for example, the sunken pit contains an abundance of plant food refuse as well as other plant remains inconsistent with offerings, burnt or otherwise, and more characteristic of activities involving the 
preparation and consumption of foods in a ritual setting. Here, the difference in ritual expression is stark when compared to other sites of the period, namely those sites having Kotosh or Mito style architecture; perhaps the similarity in architectural design of Buena Vista may be due to certain shared cultural traits rather than overlapping religious beliefs.

Discerning shared religious beliefs from shared cultural traits in the Late

Preceramic is difficult, however Benfer et al.'s (2007) analysis of astronomical alignments of the Buena Vista temple, which correspond to solstice events and the rise of the fox constellation (Benfer et al. n.d.) provides an intriguing hypothesis. Benfer et al. (2007) propose that specialized priests guarded astronomical knowledge in order to control the timing and performance of calendrical rituals associated with planting and harvesting. Other early sites in Perú have astronomical alignments, such as Chankillo in the Casma Valley (Ghezzi and Ruggles 2007) and even other Kotosh sites are apparently aligned to solstice events (Burger and Salazar-Burger 1986). However, Benfer's analysis reveals early complex astronomical expertise that may have characteristics unique to Buena Vista, although alignments are likely to be found at other Late Preceramic and Initial Period sites (Benfer, personal communication) marking the same celestial events. One could hypothesize that different styles and variations of ritual architecture reflect different ritual approaches to marking those events; perhaps this would be evidence for a shared Andean cosmology with performative variations reflected by social or political differences.

\section{RituAl FEASTING}

In the analysis of the paleoethnobotanical remains from Buena Vista, I present evidence of feasting, a different kind of ritual activity that occurred within the temple. In 
the last decade or so, there has been an increased interest in interpreting archaeological evidence of feasting (Gero 1992; Clark and Blake 1993; Lau 2002; Bray 2003a, 2003b; Vaughn 2004; Jennings 2005; Vega 2005; Berryman 2010; and others) reflecting a general surge in anthropological interest in feasting from a cross-cultural perspective. Despite early studies that showed the importance of food in ritual, social, and material aspects of society, particularly Roy Rappaport's Pigs for the Ancestors (1968), not much attention has been given to feasting until fairly recently. Some, such as Brian Hayden (2001:24), find this perplexing given the explanatory power feasting contains:

[F]easting is emerging as one of the most powerful cross-cultural explanatory concepts for understanding an entire range of cultural processes and dynamics ranging from the generation and transformation of surpluses, to the emergence of social and political inequalities, to the creation of prestige technologies including specialized domesticated foods, and to the underwriting of elites in complex societies.

Andeanists, however, have long been aware of the integral role that feasting plays in society, particularly the reciprocal role of food and labor among the Inka (Murra 1980, 1967) and among modern groups in mobilizing for community projects (Allen 2002).

What feasting is, or rather how feasting is defined, is more or less consistent among authors, at least in the broadest sense: the communal sharing of food and drink (Deitler 2001:67) within special social contexts or for special purposes (Hayden 2001:28).

Although, there are significant differences in theoretical approaches to feasts in regard to scope, meaning, and function. Hayden $(1995,2001)$ stresses the political-ecology of feasts to emphasize evolutionary implications in the transformation of sociopolitical structures. In this approach, feasts have an "adaptive value" in that they generate practical benefits for survival, reproduction, health, or standard of living for those who host them (Hayden 
2001:28). To this end, feasts may have played an integral role in the emergence of social hierarchies in "transegalitarian societies" in which early social aggrandizers acquire symbolic capital and prestige, as well as accruing debts, through hosting competitive feasts. In Hayden's evolutionary model, feasts are essential components to the emergence of inequality, heterogeneity, and ranked societies on a regional scale (Hayden 1995a, b).

In contrast to Hayden's political-ecology approach, others, such as Michael Dietler (2001) approach an analysis of feasting from a cultural or symbolic perspective. The feast is a form of public ritual activity that focuses on the communal consumption of food and drink and like all ritual activities its practice is a condensed symbolic representation of social relations (Ibid. 71). Dietler (2001:73) focuses on the commensal properties of feasts in that the public consumption and distribution of a basic human need, such as food and drink, gives the ritual activity added salience and in some cases the ritualization of food demonstrates the host's confidence and managerial skill in the realm of production. Feasts, as a way of converting food into symbolic capital, is a prime component of what Dietler calls commensal politics, in which hosts make social gains without necessarily exploiting the participants.

Both cultural and evolutionary perspectives, however, are in agreement in regard to feasting having symbolic, i.e. emic, meaning for the participants. Although as Hayden (2001:29) points out, an emic understanding of the feast may be quite different from its social function. He uses the example of a Christmas dinner, which has symbolic meaning to Christians honoring the birth of Jesus, but the meal and all its related activities serves to create solidarity and cooperative bonds among family and family affiliates. Similar to the 
practice-approach to the study of ritual discussed above, an understanding of the emic rationale behind feasting and studying the function of feasts are different levels of inquiry, but not necessarily mutually exclusive. Also, both approaches attempt to identify the function of feasts in the relationships between hosts and participants. Each approach identifies similar, overlapping functions and practical benefits that feasts serve.

Some of the more practical evolutionary benefits of feasts include the mobilization of labor paid through food; the creation of cooperative or exclusive relationships within and among social groups; the investment of surplus or extraction of surplus for elite use; advertising wealth for the attraction of mates, labor, alliances; the creation of political power over resources; or to compensate for transgressions (Hayden 2001:29-30). From a symbolic perspective (Deitler 2001), feasts can empower through the acquisition and maintenance of symbolic capital. Symbolic capital then translates into the influence on group decisions and actions. Hosting feasts can symbolically reiterate and legitimize socially institutionalized relations of power, especially where that power is asymmetrical. Feasts can also serve as symbolic diacritical devices that, through the use of special, rare, luxury foods and trappings, serve to reify ranked difference in status.

Having discussed what feasts are and what feasts do, identifying evidence for feasts in the archaeological record follows a kind of inductive reasoning that compares the archaeological observations to what we might expect to find if feasts occurred, then attempts to deduce their function and their meaning. The presence of food or food residue may be one important correlate, but the presence of food is not an a priori indication that a feast was held. For instance, a distinction might be made for food used as an offering for 
supernatural 'consumption' between foods used for consumption by people. Hayden (2001:Table 2.1) provides a list of material-based classifications, based on ethnographic analogies, that archaeologists might expect to find. Variations on these criteria may indicate what kind of feast was held depending on the archaeological context. The criteria for feasts include:

- Foods present may be superabundant, rare, exotic, expensive, or include recreational foods like drugs and alcohol.

- Food preparation vessels may be present as well as serving vessels. These may be unusually decorated, in great abundance, or unusual quality. They may also be ritualized for consumption, e.g. an Inka kero.

- Food remains may be disposed of in special features.

- Feasting facilities may be special structures or the feasting locality is special, remote, or monumental.

- Prestige items may be present or they may be broken or destroyed.

- Paraphernalia, masks, costume elements may be present.

- Food storage facilities, pits, granaries as evidence of surplus.

It is important to note that archaeological evidence for feasts need not contain all of these criteria; rather these criteria are intended to serve as possible markers of feasts that one might use to identify the material remains of feasting. Three Andean archaeological examples of feasting will help make this point.

Joan Gero's (1992) excavations at Queyash Alto in Ancash, Perú uncovered significant evidence of feasting and ritual events occurring in the Early Intermediate period (200B.C. - 600AD). Excavations at this small hilltop site with two small mounds on each end and a formally built open plaza uncovered a high status residence associated with a brief food dump of butchered llama bones, and in another area, the remains of large storage vessels and colander sherds where food was prepared. In the plaza, burned llama bones and abundant fragments of bowls for drinking, open necked jars, ladles and spoons 
for serving, and two llama cranium dippers for serving are evidence for large amounts of food and drink that were consumed. In addition, many panpipe fragments were found. Gero concluded that an emerging ranked and recognized social authority that was able to convene neighboring ayllus, possibly to impress them, or repay their labors and tributes, hosted the feasting that occurred at Queyash Alto.

Gero's analysis provides solid examples of some of the archaeological criteria laid out by Hayden. The presence of large quantities of food remains, serving and preparation vessels, musical instruments as paraphernalia of ritual, and prestige items all associated with formalized ritual space are strong evidence of feasting for the purpose of reiterating and legitimizing recognized social status.

At the site of Chinchawas, also in Ancash, George Lau's (2002) excavation revealed feasting for a slightly different purpose; it was associated with ancestor veneration during the Early Intermediate and Middle Horizon. At Chinchawas, a large complex of rooms, with evidence of food preparation, hearths and large broken ollas, surround a wellmaintained enclosed space where feasts and other rituals were likely held. In adjoining midden areas, large amounts of food remains, primarily camelid bones, deer, small mammals and guinea pigs, were recovered with finely decorated open bowls for serving, as well as other artifacts, such as a camelid crania ladle, spatulas, and tools. In addition, decorative metal and bone items were recovered. Pottery styles from vessels in the midden areas correspond to pottery found in subterranean tombs marked by architectural structures, chullpas, with monolithic sculptures. Feasting at Chinchawas was likely 
associated with ancestral ceremonies that helped individuals attain social and political clout through descent and reciprocal obligations established through hospitality.

In the final example, Rafael Vega-Centeno's $(2005 ; 2007)$ excavations at Cerro Lampay, a Late Preceramic site in the Fortaleza Valley roughly contemporary with Buena Vista, enabled him to interpret feasting associated with labor in the construction of the monumental architecture. At Cerro Lampay, construction processes consisted of temple entombment, whereby an existing architectural space was filled in and a new architectural space was constructed on top. The temple entombment process, first identified during excavations at Kotosh (Izumi and Matsuzawa 1967), is a common construction technique evident at many Late Preceramic and later monumental sites, including Buena Vista. However, Vega-Centeno was the first to identify feasting associated with the process. At Cerro Lampay, food preparation, consumption, and cleaning all occurred within architectural spaces just prior to their entombment. Burned areas on prepared floors that previously were not cooking areas, without hearths, and trash deposits over floors in the lower levels of fill that entombed the rooms suggest that activities involving food preparation and consumption occurred immediately before construction events. VegaCenteno reasons that those who participated in the feasting were the same as those who participated in the construction, therefore feasting was likely part of a labor motivation strategy invoked by an individual or group of some higher sociopolitical influence. The highly repetitive nature of construction processes over time, reflect for Vega-Centeno a weak authority not capable of mobilizing large amounts of labor for significant 
construction events. Feasts were probably an essential practice for emergent leaders or lineages to influence and garner sociopolitical and symbolic power.

These three Andean examples of feasting from archaeological contexts show not only how feasting might be identified from its material remains, but also exhibit several different functions that feasts held in the past in regard to commensal politics. For each, feasting illuminates differences in social and political power or influence. Feasting at Queyash Alto probably served to aggrandize emergent elites who then redistributed foods or reciprocated debts accrued by labor in other contexts. At Chinchawas, feasting rituals conducted within a ceremonial complex that included ancestor veneration probably helped maintain social bonds wrought through generational reciprocal relationships or reified and maintained the social and political prestige of elites. At Cerro Lampay, organizers of feasts used their limited influence to mobilize labor for temple construction.

\section{CONCLUDING REMARKS}

For the study of feasting, like any study of ritual, recognizing the material correlates of feasting events in the archaeological record is a primary goal. From there, archaeologists can examine the various functions feasts may have played. At Buena Vista, the ritual architecture provides a setting from which we can interpret how a feast may have served in commensal politics of emergent leaders who hosted feasts and other rituals there. In the following chapters, I outline the social and ecological setting of Buena Vista, then discuss in detail the material remains recovered from the sunken pit in the Gran Sala. Several converging lines of evidence for feasting at Buena Vista include the ritual space of the temple mound within which the feast(s) was held, the abundant remains of prepared and 
consumed foods deposited in a special place, and the evidence for exotic foods that may have special ritual or social significance. In the final discussion, Chapter 9, I will deduce some possible functions and symbolic meanings for feasting at Buena Vista. 


\section{Chapter Three - Environmental Setting of the Central Andes and the Chillón Valley}

The Andes mountains stretch nearly the whole of the South American continent, over $8500 \mathrm{~km}$ from $12^{\circ} \mathrm{N}$ to $56^{\circ} \mathrm{S}$ (Figure 3.1). Formed in large part by the subduction of the offshore Nasca plate under the South American plate, the tremendous vertical relief of the Andes, up to 7000 meters above sea level (masl), is mirrored offshore by the Perú-Chile trench, which descends to around 7500 meters below sea level. Geologically, the Andes are divided into three segments, North, Central, and Southern (Orme 2007a:12). The Northern Andes, trend north-northeast in northern Perú, Ecuador, Colombia and western Venezuela. The Central Andes, divided into the North-Central Andes from $5^{\circ} \mathrm{S}$ to $18^{\circ} \mathrm{S}$ and the South-Central Andes from $19^{\circ}$ to $46^{\circ}$, lie in Perú, Bolivia, Chile, and western Argentina. The Southern Andes extend to Tierra del Fuego where the South American plate is uplifted by the subducting Antarctic plate. Apart from tectonic forcing in the formation of the Andes, other geological processes have contributed to the physical relief of the region (Orme 2007b), such as volcanism in forming some of the highest peaks in the Andes and among them the earth's highest altitude volcano, Ojos del Salado (6887 masl) on the border of Argentina and Chile, and dramatic erosional downcutting of Andean rivers in the formation of the western valleys. 


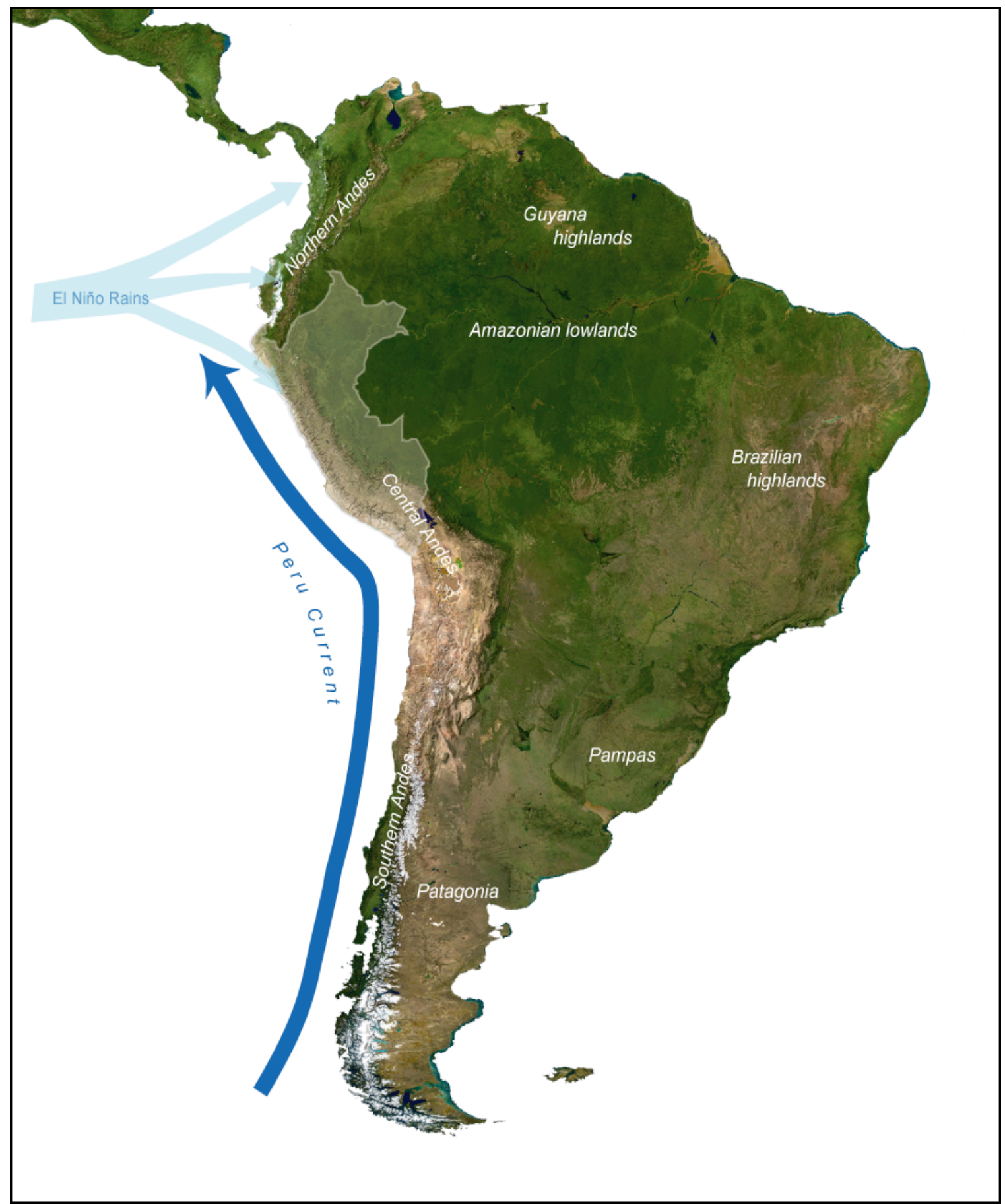

Figure 3.1 Selected ecological and geographic regions of South America, the Peru Current and primary location of increased rainfall during El Niño cycles. (Adapted from Orme 2007b: Figure 2.2.) 
Volcanism and tectonics create the extremes in physical relief of the Andean region that are, in turn, affected by the geomorphologic processes of erosion and deposition related to weather and climate (Orme 2007b). The steep slopes of the Andes are generally unstable; therefore greater than average changes in precipitation or snowmelt can have dramatic results such as landslides and downslope debris flows posing particular danger to human settlements. A complex relationship exists between the physical environment and its climate generated by ocean currents and atmospheric pressure. The upwelling cold water from the Perú-Chile trench is brought close to shore by the Perú current, also known as the Humboldt current, that flows northward along the west coast of South America. The Perú current's rich web of life brings sea mammals, fish, and birds within reach of humans inhabiting the coast, but the price for this bounty is a lack of rainfall. The warm moist trade winds that blow from the west are cooled as they cross the cold waters of the Perú current. When they hit the coast of central Perú and Chile, the air begins to warm and rise rapidly. In winter this creates a nourishing fog for coastal lomas, isolated patches of green vegetation, but no rain as the warmer air rises over the Andes. Rain falling just a few hundred kilometers east of Lima feeds the watershed of the Amazon basin and eventually the Atlantic Ocean (Quilter 1989:2), leaving a nearly $3500 \mathrm{~km}$ long belt of desert along the coast from northern Perú to Chile (Dillon et al 2003). Fortunately, rainfall and melting glaciers provide water to the coastal rivers, but only four have water throughout the year. During El Niño cycles, the trade winds falter and the Perú current briefly alters its course allowing rain to fall on the western slopes. 
Modern fisherman working off the coast of Perú and Ecuador referred to the warm, southward flowing current that periodically disrupts the cold Perú current, as El Niño ("The Christ child"), as it usually occurs around Christmas time. El Niño cycles are only part of a larger, global weather pattern, referred to as the El Niño-Southern Oscillation (ENSO), and in a complex interplay of atmospheric pressure, sea surface temperature, sea surface level and deep oceanographic patterns (Conlan and Service 2000; NOAA 2001). For example, off the coast of South America, where the sea surface temperature is cold, the air mass above it is dense and the atmospheric pressure is high, hindering the formation of rain clouds. As a result, the dry desert coastline of Perú and Chile get virtually no rainfall. High pressure in the eastern Pacific over the cold waters correlates with a low pressure in the western Pacific over warm waters. Westward blowing winds carry the moisture, condensing as it rises, to fall as monsoon rains in East and Southeast Asia. But, as the waters off northern Perú warm to higher than normal temperatures during an El Niño event, the air pressure above them decreases and approaches equilibrium with the lower air pressure over the western Pacific. As a result, the trade winds slow and are not able to push to the west the moist air rising off the eastern Pacific waters. This results in greater rainfall on the west coasts of South and North America and inversely, dry or drought conditions in East and Southeast Asia.

As the trade winds blow the heavy moist air to the west during non-El Niño years, they push the warm surface water as well, raising the sea level as much as 0.5 meter on the coast of Indonesia (Conlan and Service 2000). The thick layer of warm water depresses the thermocline, the boundary between the warm surface water and the cold, deep subsurface 
water. In the east, off the coast of South America, the layer of warm water is much thinner and the thermocline is higher, closer to the surface (Figure 3.2). This westward sloping thermocline is known as the Equatorial Front. During an El Niño event, the weakening trade winds cannot push the warm water to the western Pacific. As a result, the thermocline rises in the west and falls in the east as waters there begin to warm.

The rebound effect of El Niño, La Niña, is a cooling event in the east Pacific, and inversely, a warming event in the west. La Niña is associated with stronger than normal monsoons in Asia and colder than normal winters in northwestern North America. The effects of La Niña are ameliorated as Southern Oscillation returns to equilibrium.

The ecological effects of El Niño, especially on the northwest coast of South America, can be devastating to local environments. As the phytoplankton and zooplankton abundant in the cold current begin to disappear with the subsidence of the thermocline, so do anchovies and sardines causing massive die offs and emigration of sea birds dependent upon them for food, along with other fish and sea mammals (Arntz 1986, Caviedes 1984). The 1997 El Niño event brought rainfall up to ten times the normal rate in northern Perú and Ecuador causing flooding, mudslides, and tremendous loss of life, while droughts in Malaysia, Africa and central Brazil exacerbated forest fires there (WHO 2000). We are only beginning to understand the effects of modern El Niño events, yet archaeologists are already looking for signs of its impact on the development of human societies, in particular those in the Andes (Andrus et al. 2003; Meggers 1994; Ortloff and Kolata 1992; Reycraft 2001; Sandweiss et al. 1996, 1998, 1999, 2001, 2009 and others). Its impact on developing 
societies on the central coast of Perú during the Preceramic is a particular concern and debate (see Chapter 4).
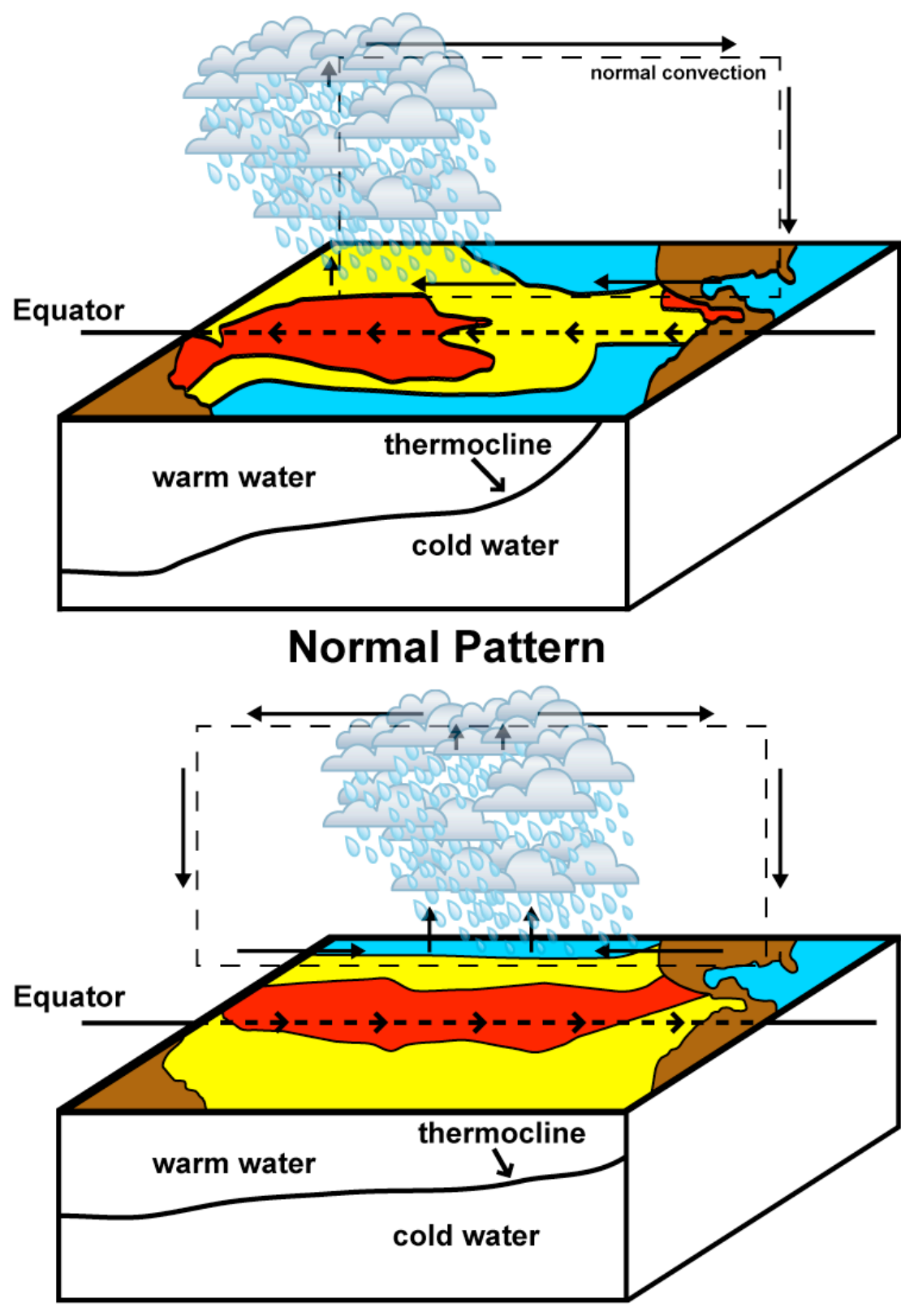

ENSO Pattern

Figure 3.2 The thermocline boundary in relationsip with ocean currents and convection during normal (non-ENSO) and ENSO cycles. (Redrawn from Conlan and Service 2000) 


\section{THE CHILlÓN River VAlley}

The Chillón River Valley lies directly north of Perú's capital city in the province of

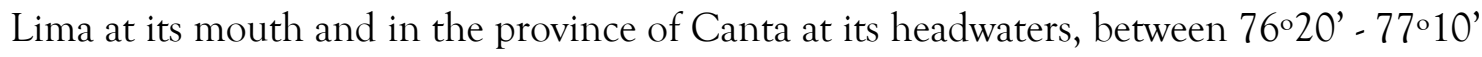


and the Chancay-Huaral Valley to the north (Figure 3.3). The Chillón river, one of Perú's major perennial rivers, is formed by the melting glaciers of the Cordillera de la Viuda, the mountain range to the east topping 4800 masl, and the precipitation collected in the canyons and valleys at mid-elevation above 2500 masl. As discussed in more detail below, this river valley has a remarkable diversity of habitats and climates due to the unique weather patterns of the region and the extreme vertical topography of the Andes, from dry desert on the coast to frozen tundra in the mountain peaks. The river valley extends to around $2444 \mathrm{~km}^{2}$ of which around $42 \%$ is considered part of the humid valley, primarily above 2500 masl (INRENA 1996:322). Cutting a deep valley with extreme slopes in its upper region, the river flows downward from $6 \%$ to just $2 \%$ beginning around Santa Rosa

de Quives where the valley bottom widens downward to its mouth (INRENA 1996) (Figure 3.4).

Like other coastal perennial rivers in Perú that empty into the Pacific Ocean, the amount of water flowing in the Chillón is related to the amount of precipitation in the humid valley (INRENA 1996). Water volume can fluctuate dramatically, especially during ENSO epochs, although the relationship of precipitation and river discharge is not always lineal (Gutierrez et al. 1998). For example the largest discharge recorded to date for the Chillón occurred in 1965 at $180.13 \mathrm{~m}^{3} / \mathrm{s}$, nearly twenty times its average yearly discharge 


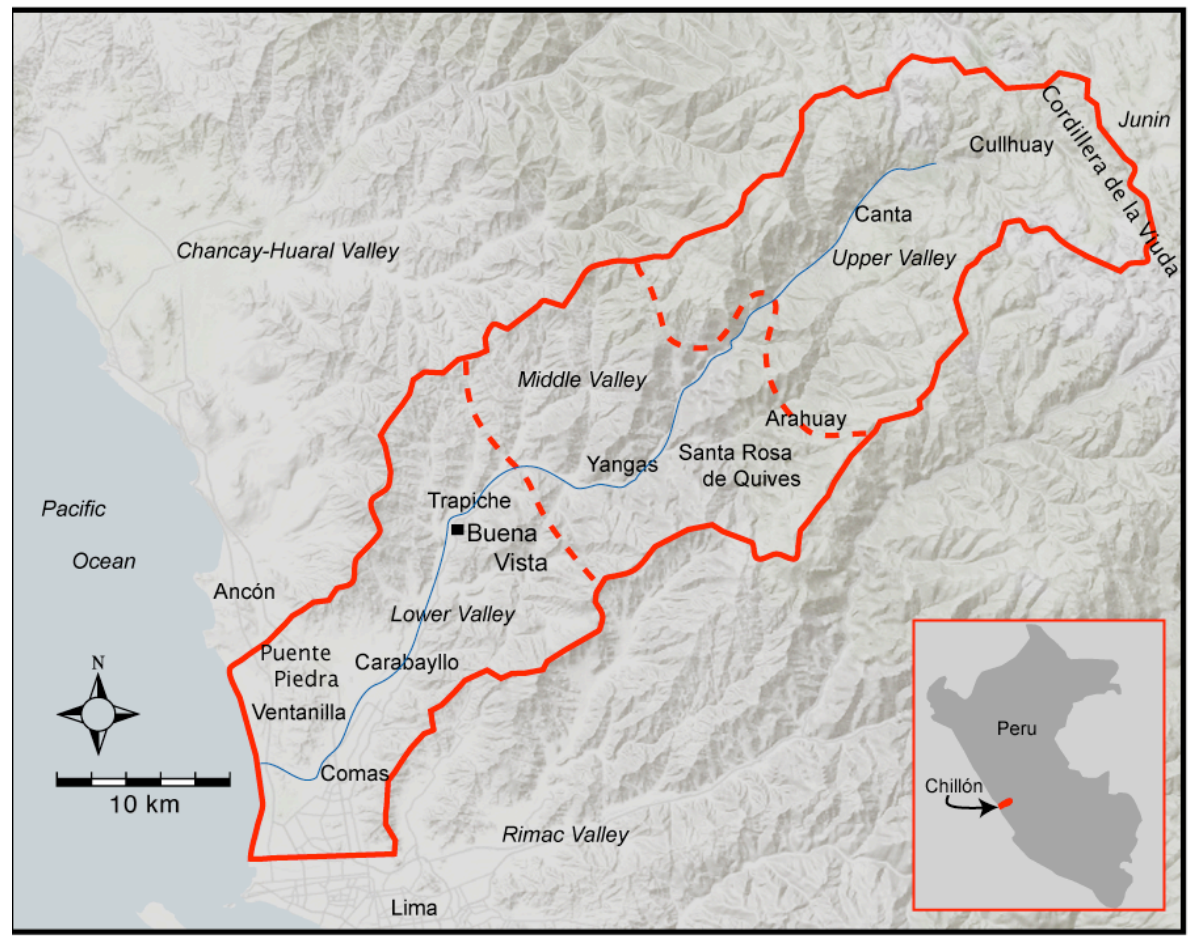

Figure 3.3 The Chillon Valley showing the location of Buena Vista and the geographic boundaries of the Lower, Middle, and Upper altitudinal zones. Base map from Google - Map data (2010).

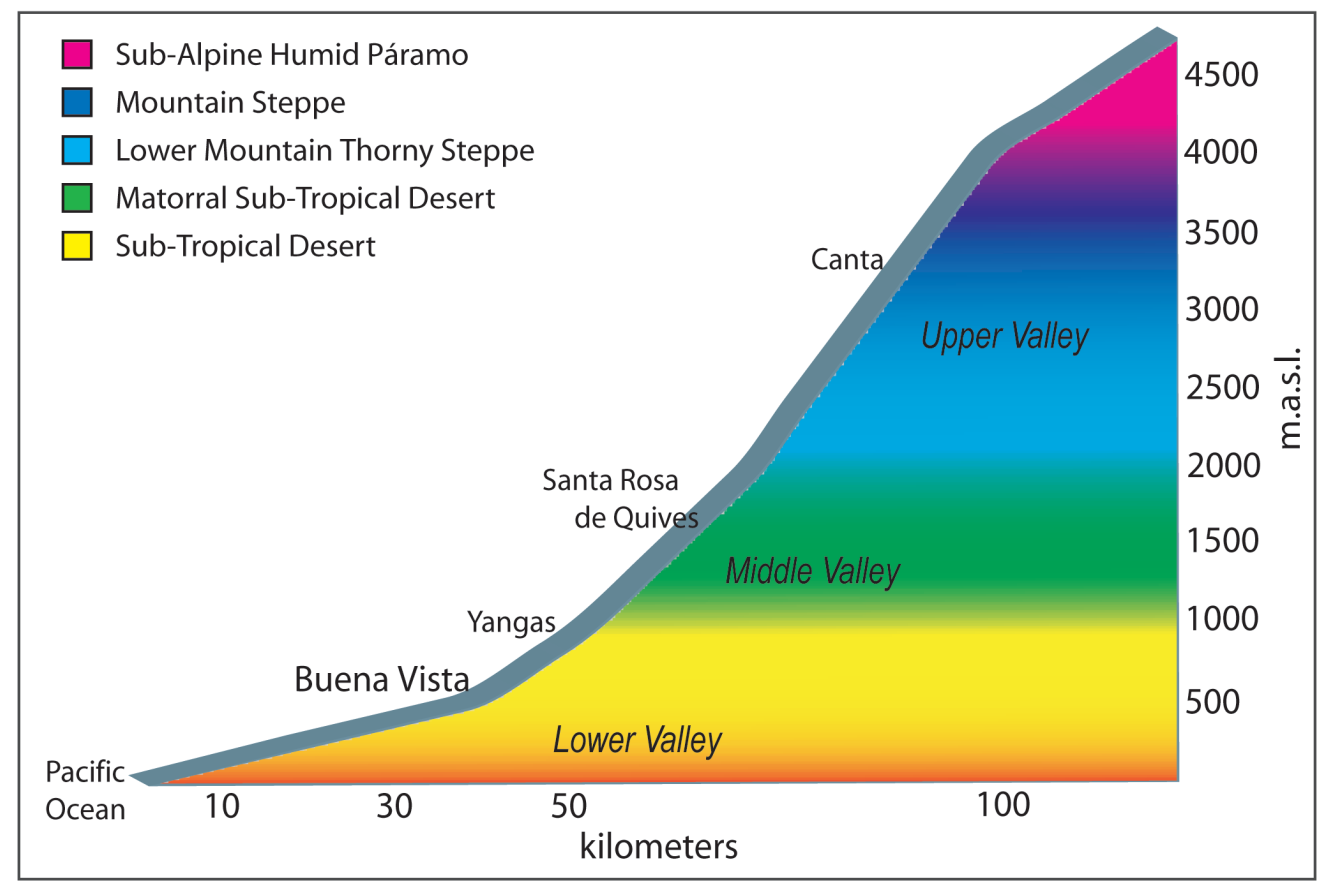

Figure 3.4 Longitudinal profile of the Chillón Valley (Redrawn from Silva 1996: Figure10) 
rate, $8.97 \mathrm{~m}^{3} / \mathrm{s}$, during the period of 1920-1965 (INRENA 1996). An El Niño event was recorded for the year 1964, affecting the discharge rates of major coastal rivers, including the Chillón, the following year. Less intensely, discharge fluctuates seasonally (Gutierrez et al. 1998). The Chillón River's rate of discharge is lowest during the austral winter from June to November, but beginning around December the rate increases and peaks around March to about ten times its winter rate (INRENA 1996; Gutierrez et al. 1998) (Figure 3.5).

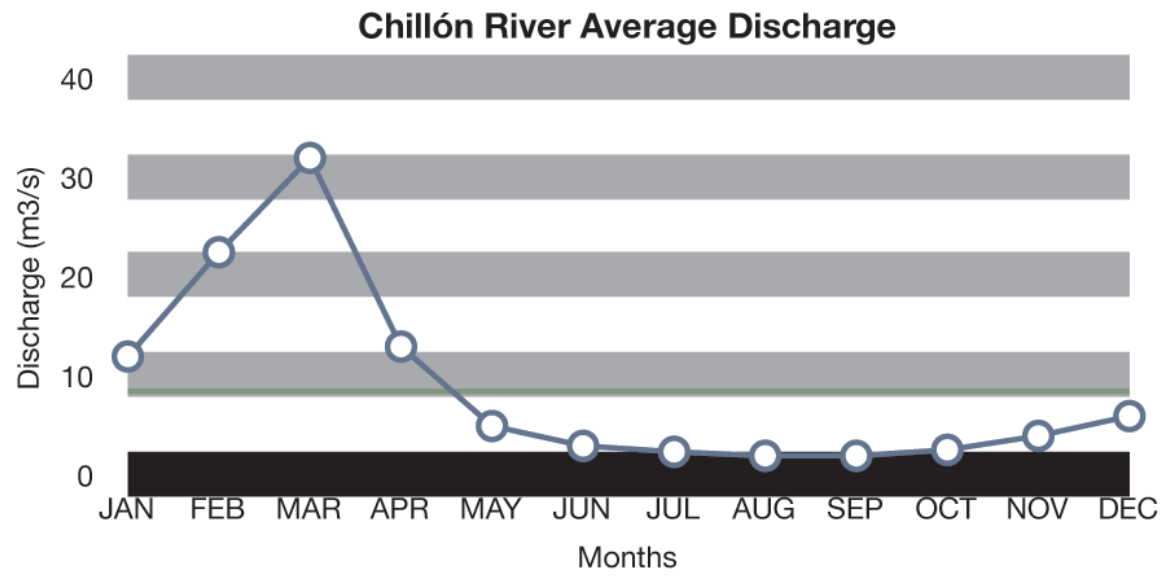

Figure 3.5 Yearly Average discharge by month of the Chillón (Redrawn from Gutierrez et al. 1998: Figure 7).

Geologically, the Chillón Valley is similar to other western river valleys of the central Andes (ONERN 1975: Map 2). At the coast, the delta of the river is mostly composed of alluvial materials, sand, gravel, and semi-consolidated clays and this material forms the basis of the valley bottom up to and beyond the confluence of the Arahuay canyon at mid elevation. The coastal hills near Puente Piedra are early Cretaceous formations of sedimentary clastic rock containing andesite, calcium carbonate, and quartzite beneath more recent dunes of alluvial sand. Volcanic andesite interspersed with 
sedimentary rock of both marine and terrestrial origin uplifted in the late Cretaceous makes up much of the middle valley. Volcanic rock of andesite and rhyolite compose much of the upper valley.

\section{ECOlOGical ZONeS OF THe CHILlón VAlLey}

Geology and weather in large part affect the ecology of the region. The direct vertical ascent eastward from the central coast of Perú rises from 40 to 5000 masl in just 100 km (Galán de Mera et al. 2004).(see Figure 3.4). With the ascending altitude and corresponding increase in humidity, the vegetation also changes.

The dramatic vertical relief ascending rapidly from the coast provides numerous ecological zones each with their own flora and fauna. Pulgar Vidal (1996), a geographer, described the Andean landscape as eight vertical zones based on both the ecology and traditional indigenous knowledge. These eight geographical zones, extending from the coast to the eastern flanks of the Andes, provide useful general descriptions of habitats unique to the Andes and serve as easy and popular reference points for the altitudinal zones. Other ecological zonations, however, have been constructed based on the Holdridge life zone model (Holdridge 1967) that calculated ecological zones from mean annual temperature, precipitation and evapotranspiration. For the Andes, the Oficina Nacional de Evaluacion de Recursos Naturales (ONERN 1975, 1976) calculated such data and summarized them into just six life zones (ONERN 1975; but see 1976 for more specific data). In addition, there are more specific regional zonations based on bioclimatic data calculated from rainfall and temperature from the central coast of Perú using descriptions 
of phytosociological communities (relationships and development of plant taxa growing together in space) corresponding to climatic zones by altitude (Galán de Mera 2004).

Recent phytosociological surveys on Perú's central coast (Galán de Mera et al. 2004; 1998; 2002; Galán de Mera 1999) have attempted to group natural vegetation patterns across the landscape using the phytosociological method of relevé analysis that describes the composition of vegetation in geographical units (Almendinger 1998), then groups the vegetation by a syntaxonomic name to describe the community in rank of association, alliance, order, or class (Weber et al. 2000). For example, the association Baccharido salicifoliae-Gynerietum sagittati, describes the major communities of scrub, cane and reeds in the western Andes and desert coast occupying the rocky soils of river bottoms (Galán de Mera 2004). The syntaxonomic name is derived from the predominant species Baccharis salicifolia, Gynerium sagittatum, and Tessaria integrifolia. At its highest rank, an association refers to a "plant community of definite floristic composition which presents uniform physiognomy and which grows in uniform habitat conditions", as proposed by the Botanical Congress at Brussels in 1910 (Weber et al. 2000). However, a more modern interpretation of phytosociological associations recognizes the continuum of vegetation patterning and spatial analysis of those associations is also useful for ecological interpretation (Dickinson and Murphy 2007:103). Nevertheless, phytosociological associations are also an additional way of describing the vegetation patterning across space based on actual data collected in situ, and yet the data often correlates to temperatureprecipitation calculated life zones. 
For the Chillón, following archaeologist Jorge Silva (1996), I have divided the valley into three altitudinal zones within which the above environmental zones can easily be discussed (Figures 3.3 and 3.4). The Lower Valley (0-600 masl) extends about $40 \mathrm{~km}$ from the shoreline to the modern town of Trapiche, just a kilometer inland from the site of Buena Vista. Proceeding inland, the valley rises rapidly in elevation. The Middle Valley (600-2000 masl) continues to rise and narrows inland from Trapiche to Yaso. Above, the Upper Valley (up to around 5000 masl) begins at only about $85 \mathrm{~km}$ inland and contains the very narrow river bottom and extreme slopes of the sierra. The site of Buena Vista is located at the upper edge of the Lower Valley at 540 masl. In the survey of ecological zones of the Chillón to follow, I will begin at the coast and travel inland and eastward.

The narrow swathe of dry desert coast, the geographic Costa or Chala (Pulgar Vidal 1996), or the Sub-Tropical Desert (Desierto Sub-tropical) ecological zone (ONERN 1975) extends inland as far as $150 \mathrm{~km}$ near Piura, Perú and as little as $40 \mathrm{~km}$ near Lima up to around 800 masl. In the Lower Chillón, dry desert environment composes most of the area of the lower Ancón-Chillón near the coast (Patterson 1971:188). Rainfall in this zone is rare, less than $20 \mathrm{~mm}$ annually and temperatures average around $20^{\circ} \mathrm{C}$ (INRENA 1996). Despite the dry climate, the Costa is diverse in habitats (ONERN 1975), including the littoral zone where halophytes such as the grass, Distichlis spicata (Poaceae), and succulents, Salicornia sp. (Amaranthaceae), can be found growing in the saline niches. Freshwater niches at lower altitude contain cattails, Typha angustifolia and T. domingensis (Typhaceae). On dry hillsides above $200 \mathrm{~m}$, abundant epiphytic Bromeliads grow, Tillandisa latifolium 
and T. purpurea (Galán de Mera 2004), often where no other plant life is found. Less common are species of Cactaceae, such as the columnar Cereus macrostibas.

Despite the nearly complete lack of rain, Perú's central coast and Chile's northern coast contain unique lush green lomas habitats. Lomas, a term literally meaning hills in Spanish, as used in coastal Perú, refers to discontinuous patches of rich desert plant communities that form along steep coastal slopes and isolated hillsides that intercept the clouds that would otherwise disperse or accumulate at higher altitudes (Rundel et al. 1991; Dillon et al. 2003). From May to October, thick stratocumulous cloud banks form below 1000 masl and dissipate over broad flat areas, but concentrate against hillsides (Rundel et al. 1991). These trapped clouds, the coastal fog known as garua in Perú, release moisture and encourage the growth of mosses and ferns, herbs, and woody plants (Figure 3.6). Among the flora of the Peruvian lomas, recent estimates include some 815 species, some of which are found nowhere else, in 357 genera of 85 families of flowering plants; in individual lomas, species endemism may be greater than 40\% (Dillon et al. 2003). El Niño conditions, contrary to human perception as disastrous events, have profoundly positive effects within the lomas formations and helped to disperse and establish lomas communities on the coast. During an El Niño season, increased temperature and moisture leads to extraordinary germination and blooming events that reestablish and help disperse annual and perennial plants (Dillon et al. 2003; Dillon and Rundel 1990).

The diverse plant life of the lomas, or "fog oases" (Ellenberg 1959) would have provided forage for both humans and other animals, including the grazing animals, deer and guanaco (Lanning 1967), however deer are rarely known to venture into the Peruvian 
lomas (Rundel et al. 2007). Only two dozen mammal species are native to the Peruvian lomas, and include two marsupials, rodents, foxes, and occasionally pumas (Rundel et al. 2007). Plants useful to early inhabitants may have included the fruits from species of Jaltomata and Lycospercicon (Solanceae) and the roots of Argylia radiata (Bignoniaceae), Begonia spp. (Begoniaceae) and Oxalis spp. (Oxalidaceae), wild potato Solanum spp. (Solanaceae) and Tropaeolum peltophorum (Tropaeolaceae) (Dillon et al. 2003). In the lower Chillon Valley, the remaining lomas vegetation at the present time lie behind the coastline at the foothills (Silva 1996:31).

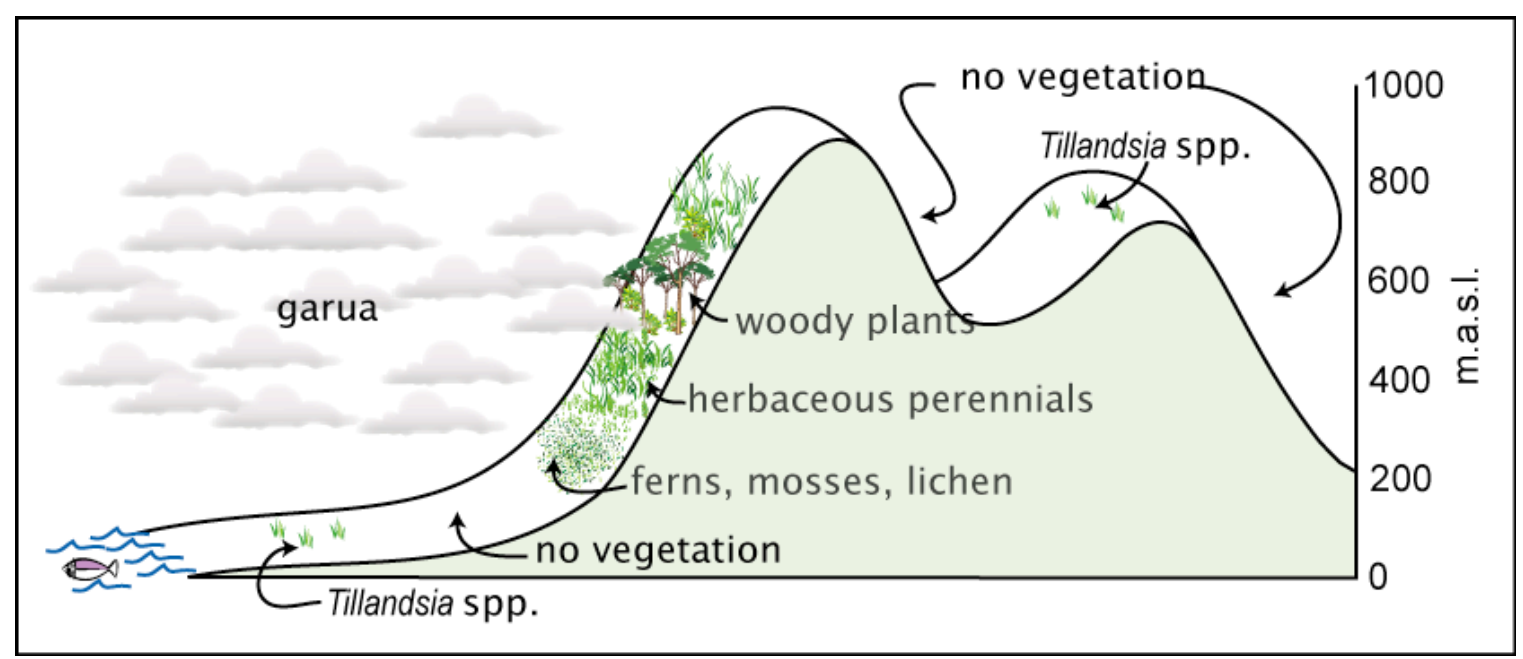

Figure 3.6 Lomas formation in central coastal Peru (Redrawn from Dillon and Rundel 1990: Figure 2)

The Costa zone is home to some of Perú's earliest archaeological sites (Lanning 1967; Duncan et al. 2008; Benfer 1982; deFrance et al. 2001; Sandweiss et al. 1989) as well as those earliest known sites in the Chillón Valley (Lanning 1967; Patterson 1971; Engel 1987) where early foragers harvested the abundant marine, riverine, and lomas resources. Over millennia, humans negatively impacted lomas and riparian habitats on the coast, 
reducing their size or eliminating them altogether underneath intensive agricultural use, or where the habitats survive, they now contain high numbers of naturalized plants (Rundel et al. 2007). One should not underestimate the influence of human activities on lomas composition and character. It is likely that many native trees such as "tara" Caesalpinia spinosa (Fabaceae), "mirto" Myrcianthes ferreyrae (Myrtaceae), and "mito" Carica candicans (Caricaceae) would have much wider distributions and populations if it not for human utilization and historical replacement with introduced species (Dillon et al. 2003; Sagástegui and Leiva 1993). The perennial expansion of urban environments, particularly in the lower Lurín, Rimac, and Chillón valleys around Lima cause further natural habitat disturbance and loss (ONERN 1975).

At 540 masl, the site of Buena Vista lies near the geographical border of the Lower and Middle valley. Ecologically, this location is a transitional zone between the dry desert coast and the shrubby desert just above. The river valley narrows dramatically $2 \mathrm{~km}$ upstream. During winter months, garua commonly invades this part of the valley, however actual rainfall is very rare. Riparian vegetation in the fertile fluvial soils here, however, is consistent with the Middle Valley, as described in the following description.

Proceeding inland, the Middle Valley, up to around 2000 masl, contains the ecozone of the Matorral Subtropical Desert (Matorral Desértico Sub-tropical) (ONERN 1975) or the Yungas (Pulgar Vidal 1996) geographical region between the dry desert coast and sierra. While still considered an arid region, precipitation is slightly higher on average, around $125 \mathrm{~mm}$ annually, than on the coast, and the mean annual temperature, around 18 - C, is only slightly less mid-valley than on the coast (ONERN 1975). Vegetation in this 
zone is almost entirely limited to the valley floor where perennial water from the river and fluvial soils provide suitable plant habitat. The hillsides, virtually devoid of vegetation, are subject to terrific landslides in extremely wet years (Pulgar Vidal 1996:63-4). Silva (1996:35) suggests the unstable terrain may in part, explain the paucity of prehispanic archaeological sites on the valley floor in favor of hilltops and protected hillsides though it would seem to be safer on the valley floor.

Riparian vegetation is relatively rich and diverse in central coastal valleys in this altitudinal zone (Galán de Mera 2004; ONERN 1975). Along the rocky river bottoms, shrubby Baccharis salicifolia and Tessaria integrifolia (Asteraceae) and dense growing grasses such as Gynerium sagittatum (Poaceae), the invasive bamboo-like Arundo donax (Poaceae) and native horsetails Equisetum giganteum (Equisitaceae) are found. Willows, Salix humboldtiana (Salicaceae), prefer the sandier soils adjacent to rivers. Deep-rooting trees, particularly "molle" Schinus molle (Anacardiaceae), "huarango" Acacia macracantha (Fabaceae), and “algarrobo" Prosopis pallida (Fabaceae), and the shrubby "tara” Caesalpinia tinctoria (Fabaceae) inhabit areas where deep taproots access underground water. Weedy and herbaceous plants include the succulent "huanarpo" Jatropha macrantha (Euphorbiaceae), and the rare and endangered "huancoy" Orthopterygium huaucui (Anacardiaceae) (León et al. 2006). Cacti are also found, including Cereus macrostibas and the "candelabro" cactus Cereus candelaris. Spermatophytes of the agave family are associated as well, and include the native Furcraea andina (Amaryllidaceae).

The mid-valley region of the Chillón also supports the management of native fruit trees (Pulgar Vidal 1996): “avacado” or "palta” Persea americana (Lauraceae), "lucuma” 
Pouteria lucuma (Sapotaceae), "chirimoya" Annona cherimola (Annonaceae), "guajava" Psidium guajava (Myrtaceae), and "ciruelo de fraile" Bunchosia armeniaca (Malpighiaceae). Macroremains from each of these fruit trees are common in archaeological assemblages throughout the Andes.

Animal diversity in the Chillón's mid-valley, excluding modern domesticates, is not likely to have differed much from the coastal lomas. As such, rodent species were likely the most diverse group, but foxes, occasional pumas, and deer could also be found. An inquisitive fox observed excavations at Buena Vista for several days in 2004 and again in 2007.

Agriculture in this region continues to be an important resource today as it was in the ancient past. However, there is much less emphasis on coca (Erythroxylum coca) as a crop than in the late prehispanic period. The mid-valley region of the Chillón was an important and contested area of great coca cultivation (Rostworowski 1972, 1989; Murra 1972; Dillehay 1977). Irrigation canals were built to supply the coca fields, but also to sustain other agricultural crops such as cotton, maize, chili, and the tree fruits mentioned above, all of which finally came under the indirect control of the Inka (see Chapter 4 for more detailed discussion). The remains of the irrigation canals and terraces on the hillsides between Quives (1200 masl) and Cullhuay (3800 masl) still exist today and were recently mapped by Silva (1996).

The Upper Chillón Valley, from around 2000 - 5000 masl, rises very quickly in altitude, therefore it includes several ecological zones often with distinct characteristics. The valley bottom narrows greatly, however limited agriculture is still possible on the valley 
floor and on constructed irrigated terraces on the hillside. In the lower section of the valley, from about 2100-3100 masl, an ecological zone referred to as the Lower Mountain Thorny Steppe (Estepa Espinosa Montano Bajo) (ONERN 1975) or the Quechua geographic region (Pulgar Vidal 1996) enjoys a semiarid and relatively seasonal climate with mean temperatures around $14.4{ }^{\circ} \mathrm{C}$ and annual precipitation between $250 \mathrm{~mm}$ to $350 \mathrm{~mm}$ in the lower portion (up to 2400 masl) and around $450 \mathrm{~mm}$ in the upper portion. The rainfall is sufficient to permit a mixed agricultural system, both dry and irrigated.

The vegetation in the lower portion of the Lower Mountain Thorny Steppe (20002400 masl) is an extension of the Matorral Subtropical Desert, but with some differences due to the drop in temperature and increase in moisture and altitude. Herbaceous and weedy plants occur in greater abundance and include Ambrosia Peruviana, Mustisia sp., Viguiera sp., Barnadesia dombeyana, Bidens spp. (all Asteraceae), Erodium cicutarium (Geraniaceae), Calceolaria sp. (Scrophulariaceae), Urtica sp. (Urticaceae), wild species of Malvaceae, and introduced alfalfa, Medicago sp. (Fabaceae), and castor bean, Ricinus communis (Euphorbiaceae). Wild tobacco, Nicotiana sp. (Solanaceae), grows along with the pharmacologically potent Datura stramonium (Solanaceae). Also in this ecozone are plants such as the epiphyte Puya sp. (Bromeliaceae), and cacti such as Opuntia spp. (Cactaceae). In addition to the arboreal taxa found at lower altitudes, "mito", Carica candicans (Caricaceae), "sauco", Sambucus Peruviana (Caprifoliaceae), "aliso", Alnus jourullensis (Betulaceae), "tara", Caesalpinea tinctoria (Fabaceae), "chachacomo”, Escallonia sp. (Rosaceae), and Eugenia quinqueloba (Myrtaceae) grow here. 
Because this Quechua zone of the central Andes has a relatively mild climate and predictable amounts of rainfall as well as nutrient rich and deep soils, agricultural production here remains as important as it was in prehistory (Pulgar Vidal 1996). Major crops include maize, Zea mays (Poaceae), squashes, Cucurbita spp. and caigua, Cyclanthera pedata, papaya, Carica papaya (Caricaceae), and the starchy root vegetable arracacha, Arracacia xanthorrhiza (Apiaceae). It is likely that arracacha and other root/tuber species such as yacón, Polymnia sonchifolia (Asteraceae), jicama, Pachyrhizus spp. (Fabaceae), mauka, Mirabilis expansa (Nyctaginaceae), and potato, Solanum sp. (Solanaceae) were domesticated in this zone, but not necessarily in this valley (Piperno and Pearsall 1998).

The upper Chillón above 3100 masl and extending to 3800 masl contains the ecological zone of the Mountain Steppe (Estepa Montano) (ONERN 1975) and roughly corresponds to the geographic Suni zone (Pulgar Vidal 1996). The region is progressively more humid with altitude; annual rainfall varies from 300 to $800 \mathrm{~mm}$ in the lower and upper portions, respectively (ONERN 1975). Mean temperatures also vary with altitude from around $11^{\circ} \mathrm{C}$ in the lower portion to $8.5^{\circ} \mathrm{C}$ in the upper. Rainfall is also fairly predictable in the summer months from October to April and sufficient to support natural vegetation, the most abundant of which are grasses, Festuca sp., Agrostis sp., and Poa sp., and other plants that are frost tolerant to survive seasonal dips in temperature to below freezing. The cold temperatures also demands careful selection and management of agricultural crops; however, soils in this region are deep and fertile with decent drainage. Root/tuber crops were likely domesticated in this zone include potato, Solanum sp. (Solanaceae), olluco, Ullucus tuberosus (Oxalidaceae), and oca, Oxalis tuberosa (Oxalidaceae), 
but not necessarily in the Chillón. Agriculture is still practiced in this region on terraces, andenes, built into the steep slopes, however, many are now abandoned and in disrepair (Silva 1996:39) as much of the population of the Suni region of the Chillón emigrated to suburbs of Lima, particularly Comas, in the lower Chillón (Pulgar Vidal 1996:110).

In the lower portion of the Mountain Steppe, the vegetation is similar to the ecozone below, although its growth is inhibited and more sparse (ONERN 1975). The environment, nevertheless, favors lupines, Lupinus sp. (Fabaceae), scrubby Baccharis sp. (Asteraceae), and the herby plants found in the ecozone below. The upper portion of the Mountain Steppe, however, contains more dense vegetation due in part to the higher amounts of rainfall, particularly the cool season grasses Stipa sp., Bromus sp., and Hordeum sp., that grow in enough abundance for grazing livestock. Arboreal species are present, though also sparsely populated. In addition to the trees growing at lower elevation that also grow in this zone, the region supports "quishuar", Polylepis sp. (Rosaceae) and "masingo", Cassia sp. (Fabaceae).

The next ecozone in altitude in the upper Chillón is the Sub-Alpine Humid Páramo (Páramo Muy Húmedo Sub-Alpino) (ONERN 1975) from 3800 to 4800 masl. It’s lower portion, up to around 4000 masl is known geographically as the Suni zone, and above 4000 masl to 4800 masl lies the Puna geographic zone (Pulgar Vidal 1996). Again, as altitude rises, so too does the rate of precipitation and conversely, a drop in temperature. The climate of the Sub-Alpine Humid Páramo is generally cold and wet, with precipitation varying from $700 \mathrm{~mm}$ in the lower portion to $1000 \mathrm{~mm}$ in the upper portion annually (ONERN 1975). The mean annual temperature huddles around $5^{\circ} \mathrm{C}$, as measured from 
the nearest weather station to the Chillon, Milloc, in the upper Rimac at 4350 masl. The zone is not favorable for agriculture, but very suitable for grazers and used today as pastures for cows, sheep, llamas and alpacas. It is likely that the Andean camelids were domesticated in this zone (Wing and Wheeler 1988; Moore 1989). The nature of herding animals creates disturbed habitats, which may benefit the reproduction particular plants. In this zone, it is likely that Chenopodium quinoa (Amaranthaceae) and Lepidium meyeniii (Brassicaeae) were two such plants that came under early domestication by Andean herders (Pearsall 1992). At this high altitude humid environment, grasses are the most abundant: Festuca spp., Calamagrostis spp., Poa spp. Muhlenbergia spp., and Bromus spp. (ONERN 1975). The grasses form natural pastures in permanently humid areas with Festuca and Calamagrosta as the dominant genera, but are also associated with herbaceous Alchemilla pinnata (Rosaceae), Trifolium Peruvianum and Vicia andicola (Fabaceae), sedges of Carex sp. (Cyperaceae) and rushes of Luzula racemosa (Juncaceae). Herbaceous spiny plants Chuquiraga sp. (Asteraceae) and Adessmia spinosa (Fabaceae) may also be found. There may remain some residual forests composed of "quinares" (Polylepis sp.), but they are limited to the most inaccessible areas where they have escaped intensive human utilization.

Lastly, the highest ecological zone in the upper Chillón is the Pluvial Alpine Tundra (Tundra Pluvial Alpino) (ONERN 1975) from 4800-5000 masl, known geographically as the Janca (Pulgar Vidal 1996). In the Chillón, this narrow high strip of mountainous terrain is continually cold and the relatively high amount of precipitation, around $850 \mathrm{~mm}$ annually, occurs as frozen rain and snow (ONERN 1975). The glaciers of the "Cordillera de la Viuda" serve as the major water source for the Chillón river and the 
Chonta Lagoon at 4850 masl at the river's head. Only hardy, cold adapted vegetation survives here in isolated patches of thin soils: perrenial Werneria sp. and Lucilia sp. (Asteraceae), stubby rushes of Dictichia sp. (Juncaceae), and grasses of Aciachne sp. (Poaceae).

\section{SOILS AND AgRiculture IN THE CHILlóN}

As previously mentioned, agricultural crop production in the Chillón Valley is an important prehistoric and modern practice. The land available for growing crops is dependent upon multiple variables, locality and altitude, water, and the necessary soils. Fortunately for early and modern farmers, soils suitable for agriculture in the valley span over 10,000 ha (ONERN 1975). The area under production may actually be less in 2009, given the seemingly endless expansion of the metropolitan area of Lima. In 1975, the total area under urban or otherwise public installments in the valley equaled 4560 ha, most of which lies atop the arable soils in the southern part of the lower valley on the large flat alluvial plain. Today urbanization extends $15 \mathrm{~km}$ up the valley. The most productive of soils in the valley are the Chillón and Magdalena series comprising around $86 \%$ of the agricultural soils.

The Chillón soil series makes up a very large portion of the alluvial plain of the valley, some 7488 ha and is used, as of 1975 , for modern production of maiz, cotton, alfalfa, beans, potato, and sweet potato. This series provides the majority of agricultural production in the lower valley up to the modern town of Caballero. This moderately alkaline $(8 \mathrm{pH})$ and arable soil is at least as deep as $90 \mathrm{~cm}$ in most locations on the alluvial 
plain. This soil type is likely beneath the urban expansion in the southern portion of the lower valley and would have provided arable land with irrigation in prehispanic times.

The Magdalena soil series comprises 1131 ha of flat alluvial terraces up to $2 \%$ slope. It is slightly less alkaline $(\sim 7.4 \mathrm{pH})$ than the Chillon series, and has good drainage qualities and little problem with salinity. It is considered one of the most productive soils in the valley and has been used for growing cotton, maize, sweet potato, beans, and other crops. This soil series is found in the upper portion of the lower valley floor from Chocas to the lower portion of the middle valley at Hornillos. The largest contiguous area of this series is found in the valley floor below Buena Vista, near the present town of Trapiche.

Of the soil series identified in the valley, four other series are well suited to agriculture, but only comprise about $3 \%$ of the total area of suitable soils, the Macas, Trapiche, Caudivilla, and Quives series occur in the middle and upper regions of the valley. These soils make up portions of alluvial terraces with texture and composition having adequate drainage and moderate alkalinity from 7.3-7.9 $\mathrm{pH}$. The areas containing these soils may be isolated or physically impossible to farm with mechanized equipment, but the alluvial terraces were farmed in antiquity with human labor (Silva 1996). Cotton, maize, chili peppers, avocado, mango, and alfalfa are grown in these soils today.

Other less productive soils have limited agricultural use. The Caballero series in the lower valley alluvial plain near the hamlet of the same name has poor drainage and large proportions of gravel and rock. The Chocas series, located in the alluvial plain near Macas, suffers from too much drainage and therefore is prone to high salinity. Nevertheless, cotton is grown today in both of these series and probably was so in the past. Overall, 
salinity poses a problem only in a few small areas such as in the Gallinazo series on the lower valley allvial plain directly adjacent to the river, and the coastal Rimac series adjacent to the ocean. Agricultural production in these soils is deemed poor.

\section{Buena Vista in ECOlogicAl AND ENVIRONMENTAL CONTEXT}

The archaeological site of Buena Vista is located at $11^{\circ} 43^{\prime} 51.72^{\prime} \mathrm{S}, 76^{\circ} 58^{\prime} 5.45^{\prime \prime W}$ in the upper portion of the Lower Chillón Valley, at an altitude of around 540 masl at kilometer marker 36 on the Lima-Canta highway (Figure 3.7). The site lies on the eastern side of the river valley at the protruding base of Cerro Puente Trapiche and commands a view of the valley floor and adjoining quebradas to the west and north. To the southeast, the mountain rises steeply to 1250 masl where it joins other peaks rising over 2000 masl. The present day communities of El Olivar and Trapiche are just a kilometer to the north. Across the valley, the quebrada leading north from Trapiche provides transportation access through the foothills to the Chancay valley. The valley floor adjacent to Buena Vista, consisting of rich soils of the Magdalena series, are farmed to the present day with simple canals to divert water from the river to the fields. Maize, beans, and chili peppers are still grown and some fruit trees, including avocado, are still managed here. However much of the flatland available is devoted to farming, and few trees grow outside of unprotected areas or household gardens. Ecologically, this area is part of the Sub-Tropical Desert zone, thus, the lack of precipitation leaves the hillsides surrounding the valley floor nearly devoid of vegetation, save for the epiphytic Tillandsia spp. known locally as achupalla. 


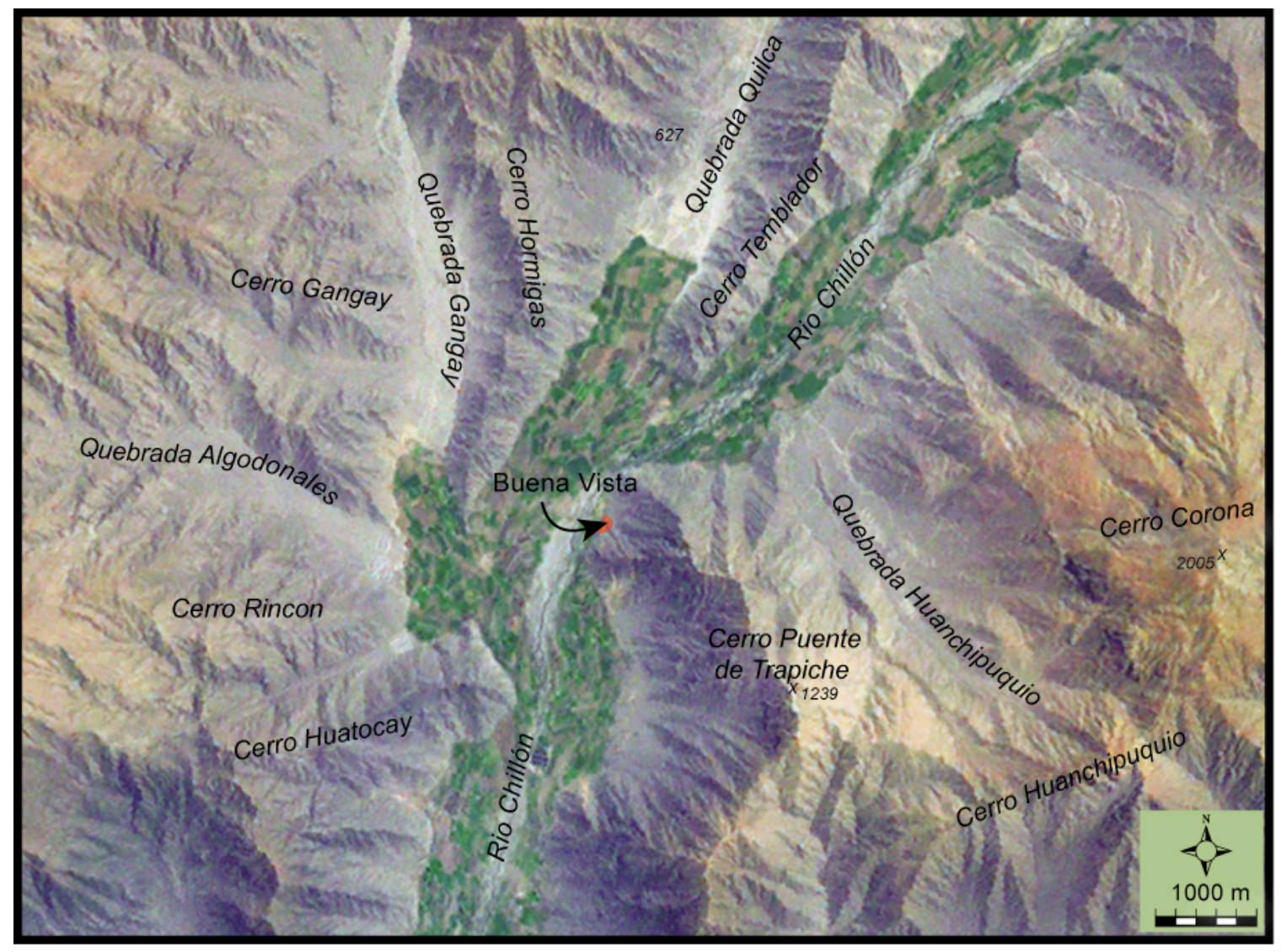

Figure 3.7 Location of the Buena Vista site near the modern pueblo of Trapiche and predominant geographic features.

It is important to understand the environment within which the people around Buena Vista lived because it helps to inform our archaeological interpretation. Unfortunately, for the Chillón at this time there are no paleoenvironmental data that would indicate how the local environment has changed in the last four thousand years, although, the climate of the region has been relatively stable since the Holocene climatic optimum. Eustatic sea level stabilization had occurred and ENSO cycles were in full swing by 5800 years ago (Sandweiss et al. 2009). However, physical changes in this active 
landscape may have significantly altered the valley over time through earthquakes, land slides, and sand dune incursion. Some evidence of pluvial episodes associated with rockslides from the hill above is present at Buena Vista on the surface of the site and also plainly visible in the road cut at the base of the site's embankment. For example, at the base of the road cut, one can see a stratigraphic layer composed of large round cobbles of andesite likely associated with runoff from late Pleistocene glaciers of the cordillera, overlain with with gravelly colluvium. At the boundary of these layers, just below a plaza floor, geographer Olivier Dollfus (1960) excavated human bones protruding from the profile in hopes of radiocarbon dating the beginning of humid episodes associated with the colluvial stratum. The bones returned dates between 1560-1400 cal B.C. ${ }^{2}$, which corresponds to the end of the Late Preceramic component at Buena Vista. On the surface of Buena Vista, there is a wash of colluvium that bisects the site and covers portions of Late Preceramic architecture (see map in Chapter 5, Figure 5.3). It is possible that the bones dated by Dollfus correspond to a colluvial event during the Initial Period occupation of the site. Further evidence for more drastic events come from the Supe Valley to the north of the Chillón, where archaeologists interpret evidence for seismic disasters, landslides, flooding and sand incursion that may have disrupted both agricultural and marine subsistence resources and spurred the abandonment of Late Preceramic sites there (Sandweiss et al. 2009). Future research may implicate the same events affecting the valleys to the south, however, that is beyond the scope of this project.

${ }^{2}$ Calibration based on Dollfus' (1960) uncalibrated radiocarbon dates 3202+/-118 B.P. and $3349+/-118$ B.P. 
Yet, we can make a best guess as to what the plant communities might have looked like in the Late Preceramic, given the relative climatic stability over the last four thousand years. The lower and middle valley floor of the Chillón, having year round water, would have provided people living in the lower valley an abundance of plant resources in the lomas and riparian areas. Many of the plants described above were likely growing in the past and one could reasonably assume that lomas and riparian forests were more extensive. Humans obviously impacted the landscape, especially with regard to deforestation as agriculture in the valley intensified along with construction of terraces in the upper valley. Unfortunately, the paleoethnobotanical data collected for this project was only collected within the boundaries of the archaeological site, thus human selection highly biases the dataset from environmental reconstruction. However, in the interpretation to follow, certain assumptions are made regarding the ecological requirements of plant taxa in the interpretation of their use by humans. For example, some remains of edible plants cultivated in South America, such as Maranta arundinaceae and Heliconia sp. are found at the site but are not native to the inland valleys of Perú. Therefore, the most parsimonious explanation of their presence in archaeological sites on the coast is that people were actively growing them. 


\section{Chapter Four - The Archaeological and Cultural Setting of the Chillón Valley}

The purpose of this chapter is to provide a brief summary of archaeological work in the Central Andes from the time the first human pioneers arrived to the conquest of the upper Chillón by the Inka in the sixteenth century. Obviously, a very, very long span of time connects these two events and, as a result, archaeologists have devised tidy frameworks for conceptualizing the economic, social, and political developments observed in the archaeological record. These frameworks that we refer to as chronologies have also changed over time with advances in information, particularly radiocarbon dating. But because they also serve, to various degrees, rightly or wrongly, as starting points for interpretation, I would like to begin with a short discussion of chronologies and how they are used in the Peruvian archaeology to organize cognitively very complex changes over a vast amount of time. Then, the chapter will continue with a discussion, chronologically arranged, of central Andean archaeology with dual emphasis on the region surrounding the Chillón Valley and the time leading up to and immediately following the occupation at Buena Vista.

Early archaeological pioneers, Max Uhle and Julio Tello, laid the initial framework for cultural chronologies of the Andean region. Max Uhle's study of museum collections from Cusco and Tiwanaku (Tihauanaco) inspired him toward excavation at the richly 
occupied coastal center of Pachacamac in the 1890's (Figure 4.1). There, the stratigraphy showed overlapping layers of Inka, Tiwanaku, and local pottery styles, from which he could extrapolate a basic chronology to be used at other sites in the south coast valleys of Perú (Moseley 2001). Tello, Perú’s first native-born archaeologist, broadened archaeological investigations into the highlands where he discovered the site of Chavin in the eastern highland valley of the Huallaga River. He predicted Chavín was the origin of cultural similarities, as expressed in the ceramic and architectural features, that other archaeologists, including Uhle, had observed on the coast (Lumbreras 1974). Each in their interpretations was influenced by the regions they worked. Uhle proposed a coastal origin of Andean civilization with roots in Mesoamerica. Whereas Tello favored a highland or even tropical forest origin for civilizations in Perú. Both ideas were later explored and extrapolated from by other archaeologists.

Tello and Uhle conceptualized the prehistory of the Andes differently. For Tello, the passage of time involved convergence and divergence of an Andean "mother-culture" having culminated at Chavín (Moseley 2001). Uhle, divided time into periods within which are chronological horizons that refer to uniform artistic styles found over a broad area (Rowe 1962:45), such as the Tihuanaco horizon in Uhle's Second Period or Inka chronological horizon in his Sixth Period.

In subsequent years, as archaeologists focused more attention on typologies, based primarily on Uhle's collections, Uhle's chronology was expanded and adapted. In the 1920s, Alfred Kroeber with William Duncan Strong reduced Uhle's time periods to four, that emphasized two major styles Tiwanaku and Inka, such as Pre-Tiwanaku, Tiwanaku, Pre- 
Inka and Inka horizons, however later Kroeber would emphasize the distinction between time, in reference to periods, and style in regard to horizon (Rowe 1962:46). With new archaeological data, Kroeber abandoned his scheme by 1943, because the Early Period now incorporated so much "early" that the Middle was no longer in the "middle".

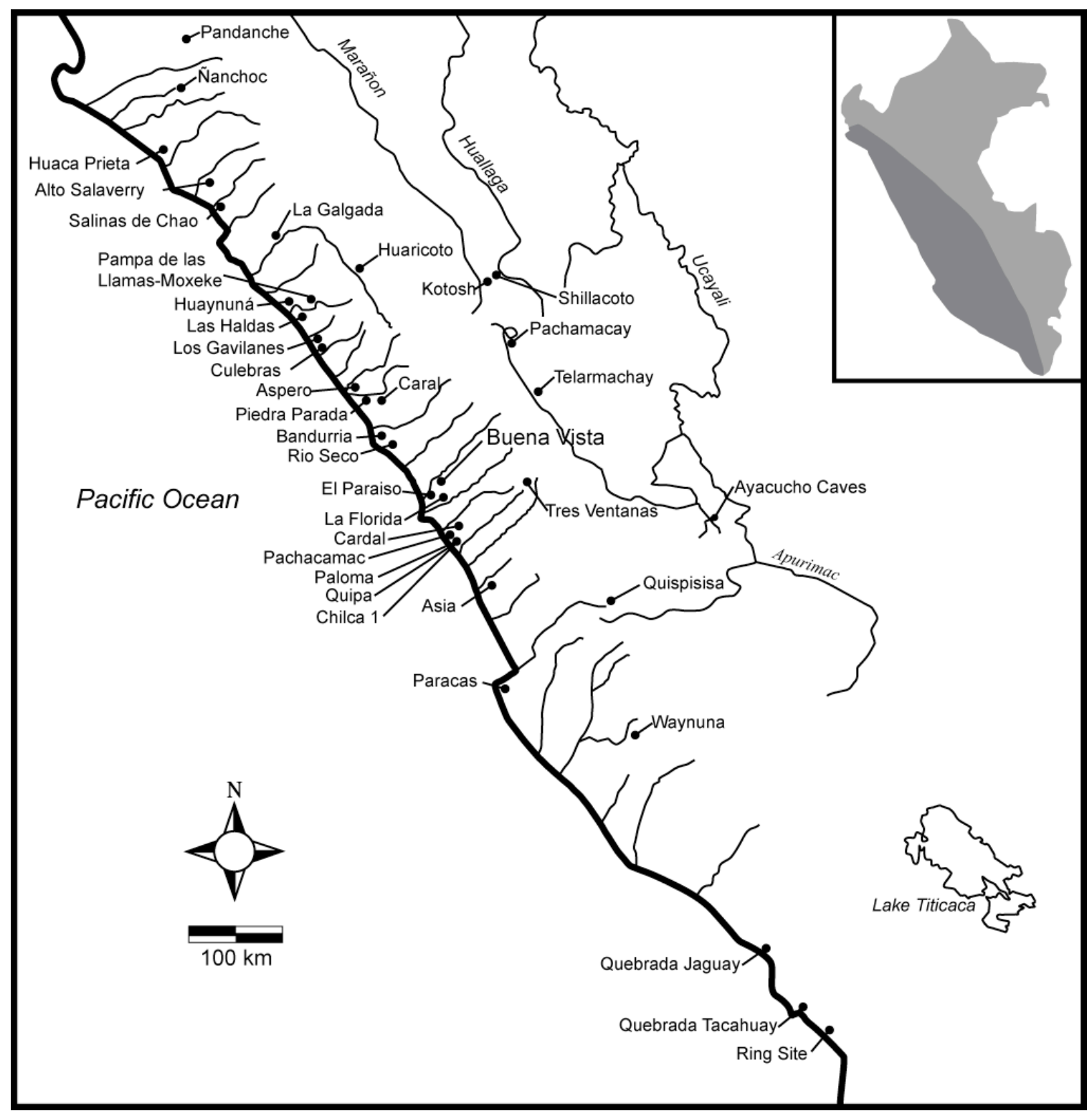

Figure 4.1 Map of western Perú showing the location of sites discussed in text. Most of the sites on the map date to the Preceramic through Initial Periods. 
Gordon Willey (1945) returned to the use of horizon style to refer to a wide distribution of similar ceramic traits within a single span of time. The usefulness of horizons, in Willey's chronology is that they can be used as "horizontal stringers" that tie together periods of time in regional developments (Willey 1945:55). Willey, like Wendel Bennet, now recognized the Chavín horizon first claimed by Tello.

Following more intensive and extensive archaeological excavations, John Rowe (1967), building upon earlier chronologies, proposed a new chronology for the Central Andes that emphasized regional developments. Based on relative temporal relationships gleaned through ceramic sequences and settlement patterns, Rowe divided the chronologies between and within the coastal and sierra regions. Rowe recognized that relative chronologies are associated within regional developments. Influenced by earlier work of Uhle and Kroeber (Rowe 1962:47), he revised the period and horizon framework recognizing that time periods are relative markers of contemporaneous time whereas horizon styles do not necessarily represent contemporaneity. For instance, Inka ceramics appear in Cusco earlier than in the northern valleys. For a system of periods to be useful, and archaeologically relevant, Rowe proposed, it needed to be relative to a particular valley, what he called a "master sequence", in this case, the Ica Valley (Rowe 1962:48-9).

Rowe, like Kroeber, used the period system, in part, as a way to avoid the use of evolutionary stages which, at the time, were rife with false assumptions and lacking archaeological evidence, and to avoid the assumption inherent evolutionary theory, as it was ethnologically reconstructed, that subsistence patterns and technology in the archaeological record predict social organization (Rowe 1962:44). Therefore, in Rowe's 
chronology, a time period is only a simple marker of contemporaneity, not an evolutionary stage, and a horizon is simply the spatial appearance of a trait or complex of traits within a given time. A majority of archaeologists trained in North American institutions continue to use and adapt Rowe's chronology today.

Scholars trained in Perú more commonly use a temporal scheme proposed by Luis Lumbreras (1974) who adapted the periods of Willey and Phillips (1958) corresponding to Rowe's period divisions and added epochs of regional change and the emergence of empires and states. In contrast to Rowe's chronology, the way Lumbreras' system is utilized is inherently evolutionary. The Lithic, Archaic, and Formative periods cover the span of time from early hunters and gatherers with only limited lithic technology who then begin to use agriculture and eventually settle in villages and make pottery. Thus, the Formative is conceived of as the beginnings of civilization, transitioning to regional developments toward polities that eventually become states and empires. Like Rowe's chronology, however, Lumbreras recognizes the importance of regional specific sequences

The decision to use a chronology based on either Rowe's or Lumbreras' framework can be a theoretical or a practical one. However, both chronologies provide a useful and convenient way of marking time in the past, especially if one recognizes that the periods within the chronologies are, fundamentally, markers of contemporaneity, as Rowe argued. For example, in Rowe's chronology, the Preceramic Period is an almost unfathomable amount of time incorporating the earliest human inhabitants in Perú some 12000 years ago up to the moment when ceramics are adopted around 4000 years ago (2000 B.C.). By the beginning of the Initial Period, societies had undergone enormous change associated 
with a broad complex of technological, social, political and cultural forces, before pottery arrives in the region. I chose to use Rowe's chronology for theoretical reasons. Used as a marker of time, Rowe's chronology adequately adapts to the discontinuities in the archaeological record. In the discussion that follows, I outline major changes through time that did not necessarily follow prescribed evolutionary stages, but occurred in arbitrarily defined periods of time.

\section{PRECERAMIC PERIOD ( 12,000 TO 2000 B.C.)}

Timing the arrival of the first humans in South America was contentious for a number of years as scholars debated, sometimes ferociously, radiocarbon dates from "preClovis" sites in North and South America (Lynch 1990). Today, that debate has quieted a great deal and a consensus generally exists that early humans occupied parts of the Americas by at least 12,500 years ago (14550 B.C.). The most widely accepted pre-Clovis site is Monte Verde in south central Chile (Dillehay 1997, 2000; Dillehay et al. 2004; 2008). Excavations of this small village uncovered the remains of architecture, stone choppers and blades, butchered remains of mastodon, camelids and small game, and the remains of plants used as food and tools. The residents of Monte Verde gathered a wide variety of plants in different parts of the year, and probably remained there through multiple seasons (Rossen and Dillehay 1997). The occupants of the site also exploited a wide variety of resources, including seaweed gathered from distant beaches for both food and, presumably, medicine (Dillehay et al. 2008).

The semi-permanent residences of Monte Verde foretells the lifestyles of later hunting and gathering groups in the Central Andes, both in the highlands and on the 
coast. In the highlands, At Pachamacay Cave near Lake Junín, a pattern of sedentism is evident by 7000 B.C. These early inhabitants hunted vicuñas and guanaco, wild relatives of alpacas and llamas, and collected plant food from multiple resource zones (Rick 1980, Pearsall 1980). Likewise at Lauricocha Cave near Pachamacay, sedentary peoples exploited wild game and collected a variety of wild plant foods as early as 5500 B.C. (Cardich 1958, 1964; Lynch 1983). Also, early evidence for the consumption of guinea pig (Cavia porcellus) appears with their skeletons in archaeological sites near Ayacucho around 8500 B.C. (Stahl 2008). The camelids, llamas (Lama glama) and alpaca (Vicugna pacos), who with the guinea pig would become icons of Andean culture, also have an ancient relationship with humans. The exploitation of wild camelids likely began with humans first arriving in the region (Lynch 1983) and over time lead to their eventual domestication by at least 2500 B.C. (Wing 1986; Stahl 2008). Camelid bones show initial signs of utilization around 6000 B.C. at Telarmachay Cave in the Junín puna (Wheeler et al. 1976; Wheeler 1984). However, there is a discontinuous pattern in the archaeological record for camelid utilization in the highlands. For example, at Kotosh and Huaricoto, deer hunting continued to be the primary meat source well into the Initial Period (Burger 1995:44).

Evidence for plant cultivation appears as early as 8000 B.C. At Tres Ventanas Cave in the Upper Chilca Valley, potato, manioc, sweet potato, ullucu, and jicama were found in strata dating between 8000 and 6500 B.C. (Engel 1957, 1973; Pearsall 2008). Begonia tubers found at coastal Paloma may also represent a locally domesticated species (Weir and Dering 1986). Excavations at other cave sites, such as Guitarrero cave, produced assemblages of cultivated plants, oca, chili peppers, lucuma, and beans in strata dating 
between $8000-7500$ B.C. Stratigraphic sequences, unfortunately, have been problematic at highland cave sites, Guitarrero included, where subsequent AMS dates of a bean (430 B.C.) and lima beans (1495 B.C., 1325 B.C.) are much later than previously reported dates (Kaplan and Lynch 1999). The early dates, 7200-5600 B.C., associated with plant remains from sites in the Zaña Valley in northern Perú have also been problematic (Rossen and Dillehay 1996). Despite ancient-looking morphology and consistent archaeological contexts, initial AMS dates of peanut, squash, and quinoa returned modern results leading the researchers to reject the modern dates for these plants as due to contamination, a significant problem for the tiny amounts used in AMS dating, in favor of their archaeological contexts. The excavators have since supported that conclusion; early agriculture is evident in household clusters associated with irrigation canals and garden plots, along with the macroremains of squash, peanuts, and cotton, dating between 8000 and 4050 B.C. at Nanchoc in the Zaña region (Dillehay et al. 2007). Agricultural adaptations had begun there by at least 10000 years ago. Direct evidence of the consumption of squash and peanuts, as well as beans (Phaseolus spp.) and pacae (Inga feuillei) from starch grains recovered from human dental calculus confirms people living around Ñanchoc had a broad crop diet at this time (Piperno and Dillehay 2008).

Ancient sites on Perú's coast also attest to early South American peoples' ability to live in widely disparate environs. But finding the earliest of these occupations has proven problematic due to certain environmental and geological conditions. On the western coast of South America, known sites early in the Preceramic period (12,000-8000 B.P.) are found in areas where the continental shelf remains narrow and not inundated when sea levels 
rose between 12,000 and 5000 years ago, or these sites are found in areas located away from the shoreline near freshwater sources (Richardson 1981, 1998:43-44; Wells and Noller 1999). In the absence of significant tectonic uplift, the earliest sites once located near the ancient shoreline would now be underwater. Glimpses of early maritime adaptations can be seen mainly at locations on the South Coast near the border with Chile and on the North Coast of Perú and Southern Ecuador. These sites clearly show a very early adaptation to marine environments that would continue to intensify throughout the Preceramic period (Sandweiss 2008). To the south, ancient sites near the coastline confirm maritime adaptations as early as 11,000 B.C. at sites such as Quebrada Jaguay (Engel 1987; Sandwiess et al. 1998), Quebrada Tacahuay (Keefer et al. 1998; deFrance et al. 2001; deFrance and Umire 2004), the Ring Site (Sandweiss et al 1989), and in Chile at Heuntelauquen (Llagostera et al. 2000). To the north, Preceramic sites also as early as 10,000 B.C. show evidence of both maritime and mixed resource subsistence in southern Ecuador at the Las Vegas site (Stothert 1985), northern Perú at Amotape (Richardson 1978), and several Paijan sites (Chauchat et al. 1992).

In the Ancón-Chillon region, however, archaeological sites of early maritime adaptations that laid the foundations for the development of the precocious maritime societies in the area during the Late Preceramic, beginning around 4000 B.C., are absent (Lanning 1967), inundated by sea level rise along the wide continental shelf (Richardson 1981; 1998). The early sites near the coast today in the lower Chillón seem to have favored terrestrial resources. A small Chivateros campsite was dated to around 10000 B.C. in the Ancón-Chillon, with burins, scrapers, and bifaces, that Lanning (1967) interprets were for 
subsisting on hunting not fishing. However, Chauchat (1988) argued that there could have been a shift to maritime exploitation.

Just south of Lima, in the lower Chilca Valley, maritime oriented sites near ancient lomas provide fairly early dates: Chilca I (Engel 1958, 1963, 1967, 1980, 1987; Weir et al. 1988), Paloma (Engel 1980; Benfer 1982, 1984, 1987, 1990, 1999, 2008) and Quipa (Engel 1984, 1987, Duncan et al. 2008). These sites are located several kilometers from the modern (and ancient) shoreline in locations that would have been expedient for utilizing abundant marine resources as well as the resources of the lomas.

At Quipa, a recent re-excavation of a house documented the earliest inhabitants known on the Central Coast (Duncan et al. 2008) and confirmed one of Frederic Engel's (1984, 1987) radiocarbon dates to around 7355 B.C. Like Paloma and Chilca I nearby, Quipa was probably an early maritime village, but little is known regarding subsistence there. At Paloma (5850 - 2750 B.C.), a few kilometers away, residents were primarily sedentary (Benfer 1984; Engel 1980; Quilter 1989) and utilized the abundant marine resources from the cold upwelling of the Perú current (Weir, Benfer, and Jones 1988; Reitz 1988, 2003) as well as the lomas (Weir and Dering 1986). Early dwellings were smaller and simpler (Benfer 1990). Over time, populations at Paloma increased and, at the same time, so did health and life expectancy, indicating a continuously successful adaptation to their environment (Benfer 1982, 1984, 1990, 1999). Social stratification may also have been forming at Paloma, as interpreted by special grave goods, but may relate to social achievement, not inequality (Quilter 1989). The beginning of ancestor worship is indicated by attempts to preserve cadavers by building small fires in the burial pit, using up to $50 \%$ 
salt from a nearby coastal mine, and marking graves, never seriously disturbed in prehistory, by pebbles above the grave (Benfer 1999; although see Isbell 1997 for an argument for a more recent origin). Coastal-sierra connections existed as early as 4400 B.C. as evidenced at Paloma by the presence of obsidian sourced from Quispisisa in the southern highlands near Lake Titicaca (Burger and Glascock 2000).

Macroremains of plants from the earliest sites on the coast suggest foraging for horsetails, prickly pears (Sandweiss 2008) and possibly sedge tubers. However, by 5700 B.C., simple agriculture at coastal sites is evidenced by the remains of several cultivated plants. Gourds, squash and common beans (Phaseolus spp.), are likely to have been grown and guava trees may have been managed at Paloma as well as tuberous begonias (Benfer 1982; Dering and Weir 1979, 1981; Weir and Dering 1986). At Paloma, in a reoccupation about 2,500 B.C., common beans were abundant (Benfer 1991). At Chilca I, gourds, squash and common beans are present (Jones 1988) and the remains of jack beans, achira, and jicama appear for the first time (Pearsall 2008; Jones 1988).

It is clear from the presence of cultivated plants, squash, gourds, beans, manioc, achira, and peanuts in these early highland and coastal Peruvian assemblages that agricultural practices are very early adaptations in the Andes, yet the highland sites seem to provide the earliest evidence of agriculture. The highlands of Perú were not likely settled before 9000 B.C., when glaciers were at maximum and environments would have been relatively extreme for human occupation (Aldenderfer 1999; 2008); this explains why the earliest dated archaeological sites are known on the coast. After 9000 B.C., as glaciers recessed and modern Andean flora and fauna replaced that of the Pleistocene, these 
environments would have attracted early human foragers. Pearsall $(2003,2008)$ suggests that, if the model is correct, these foragers would have focused on the mid-elevation roots and tubers, such as arracacha (Arracacia xanthorrhiza), yacón (Smallanthus sonchifolius), ulluco (Ullucus tuberosus), and achira (Canna edulis), then directed attention later on highland plants, oca, ulluco, potatoes, lupines, and quinoa. Interestingly, some of the earliest evidence of cultivated plants in the highland sites represent taxa that were domesticated elsewhere. Manioc, peanuts, and sweet potatoes were domesticated on the edge of the Amazon basin (Piperno and Pearsall 1989; Pearsall 2008). Squash and gourds, also have extra-highland origins (see Chapter 6 for a discussion of the origins of squashes and gourds). The presence of these plants most likely reflects ancient interconnectedness between the northern and eastern lowlands, the coast and the highlands (Lathrap 1973; Spinden 1917; Pearsall 2003, 2008; Perry et a. 2006).

\section{The Late “Cotton” Preceramic}

Junius Bird's (1948) excavations at Huaca Prieta, a large settlement next to the ocean on the north coast of Perú with complex architecture, cotton textiles, and cultivated plants, provided the first glimpse at social complexity at a site before the adoption of ceramics. Following Bird's excavations, archaeologists focused more attention on coastal sites with large mounds and visible remains of architecture. What they were to find, inspired a careful re-thinking regarding the development of society there. Frederic Engel, an early pioneer of coastal archaeology and in the archaeology of preceramic sites, excavated a great number of sites including Paracas, Culebras, Rio Seco and El Paraíso, and 
surveyed entire coastal valleys, including the Chillón and Chilca (Engel 1957, 1958, 1962, 1963,1964, 1966a, 1966b, 1973, 1980, 1984, 1987). Engel's interest in agriculture was a driving force behind his work. Through his varied excavations, he was the first to notice an association of cotton textiles and nets with monumental sites that set them apart from earlier coastal sites. This period of time from around 2500-1800 B.C. became known as the Cotton Preceramic (Engel 1957; Moseley 1975; Pozorski and Pozorski 1987), although when the period actually begins is fuzzy, since cotton textiles do not appear simultaneously at contemporary sites on the coast (Quilter 1991). The terms Cotton Preceramic and Late Preceramic are often used interchangeably, but most often Cotton Preceramic is used in reference to coastal sites, whereas for highland sites, Late Preceramic is used almost exclusively to refer to the same period of time.

The appearance of cotton textiles is a small part of larger technological and social innovations of this time period. Agriculture is marked by dramatic increases in plant richness in Cotton Preceramic sites and new taxa appear. In addition to beans and lima beans (Phaseolus spp.), manioc, ciruela, peanuts, squash and gourds in earlier contexts, now cotton, chili peppers, jicama, pacae, tree fruits such as lucuma, avocado, cherimoya, and guava are common finds in coastal sites (Pearsall 2003a, 2008). At Buena Vista, starch grains of arrowroot, manioc, and algarrobo were recovered from residues on gourd and squash artifacts in well stratified contexts dating to 2200 B.C. (Duncan et al. 2009; see also Chapter 6). Maize, chili pepper, arrowroot and potato microfossils from well dated contexts at 2000 B.C. from the highland Preceramic site of Waynuna in the Cotahuasi Valley near Arequipa (not to be confused with the Huaynuna in the lower Casma region of 
north coast) are found in soil samples and in the residues of stone tools (Perry et al. 2006; Perry et al. 2007).

The identification of maize starch and evidence of its processing at Waynuna raises again the issues of maize at late Preceramic period sites in Perú. Maize has been problematic because its presence is highly discontinuous and the contexts in which maize has been found, its morphology, and in some cases the dates themselves, have been questioned (Bird 1990). Although an integral part of subsistence in later polities, e.g. Wari, Tiwanaku, and Inka, maize did not seem play an equally important role in the development of preceramic Andean societies (Burger and Van der Merwe 1990). Maize macroremains (Bonavia 1982; Bonavia and Grobman 1989) and pollen from coprolites (Weir and Bonavia 1985) have been identified at Los Gavilanes and several other preceramic sites, including early, around 3000 B.C., samples reported from Ayacucho caves (MacNeish et al. 1980; see Bonavia 1982:346-352, 356-367 for review of other sites). Direct radiocarbon dating of the maize from Los Gavilanes returned late dates between 200 and 800 B.P., but this could be due to contamination (Bonavia 1982.) Isotopic signatures from human skeletal material at Huaricoto (Burger and Van der Merwe 1990) suggest maize consumption there beginning around 2200 B.C. Recently, maize macroremains are reported from reported preceramic contexts at Caral, found in construction fill (Shady 2006). Considering the extensive excavations there, and the fact that only a small number of specimens were recovered: a total of 15 cobs, two husks, and one inflorescence in contexts dating after $\sim 2300$ B.C., one must reserve judgment as to what role maize would have played. Shady reasonably concludes, that the limited representation of maize is 
indicative of its minor role in preceramic society, perhaps serving a ceremonial purpose since several of the remains were associated with ritual architecture. Maize cobs were also found in construction fill and disturbed contexts at Buena Vista, however all appear to be intrusive or in late contexts; one from the numerous cobs found in shicra fill that covered a Preceramic floor produced a much later date (UGAMS 3130, 460+/-25 a.p.) (Benfer, personal communication). This suggests great caution in dating maize specimens from fill. Nevertheless, maize was present at highland sites during the Preceramic by 2000 B.C. and it is certainly plausible it was present on the coast. However, it seems maize did not make up a significant portion of the diet anywhere in a region with outstanding preservation.

Industrial cultigens, cotton and gourd, are common to most sites of the Cotton Preceramic on the coast. Seed size and fiber diameter of cotton increases through time and have been used to interpret cotton's domestication on the coast of Perú from wild Gossypium barbadense (Stephens and Moseley 1974). Gourds were grown for their useful hard rinds to make containers for daily use. In addition, gourds have been found attached to fishing nets to use as net floats (Whitaker and Bird 1949).

The suite of cultigens grown and managed by peoples of the Cotton Preceramic indicates a maturing system of agriculture. Although, we still know little about cultivation methods. Irrigation canals may have been in use near La Galgada (Grieder and Bueno 1985) and sunken fields or plots in the lower Chilca Valley may have been used for cultivation (Parsons and Psuty 1975; Benfer et al. 1987). The inland valleys of perennial rivers, such as the Chillón, Rimac, Lurín, and Supe, provide fertile floodplains where simple water divergence could irrigate fields without construction of complex water 
infrastructure, especially when outflow is highest, between January and May (Denevan 2001; see also Chapter 2). Prolonged intensive agriculture in these valleys would have destroyed any evidence of water management in the Preceramic (Raymond 1981; Quilter 1991:401).

In recent decades, (Moseley's (1968, 1975, 1985; Sandweiss and Moseley 2001) Maritime Foundations of Andean Civilization (MFAC) provided a model to explain the development of complex society on the coast of Perú based on maritime subsistence. Moseley's idea was contrary to predominant explanations, largely inspired by V. Gordon Childe's (1950) concept of the Neolithic and Urban Revolutions, that societies underwent fundamental changes following the domestication of plants and animals and after a period of time, these social changes would accumulate until urbanism resulted. He followed the earlier Peruvian investigator, Larco Hoyle, in siting the development of civilization on the coast rather than in the Andes (Larco Hoyle, Rafael 1948). In Childe's model, the origins of complex society are based on the changes brought about by adopting agriculture, such as sedentism, surplus, divisions of labor, craft specialists, and so on. Lanning (1963, 1967, 1974), proposed just such a sequence of events on the coast of Perú: foraging groups first exploited the lomas, then a shift to marine resources, first shellfish then fishing, and finally people adopted agriculture, with maize as the dominant cultigen as it was in Central Mexico. Engel's $(1976 ; 1987)$ focus on subsistence also conceptualized Childe's model as a sequence from pre-agricultural to bean planter's society and finally maize agriculture.

Childe (1950) was aware of North American northwest Pacific coast environments where marine resources enabled higher population densities, but did not consider this case 
to be common. In Moseley's model, like that in the Northwest Pacific Coast, sedentism and surplus was possible along the coast of Perú because of abundant marine resources. Agriculture would not be a prerequisite for complex society with such a tremendous source of food from the ocean. With sedentism afforded by the rich marine diet, technological advance, in the form of cotton net production, enabled rapid replacements of cotton nets, as they would wear quickly with use, thus increasing yields of marine fishes of small size. Cotton would not contain larger fish, so they would have had to be directed it at small schooling fish such as anchovies and sardines. As a result, cotton, a necessary industrial cultigen, became ubiquitous on the central coast by 3000 B.C. (Moseley 1992:105). As maritime subsistence continued to feed growing populations, coastal sites emerged with large ceremonial architecture, seemingly before acquiring a dependence on agriculture to feed the population and before the adoption of ceramics. Middens contain agricultural remains of food plants such as legumes, achira, and squash, but the emphasis remained on industrial crops for maritime subsistence, cotton and gourds (Moseley 1975,1992). The largest Cotton Preceramic sites, such as Aspero and El Paraíso, were thought to be located where there is the least arable land. Without intensive water management, large populations would not have supported themselves without a dependence on marine resources (Moseley 1975, 1992:102). Once the social organization allowed for the construction and maintenance of coastal irrigation systems, the dependence on marine resources was reduced (Moseley 1992:102) with larger populations in the middle valley growing more agricultural products. In the time to follow, the Initial Period, settlements shifted inland as a result of increased dependence on agriculture. 
The Maritime Foundations of Andean Civilizations model was supported by Feldman's (1980) excavations at Aspero in the lower Supe Valley, and used to explain developments at Huaca Prieta and El Paraíso (Quilter and Stocker 1983), all sites close to the ocean, having large-scale architecture and middens composed primarily of marine foods. Benfer (1991) supported the hypothesis as explaining the origins of large villages before monumental architecture was erected. However, the model certainly has had its critics. David Wilson $(1981,1999)$ argued that marine resources, such as anchovies in Moseley's model, would not have provided a large enough caloric base (see also Raymond 1981) and a surplus of marine foods was unlikely due to the inability to preserve them. Furthermore, Wilson asserted that El Niño cycles would have made maritime resources unpredictable, therefore agriculture, in particular, maize agriculture, was likely the cornerstone of Cotton Preceramic economies. Wilson's arguments, however, were flawed in that he did not take into account other marine resources, shellfish, sea mammals, birds, and crabs, that were also utilized (Weir, Benfer, Jones 1988) and that preservation would be possible by drying or drying and grinding (Quilter and Stocker 1983). Storage pits containing anchovy remains were excavated at Paloma (Benfer 2008). El Niño may be unpredictable and potentially deadly, but during the cycles, cold-water marine fauna are temporarily replaced by more warm tolerant species (Caviedes 1984; Flores Palomino 1985; Arntz 1986). Also, as noted earlier, there is little evidence that maize played a significant role in the Late Preceramic. Moseley probably overstated the lack of arable land, especially in regard to El Paraíso, as it is located adjacent to the largest arable portion of the lower Chillón Valley (see Chapter 3). Raymond (1981) noted, contrary to Moseley's observation, 
that the distribution of Cotton Preceramic sites are in areas feasible for agriculture and that the contribution of agriculture may be greatly underestimated. He argued that root crops, manioc, achira, and sweet potatoes, could have been staple crops, not maize. Root crops are present and identified in other coastal sites (Towle 1961; Martins 1976) as well as at Buena Vista. Poor preservation and the fact humans eat most of the tuberous part of the plant would explain the low frequencies reported in archaeological assemblages.

Agriculture during the Cotton Preceramic associated with the large monumental sites on the coast has been poorly understood due, in large part, to a lack of knowledge regarding subsistence at contemporary inland sites. Maritime resources, however, do appear to be important parts of Cotton Preceramic economies, as they represent the principle source of protein in the diets of both coastal and inland, inhabitants. It is also apparent that marine resources were fundamental in providing a subsistence base for early villages prior to the Cotton Preceramic (Benfer 2008; Sandweiss 2008). However, the discovery of inland sites in locations adjacent to large areas of arable land and contemporaneous with large coastal sites suggests that agricultural and maritime economies were integrated (Shady 1999, 2006, 2005; Shady et al. 2001; Haas et al. 2004; Haas and Creamer 2006). In light of these new data, Moseley himself has retooled the MFAC to accept a greater role of agriculture in the development of complex society on the coast of Perú; he refers to a "fishing-farming symbiosis" (Moseley 2001:112; Sandweiss and Moseley 2001) that establishes later economic adaptations that increase agricultural dependence with the advent of irrigation. 
The impetus for new thinking on the importance of agriculture in the Cotton Preceramic comes from excavations in the Supe Valley, about $200 \mathrm{~km}$ north of Lima, at the site of Caral (Figure 4.2). Paul Kosok (1965) visited the site in the 1960s and published an aerial photograph. Later, Bernardino Ojeda with Frederick Engel (Engel 1980) mapped the site. In the early literature, the site is known as Chupacigarro for the local hacienda there; Kosok (1965) also found some stone artifacts that resembled cigars. Engel recognized a larger center as Chupacigarro Grande. Shady and colleagues (2001) changed the name of Chuacigarro as published by Kosok to Caral after a local modern community. The site lies approximately $23 \mathrm{~km}$ inland from the coast and its main complex of architecture spans some 65 ha (Shady et al. 2001). It is the largest preceramic site in the Supe Valley, actually one of the largest sites in the Andes in area of monumental architecture, containing multiple buildings: six large platform mounds, a couple of sunken circular plazas, multiple platforms and structures some of which may be residential. Caral was occupied from 2627 to 1977 calB.C. (Shady et al. 2001), therefore it was probably built earlier than El Paraíso ( 2230-1270 calB.C.) in the Chillón.

The shear complexity of Caral leads Shady $(1997,1999,2005)$ to conclude that the site represents the first evidence of urbanism in South America, thus America's first city. Urban center or not, the location of Caral so far from the ocean and its enormous size does imply Caral was culturally and politically significant as, perhaps, a political-religious center. Although, the area immediately surrounding the site is not thought to be suitable for agriculture (Engel 1987; Shady 2001), significant portions of the lower valley did support floodplain agriculture and, later, canal irrigation. Domesticated plant remains 
found at Caral, in addition to maize as previously noted, include squash and gourds, beans, pacae (Inga pacae), sweet potato, achira, cotton, and tree fruits of lucuma and guava (Shady 1999, Shady et al. 2001). Marine products, mussels, clams, anchovies, and sardines indicate the major protein resource came from the sea. Excavations at other Cotton Preceramic sites in the inland Supe Valley (Vega Centeno 2005, 2007) and settlement surveys (Zechenter 1988) show similar patterns of mixed agriculture and marine resources.

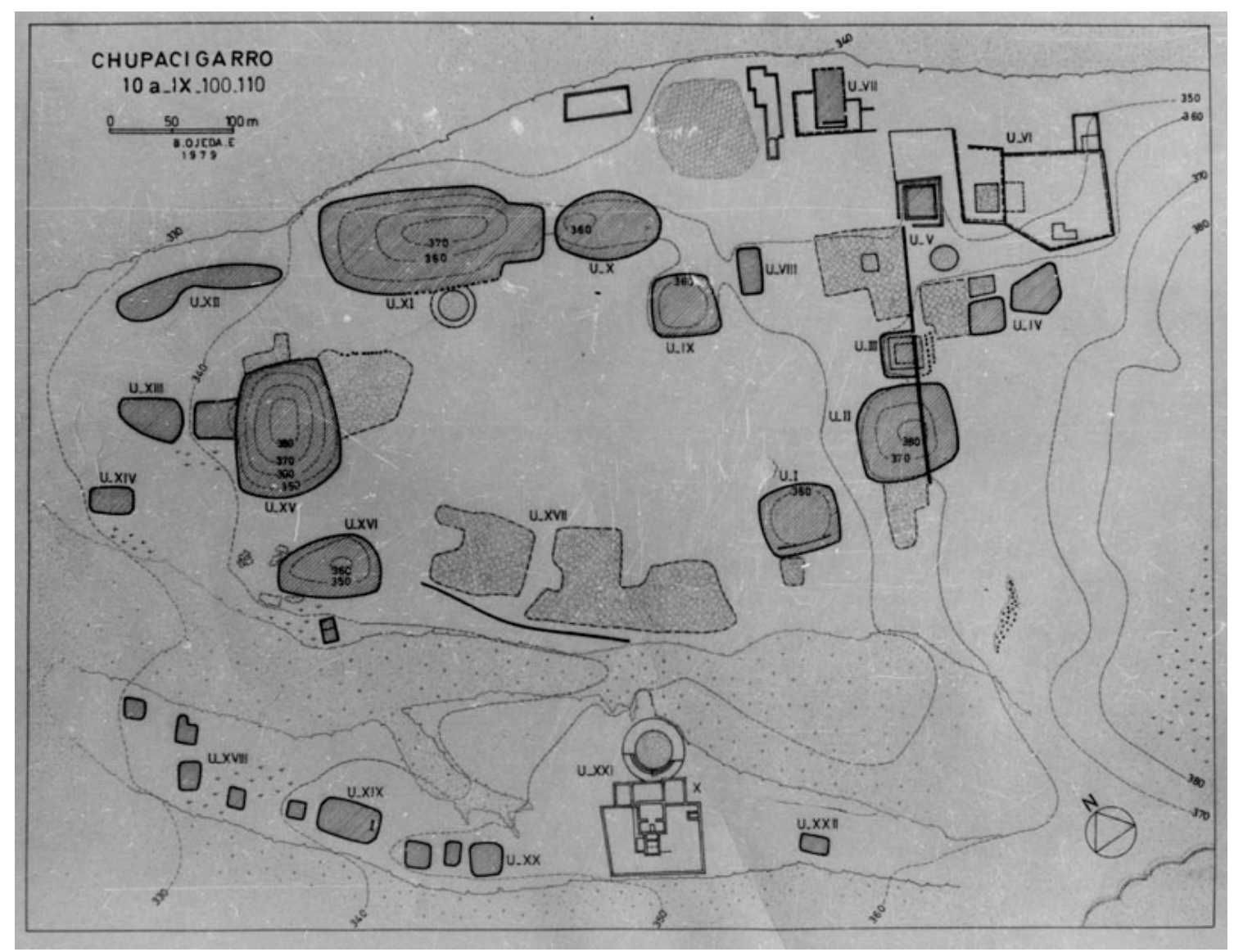

Figure 4.2 Map of Chupacigarro, or Caral. Credit: Bernardino Ojeda.

In contrast to the coastal sites that inspired the MFAC hypothesis, Caral and other inland sites have been found to be even larger and more complex than many coastal contemporaries (Haas and Creamer 2006). Aspero, in the lower, coastal Supe Valley was a 
key site in support of the MFAC. It is a relatively large site, approximately 15 ha, but less than a fourth the size of Caral only $20 \mathrm{~km}$ inland. Feldman's $(1980,1985)$ excavations recovered copious amounts of maritime foods associated with complex architecture, from which he interpreted a chiefdom type social organization centered at Aspero. However, the presence of several larger neighbors in the same valley suggests that the nexus of social relationships was inland, not coastal. The early dates from Aspero lead Pozorski and Pozorski (2008:611) to speculate that inland agricultural communities having coastal satellites is a settlement pattern that spread from the Supe area to the north and south and continued into the Initial Period of ceramics.

The relationship of coastal and inland valley sites with their contemporaries in the central highlands is a key issue during the Cotton Preceramic, or Late Preceramic. Llamas and alpacas were probably fully domesticated by this time and provided important sources of wool and meat, as well as their ability to carry loads (Wing and Wheeler 1988). Llama and alpaca remains are uncommon at the Late Preceramic sites in the intermontane valleys below the puna. Therefore, it is thought that the different ecological zones were also home to two different types of societies, the high puna herders and the agriculturalist-hunters of the lower valleys of the quecha and suni (Burger 1995:45). In the intermontane valleys, subsistence economy was primarily agricultural, supplemented with domesticated guinea pig, although hunting deer continued to provide an important source of protein, for example, at Kotosh (Wing 1972). Several important sites in the intermontane valleys contain monumental architecture. The first to be extensively excavated is Kotosh in the Huallaga river valley (Izumi and Terada 1972). The "Kotosh Religious Tradition" (Burger 
and Salazar-Burger 1980,1986) describes the characteristic architectural style of small freestanding buildings with central stone fire pits often with ventilation shafts, and split level floors first excavated at Kotosh. The temple structures, often on elevated platforms, appear in the late Preceramic and are referred to as Mito-phase or Mito-style (Bonnier 1997). The buildings are thought be centers of religious ritual, and have been defined as representing the Kotosh Religious Tradition (Burger and Salazar-Burger 1980). The ritual usually involved fire. Often, the buildings are carefully buried underneath new buildings, creating accretional mounds of large size (Burger 1995:46), a common construction technique at contemporary coastal (Feldman 1980) and inland sites (Vega Centeno 2005), including Buena Vista. Sites with these Kotosh-like features include Shillacoto and Wairijirca in the same valley as Kotosh, Huaricoto in the Callejón de Huaylas (Burger and Salazar Burger 1980, 1986), La Galgada in the Tablachaca Valley (Grieder and Bueno 1985), and Piruru in the Tantamayo valley (Bonnier and Rozenberg 1988).

The Kotosh-style architectural features suggest an underlying religious ideology that was expressed in similar ways at all of these sites (Burger and Salazar Burger 1980, 1986; Burger 1995), although some variation did occur. At Huaricoto (Burger and Salazar Burger 1986) and La Galgada (Grieder and Bueno 1985), for example, Mito-style chambers were constructed with rounded corners, rather than squared as at Kotosh. La Galgada also contains a sunken circular court and deep stone lined shaft tombs (Grieder and Bueno 1985), but is smaller than the temple at Buena Vista. That variation persisted suggests that many different social groups participated in rituals at Kotosh themed sites, but they were not unified under a central political authority (Burger and Salazar Burger 1986). 
The Late Preceramic in the central highlands and the Cotton Preceramic of the coast exhibit similar social developments underway after 3500 B.C. Economic interconnectedness is suggested by the agricultural suite at coastal sites and cultural transmission was likely important as well. Kotosh-like ventilated hearths are reported at Caral (Shady 2006) and at Huaynuna in the lower Casma Valley (Pozorski and Pozorski 1990) and a feature badly damaged by looters at Buena Vista that may also be a ventilation feature (Unit C-1, see Chapter 4). Therefore, aspects of belief systems may have been shared by both coastal and highland peoples (Pozorski and Pozorski 1996).

\section{The Initial Period of Ceramics ( 2000-850 B.C.)}

Between 2500 and 2000 B.C., pottery appears in archaeological contexts in coastal and highland Perú. Much attention given to the adoption of pottery has situated the technology into a marker of complex society or an evolutionary stage following incipient horticulturists. From an evolutionary perspective, why pottery appears at one site and not another nearby with similar architectural development and, seemingly, similar kinds of social organization at the same time is not easy to explain. To remedy this, Pozorski and Pozorski (1990, 2008:622) suggested that these anomalous monumental sites, such as La Florida in the Rimac valley with pottery bearing deposits and Late Preceramic radiocarbon dates, be referred to as aceramic Initial Period sites and that these sites are anachronistic holdovers from earlier preceramic times. This, unfortunately, conflates Rowe's chronology with an evolutionary model whereby the presence of ceramics is the sole marker of evolutionary change in the Initial Period, when, on the other hand, the presence or absence of early ceramics does not necessarily correlate to other features of social 
organization, architectural technology or subsistence. It should be no surprise that the adoption of ceramics in Perú between 2500 to 2000 B.C. shows a similar pattern, or nonpattern, of discontinuity as the presence of maize, chili peppers, cotton textiles, coca, and camelid bones do at Late Preceramic sites; thus, a presence or absence of ceramics reflects a normal, not anomalous, situation. By extension, since the earliest pottery in Perú is predated by pottery in Colombia and Ecuador by at least a millennium and even more in the Amazon basin (see Hoopes 1994), the Peruvian situation, with its relatively late adoption of ceramics itself is an anomaly if one considers pottery as the only marker of social change out of context with other developments such as the appearance of heddle looms.

A more difficult and satisfying question to answer, and one beyond the scope of this dissertation, is why ceramics are adopted at all (Barnett and Hoopes 1995). As Arnold (1985) summarized, ceramics have certain obvious advantages to other materials in cooking efficiency and increasing nutrition from cooked foods. Although most sedentary societies did employ ceramics (Arnold 1985), the adoption of pottery preceded intensive agriculture (Harry and Frink 2009; Pavlu 1997; Rice 1999) in most areas of the world. Therefore, it would be a mistake to assume that pottery use in the Andes correlates to intensive agricultural production, let alone a fundamental shift in social organization and subsistence. The adoption of pottery may also have social stimuli, such as for serving vessels in ritual (Hayden 1995a). One idea worth exploring is to correlate the adoption of pottery to intensive maize production in the central Andes for the production of maize beer. 
John Hoopes (1994) provided a useful summary of the earliest ceramic complexes of the Americas and it shows that the appearance of pottery in the earliest Amazonian sites around 5500 B.C., Ecuador by 4000 B.C., North America around 3500 B.C., and finally on the Peruvian coast as early as 2500 B.C. was neither continuous nor rapid, and shows a tremendous amount of variation in material composition, manufacture, and style inconsistent with a convenient diffusionist model. Hoopes provides the following ceramic highlights with calibrated dates. Arguably, the earliest pottery in Perú is reported from samples at Pandanche in the northern highlands at 2500 B.C. and 1700 B.C., in reversed stratigraphic order (Kaulicke 1981) but another context was dated to 2185 B.C. (Kaulicke 1975). Early ceramic contexts appear at Pampa de las Llamas-Moxeke from 2175 B.C. to 1275 B.C. (Pozorski and Pozorski 1990), at Las Haldas by 1950 B.C. (Matsuzawa 1978) and 1725 B.C. (Grieder 1975). In the central highlands at La Galgada, pottery appears as early as 1990 B.C. (Grieder et al. 1988) and at Kotosh possibly by 2235 B.C., but tentatively dated to around 1400 B.C. (Izumi and Terada 1972). The southern coast and southern highlands have pottery beginning possibly as early as 2500 B.C. (Hoopes 1994:37).

The earliest radiocarbon dates associated with ceramics on the central coast come from La Florida in the Rimac Valley, just south of the Chillón (Patterson 1985:64; Fung 1988:96; Hoopes 1994:36-37). Patterson (1985:64) reports three dates: N-87: $3660 \pm 170$ B.P. or 2032 cal B.C. from charcoal associated with pottery bearing deposits collected by Jorge Muelle near the base of the north wing; GX-04456: $3645 \pm 120$ B.P. or 2040 cal B.C. collected by Gary Vescelius and Dorothy Menzel which "probably came from the refuse overlying the final floor" of a house (ibid p. 64); GX-1210: 3680 120 B.P. or 2035 cal B.C. 
associated with a ceramic assemblage in the quarry area (Patterson and Moseley 1968:129); and an additional date N-44: $3760 \pm 170$ B.P. or 2155 B.C. is also reported from La Florida by Ravines and Alvarez (1975) and Mejía Xesspe (1978:512).3 Patterson communicated to Hoopes $(1994: 36)$ that there was some uncertainty regarding the citation of N-44 (2155 cal B.C.) and, also problematic, N-87 (2032 cal B.C.) is published to have come from Paracas (Yamasaki et al. 1966:337). For the other two dates, GX-04456 (2040 cal B.C.) and GX-1210 (2035 cal B.C.) very little in way of description of these contexts and their direct ceramic associations is available, and since they date some of the earliest ceramics on the central coast, they, surprisingly, have been subject to little scrutiny. Therefore, it is not certain if the ceramics correlate to the earliest phases of construction at La Florida. Although, the radiocarbon dates do support the conclusion that La Florida's construction was underway by 2040 cal B.C., but this may predate ceramics there.

The timing of ceramics at La Florida is an important issue because the construction of the site overlaps the occupation of its neighbors $\sim 40 \mathrm{~km}$ north, El Paraíso and Buena Vista, where no pottery is found their earliest contexts. La Florida's architectural layout with a central pyramidal structure, nearly 17 meters tall, with two lower lying outstretched parallel arms, nearly $500 \mathrm{~m}$ in length, give the site what Carlos Williams $(1980,1985)$ referred to as a U-shape that would become a hallmark of Initial Period architecture. Williams considered El Paraíso to be the first example of U-shaped architecture, however, in comparison to La Florida and later U-shaped sites, El Paraíso is an atypical example. El

\footnotetext{
${ }^{3}$ B.C. dates from La Florida samples N-44, GX-04456, and GX-1210, were calibrated by Hoopes (1994:36-37) and the date ranges averaged. N-87 was calibrated using Calib 5.1 Beta, Southern Hemisphere correction (Stuiver and Reimer 1993) and the date range averaged.
} 
Paraíso consists of at least nine separate buildings, two of which are nearly $450 \mathrm{~m}$ long "wings" or "arms" (Units II and VI) running in parallel, but the structure nearest the apex of the "U" (Unit I) is much smaller than the arms and not centrally located (Quilter 1985:282). The U-shape, lopsided as it appears, suggests El Paraíso was constructed in a piecemeal fashion with a central concept in the mind of the builders. Some (Williams 1980; Moseley 2001:129) suggest the orientation of El Paraíso and later U-shaped monuments reflects ideological and organizational transformations beginning in the Initial Period as societies turn inland to more intensive agriculture; the U-shaped centers turned their back on the sea to face the mountains, their outstretched arms open to embrace the sun and sacred sources of water. But not all are oriented in this way.

By 1800 B.C., more sites with monumental architecture appear in inland western valleys and in the highlands from Cajamarca south to Lake Titicaca associated with a shift to intensive agriculture supplemented by canal irrigation from perennial streams and springs. Canal irrigation, and the requisite labor in construction and maintenance, also permitted a demographic shift inland adjacent to irrigated areas (Moseley 2001:134). Canal irrigation leaves a more permanent record of landscape modification beginning in the Initial Period that later intensifies with the construction of large-scale terracing of entire mountainsides in the upland valleys in later epochs. During the Initial Period, the richness of agricultural plants continues from that of the late Preceramic, with maize and chili peppers now appearing in reliable contexts at Initial Period sites (Pearsall 2003a, 2008; Perry et al. 2007). Evidence for root crops seems to decline, but potato appears at several sites. 
In the Chillón Valley, settlements with surviving architecture jump in number from just three in the late Preceramic, Punta Grande, El Paraíso, and Buena Vista, to twentynine by the end of the Initial Period (Silva 1996). This settlement pattern is characteristic of western valleys during this time. Silva recorded eight of these settlements associated with U-shaped architectural complexes in his survey of the valley. Unfortunately, three of the sites recorded in aerial photos of the region from the 1940s, Oquendo, Cueva, and Pro, no longer exist. The largest complex is Huacoy in the Lower Chillon occupying 27 ha of the valley floor (Ludeña 1970; Silva 1996). Its central mound at the apex of the "U" rises over 240 meters above the plaza in between the arms of the complex. Like other U-shaped sites, Huacoy parallels the river and opens up to the sierra. Chocas, the second largest complex, lies on the valley floor near its predecessor Buena Vista. Like Huacoy, the arms of the "U" parallel the river and open toward the highlands. The site covers nearly 19 ha adjacent to the river (Silva 1996). The two sites appear to have been utilized by peoples in surrounding villages at the same time (Silva 1996:120). The other U-shaped sites recorded by Silva (1996) are much smaller in size to Huacoy and Chocas: near the coast, Pampa de Cuevas occupies just an area of $3000 \mathrm{~m} 2$ and Chiquitanta A, about 9 ha. Three other small sites are thought to have been U-shaped, but have not survived: Chiquitanta B near Chiquitanta A, Salamanqueja $500 \mathrm{~m}$ from the ocean, and Pro in the lower valley since destroyed to build a modern settlement. Finally, the small site of Pucará is the only Ushaped complex in the middle Chillón at 1000 masl; the total area of the site is less than a hectare. Stone terraces surrounding the site may have been living surfaces. Silva (1996:377; 1993) hypothesizes that Huacoy, because it is the largest U-shaped site in the Chillón, was 
home to the elites of a chiefdom society who attempted to expand their religious beliefs throughout the lower and middle valley, as reflected in the similar architectural features of the U-shaped sites, although he suggests that numerous groups may have competed for control of the temple at Haucoy. Or, they may have built their own competing temples.

Some data from the Lurín Valley, the next valley south of the Chillón, provides an example of what relationships might have existed in the Chillón at the time. The U-shaped centers Cardal, Mina Perdida, and Manchay Bajo were also simultaneously occupied, and they overlap temporally with Garagay, another monumental center in the Chillón (Burger and Salazar-Burger 1991). One hypothesis is that there were multiple coeval social groups in the lower Lurín who constructed their own public architecture; midden contents and burial goods suggest only a limited prestige status was inferred on certain individuals who led by charisma or sacred knowledge (Burger and Salazar-Burger 1991:293-294). These interpretations are in stark contrast to Pozorski and Pozorski (1987) who postulated the development of the first Andean autocratic elites who organized multiple peoples from multiple sites in the Casma Valley during the Initial Period where the sites are much bigger. But evidence in support of the Burger and Salazar-Burger hypothesis comes from Chevalier's (2002) comparison of paleoethnobotanical materials from Mina Perdida and Garagay in which he interprets little evidence for diametric opposition. Also later in time, no central unifying authority appears to be present during the Early Horizon between lower valley sites of the region: ceramic analyses of samples from Ancon and Garagay found no ceramic resource sharing or ceramic exchange between these two coastal sites 
(Druc et al. 2001), despite both having stylistic similarities derived from Chavin in the central highlands.

As the examples above show, for as much evidence as there is regarding interconnections of multiple regions from the dispersal of cultivated plants, pottery and lithic materials, there are multiple lines of evidence for cultural heterogeneity. Therefore, if El Paraíso's U-shape construction began before La Florida's, or even if the reverse, one could argue there were ideological transmissions between populations in the Rimac and Chillón Valleys, but no hierarchical structure existed. Local societies chose their own paths. This model may have continued for a number of centuries in the Chillón region after the abandonment of most of the Initial Period monumental centers around 800 B.C. (Burger 1981a), but it is necessary to note that the terminal dates of U-shaped centers in the Chillon, Huacoy and Chocas, are not known and occupations there may have continued into the Early Horizon.

\section{Early Horizon ( 800 B.C. - A.D. 250) The EMERgence of Chavín}

Toward the end of the Initial Period, many coastal sites were abandoned including Cardal and Mina Perdida (Burger 1995). The abandonment may have been rapid and dramatic; at Las Haldas, for example, Grieder (1975) uncovered a sting line for laying out construction still in place. Many of the Initial Period monumental sites in the highlands continued to thrive, especially Chavín, which flourished for several more centuries (Rick et al. 1998) and became a major ideological and political center (Burger 1995). Iconography with Chavín derived features appears in sites throughout the highlands and central coast 
on textiles, ceramics, and metal work, and shells of the thorny oyster Spondylus at Chavín attest to far reaching interregional exchange. Most of the iconography appears to be of a religious nature, suggesting the spread of Chavín style was mostly ideological, and locally independent societies were tied to a regional interaction sphere (Burger 1988, 1995; Keatinge 1981). The Chavín horizon, then, is much like the spread of new religious and ritual practices, not a political empire.

There is considerable evidence for regional social developments at this time as well. For example, in the Chillón Valley, ceramics from sites in the lower valley, near Haucoy, show most Chavín influence while middle and upper valley sites lacked ceramics with Chavín motifs (Scheele 1970; Silva 1996:378). Likewise, in the Lurín Valley, Early Horizon archaeological sites are dispersed and seemingly culturally unconnected and lacking shared pottery styles (Stothert 1980), later to be bound politically under the Lima State.

\section{EARLY INTERMEDIATE PERIOD (A.D. 250 - A.D.600)}

The Early Intermediate is characterized as a time of major transition to regional autonomous societies and the rise of states, in particular the Moche in the north, Paracas and Nasca to the south, Tiwanaku in the southern Highlands, and a possible state, the Lima culture, on the central coast. After more than a century of archaeology in Perú, little is known about the Lima culture due to the fact that many of the sites are now beneath or severely destroyed by the modern city of Lima. Its center has been suggested to be at the Maranga complex in the Rimac Valley (Moseley 1992:184) or at its most famous manifestation, the site of Pachacamac in the Lurín. Its influence can be seen by the spread 
of its distinct adobe brick architecture style and its stylistic motifs of fish and serpents with triangular heads found on white-on-red ceramics and textiles (Moseley 1992:184) found throughout the Rimac, Lurín, Chancay, and Chillón valleys.

Several sites in the Chillón contain pottery and architectural construction consistent with the Lima culture (Silva 1996). The focus of Lima power in the Chillón is thought to be at the sites of Copacabana and La Uva in the lower region near Puente Piedra (Silva 1996:384). Silva also reports several other public buildings in the middle Chillon in addition to Cerro Media Luna and Culebras (Quilter 1986; Silva et al. 1988).

\section{MidDle HoRIZON (A.D. 600 - A.D. 1000)}

The Middle Horizon is characterized by the rise of two expansive states, Tiwanaku in the Lake Titicaca Basin and Wari in the Ayacucho Valley. The Tiwanaku expanded east to the Cochabamba Valley and south to northern Chile, but only as far north as the Moquegua Valley by 600-700 A.D.(Richardson 1994:130). Wari's expansion out of the Ayacucho Valley may have been through adaptive dispersal of their very successful agricultural techniques rather than through coercive force (Mosely 1992:221). Farmers and herders at high elevations (above 3300 meters) were brought down to the quechua environmental zone (3000-3300 meters) where maize production could be maximized for the production of chicha and for tribute (Richardson 1994:133). Wari populations utilized terraces that could adapt highly inclined land to irrigation agriculture, which may have helped them and the populations in the valleys they subsumed to survive drought conditions (Erickson 1999). This feature of Wari culture undoubtedly would have helped 
them spread their influence (Mosely 1992:219). The Wari influenced the upper Mantaro Valley, in the highlands to the southeast of the Chillón, extensively in this way, helping to change the regional herding and horticulture economy to intensive agriculture (Browman 1974; Hastorf and Earle 1985). Still large portions of the region, in particular the JaujaHuancayo sector, were still dominated by pastoralism (Browman 1974:189).

In the Chillón, Wari influence does not appear to be extensive in the Middle Horizon (Silva 1996; Menzel 1977). Ceramic styles in the lower Chillón derived from Pachacamac, with Wari influences present in burials at Ancon, but most ceramic styles there appear to be related to the Chancay Valley to the north. However, one small site, Socos, in the middle valley appears to have Wari ceramics (Silva 1996:389).

\section{Late INTERMediate Period ANd Late Horizon (A.D. 1000 - A.D. 1534)}

One of the advantages of research in the Late Intermediate Period and Late Horizon is the rich ethnohistorical information contained in Spanish documents dating to 1534 and after, researched and analyzed by John Murra (1972) and Maria Rostworowski (1988, 1989). Archaeological evidence in the region also tells an interesting, story of ethnic conflict and competition for resources before the arrival of the Inka in the highlands above the Chillón. By the time the Inka arrived, the Chillón Valley was undergoing a long period of ethnic conflict, seen in the construction of numerous settlements on hillsides and hilltops with fortified walls to protect those inside (Silva 1996). The settlement pattern is common during the Late Intermediate. In the Mantaro, for example, Wanka settlement patterns shift from low-lying sites to defensible ridge tops and hillsides (Hastorf and 
Johannessen 1993). A shift in agricultural emphasis occurs as well, specializing in multiple varieties of maize for chicha production (Hastorf and Johannessen 1993). Populations appear to be growing rapidly, and there was an increase in warfare and competition for local resources (Earle et al. 1980:21).

Later Spanish documents provide a glimpse into the conflicts between groups in the Chillón in the centuries before the Spaniards arrival and these documents uniquely record the histories of peoples in the Chillón region under Inka control and the years preceding the Inka expansion into the valley (Murra 1972; Rostworowski 1989). A group known as the Quivi inhabited the lower sierra of the upper Chillón valley. This area, as it is today, was an important ecological zone for growing valuable crops, especially coca. The region was contested and negotiated over by at least two rival kingdoms, the Collique who occupied the lower valley, and the Canta in the upper highlands of the valley. A third group, the Chacalla, highland peoples living just south of the Canta, also had access to the coca lands. Just, prior to the arrival of the Inka around $1470 \mathrm{AD}$, the Quivi had fallen under the control of the Collique kingdom. Military pressure from highland groups wanting greater access to the Quivi lands forced the Collique to cede some of the Quivi lands to the Canta kingdom and their neighbors, the Chacalla (Rostworowski 1989, Murra 1972, Netherly 1988). The Collique ceded parcels of the land in order to retain some access to the Quivi region, rather than lose it outright to a highland takeover.

The Collique kingdom retained much of its control over the lower valley inhabitants, however. Archaeological surveys of the valley have shown that ceramic variability, specific types and styles, are shared among the lower valley sites during this 
period, but the same cannot be said for the upper valley sites (Dillehay 1979). In the middle and upper valley, ceramic types represented in these sites are more variable and bear links to highland types. This suggests that although the Collique controlled much of the lower valley and large portions of the mid valley, the inhabitants of the mid-valley may have had simultaneous and advantageous alliances with highland groups (Dillehay 1979).

The arrival of the Inka to the region added yet another claim to the lands of the Quivi. Having defeated the Collique kingdom in the lower valley, the Inka seized the parcels of Quivi land held by the Collique and parcels of the Canta in the name of Topa Inka Yupanqui, the 10th Inka ruler (Rostworowski 1989, Netherly 1988, Silva 1996). The Inka were ruthless in their conquest, killing nearly all of the original inhabitants of Quivi Rostworowski 1989; Silva 1996). The final blow came as the leader of the Quivi, accused of conspiring against the Inka, was taken prisoner and executed in Cusco. For greater punishment, the Inka killed all of the remaining males of Quivi leaving only a few women and children.. The Inka sent mitmae - populations of people from one area sent to work in another in order to provide the Inka state tribute - to the Quivi lands to replace the labor they executed, and sent a representative from Cusco to supervise them. Strategically playing off of the old ethnic conflicts, the Inkas chose mitmae from Chacalla, who, already aligned with the Inka, could the have full access to the Quivi lands and, in turn, provide the Inka with supplies of coca, chili peppers, peanuts, and manioc (Rostworowski 1989;Silva 1996. This scenario continued through Topa Inka Yupanqui's successor, Huayna Capac. 


\section{Summary: The CUltural Setting OF BUENA Vista}

The Central Andes region is rich with archaeological opportunities. As in all things archaeological, there are far more questions than answers, and this predicament, opportunity, really, is apparent in the early attempts at creating a chronology for the region. New information and techniques are always forthcoming, and in true scientific fashion, these require archaeologists to continually shape and reshape theoretical positions. For example, the presence of large inland sites of the Supe region does not fit well into Moseley's original version of the Maritime Foundations of Andean Civilizations. As such an example, the significance of Caral, and other even earlier large inland sites, requires archaeologists to re-examine the role of agriculture in the development of complex society on the coast of Perú. On a social level, new questions about the role of the inland sites are now open to investigation and debate. How are Buena Vista and El Paraíso socially, culturally, and ideologically related? Or are they not? Are elites present, if so, just how elite were they and how did they lead? These questions will be addressed, to various degrees of satisfaction, with paleoethnobotanical data from Buena Vista. In the time that followed Buena Vista's, and El Paraíso's, occupations, the region cycled through periods of ideological unity and social contrasts to stark ethnic divisions culminating in violence and warfare. It is likely that some of these patterns have roots in the Late Preceramic and earlier and with this in mind, our answers to the questions above can be informed. 


\section{Chapter Five - Archaeology at Buena Vista}

\section{BACKGROUND OF EXCAVATIONS AT BUENA VISTA}

Frederick Engel (1976) first recorded the Buena Vista site in his survey of the coastal valleys of Perú. Many years later, Bernardino Ojeda, an archaeologist who worked for Engel at the Centro de Investigaciones de Zona Aridas (CIZA) in Lima, recommended to Robert Benfer, a longtime collaborator with Engel and Ojeda, that the Buena Vista site should be investigated further as a potential sister-site to El Paraíso in the lower part of the valley. Bernardino Ojeda had made the first excavations at the site with Engel. Having an early date contemporaneous with El Paraíso, the site was thought to be an inland satellite of a large population center on the coast (Engel 1976; 1987). However, very little was known about the site, and at least one previous survey only recorded the Late Intermediate ruins in the northeastern portion of the site, despite the thick adobe walls visible from the surface immediately to the south, and despite Engel's radiocarbon date (Table 5.1) placing part of the site in the Late Preceramic period (Engel 1976). Bernardino Ojeda, Robert Benfer, and I visited the site in 2001. A previous excavation, possibly Engel's but this is not certain, uncovered part of the western portion of the temple mound and exposed a wall with a series of stair-shaped niches (Figure 5.1). Engel's notes refer to Buena Vista as Los 
Frisos, in reference to these niches, a minor misnomer. Apart from this professional excavation at Buena Vista, surreptitious looting has left many scars.

Table 5.1 Radiocarbon dates discussed in text.

\begin{tabular}{|c|c|c|c|c|c|}
\hline $\begin{array}{l}\text { Field } \\
\text { Sample\# }\end{array}$ & Lab \# & Provenience & $\begin{array}{l}\text { Radiocarbon Age } \\
\text { B.P. }\end{array}$ & $\begin{array}{l}\text { Calibrated } \\
\text { Range* B.C. }\end{array}$ & $\begin{array}{l}\text { Rounded } \\
\text { calendar } \\
\text { years }\end{array}$ \\
\hline Engel* & PI-1845 & B-10 & $3390+/-70$ & $1880-1520$ & 1700 B.C. \\
\hline 02.10874 & GX-29935 & B-10 Lintel from M-8 & $3290+/-80$ & $1750-1410$ & 1580 B.C. \\
\hline BXI-073 & GX-31276 & $\begin{array}{l}\text { B-10, F-1, Level } 300 \\
\text { sunken pit charcoal }\end{array}$ & $3770+/-80$ & $2,460-1,980$ & 2,220 B.C. \\
\hline BXI-099 & GX-32177 & $\begin{array}{l}\text { B-10, F-1, Level } 425 \\
\text { sunken pit charcoal }\end{array}$ & $3790+/-80$ & $2,470-2,020$ & 2,220 B.C. \\
\hline 13.10832 & GX-29940 & $\begin{array}{l}\text { C-4 base of wall, } \\
\text { charcoal }\end{array}$ & $7750+/-100$ & 6640- 6456 & 6548 B.C. \\
\hline 13.11457 & GX-30695 & $\begin{array}{l}\text { C-6 F-1, Level 250, } \\
\text { charcoal }\end{array}$ & $3600+/-50$ & 2060-1870 & 1,940 B.C. \\
\hline
\end{tabular}

*Lawn, B. (1974) University of Pennsylvania Radiocarbon Dats XVII. Radiocarbon 16(2):219-237.

Calibrated age range based on 2 sigma with highest relative area under probability distribution (McCormac et al. 2002)

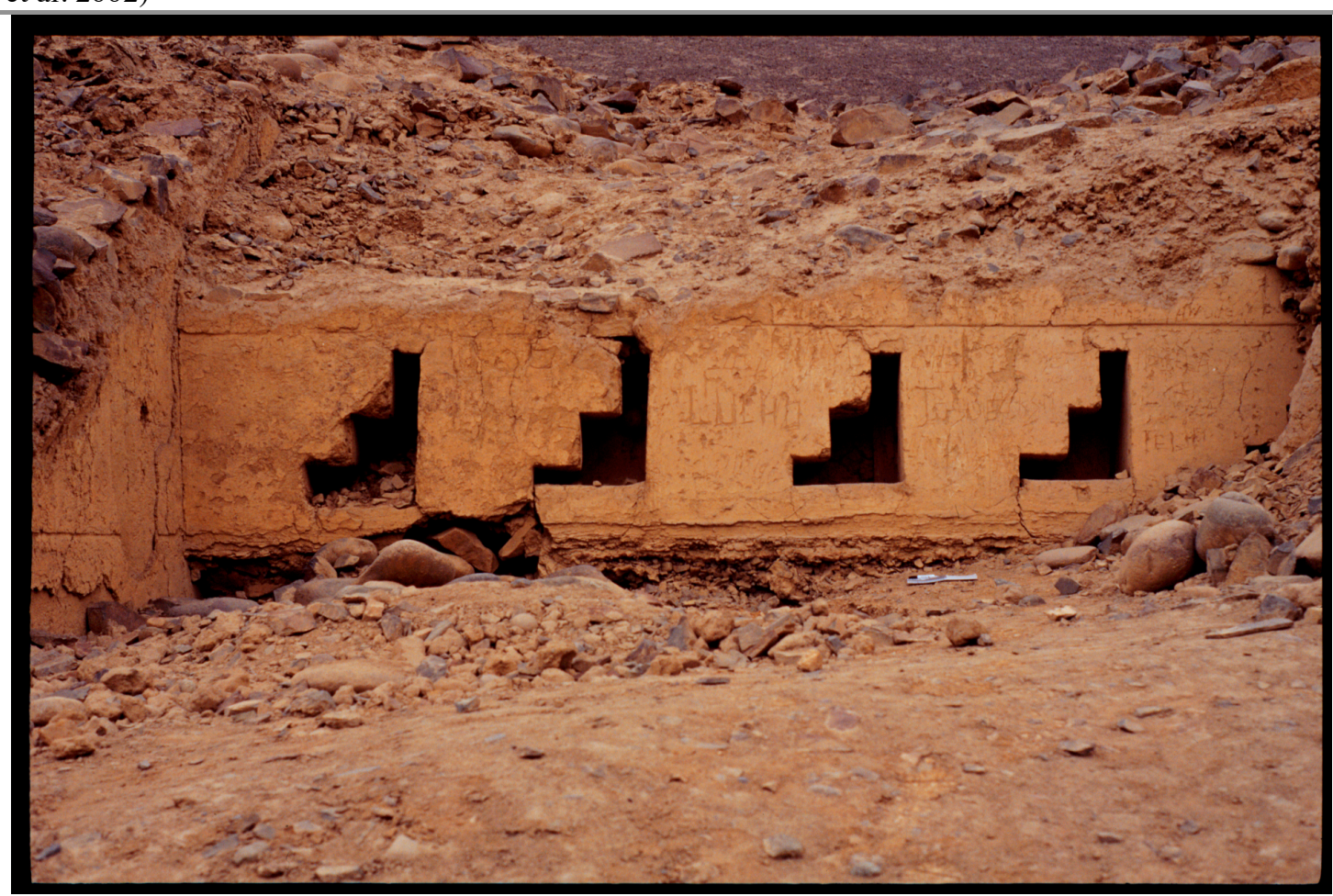

Figure 5.1 Wall M-17 at Buena Vista with eight-sided stair shaped niches exposed presumably by Engel in the early 1970s. Vandalism has damaged the surface and looting activity significantly undercut the wall's northern end. Photo: N. Duncan 
The looting activity at Buena Vista has been indiscriminately widespread and evidence of freshly looted contexts was easy to spot in 2001 and again until 2004. Since then, looting has abated. Most damaging, however, was the construction of a large concrete cistern and the use of a bulldozer to raze and level a $75 \mathrm{~m}$ by $20 \mathrm{~m}$ swathe on the western edge of the site (Figure 5.2). Yet, even though damage is extensive, we considered the site to have great potential. We returned to the site again in 2002 with a small crew and mapped much of the architecture visible on the surface, and opened several test units in both the Preceramic and Late Intermediate sectors of the site. Descriptions of these excavations are available in the preliminary report filed to Perú's Insitituto Nacional de Cultura (Benfer et al. 2004). These test excavations only seemed to scratch the surface of a complex site with multiple building events and overlapping contexts. Therefore, in 2003 and again in 2004, field schools were organized through the University of Missouri in conjunction with the Universidad Nacional Federico Villarreal and the Centro de Investigaciones de Zonas Áridas de la Universidad Nacional Agraria, to execute larger area excavations with the added benefit of providing students with a rare opportunity to excavate in such a unique context. Other student volunteers were welcomed and came from the Universidad Nacional Mayor de San Marcos. Benfer has continued excavation in the Preceramic sectors of the site from 2005 and on, but now focuses on finding additional reference points for astronomical alignments (Benfer and Adkins 2007; Benfer et al. 2009; Adkins and Benfer 2009).

The contrast in architectural styles of the visible ruins on the surface give one the impression that Buena Vista is actually two sites right next to each other and, in a sense, 


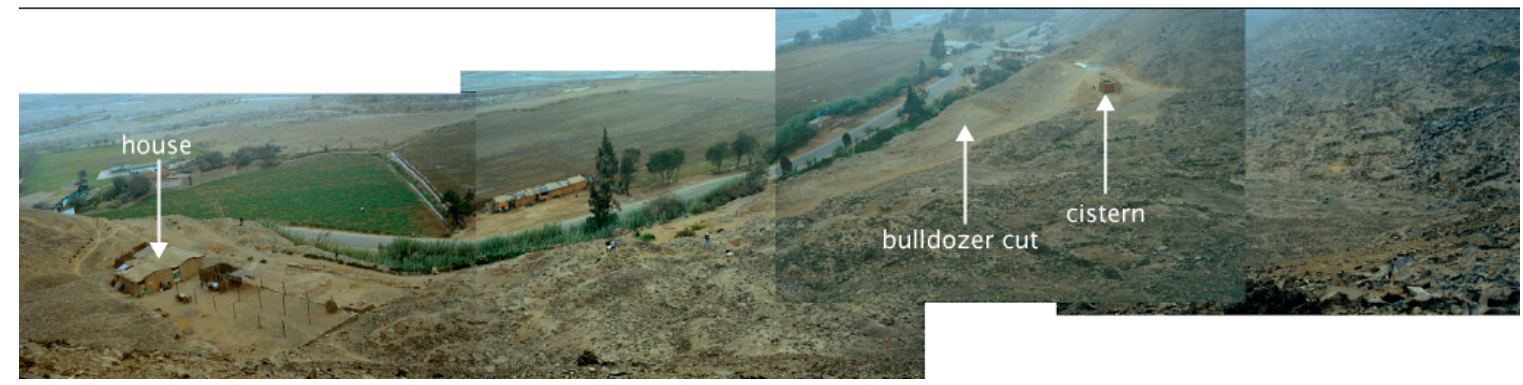

Figure 5.2 Composite photo of the Buena Vista site. Photo taken from the hillside on the southeast, facing north. The bulldozer cut and modern cistern are labeled. Also, a modern house on a recent raised platform is visible on the left. Photo: N. Duncan

this is true (Figure 5.3). Massive adobe walls, some a meter thick or more, abutting to right angles of large square rooms are still visible on the surface in the eastern and southern sectors of the site. Here, the architecture follows formal rules and an orderly layout. To the east, rocks that once formed the bases of walls follow the contours of the hillside in freeform fashion that suggests no pre-planning was followed. These two contrasting areas formed the basis of how the site would be sectioned off according to intra-site boundaries based on cultural features, temporal distinctions, or geographical areas as Sector A, B, C, and so on as indicated in Figure 5.3. The boundaries between these arbitrary sectors are fuzzy and sometimes elastic, in that they can expand and contract as the testing progresses. During fieldwork, they also served the purpose of quick and easy reference to areas of the site where crews are undertaking simultaneous excavations. Nevertheless, the sector system requires some explanation before proceeding with a description of the excavations in Sectors B and C, the focus of this dissertation. 


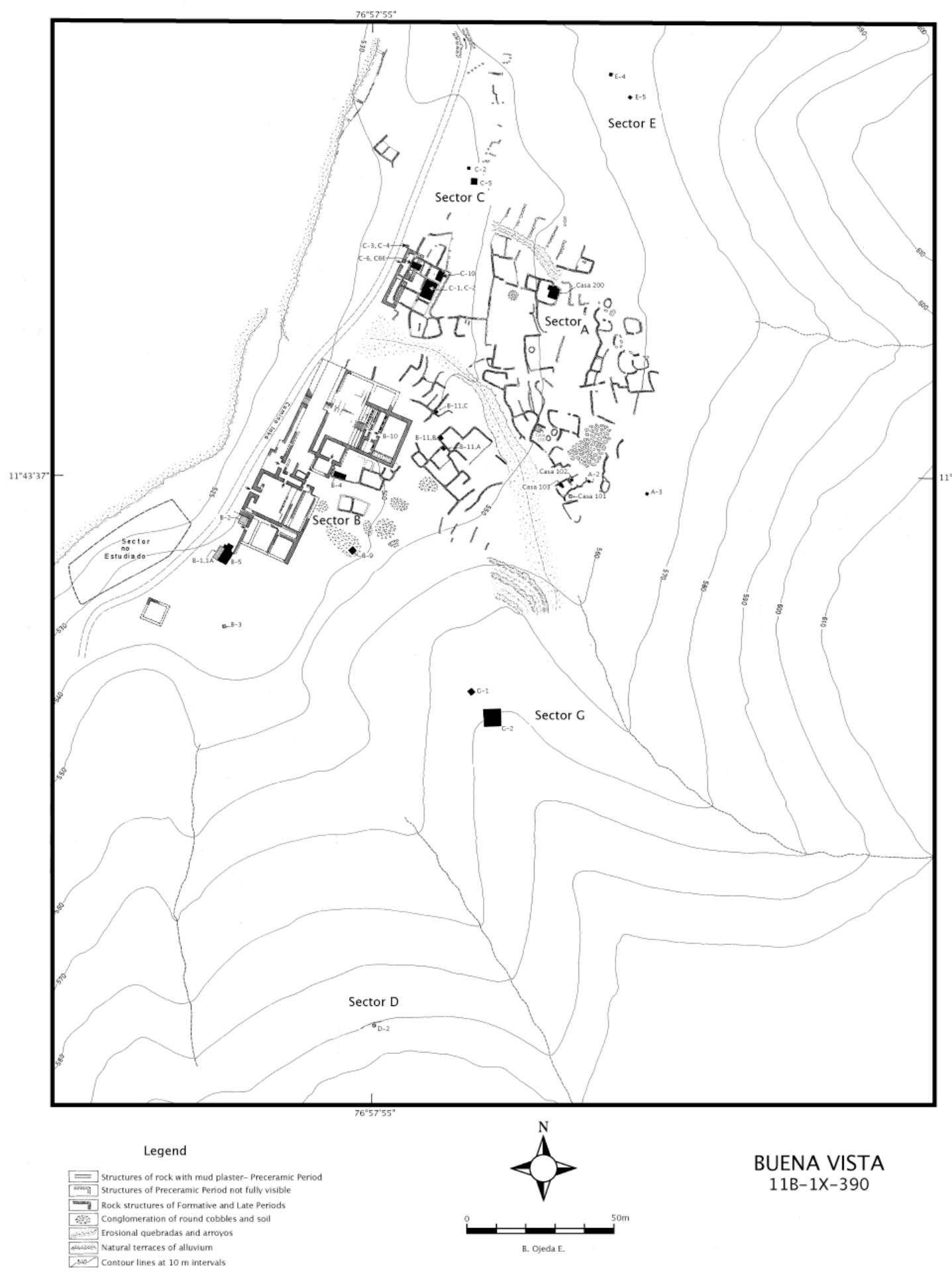

Figure 5.3 Plan view of Buena Vista. Map: Bernardino Ojeda 
Sector $\mathbf{A}$ contains much of the northeastern portion of the site containing Late Intermediate period architecture. As described above, the rock wall bases can still be seen on the surface. Several test units were located here to provide a cultural and temporal context for this later occupation. Looters have dug out a number of human burials, at least two of them from stone-lined pits in this area. Test units in 2002 and 2003 were positioned in several of the domestic enclosures of Sector A.

Sector $\mathbf{B}$ and Sector $\mathbf{C}$ are the main contexts in this report and are discussed in more detail below. Sector $B$ includes the bulk of the large monumental architecture on the western edge of the site. Sector C is located just to the north of Sector B. Formally arranged, thick adobe walls are present in this area again, with a similar orientation to the architecture Sector B. An alluvial wash of gravel from the slope above (visible on the map (Figure 5.3) separates these two sectors. Likely occurring during an exceptional rainfall event sometime between the abandonment of the monumental architecture and the Late Intermediate re-occupation, the alluvium covers portions of adobe architecture beneath it between Sectors B and C. None of the Late Intermediate architecture appears to have been affected by this event, rather some of the architecture conforms to the topographical changes the landslide brought about.

Sector $\mathbf{D}$ is located on the extreme southern end of the site, on the hillside $60 \mathrm{~m}$ above the site's center where reconnaissance noted several rock-outlined terrace platforms. Two small test units, totaling $14 \mathrm{~m}^{2}$ were excavated there in 2002 and 2003. One unit (D-2) uncovered a small circular hearth with domestic refuse and undecorated ceramics. The remains of peanuts, maize, mussel shells, bird bones, camelid fur, and cotton 
thread were also collected here. Radiocarbon dates of this area are pending, but the domestic contexts excavated in this sector do not appear to be temporally related to the structures in Sector A on the hillside to the north.

Sector $\mathbf{E}$ has a rather ambiguous outline, but it generally incorporates the northernmost portion of the site. It includes the small terraces on the west-facing hillside above Sector A, and the north end of the bulldozer cut, but also refers to the northernmost structures associated with the Late Intermediate architecture. The terraces on the hillside suggested the presence of domestic units there, though no structural remains are visible on the surface. Two small $1 \mathrm{~m}^{2}$ test units were placed in two of the terraces. Ten centimeters or less of fine silty soil gave way to yellowish clayey, culturally sterile soil below. One plain ceramic sherd was found in one of the units near the surface. The terraces may have been used for temporary campsites, but lack charcoal and food remains. Alternatively, the terraces are agricultural, but could only have been used in extremely wet ENSO cycles, since no evidence of irrigation is present.

Sector $\mathrm{E}$ also refers to the area at the north end of the bulldozer cut, where damaged adobe architecture is visible below. Two small test units were opened in this area. The first unit (E-2) exposed portions of a broken plastered floor and partially exposed an adobe wall damaged by the bulldozer. The second unit (E-3), $4 \mathrm{~m}^{2}$, was placed at the top of the bulldozer-cut adjacent to the modern cistern constructed on the site. A damaged prehistoric wall is visible in the bulldozer cut, next to which I collected several artifacts eroding out of the profile, three shell, and one tooth, pendants (Figure 5.4). The test unit was excavated down to the top of the wall in the profile of the bulldozer cut. Plain pottery, 
maize, lucuma, peanuts and a large amount of mollusk shells were present in the first 40 $\mathrm{cm}$ of fill, then only an occasional mollusk shell or fragment of lucuma pit in the $20 \mathrm{~cm}$ of fill above the level of the rock wall.

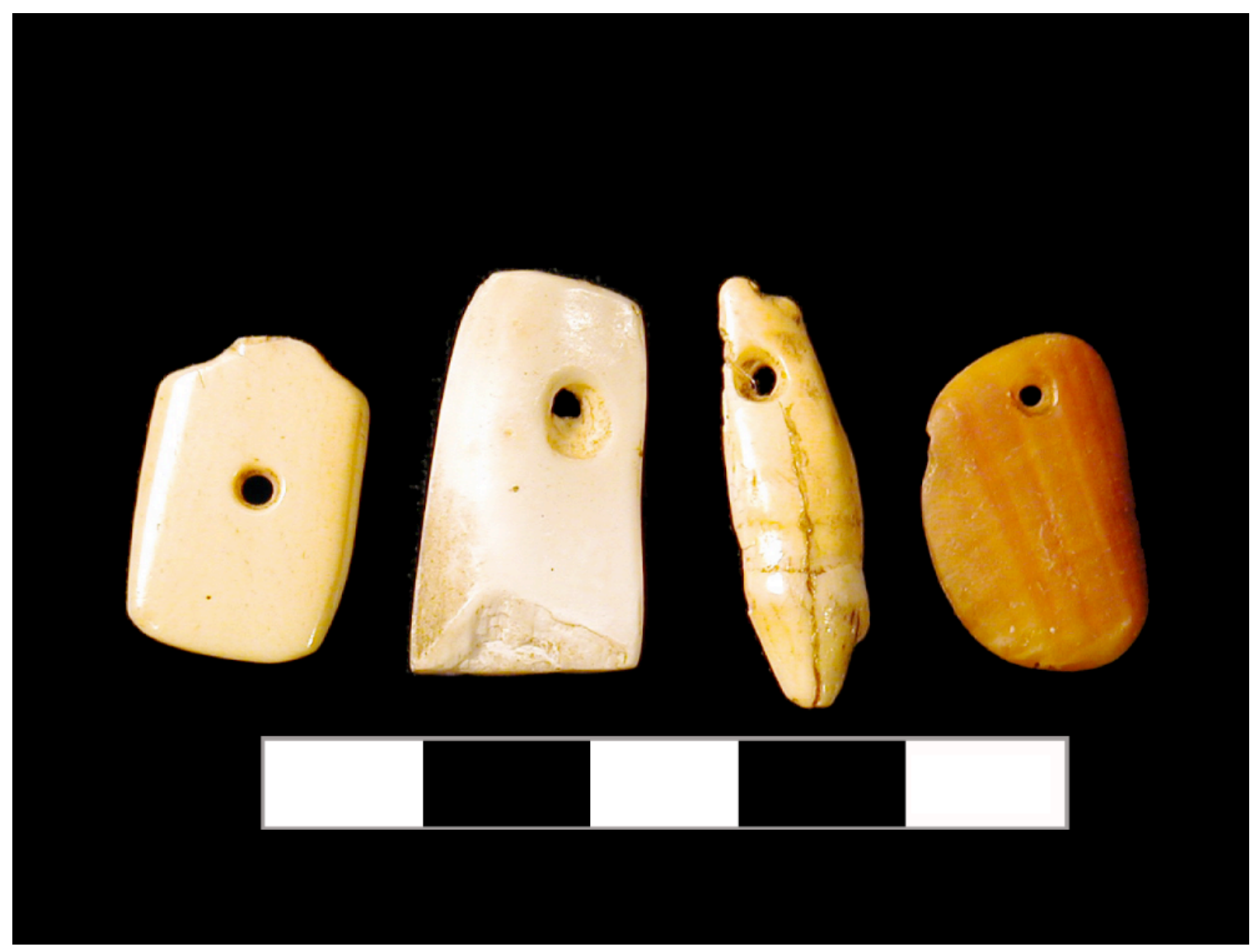

Figure 5.4 Pendants recovered from bulldozer cut. Three are made of shell but the second from right is made from a mammal tooth, possibly pinniped. Photo: N. Duncan

Unfortunately, we cannot accurately assess the extent of the damage the bulldozer caused, but it is clear from the limited test units here that a significant portion of the site was irreparably compromised. The impacted area was razed and leveled years before our archaeological investigations commenced, and no record of the area prior to the damage is known. Although, it is highly likely that intact architectural features below the surface of 
the damaged area still exist. This area most likely is temporally associated with the adobe architecture in Sectors B and C.

Sector $\mathbf{F}$ (outside the area mapped in Figure 5.3) is located some $120 \mathrm{~m}$ in altitude above the center of the site on the same hillside above Sector D, near the crest of the westrunning ridge of Cerro Puente de Trapiche. This area contains several platforms adjacent to large outcrops of boulders. One unit was excavated, $2.5 \mathrm{~m}^{2}$, but recovered no cultural material. It is likely that these platforms are natural terraces.

Sector $\mathbf{G}$ comprises the top of the knoll immediately to the southeast of the main portion of the site where several rock wall-bases are visible on the surface. Also found in the area were several large grinding stones and grinding stone fragments. Two units were designated, but only one unit, G-1 at $4 \mathrm{~m}^{2}$, was excavated within one of the structures. Excavators recovered undecorated pottery sherds and a large amount of plant and animal remains. Maize, beans, peanuts, lucuma, and gourd fragments were collected. The presence of pottery, maize, and peanuts indicates these structures are not contemporary with the adobe architecture at the bottom of the knoll.

\section{Archaeological Context of Sector B, Unit B-10: The Fox Temple}

Before describing the excavation of Unit B-10, I would like to put the architecture exposed during the excavations into a hypothetical temporal context. Sector B comprises the earliest and most elaborate architectural sequence at Buena Vista (Figure 5.5). Standing at the western edge of the site, looking to the southeast, one would see the artificial mound of walls and rubble fill rising nearly twenty-five meters above at the base of the rapidly sloping Cerro Puente de Trapiche in the background. Walking the surface of this mound, one 
would see the remains or the adobe walls outlining large rooms ten meters long, the remains of stairways, passages, and where looters uncovered buried floors and exposed layers of multiple events that built the mound. The sequence of construction is quite complex and the number of different events that took place is still unknown and difficult to correlate within different areas of Sector B. Like other monumental sites of this time, the early architecture was modified or filled in, leveled off, then new architecture built on top, then the sequence was repeated some years later. Our first excavations in Sector B were an attempt to uncover a sequence of events and gain a better understand the chronology of construction phases in order to temporally associate different rooms, walls, and features within the complex.

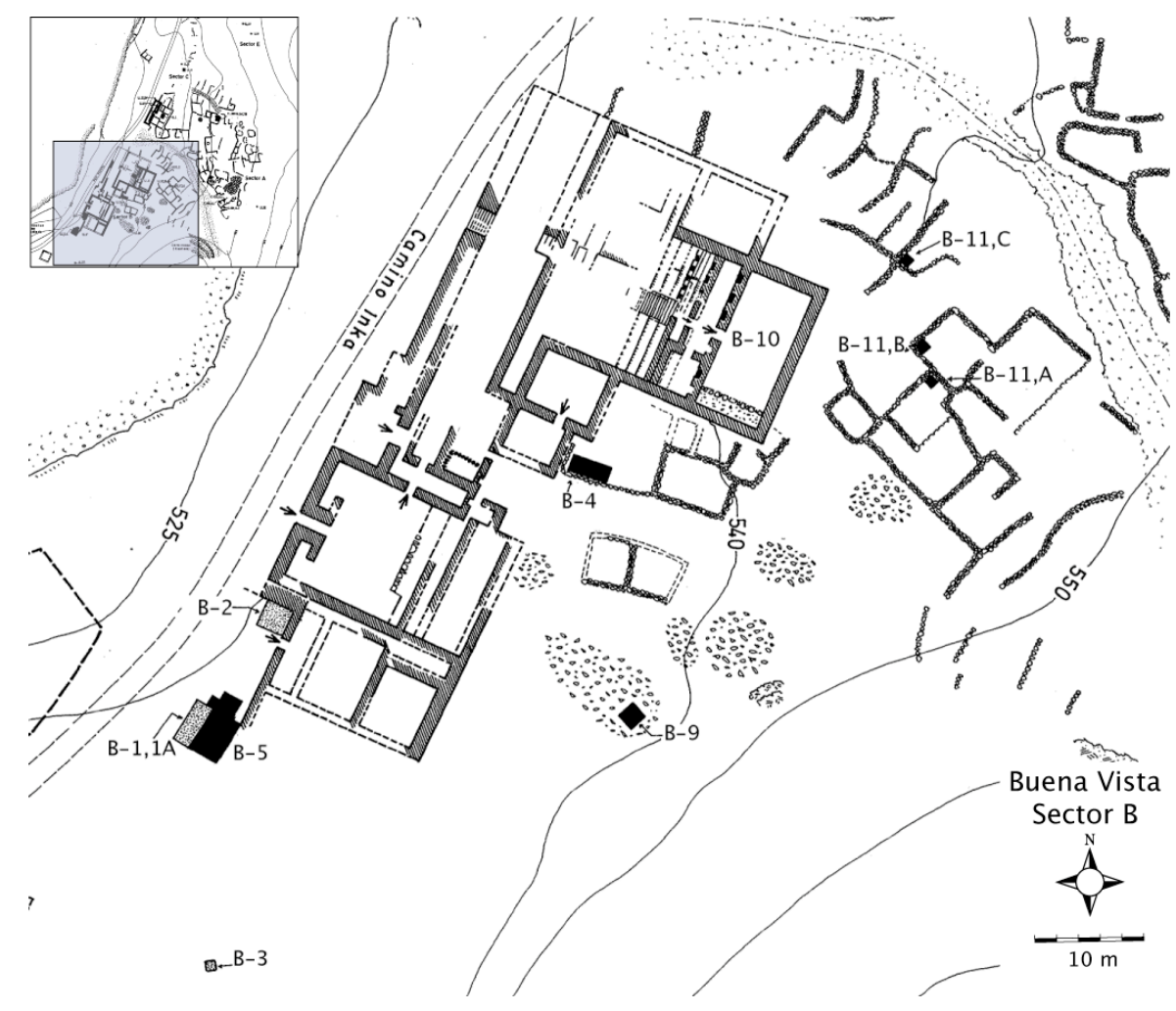

Figure 5.5 Detailed plan view of Sector B and excavated units. Map: Bernardino Ojeda 


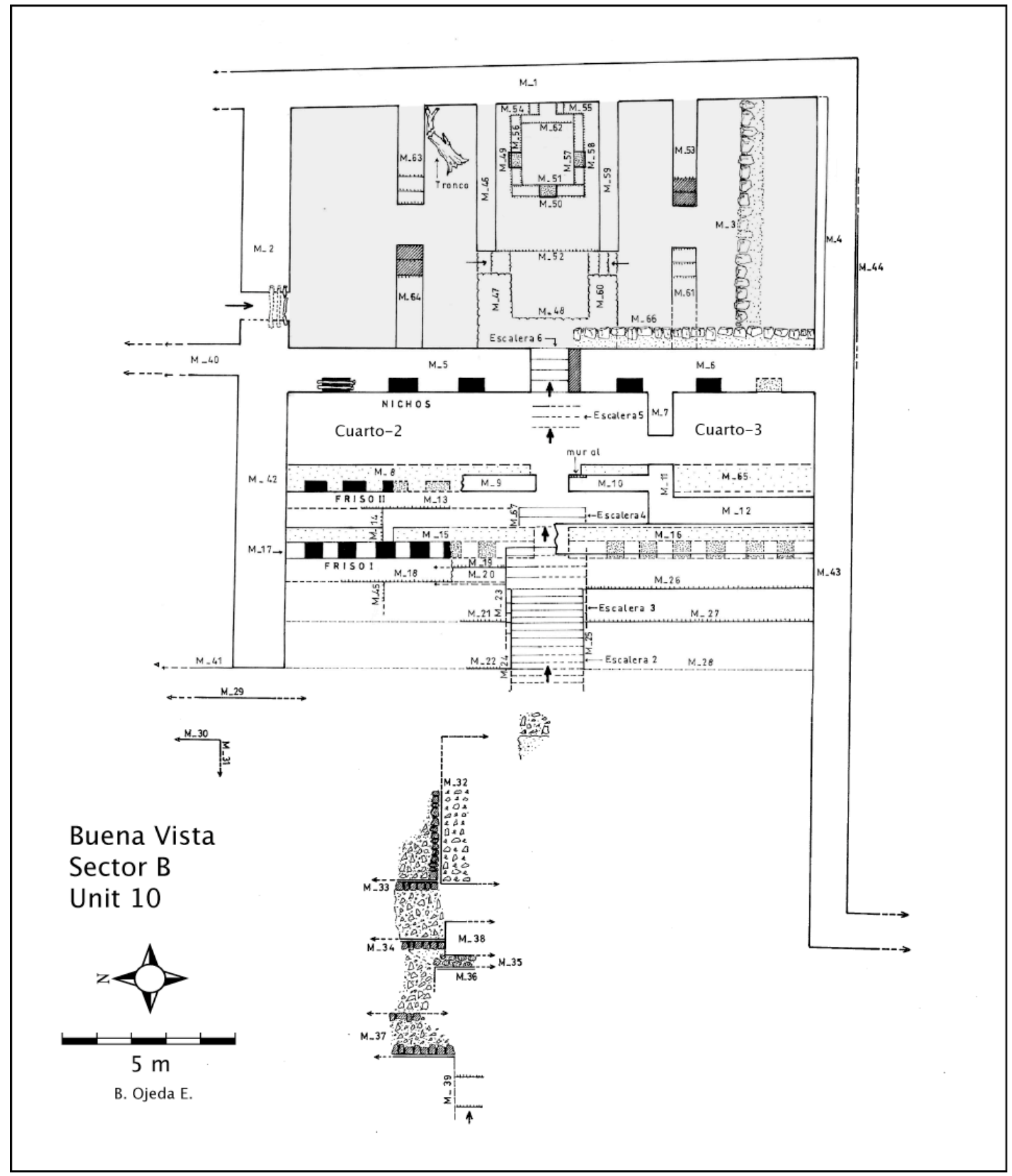

Figure 5.6 Plan view of Sector B, Unit 10, the Fox Temple. The Gran Sala at the top of the Fox Temple is shaded in gray 


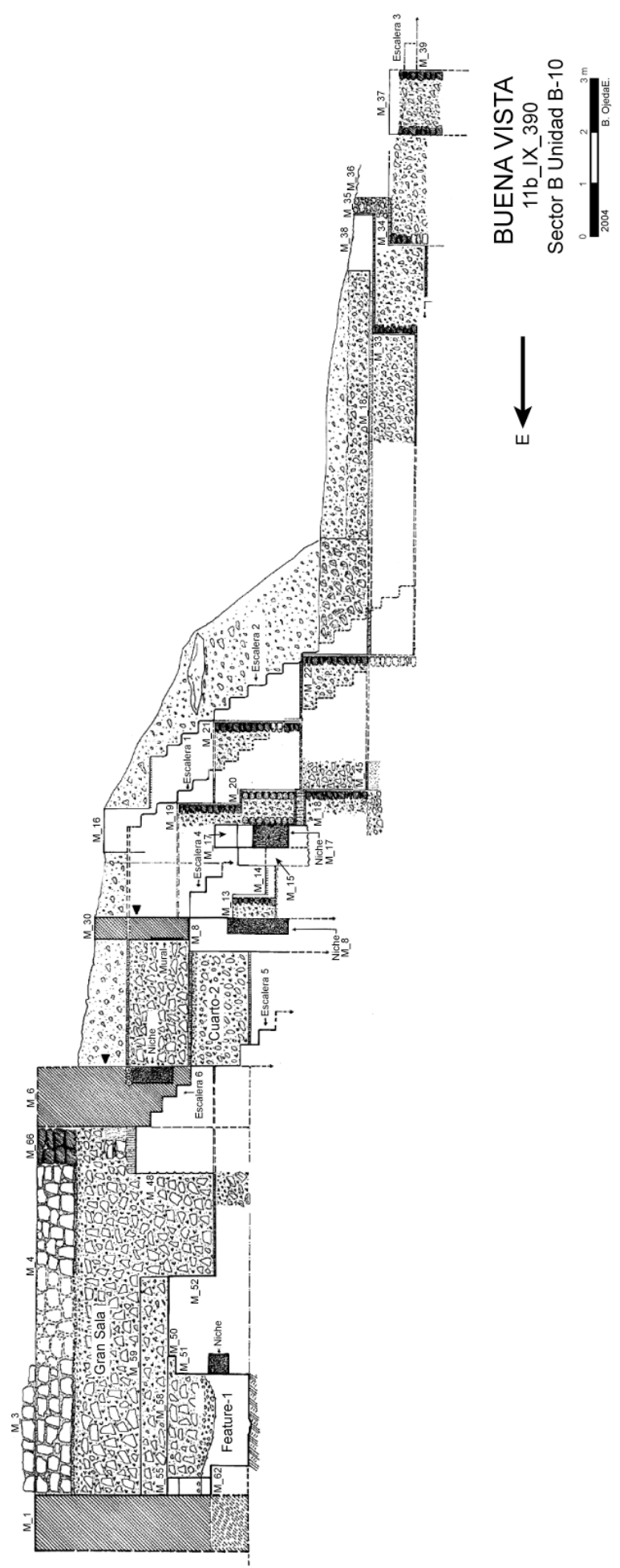

Figure 5.7 South-facing profile of Sector B, Unit 10, the Fox Temple. Map: Bernardino Ojeda 


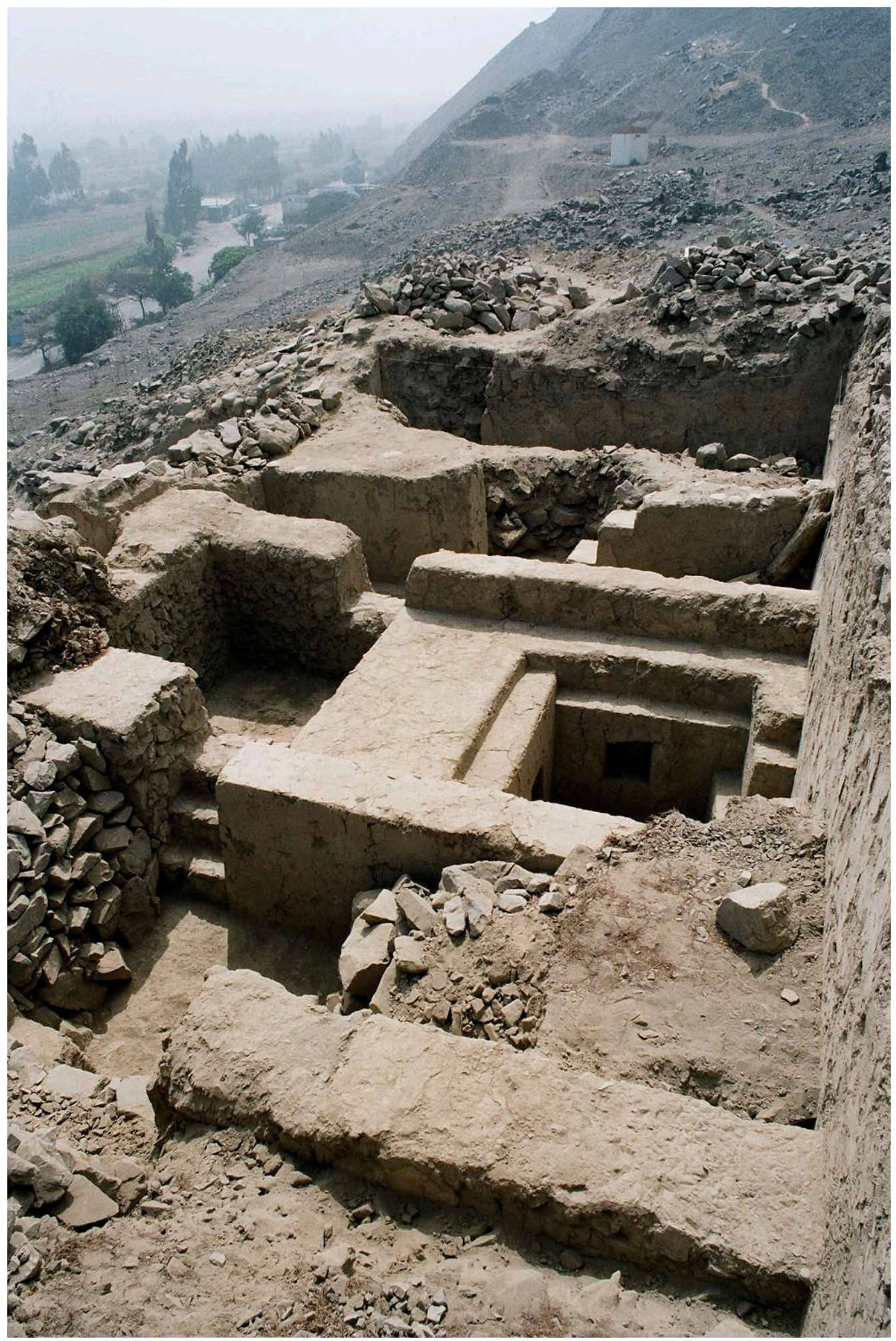

Figure 5.8 Photo of the Gran Sala, partially excavated, facing northwest. The raised platform with sunken pit can be seen at center-right. Note two niched walls of the pit are visible. Photo: Elisa Peterson 
In Sector B, a large area of excavation is collectively labeled Unit B-10, part of the architecture referred to as the Fox Temple (Benfer et al. 2007), within which smaller test units were opened prior to expanding the excavation in the area (Figures 5.5 and 5.6). These units include B-3, B-7, B-6, and B-9. During the 2003 field season, we focused our attention on the area to the west, encompassing the wall with the stair-shaped niches. The large room, the Gran Sala in gray in the plan view (Figure 5.6), was excavated in 2004. This is the room containing the sunken pit and is one of the earliest constructions at the site. From our excavations, we can propose a sequence of building events that ensued. Figures 5.6 and 5.7 show the walls and features discussed in the following paragraphs.

The first construction in B-10 was likely the walls surrounding the Gran Sala, labeled M-1, M-2, and M-4. These walls are up to $1.4 \mathrm{~m}$ thick and over $4.85 \mathrm{~m}$ high where not damaged at their tops. The Gran Sala is a large rectangular room measuring about 15.5 meters long and between 7 and 7.5 meters wide. It had at least two entryways, one in the center of the east walls, M-5 and M-6, and one on the north wall, M-2, near the northwest corner. On the floor of the north entrance, fragments of huarango (Prosopis sp.) and sauce (Salix sp.) were found that might have served as the header for the entranceway. It is possible a third entrance on in the southeast corner exists as well, but our excavation in the Gran Sala did not extend to the its southern wall, since it was below the base of an Initial Period wall, M-3, that runs east-west in the southern quadrant of the room (Figure 5.7). On the floor of the room, flanking either side of the central platform, two pairs of east-west walls nearly $2 \mathrm{~m}$ high protrude toward the central axis of the room but leave about a120 $\mathrm{cm}$ space between their ends. They effectively sub-divide the north and south halves of the 
room, leaving a passage way open between them. The end of each wall was constructed in a step-shape fashion, but in a kind of dual reflection, the stepped ends of two of the walls are concealed so that each opposite wall is different.

In the center of the Gran Sala lies a small platform, approximately one meter high, about $4 \mathrm{~m}$ wide and $4.3 \mathrm{~m}$ long with two "wings" along the north and south edges rising 50 $\mathrm{cm}$ above the top and connected to the main east wall (see Figure 5.8). At the east end of the platform, a square pit, $1.6 \mathrm{~m}$ wide by $2 \mathrm{~m}$ long descends $1.6 \mathrm{~m}$ from the top of the platform. During excavations, this pit was labeled Feature-1 of Unit B-10, but this is also the feature referred as the sunken pit. The pit is distinctly ornate, built with square, $50 \mathrm{~cm}$, niches in the south, west, and north walls of the pit. The east wall of the pit exhibits a rectangular niche opened at the top. At the base of the pit, a central circular-shaped ridge of plaster is visible, and may be a symbolic hearth, but lacks any evidence of fire damage. The excavation of this feature is detailed below.

Directly to the west of the platform in the center of the Gran Sala, a construction of walls, M-47, M-48, and M-60, create a square room with two steps leading down on each of the east-west walls. The room created by these walls is a later edition, hastily built. The walls are constructed of large rocks and mud mortar but not finished with a plaster surface, unlike the rest of the walls in the Gran Sala. Likewise, the rubble that filled the small room was different than the rock-fill and shicra of the Gran Sala, the fill contained smaller loose rock and gravel as well as cotton textile fragments and Initial Period ceramics, which were entirely absent in the fill of the Gran Sala. It appears that this room was constructed just prior to the interment of the Gran Sala and left open for some time, to be filled later. 


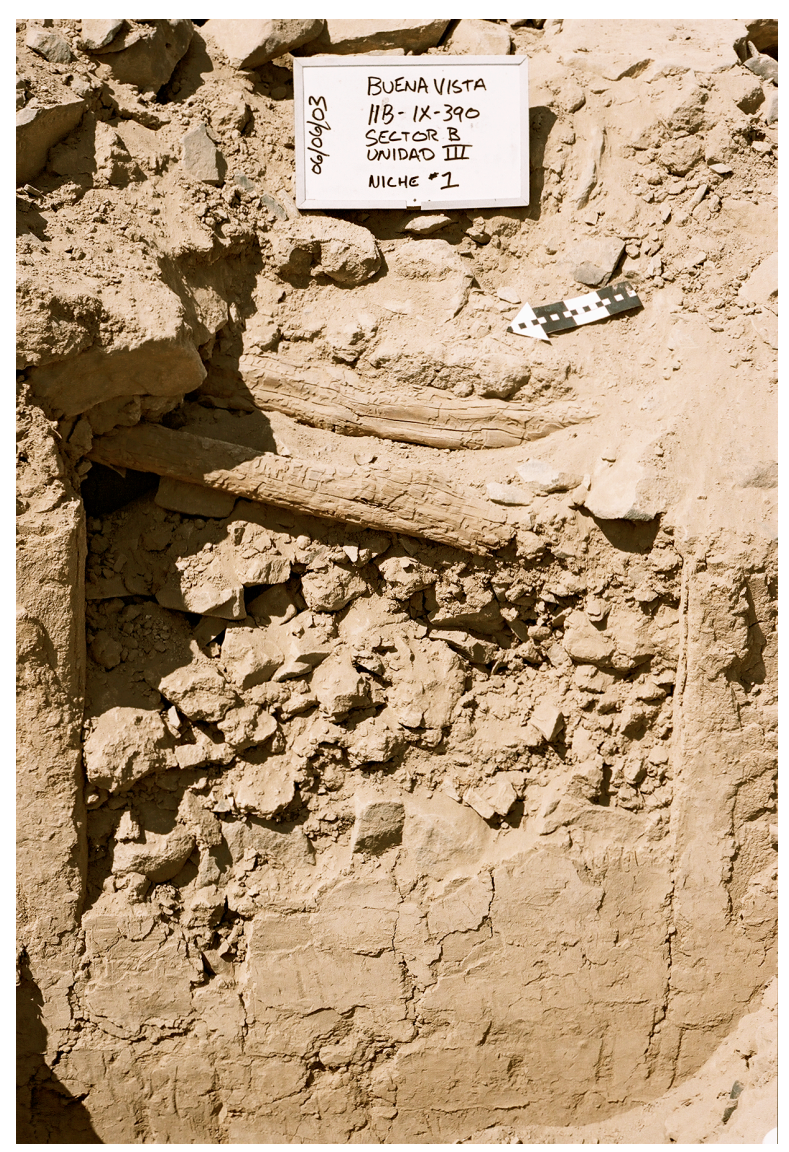

Figure 5.9 Photo of lintel from wall M-6 in Unit B-10. The lintel was radiocarbon dated to 1580 cal BC.

Walls M-5 and M-6 form the $1 \mathrm{~m}$ wide, entranceway into the Gran Sala. On their western faces, a series of three, square niches, $80 \mathrm{~cm}$ x $80 \mathrm{~cm}, 40 \mathrm{~cm}$ deep, decorates each of the walls. The niches appear to have been repaired or remodeled and filled-in at least once. The niches are built into the plastered rock wall and supported by lintels of wood from sauce (Salix sp.) and huarango (Prosopis pallida). Looters prior to our excavation exposed one of the lintels, shown in Figure 5.9. This lintel from the northernmost niche in M-5 was radiocarbon dated to 1525 cal B.C. (GX-29935: 3290+/-80 B.P.). This post-dates the fill of the sunken pit in Gran Sala (see below). Despite the renovations of the mound, it appears 
the niches were probably filled-in and plastered over in this wall during the Initial Period occupation of the site.

The walls, M-5 and M-6, parallel walls M-8 and M-65 and created a narrow $2 \mathrm{~m}$ wide antechamber to the west of the Gran Sala (built before walls M- 7, 9, 11, 12 enclosed Cuarto-3). Wall M-8 is likely temporally related to walls M-5 and M-6 east of it. The original stairway, Escalera-5, led up to the Gran Sala probably from a floor at the base of the antechamber between the walls of M-5,6 and M-8,65, however our excavations only partially exposed the stairway and its actual depth is unknown. The western face of M-8 also displays niches, but these have a different design than the square niches of M-5,6 (Figure $5.10 \mathrm{~A}, \mathrm{~B})$. The niches in $\mathrm{M}-8$ are tall step-shaped, eight cornered, and about $65 \mathrm{~cm}$ wide by $1.16 \mathrm{~m}$ tall. Inside the niche second from the north, graffiti of intersecting lines was drawn, and on the side of the niche, animal representation, probably a llama, was sketched (Figure 5.10 C). Our excavations up to 2004 only uncovered three of the niches on the northern portion of the wall, but later excavation revealed that the niches continue along the southern counterpart, M-65, on the other side of the entranceway into Cuarto-2 (Benfer, personal communication). At some point, Escalera-5 and the antechamber was filled in and a plaster floor laid atop the fill, approximately $1.5 \mathrm{~m}$ below the base of the square niches in M-5,6. Also, it is unknown to what depths a floor exists in front of M-8, the western side, due to the building renovations that took place after its construction. Nevertheless, it appears that the earliest construction of the mound created a step-like platform mound. A platform probably existed in front of M-8 with the tall step-shape niches, stepping up to a platform behind it to wall M-5 and into the Gran Sala. 

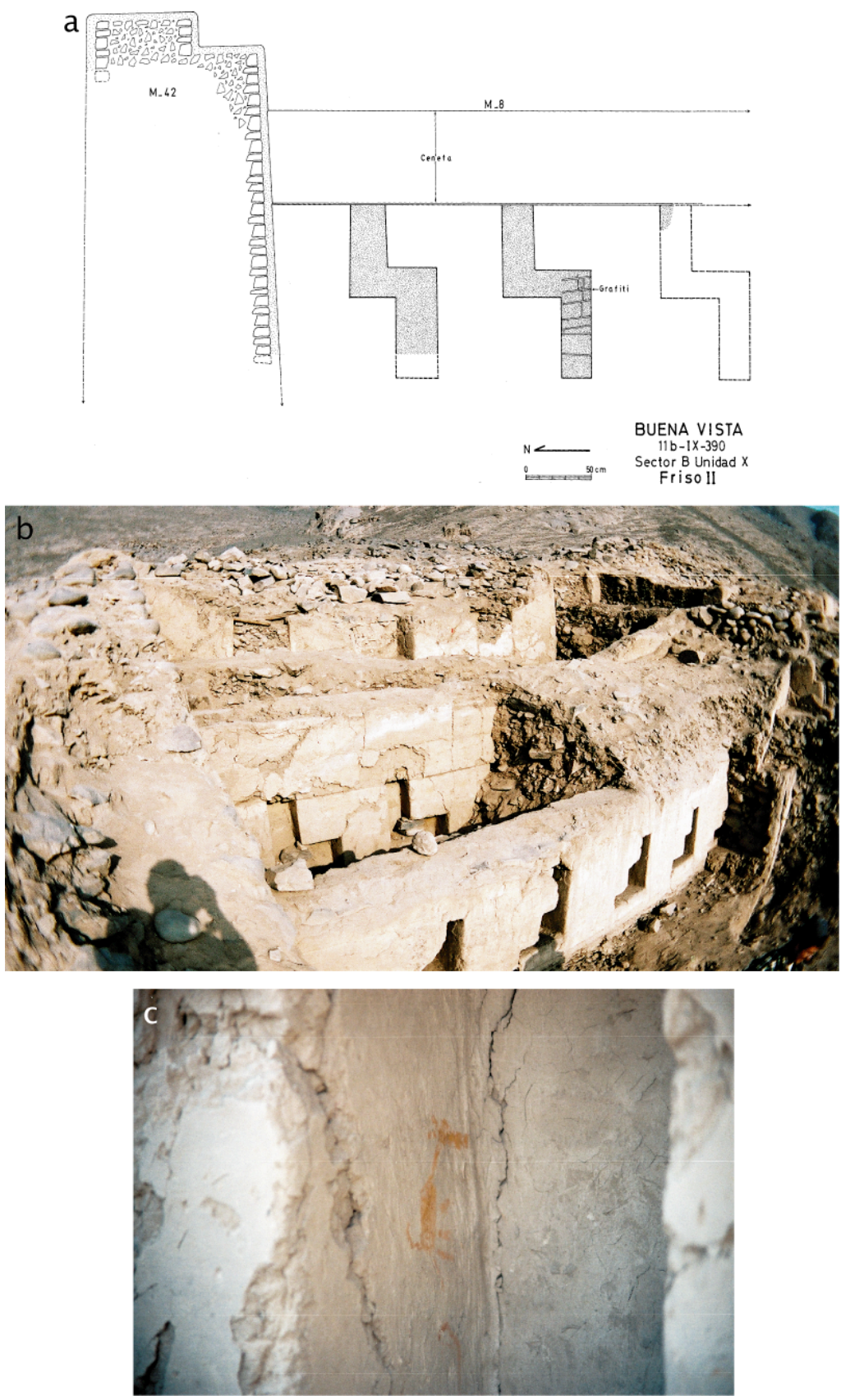

Figure 5.10 Eight-sided niches in wall M-8, Sector B. (A) Diagram of wall M-8 with eight-sided niches and graffiti etched in the interior. Drawing: Bernardino Ojeda. (B) Photo of Unit B-10 niched walls. Wall M-17 in foreground, M-8 behind M-17, and wall M-6 with square niches in background. Photo: N. Duncan (C) Photo of llama graffiti on the interior wall of the third niche from the north in wall M-8. Photo: N. Duncan. 
Another wall with a series of niches, $M-17$, was built in front of $M-8$ to the west (Figure 5.11). The temporal relationship of this wall to the other niched walls is not clear, however, this wall appears to have been built at around the same time as $\mathrm{M}-8$, or was a slightly later addition, since it eclipses the view of M-8 if one were looking toward the eastern face of it. Wall M-17 contains a series of stair-shaped niches of a different design than M-8, but both sets of niches are stylistically similar in that they both contain eight right angles within them. Six of the niches in M-17 are visible and it is likely they continue along the wall as it extends to the south. At least one of the niches closest to the stairway may have been open like a window, but the back of the niche was later closed with a thin layer of plaster. The face of this wall was covered with a fine clay finish tinted red, but now almost entirely faded. This is the wall exposed by Engel's investigation (Figure 5.1). Below M-17, a support wall, M-18 creates a platform atop which the niched wall sits and extended out below M-17 forming a step platform or "altar" on the eastern side of the wall. The exterior part of M-18 was badly damaged by looting that also undercut M-17. Ojeda performed an emergency restoration of the support wall with carefully placed rocks and fresh plaster.

The antechamber, Cuarto-2 and Cuarto-3, in front of the Gran Sala was filled in again and a plaster floor laid down just below the level of the base of the square niches (the middle floor the profile between M-6 and M-8 in Figure 5.7. On the western side of the antechamber, atop $\mathrm{M}-8$, a narrower wall, $\mathrm{M}-9$, about $50 \mathrm{~cm}$ wide, was built from the entranceway to the north wall of M-42 (which is $\mathrm{M}-2$ ). On the south side of the entrance, a corresponding wall M-10 runs south adjoining the walls that now enclose the new room 


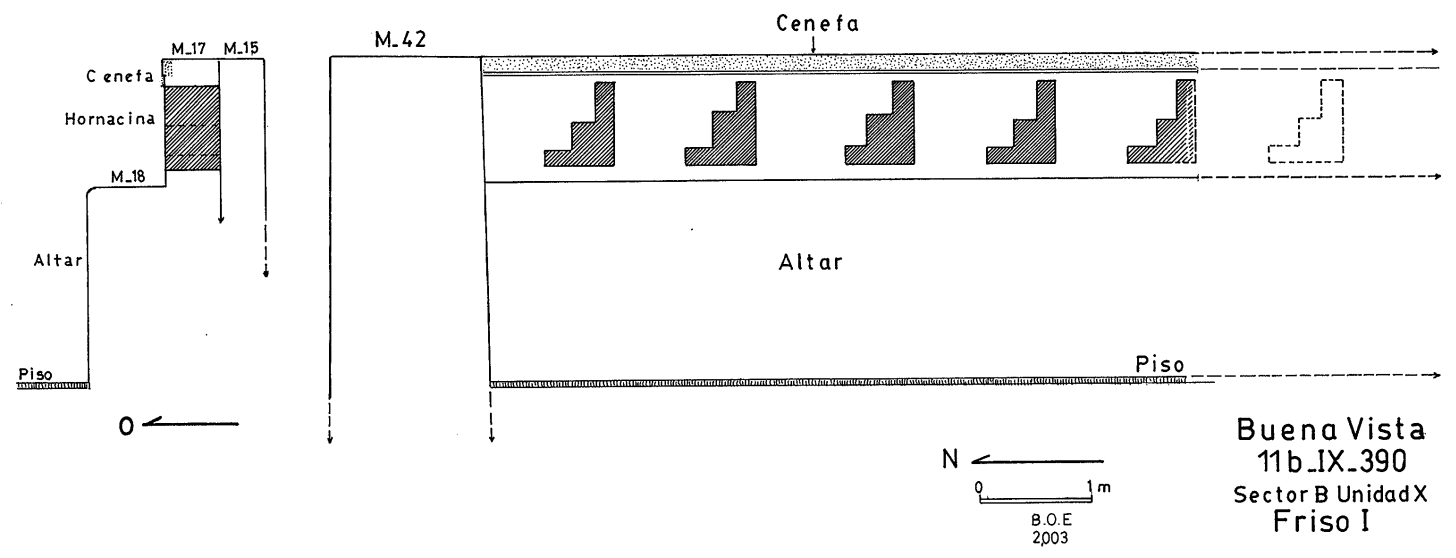

Figure 5.11 Diagram of stair-shaped niches of wall M-17. Note "altar" platform in foreground. Drawing: Bernardino Ojeda.

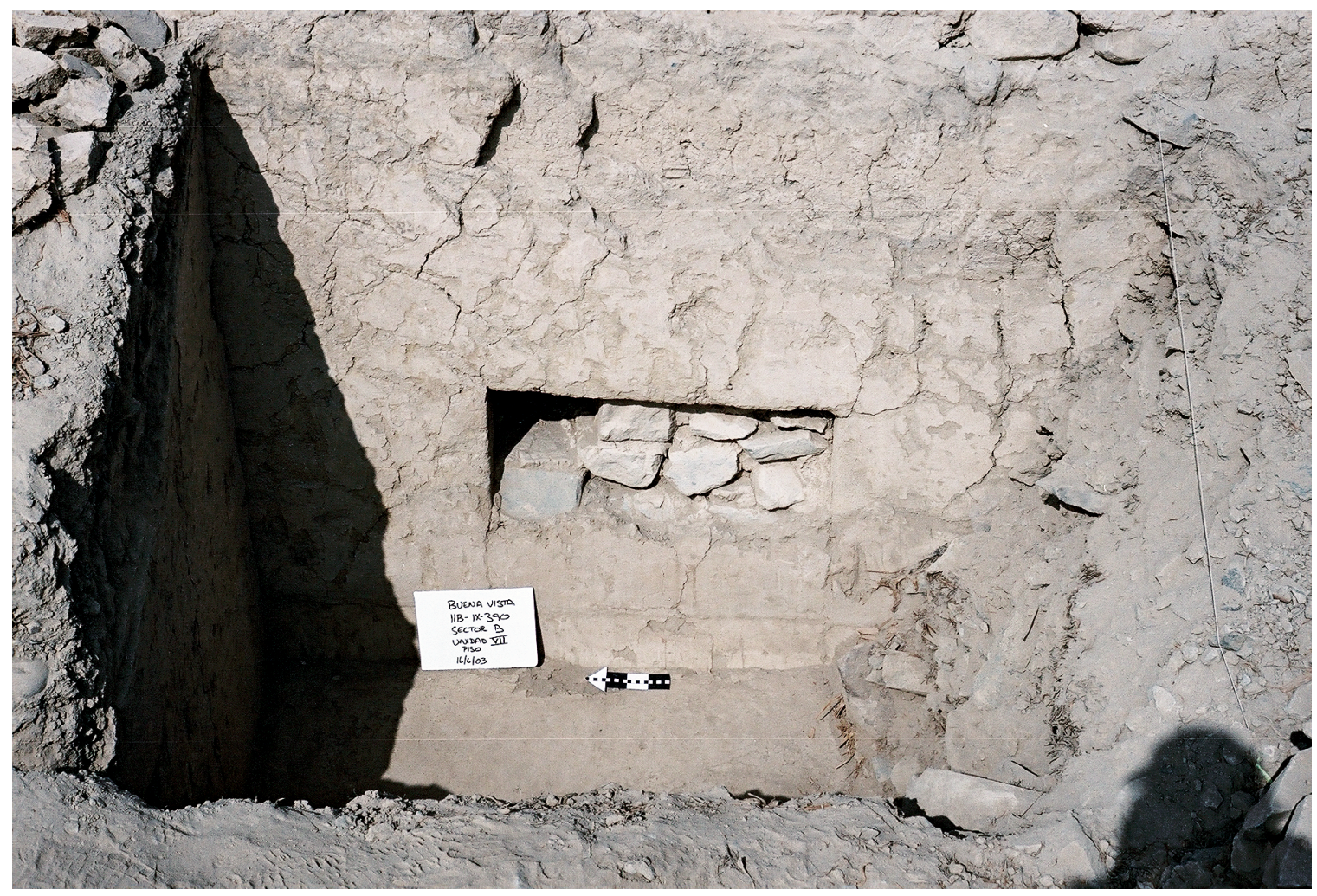

Figure 5.12 Photo of Unit B-7 excavated to the floor of Cuarto-3 in Unit B-10. Photo: N. Duncan 
Cuarto-3. Now, the antechamber consisted of two rooms. The north room retained the square niches. With the construction of M-7, the first niche south of the entrance was filled in and sealed. Test unit B-7 in the south room, Cuarto-3 (Figure 5.12), collected material preserved atop this floor. The construction of M-9 and M-10 also narrowed the entryway to the antechamber to about one meter wide. At the same time, the entryway to the Gran Sala was also narrowed and a staircase, Escalera-6, was built that landed at the top of wall M-48 inside the Gran Sala. While this room was in use, or just prior to its interment, a mural of a stylized fox was etched into the eastern, interior face of the entryway, though it appears to be unfinished (Figure 5.13).

Possibly at the same time or slightly after the division of the antechamber to the Gran Sala, walls were built behind M-17, the wall with stair-shaped niches, which covered the step-shaped niches of M-8. Walls M-19 and M-20, were also built in front of and parallel to M-17, and would have completely obscured the niches in this wall. The space between $\mathrm{M}-17$ and $\mathrm{M}-8$ was then filled-in with rock and chunks of plaster up to the level at the top of M-19. A plaster floor lay atop the fill between the niched walls $\mathrm{M}-8$ and $\mathrm{M}-17$, and became a platform in front of the entryway to Cuarto-2, with its new floor at the level of the base of the square niches. This construction event likely dates to the repairs of the niches in M-8 from which the radiocarbon date of one of the lintels, 1525 cal B.C., was obtained.

Afterwards, the antechamber was filled again with rock and chunks of plaster up to the level of the top of the niches and another plaster floor was laid on top. The entranceway to the antechamber was maintained and a stairway was constructed on the 

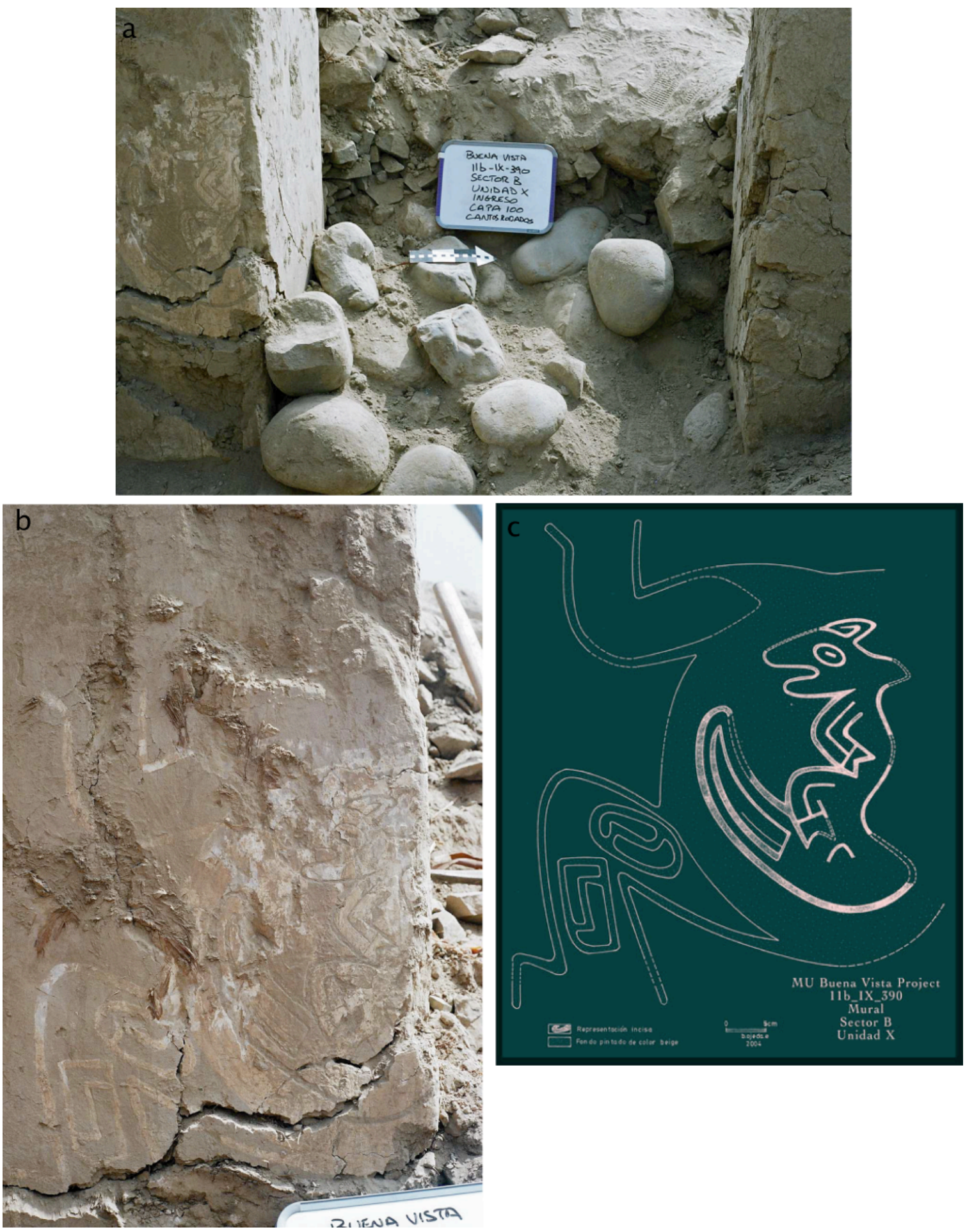

Figure 5.13 The entry-way of wall 1M-10 of Unit B-10 with fox mural. (A) Photo of entranceway facing west, round river cobbles used as fill in foreground. Photo: N. Duncan. (B) Photo of fox mural on the interior side of M-10, entrance way to Cuarto-2. Photo: N. Duncan. (C) Detail of fox mural Credit: B. Ojeda. 
western side of the mound leading all the way up to it, Escalera-1 in map and profile. Again, the mound was remodeled with the construction of two terraces on the western side, $M-21$ and M-22. These terraces covered completely the western face of the mound and provided the support for a new stairway, Escalera-2, leading up to the top. At this time the entryway to Cuarto -2 was maintained as well as its plastered floor. At the top of the mound was constructed a new room, seen as walls M-3 and M-66, stratigraphically above the Gran Sala, but using the top of the large walls of $M-1$ and $M-2$ as the east and north limits of the room. Because of extensive looter's damage at the top of the mound, no floor for this room was visible. At the base of Escalera-2, there appeared to be a $6 \mathrm{~m}$ wide platform at the base of the mound, which was then filled in by the construction of a larger platform. Finally, the mound was buried almost entirely, obscuring the stairway and the associated platforms.

\section{Excavation of Unit B-10}

As previously noted, Unit B-10 contains a large area at the top of the temple mound. The description that follows outlines the excavation of the Gran Sala and the associated sunken pit, Feature-1, in the platform at the room's center. Excavation began with a 4 m wide cross section, Quadrant-1, extending from the east to the west walls of the Gran Sala that were visible on the surface and adjacent to the entryway into the room. As the excavation of Quadrant-1 progressed, the top of the platform in the center of the room was partially exposed; therefore it became necessary to expand the excavation to either side of the room. Quadrant -2 was extended to the south, a little over $5 \mathrm{~m}$, only as far as the Initial Period wall, M-3, that we did not want to remove. Therefore, approximately 2 meters, or an area of 15 square meters, of the south end of the room was not excavated. 
The excavation of these two quadrants occurred simultaneously. After removing the contents of the room to the plastered floor, the excavations expanded to the north with Quadrant-3 extending an additional four meters to the limits of the north wall, $\mathrm{M}-2$.

The stratigraphy of the fill contained in the Gran Sala was not complex. A large portion of the top of the room's fill in the northern half had already been removed by looters to within a few centimeters of the top of wall M-63 excavated in Quadrant -3. In the southern half, a few centimeters of mixed surface material was removed to expose rock fill of angular gravel associated with the Initial Period rock wall, M-3. This fill probably once extended across the top of the room as a level base to the Initial Period architecture atop the Gran Sala. Within this angular rock fill, one human burial was found intact, directly east of the entryway at the top of the room (Figure 5.14) confined by later walls M-47, M48, M-60 that were built to the west of the platform in the Gran Sala. The female burial was flexed and wrapped in cotton textile tied with cotton and wool rope. In the looterdisturbed fill adjacent to the burial, a bundle of torn cotton textile similar to that that wrapped the burial was found. Several human bones of another individual were also found commingled with the fill. There were probably two Initial Period burials in this location. The fill surrounding the burials was also consistent with the fill that was contained in the late room below it, all the way to its base.

Beneath the layer of angular rock, in the rest of the room, we uncovered a layer of cane-bags of rock, shicra, which would have extended across the entire room. The bags of shicra filled the room from the level at the top of the platform walls in the center. Only parts of this original fill material were present in the northern quadrant of the room. 


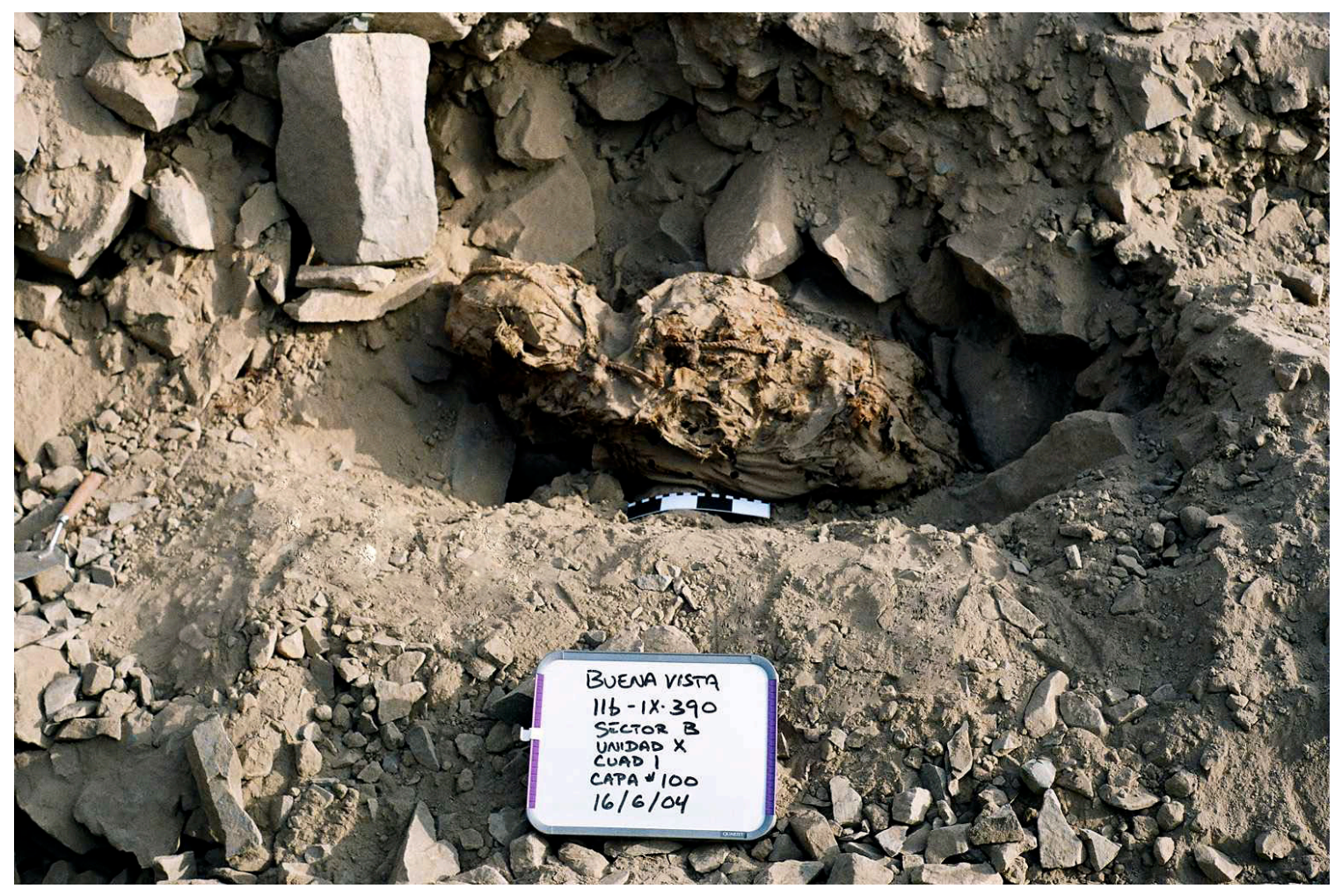

Figure 5.14 Photo of Initial Period burial of a woman found in Level 100 fill of unit B-10 above wall M-60. Photo: N. Duncan.

Mixed within the surface material, an excavator recovered several camelid bones, but because looting damage was extensive here, and even more profound along the north wall of the Gran Sala, the original context of the bones is not known. Among other materials in this disturbed fill, small fragments of spondylus shell were found. Beneath the level of shicra, a layer of large angular rocks and boulders filled the room to the base of the plastered floor. The large-rock fill of the Gran Sala was nearly perfectly clean of all refuse. Other than a large, broken tree trunk, possibly sauce (Salix sp.), in the space just north of the platform (Figure 5.15a), the room was pristine. The tree trunk may have served to hold up part of ceiling for the Gran Sala, though there is no evidence on the floor of the room 
where it may have stood. A small portion of grass roof was uncovered in the fill in the northern section of the room, in Quadrant 3, but it is unknown if this material is associated with the tree trunk (Figure 5.15b). Other evidence for roofing is scant, however at the Preceramic site of Aspero, several examples suggest wood posts may have supported roofing rather than the tops of the walls (Feldman 1980:50-51). Like the tree trunk in the Gran Sala, posts at Aspero in Huaca Alta and Huaca de los Idolos were found close to a nearby wall, $20-30 \mathrm{~cm}$. Unlike posts at Huaca Alta, the tree trunk in the Gran Sala is not associated with a posthole, but its flat base may have provided adequate support.

In the Gran Sala, the sunken pit, Feature-1, in the center of the platform, was filled much differently than the rest of the room. Following the "natural" levels within the pit, we first removed the shicra bags and mixed soil and rock as Level 100 (Figure 5.16 A-B) that exposed the top of the pit. A layer of loose fill of small angular rock and gravel, Level 200, approximately $60 \mathrm{~cm}$ deep was then removed from inside the pit, exposing the top of the niche in the west wall (Figure 5.16 C). At the base of this level, more and more plant material began to appear along with several artifacts, and together was excavated as a single level, Level 250 (Figure 5.16 D). Along the east wall, disarticulated mollusk shells were uncovered, but scattered in place, in no apparent order. One whole bone aguja, needle, was recovered along with several fragments of another found in the fine-screened material (Figure 5.16e). Several small pieces of cotton textile were dispersed in the material as well as small amounts of hair and wool. Fragments of plants were noted, including leaves of Furcraea andina, an agave-like plant, grass, cotton and squash seeds, and lucuma pits. 
The abundant plant remains increased; Level 300 (Figure 5.16 F) consisted almost entirely of organic material, abundant amounts of grass leaves, small twigs, and more remains of food plants, seeds of squashes, guava, lucuma pods, and the skins of several roots and tubers. Faunal items were noticeably less abundant. A small concentration of cotton textile fragments (Figure $5.16 \mathrm{G}$ ) was noted along the south wall, but did not cover or contain any items. Charcoal fragments were present, as well as partially burnt twigs. It is possible there was an attempt to ignite this material, but without ventilation, it would have only smoldered for a short while, as the other materials lacked any evidence of charring or heat deformation, nor is the pit itself charred. Charcoal fragments from this level were radiocarbon dated to between 2460 and $1980 \mathrm{cal}$ B.C. (GX-31276: 3,770 +/- 80 B.P).

The nearly $12 \mathrm{~cm}$ layer of organic material in Level 300 was removed to expose a layer of small round cobbles, 8 to $10 \mathrm{~cm}$ in diameter, intermixed with gravel in Level 350 (Figure $5.16 \mathrm{H}$ ). Organic materials, primarily grass, wood twigs, and some food remains, continued to occur, in less abundance for about $30 \mathrm{~cm}$ more (Figure $5.16 \mathrm{I}$ ). More mixed organic material, similar to that in Level 300, began to appear in Level 400 (Figure $5.16 \mathrm{~J}$ ). Again, the remains were deposited in no discernable pattern of placement. Beneath this thin, 10 to $15 \mathrm{~cm}$ layer of organics, a layer of grass was uncovered. The grass, excavated as Level 425 (Figure $5.16 \mathrm{~K}-\mathrm{L}$ ), also contained some charcoal fragments and other plant materials, probably the remains that were placed atop the grass. Also, a small bead or phiruro was found within the grass. A radiocarbon date from charcoal in this grass layer dated between 2470 and $2020 \mathrm{cal}$ B.C. (GX-32177: 3,790 +/- 80 B.P.). Immediately 
beneath the 5 to $10 \mathrm{~cm}$ layer of grass we encountered the plastered floor of the pit and the excavation was stopped (Figure 5.16 M-N).

The radiocarbon dates from Levels 300 and 425 of Feature-1, the sunken pit, both were from 2200 B.C. (Table 5.1). It is possible that the pit was filled-in during a single event, or perhaps the stratified contents of the pit represent more than one event over a relatively short period of time. As mentioned above, other remains found within the pit do not show evidence of charring, nor does the pit exhibit any other evidence of burning, despite the presence of partially charred wood and charcoal fragments. It is possible that the contents of the pit were collected from several locations simultaneously where burning occurred, or perhaps some of the wood was already alight as it was deposited in the fill but then smothered by the other remains. Although, bundles of charred wood were not found. The charcoal is addressed more specifically in Chapter 6 and Chapter 9. The sequence of burial of the pit began with what might be an "organic protective layer" similar to that described in the temple entombment at Huaca Soledad (Shimada 1986), a 5-10 cm deep layer of grass and fine silt that covered the bottom of the pit, atop which commingled organics, grass, leaves, and food remains were dropped or swept into the pit. Small round cobbles and gravel topped this layer, followed by more mixed organic material, and then capped with small angular gravel. The surrounding room was then filled with large rocks, some as large as $60 \mathrm{~cm}$ in diameter, to the level of the top of the platform. Lastly, the entire room was filled with shicra, cane bags filled with rock (see Chapter 6, Figure 6.1 for a profile drawing of the sunken pit's stratigraphy). 

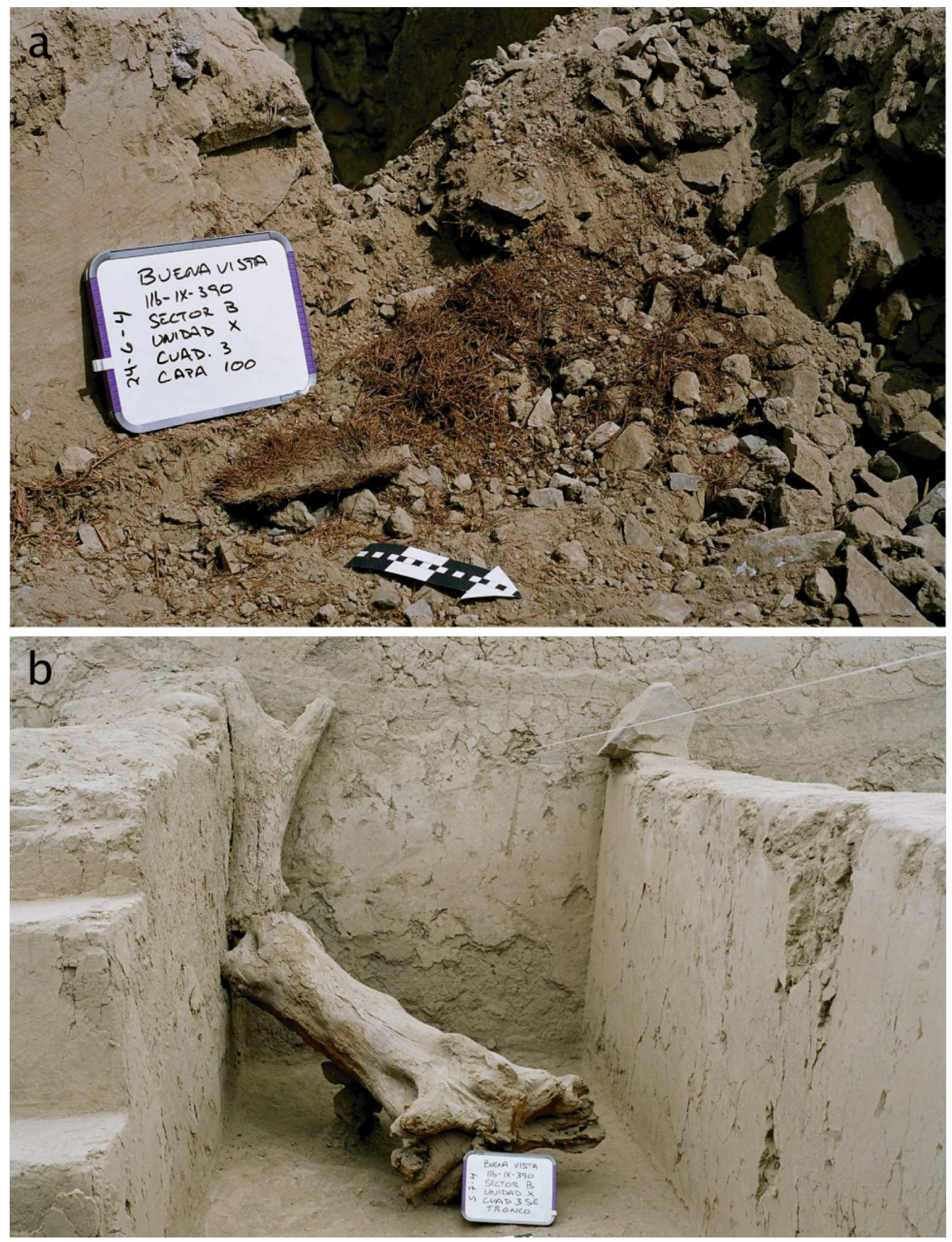

Figure 5.15 Roofing material and support in the Gran Sala. (A) Roofing material of twigs and cane found in the fill in the north end of the Gran Sala. (B) Tree trunk possibly used as roof support uncovered near the center of the Gran Sala to the north of the sunken pit, Feature-1. Photos: N. Duncan 

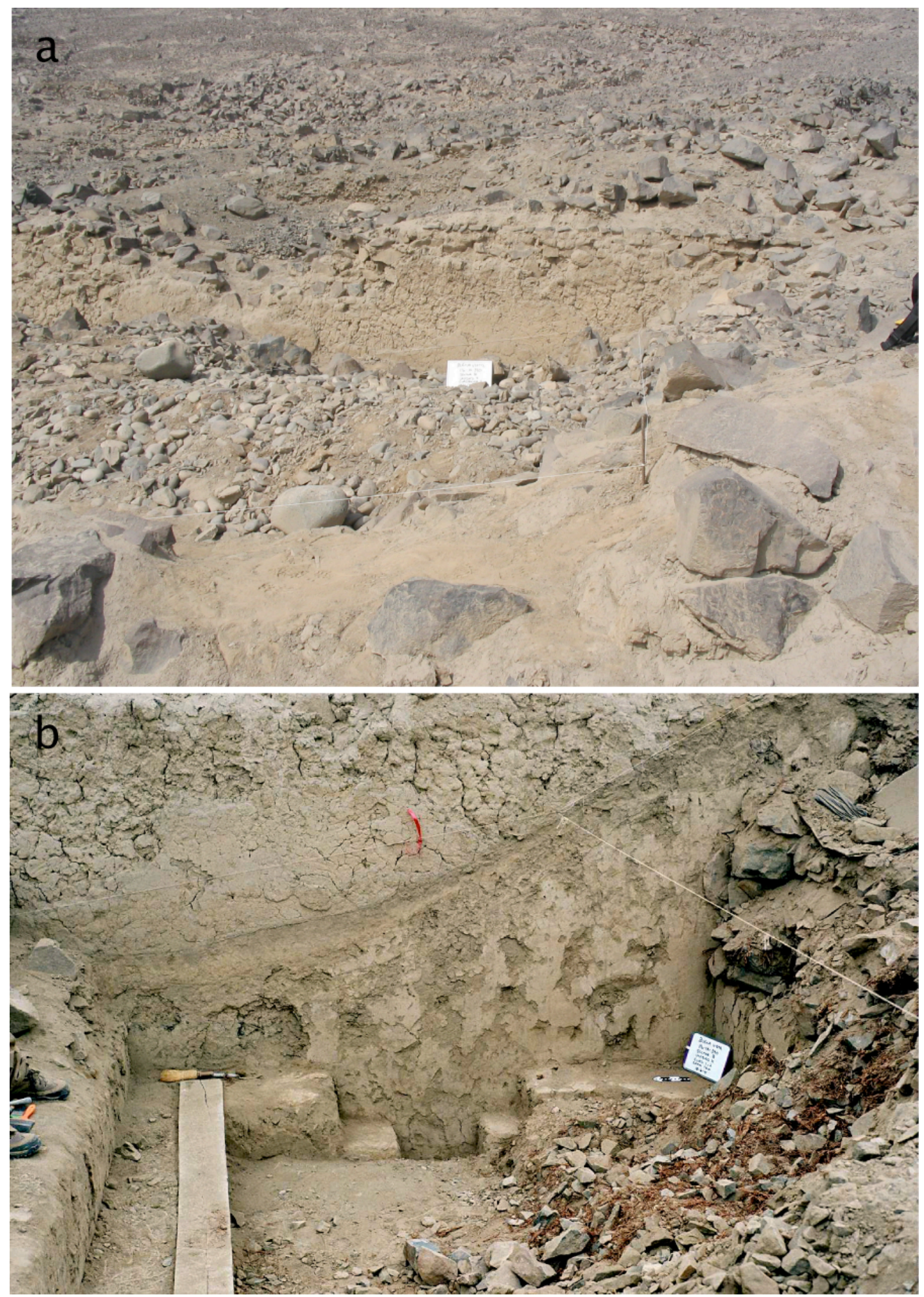

Figure 5.16 Photo series of excavation of the sunken pit, Feature 1 of Unit B-10 in the Gran Sala. (A) Unit 10, surface. (B) Base of Level 100, exposing the top of the pit visible on the east wall of the Gran Sala. Shicra bags and rock are shown on right side. Photos: N. Duncan 

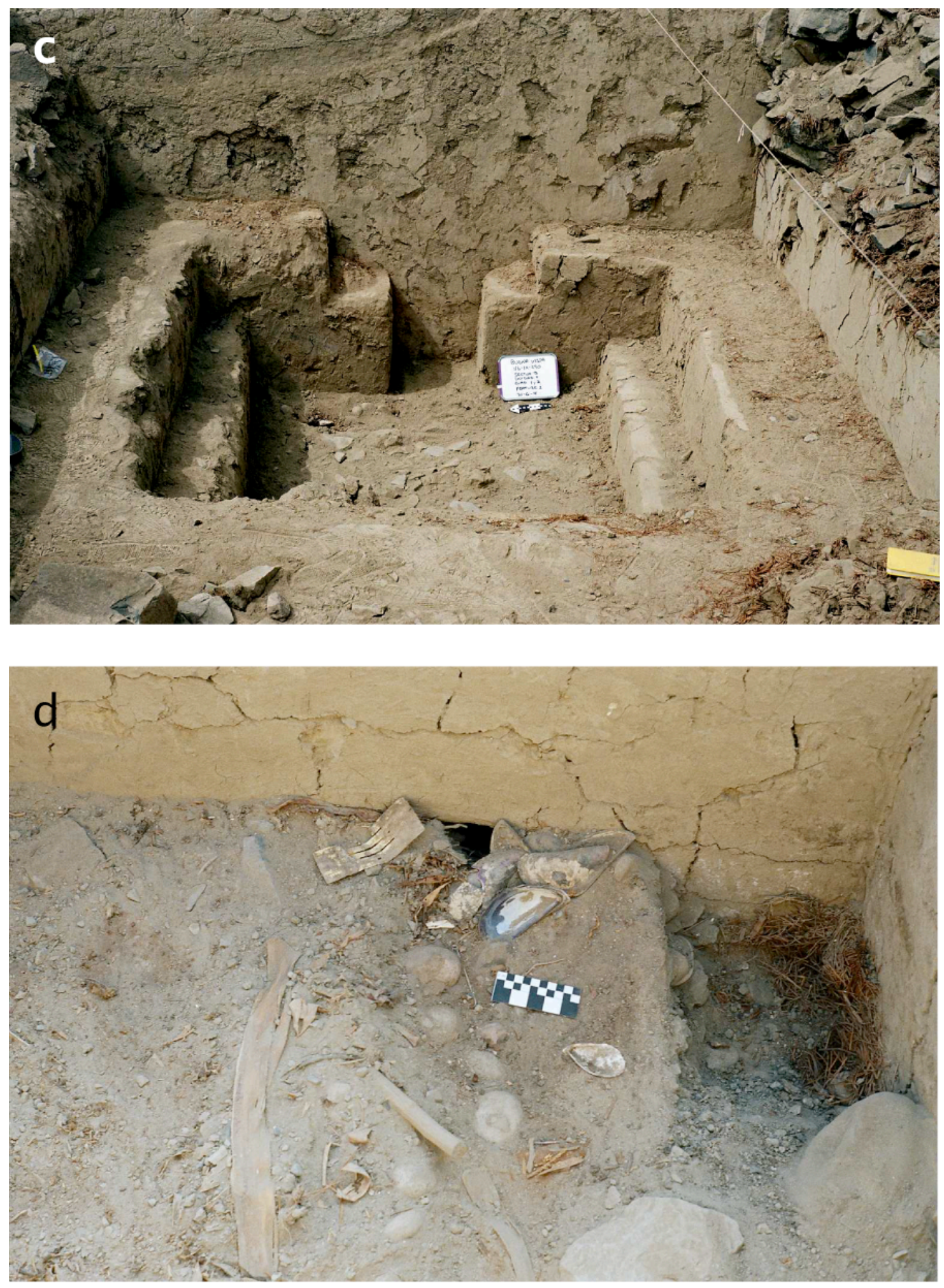

Figure 5.16 continued. (C) Excavated pit to the base of Level 20. (D) Top of Level 250, organic material and a few artifacts mixed with soil and rock. Note scattered mollusk shells at top of photo near the scale. Photos: N. Duncan 

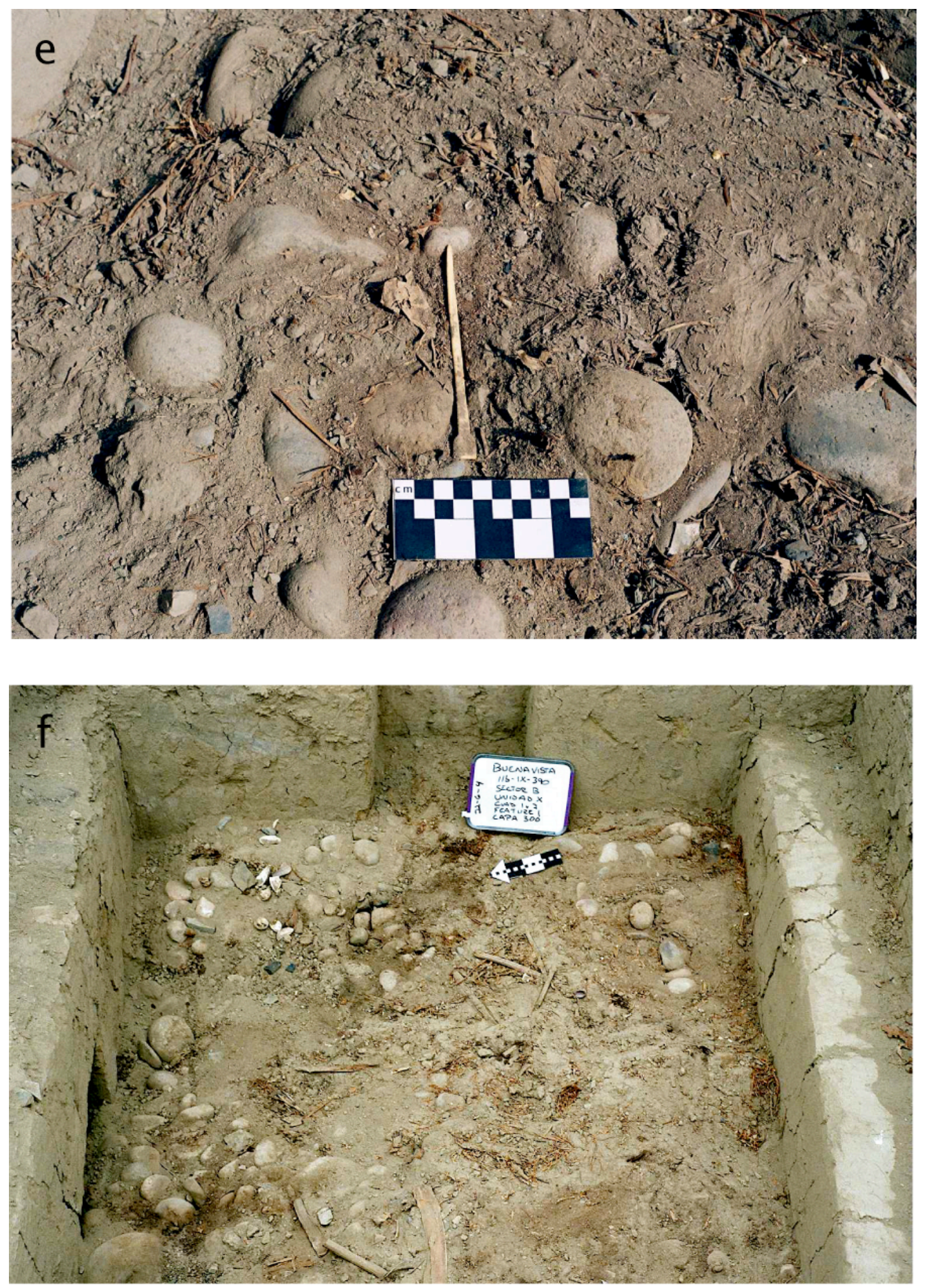

Figure 5.16 continued. (E) A bone pin at the base of Level 250. (F) The top of Level 300, mixed plant material and small round cobbles visible. Photos: N. Duncan 

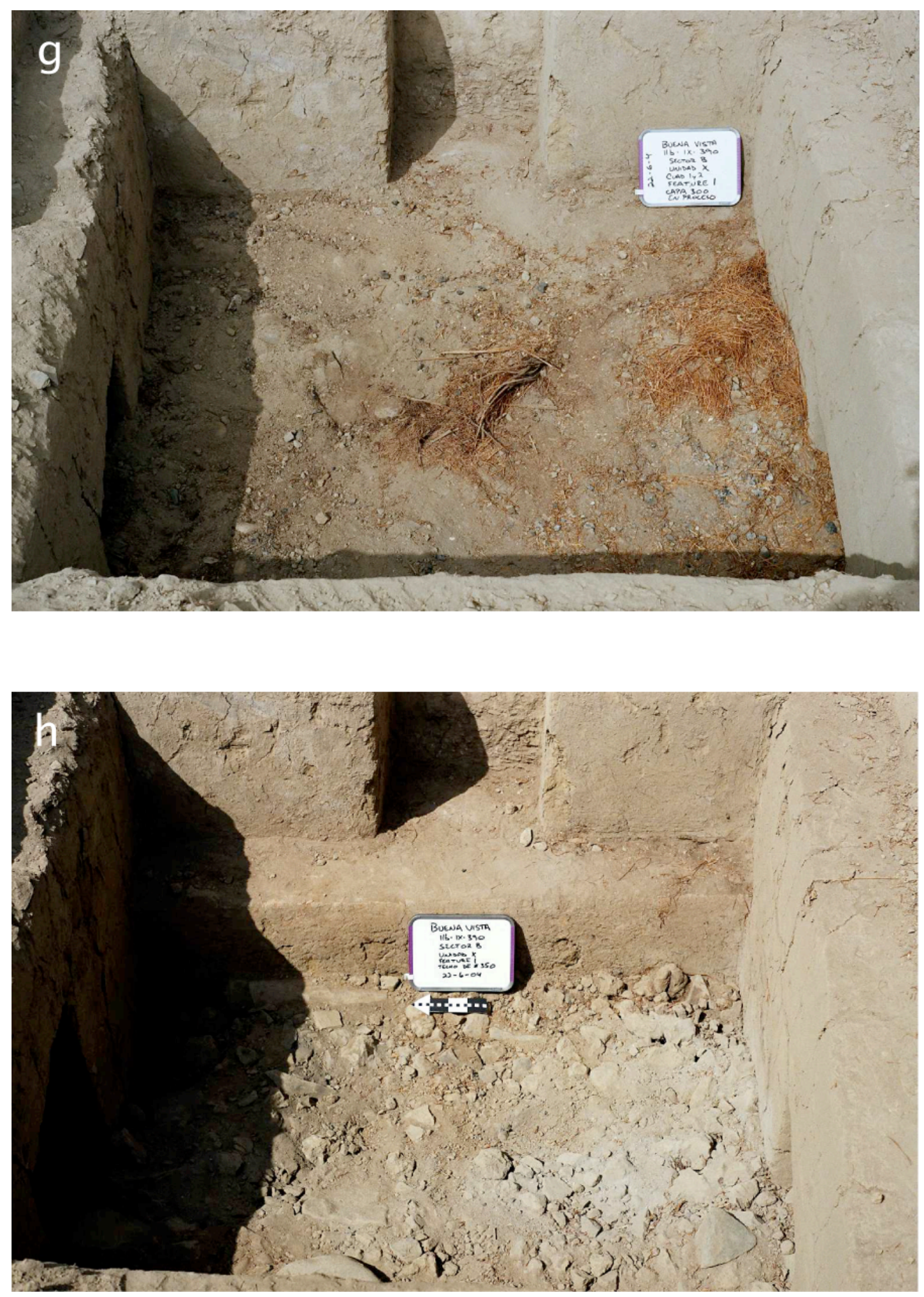

Figure 5.16 continued. (G) Excavation of Level 300 in process. A concentration of grass lies in the center, fragments of cotton textile to the right nearest the wall. (H) Top of Level 350 containing a large number of small round river cobbles. Photos: N. Duncan 

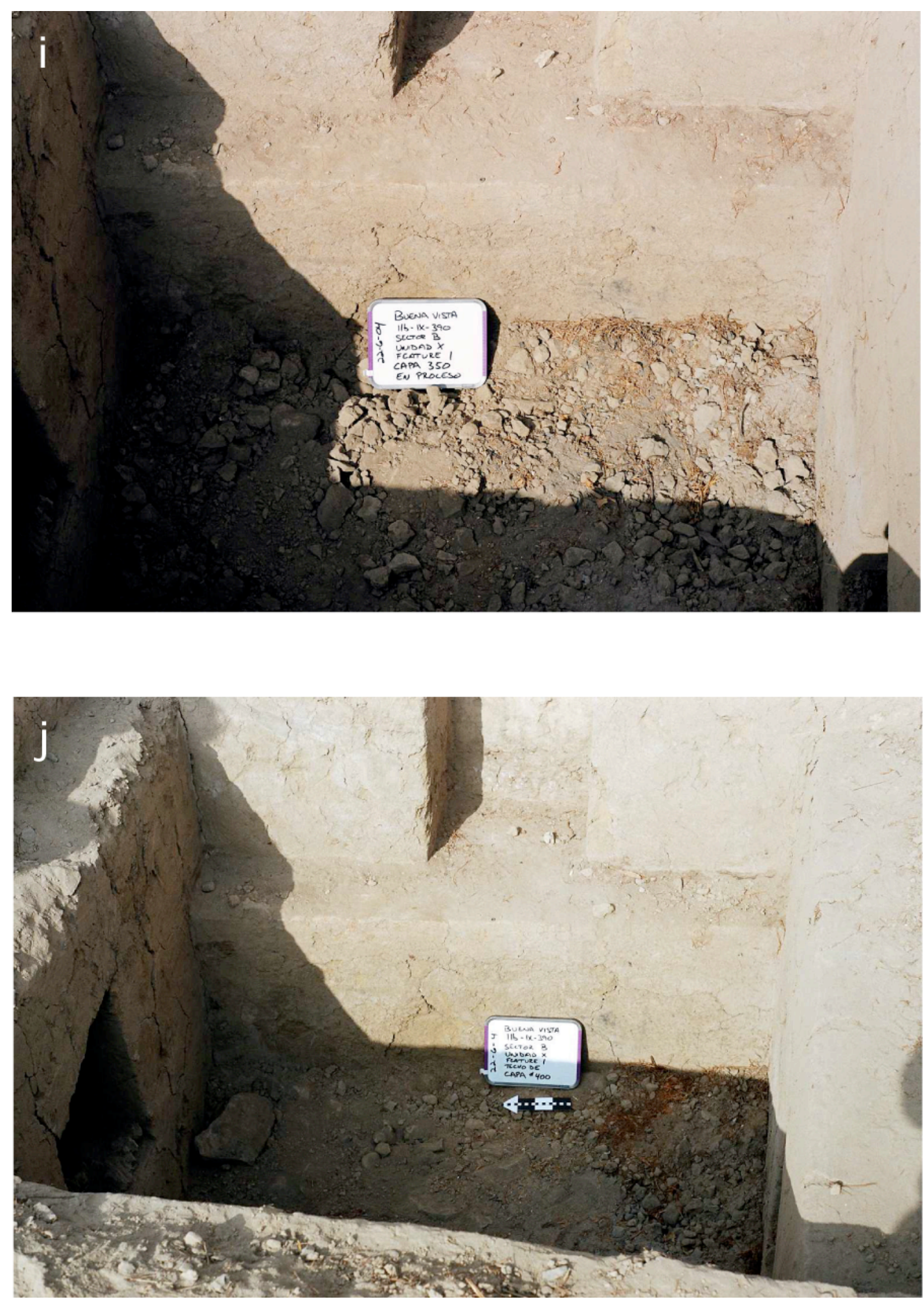

Figure 5.16 continued. (I) Excavation of Level 350 in progress. Small cobbles and grass are visible. (J) The top of Level 400 containing mixed plant material and abundant grass. Photos: N. Duncan 

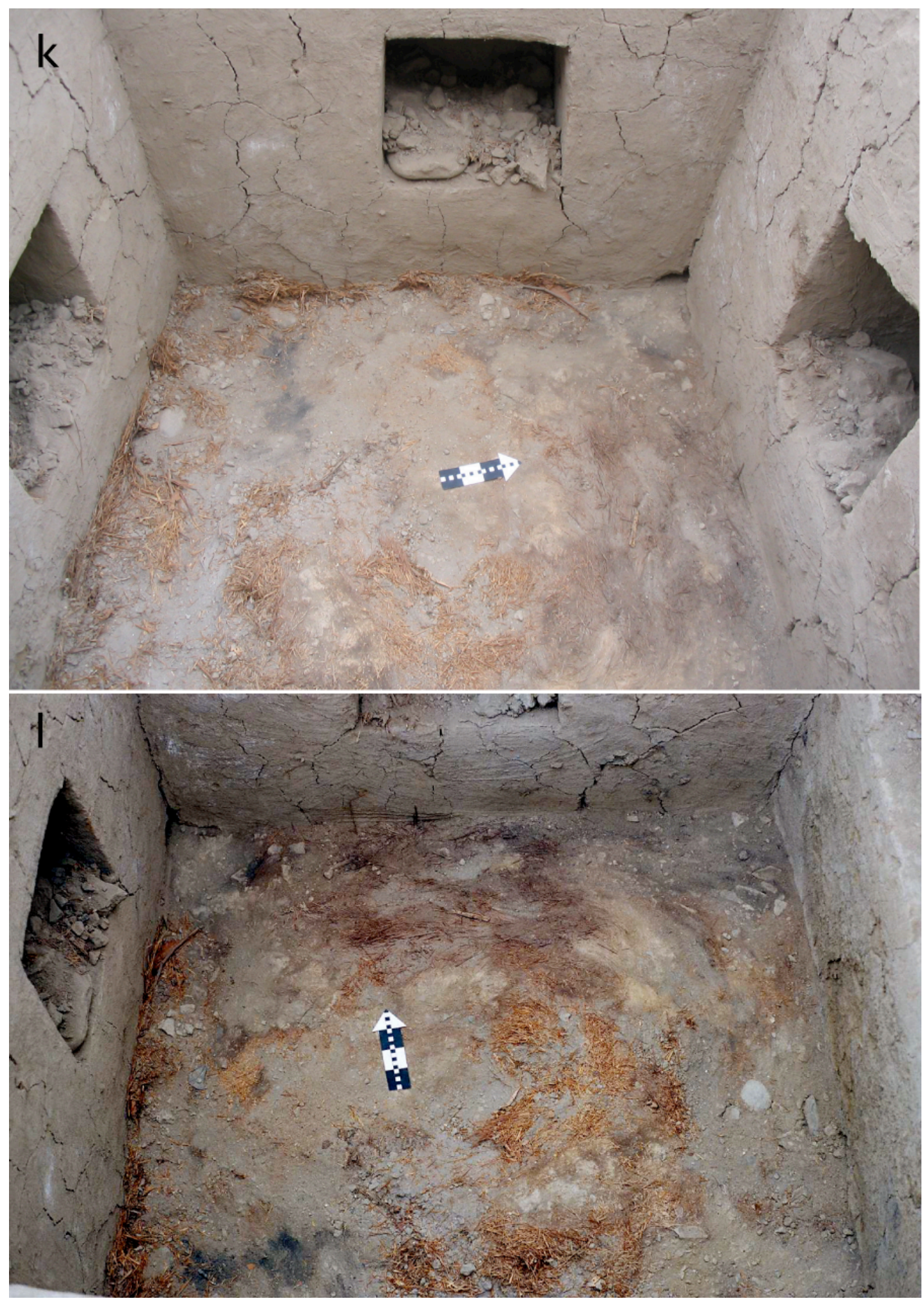

Figure 5.16 continued. (K) Top of level 425, brushed. (L) Detail of grass layer in Level 425 atop the floor of the pit. Photos: N. Duncan 

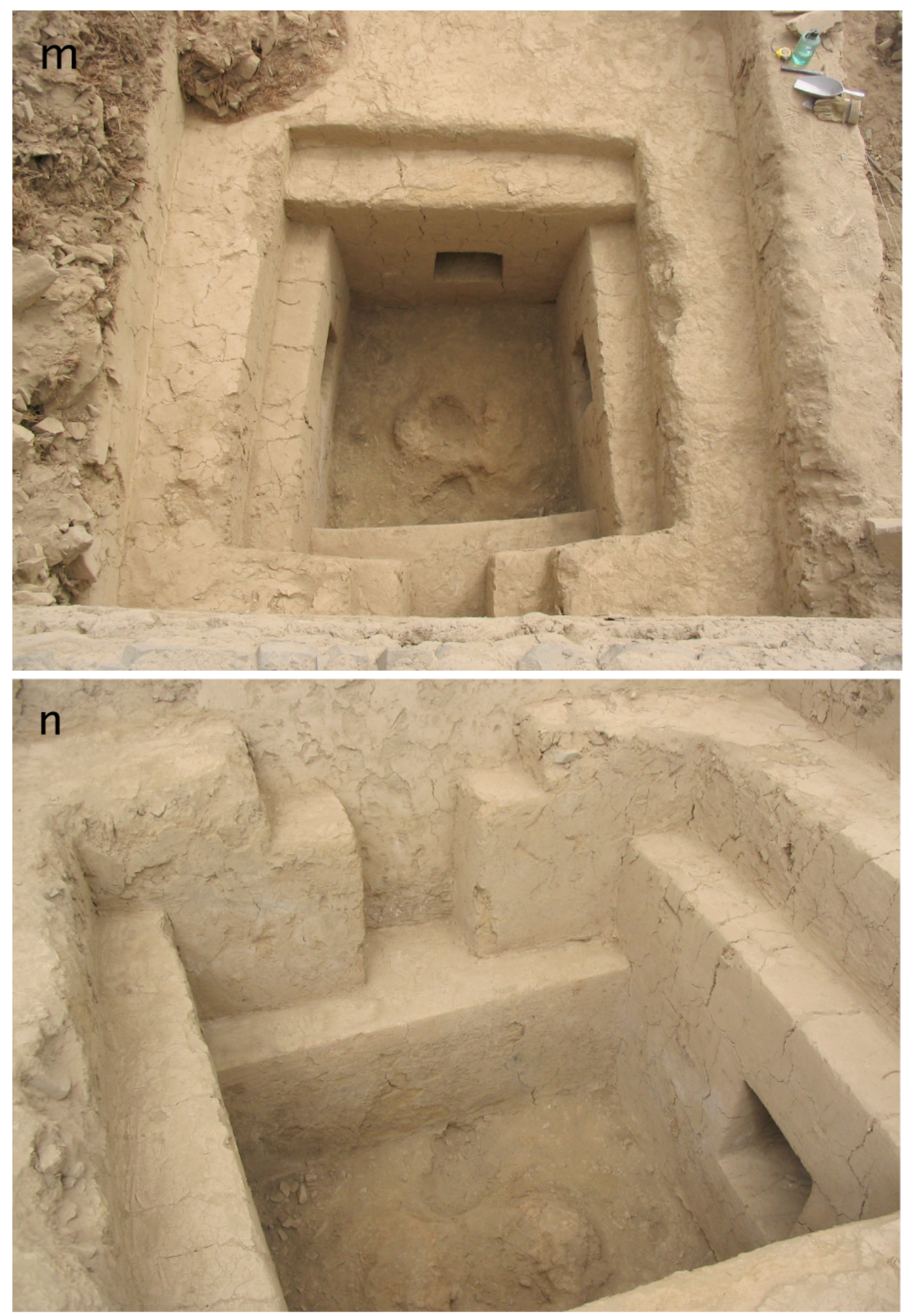

Figure 5.16 continued. (M) The excavated pit photographed from above. Note central circular ridge on the floor of the pit. (L) The excavated pit facing southeast. 


\section{Archaeological ConteXt of Sector C}

Sector $\mathrm{C}$ comprises an area containing thick rock walls with plastered faces and several rooms visible in outline on the surface. This complex of Preceramic period architecture overlain with later renovation lies about $25 \mathrm{~m}$ to the northeast of Sector B's main complex (Figure 5.17), separated by an alluvial wash of gravel. Like the architecture in Sector B, the complex of rooms is built onto the hillside, a large wall at least one to two meters thick, $20 \mathrm{~m}$ long, and about $1.5 \mathrm{~m}$ tall, serves as the western face of the mound. A staircase in the center of the wall leads up into the complex. To the west of the wall, lies

the bulldozer cut. Two small $1 \mathrm{~m}^{2}$ test units (C-3 and C-4) excavated in 2002 at the terminal end of this wall on the western side recovered charcoal from below the level of the wall's footing and radiocarbon dated to $6548 \mathrm{cal}$ B.C. (GX-29940: 7750+/-100 B.P.) (Table 4). The date, however, does not correspond to the construction of the wall, but may indicate an early occupation on the hillside beneath the architecture.

Several test units were excavated within the boundaries of the walls visible on the surface of Sector C in 2002, 2003 and 2004 (Figure 5.17). In all of the units excavated here, extensive damage from looters was present and in some cases severely compromised potential for interpreting the original contents. However, it became clear that several of the rock walls visible on the surface represent the Initial Period occupation and are not temporally or architecturally associated with some of the plastered walls below. Initial Period ceramics were found in the looted fill, as well as modern garbage. In spite of the 
significant disturbances to the mound, some of the stratigraphy of the excavated units, where not disrupted by looting, revealed plastered walls, identical in construction to those

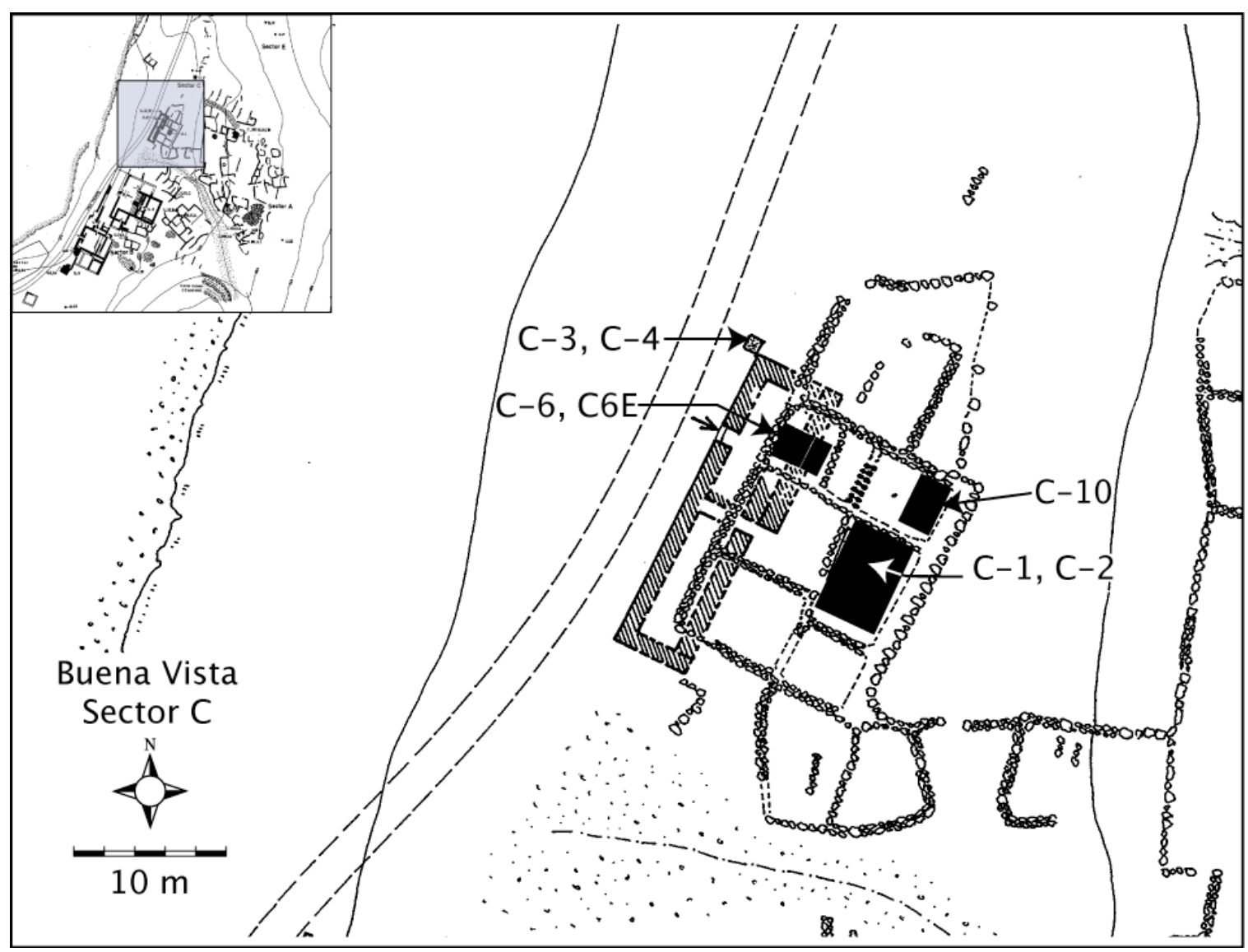

Figure 5.17 Detail plan view of Sector C showing excavated units shaded in black. Map: Bernardino Ojeda

of Sector B, in the lowest levels of the mound. The rooms and spaces formed between the early walls were buried by a layer of shicra, cane bags of rock, followed by another series of walls and rooms. The main wall at the edge of the mound continued to serve as the western boundary and it is possible that some of the early walls continued to be used continuously throughout successive reconstructions, but the looting damage is so extensive here, having removed sections of walls and entire floors, that the architectural relationships are unclear. Nevertheless, our controlled excavation in Sector C did reveal some intact 
architecture and several undisturbed contexts that could be sampled reliably. The most intact, undisturbed contexts that were sampled for this study came from Unit 6 and Unit 6E, and Unit 10 discussed in more detail below.

In one interior room of the complex, test units excavated in 2002 revealed an intriguing architectural feature, although looters had previously disturbed the area. Unit C$1\left(4 \mathrm{~m}^{2}\right)$ and an extension of it, Unit $2\left(2 \mathrm{~m}^{2}\right)$, uncovered a raised plastered floor with a canal-like feature running parallel to it (Figure 5.18). First, excavators removed a layer of looter's backfill containing modern goat dung and achupalla (Tillandsia sp.) with Initial Period ceramics mixed in the fill, Level 100. Then a thin layer of fine silty soil, Level 200, was removed to expose a canal-like feature that formed a $20 \mathrm{~cm}$ deep trench with a line of cobbles and adobes running parallel to a raised plastered floor. The surface between the row of adobes and cobbles and the raised floor was also plastered. The unit was extended to the south to expose more of the feature. Unit C-2 was excavated to determine if associated architectural features survived but instead exposed considerable looting damage that obliterated any architectural features that were there. The fill of the looter's pit contained a number of camelid bones, and incomplete human remains of at least one individual. The function of the canal-like feature is not known, but it may have been associated with a ventilated hearth similar to other sites with Kotosh features. Unfortunately, because of the disturbed contexts, no associated material will provide a reliable radiocarbon date. Elsewhere in Sector C, two units provided intact contexts from which we were able to acquire good archaeological samples for study. These test units, C-6 and $\mathrm{C}-10$ are discussed below. 


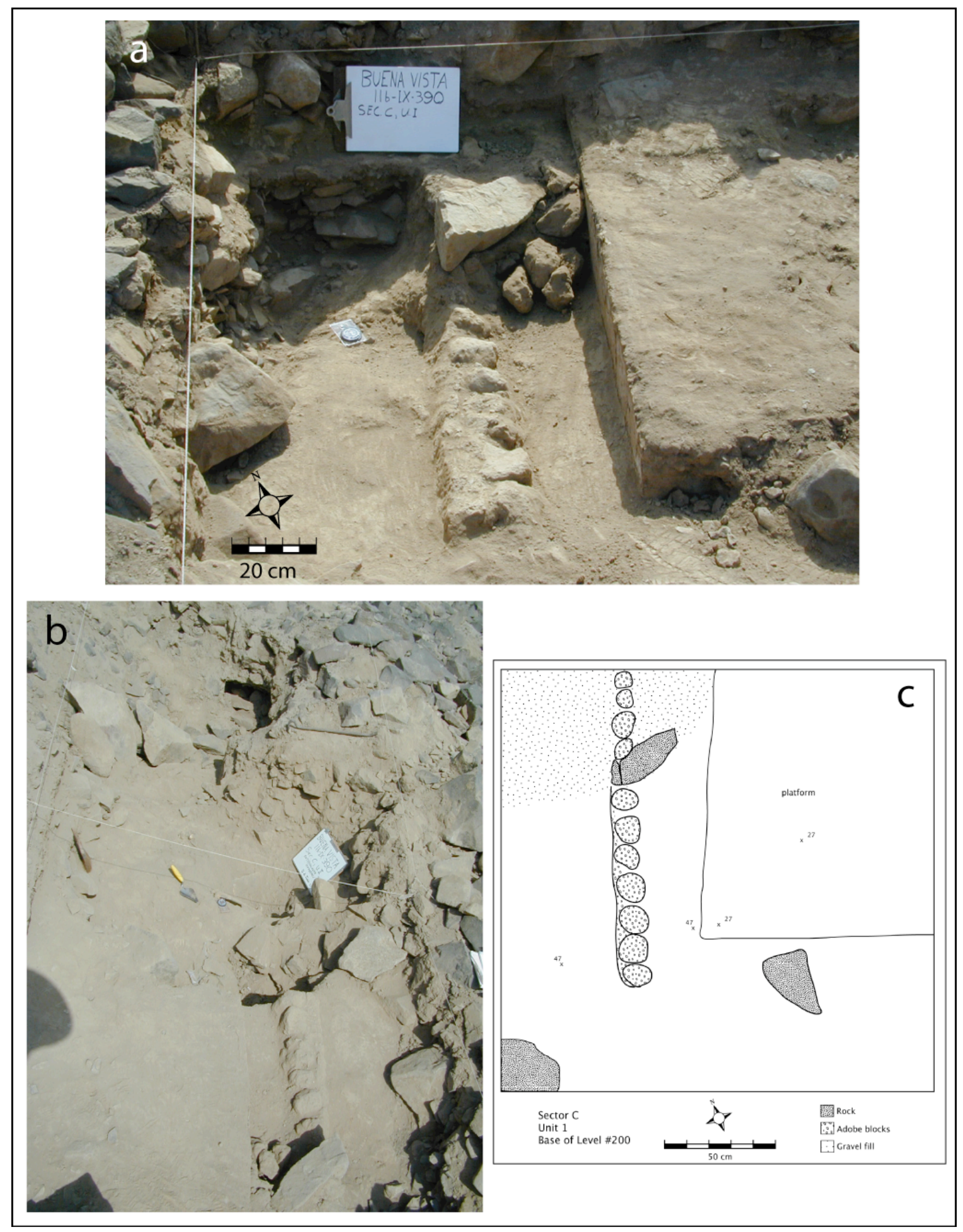

Figure 5.18 Photos and plan of Unit C-1. (A) Unit C-1 excavated facing northeast. The adobe-lined trench is visible in center, raised platform on the right. Photo: Robert Benfer. (B) Unit C-1 excavated facing south. Extensive looters' damage visible in top portion of the photo Photo: Robert Benfer. (C) Plan view of C-1 excavated to Level 200. 
Excavation of Units C-6 and C-6E

In 2002, we opened Unit C-6, a $2 \mathrm{~m}$ by $4 \mathrm{~m}$, test unit in a room demarcated by rock walls visible on the surface to the northeast of Unit C-1 discussed above. In 2004, an extension of the unit was added, Unit C-6E, adjacent to the east of C-6 to open the area further (Figure 5.19). Excavation began with a cleaning of the surface, Level 000 followed by removing mixed rubble and fill, Level 100. This level consisted entirely of backfill from nearby looted contexts in the area and contained fragments of newspaper and numerous fragments of Initial Period pottery, camelid bones, and several human bones from at least one adult and one juvenile. At about $40 \mathrm{~cm}$ below the surface, where looting apparently stopped, very large rocks were encountered underneath which a hard-packed floor was encountered in the northwest portion of the test unit. On the eastern side of the floor's edge, a circular pattern of rocks was visible, associated with an abundance of mollusk shells, charcoal, and fragments of plant material. Consistent with a hearth, the interior of the $50 \mathrm{~cm}$ ring of rocks was labeled Feature-1 and excavated separately. The material surrounding the hearth, forming a distinct stratigraphic lens, was excavated as Level 250 and contained copious amounts of organic material: mollusk shells, twigs and charcoal, and other plant remains. Charcoal obtained from Level 250 within the hearth returned a date of 1940 cal B.C. (GX-30695: 3600+/-50 B.P.) (Table 5.1). Outside the lens of \#250, the material was excavated as Level 200 and consisted of silty soil with much ash content. As the level descended, it became apparent that the compacted soil in the western portion of the unit was a bench up to which the hearth was built. The bench, about $20 \mathrm{~cm}$ high, paralleled the western wall of the room and a plastered floor extended to the east around 

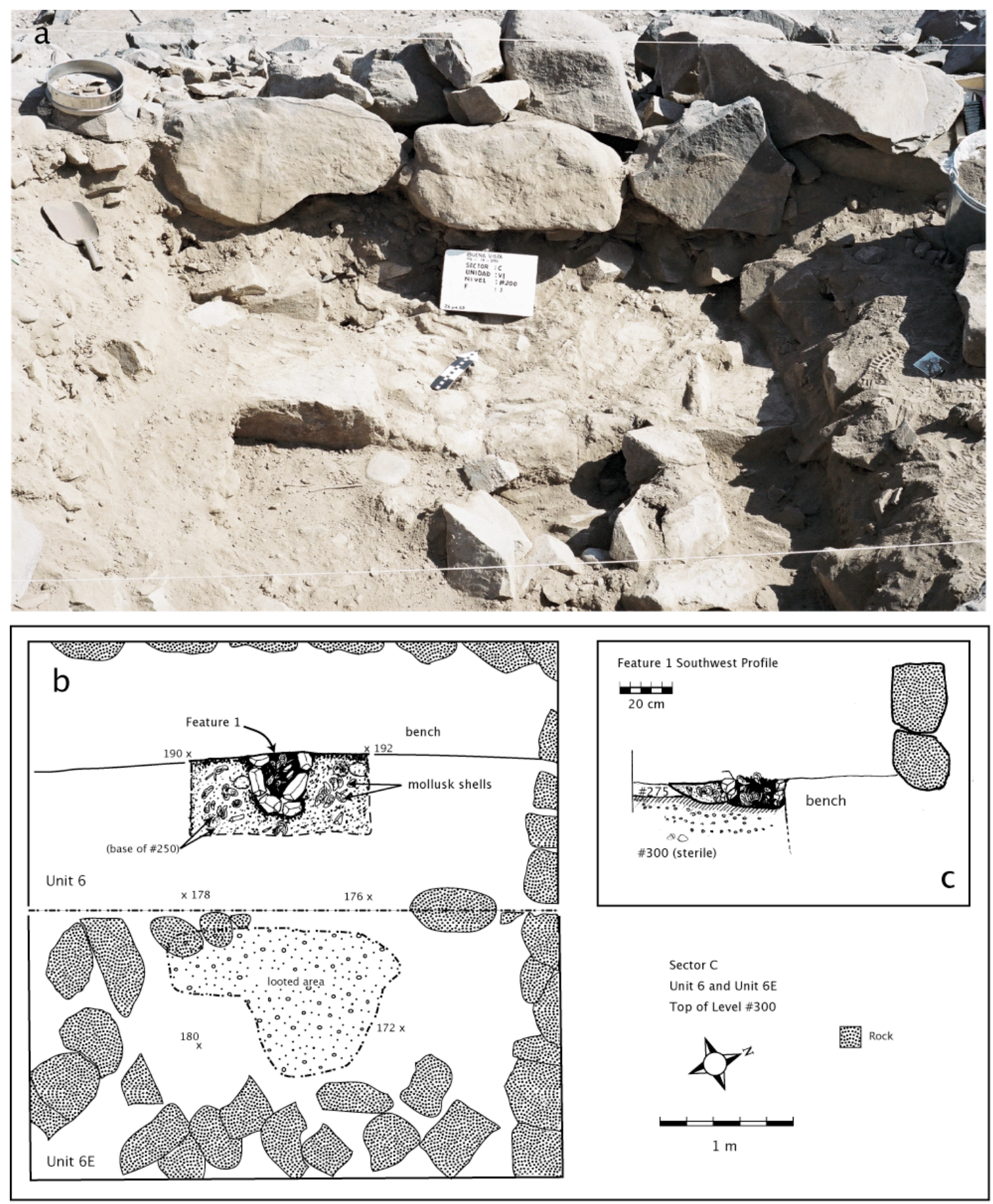

Figure 5.19 Photo and plan of Unit C-6 and C-6E. (A) Photo of excavation of C-6 in progress facing north-northwest. The plastered bench is visible at the base of the rock wall, the hearth feature in foreground. Photo: N. Duncan. (B) Plan view of C-6, top, and C-6E, bottom. Extensive looting was noted in C-6E. (C) Southwest profile of hearth and bench in C-6. Map: Miriam Gonzales. 
the hearth feature. Beneath the plastered floor, alluvial material of approximately $75 \%$ gravel, Level 300, was encountered that was devoid of cultural material.

In 2004, an extension of Unit C-6 was opened to the east in the hopes of further exposing the floor encountered in that unit the year before. In this area, Unit C-6E, again a layer of mixed fill from looters' backdirt was removed as Level 100; field crew digging this unit did not ascribe a surface Level 000, therefore the corresponding levels associated with Unit C-6 are not in sync. Unfortunately, due to looting, the mixed fill in this unit extended well below the level of the floor found in Unit 6. After delimiting the extent of the looter's pit, part of the floor was uncovered in the northern portion of the unit and charcoal and ashy silt of Level 200 in C-6 was found intact. Excavation continued outside the extent of the looter's pit, and revealed very large amounts of ash and charcoal along the eastern wall of the room, now labeled as Level 300E, but consistent with Level 200 of Unit C-6. The ashy silt layer gave way to more gravel, Level 400 (Level 300 in Unit C-6). A broken wooden stick with rounded ends, possibly a digging stick, and a bifacially flaked stone tool were collected at the base of the east wall of the room.

\section{Excavation of Unit C-10}

Located about two meters to the southeast of Unit C-6, Unit C-10 was opened to explore the northeastern room visible from the surface of Sector C. The unit began as a rectangular $3 \mathrm{~m}$ by $1.5 \mathrm{~m}$ test unit but was expanded in the eastern half to a width of 2 meters (Figure $5.20 \mathrm{c}$ ). Surface material was removed to a depth of about $5 \mathrm{~cm}$ across the unit. Below, mixed fill, Level 100, of modern trash, charcoal, ceramic fragments, modern Tillandsia, and large amounts of mollusk shells graded into a fine grayish-brown silty soil 
with gravel and a high ash content about 15 to $20 \mathrm{~cm}$ below the surface. Level 200 continued to contain large amounts of mixed, loose fill, abundant charcoal and mollusk shells, approximately $20 \mathrm{~cm}$ deep. During the excavation of Level 200, the top of a damaged plastered wall became visible running NE-SW through the center of the unit (Figure 5.20c). The damage to the wall appeared on the top and on its western side. The fill material continued in the western portion of the unit, to the west of the wall and it became apparent that previous looting activity had occurred there, but not in the eastern side of the wall. On the eastern side, the loose fill of Level 200 yielded to more compact soil of with less gravel, Level 300. Excavation was paused in the western portion of the test unit, but a $50 \mathrm{~cm}$ extension was added to the eastern half of the unit where the deposits appeared undisturbed by looting activity. The almost $12 \mathrm{~cm}$ deep Level 300 contained abundant food remains and charcoal similar to the preceding levels and one plain Initial Period pottery sherd was recovered in the 1/4" screened material was likely dislodged from the wall of the unit at Level 100. At the base of the unit, excavators came down upon a nearly flat surface of hard packed gravel, a likely floor. Abundant ash and charcoal was found around the center of the unit, but no discernable boundary was found to indicate an intact hearth or other feature. Unfortunately, no matrix or fine screen samples were collected from this level. On top of the packed gravel floor, excavators collected a ground and polished stone artifact unassociated with other materials. The object is made of greenish black stone, identified as hematite in the field (Figure 5.20b). Its function is unknown. Beneath the 5-6 cm deep floor of Level 400, excavation uncovered undisturbed natural soil Level 500, and the excavation was terminated. Excavation in the western half 
of the unit continued to remove the disturbed fill down to the top of the sterile soil of Level 500.
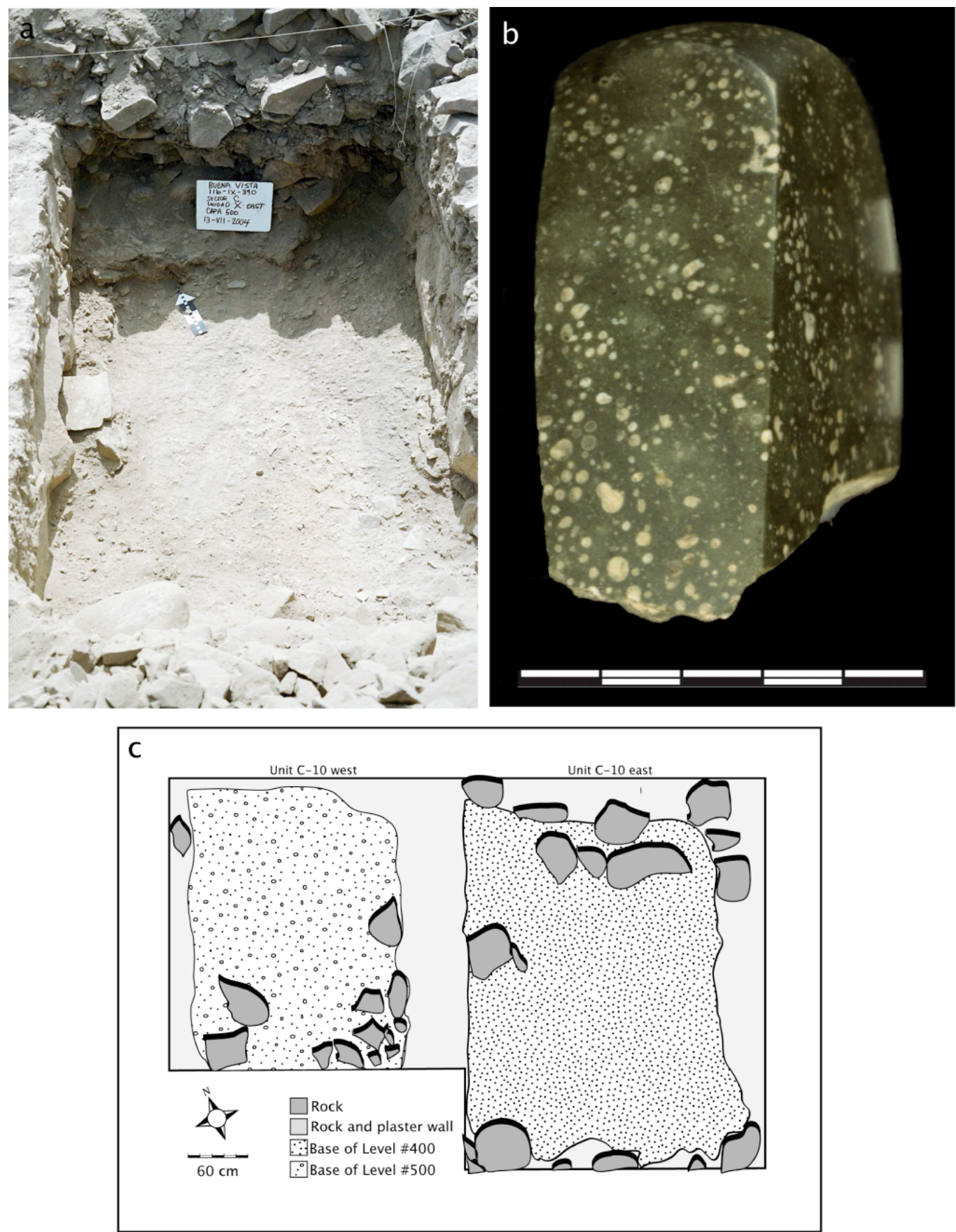

Figure 5.20 Photo and plan of Unit C-10. (A) Photo of unit C-10 excavated to compact floor, base of Level 500. (B) Stone artifact of ground and polished stone recovered from C-10 east in level 400, above the floor. (C) Plan view of base of level 500 west, 400 east with remaining walls evident. 


\section{DISCUSSION}

Excavations at Buena Vista have been severely hampered by looting activity that occurred before, and in some cases between our field seasons. I have chosen only several of the test units in Sectors B and C for paleoethnobotanical analysis because these are the most complete, undisturbed, and reliable contexts that were excavated up to 2004. There is a sampling bias here toward the earlier occupation at the site due in part to our interests in the cultural and social developments underway in the Preceramic, but more so because the Initial Period component is exposed on the surface and has been almost entirely looted leaving only commingled deposits in looters' backfill piles. Nevertheless, our excavations did result in a better understanding of the depth of time people lived at the site and some of the modifications that they made over many generations. Our earliest radiocarbon date suggests human activity in this location as early as $6548 \mathrm{cal}$ B.C., but very little is known about this first group of people. It is not likely the site was continuously occupied since then. We do not know precisely when the monumental construction at Buena Vista began, but our earliest dates thus far associated with the architecture come from the contents of the sunken pit in Sector B, Unit 10, around $2200 \mathrm{cal}$ B.C. These dates correspond to an event that filled in the pit and was followed by a renovation of the mound and the interment of the Gran Sala. Prior to its interment, the Gran Sala appears to have been used and modified several times, therefore the dates from the fill inside the pit most likely represent the terminal dates for pit and the original plan of the Gran Sala. It is very likely that earlier phases of construction will be uncovered in future excavations. 
Several modifications and renovations were carried out on the mound of Sector B, and to a lesser extent in Sector C during the Preceramic and continued into the Initial Period. The largest walls in Sector B surround the Gran Sala at the top of the mound and provided support for and reference to additional renovations that abut or cover them. To the west of the Gran Sala, a complex sequence of modifications is evident as the mound was reshaped from a simple stepped mound to an elaborate series of niched walls and central stairways leading to the room at the top. The modifications took place over several centuries. These successive renovations followed formal rules of elaboration, or rather, variations on the theme prescribed by the original design of the mound. The mound grew accretionally, but each renovation maintained the approximate form of the mound and general orientation of the original walls that surrounded the Gran Sala (See Benfer et al. 2007 for detailed description of wall alignments). On the mound's western face, the stepped platforms gave way to additional walls with niched faces behind which narrow confines created isolated spaces and staircases connected the base to the top. Each renovation was not a revolution in design, but a careful refinement of previous forms. At Buena Vista as at other Preceramic sites, such as Aspero on the coast (Feldman 1980:111), the renovations appear to be conceptually driven, not as required by maintenance or repair. Each renovation is associated with some other modification, the raising of a floor, creating a new room, sealing a niche, or changing shape of a wall, that adds a new meaning to the structure as well as a new space in which an activity can occur. In contrast, by the Initial Period, the modifications made to the mound begin to appear less refined and formal, with many of the walls left unplastered. By this time, the original rooms of the 
Preceramic period architecture have been filled in with rubble and shicra, and the later structures that top the mound are smaller and less elaborate than what came before. The presence of late period burials associated with the early architecture indicates that despite the changing focus of Initial Period architecture, the mound continued to have powerful symbolic significance.

In Sector C, it appears that fewer changes occurred over time following the construction of the large plastered walls that abut the main north-south wall on Sector C's western face. The rooms were filled with rock and rubble then later topped with Initial Period rooms that utilized some of the original layout. This area is one of the most disturbed portions of the site and excavations here uncovered evidence of significant looting in every test unit. The functional association of the buried architecture is difficult to discern. For example, the adobe lined trench that parallels a raised floor in unit C-1 does not connect to a hearth or other intact architectural feature, so it is unknown for what purpose the trench was built. However, Unit C-6 revealed a buried hearth associated with a similar raised floor. The contents of the hearth and the remains on the floor surrounding it contained abundant food remains. It is possible that the rooms in the Sector C complex served as domiciles for residents or visitors who performed rituals within the spaces of the temple mound of Sector B. On the other hand, the rooms in Sector C may have served their own ritual purposes or were the location for preparing meals to be served in other parts of temple complex. A comparison of the plant remains, starch and phytoliths from C-6 and the sunken pit in the Gran Sala is discussed in detail in subsequent chapters. 
Buena Vista shares many architectural features with other Preceramic period sites in central Perú both on the coast and in the highlands. In comparison to sites on the coast, the layout of the Preceramic architecture at Buena Vista is surprisingly regular and formal. Walls were built at near right angles and rooms were constructed with closely parallel walls. Not all of the rooms have been excavated and it is still unclear how they may be interconnected, but it is likely that, like the Gran Sala, other rooms have multiple entrances creating a flow between rooms and unifying the temple complex in Sector B. A similar layout is found at El Paraíso, however the walls of Unit 1, the main construction at the 'apex' of the U-complex, are less regular, though still rectangular in form, and the layout appears more haphazard (Engel 1967; Quilter 1985). Like Buena Vista, access to the rooms within the mound appears to be limited and creates a series of confined spaces through which ritual processions may travel and within which ritual activities may occur. Similarly at Aspero on the coast in the Supe Valley to the north, the temple mound is topped with confined rooms with limited access provided by only discreet entrances into the temple mound (Feldman 1980). Buena Vista, El Paraíso, and Aspero differ markedly in that the main complexes at El Paraíso and Aspero are freestanding mounds whereas Buena Vista is built onto a hillside. Unlike El Paraíso, Buena Vista shares the use of wall niches as architectural features with Aspero and other Preceramic highland sites such as Kotosh (Izumi and Terada 1972) and La Galgada (Bueno and Grieder 1979). The niched walls at Kotosh and La Galgada are set above a projecting shelf on the wall, referred to as a "dado" (Grieder and Bueno 1985:97). At Buena Vista, the base of the wall M-17, with the stepshaped niches, protrudes to form a platform, larger than a shelf, labeled altar in Figure 
5.11, but the two other niched walls at Buena Vista lack this feature; the niched walls at Aspero also lack this feature. Like the highland sites, El Paraíso and Aspero have rooms with central hearths, but unlike the highland sites, the hearths on the coast lack ventilation shafts. At Buena Vista, the central feature of the Gran Sala is not a hearth in the same fashion as these other sites, but a room excavated in 2007 to the south of the Gran Sala contains features identical to the "offering chamber" at El Paraíso (Benfer et al. 2007). The adobe lined trench in C-1 at Buena Vista is intriguing as it may have been associated with a ventilated hearth but no other evidence of it survived. Other differences between the coastal and highland sites are consistent at Buena Vista, such as the rounded corners of Preceramic constructions of the highland sites Kotosh and La Galgada in contrast with the rectilinear rooms at Buena Vista.

It is clear that differences between highland and coastal sites, and even among sites in similar regions, are significant. Shared features appear to be regional dialects of a shared symbolic language, however we still know little regarding the rituals that took place within these seemingly sacred places. Excavations at Buena Vista are being carried out by Robert Benfer in Sector B and the recent discovery of features that unite Buena Vista with El Paraíso is exciting, but the features that are unique to Buena Vista alone, such as the menacing disk flanked by foxes uncovered in 2005 sets Buena Vista apart. For this dissertation, I selected several units that contained undisturbed contexts excavated in 2004 and earlier. The paleoethnobotanical data collected within these contexts provides rare and much needed insight into the rituals conducted within these built spaces and may help us better understand the ideology behind the ritual that guided their construction. 


\section{Chapter Six - Botanical Macroremains}

In this chapter, I will describe the study of plant materials collected from selected archaeological contexts at Buena Vista. Field sampling and laboratory methods are outlined in detail, as well as procedures utilized in indentifying macroremains. The contexts under study include the sunken pit in the center of the Gran Sala of Unit B-10, F1; a small collection of remains found on a floor just outside the Gran Sala in Unit B-7; a hearth next to a raised floor and the surrounding matrices within a room in Sector $\mathrm{C}$ in Unit C-6; and the floor and matrix contents of interior rooms in Unit C-10. Because much of the site has been badly looted, I selected contexts with the most complete sampling from undisturbed areas when possible. Fortunately, the contents of the pit found in the Gran Sala escaped the looter's probes and represents a large and unique sample of plant macroremains that warranted a more thorough and detailed analysis of its contents with special emphasis on the food remains. The interpretation of the archaeological plant materials is presented both qualitatively and quantitatively. Qualitatively, the use and usefulness of the plant remains are inferred from modern and archaeological analogues. Quantitative assessments of the remains were made using simple counts, weights, density ratios, and percentage occurrence of taxa. For the pit contents in the Gran Sala, B-10, F-1, I present a more detailed analysis of the richness, diversity, and evenness of the food remains in order to compare the contents of each stratigraphic level and to infer different behaviors associated with the pit's interment. For example, using density and ratio measurements, I 
compare the stratigraphic levels of the pit to show that the how the density and proportion of food remains increases in the upper levels of the pit. By using richness and diversity measures, I compare the composition of the food remains by level in the pit to look for changes in consumption patterns, such as kinds of and abundance of foods. For other contexts, I interpret the function of the contexts where possible. For example, the hearth contents and surrounding matrices of C-6 are interpreted as a kitchen area, but other contexts, C-10 and B-7, still have unknown functions or represent secondary discard of plant remains there.

\section{Field SAmpling Procedures And ConteXts of Study}

Macroremain field sampling for floral and faunal remains was a protocol of excavations at Buena Vista. The materials recovered for this study were collected in 2003 and 2004 during the MU field school seasons. Three sample types were collected, finescreen, bulk, and matrix samples, depending upon the nature of archaeological context. Bulk samples contain either individual organic specimens or organic materials that were collected and bagged without the need of screening. Smaller contexts or features that were collected entire and sediment samples that were collected and not screened in the field are referred to as matrix samples.

For finescreen samples, usually ten liters of soil, from an excavation level or feature were collected for fine screening. These finescreen samples were passed through a series of three nested sieves, sized $6 \mathrm{~mm}(1 / 4 \mathrm{inch}), 3 \mathrm{~mm}(1 / 8 \mathrm{inch})$, and $1.6 \mathrm{~mm}(1 / 16$ inch), into a container. Field school students were instructed in proper technique of screening, not to force materials through the sieves and take care to avoid damaging the samples. The dry, 
silty soils were mostly devoid of clay; therefore a gentle shaking of the screens was enough to pass the sediment through even the smallest fraction. The pre-screening weight of the finescreen samples in the field is not known, but the fractionated samples were weighed in the laboratory at CIZA, and give some insight into how much the contents of an individual 10-liter sample weighs. Once the sample is poured through the nested sieves, the field technicians saved only the plant, animal, and artifact remains in the largest fraction, $6 \mathrm{~mm}$, discarding rocks and large chunks of mud plaster. The remaining $6 \mathrm{~mm}$ fraction, usually, mostly plant remains and charcoal at this point, may weigh as much as $1 \mathrm{~kg}$, but usually no more than 300 grams (Table 6.1). The next sized sieve, $3 \mathrm{~mm}$, usually contained an abundance of small rocks and compact dirt fragments intermixed with fragments of plants and smaller seeds. This fraction tended to produce the heaviest portion of the sample, from $400 \mathrm{~g}$ to $700 \mathrm{~g}$. This $3 \mathrm{~mm}$ fraction was collected and bagged in the field in its entirety because removing the plant and animal fragments in the field would have been too time consuming and would have required more training of the field assistants in the identification of small seeds and animal bones and may have introduced inconsistencies in the sampling. Likewise, all of the material that did not pass through the smallest fraction, $1.5 \mathrm{~mm}$, was collected in the field. The sediments collected in this $1.5 \mathrm{~mm}$ fraction usually weighed from $400 \mathrm{~g}$ to $1 \mathrm{~kg}$, depending on the how much small gravel the sample contained. For each finescreen sample, a portion of the finest fraction, that which passed through the smallest $1.5 \mathrm{~mm}$ sieve, was also collected, usually about $500 \mathrm{~g}$. The soils in the archaeological contexts at Buena Vista are very fine-grained and very dusty, and would have produced a sample too large to be practically studied, therefore just a standard portion of 
Table 6.1 Contexts sampled and analyzed from Sectors B and C at Buena Vista.

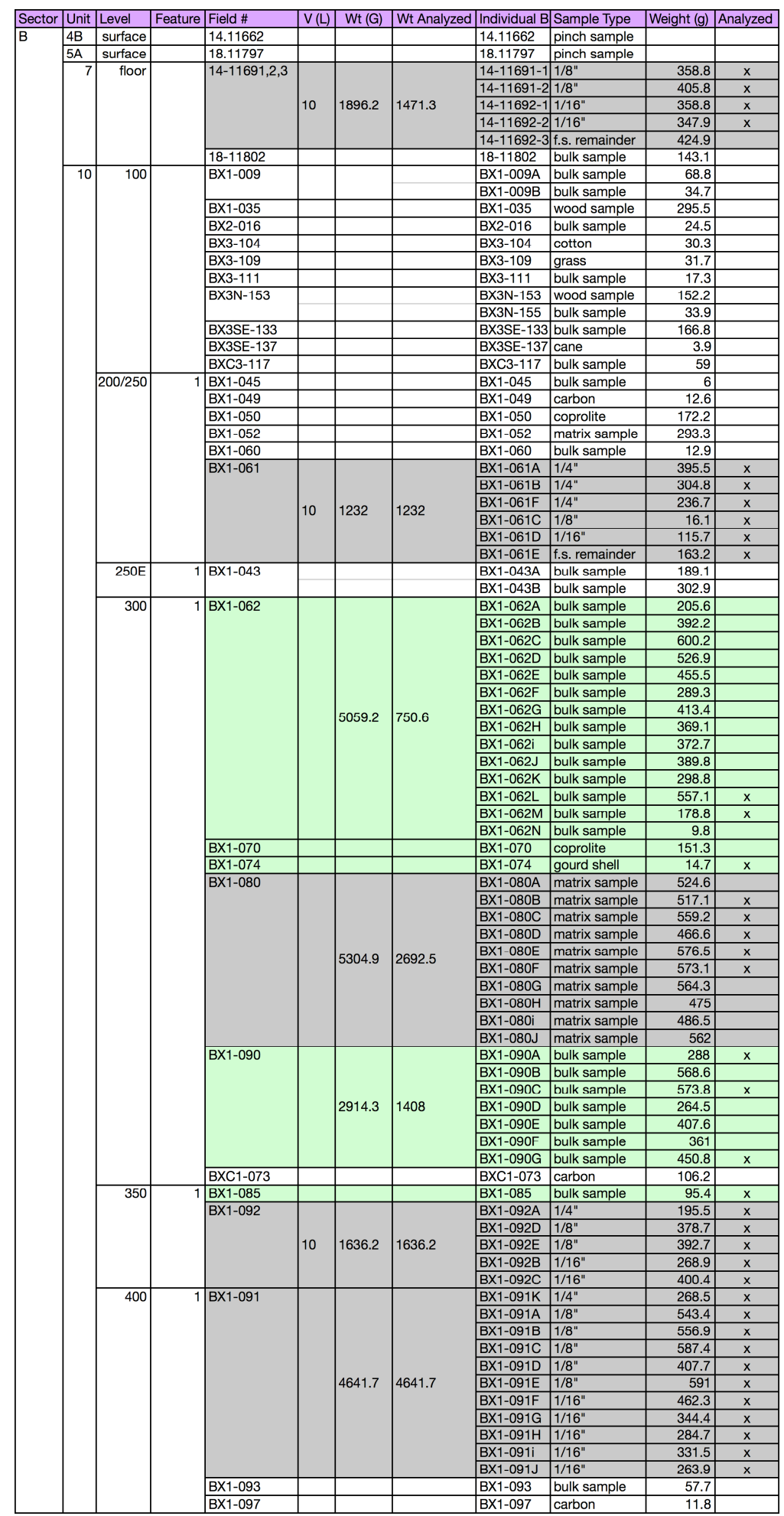




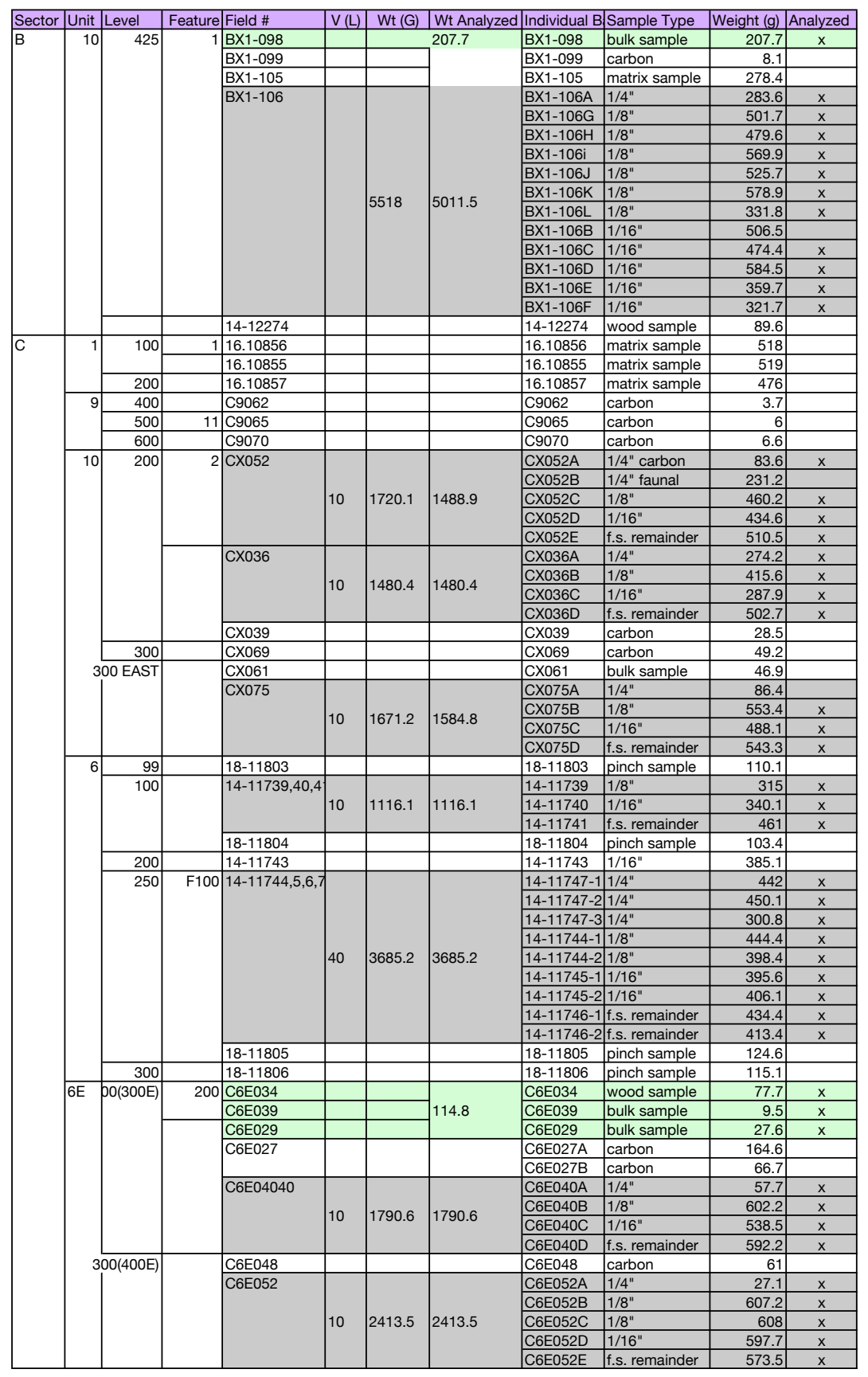


the fraction was collected in order to recover the smallest of seed or fish bones less than 1.5 $\mathrm{mm}$ in size.

Special contexts, such as the sunken pit, required a different strategy. During excavation, organic remains in the pit were very dense and an attempt was made to collect all organic material if possible without causing damage to the remains that might occur through sieving. This material was simply placed in bags as bulk samples from each level and, if needed, sieved and sorted in the laboratory. Most bulk samples contained very little soil matrix, being mostly plant remains, but also occasional mussel shells or artifacts. In additon, 10-liter finescreen samples were then taken from the matrix of each level. In Level 300 , organic remains were extremely abundant and collected in 21 bulk samples of plant remains weighing as little as $10 \mathrm{~g}$ to as much as $600 \mathrm{~g}$. The soil matrix of Level 300 was then collected as a matrix sample to be sieved and sorted in the laboratory.

\section{LABORATORY PROCEDURES}

Once the samples were imported to the Paleoethnobotany Laboratory at MU, sorting to remove plant material from the samples began. This turned out to be a greatly time consuming task due to the large size of the samples and the fine silty dust adhering to the remains. To help speed up the sorting time and clean the contents further, the contents of the bags were often gently re-screened in the lab through another series of two sieves to help remove some of the dust, each fraction then was sorted, then the plant remains were recombined as a single bag. For example, a single bag of material from the field-screened $3 \mathrm{~mm}$ fraction was then passed through another set of screens, $2 \mathrm{~mm}$ being 
the largest, $0.5 \mathrm{~mm}$ the smallest. The largest fraction was then sorted under a compound microscope. The smallest fraction, $>0.5 \mathrm{~mm}$, was then examined, also under the compound microscope, to recover any small seeds or diagnostic seed fragments that might be present. The small fraction and the large fraction were then recombined as the $3 \mathrm{~mm}$ field-screened fraction and the fine dust $<0.5 \mathrm{~mm}$ was saved in a bag labeled as remainder. Because this was often necessary to prepare a sample for sorting, recombining the second set of laboratory sieving as a single sample kept the standard sampling procedure established in the field and avoided the confusion that might result in the generation of multiple sub-samples. Still, even with this second clean-up sieving, the sorting continued to take long hours.

I conducted another attempt at speeding-up sorting time through the use of a seed blower. Ramenofsky and colleagues (1986) were successful using a seed blower to help clean up flotation samples from archaeological sites in South Dakota. Their seed blower was manufactured to sort seeds by density and remove unwanted organic matter for the purpose of evaluating seed size and quality. The sample is placed in the machine at the base of a tube that sits atop an airflow generated by an electric motor. Within the tube are shelves placed at angles, around which air can flow. With the fan turned on, the air blows the light particles up into the tube that then fall back down on top of the sieves while a screen at the top of the tube keeps any material smaller than the pores of the screen from escaping. To experiment, I borrowed a seed blower from MU's Agronomy Department, but it was significantly different than the one used in the South Dakota study. In fact, this machine, as I later found out, was designed to quickly separate chaff from wheat or dry 
pods from beans, operating more like a seed cleaner. Thus, the machine works slightly differently. One pours a sample through a large screen at the top that collects large particles and rocks, as the sample falls, a column of air blows the light fraction out the end of a chute, the heavier particles, the seeds, then fall to the bottom and are collected in a pan. This would not work to separate archaeological samples, since the heavier plant materials would still fall to the bottom, but I thought it might work to help blow the fine silty dust out of the sample making them easier to sort. I experimented with two bags from two samples from Buena Vista. The first bag, collected in the field from Unit 2 in Sector G during excavations in 2001, was a $1 \mathrm{~mm}$ fraction screened in the field. The other, a larger 3 mm fraction was collected in 2002 from Unit 7 in Sector B.

I modified the blower in order to collect any botanical remains that might get blown out the chute along with the dust by making a bag of very finely porous nylon cloth and attaching it to the output of the chute. By slowly pouring the sample into the blower set at low fan speed, the dust blew out the chute in a surprisingly large plume, a good sign. Some of the lighter plant materials, grass stems and florets, were collected in the bag, while the majority of the remains settled in the pan below. Higher fan speeds resulted in more botanical remains collecting in the bag, however this would not be a sufficient solution to separate botanicals from matrix, as with the South Dakota machine, since most of the larger charcoal fragments still settled in the pan. With a low airflow, the machine did not seem to damage the botanical remains, although these samples contain very robust specimens. The results of this experiment, though qualitative, suggest that this machine could be used to clean dust and fine silt from dry dusty samples, but coarse inorganic 
particles remain and still require manual sorting of the sample, and, therefore does not necessarily speed up the process anymore than re-sieving the field samples in the lab. One advantage a machine like this might have in the field, however, would be to remove significant amounts of dust from individual samples and slightly reducing the volume and weight of dry-screened samples. But, because there might be a risk in damaging less robust or fragile materials in the sample, I would use extreme caution.

Finally, water flotation of the field-screened samples proved to be the most efficient use of time. In most cases, dry screening of samples from desiccated contexts is the correct approach to take, as opposed to water screening or flotation, because wetting dry remains may speed up the degradation of the plant material, cause breakage, or the sloughing off of diagnostic features, and introduce the risk of mold (Pearsall 2000:81). Some of that risk can be minimized by carefully limiting the amount of time the samples are in contact with the water to avoid excessive absorption of moisture, and controlling the amount of agitation to protect the remains from collision and abrasion, and finally drying the samples slowly out of direct heat or sunlight. These techniques were used by Alex Chevalier (2002) on previously dry-screened materials from coastal Peruvian sites Mina Perdida and Pampa Chica and seemed to provide as good or better recovery than provided by sorting the dry sieved materials. Field sampling at Pampa Chica, like Buena Vista, also passed sediment through three nested screens, $6 \mathrm{~mm}, 3 \mathrm{~mm}$ and $1.6 \mathrm{~mm}$. The sorting time of the floated samples as compared to dry samples was reduced by almost $90 \%$. Since the largest fraction of dry screen material (> $6 \mathrm{~mm}$ ) is usually clean of gravel and other non-organic debris, Chevalier only floated the smaller $3 \mathrm{~mm}$ and $1.6 \mathrm{~mm}$ fractions. In light of this success, I 
proceeded to float the largest set of small fraction $(3 \mathrm{~mm}$ and $1.6 \mathrm{~mm}$ ) samples from the sunken pit.

Outside the Museum Support Center at MU, we used a SMAP (Shell Mound Archaeological Project) style machine (Watson 1976). This machine ${ }^{4}$ consists of two drums, the largest of which has a sprayer at the bottom that attaches to an outdoor water tap. The second, smaller drum sits inside the larger, above the level of the sprayer head. The bottom of the smaller drum is $1 / 16$ " hardware cloth. Once the larger drum fills with water, the smaller drum is placed inside and the sprayer is turned on agitating the water from the bottom up. For flotation, a dry fine-screen fraction is slowly poured into the water, the heavier non-organic material sinks to the bottom, while the agitation of the sprayer helps to push the lighter organic material to the top where it floats and flows through an overflow chute into a smaller bucket with a bottom of $0.5 \mathrm{~mm}$ mesh. This material in the smaller bucket is the light fraction. To increase recovery, a small hand sieve with $0.5 \mathrm{~mm}$ mesh is used to help push the floating material out the chute into the bucket and capture suspended organic material that does not float to the top. Once the sprayer is turned off, the hand sieve can be used to capture any remaining suspended organics. Some organic material may not be buoyant enough to float, therefore we used a siphon, the kind used to clean the gravel in a household aquarium (Gumerman and Umemoto 1987). Once the siphon is operating, the output flows into the bucket with the light fraction. The other end is passed over and into the heavy fraction that rests atop the $1 / 16$ " hardware cloth of the inner barrel, siphoning up the lighter organic material. When recovery is completed,

\footnotetext{
${ }^{4}$ The MU SMAP machine is built by the able craftsmen of B \& Mgineering (sic).
} 
the light fraction was tapped onto a square of cotton cloth and tied in a bundle, as was the heavy fraction to its own cloth square. The machine was then rinsed and the next flotation of dry screen fraction commenced. To dry the samples, the bagged fractions were then suspended from a line, or, for the heaviest heavy fractions, placed on top of upside-down milk crates, indoors in an air conditioned room at around $74^{\circ} \mathrm{F}$. The cool temperature helped the bundles dry slowly and the low humidity prevented the growth of mold.

Flotation of the fine-screened fractions greatly reduced the sorting time, even when considering the time to undertake the flotation. Over a dozen bags of finescreened material could be floated in just a few of hours. Sorting time for the flotation fractions took, on average, 45 minutes, although some of the more productive fractions still took several hours, especially those with hundreds, thousands, of small guava or cotton seeds. Both the fractions, light and heavy, were examined and sorted for botanical remains. The light fractions by far contained most of the organic material, but examining the heavy fractions to ensure as complete recovery as possible was necessary because, even with the siphoning, organics were sometimes present in the heavy fraction. Also, because the original finescreen fractions would have been sorted as a single bag, even after a secondary sieving in the lab, both fractions of the flotation were considered a single bag of a sample for the purpose of this analysis.

\section{IDENTIFICATION OF PLANT MACROREMAINS}

The identification of the archaeological plant macroremains in this study used a three-tiered classification. First, at the most inclusive level, the item recovered was identified to type of material. In some cases the material type refers to a plant's vegetative 
part that is represented, e.g., bark, peduncles/stems, pods, seeds, fruit, root/tuber/rhizome, rind/peel, and charred or uncharred wood. Leaves were distinguished by venation pattern characteristic of either monocotyledonous or eudicotyledonous plants. Other materials may be of plant origin but also classified as artifacts, most commonly cotton thread fibers and textile fragments, twisted grass or cane, and modified wood. Other materials, not the focus of this study, but occurring in the samples were included in the material type category, such as faunal remains, crustaceans, bivalves, fish, insect parts, dung, or small mammal bones.

The second level of classification was to identify the sample to botanical family, and, in the third level to genus and species. In general, family level identification was possible with most material, however not all macroremains are easily identified, due to either a lack of preservation of their diagnostic features, such as in the case of the leaf fragments, where only a monocot or eudicot distinction could be made, or where specialized training is necessary for accurate identifications, as with charred wood or wood fragments. I was only able to identify wood to family in some cases, and less often to species when the fragments contained unique easily identifiable characteristics. Family level identification of taxa was made whenever possible, however, in certain instances when the plant material was incomplete or lacking diagnostic features, but shared enough common features with known taxa, these remains were given a cf Family designation meaning their features compare favorably to the family indicated. Therefore, the $c f$ designations denote tentative identifications. The same $c f$ criteria hold for taxa identified to genus and species. 
Some diagnostic features of genus or species may be missing or the particular item compares favorably to other taxa in same genus or species.

The process of taxonomic identification of the plant remains utilized the comparative specimens from Perú and Ecuador housed in the Paleoethnobotany Lab at MU, which also contains coastal Peruvian materials sampled by Marcel Umlauf with permission from the herbarium at Centro de Investigaciones de Zonas Aridas (CIZA) in Lima, and Neotropical specimens sampled by Deborah Pearsall with permission from the herbarium at the Field Museum of the University of Chicago. Additional Peruvian comparative materials were purchased at various markets in Lima and Chiclayo. Published identification manuals and botanical and ethnobotanical references were also consulted including Martin and Barkley (1961), Lentz and Dickau (2005), Towle (1961), Cárdenas (1969), Ugent and Ochoa (2006), Soukup (1970), Ferreyra (1982), Gentry (1996), Whitaker and Bird (1949), MacBride (1936; 1980), Baehni (1970), Correll (1967) Edwin (1971), and Steele (1964). Archaeologist Bernardino Ojeda assisted with the preliminary identifications of some of the materials and Thomas Andres of the Cucurbit Network assisted in the identification of squash seeds.

Counts and weights of the botanical remains were recorded for most items. In some cases, where the materials were too fragmentary and numerous to count, such as certain samples of grass leaf fragments, charcoal and wood, only weights were recorded.

\section{INTERPRETATION OF MACROREMAIN DATA}

The ecology at the site and valley below and the cultural contexts in which the plant remains were recovered help to shape our interpretation of the human behaviors in 
the past with regard to the plant remains recovered at Buena Vista. Ecologically, as described in Chapter 2, the hillsides of the lower-inland Chillón Valley are nearly devoid of vegetation, save for sparsely scattered epiphytic bromeliads. The soils on the dry slopes lack much of the necessary nutrients for rooting plants and do not hold sufficient moisture to permit their growth. For a recent example, at Buena Vista, the current residents at the base of the site attempted to plant small pine saplings on the hillside above, but despite manual (bucket) irrigation, none of the saplings survived. On the other hand, a large stand of planted Opuntia cactus seems to thrive with the frequent attention the residents give it, and they have managed to grow a few stalks of corn and beans in the lowest portion of the site with the aid of drip irrigation and fertilizer.

For the archaeological plant remains, we have an idea of the ecology of many of the identified plants in the assemblage (see Appendix 1) Most plants, including cultivated plants, grasses, wood, and even weedy plants, were not likely to have been growing on the hillside at Buena Vista, but could have been cultivated or managed in the river valley below or occurred naturally along riparian edges. For example, Cucurbita moschata (squash) was likely domesticated in the tropical lowlands (Nee 1990; Sanjur et al. 2002; Piperno et al. 2000) and requires cultivation on the coast of Perú and does not grow wild on the hillsides of the inland valleys ${ }^{5}$. Also, the archaeological plant remains were recovered from inside built architectural spaces where human activities are explicit. Therefore, this assemblage is very different from other archaeological assemblages where differentiating the source of the material, either through human or through natural deposition; such as seed rain (Minnis

\footnotetext{
${ }^{5}$ A detailed description of cucurbit materials from Buena Vista is given in Chapter 8.
} 
1981) is of major concern. The use of fuel or building material would explain the presence of grasses and wood in the architectural areas. The dry coastal climate combined with the sealed architectural contexts creates a unique environment for near-complete preservation of organic material for thousands of years and therefore indirectly associated with some kind of human behavior that brought the plants there.

For a qualitative assessment, the plant macroremains have been grouped into categories according to some of their primary uses based on inferences from modern and archeological analogues (Cárdenas 1969; Ugent and Ochoa 2006; Towle 1961; Franquemont et al. 1990) such as Food and Industrial plants. Other plants are grouped by types and no particular function of the plant is assumed. These groups are the Grass/Sedge, Wood, Herbaceous/Weedy, and Other/Unknown. These categories are arbitrary and may gloss over emic categories of use or multiple uses possible for a single taxon, but provide a general and basic framework for description. Appendix 1 describes the ecology of each identified taxon and describes known uses and potential uses based on properties of the plant and ethnographic information available.

Plants categorized as Food remains include edible parts of plants, or the non-eaten remains directly associated with those edible plant parts, which are consumed by humans today and we infer were eaten in the past. Many foods identified in the macroremains are still common in the diet of modern peoples in the region and beyond: Ullucus tuberosus (ulluco), Ipomoea batatas (sweet potato), Cucurbita spp. (squashes), Capsicum sp. (chili peppers), and others. However, one taxon identified in the assemblage, Begonia geraniifolia, is not used as a food plant today, but may have been managed for its purportedly edible 
rhizome. The propagative parts, the "eyes" of the rhizome, were common at Paloma, thus and Weir and Dering (1986) hypothesized the plant may have been subject to early management. Also, remains of Begonia epidermis were tentatively identified in a human coprolite from the preceramic site of Asia (Jones 1988:81). However, in experimenting with various cooking methods, Weir and Dering were unable to palliate the acrid taste of the rhizome. Possibly, the rhizome was used as a flavoring agent or even as a medicinal. Ethnographically, the rhizome is consumed medicinally in an infusion, ground, or eaten fresh as a purgative (Ruiz 1952 in Soukoup 1970:41). For the purposes of this study, Begonia tubers are included in the Food category and presumed eaten, but may represent a pharmacological component as well.

The Industrial category includes those plant remains that would have provided useful materials in the making of artifacts. These include the fibrous leaves of Furcraea andina that can be used to make twine, sandals, and other useful items (Yacovleff and Herrera 1934), and fragments of gourd rinds (Lagenaria siceraria) used for containers and serving vessels. Also included in the Industrial category are portions of artifacts, such as cotton textile fragments and cotton thread, which were found in the matrix samples as well as twisted grass cordage. Camelid fibers were also recovered from two contexts and are included in this category as well. Cotton fiber (Gossypium barbadense) used to produce textiles, nets, and other items was present along with many seeds and seed fragments.

There is some speculation that cotton seed may have also been used as a food source during the Preceramic (Smith 1988:145). Cotton seeds were found split lengthwise at La Galgada, possibly to extract the oil-rich endosperm for direct consumption or to press 
for oil. Cotton seeds are high in carbohydrates and fat, but also contain a high amount of protein, up to $25 \%$, and would have been a significant potential food source if not for one major drawback, the seeds are toxic (Bressani et al. 1965) and the crude oil recovered from cotton seeds requires further refining before consumption. Cotton seed contains gossypol, a polyphenolic compound that is cardio- and hepatotoxic to animals with only one stomach, such as humans (Lusas and Jividen 1987; Risco and Chase 1997) and even ruminants can only tolerate moderate amounts. The gossypol is found in "glands" visible as black specks on the seed, but also in the leaves, stems and green bolls (Lusas and Jividen 1987). Interestingly, these glands are still visible on cotton seed endosperms in the Buena Vista assemblage. In recent decades attempts at breeding glandless cotton as a food source were somewhat successful, but the glandless varieties were highly susceptible to pests and disease, and only in the last few years have geneticists been able to produce viable cotton with reduced gossypol levels suitable for human consumption (Sunilkumar et al. 2007). Therefore, it is unlikely that seeds of cotton cultivated on the coast of Perú lacked gossypol and were edible. But the oil, as a byproduct of the seeds, could have been used for an industrial purpose. For example, the Hopi of North America have used cotton seed oil is to polish stones (Titiev 1971), but similar usage in Coastal Perú is not documented.

As a broad category, Grass/Sedge includes leaf and stem fragments, as well as seeds, of monocot grasses and sedges that likely grew in the area. Other monocots, such as Juncaceae and Typhaceae, may also be present among the fragments of leaves, but diagnostic parts were not found in the assemblage. Worked stems made into cordage were placed among the Industrial plants. Grasses and sedges may have had any number of uses 
in construction, as temper for mud plaster or for roofing materials, or in the production of woven mats and baskets. Most of the grass and sedge remains is not evidently worked or occurs as loose fragments in the assemblage and it is difficult to determine the intended use in most contexts. On the other hand, it appears that a layer of grass was intentionally placed on the floor of the sunken pit in Unit B-10, but this grass does not serve an architectural function. Other grass and sedge fragments may have been brought in as fuel. Grasses and sedges may have also played a role as a food source; their seeds are edible and many rhizomes of grasses and sedges are edible and may have been eaten. In coprolites from Chilca and Paloma, grass seeds were often abundant (Weir and Dering 1986; Jones 1988), and seeds may have been ground for food. Yacovleff and Herrera (1934:263) report one Mochica ceramic vessel decorated with the rhizome of Phragmites that may indirectly suggest the rhizomes were consumed. However, because of the myriad uses for grasses and sedges, their presence is better interpreted for each individual context.

As a category, Wood includes fragments of woody plants. For the purpose of this study, wood is grouped as a single category and sub-divided by charred and uncharred wood. Wood, of course, is a highly valuable material for any number of tasks including the construction of shelters, making of tools, and burning for fuel. These seemingly mundane activities belie complex cultural and ecological interrelationships in the selection, management, and use of wood resources that are often overlooked by archaeologists (but see Goldstein 2007). I recognize the potential for a more detailed analysis of the wood from archaeological contexts at Buena Vista, but, having limited skills in properly identifying wood to taxa, I must rely on only the largest of wood categories for analysis. As 
noted earlier, the identification of wood to taxa was only done when diagnostic features were obvious. Wood use at Buena Vista for fuel is abundantly apparent in hearth contexts and suggested by the abundant remains of charred wood in secondary deposits throughout the site. Architecturally, wood was used as wall supports and may have also been used for roofing (see Chapter 5). In one context, Unit C-6, a stick of wood with rounded ends appears to have been used as a tool.

The Herbaceous/Weedy category of macrobotanical remains contains plants that may have been brought to the site as fuel or some other purpose. This group includes weedy species growing in the area, but not necessarily on the site, such as seeds from a weedy member of Fabaceae, and those items for which their use is unknown, such as the seeds of plants identified only to a Family level, Apiaceae, Verbenaceae, Convolvulaceae and Euphorbiaceae.

Lastly, the Other/Unknown category includes those items recovered in the samples that are of mixed botanical origin such as mixed fragmentary floral material of very small size, organic conglomerates of unknown origin, and animal dung.

\section{CONTEXTS OF STUDY}

For this research, I selected for analysis archaeological contexts from within the Preceramic architecture of Sectors B and C where, generally, secure deposits of material undisturbed by looting were excavated (Table 6.1). In the following section, I will explore the macroremain assemblages from each individual context that complements the archaeological description of each context in Chapter 4. Macroremain data will be presented both qualitatively and quantitatively. The plant assemblages are displayed as item 
counts and weights by context in Tables 6.2 through 6.8. Qualitative descriptions of the botanical material present in the archaeological contexts allow for an interpretation of how certain plants may have been used, for instance, the presence of rinds rather than whole tubers would suggest that the rinds represent the discarded portions of the eaten tubers. Also, a patterns of discard viewed qualitatively, have interpretive value in discerning areas of primary activities versus areas where remains are secondarily deposited. Qualitative interpretations are then supported by quantitative data on the plant macroremains. Using simple measures of density ratios and percentage abundance displayed in bar and line graphs, differences between contexts are teased out. More complex calculations of richness and diversity were carried out on the material from within the pit, Feature 1 in Sector B Unit 10. The overarching goal of this macroremain study is to identify those human actions in which the plant remains played a role and these will be considered for each archaeological context separately and then more broadly interpreted for the site in general.

Sector B, Unit 10

The majority of the samples studied from Sector B were collected from the sunken pit in Unit 10, Feature 1. Most of the macroremains studied are from 10-liter finescreen samples and matrix samples sorted in the laboratory, but several bulk samples, those that contain materials collected in the field without the need for screening, were also selected, particularly from Level 300 (Table 6.1). Level 100, the stratigraphic layer that overlaid the sunken pit was not studied due to significant looter disturbance. As will be shown in the evaluation of the remains below, unlike votive offerings or a storage feature, the vast majority of botanical remains in the pit are more consistent with discard processes of 
activities that occurred outside the pit itself. Even so, the stratified contents suggest a deliberate, ordered, burial of the pit. Therefore, the first goal is to evaluate the assemblage of plants by pit level. If the composition, density, or presence of plant remains differs, level by level, this would support the archaeological observation that the stratigraphic levels of the pit followed a deliberate sequence of interment. Also, because there is an abundance of food remains, comparing their composition, density, richness and diversity in relation to other plant remains, such as charred wood and uncharred wood, might provide some insight into the kinds of activities that the food remains represent. For example, if differences in richness and diversity of food remains is high between levels of the pit or in relation to density of other non-food remains, we may infer that behaviors associated with consuming food are reflected in the assemblage.

The excavation of the pit followed "natural" stratigraphic layers as defined by fill content (Figure 6.1). The strata seem to follow a deliberate sequence of deposition beginning with the placement of the layer of grass at the pit's base (Level 425), atop which mixed organic remains, including food and other materials were placed (Level 400). Carbonized wood collected from this level was dated to 2200 calB.C. (see Table 5.1). This layer was then covered by a layer of small cobbles ranging in size from around 10 to $20 \mathrm{~cm}$ in diameter interspersed with gravel, however organic materials were also commingled with the rock. Atop the layer of cobbles and gravel, a distinct layer of mixed organic material was placed (Level 300). Carbonized wood collected from this level was also dated to 2200 calB.C. An addition of fill material, containing organic remains and angular gravel (Level 200/250) continued the sequence of burial which finished with angular gravel near the top 
of the pit. It is important to note that in the excavation of the pit, it was observed that the concentration of botanical materials in Level 200 began to increase toward the bottom of the pit and was designated as Level 250. However, the sampling of this level was combined in the field as only Level 200, thus for our purposes, these samples are analyzed as a single level - referred to as Level 200/250 - above Level 300. Finally, the pit and the surrounding platform was buried under cane bags of rock, shicra.

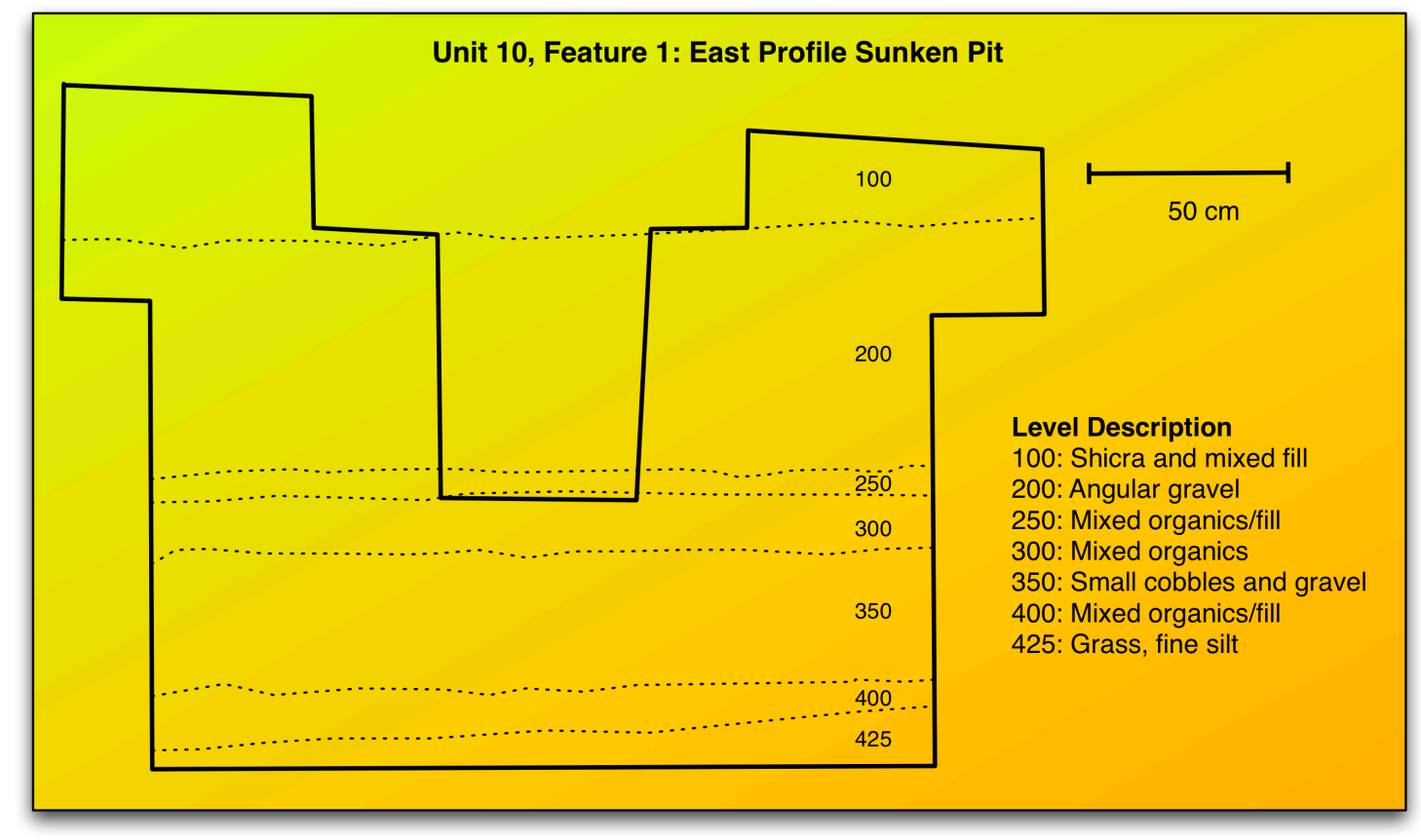

Figure 6.1 East profile of the sunken pit in Unit B-10, Feature 1. 
Table 6.2 Sector B, Unit 10 macroremains by count and weight.

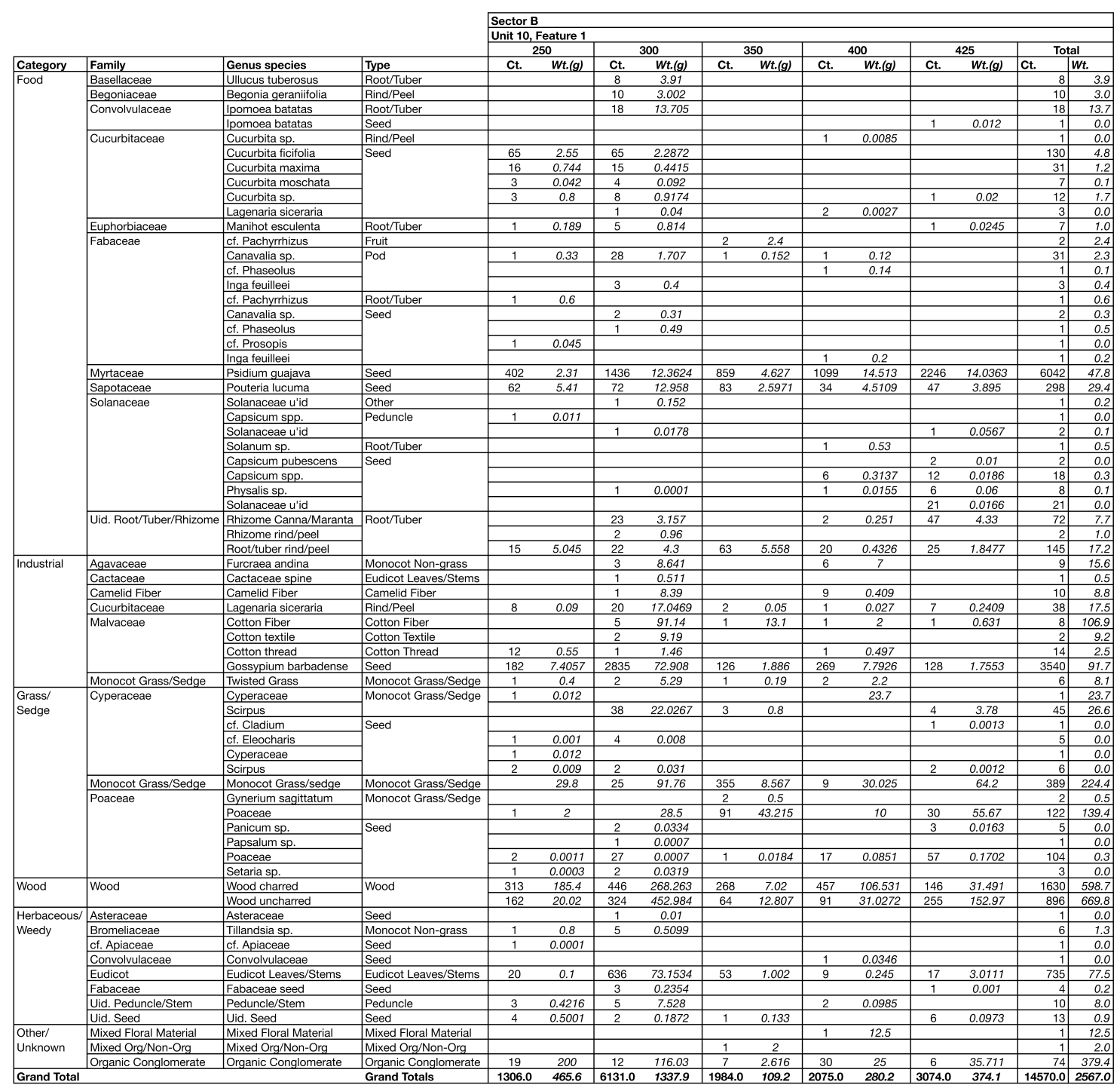


In general, the contents of the pit contain large quantities of plant materials, including food, industrial plants, grasses, charred and uncharred wood, herbaceous and/or weedy plants, and other materials such as conglomerated organic material (Table 6.2). During excavation, it was apparent that commingled materials were, effectively, dropped or scattered into the pit as there was no evidence that any particular materials were placed in carefully selected areas or in bundles of like kind, with the exception of the layer of grass that was placed over the base of the pit. The not-so-careful attention to which the materials were deposited, suggests that the materials were collected from other locations, probably in the cleaning of the Gran Sala and other rooms just prior to the temple's interment. Also, the nature of the materials themselves, fragmentary and incomplete, suggests the remains were used elsewhere.

The artifacts recovered from the pit seem to follow a similar pattern of discard to the botanical remains. Artifacts, however, were very rare in comparison to the plant materials. Just beneath the layer of Shicra in Level 100 and near the top of the pit, excavators recovered a thin bone paddle-shaped ornament (Figure 6.2). Fragments of cotton textile adhered to the ornament's interior side and this suggests the artifact was worn on one's clothing. In the fill below, in Level 200, excavators recovered a thin rectangular piece of dried reptile skin with rectilinear parallel perforations, the function of which is assumed to be ornamental and another piece of reptile skin, undecorated, was found in Level 300. In Level 200 and in Level 300, excavators also recovered simple bone pins (Figure 6.2 right) that may have been used as a hair or clothing pins. Very similar versions of these bone pins, as well as more highly decorated ones, are reported from the 
contemporaneous highland site of La Galgada (Grieder et al. 1988) and Late Preceramic burials at Asia in the Omas Valley to the south (Engel 1963). Also in Level 300, a bird bone cut on both ends was found. Similar bird bone tubes were found on strings of cotton in thick necklaces in burials at Asia (Engel 1963:53). In Level 425, near the base of the pit, a small, carved stone bead was also recovered. All of these artifacts recovered from the pit were probably used as personal adornment, but are not archaeologically associated with a particular person, such as one would find in a burial context. Also, the artifacts did not appear to be directly associated with each other in the pit contents; rather, it is as if they were left not as offerings but as discarded items.

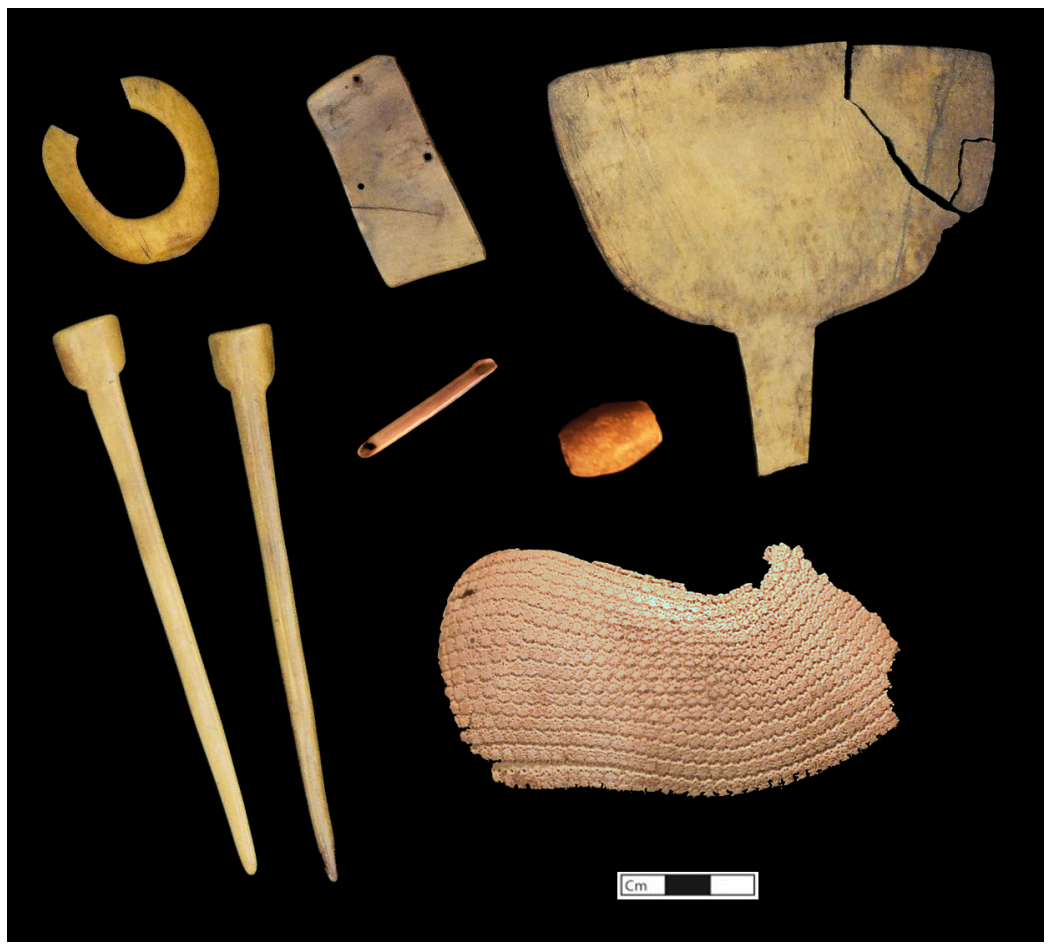

Figure 6.2 Artifacts from Unit B-10. Clockwise from top left, carved bone disk, bone pendant, bone plate, two bone pins, a cut bird-bone bead, a stone bead, and at the bottom, a fragment of dried reptile skin. 
Qualitative descriptions of the food remains from the pit show a pattern of discard that differs from what one would expect if the plant remains were offerings. The remains of food plants are abundant (Table 6.2) and include root, tuber, and rhizome peels and fragments representing Ullucus tuberosus (ulluco), Begonia geraniifolia (begonia), Ipomoea batatas (sweet potato), Manihot esculenta (manioc), and fragments tentatively identified as cf. Pachyrrhizus sp. (jicama). Other rhizome peels identified as "Rhizome Canna/Maranta" are consistent with those produced by arrowroot (Maranta arundinacea) or achira (Canna sp.), but not distinguishable. Several squashes were identified by their seeds, including Cucurbita ficifolia, C. maxima, and C. moschata, and a rind fragment, not identifiable to species, was also found. Also, edible seeds of Lagenaria siceraria (gourd) are present. Several specimens of pod fragments and beans represent Canavalia sp. (jack bean) and possibly cf. Phaseolus sp. (common bean). Pod fragments and a single seed of Inga feuilleei (pacae) were also recovered. Seeds represent chili peppers from Capsicum pubescens as well as other Capsicum species, but these are not distinguishable through seed morphology. Small seeds from Physalis sp. (ground cherry) and several seeds in the Solanaceae family not identifiable to genus or species are also present in the assemblage. Pit fragments of Pouteria lucuma (lucuma) numbering in the hundreds and seeds of Psidium guajava (guava) numbering in the thousands are the most abundant food taxa in the assemblage.

The food remains recovered from the pit, Feature 1 in Unit B-10, are composed of the non-eaten or non-edible parts of food plants, such as pods, peels, rinds, peduncles, and seeds. Some seeds are edible, particularly the squash and chili pepper seeds, so their presence may be the result of certain preparation procedures or culinary preferences. 
However, neither whole nor partial fruits were recovered, with the exception of a squash rind and several gourd rind fragments that apparently served a utilitarian purpose as containers or serving vessels (see Chapter 8 for discussion of cucurbit materials). This strongly suggests that the plant foods were processed elsewhere, possibly in preparing for meals, and the waste materials then collected and deposited in the pit. A reasonable assumption is made that these plants were eaten or processed for food. It is also important to note that the vast majority of the food remains, other than several charred tuber fragments, show no evidence of charring.

Industrial plant materials recovered from the pit were found most often in unworked form, such as Gossypium barbadense (cotton) seeds and fiber, or less often as small fragment of finished objects, such as bits of cotton textile. Also, Lagenaria siceraria (gourd) is present only as fragments. Several gourd fragments and the single squash rind were sampled for starch residues and the results indicate they were used as containers or servers for other foods (see Chapter 8). Of the several leaves from Furcraea andina, a native agave found in the pit, one appears to have been pounded in preparation for separating the fibers for some other use. Cotton seeds are very abundant and found in all levels of the pit and a small mass of cotton fiber (91g.) with several adhering seeds was recovered in Level 300. Only two small shreds of woven cotton textile and several fragments of cotton thread were found. In addition, several snippets of camelid fiber were recovered in the fine-screen samples from two of the levels of the pit. Grass found in twisted strands no more than several centimeters in length were found in all but one level of the pit. Lastly, a single Cactaceae spine, possibly used as a needle, appears in the assemblage. In general, most of 
the industrial plant materials appear to be in pre-production form, as fragments of finished objects are rare. Similar to the food remains, it is likely that the industrial remains were collected from areas in the vicinity where they would have been used for certain tasks and later deposited into the pit.

The other plant remains in the pit include both charred and uncharred wood fragments. Because most of the other plant remains are not charred, it is highly unlikely there was an attempt to ignite the contents of the pit. Like the other materials, the wood fragments were probably collected from other areas, possibly hearths, and deposited in the pit commingled with other botanical remains. Leaves, culms, florets and seeds of grasses and sedges are abundant in the assemblage as well. With the exception of the layer of grass in Level 425, the grass and sedge remains were commingled with other plant materials and not deposited as a discrete bundle or in direct association with other materials.

Finally, seeds and leaves from other herbaceous plants simply may represent weedy taxa brought incidentally as detritus collected in the cleaning of the room or perhaps represent plants that may have been used for ritual, medicinal, or edible purposes. Several seeds in the Herbaceous/Weedy category are not identified to genus and others are only tentatively identified to family, therefore it is difficult to discern how they may have been used. Other material in the pit included dung pellets from small rodents, mixed floral material composed primarily of very small fragments of grass or eudicot leaves remaining after the sample had been thoroughly sorted for identifiable remains. Lastly, organic conglomerates, which are clumps of material bound by some kind of organic matrix, are 
present in all levels. Some of the organic conglomerates were found with seeds in the matrix, particularly guava seeds, but also grass and leaf fragments.

The botanical assemblage in the pit is extremely well preserved due to the hyperarid environment on the coast of Perú and preservation was further enhanced by the architectural context in which they were found that created a virtually impervious container for the remains. The plant remains are desiccated, yet still robust, and have been spared taphonomic phenomena that would have biased the assemblage, such as abrasion, wetting, mold, freezing and thawing and so forth. However, the presence of rodent dung might indicate some slight degree of taphonomic bias, since rodents burrow, chew, and may even eat seeds when freshly deposited (Miksicek1987:231). I did not find much evidence of rodent activity other than the dung pellets in the materials. The effect rodents may have had on these materials cannot be evaluated here, though I suspect the effect on the assemblage is minimal, given the low amounts of dung recovered. Given the isolation and apparently deliberate sequence of deposits, the botanical assemblages of each stratigraphic level of the pit are representative of human behaviors. The radiocarbon dates from overlying stratigraphic levels are virtually identical at 2200 calB.C. and, therefore, do not provide a diachronic framework for events that culminated in the interment of the pit even though each stratigraphic level appears to contain a distinct and probably intentional filling event.

The pit-fill, in the parlance of Schiffer (1976), is secondary fill and not directly associated with human activities except as discard, as opposed to remains in a primary context found in situ, such as spent food waste in a cooking hearth or food recovered in a 
storage pit. This in no way should preclude an interpretation of activities that generated the discard (LaMotta and Schiffer 1999), as human behaviors contributing to secondary discard can still be interpreted in most cases. It is likely that the vast majority of plant remains in archaeological contexts are from secondary refuse (Miksicek 1987:225) and this also would apply to artifacts or other residues of human activity. Finding primary deposits in hearths or storage pits is rare and even a primary context such as a house-floor may have very little primary discard in it. For example, using HRAF data, Murray (1980) demonstrated that household activities leave behind very little evidence of what went on in those primary contexts; most if not all discard generated from activities in the household was removed and deposited elsewhere simply through the cleaning of the household. This pattern of secondary discard from inside living quarters has been corroborated through ethnoarchaeological work among modern Maya (Hayden and Cannon 1983). This would seem to support Glynis Jones' (1991:63) assertion than an archaeologist needs to have an understanding of the archaeological context and that it is necessary to make a clear "qualitative distinction between plant taxa that were selected for use or those represented as discarded refuse." On the other hand, that qualitative distinction may not be a simple one to make as formation processes can also involve de facto refuse that could have been selected for use but was abandoned (Schiffer 1976) or the result of ritual formation processes that may mimic de facto refuse (LaMotta and Schiffer 1999). Still, spatial distributions of and associations between contexts may even reveal primary areas, where waste is generated and from secondary areas, where waste is discarded (Siegel and Roe 1986), although this may not be distinguishable with this dataset. 
A few researchers (i.e. Hubbard and Clapham 1992) maintain that only a simple description, e.g. presence/absence or frequency, is all that reasonably can be accomplished for those secondary deposits where the origins of the materials are not known or not clear. This approach precludes an analysis of assemblage composition for interpreting ecological, economic, or ritual significance in most cases. However, most paleoethnobotanists agree that the secondary deposits still reflect human behavior and warrant more detailed analysis to "tease apart interesting human-plant relationships" (Pearsall 2000:193-4) and especially in examples where secondary and primary deposits can be directly compared (Lennstrom and Hastorf 1995). In this case, the activity areas in which those materials that filled the pit were utilized are not known, but the pit contents themselves and the stratigraphic sequence of the deposits indicate an ordered event. In other words, the discarded plant remains that filled the pit are also part of a primary activity, that of deliberately filling the pit. To interpret the sequence of events, I use density ratios of the botanical remains to compare the strata of the pit, and with special emphasis on the food remains, I will show how the richness and diversity of the food remains between the strata differ.

\section{Density of Botanical Remains in B-10, Feature 1}

Density ratios have been used effectively to assess taphonomic effects, such as preservation bias (Pearsall 1999), intensity of site occupation (Pearsall 1983), and can be used to test assumptions of uniform deposition and recovery rates (Miller 1988). Density ratios are calculated using item count or item weight in the numerator and sample volume or sample weight in the denominator. For example, Lepofsky and Lyons (2003) use density ratios of the average number of seeds per liter of soil or grams of charcoal per liter of soil to 
compare inside structures to outside contexts and as measure of intensity of use correlating to the length of stay. In this dataset from the pit, I use density measurements to compare the botanical densities between stratum to measure the contribution of plants in each stratigraphic level. In calculating density, I chose to use the sample weight, i.e. the weight of each individual sample bag collected from the fine-screen sets, rather than volume of the sample to estimate the density of taxa per sampled context. As described previously, excavators utilized standard sampling of the pit, 10- liters of matrix passed through nested sieves in the field, however the volume of matrix samples taken from Level 300 was not recorded in the field. Therefore, using sample weight rather than sample volume as the denominator in the density ratio provides a better estimate for comparison of levels within the pit. Also using the weight of the botanical remains, rather than raw counts, was deemed more accurate due to the extremely high numbers of individuals of only a few taxa, namely guava and cotton seeds. Also, weight, instead of count, includes organic material too numerous to count in the laboratory, such as tiny fragmentary leaves of grass and fine bits of charcoal and uncharred wood for which weighing provided a much more efficient means of analysis.

Figure 6.3 illustrates the density of botanical remains by level in the pit expressed as a ratio of the weight of the botanical remains identified to the sample weight. Density of plant remains by level generally corresponds to the archaeological descriptions of the strata. For example, Levels 200/250 and 300, having the highest density ratio of botanical materials, were also observed in the field as being primarily composed of plant remains. Level 200/250 was described as plant remains and fair amounts of fill; Level 300 below was 
observed to be primarily of mixed organic material. However, based on the subjective archaeological description, Level 300 should have the higher ratio of plant remains. The difference may be explained partly by sampling bias: Level 200/250 was sampled and finescreened in the field where rocks larger than $6 \mathrm{~mm}$ mesh were removed, whereas several of the analyzed samples from Level 300 were unscreened matrix samples that would have had those larger rocks still in situ, thus the decreasing the ratio of plants to the sample weight. Nevertheless, density of plant remains in Level 300 is much greater than the underlying levels. Level 350 was excavated as a layer of small cobbles and gravel fill and has the lowest relative weight of plant remains. Level 400 below contained a slightly lower ratio of plant remains. The description of its stratum, mixed organics and fill, would have predicted a higher density of botanical materials, however, abundant small rock and fine silt increase the sample weight. Finally, in Level 425 there is a slight increase in the weight of botanical remains due to the relatively large amounts of grass and also uncharred wood.

Figure 6.4 illustrates for comparison the weight of food remains per sample weight by level alongside the four most abundant non-food materials, by either count or weight, that occur in the assemblage: grasses and sedges, cotton seeds, wood, and charred wood. This graph better shows the composition of the botanical materials making up the total density by level. The lowest stratum, Level 425 , shows a predicted high proportion of grasses and sedges relative to food and charcoal, corresponding to the layer of grass observed at the bottom of the pit. Wood fragments, being dense and naturally heavy, make up the largest portion of the botanical weight. Cotton seeds and food remains are in similar proportion. Level 400, having the lowest botanical density is composed in large part 


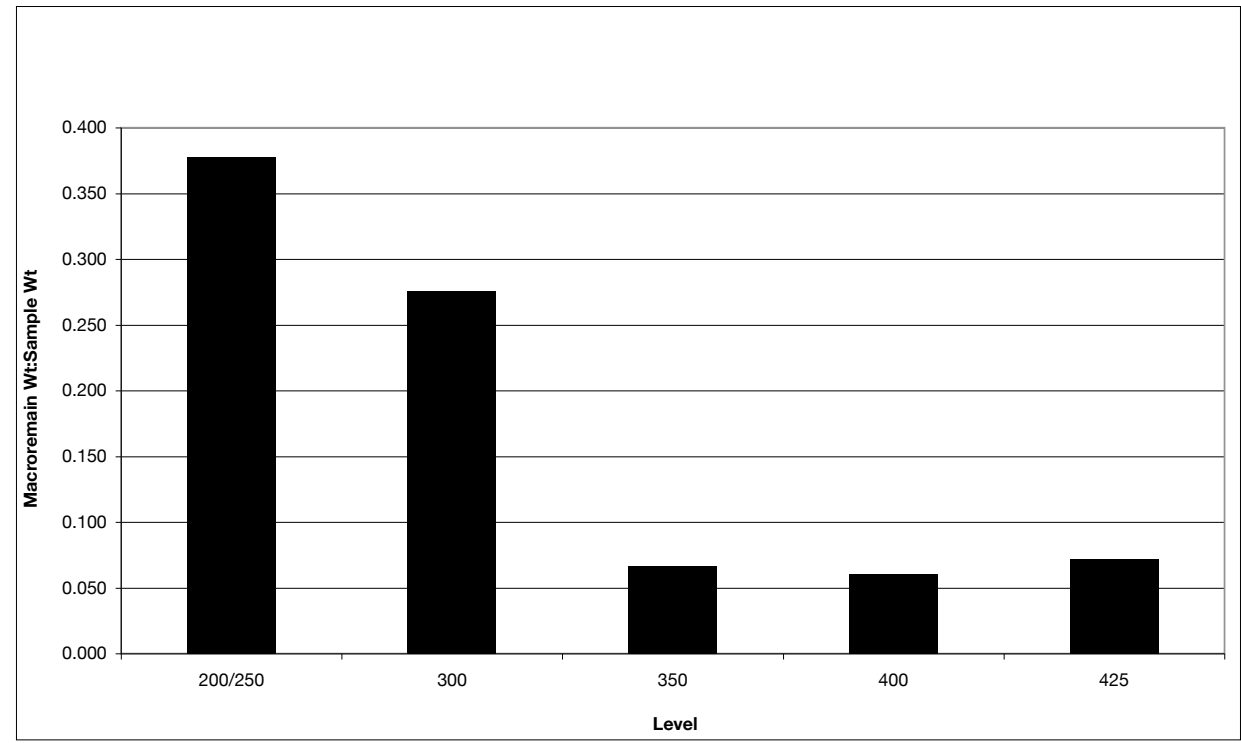

Figure 6.3 Unit B-1-, F-1 density of plant remains by stratigraphic level. Density was calculated by dividing botanical macroremain weight by sample weight.

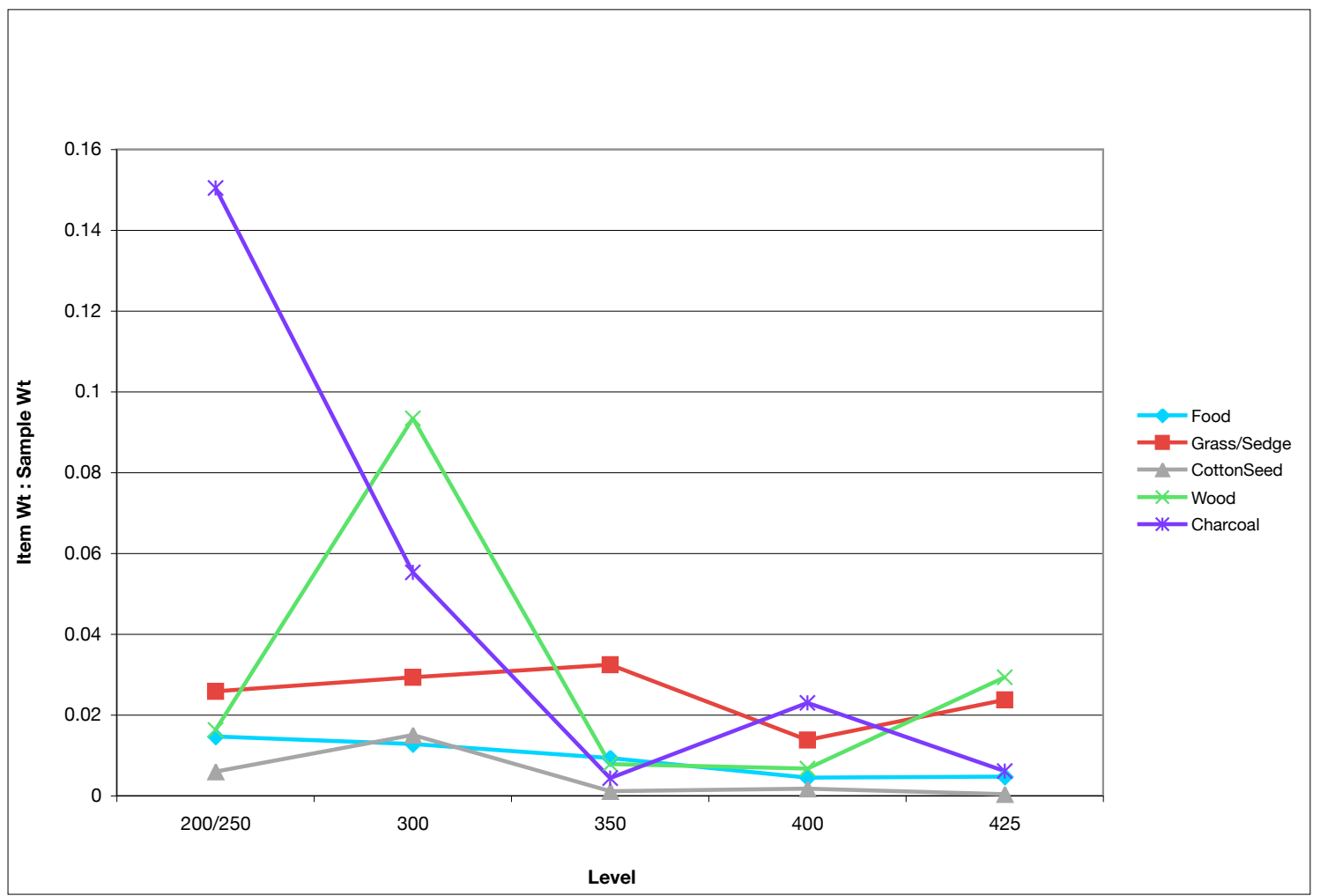

Figure 6.4 Unit B-10, F-1 density of grouped plant remains by stratigraphic level. 
of charred wood and grass, followed by uncharred wood, cotton seeds and some food remains. An increase in grass and sedge density disproportionately contributes to the overall botanical weight in Level 350. Finally, Levels 300 and 200/250 show a marked increase in charred wood that spikes in Level 200/250. Both wood and cotton seeds increase in Level 300, but fall in weight in Level 200/250 above. The density of food remains generally climbs with each successive level in the pit.

While the density of food increases by level, there are significant fluctuations of uncharred and charred wood, especially in Level 300 and 200/250. The amount of charred wood in an assemblage has been used to evaluate the intensity of use by people in a particular activity area or at a site (Pearsall 1983; Asch and Asch 1975; Johannessen 1984). Usually, one can assume that the charcoal present in a particular area reflects the use of wood for fuel, unless there is other evidence that the charcoal may be the result of a structure fire (Miller 1988) or wildfire. In the secondary deposition of the pit, perhaps the charcoal and wood represent cooking fires or fires used in ritual in the temple vicinity, but may also represent roofing or other structures that were burned. In either case, the dramatic increase in density of charred wood in Levels 300 and 200/250 might signify an intensification of activities associated with the discard in the pit.

Comparison ratios of food:charred wood and food:uncharred wood were constructed using total food weight as the numerator and charred wood and uncharred wood as the respective numerators (Figure 6.5). Usually, ratios using charcoal as the denominator are used to compare the relative amounts of two different variables with the assumption that 
the values being compared are mutually exclusive (Miller 1988). However, in comparing the ratios of food:charred wood and food:uncharred wood by level in the pit, I assume that these

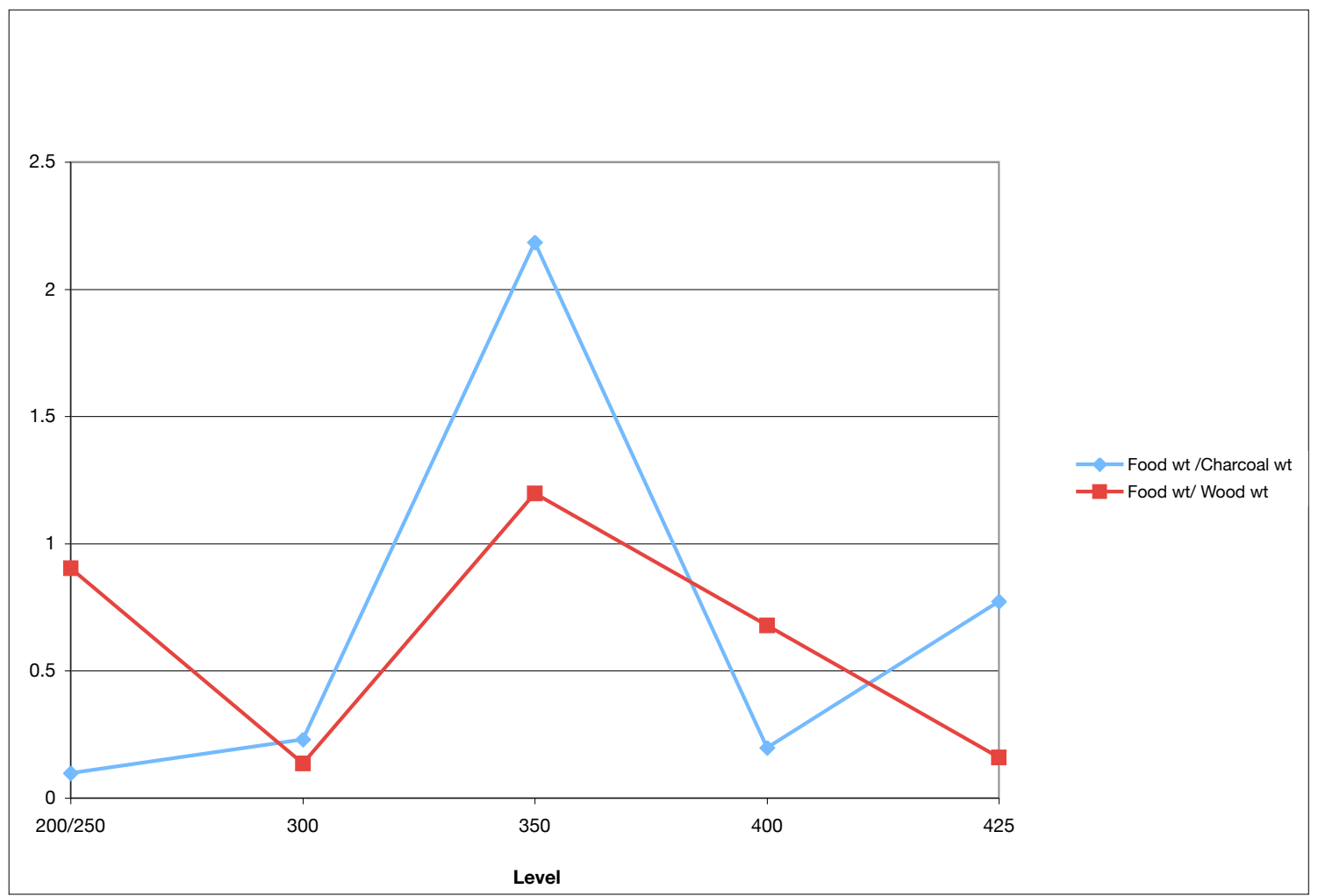

Figure 6.5Unit B-10, F-1 ratio of food weight to charred wood versus ratio of food weight to uncharred wood by stratigraphic level.

relationships are not mutually exclusive since food production and fuel use are likely related. Therefore, if the ratio of food to charred wood or food to uncharred wood increases, there may be a greater relative contribution of discard from food consumption, and inversely, if charred wood and uncharred wood are higher than food, this may indicate a greater contribution of food preparation discard collected in cleaning the area and/or discard from other activities not directly associated with food consumption in the cleaning of the Gran Sala in the last stage of its use. There are other reasons charcoal and wood 
enter the archaeological record, including the burning of structures, fires for heat or light, and even ritual fires in which offerings of food were burned such as those identified at Coastal and Andean sites with Kotosh-style ventilated hearths (Burger and Salazar Burger 1980; Pozorski and Pozoski 1996). However, the relatively high densities of food remains in the pit, with only rare examples being charred, counter indicates their use as food offerings to be burned. Evidence for burned structures in the Gran Sala is absent, as is much or all of any roofing that may have existed. It is still possible that some of the structural materials were discarded in the pit, and that there were fires for light and heat that also contributed material, but one might expect an even higher density of charcoal and wood if these sources were predominant. It is therefore a reasonable assumption that there is a strong association of food and fire and that the charred wood and uncharred wood fuel are at least, in part, associated with preparing food.

In examining these density ratios, I predicted that higher ratios of food to wood or charred wood suggests a greater contribution from consumption discard, whereas a lower ratio of food to wood or charred wood suggests a greater contribution of food preparation, i.e. fuels and charcoal, collected during cleaning of food preparation areas other activity areas. The results of the food ratios to wood and charred wood, displayed graphically in Figure 6.5, show some patterning similar to the density data in Figure 6.4. For example, in Level 200/250, where the density of charred wood weight to sample weight is very high, the food:charred wood ratio is low. Also, the density of wood is relatively low and very close to that of food density and the food:uncharred wood ratio is also close to equal. In Level 300, charcoal and wood densities are both relatively high, and correspondingly, the the ratios of 
food:charred wood and food:uncharred wood are relatively low. Interestingly, where both food, charcoal and wood densities are most similar, in Level 350, the ratios of food:charred wood and food:uncharred wood are significantly higher than other levels. As a result, it seems that the food remains deposited in Level 350 have a different origin than the levels above and below and, relative to wood and charred wood, the food remains are primarily the discard from consumption. In the levels above, a greater contribution of wood and charred wood relative to food suggests a more mixed contribution of food and non-food materials related to cleaning up food preparation areas or other areas utilized within and outside the Gran Sala. If so, we may also see patterning in the kinds of food remains that would have been collected in the cleaning along with the other discarded materials. Also, with the cleaning of the area, we might predict a greater richness and diversity of the food assemblage in the upper levels of the pit.

Composition of Food Remains by Percentage Occurrence in B-10, Feature 1

Before examining richness and diversity of the pit remains more closely, I compared the food assemblage by level to look for additional patterning in the composition of the remains by looking at the percentage occurrence of types of foods and individual taxa. Percent occurrence was calculated for items by count (Figure 6.6), dividing the item count by the total food count for each level, and by weight (Figure 6.7), dividing the item weight by the total food weight for each level. For the purpose of comparison, foods were grouped according to food type. For example all root, tuber and rhizome fragments in the food category form one group, while squash seeds, chili peppers, and legumes form their own respective groups. Because the overall counts of seeds from the 
most abundant taxa, the tree fruits of Psidium guajava (guava) and Pouteria lucuma (lucuma), are so high, I kept these items independent. Still, comparing the percentage occurrence of foods by count is confounded by the dominance of guava seeds in the assemblage. In Figure 6.6 , guava seeds compose from $70 \%$ to $94 \%$ of the food counts in each stratum in the pit. The relatively low abundance of individuals of other taxa is therefore difficult to compare. Guava fruits can produce numerous seeds, from 100 to over 500 seeds per fruit and only rare varieties produce soft chewable seeds (Morton 1987). The guava seeds in this assemblage are fairly robust, and probably were not chewable and, given their high abundance here, were probably not consumed. Squash seeds, which are very edible, were likely to be consumed, and they may be underrepresented in the counts. Nevertheless, squash seeds make up about 15\% of the food counts in Level 200/250 and about 5\% in Level 300, but are absent or infrequent in the levels below. The general pattern for other food items is similar to squash, root/tuber/rhizome peels, chili pepper seeds, legumes, and lucuma are greater in abundance in the upper levels of the pit.

By weight, the abundance of food remains in the pit, as shown in the graph in Figure 6.7, is somewhat normalized for Levels 200/250 and 300, but guava seeds are still the most abundant taxa in Levels 350, 400, and 425. Lucuma makes up considerable percentages of the foods in each level, from around 41\% in Level 200/250 to 17\% in Level 425. Root/tuber/rhizome peels are well represented in Level 300 especially, making up around $44 \%$ of the food remains by weight in this level, but also make up over $19 \%$ of the food remains in Level 425. Similar to the percentages by counts, Levels 200/250 and 300 appear to have greater contributions of other taxa than the lower levels of the pit when 
percentage occurrence is calculated by weight; there is an increase in percentage occurrence for legumes and especially squashes in these upper levels.

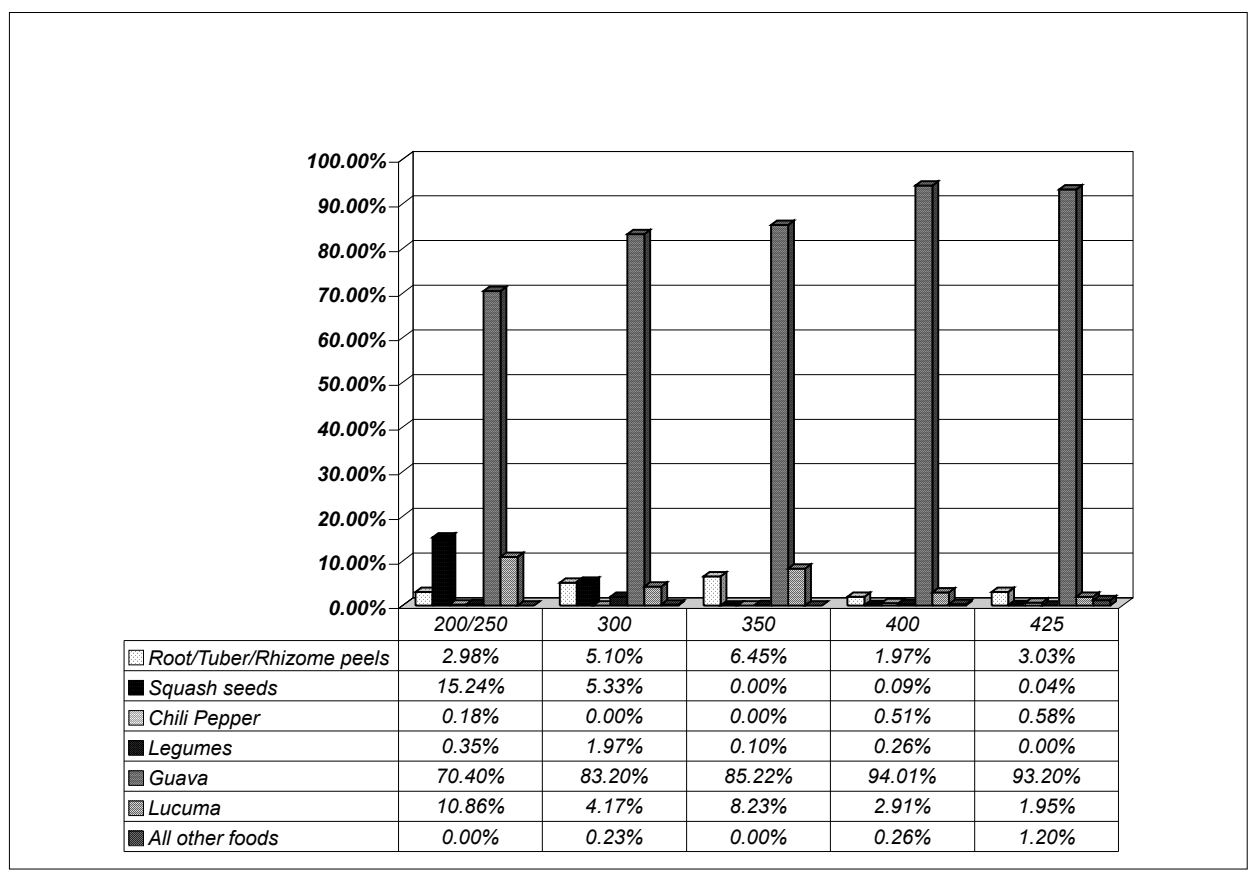

Figure 6.6 Unit B-10, F-1 percentage occurence of food types by count.

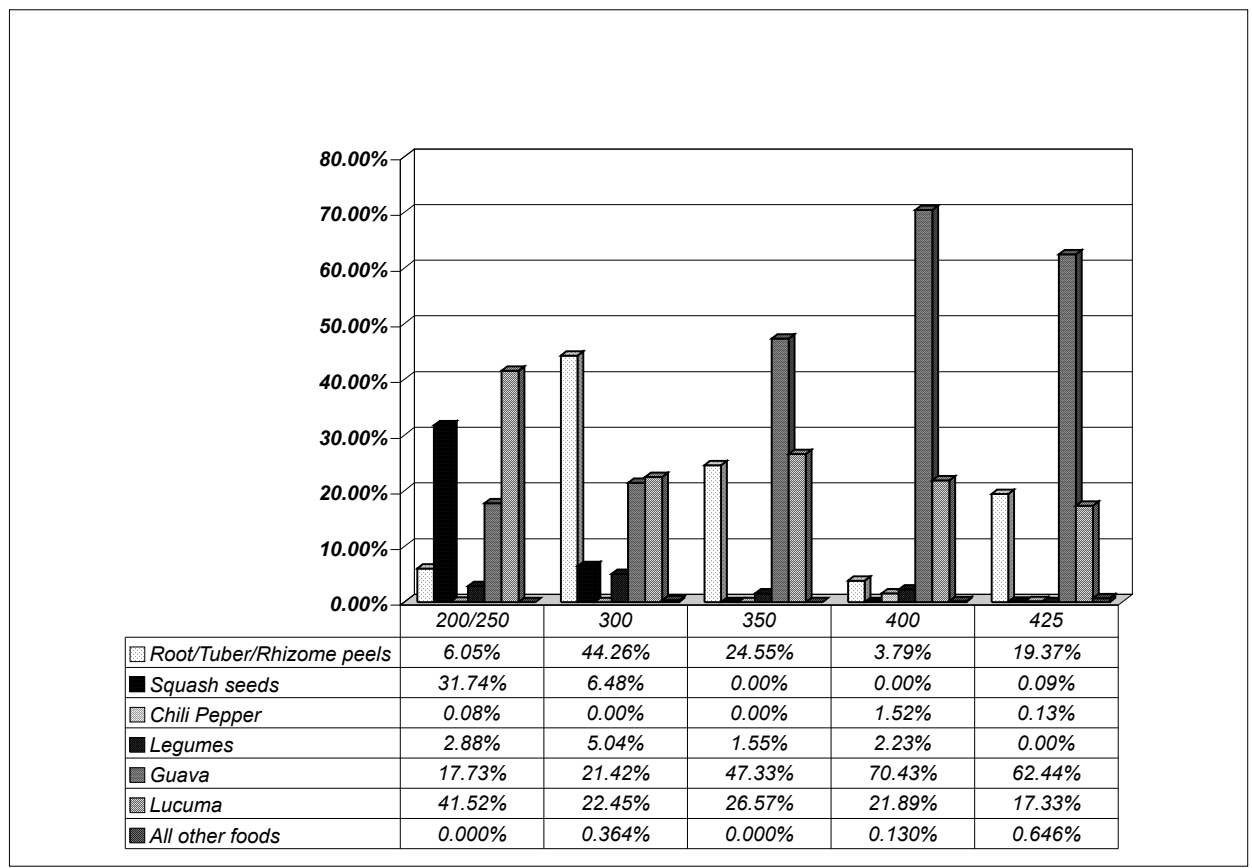

Figure 6.7 Unit B-10, F-1 percentage occurence of food types by weight. 
When comparing the food percentage occurrence by weight or count for each level, the contribution of food materials appears to be different in the upper levels of the pit, Levels 200/250, 300, and 350. The density data for food to wood and food to charred wood, presented previously, suggested a more mixed contribution of food and non-food materials related to the cleaning of food preparation areas or other activity areas nearby. This also may explain differences in contributions of food taxa in the upper levels of the pit as well. For instance, if these deposits in the upper levels are the collected discard material from consumption, preparation, and other activities combined, we should expect to find a more even contribution of food types than in other levels. From the density and percentage occurrence results, we should also find greater richness and diversity of food materials in the upper levels of the pit compared to the lower levels. In the following section, richness and diversity of the food remains is calculated and shows this predicted pattern.

Richness and Diversity of Food Remains in B-10, Feature 1

Species richness (S), the total number of individual taxa, provides a comparison of food composition by level in the pit. In the calculation used here, if multiple plant parts of a taxon are present, such as a seed and rind each from a Cucurbita sp., they are treated as a single taxon. Family level identifications, where genus and species are not known, are treated as single taxa and unidentified taxa of like kind are also treated as individual taxa, i.e. root/tuber rind/peels and rhizome rind/peels are two individual taxa, respectively. Taking the pit as a whole, 24 taxa are present. Looking at the levels in the pit, the highest overall number of individual species was identified in Level 300 (S=19). But Level 200/250 
above, which has a higher density of plant material (Figure 6.3), has a lower species richness $(S=12)$. Level 350 has the lowest number of species $(S=5)$, which may be related to a low density of plant remains.

Species richness is highly affected by sample size and sample effort. As the sample size increases, so too does species richness until at some point the size of the sample contains the true number of species in the population. This relationship has been explored and presented extensively in ecology (Krebs 1989:368; Brose et al 2003), but also in zooarchaeology (Grayson 1984; Lyman and Ames 2004), and paleoethnobotany (Rocek 1995:227; Lepofsky and Lyons 2003; Lepofsky and Lertzman 2005). In order to determine if sample size or sample effort is sufficient to compare richness and diversity between contexts, simply plotting the number of identified taxa against the number of individual specimens in a species richness curve will provide a quick assessment (Lepofsky and Lyons 2003). If the number of individuals is approaching the true maximum, the curve should level off and the sample is sufficient. The curves for the food plants from the pit are presented in Figure 6.8. In calculating the curves, the number of guava seeds, being the by far the most abundant species in the samples (see Figure 6.6), was truncated to 100. No other taxa in the assemblage contain individuals totaling more than 100 . In general, most of the species curves appear to approach the true maximum number of individuals, but do not plateau indicating that sampling has not yet reached redundancy. This is especially true for Level 350, where the number of individuals climbs dramatically against the number of taxa and may be explained, in part, by the overall low density of plant material in this level. For other levels, despite extensive field sampling of the pit contents, redundancy has not 
been achieved in terms of richness and the number of individual items. Increasing the sample size of materials from the pit would increase the number of individual food items and might add new food taxa, but given the architecturally limited space, there is only so much material that could be sampled. Also, the composition of the food materials in the pit are affected by human selection as foods, the number of items is affected by what was eaten and what was discarded. The true maximum number of individuals may be reached, but when plotted to richness, the curves may not plateau given the inherent unevenness in the number of items. Therefore, a comparison of the diversity of the food remains by pit level was done with caution.

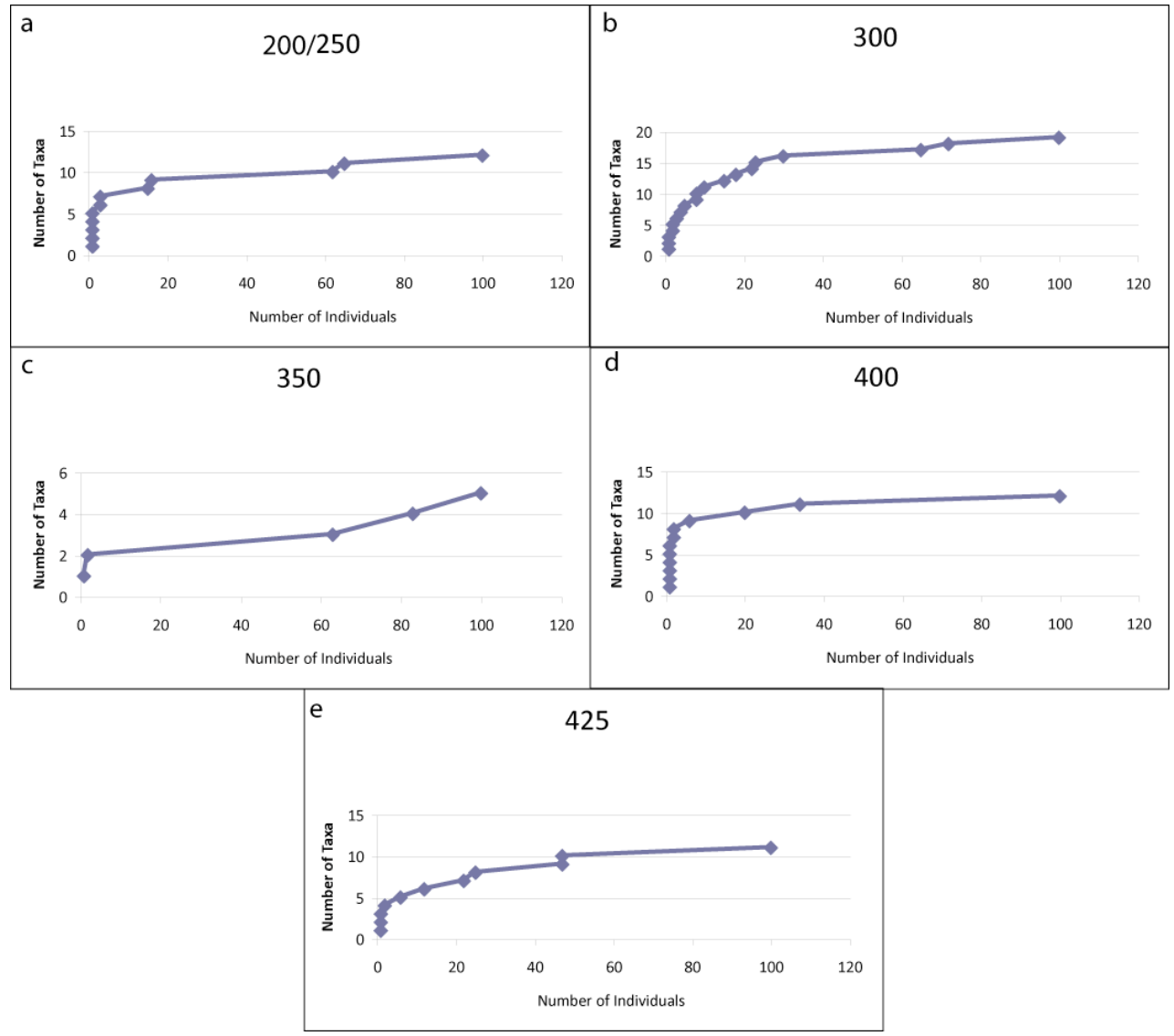

Figure 6.8 Unit B-10, F-1 species richness curves for each stratigraphic level. 
Diversity measures both the total number of taxa (richness) and the relative contribution of individuals of each taxon to the assemblage. In paleoethnobotany, indices of diversity, borrowed from ecological science, have been used, such as the Shannon index (or Shannon-Weiner or Shannon-Weaver) to interpret, for example, the stability of resource use over time (Pearsall 1983), or to compare the diversity of diets of elites and non-elites (Lentz 1991), or the Simpson index as, for another example, a means of evaluating plant assemblages in relation to mobility strategies of hunter-gatherers (Bonzani 1997). Diversity indices are widely used in ecological studies (Magurran 2004; Peilou 1977) to identify and track changes in landscape composition over space and time, although diversity measurements can be applied to any combination of objects, provided that the different types of objects can be considered types for comparison and whether objects classed together are of sufficient kind (Huston 1994:65). In addition, diversity indices can be calculated from other values such as the density of individuals per sample unit, rather than just abundance alone. The choice of which unit of analysis to use should be influenced by the nature of the data, and in this case, the evenness of the distribution of individuals among the taxa. The assemblage of botanical food remains in the pit appears to be dominated by certain taxa, namely Psidium guajava (guava), and the sampling of the remains does not reach redundancy. Therefore, I calculated diversity using several different methods for both the counts and the density of food remains in the pit so that unevenness and dominance is taken into account.

There are a number of indices to choose from, however, they vary in emphasis on richness (the number of taxa) or evenness as a measure of the equitability of distribution 
among the types under study (Huston 1994:67). Diversity indices can be very sensitive to evenness and the number of individuals (Peilou 1977) and especially for archaeobotanical assemblages, the preservation and sample size also effects diversity measures (Pearsall 1983:130; Popper 1988:68; Lepofsky and Lertzman 2005). Usually, different diversity indices will provide similar results for a given population and only in very rare instances will two different measures provide entirely opposite results, reflecting differential sensitivity to rare or dominant types among the indices (Nagendra 2002). Therefore, selecting an appropriate diversity index should be based on the kind of data under comparison or, even better, present the comparison using more than one index and include an evaluation of the evenness of the data and the possible dominance of the assemblage by a single taxon. For example, if the contexts compared have similar values for richness, but abundance of individuals varies between the contexts, a diversity measure that emphasizes evenness, such as Simpson's, would be useful to better compare the contexts (Huston 1994:67). Shannon's index, being more sensitive to rare types, then would be useful in cases where evenness or richness changes (Nagendra 2002). Also, the effect of a single dominant taxon should also be considered when calculating diversity. For example, as discussed below, the dominance of guava seeds is measured using the Berger-Parker dominance index (Berger and Parker 1970) and expresses the abundance of guava seeds in proportion to the rest of the sample. In very uneven assemblages, a measure that standardizes richness with abundance, such as Margalef's index (Margalef 1958; Magurran 2004) would also be useful. The Margalef index attempts to compensate for sampling 
effects by dividing species richness by the total number of individuals (Magurran 2004:7677).

For this study, I present the data from the pit using several different indices of richness, diversity, and dominance (Figure 6.9; Tables 6.3 and 6.4) calculated using both abundance (the count of each taxon) and density (the weight of each taxon/sample weight). The results of the calculations based on abundance are impacted by the uneven distribution of individuals within certain taxa, in this case the abundance of guava seeds numbering in the hundreds or thousands in a given level of the pit. Alternatively, calculations of diversity based on density, the ratio of the weight of a taxon's individuals to the total sample weight normalized by multiplying the quotient by 1000 , lowered the dominance of guava seeds for most levels and increased evenness in some levels. The resulting diversity values from density, more closely match those from simple species richness.

The formulas used in the calculations are described below:

Shannon's diversity index is calculated with the following formula:

$$
H=-\Sigma p_{i} \ln \left(p_{i}\right)
$$

where $p_{i}$ is the proportion of the total number of individuals, or total density, composed of $i$ species and $\ln$ is a natural logarithm.

Also, to calculate evenness, I chose Shannon's analogous evenness index that uses the observed Shannon diversity value divided by the maximum possible diversity with maximum evenness, i.e. equal numbers of individuals, or equal densities, of each taxa $S$. 
Evenness is calculated as a value from 0 to 1 , with 1 being entirely even. The following formula was used:

$$
E=H / H_{\max }
$$

where $H$ is the observed Shannon diversity score and $H_{\max }$ is $\mathrm{H} / \log (\mathrm{S}) . \mathrm{S}$ is the number of species.

As another measure of diversity, Simpson's diversity index was calculated by:

$$
D=\Sigma p_{i}^{2}
$$

where, as in the Shannon index, $p_{i}$ is the proportion of the total number of individuals, or total density, composed of $i$ species.

The Margalef diversity index calculates richness by taking into account the number of individuals, or density values, encountered without evaluating evenness. I used the following formula:

$$
D=(S-1) / \ln N,
$$

where $\mathrm{S}$ is the species richness and $\mathrm{N}$ is the total number of individuals.

To measure the dominance or proportional abundance of guava seeds for each sample, I used the Berger-Parker index that simply divides the abundance or density of the item with the highest abundance or density (Nmax) by the total number of items or total density $(N)$ :

$$
D=N \max / N
$$




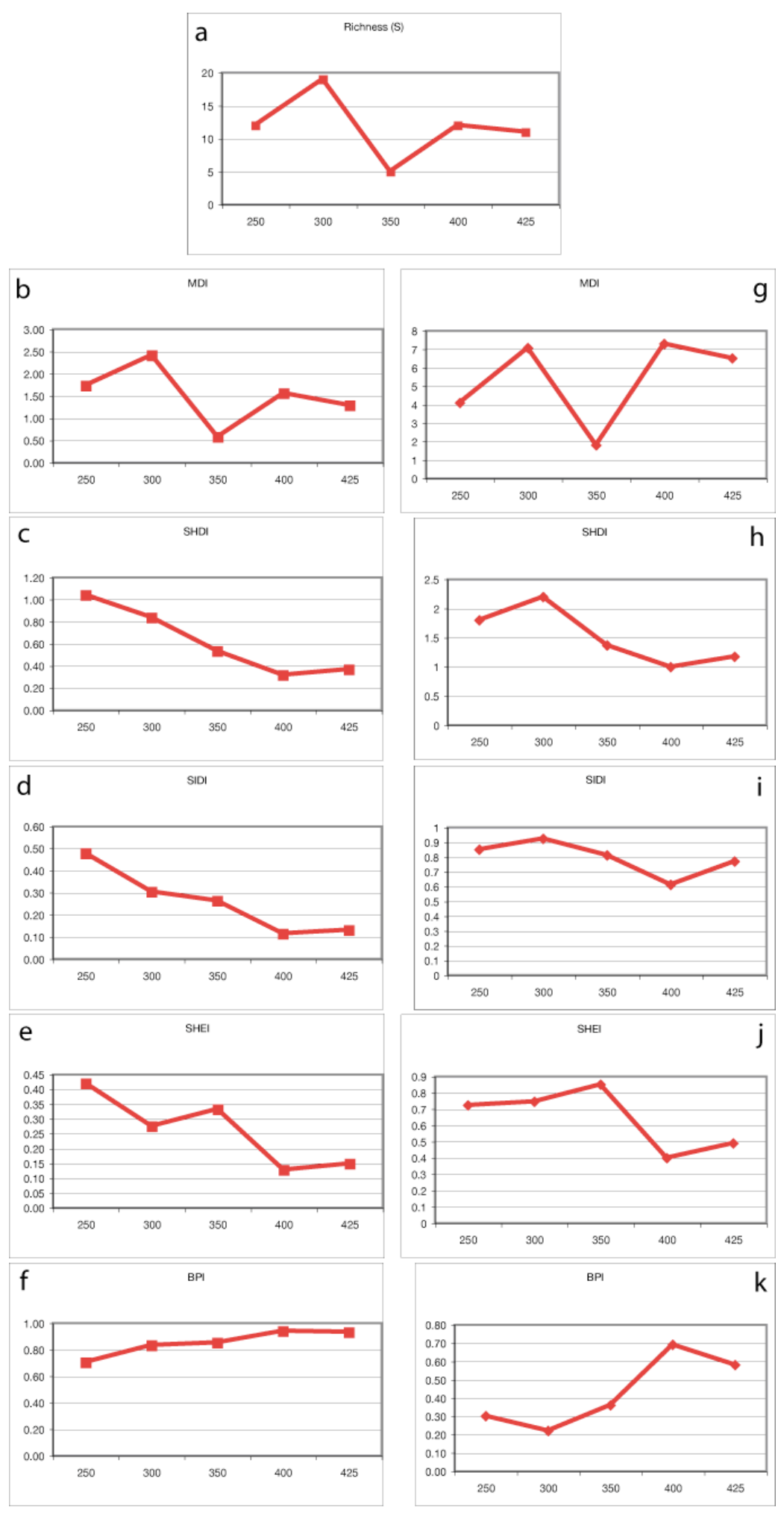

Figure 6.9 B-10, F-1 species richness, diversity, and evenness by stratigraphic level . (A) simple species richness. Graphs in left column calculated using count data and graphs on right column calculated using density data. (A\&G)

Margalef's diversity; (C\&H) Shannon diversity; (E\&J) Shannon's evenness index; (F\&K) Berger-Parker dominance index. 
Diversity from abundance (count)

Using abundance, or count data, each of the diversity indices in Figure 6.9 clearly shows differences in richness and diversity of food remains in the pit for each stratigraphic level (Figure 6.9 a-f; Table 6.3). Species richness (S) and Margalef's index (MDI) show very stark differences in food plant richness, especially in level 300, where both values are highest. However, both Shannon's (SHDI) and Simpson's (SIDI) diversity indices indicate diversity is highest in Level 200/250. Also, both Shannon's and Simpson's diversity indices give a lower relative richness value for Level 400 than did species richness and Margalef s. Together, both Shannon's and Simpson's indices provided similar trends in diversity in the stratigraphic sequence, an overall increase in diversity from Levels 400 to 200/250. The reason the two indices, Shannon's and Simpson's, differ so dramatically from the Margalef values and species richness lies in the effect of evenness of the samples in this study.

For both Margalef's index and species richness, the evenness of the sample is not reflected in the value of the calculation, thus both indices show similar results between levels, in spite of the difference in abundance of guava seeds. When considering the evenness of the data from each level, calculated with Shannon's evenness index (SHEI), the taxa are not equitably distributed, having values no higher than 0.42 in Level 200/250 and as low as 0.13 in Level 400. In three of the levels, 200/250, 300, and 350, the evenness and species richness seem to be inversely related. For instance, Level 200/250 is the most evenly distributed, but not the richest, whereas Level 300 is the richest but not the most even. The unevenness of the samples comes from relatively high numbers of guava seeds; the Berger-Parker dominance index (B.P.I) shows that for each level in the pit, the food remains are highly dominated by a guava, from 0.7 (70\%) in Level 200/250 to 0.94 (94\%) 
in Level 400. The dominance of the guava seeds in the food remains, therefore, clearly affects the evenness of the food assemblages of each level.

Table 6.3 Unit B-10, F-1 counts of food items and rank (r).

\begin{tabular}{|c|c|c|c|c|c|c|c|c|c|c|}
\hline Level & $200 / 250$ & $r 200 / 250$ & 300 & $r 300$ & 350 & r350 & 400 & $\mathrm{r} 400$ & 425 & $\mathbf{r 4 2 5}$ \\
\hline Begonia geraniifolia & & & 10 & 9 & & & & & & \\
\hline Canavalia sp. & 1 & 10 & 30 & 4 & 1 & 5 & 1 & 9.5 & & \\
\hline Capsicum pubescens & & & & & & & & & 2 & 8 \\
\hline Capsicum spp. & 1 & 10 & & & & & 6 & 4 & 12 & 6 \\
\hline cf. Pachyrrhizus & 1 & 10 & & & 2 & 4 & & & & \\
\hline cf. Phaseolus & & & 1 & 18 & & & 1 & 9.5 & & \\
\hline cf. Prosopis & 1 & 10 & & & & & & & & \\
\hline Cucurbita ficifolia & 65 & 2 & 65 & 3 & & & & & & \\
\hline Cucurbita maxima & 16 & 4 & 15 & 8 & & & & & & \\
\hline Cucurbita moschata & 3 & 6.5 & 4 & 13 & & & & & & \\
\hline Cucurbita sp. & 3 & 6.5 & 8 & 10.5 & & & 1 & 9.5 & 1 & 10 \\
\hline Inga feuilleei & & & 3 & 14 & & & 1 & 9.5 & & \\
\hline Ipomoea batatas & & & 18 & 7 & & & & & 1 & 10 \\
\hline Lagenaria siceraria & & & 1 & 18 & & & 2 & 5.5 & & \\
\hline Manihot esculenta & 1 & 10 & 5 & 12 & & & & & 1 & 10 \\
\hline Physalis sp. & & & 1 & 18 & & & 1 & 9.5 & 6 & 7 \\
\hline Pouteria lucuma & 62 & 3 & 72 & 2 & 83 & 2 & 34 & 2 & 47 & 2.5 \\
\hline Psidium guayaba & 402 & 1 & 1436 & 1 & 859 & 1 & 1099 & 1 & 2246 & 1 \\
\hline Rhizome Canna/Maranta & & & 23 & 5 & & & 2 & 5.5 & 47 & 2.5 \\
\hline Rhizome rind/peel & & & 2 & 15.5 & & & & & & \\
\hline Root/tuber rind/peel & 15 & 5 & 22 & 6 & 63 & 3 & 20 & 3 & 25 & 4 \\
\hline Solanaceae u'id & & & 2 & 15.5 & & & & & 22 & 5 \\
\hline Solanum sp. & & & & & & & 1 & 9.5 & & \\
\hline Ullucus tuberosus & & & 8 & 10.5 & & & & & & \\
\hline Total count & 571 & & 1726 & & 1008 & & 1169 & & 2410 & \\
\hline
\end{tabular}

Diversity from Density

In an attempt to even the sample data and minimize the dominance of guava seeds, the same measurements were made using the density of food remains relative to sample weight rather than abundance (Figure $6.9 \mathrm{~g}$-h; Table 6.4). Density values per pit levels were calculated by dividing the weight of the individuals of a taxon by the total weight of the sample, then, to normalize the data, the values were multiplied by 1000 . Guava seeds are 
superseded in density by lucuma, root/tuber rinds, and C. ficifolia seeds in Level 200/250, by lucuma and sweet potato in Level 300, and by root/tuber rind/peel in Level 350. In Levels 400 and 425, guava seeds have the highest density value.

Using density values when applying the Berger-Parker index (B.P.I), the dominance of guava seeds is still disproportional in Levels 400 and 425. However, in the higher levels of the pit, where the density of guava is superseded by other taxa, the food assemblages by level are much less dominated by any individual taxon, especially Level 300, having the lowest dominance value (0.22). Where dominance by a single taxon is high, Levels 400 and 425, evenness is inversely low in Shannon evenness. However, Levels 200/250, 300, and 350 have much higher evenness (0.72-0.85) when calculated with density than with abundance.

In calculating Margalef diversity using density values, diversity of the levels no longer follow a similar pattern to species richness; the diversity of Levels 400 and 425 appear to be much higher in relation to the other values. When calculating diversity using density, Level 400 shows less diversity than Level 425 in both Shannon and Simpson, and an inverse relationship to species richness and Margalef, similar to the pattern observed using abundance. Again, the unevenness of the assemblages seems to affect both Simpson's and Shannon's diversity for Levels 400 and 425 in a similar way unevenness affected the same levels when calculated through abundance. On the other hand, in the three levels where the assemblages are more evenly distributed by density, 200/250,300, and 350, the Shannon and Simpson indices show a more similar relative pattern of diversity in 
comparison to species richness, with Level 300 having highest diversity and richness, followed by $200 / 250$ and 350 .

Table 6.4 Unit B-10, F-1 density of food items and rank (r).

\begin{tabular}{|c|c|c|c|c|c|c|c|c|c|c|}
\hline Level & $200 / 250$ & $\mathrm{r} 200 / 250$ & 300 & r300 & 350 & r350 & 400 & $r 400$ & 425 & $r 425$ \\
\hline Begonia geraniifolia & & & 0.620 & 7 & & & & & & \\
\hline Canavalia sp. & 0.270 & 8 & 0.420 & 9 & 0.090 & 5 & 0.030 & 9 & & \\
\hline Capsicum pubescens & & & & & & & & & 0.002 & 11 \\
\hline Capsicum spp. & 0.010 & 12 & & & & & 0.070 & 5 & 0.002 & 9 \\
\hline cf. Pachyrrhizus & 0.490 & 7 & & & 1.470 & 4 & & & & \\
\hline cf. Phaseolus & & & 0.100 & 13 & & & 0.030 & 8 & & \\
\hline cf. Prosopis & 0.040 & 10 & & & & & & & & \\
\hline ucurbita ficifolia & 2.070 & 3 & 0.470 & 8 & & & & & & \\
\hline Cucurbi & 0.600 & 6 & 0.090 & 14 & & & & & & \\
\hline Cucurbita moschata & 0.030 & 11 & 0.020 & 17 & & & & & & \\
\hline Cucurbita sp. & 0.650 & 5 & 0.190 & 11 & & & 0.002 & 11 & 0.004 & 8 \\
\hline Inga feuilleei & & & 0.080 & 15 & & & 0.040 & 7 & & \\
\hline Ipomoea batatas & & & 2.830 & 1 & & & & & 0.002 & 10 \\
\hline Lagena & & & 0.010 & 18 & & & 0.001 & 12 & & \\
\hline Manihot esculenta & 0.150 & 9 & 0.170 & 12 & & & & & 0.005 & 7 \\
\hline Physalis sp. & & & 0.00002 & 19 & & & 0.002 & 10 & 0.010 & 6 \\
\hline Pouteria lucuma & 4.390 & 1 & 2.670 & 2 & 1.590 & 3 & 0.970 & 2 & 0.750 & 3 \\
\hline Psidium guayaba & 1.880 & 4 & 2.550 & 3 & 2.830 & 2 & 3.130 & 1 & 2.690 & 1 \\
\hline Rhizome Canna/Ma & & & 0.650 & 6 & & & 0.050 & 6 & 0.830 & 2 \\
\hline Rhizol & & & 0.200 & 10 & & & & & & \\
\hline $\mathrm{nd} /$ peel & 4.090 & 2 & 0.890 & 4 & 3.400 & 1 & 0.090 & 4 & 0.350 & 4 \\
\hline Solanaceae u'id & & & 0.040 & 16 & & & & & 0.010 & 5 \\
\hline Solanum sp. & & & & & & & 0.110 & 3 & & \\
\hline Ullucus tuberosus & & & 0.810 & 5 & & & & & & \\
\hline Total density & 14.7 & & 12.8 & & 9.4 & & 4.5 & & 4.7 & \\
\hline
\end{tabular}

Discussion of Diversity of Food Remains from B-10, Feature 1

Using density (weight of each taxa by sample weight) provided more similar

estimations of diversity between the various indices employed here, in part due to a more equitable distribution of taxa by density in the upper levels of the pit. However the lowest levels, 400 and 425, are still unevenly distributed due to the dominance of guava seeds. Despite the dominance of guava seeds in all levels and the related unevenness of the samples, Margalef's diversity index, which calculates richness in relation to abundance, 
closely matched simple species richness. However, the unevenness of samples clearly affected the results of both Shannon's and Simpson's calculated using abundance. Using density to calculate diversity, the three indices are much more similar in the samples where density is most even, Levels 200/250, 300, 350 and thus more robustly supported.

In terms of abundance and density, diversity is highest in upper levels of the pit, Levels 300 and 200/250, when calculated with Shannon and Simpson indices, and these levels are also highest in species richness. With the exception of Margalef values that measure high diversity in Levels 400 and 425, these two lower strata, highly uneven and dominated by a single taxon, both score relatively lowest in diversity using Shannon's and Simpson's indices. The use of richness and diversity measures in paleoethnobotanical assemblages clearly requires some caution, as the choice of measurement and the values measured can provide inconsistent results. That said, the comparisons are useful in eliciting some broad patterning that can be compared to the results of other measures such as the density data. With this in mind, comparing the differences in the food assemblage between levels in the pit may provide a more insightful interpretation of the sequence of the pits interment. For example, the Shannon and Simpson indices show an overall increase in diversity of food remains per level of the pit and this corresponds to an overall increase in density of plant remains as well. The highest levels of the pit, Levels 300 and 200/250, have the highest food richness and diversity and thus, along with density, signal a significant difference between Levels 350 and above from the bottom two levels of the pit. 
Summary of plant macroremains from Sector B, Unit 10, Feature 1

Overall, the measured density of botanical remains in the pit corresponds to observations of the strata during excavation. However, there are significant fluctuations of wood and charcoal densities that suggest different activities may have contributed to the remains in the pit. When the composition of the food remains is examined more closely as percentages of abundance and density, and in terms of the richness and diversity of the food assemblage, fluctuations in the food assemblage are also evident among all levels. Similar to the observed archaeological sequence, the data from plant macroremains suggest that the levels of deposition in the pit reflect different patterns of discard that are associated with an intensification of activities involving food. Beginning in Level 425, with the abundance of grass observed upon excavation to cover the pit floor, the presence of food remains is relatively low in terms of richness, diversity and density. There is, however, a significant amount of guava seeds in this level, as well as a fair percentage of root/tuber/rhizome fragments and lucuma pits. Level 400, containing a mix of organic remains and fill, likewise contains a high count and density of guava seeds and lucuma pits, with a lower percentage of root/tuber/rhizome fragments by density.

By Level 350, described as a level of round river cobbles and gravel, the percentage density of root/tuber/rhizome fragments in the food assemblage increases significantly from the lower levels, with a corresponding drop in the percentage density of guava seeds. This level also sees a drop in richness of food taxa, but there is a relatively high ratio of food remains to charred wood and to uncharred wood. The food:charred wood and food:uncharred wood ratios suggested a greater relative contribution of food remains in Level 350 in the context of lower food diversity. 
Uncharred wood and charred wood densities increase markedly in Level 300, but this level also sees the highest overall richness of food taxa and, by density, the highest overall diversity of food taxa. Root/tuber/rhizome fragments make up the largest proportion of food remains by density, legumes have the highest density of any other level, and squash seeds increase in both number and density from lower levels. Above, in Level 200/250, charred wood density is highest, overall food diversity remains high, but richness falls. Root/tuber/rhizome fragments make up a considerable proportion of the assemblage density, as do squash seeds, lucuma pits, and guava.

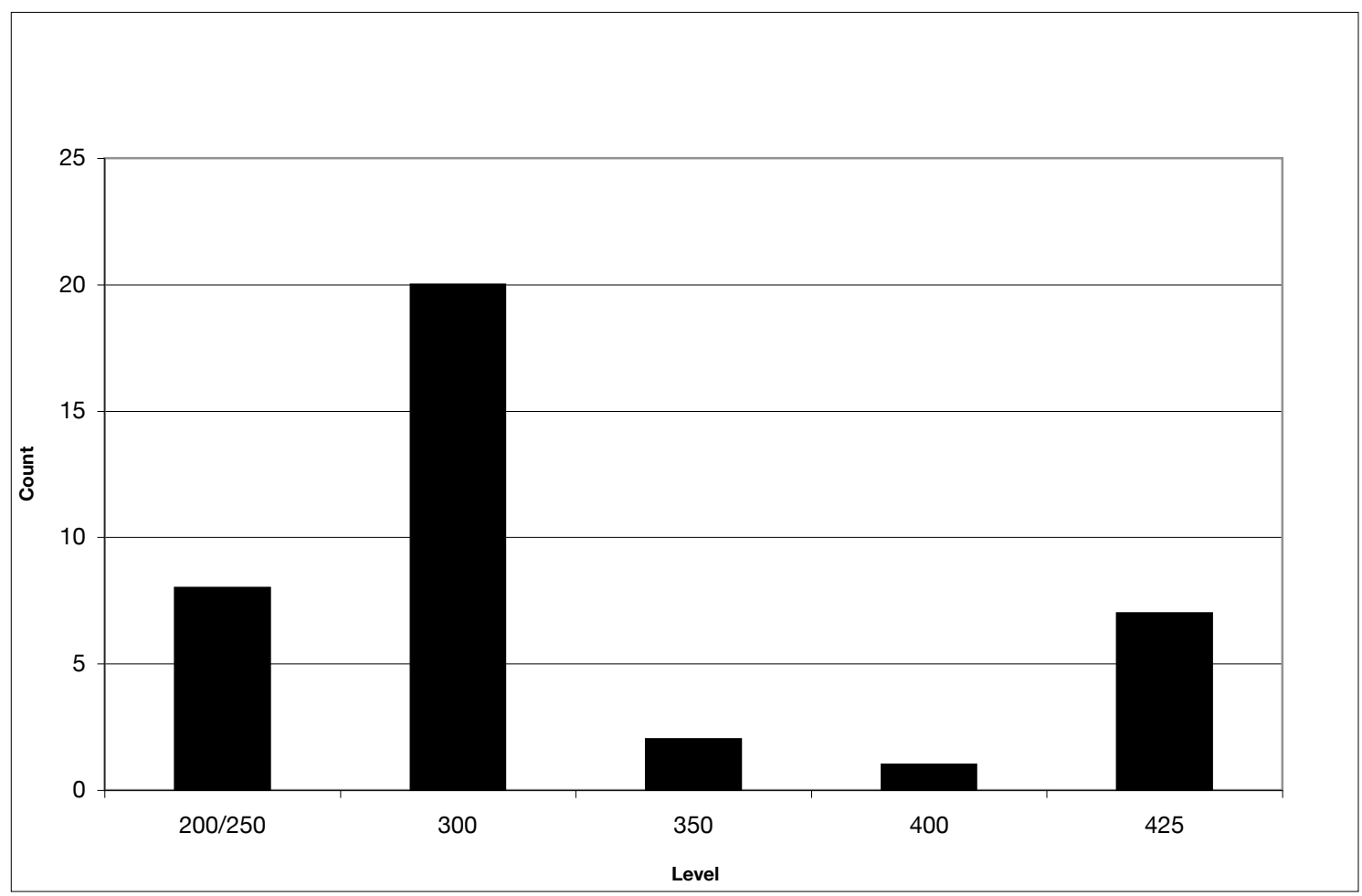

Figure 6.10 Unit B-10, F-1 gourd fragments by stratigraphic level.

The sequence of deposition, the density of the botanical material, and the richness and diversity of the food assemblage are not patterned in such a way that would suggest a 
single moment of discard. Food remains are relatively low in density, richness, and diversity in the lowest levels of the pit, but increase dramatically above the layer of round river cobbles of Level 350. This suggests that there is a greater contribution of discard associated with activities involving food in the upper levels. In addition, the number of gourd fragments is highest in Level 300 (Figure 6.10), and this too suggests a greater contribution of food remains, since gourds could be used as serving vessels and food containers (see Chapter 8). The differences between the levels above and below Level 350 are clearly evident, which supports the interpretation that the pit was not filled in one single deposition event, rather, the placement of the round river cobbles signifies an intentional separation of the lower deposits from the upper. Perhaps the lowest levels represent the symbolic cancelation of the pit or what has been interpreted as a kind of organic protective layer seen on the floors of other Late Preceramic architecture (Shimada 1986). In this case, the presence of foods and fragments of gourd containers would suggest a ritual use of food, and probably drink, in a feasting event or events associated with the material deposited in the pit. Interestingly, the layer of round cobbles in Level 350 is a feature of later ushnu, or ritual platforms, structures upon which liquid offerings are poured (Pino-Matos 2004) and may have been used in a similar way in this context (Benfer et al. 2007) prior to its final interment. This idea will be explored further in the study of starch and phytoliths from soil samples taken in the pit.

Sector B, Unit 7

In Sector B, a 7.5-liter fine screen sample collected from the floor of Cuarto-3, the south room of the antechamber to the west of the Gran Sala (see Figures 5.6 and 5.12) was 
analyzed. The Food plant remains recovered (Table 6.5) include the seeds of fruits from squash (Cucurbita sp.), guava (Psidium guajava), and two seeds identified as Physalis sp., ground cherry. Seeds and leaves and stems represent the Grass/Sedge category and include Scirpus sp., Papsalum sp., Eleusine sp., and several grass seeds identified only to family. One seed from an unidentified Herbaceous/Weedy taxon is represented. A rind fragment from gourd (Lagenaria siceraria) and a cotton seed (Gossypium barbadense) represent the Industrial category. Only three grams of uncharred wood fragments were recovered in the sample.

This small assemblage of plant remains found on the floor of this small room probably represents a secondary deposition of materials associated with activities in the area. The presence of seeds of edible plants and a single gourd fragment, possibly from a container, suggests the assemblage was associated with activities involving food consumption. The cotton and grass and uncharred wood, may also be the secondary remains of other activities that occurred nearby, or are material components of ritual activities that also involve food. It is likely that these remains are associated with materials that filled the sunken pit in the Gran Sala adjacent to this room.

Table 6.5 Unit B-7 plant macroremain counts

\begin{tabular}{|c|c|c|c|c|c|}
\hline \multicolumn{2}{|l|}{ Sector B } & \multirow[b]{3}{*}{ Genus species } & \multirow[b]{3}{*}{ Type } & \multirow[b]{3}{*}{ Ct. } & \multirow[b]{3}{*}{ Wt.(g) } \\
\hline \multicolumn{2}{|l|}{ Unit 7, Floor } & & & & \\
\hline Category & Family & & & & \\
\hline \multirow[t]{3}{*}{ Food } & Cucurbitaceae & Cucurbita sp. & Seed & 2 & 0.0001 \\
\hline & Myrtaceae & Psidium guayaba & Seed & 5 & 0.0171 \\
\hline & Solanaceae & Physalis sp. & Seed & 2 & 0.0001 \\
\hline \multirow[t]{2}{*}{ Industrial } & Cucurbitaceae & Lagenaria siceraria & Rind/Peel & 1 & 0.003 \\
\hline & Malvaceae & Gossypium barbadense & Seed & 1 & 0.008 \\
\hline \multirow{5}{*}{$\begin{array}{l}\text { Grass/ } \\
\text { Sedge }\end{array}$} & Cyperaceae & Scirpus & Seed & 3 & 0.0002 \\
\hline & \multirow[t]{4}{*}{ Poaceae } & Poaceae & Monocot Grass/Sedge & & 2 \\
\hline & & cf. Eleusine indica & \multirow[t]{3}{*}{ Seed } & 1 & 0.0001 \\
\hline & & Papsalum sp. & & 1 & 0.0001 \\
\hline & & Poaceae & & 4 & 0.0001 \\
\hline Wood & Wood & Wood uncharred & Wood & & 3 \\
\hline $\begin{array}{l}\text { Herbaceous/ } \\
\text { Weedy }\end{array}$ & Uid. Seed & Uid. Seed & Seed & 1 & 0.0025 \\
\hline \multicolumn{4}{|l|}{ Grand Total } & 21.0 & 5.0 \\
\hline
\end{tabular}


Sector C, Unit 6

Unit 6 in Sector C is two adjoining units combined, C-6 and C-6 East, excavated in separate field seasons (see Chapter 5). On excavation, the archaeological strata encountered in both units were continuous, however, due to a minor mistake in record keeping in the field during the excavation of C-6E, the level numbering between the units does not correspond. The mistake resulted from the labeling of the disturbed fill and surface material as Level 100 in C-6, and Level 000 in C-6E. Therefore, Level 200 in C-6 is continuous with "Level 300E", and C-6 Level 300 is continuous with "Level 400E", and so on. For comparison, I selected a fine-screen sample from Level 100 of C-6, Level 200 (or 300E) from the adjacent C-6E, and Level 300 (or 400E) also from C-6E. In unit C-6, an intact hearth was uncovered during the excavation of Level 200, and this feature, F-1, was also given a level number as Level 250. Due to the extent of looting in the associated material in Level 200 of C-6, only a small sample of the soil could be taken, but a much larger and complete sample was obtained from C-6E. This level consisted of a layer of silty soil with a high ash content that lay atop a plastered floor. In Unit 6E, the material beneath this floor, Level 300, consisted of mostly gravel and was also sampled. The looting activity in this vicinity makes for a less than perfect area to sample. Even so, looters did not impact the hearth uncovered in Level 200 and we were able to get reliable samples from soils in the same stratigraphic levels from both units. We assume these levels would have been continuous across both excavation units had looting not occurred. This makes an interpretation and comparison of the hearth contents to the surrounding and underlying matrix possible. 
Density and composition of the botanical contents of each level and the hearth will help to interpret how the hearth and room were used. As discussed previously, primary contexts, such as the hearth and floor in C-6, are rare and do not follow predictable patterning. Hearths and floors may or may not be cleaned and the density and composition of material remains recovered will vary. Although some predicted patterns associated with formation processes of botanical assemblages are useful in interpreting archeological contexts (Miksicek1987: van der Veen 2007), one needs to avoid a priori assumptions regarding the function or utilization of a particular feature or context. As Lennstrom and Hastorf (1995) show through comparing hearths to their overlying and underlying deposits, no universal pattern for botanical deposition exists. For example, hearths may have more or less refuse than surrounding deposits depending on how it was used or how it was cleaned. Therefore it is important to examine and compare contexts, and in the case of hearths, contrast the contents with other contexts to recognize their unique characteristics.

The botanical assemblages from the hearth (F-1) and surrounding matrices are displayed in Table 6.6. Both counts and weights for botanical materials were measured, except for wood fragments in Level 300, which were too fragmentary to count efficiently but were weighed. Similar to the pit assemblage in B-10, several items have disproportionately high frequencies, such as guava seeds in Level 300 and uncharred wood and charred wood in the hearth (F-1). Therefore, in calculating the density of botanical material for each level, I use the item weight rather than count to even the distribution of items. 
Table 6.6 Unit C-6 macroremains counts and weights.

\begin{tabular}{|c|c|c|c|c|c|c|c|c|c|c|c|c|}
\hline \multicolumn{2}{|l|}{ Sector C } & & & & & \multicolumn{6}{|c|}{ Unit 6} & \\
\hline \multicolumn{2}{|l|}{ Level } & \multirow[b]{2}{*}{ Genus species } & \multirow[b]{2}{*}{ Type } & \multicolumn{2}{|r|}{100} & \multicolumn{2}{|c|}{$F-1(250)$} & \multicolumn{2}{|c|}{ 200(300E) } & $300(400 E)$ & \multicolumn{2}{|c|}{ Total } \\
\hline Category & Family & & & & Wt. $(g)$ & Ct. & Wt. $(g)$ & Ct. & Wt. $(g)$ & \begin{tabular}{|ll} 
Ct. & Wt. $(g)$ \\
\end{tabular} & Ct. & Wt. $(g)$ \\
\hline \multirow[t]{12}{*}{ Food } & Basellaceae & Ullucus tuberosus & Root/Tuber & & & 5 & 0.58 & 2 & 0.55 & & 7 & 1.13 \\
\hline & \begin{tabular}{|l|} 
Convolvulaceae \\
\end{tabular} & Ipomoea batatas & Root/Tuber & & & & & 1 & 0.117 & & 1 & 0.117 \\
\hline & \multirow[t]{3}{*}{ Cucurbitaceae } & Cucurbita moschata & \multirow[t]{3}{*}{ Seed } & & & & & 1 & 0.04 & & 1 & 0.04 \\
\hline & & Cucurbita sp. & & & & 1 & 0.0008 & 2 & 0.037 & & 3 & 0.0378 \\
\hline & & Lagenaria siceraria & & & & 1 & 0.0373 & & & & 1 & 0.0373 \\
\hline & \multirow[t]{2}{*}{ Fabaceae } & Canavalia sp. & \multirow[t]{2}{*}{ Pod } & & & 2 & 0.166 & & & & 2 & 0.166 \\
\hline & & cf. Phaseolus & & & & 1 & 0.078 & & & & 1 & 0.078 \\
\hline & Myrtaceae & Psidium guayaba & Seed & 31 & 0.165 & 54 & 0.109 & 28 & 0.529 & \begin{tabular}{|ll}
144 & 0.3673 \\
\end{tabular} & 257 & 1.1703 \\
\hline & Sapotaceae & Pouteria lucuma & Seed & 1 & 0.0192 & 13 & 0.914 & 8 & 2.71 & $\begin{array}{|ll|}17 & 0.0555 \\
\end{array}$ & 39 & 3.6987 \\
\hline & Solanaceae & Capsicum spp. & Seed & 1 & 0.03 & 1 & 0.0031 & & & & 2 & 0.0331 \\
\hline & \multirow[t]{2}{*}{ Uid. Root/Tuber/Rhizome } & Rhizome rind/peel & \multirow[t]{2}{*}{ Root/Tuber } & & & 1 & 0.237 & & & & 1 & 0.237 \\
\hline & & Root/tuber rind/peel & & & & 5 & 0.169 & 1 & 0.05 & & 6 & 0.219 \\
\hline \multirow[t]{2}{*}{ Industrial } & \multirow[t]{2}{*}{ Malvaceae } & Cotton thread & Cotton Thread & & & 1 & 0.5 & & & & 1 & 0.5 \\
\hline & & Gossypium barbadense & Seed & & & & & & & $\begin{array}{|ll|}18 & 0.0613 \\
\end{array}$ & 18 & 0.0613 \\
\hline \multirow{4}{*}{$\begin{array}{l}\text { Grass/ } \\
\text { Sedge }\end{array}$} & Cyperaceae & Scirpus & Seed & 1 & 0.001 & & & 1 & 0.01 & & 2 & 0.011 \\
\hline & Monocot Grass/Sedge & Monocot Grass/sedge & Monocot Grass/Sedge & & & 21 & 2.394 & & & & 21 & 2.394 \\
\hline & \multirow[t]{2}{*}{ Poaceae } & Panicum sp. & \multirow[t]{2}{*}{ Seed } & & & 3 & 0.0011 & & & & 3 & 0.0011 \\
\hline & & Poaceae & & & & 1 & 0.0032 & & & & 1 & 0.0032 \\
\hline \multirow[t]{2}{*}{ Wood } & \multirow[t]{2}{*}{ Wood } & Wood charred & \multirow[t]{2}{*}{ Wood } & 40 & 0.3776 & 465 & 46.816 & 32 & 2.72 & \begin{tabular}{|ll}
281 & 12.556 \\
\end{tabular} & 818 & 62.4696 \\
\hline & & Wood uncharred & & 51 & 0.267 & 352 & 17.6789 & 14 & 64.107 & 6 & \begin{tabular}{|l|}
417 \\
\end{tabular} & 88.0529 \\
\hline \multirow{5}{*}{$\begin{array}{l}\text { Herbaceous/ } \\
\text { Weedy }\end{array}$} & Bromeliaceae & Tillandsia sp. & Monocot Non-grass & & & & & 6 & 6.978 & & 6 & 6.978 \\
\hline & Eudicot & Eudicot Leaves/Stems & Eudicot Leaves/Stems & & & 2 & 0.0029 & & & & 2 & 0.0029 \\
\hline & Euphorbiaceae & Euphorbiaceae & Seed & 2 & 0.012 & & & & & & 2 & 0.012 \\
\hline & \begin{tabular}{|l|} 
Uid. Peduncle/Stem \\
\end{tabular} & Peduncle/Stem & Peduncle & & & 1 & 0.0021 & 1 & 0.136 & & 2 & 0.1381 \\
\hline & Uid. Seed & Uid. Seed & Seed & & & 2 & 0.0021 & 4 & 4.0124 & 0.011 & 9 & 4.0255 \\
\hline \multirow{2}{*}{\begin{tabular}{|l|} 
Other/ \\
Unknown \\
\end{tabular}} & Dung & Dung & Dung & & & 4 & 0.017 & & & & 4 & 0.017 \\
\hline & Organic Conglomerate & Organic Conglomerate & Organic Conglomerate & & & 2 & 0.0002 & & & 0.099 & 6 & 0.0992 \\
\hline Grand Total & & & & 127 & 0.9 & 938 & 69.7 & 101 & 82.0 & 19.2 & 1633 & 171.7 \\
\hline
\end{tabular}

Table 6.7 Unit C-6 density of macroremains weight to sample weight and sample volume.

\begin{tabular}{lccccc}
\hline \multicolumn{1}{c}{ Context } & Botanical Wt & Sample Wt & Density by Wt & Sample VI & Density by VI \\
\hline $\mathbf{1 0 0}$ & 0.9 & 1116.1 & 0.001 & 10 & 0.1 \\
$\mathbf{2 0 0 ( 3 0 0 E )}$ & 82.0 & 1905.4 & 0.04 & 10 & 8.2 \\
F1-250 & 69.7 & 3685.2 & 0.02 & 40 & 1.7 \\
$\mathbf{3 0 0 ( 4 0 0 E )}$ & 19.2 & 2413.5 & 0.01 & 10 & 1.9 \\
\hline
\end{tabular}

Density was calculated for both sample weight and total sample volume (Table 6.7).

As similar to the pit contents in B-10, sample weight refers to the weight of each individual sample bag that contains material collected from the set of fine-screens for each context, whereas sample volume is the known total volume of the sample before fine-screening. The density of botanical remains in each level is not necessarily predicted by sample weight or sample volume. For instance, 40 liters (4, 10-liter buckets) of sediment were sampled from the hearth (F-1) but the density of botanical remains by volume (density value of 1.7 ) is 
superseded by surrounding contexts. Level 300 (1.9) and Level 200 (8.2) were only 10-liter samples. Density of the hearth contents by weight (0.02) is slightly higher than in the underlying Level 300 (0.01). Level 200, the material outside the hearth and atop the floor, has the highest density by both weight (0.04) and volume (8.2). Level 100, disturbed fill and looters' backdirt, has the lowest density of botanical material.

The hearth (F-1) contained a large percentage of charred wood by weight and a smaller percentage of uncharred wood (Figure 6.11). Grass leaf fragments and a few seeds are also present and probably represent some grass being used as fuel. Other items, such as the eudicot leaves, probably also entered the assemblage as fuel. Food remains are present in the hearth as well. For the food remains, by percentage of weight (Figure 6.12), rind fragments from Ullucus tuberosus (ulluco) and unidentified root/tuber/rhizome taxa make up the largest portion of the food assemblage in the hearth, followed by Pouteria lucuma (lucuma) pod fragments. Psidium guajava (guava) seeds are abundant by count, but make up only $5 \%$ of the food remains by weight. Pod fragments from Canavalia and possibly Phaseolus are well represented by weight and complement the seeds of Cucurbita spp. (squash) and Capsicum spp. (chili).

The contents of the hearth are roughly similar to the botanical assemblage of the matrix surrounding it and overlying the floor associated with the hearth's base, but differ significantly in density, which is largely the result of the weight $(64 \mathrm{~g})$ of a few $(n=14)$ uncharred pieces of wood. The wood makes up a significant percentage of the assemblage weight (Figure 6.10), whereas charred wood fragments are much less concentrated, which is surprising given high ash content of the matrix observed during the excavation. 

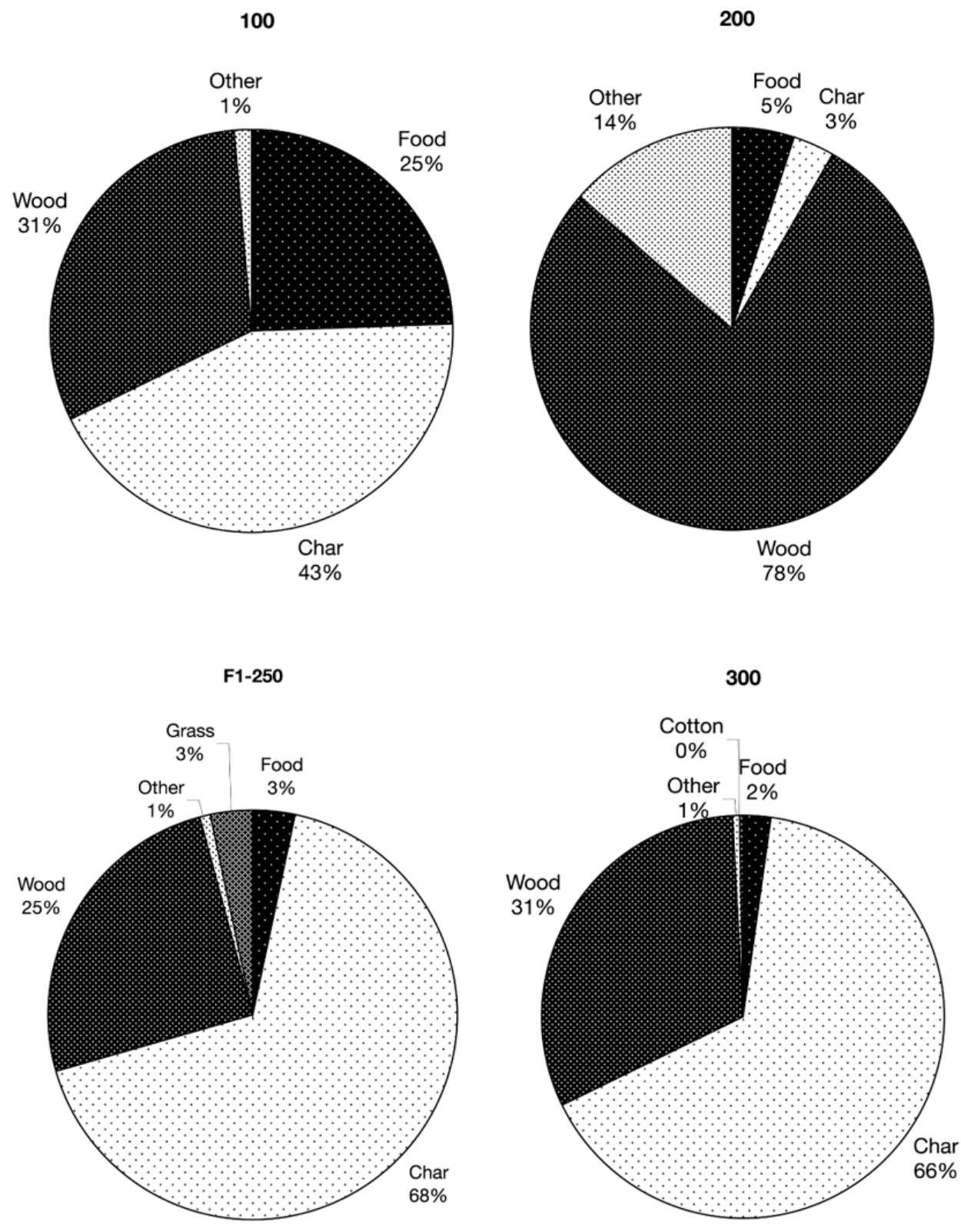

Figure 6.11 Unit C-6 relative proportions of plant macroremains by type and context. 
100

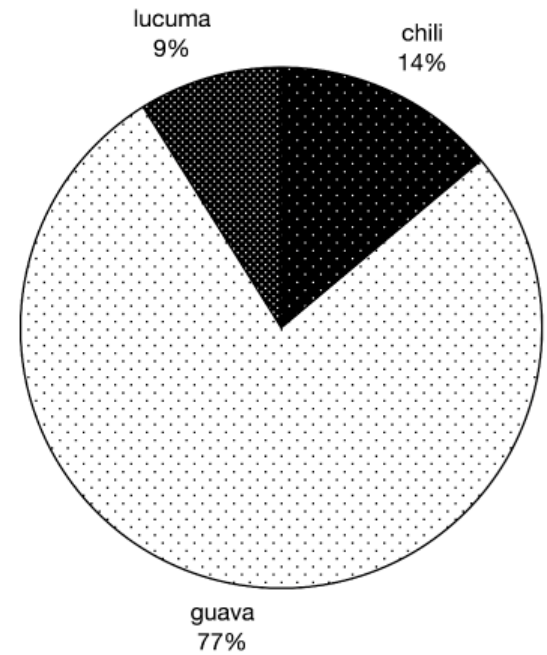

F1-250

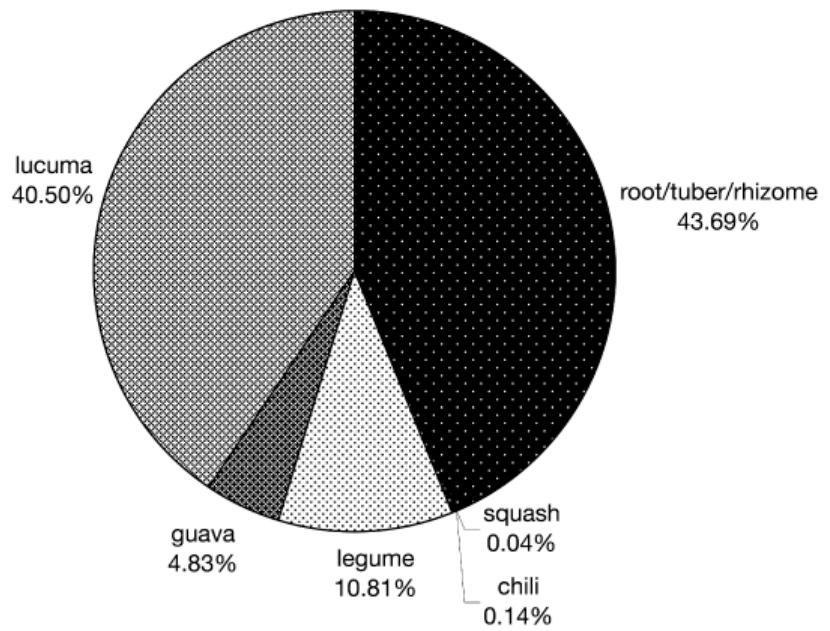

200

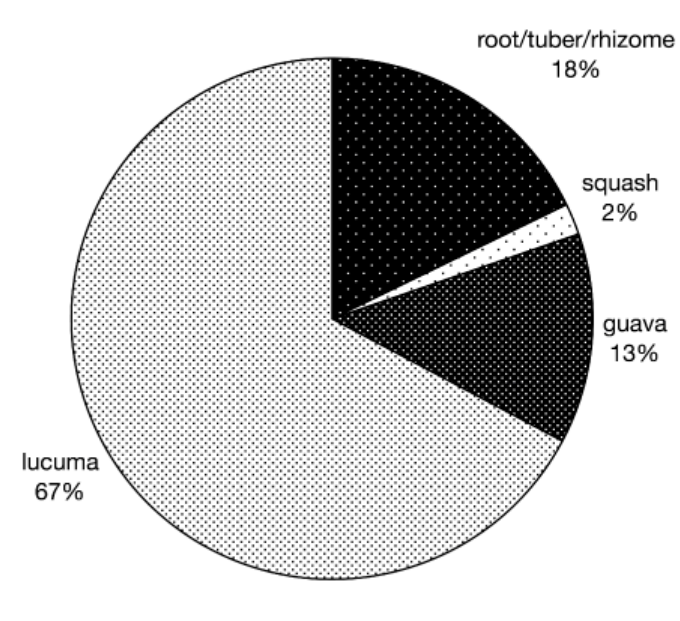

300

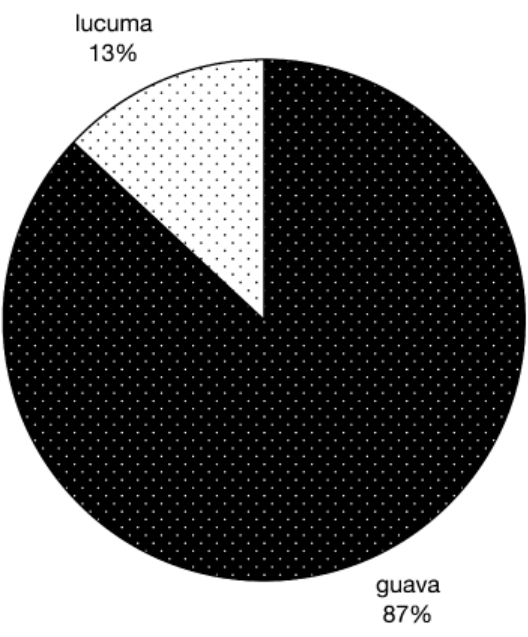

Figure 6.12 Unit C-6 relative proportion of food types by context. 
Other materials recovered in the level outside the hearth include Tillandsia leaves, a single seed from sedge, Scirpus, which also represent potential fuels. Several unidentified seeds, and a peduncle of a small fruit were also found. Food remains are well represented in Level 200, as well, and include rinds from Ipomoea batatas (sweet potato) and Ullucus tuberosus (ulluco) and unidentified roots or tubers, Cucurbita (squash) seeds, pit fragments of Pouteria lucuma (lucuma) and the ubiquitous Psidium guajava (guava) seeds. Charred wood from inside the hearth was radiocarbon dated to $1940 \mathrm{cal}$ B.C. (see Table 5.1).

Food remains found in the hearth (F-1) and outside it in Level 200 are not markedly different, but the hearth has a slightly richer and more abundant assemblage. Given the differences in sample size, 40 liters from the hearth and 10 liters from Level 200, the differences in richness are probably the result of sampling effect. The differences between Level 200 and the hearth contents are greatest in terms of the percentage of charred wood. It is apparent that the hearth was not cleaned after its last use, but the contents of the surrounding matrix are consistent with a discard of hearth contents within the room itself. Therefore, it is possible that the hearth was cleaned and reused several times with the accretion of hearth contents on the floor of the room. This would explain the similar botanical assemblage. This would also explain the low percentage of charcoal in the matrix of Level 200; the high ash content of the soil could be the result of both discard from the hearth combined with bioturbation that would have crushed much of the discarded charcoal. It is also possible that the matrix of Level 200 contains discard from multiple hearths in other rooms. 
Beneath the floor at the base of the hearth, Level 300, excavators encountered a layer of coarse gravel. The plant macroremains recovered from the 10-liter finescreen sample of the gravelly matrix show a slightly lower density by weight and slightly higher density by volume compared to the hearth above. But the material recovered is much less rich (Table 6.6). By weight, charred wood makes up the largest percentage of the material, followed by wood (Figure 6.10). Food remains are limited to just two taxa (Figure 6.11): seeds and pit fragments of guava and lucuma. Several unidentified seeds and fragments of organic conglomerate were also noted. Only in this level do we find seeds from cotton.

The botanical content of the gravelly matrix of Level 300, below the compact floor associated with the hearth above, is not thought to be associated with a living surface or other primary activity. In other parts of the site, gravel was commonly found beneath plastered or compacted floors, apparently placed there to level the surface. The botanical contents of the gravel are probably remains discarded during the time of construction or perhaps the gravel fill was collected from another location in the site during a renovation and the remains were inadvertently mixed. Tools found at the base of the east wall of the structure and the bottom of Level 300, a small wooden stick with rounded ends near a bifacially flaked stone tool, may have been tools used in the construction or renovation of the room and discarded there.

In contrast to the Gran Sala and the smaller rooms uncovered in Sector B that were found in near pristine condition and lacking refuse on the floors, the room in unit C-6 with its bi-level floor and central hearth was not cleaned prior to the room's interment. On the contrary, there was a high density of botanical remains, largely from food plants, 
uncharred and charred wood, in the ashy silt atop the floor, as if the contents of the hearth had been removed and discarded on the floor and this may have occurred multiple times. Likewise, the hearth was not cleaned after its last use before the room was interred. In contrast, Preceramic architecture seems to follow conventions of ritual cleanliness (Burger and Salazar-Burger 1985:115) where the sacred space is kept pure and unpolluted. This idea helps to explain the paucity of artifacts and garbage, except in dedicatory offerings or where the deposition of garbage serves in canceling the sacred through ritual defilement. But also, living-surfaces within households are usually clean of refuse as well (LaMotta and Schiffer 1999). With this in mind, how do we interpret the behaviors in the room that led to the discard of the food remains and other waste materials in C-6? There are several possible scenarios. In one, the room was used as a small ritual chamber with a central fire pit into which offerings of food were placed and burned. Central fire pits, often with ventilated shafts, commonly contain burnt offerings at Late Preceramic highland sites as part of the Kotosh Religious Tradition (Burger and Salazar-Burger 1980) and at coastal sites with similar features (Feldman 1985; Pozorski and Pozorski 1996). The burning of chili peppers in some of these features, as suggested by the presence of chili seeds, at La Galgada, for example, is speculated to be ritually significant; chili infused smoke would have caused the participants eyes to water as a symbol of renewal (Grieder and Bueno 1985:97). At Buena Vista, only one chili seed, an uncharred one, was found in the hearth contents in Unit 6 and none from the floor in Level 200 or below in Level 300. If chilies were being burned in offering in this context, one would expect a much higher number of charred chili seeds, but also the abundance of other uncharred food plant remains in the 
hearth and surrounding contents does not support an interpretation of burnt offering here. Also, unlike other specially used central firepits characteristic of the Kotosh Religious tradition or coastal variants, the hearth in C-6 appears to be more ephemeral and nonpermanent, and not incorporated in a distinctive architectural form (Burger and SalazarBurger 1980; Grieder and Bueno 1988:59; Pozorski and Pozorski 1996), despite being located within elaborate architecture - a raised plaster floor - and nearby to other unique architectural features. Consisting of a simple ring of rocks and lacking a ventilation shaft, the hearth could have been built in just a few minutes.

Most likely, the hearth feature in C-6 served a more mundane, if not specialized purpose in the preparation of food. If this were the case, the room may not have been subject to the same symbolic prescription of ritual cleanliness. Also, unlike other contexts of burnt offerings in the Kotosh Religious Tradition, the remains of the hearth were not reduced to a near complete ashen state (Burger and Salazar-Burger 1980). The preparation of food in this context is certainly indicated by the abundant remains of food plants in the hearth and in the floor sediment surrounding it, particularly the rinds and peels of starchy roots and tubers, ulluco and sweet potato, and unidentified root/tuber and rhizome peels, but also the remains of mussel shells noted both within and outside the hearth (see Figure 4.19). Notably absent are gourd rind fragments in C-6, but one gourd seed was found in the hearth. If food was prepared here, it was probably served in gourd containers and consumed at another location at the site. The radiocarbon date of $1940 \mathrm{cal}$ B.C. from charcoal within the hearth is several centuries younger than the dates from charcoal in the 
pit of B-10, therefore the hearth and activities that took place around it are not directly associated with contents of the pit.

Lastly, because of the impermanence of the hearth, it may represent a re-purposing of the room in C-6. The plastered floor with raised bench along the western wall of the room may have served as part of the original ceremonial architecture here, before the room was converted into a kitchen area. In this scenario, the ashy contents of the hearth and food remains discarded on the floor dually represent preparing of food and symbolically canceling the room.

Sector C, Unit 10

The excavation unit C-10 is bilaterally split by an architectural wall that was not visible on the surface due to the accumulated backfill from looting activity (see Figure 4.20). Unfortunately, Unit C-10 was not well sampled for paleoethnobotanical material, but complete finescreen sets were taken from two discrete stratigraphic levels, one on either side of the bisecting wall, each containing fill material from the separate architectural rooms uncovered in the excavation. Both samples represent architectural fill and contain secondary discard of materials used to fill the rooms presumably during a renovation. One sample was taken from the western room of the unit from a level disturbed by looting activity (Level 200W) and the other from a $12 \mathrm{~cm}$ layer of compact soil atop a hard packed gravel floor (Level 300E). Since the interpretive value of the materials from the looterdisturbed level is limited and the botanical contents of the undisturbed compacted soil is very sparse (Table 6.8), the materials are only described briefly in this report. 
Unfortunately, the botanical remains from C-10 provide only a limited set for comparison and do not provide much insight into the function of either room uncovered in the unit. In the looter-disturbed stratum, Level 200W, guava, root/tuber rinds or peels, and chili pepper represent food remains. A cotton seed and fragment of fiber are present as well. Charred and uncharred wood fragments are most abundant. The discarded food remains and charcoal were possibly collected along with the gravel and fill from a nearby area of the site. In Level 300E, guava seeds are again well represented plus a single pit fragment from lucuma and two unidentified seeds from a possibly eaten food in the Solanaceae family. Wood and charcoal are most abundant. A single unidentified seed was also recovered. The function of the two rooms is still unknown.

Table 6.8 Unit C-6 macroremains counts and weights.

\begin{tabular}{|c|c|c|c|c|c|c|c|}
\hline \multirow{2}{*}{\multicolumn{2}{|c|}{$\begin{array}{l}\text { Sector C } \\
\text { Unit } 10\end{array}$}} & \multirow[b]{3}{*}{ Genus species } & \multirow[b]{3}{*}{ Type } & \multirow{2}{*}{\multicolumn{2}{|c|}{$200 W$}} & \multirow{2}{*}{\multicolumn{2}{|c|}{$300 \mathrm{E}$}} \\
\hline & & & & & & & \\
\hline Category & Family & & & Ct. & Wt.(g) & Ct. & Wt.(g) \\
\hline \multirow[t]{5}{*}{ Food } & Myrtaceae & Psidium guayaba & Seed & 19 & 0.070 & 13 & 1.019 \\
\hline & Sapotaceae & Pouteria lucuma & Seed & & & 1 & 0.001 \\
\hline & \multirow[t]{2}{*}{ Solanaceae } & Capsicum spp. & \multirow[t]{2}{*}{ Seed } & 1 & 0.001 & & \\
\hline & & Solanaceae u'id & & 1 & 0.000 & 2 & 0.001 \\
\hline & Uid. Root/Tuber/Rhizome & Root/tuber rind/peel & Root/Tuber & 6 & 0.259 & & \\
\hline \multirow[t]{2}{*}{ Industrial } & \multirow[t]{2}{*}{ Malvaceae } & Cotton Fiber & Cotton Fiber & 1 & 0.070 & & \\
\hline & & Gossypium barbadense & Seed & 1 & 0.069 & & \\
\hline \multirow{3}{*}{$\begin{array}{l}\text { Grass/ } \\
\text { Sedge }\end{array}$} & Monocot Grass/Sedge & Monocot Grass/sedge & Monocot Grass/Sedge & & 0.125 & & \\
\hline & \multirow[t]{2}{*}{ Poaceae } & Poaceae & Monocot Grass/Sedge & & 0.680 & & \\
\hline & & Poaceae & Seed & 1 & 0.000 & & \\
\hline \multirow[t]{2}{*}{ Wood } & \multirow[t]{2}{*}{ Wood } & Wood charred & \multirow[t]{2}{*}{ Wood } & 464 & 104.531 & 119 & 0.639 \\
\hline & & Wood uncharred & & 48 & 16.480 & 26 & 2.404 \\
\hline \multirow{2}{*}{$\begin{array}{l}\text { Herbaceous/ } \\
\text { Weedy }\end{array}$} & cf. Verbenaceae & cf. Verbenaceae & Seed & 1 & 0.000 & & \\
\hline & Uid. Seed & Uid. Seed & Seed & 3 & 0.012 & 1 & 0.030 \\
\hline \multicolumn{4}{|l|}{ Grand Total } & 546 & 122.3 & 162 & 4.1 \\
\hline
\end{tabular}




\section{Discussion of Botanical MaCroremains}

The exquisite preservation of plant remains recovered from within ancient architectural features at Buena Vista provides a unique opportunity to explore the use of plants for food, fuel, industry, and ritual during the Late Preceramic of Perú. The remains from the sunken pit it the center of the Gran Sala are particularly important in that the pattern of deposition likely reflects rituals performed just prior to the rooms interment.

Although it is difficult, if not impossible, to reconstruct those events as they happened, the pattern of deposition of plant remains, especially those of foods, is indicative of a deliberate sequential burial of the pit associated with multiple ritual events over a short period of time. A layer of round river cobbles and rock fill in the pit separates the upper from lower portions of the pit. Beneath the cobbles, grass lines the bottom of the pit atop which discarded food remains and other plants, including cotton seeds, were scattered. In the levels above the layer of cobbles, a greater richness and diversity of food remains and overall high density of plant materials suggest an even greater contribution of plant remains associated with activities involving food. The assemblage of plant remains in these upper levels is consistent with materials collected in the cleaning of the area around the pit as a final act of its burial. The remains themselves, perhaps still imbued with symbolic importance from their use in ritual, were probably gathered from inside and outside the Gran Sala, to be disposed of deliberately in the pit, leaving the room nearly perfectly clean, save for the tree trunk next to the raised platform.

In Sector C, we see a very different pattern evident inside the room of Unit C-6 in which cleaning did not take place. The hearth in the center of the room contained 
materials, including food remains that were similar to those found in the surrounding matrix as well. The hearth may have been used several times over a short period where its contents were simply brushed out onto the floor of the room. Given the amount of debris on the floor of the room, it is less likely the room was used residentially, but could have been used as a kitchen for those residing at the site or participating in rituals there. Upon its interment, this room, unlike the Gran Sala, was not ritually cleaned. Unfortunately, other rooms excavated in the complex of architecture in Sector $\mathrm{C}$ are much more difficult to interpret due to the extensive looting that has taken place there. However, in C-10, the plant remains collected in this unit suggest activities involving food here as well, roots and tuber rinds were found along with guava and chili pepper seeds.

In the following chapters, I will present data from the microfossils, starch and phytoliths, recovered from sediments from the same contexts from which the macroremains were analyzed and an additional unit not selected for macroremain analysis, Unit C-1. Together, the macroremain and microfossil assemblages provide an even broader data set from which an interpretation of the use of plants for food, industry, and ritual can be based. 


\section{Chapter Seven - Phytoliths and Starch Grains from}

\section{Archaeological Sediments}

Sediment samples from archaeological contexts at Buena Vista were processed and analyzed for starch grains and phytoliths. This chapter presents a very brief history of phytolith and starch research pertinent to the study area, describes the field and laboratory techniques utilized in the extraction of microfossils from the sediments, and presents the results for each of the microfossil analyses. The contexts sampled for starch and phytoliths correspond to the contexts analyzed for plant macroremains, and these results are then compared. Although the starch recovery was low, phytolith recovery was quite successful in eliciting several taxa that were not identified in the macroremains. Significantly, several phytolith types represent plants not native to the coast of Perú and their origin and potential use are discussed in more detail. In all, the microfossil study complements the results of the macroremain analysis and provides a more nuanced understanding of plant use in a ritual setting at Buena Vista.

\section{Phytolith AND Starch Research in Peruvian Archaeology}

Phytoliths, opal silica bodies $\left(\mathrm{SiO}_{2}-\mathrm{nH}_{2} \mathrm{O}\right)$, are formed in the cells of a plant's tissues as water is taken up through the tissue's cells. Silica from the water is deposited in the cells or in intercellular spaces of the plant tissue. The phytolith shape reflects either the shape of the cell in which it was formed, such as epidermal cells, stomata, hair and hair bases, or the 
shape is determined by the intercellular spaces in which the silica is deposited (Piperno 1991), such as short cell phytoliths, including rondel types, abundant in many grasses. Cellular structures in plants are strongly influenced by genetic processes; thus, phytolith formation is also genetically determined in many cases (Piperno and Pearsall 1993: Piperno et al. 2002) and can be seen in the phytolith production patterns by plant family.

Phytolith research has proven to be particularly useful in identifying cultivated plants in the archaeological record and has enhanced our understanding of crop dispersals. Phytolith analysis has also been important in helping to reconstruct past landscapes and track ecological changes associated with agriculture (Neff et al. 2006a, 2006b; Piperno et al. 2007; Iriarte and Paz 2009; McKey et al. 2010). In the New World, identifying maize was the first directive in phytolith studies of cultivated plants in the archaeological record (Pearsall 1978, 1979). By comparing cross-shaped short-cell phytoliths, their size and morphological features, to other Panicoid grasses, Pearsall was able to identify maize in sediment samples at the Real Alto site in Ecuador. This technique provided evidence of maize cultivation at Real Alto by 2450 B.C., whereas macroremains of maize are only preserved in archaeological deposits in the region a millennium later. Thus, from the beginnings of phytolith research, phytoliths have proven successful in identifying 'missing' taxa in archaeological contexts. Further research on cross-shaped phytoliths from maize and related grasses has supported and refined the identification potential of maize by crossshaped phytoliths (Piperno 1984; 1988; 2006; Pearsall 2000; Iriarte 2003). Also, new phytolith types are now known to be diagnostic of maize cobs. These types, as well as maize starch, were later identified on the residues of stone tools from Real Alto, verifying 
Pearsall's original results (Pearsall et al. 2004). To date, multiple researchers have studied over 500 wild species of grasses and more than 40 maize races in an effort to identify maize and have provided multiple criteria to identify maize in the archaeological contexts (Piperno 2008). In spite of the overwhelming attention lavished on maize, phytolith researchers have also been successful in identifying a number of other important cultigens in New World archaeological contexts, including squash at sites in Ecuador (Piperno and Stothert 2003) and Panama (Piperno 2006a), as well as Calathea allouia (llerén), manioc, and arrowroot, at Real Alto (Chandler-Ezell et al. 2006).

Archaeological phytolith research in Perú began as early as the 1960s with a preliminary assessment of phytoliths in ash samples from the highland site of Kotosh (Matsutani 1972). Since then, surprisingly little phytolith research has been undertaken in Perú. Among the few phytolith studies to date, Lawrence Kaplan (1985) reported on spatial differences in the composition of phytolith assemblages from different locations at a highland site in the Andes. The presence of maize in Initial Period contexts at Cardal was confirmed by Marcel Umlauf (1988) through phytoliths and, as at Real Alto, in spite of a lack of maize macroremains there. Phytoliths (and pollen) were identified in the residue of a colonial period ceramic vessel by John Jones (1993). I examined the potential for identifying corral from non-corral sediments at the Chilca Valley site of Antibal (Duncan 2003). Also, interesting preliminary results reported by Alexandre Chevalier (2008) at the southern coastal site of Quebrada de los Burros suggest early cultivated plants in deposits dating to around 6800 B.P. In recent years, phytolith analysis has been carried out simultaneously with starch grain research. Amanda Logan (2006) examined Formative 
subsistence, trade and ritual through phytolith and starch research, and also contributed an additional method of identifying maize in Andean contexts. And lastly, at Waynuna, phytoliths and starch grains firmly establish the presence of maize and arrowroot in 4000year-old contexts at this highland Peruvian site (Perry et al. 2006).

The usefulness of starch grains as taxonomic identifiers was first investigated in the late 1800s (Czaja 1978). Later, Edward Reichert (1913) presented starch grain descriptions along with images of their bi-refringent properties under cross-polarized light for many taxa. Starch grains are polysaccharide compounds ( $\alpha-1,4$-glucopyranoside) produced in plants for high-energy storage (Simpson 2006:51) and can be found in various plant parts. Starch grains referred to as transitory starches are formed in the chloroplasts, mainly in the leaves, as a product of photosynthesis and are utilized quickly by the plant (Haslam 2004; Cortella and Pochettino 1994). Storage starch formed in amyloplasts in roots, tubers, rhizomes, seeds and fruits ensure the plant's growth and survival and aid in germination and fruiting (Haslam 2004). Storage starch grains are more abundant and generally larger than transitory grains and therefore most useful for characterization and identification in the archaeological record.

As for archaeological starch grain studies in recent years, starch research has contributed greatly to the study of early plant use and consumption by humans (Cortella and Pochettino 1994). Starch grains of economic plants are successfully identified in the residues of stone tools and ceramics (Ugent and Peterson 1988; Loy et al. 1992; Piperno and Holst 1998; Perry 2001, 2004; Balme \& Beck 2002; Chandler-Ezell and Pearsall 2003b; Pearsall et al. 2004; Pagán-Jimenez 2005; Crowther 2005; Chandler-Ezell, Pearsall 
and Zeidler 2006; Fullagar et al. 2006; Zarillo \& Kooyman 2006; Barton 2007; Dickau et al. 2007). Starch grains sometimes survive in sediments as well, proving to be useful indicators of economic plants even when macrobotanical remains are scant or absent (Therin et al. 1999; Piperno et al. 2000; Balme and Beck 2002; Parr and Carter 2003; Haslam 2004; Horrocks 2005; Perry et al. 2007; Perry and Flannery 2007). Starch granules also have been extracted from dental calculus (Boyadijian et al. 2007; Henry and Piperno 2008; Piperno and Dillehay 2008; Hardy et al. 2009) providing direct evidence of prehistoric diet.

In Peruvian archaeology, despite very early allusions to the usefulness of starch grains in helping to identify macroremains, starch grain research is still a novel approach in investigating the archaeological record. Wittmack (1880-1887: Plates 106-107), in his analysis of plant macroremains from the Necropolis of Ancón, displayed illustrations of starch grains from archaeological specimens of maize and sweet potato. In Margaret Towle's (1961: Plate 1) seminal paleoethnobotany of Perú, starch grains are illustrated for cultivated tubers oca, potato, jicama, manioc, sweet potato and the rhizome of achira. Donald Ugent, together with Shelia and Tom Pozoski, illustrated starch grains in specific cultivated tubers including sweet potato (1981), potato (1982), achira (1984), and manioc (1986). In more recent years, the focus of starch grain research in Peruvian archaeology has centered on extracts from sediments and stone tool fragments (Perry et al. 2006; Perry et al. 2007) and most recently from human teeth (Piperno and Dillehay 2008) and from gourd and squash artifacts (Duncan, Pearsall and Benfer 2009; see also Chapter 8). 


\section{CONTEXTS AND FIELD SAMPLING METHODS}

The Buena Vista contexts selected for phytolith and starch grain study mirror those selected for macroremain analysis, with the exception of the samples from the floor of the room in Unit B-7 from which microfossils were not studied (see Table 6.1). In addition, microfossils from sediments were analyzed from another archaeological unit, Unit C-1 that contained a cobble-lined, plastered trench that may have served as an open ventilation shaft. Surface samples from two locations on the site from Unit B-4a and Unit B-5a were also studied for comparison (see Chapter 5, Figure 5.3 for unit locations).

Table 7.1 Contexts of sediments analyzed for macroremains, phytoliths, and starch

\begin{tabular}{clccc}
\hline Unit & Level & Macros & Phytoliths & Starch \\
\hline & $200 / 250$ & $\mathrm{x}$ & $\mathrm{x}$ & $\mathrm{x}$ \\
B-10, Feature 1 & 300 & $\mathrm{x}$ & $\mathrm{x}$ & $\mathrm{x}$ \\
& 350 & $\mathrm{x}$ & $\mathrm{x}$ & $\mathrm{x}$ \\
& 400 & $\mathrm{x}$ & $\mathrm{x}$ & $\mathrm{x}$ \\
& 425 & $\mathrm{x}$ & $\mathrm{x}$ & $\mathrm{x}$ \\
\hline \multirow{2}{*}{ C-1 } & 100 & & $\mathrm{x}$ & $\mathrm{x}$ \\
& 200 & & $\mathrm{x}$ & $\mathrm{x}$ \\
\hline & Surface & $\mathrm{x}$ & $\mathrm{x}$ & \\
& 100 & $\mathrm{x}$ & $\mathrm{x}$ & $\mathrm{x}$ \\
C-6, 6E & 250 & $\mathrm{x}$ & $\mathrm{x}$ & $\mathrm{x}$ \\
& 300 & $\mathrm{x}$ & $\mathrm{x}$ & $\mathrm{x}$ \\
& 400 & $\mathrm{x}$ & $\mathrm{x}$ & $\mathrm{x}$ \\
\hline C-10 & 200 & $\mathrm{x}$ & $\mathrm{x}$ & $\mathrm{x}$ \\
\hline B-4B & 300 & & $\mathrm{x}$ & $\mathrm{x}$ \\
\hline B-5A & Surface & Surface & $\mathrm{x}$ & $\mathrm{x}$ \\
\hline B-7 & Floor & $\mathrm{x}$ & & \\
\hline
\end{tabular}

\section{LABORATORY METHODS}

Microfossil extraction for both starch and phytoliths from soils is a two-phase process that begins with starch extraction, then follows with phytolith extraction. Starches 
are fragile and highly susceptible to temperature and chemical dissolution, so extraction from soils follows a gentler procedure similar to that used with extractions of starches from artifacts (see Chapter 8). Phytolith extractions from sediments require more intensive processing of the soils to deal with larger amounts of organic content and require adapting the process in response to the soil type and its mineral and chemical components. For this study, I processed 5 to 7 grams of soil from each context for starch, and then proceeded with phytolith extraction from the same soil sample.

For the starch, I adapted published methods of extracting starch from sediments (Zarrillo and Kooyman 2006; Perry 2001; Horrocks 2005). In the first phase of starch extraction, it is necessary to release electrical and chemical bonds that hold the starch granules to soil particles. Using a gentle chemical dispersion with disodium ethylenediaminetetraacetate (NaEDTA) and disaggregation in a reciprocal shaker, the chemical and electrical bonds are broken. The second phase dissolves organic material that may continue to hold starch granules in the soils: the sediments are exposed to a $6 \%$ solution of hydrogen peroxide for ten minutes, then rinsed and centrifuged, twice again, decanting the supernatant solution each time. Finally, starch granules having a specific gravity less than 1.6 were floated from the remaining soil using a heavy liquid solution of cesium chloride $(\mathrm{CsCl})$. The suspended solution of starch was then centrifuged and rinsed several times. The rinsed starch solution was mounted on a standard microscope slide in glycerin, under a coverslip sealed with lacquer to prevent leaking. Slides were scanned under a Zeiss Standard transmitted light microscope under polarized light at 375x. 
Photographs were taken at a magnification of 400x. Ten to twelve rows were scanned from each slide.

Following starch extraction, the sediment samples were processed for phytoliths using the standard laboratory procedure in the Paleoethnobotany Laboratory at MU (Pearsall 2000:424-433; Zhao and Pearsall 1998.) First, soils were dried, sieved to remove large particles, and tested for $\mathrm{pH}$. Carbonates and certain oxides are then removed from the soils using a hydrochloric acid $(\mathrm{HCl})$ and nitric acid $\left(\mathrm{HNO}_{3}\right)$ solution. Organic matter was then dissolved using a sequence of household bleach $(\mathrm{NaClO})$ and hydrogen peroxide $\left(\mathrm{H}_{2} \mathrm{O}_{2}\right)$ further releasing phytoliths from organic bonds. Following the removal of organic material, the sediments were dispersed in a solution of NaEDTA. This was followed by clay removal through a centrifuge sedimentation method similar to Lentfer and Boyd (1999). Finally, heavy liquid chemical flotation with Zinc Iodide $\left(\mathrm{ZnI}_{2}\right)$, at a specific gravity of 2.3, separated the phytoliths from the sediments. The phytolith extract was then rinsed thoroughly and dried before mounting on microscope slides in a medium of Canada balsam. In the identification of phytoliths, it is crucial to be able to rotate the phytoliths in the mounting media to observe all of their features; therefore a slow-hardening medium, such as Canada balsam, is preferred. Slides were scanned on a Zeiss Standard transmitted light microscope at 400x, ten to twelve rows each. The number of phytoliths, diatoms, and sponge spicules were recorded. For phytoliths, counts were made up to $\sim 200$ when possible. Phytolith identification were made in consultation with the comparative phytolith collections in the Paleoethnobotany Laboratory at MU and the phytolith database (Pearsall 2008). 

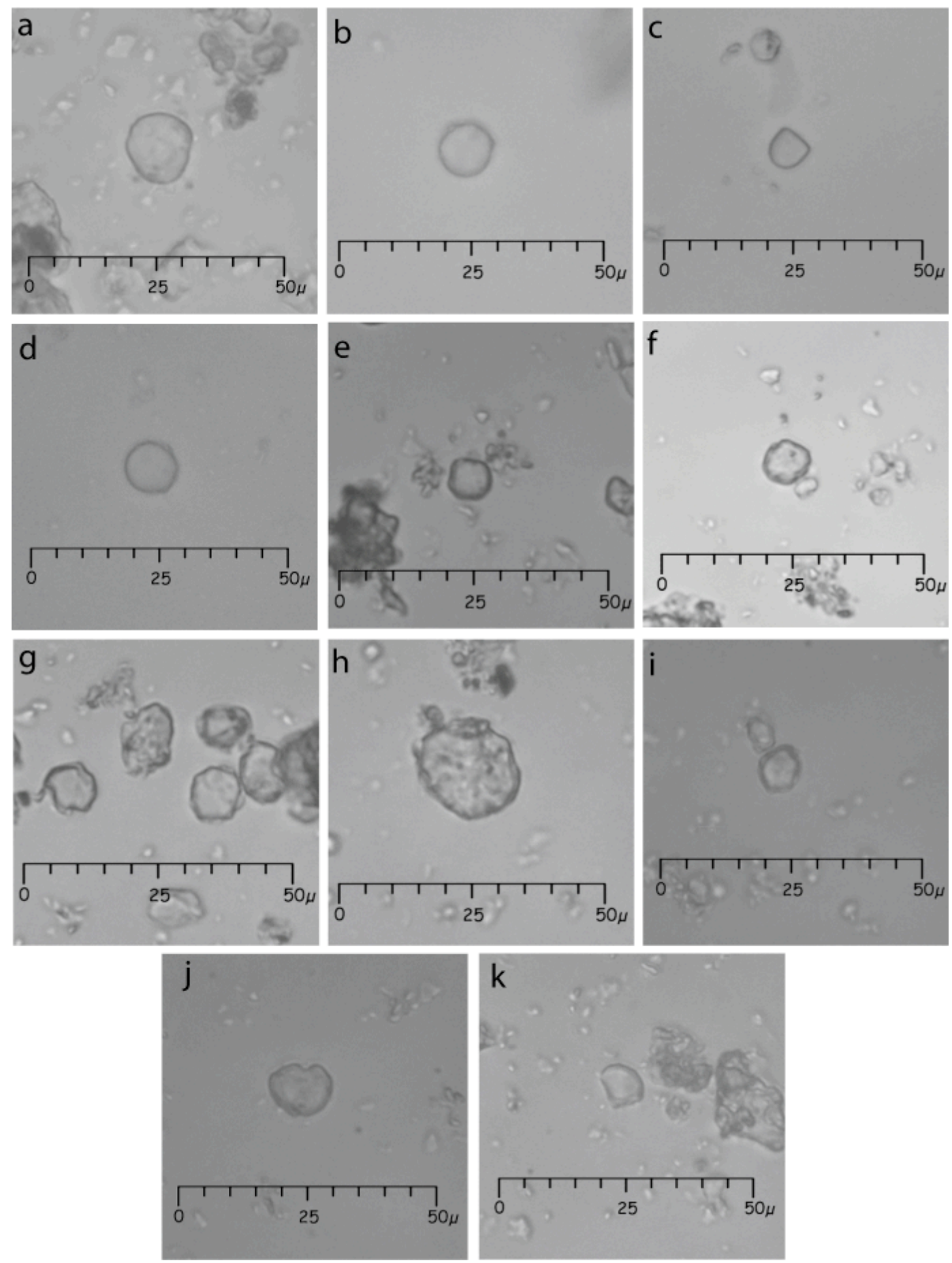

Figure 7.1 Starch grains recovered from sediments: (a) unidentified transitory starch from Unit 4-B, surface; (b) unidentified transitory grain from Unit B-10/200; (c) Cucurbitaceae starch grain from Unit B-10/200; (e through g) unidentified transitory starch from Unit C-1/100; (h) possible starch from grass Unit C-1/100; (i through $j$ ) unidentified transitory starch from Unit C-6/250; (k) possible starch grain from manioc, cf. Manihot sp. from Unit C$10 / 200.2$ 


\section{Results of Starch ANd Phytoliths Studied FROM SEDIMENTS}

Starch

Starch recovery from the sampled sediments produced low counts and only tentative identifications of two of the starch grains to taxa were made at this time (Table 7.2; Figure 7.1). The majority of grains share similar morphology; these grains are spherical in shape with irregular, bumpy surfaces, have closed hila, and only weak birefringence under polarized light. They are sized between $8 \mu$ and $10 \mu$ across. These bumpy-surfaced grains were recovered from the surface of Unit 4-B (Figure 7.1 a) and in unit levels of Unit C-1 (Figure $7.1 \mathrm{e}-\mathrm{g}$ ) and Unit C-6 (Figure $7.1 \mathrm{i}-\mathrm{j})$. These small starch grains may be transitory starch grains and thus difficult to identify to plant taxon. One larger grain with similar surface characteristics is disk shaped in rotation, being half as wide when viewed from the side than from the top (Figure $7.1 \mathrm{~h}$, viewed from top). This starch grain is also not yet identified. Similarly sized grains with bumpy surfaces occur in several genera of Poaceae; however, much more detailed starch characterization studies are needed for Poaceae before this starch grain can be identified to taxon. Of the three starch grains recovered from Unit B-10 in the pit feature, all from Level 200, two are simple smoothsurfaced spherical grains exhibiting double outlines and open hila, and under polarized light, have extinction crosses with straight arms (Figure $7.1 \mathrm{~b}, \mathrm{~d}$ ). Spherical starch grains with similar characteristics are produced as storage and transitory starch in a great variety of plants, therefore, without distinguishing characteristics, they are very difficult to identify. 
The other grain found in the same excavation level is a small hemispherical grain (Figure 61 c) exhibiting a double outline, open hilum and straight armed extinction cross visible in polarized light. This starch grain is similar to grains produced in the Cucurbitaceae, but this grain does not exhibit diagnostic features of the family (see Chapter 8), so only a tentative identification of the grain is possible. Lastly, a single starch grain (Figure $7.1, \mathrm{k}$ ) was recovered from sediment in Unit C-10. This grain is small, spherical, but flattened in side view, with two basal facets characteristic of manioc, but not necessarily diagnostic. Therefore, a tentative identification as cf. Manihot sp. is made for this starch grain. Similar starch grains were identified in the residue of one gourd artifact (see Chapter 8).

Table 7.2 Identification of starch grains recovered in sediment samples.

\begin{tabular}{|c|c|c|c|c|c|}
\hline Starch Soil \# & $862-2$ & 1029 & 1032 & 1038 & 1025,6 \\
\hline Sector Unit & B-10 & C-6 & C-10 & $B-4 B$ & C-1 \\
\hline Level & $200 / 250$ & 250 & 200 & Surf. & 100 \\
\hline Feature & F-1 & F-1 & F-1 & & \\
\hline cf. Cucurbitaceae & 3 & & & & \\
\hline cf. Manihot sp. & & & 1 & & \\
\hline Unidentified & & 2 & & 1 & 4 \\
\hline Total Starch & 3 & 2 & 1 & 1 & 4 \\
\hline
\end{tabular}

Phytoliths

Phytolith recovery was productive in most of the archaeological contexts. Raw counts of the phytolith data are displayed in Table 7.3. Phytolith identifications were made with the aid of comparative phytolith material from Neotropical taxa in the MU Paleoethnobotany Laboratory collection. For the purposes of this study, phytolith types are grouped into two categories based on major plant characteristics, those produced in grasses and sedges and those produced in herbaceous and woody plants. 
Table 7.3 Phytolith counts from archaeological sediments at Buena Vista

\begin{tabular}{|c|c|c|c|c|c|c|c|c|c|c|c|c|c|c|c|c|c|}
\hline Phytosoil & 2422 & 2423 & 2425 & 2426 & 2424 & 3404 & 3405 & 2427 & 3314 & 2429 & 3412 & 3315 & 3409,10 & 3411 & 3414 & 3415 & \\
\hline Sector-Unit & B-10 & B-10 & B-10 & B-10 & $\mathrm{B}-10$ & C-1 & $\mathrm{C}-1$ & C-6 & $\mathrm{C}-6$ & $\mathrm{C}-6$ & C-6 & C-6 & C-10 & C-10 & B-4B & B-5a & \\
\hline Level & $200 / 250$ & 300 & 350 & 400 & 425 & 100 & 200 & Surf. & 100 & 250 & $200 \mathrm{E}$ & $300 E$ & $200 \mathrm{~W}$ & $300 \mathrm{E}$ & Surf & Surf & \\
\hline Feature & $\mathrm{F}-1$ & $\mathrm{~F}-1$ & $\mathrm{~F}-1$ & $\mathrm{~F}-1$ & $\mathrm{~F}-1$ & & & & & $\mathrm{~F}-1$ & & & & & & & \\
\hline \multicolumn{18}{|l|}{$\begin{array}{l}\text { Herbaceous/Woody } \\
\text { Herbaceaous }\end{array}$} \\
\hline \multicolumn{18}{|l|}{ Herbaceaous } \\
\hline Asteraceae perforated sheet & & 6 & & & & & & 1 & & & 4 & & & 4 & & & \\
\hline Cordia lutea hair cell base & & & 1 & & & & & & & & & & & & & & \\
\hline Phaseolus hair cell & & & & & & 1 & 1 & & & & & 1 & & & & & \\
\hline Calathea allouia 80IKb stellate sphere & 21 & 1 & 38 & 55 & & & & & & & & 1 & & & 1 & 2 & 2 \\
\hline Heliconia sp. troughed body & & & 2 & 1 & & & & & & & 1 & & & & & & \\
\hline Cucubita sp. faceted sphere & 1 & & & & & & & & & & & & & & & & \\
\hline Marantaceae/Cannaceae Rugulose $>10$ um sphere & 42 & 3 & 12 & 5 & 1 & & & & & & 1 & & & & & 4 & 4 \\
\hline Marantaceae nodular conical 80IIIB & & & & & & & & & 1 & & & 1 & & & 1 & & \\
\hline Marantaceae/Bombacoideae nodular sphere $80 \mathrm{ICa}$ & 5 & & 4 & & & 2 & 2 & 1 & 4 & 1 & 6 & 1 & & 7 & 5 & 3 & 3 \\
\hline Costaceae/Bombacoideae nodular sphere $801 \mathrm{Cc}$ & & & & & & 1 & 1 & 1 & & & & & & & & & \\
\hline Smooth sphere small & & & & & & & & & & & 1 & & & & 1 & 1 & 1 \\
\hline \multicolumn{18}{|l|}{ Woody Eudicots } \\
\hline Annonaceae facetate body 80IFb & & & & & & & & & & & & & & 1 & & & \\
\hline Arecaceae Spinulose Spheres 80ID $(>6 \mu)$ & 3 & & & & & 1 & 1 & & 1 & 2 & 1 & & & & & & \\
\hline Woody Eudicot Rugulose $<10 \mu$ sphere & 1 & & & & & & 1 & & & & & & 1 & 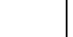 & & 2 & 2 \\
\hline Schlerid & & & & & & & & & & & & & & & 2 & & \\
\hline Anticlinal Cells - Unidentified Seed/Fruit & & & & & & & & 2 & & & & & & 6 & 2 & 6 & 6 \\
\hline Transport elements Seed/Fruit 140I & & & 1 & & & & & 1 & 5 & ; & 1 & & & 3 & & & \\
\hline Misc. Herbaceous/Woody & & & & & & & & & & & & & & & & & \\
\hline Cystolith & 1 & & & & & & & & 1 & 13 & & & & & 4 & & \\
\hline Darkened smooth sphere/cystolith & 5 & 6 & 17 & 7 & & 7 & 1 & 12 & 2 & 17 & 4 & 3 & 9 & 3 & 3 & & \\
\hline Epidermal quadrilateral - blocky & & & & & & & & & & 9 & 1 & & & 17 & 4 & & \\
\hline Eudicot hair cell base small & 2 & & & & & & & & 1 & & & & & & & & \\
\hline Eudicot hair cell A & & & & & & & & & & & & & & & & 1 & 1 \\
\hline Eudicot hair cell B & & & & & & 1 & 1 & 1 & 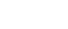 & & & & & & & 1 & \\
\hline Eudicot hair cell C & & & & & & & & & 2 & ? & & & & & & & \\
\hline Eudicot hair cell D & & & & & & & & & & & 1 & & & & & & \\
\hline Eudicot hair cell E & & & & & & & 1 & & & & & & & 1 & & & \\
\hline Eudicot hair cell $\mathrm{F}$ & & & & & & & & & & & & & & 1 & & & \\
\hline Grass/Sedge & & & & & & & & & & & & & & & & & \\
\hline Redundant Poaceae indicators & & & & & & & & & & & & & & & & & \\
\hline Bulliform & 16 & 4 & 15 & 16 & 1 & 6 & 5 & & 14 & 15 & 5 & 15 & 3 & 32 & 4 & 6 & 6 \\
\hline Grass prickle & 1 & & & & & 2 & 3 & & 2 & 3 & 1 & & 2 & 6 & 7 & 2 & \\
\hline Grass Epidermal cells - long & 8 & 39 & 6 & 11 & 21 & 15 & 3 & 4 & 15 & 23 & 12 & & 8 & 21 & 22 & & \\
\hline Grass epidermal sheets & & & & & & & & & & & 4 & 6 & & & & 19 & \\
\hline Poaceae epidermal hair cell & 1 & & & & 1 & 6 & 5 & 1 & 1 & & 1 & & & 1 & & 3 & 3 \\
\hline Grass tubular body $22 \mathrm{VIIE}$ & & & & & & & & & & & & & 1 & 1 & & & \\
\hline Redundant Poaceae short cells & 1 & 7 & & 1 & 6 & 11 & 3 & 16 & 13 & 9 & 9 & & 3 & 18 & 21 & 19 & \\
\hline Grass epidermal non-quadrilateral & & 44 & 46 & 8 & 18 & & & & & 2 & & & & & & & \\
\hline Chloridoid & & & & & & & & & & & & & & & & & \\
\hline saddles & 13 & 32 & 15 & 61 & 139 & 46 & 6 & 86 & 39 & 28 & 18 & 6 & 8 & 32 & 65 & 50 & \\
\hline Panicoid & & & & & & & & & & & & & & & & & \\
\hline Bilobate & 48 & 11 & 12 & 9 & 8 & 11 & 4 & 32 & 52 & 36 & 11 & 13 & 7 & 24 & 44 & 55 & 5 \\
\hline Crenate & 11 & 5 & 2 & & 1 & 1 & 1 & 5 & 9 & 3 & 2 & & & 2 & 4 & 4 & 4 \\
\hline 3-lobed & 2 & 3 & & & & & & 1 & & 2 & 1 & 1 & & 1 & 5 & 3 & 3 \\
\hline Cross Var 5/6 & & 2 & & 1 & 1 & 4 & 4 & 3 & 4 & 3 & 3 & 1 & & 7 & 3 & & 5 \\
\hline Unilobate & 3 & 6 & & & 1 & 6 & 1 & 4 & 1 & 1 & 3 & & & 4 & 8 & 10 & \\
\hline Complex topped Panicoid & 9 & 7 & 3 & 1 & 4 & 13 & & 14 & 16 & 28 & 10 & 4 & 2 & 13 & 21 & 24 & \\
\hline Zea spp. ruffle top & & & & & & & & & & & & & & & 1 & & \\
\hline Zea spp. and some Pancioid IRP & & & & & & & 1 & 1 & 1 & & 2 & & & 5 & 2 & & \\
\hline Zea mays and some Panicoid - Cross Var 1 & & 1 & & & 2 & 1 & 1 & 2 & 2 & 1 & 1 & & & 2 & 3 & 3 & 3 \\
\hline Zea mays narrow elongate rondel & & & & & & & & 12 & & & & & & & & & \\
\hline Bambusoid & & & & & & & & & & & & & & & & & \\
\hline Bambusoid bilobate & & & & & & 2 & 2 & & & & & & & & & & \\
\hline Bambusoideae saddle/bilobate & & & & 3 & & 6 & 5 & 1 & 23 & & 1 & & 1 & 3 & & 4 & \\
\hline Bambusa short cell $12 f$ & 1 & & & & & 1 & 1 & & 1 & & & & & 1 & & & \\
\hline Gadua/Chusquea & & 1 & 4 & 1 & 4 & & & & 3 & 1 & 2 & & & 4 & & 6 & \\
\hline Chusquea & & & & & & 2 & 2 & & & & & & & & & & \\
\hline Other Bambusoid & 2 & & & 1 & 1 & & & 10 & & 21 & 2 & & & 3 & & 2 & \\
\hline Poaceae/Cyperaceae & & & & & & & & & & & & & & & & & \\
\hline Elongated stomate & 5 & 30 & 23 & 12 & 8 & 7 & 7 & 7 & & 3 & 2 & & & 3 & 2 & 4 & \\
\hline Short Stomate & 3 & 6 & & & 3 & 1 & 1 & & & 3 & & & & 1 & & 11 & \\
\hline Sedge & & & & & & & & & & & & & & & & & \\
\hline Cyperaceae seed epidermis 22II & & & & & 2 & & & & 1 & 1 & & & & & 1 & & \\
\hline Epidermal Non-Quadrilateral - probable Cyperaceae & & & & & & & & & & 2 & & & & & & & \\
\hline Scirpus seed epidermis 22IIB & 4 & & & & & & & & & & & & & & & & \\
\hline TOTAL PHYTOLITHS & 209 & 214 & 201 & 193 & 226 & 154 & 30 & 218 & 214 & 227 & 111 & 53 & 45 & $5 \quad 226$ & 236 & 250 & \\
\hline Diatoms & & & 7 & & & 2 & 3 & 8 & 11 & & 5 & & & & 11 & 7 & \\
\hline Sponge Spicules & & & & & & & 2 & & 7 & & 4 & 5 & & & 4 & + & \\
\hline
\end{tabular}


Phytolith types representing herbaceous and woody plants include several that are

diagnostic to plant family or genus as well as other types produced in this category of plants not necessarily identifiable to taxa. Figures 7.2 through 7.6 illustrate several of the types discussed. The identifications include:

Facetate phytoliths

These phytoliths are produced in leaves of the family Annonaceae (the custard apple or guanabana family). These plants could have been harvested for wood and species with edible fruits such as Annona cherimola and Annona muricata may have been managed.

Spheres with spinulose surfaces

These phytoliths are produced in the leaves of palms, Arecaceae (Figure 7.2). Phytoliths of this type, spinulose spheres, are also produced in genera of Bromeliaceae, several of which grow in the coastal lomas of Perú. Palm and bromeliad phytoliths can be separated by size and shape, however: those of palms are larger, $6-25 \mu$, and have regular spinule distribution, whereas the size range for similar phytoliths in Bromeliads does not exceed $10 \mu$ (Piperno 2006b:37). Therefore in this study, for Arecaceae to be indicated the sphere must exceed $10 \mu$. In Perú, the natural distribution of palms is limited to the eastern slopes of the Andes and generally north of $7^{\circ}$ South latitude in inter-andean areas on the western slopes (Weberbauer 1945:146-7; Milan 2006; Llatas and Lopez 2005), well north of the Chillón Valley. Palms are widely used by humans: fibrous leaves are used for roofing and weaving, palm wood is durable, and the fruits are edible (Heiser 1990). A fragment of a palm seed was reported at the highland site of La Galgada (Smith 1988). Phytoliths of this type are produced in the leaves, stems, petioles, and fruits of Arecaceae. 

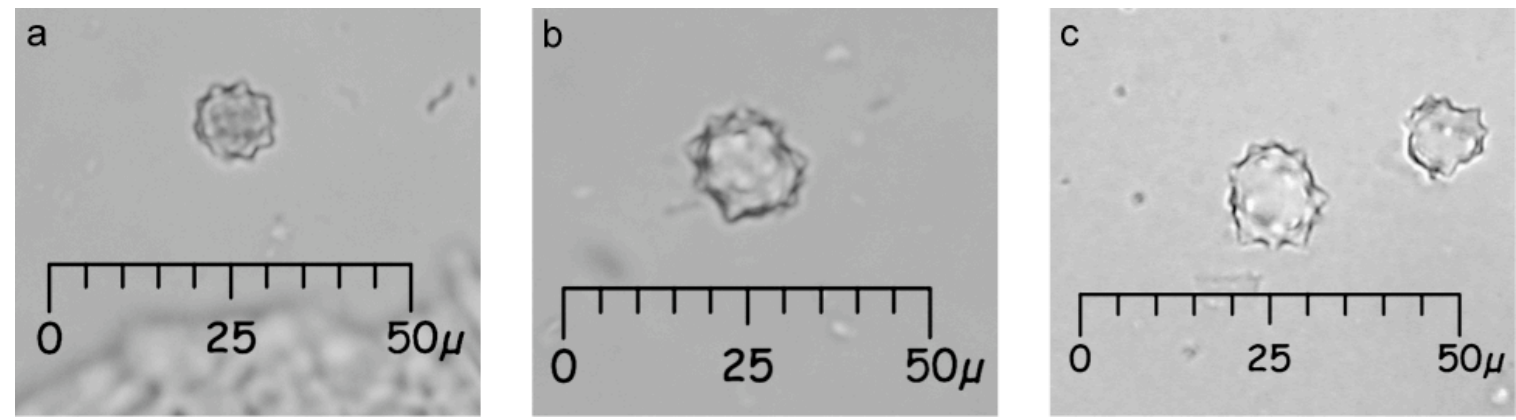

Figure 7.2 Arecaceae spinulose spheres, Type 80ID. (a and b) phytoliths from archaeological sediments at Buena Vista; (c) a modern comparative phytolith from Cocos nucifera in the MU type collection.

\section{Perforated sheet phytoliths}

These are produced in weedy Asteraceae (Compositae). These plants are common herbs and shrubs and likely grew along the valley floor. Numerous species are distributed on the coast of Perú.

Basal hair cell phytoliths

$$
\text { Phytoliths produced in Cordia lutea in the Boraginaceae (the borage family) are }
$$

present. These shrubby plants are common along the coast of central Perú and may occur on rocky slopes given appropriate soils.

Hair cell phytoliths from Phaseolus sp.

These are diagnostic phytoliths of Phaseolus in Fabaceae. Both Phaseolus lunatus and P. vulgaris are early-domesticated beans on the coast of Perú. Other species of Phaseolus are not known from this region, so these phytoliths likely represent one of the domesticated beans. 
Faceted spheres from Cucurbita sp.

These phytoliths are diagnostic of genera in the Cucurbitaceae family (Figure 7.3).

Faceted sphere phytoliths are developed in the rind of the fruit between epidermal and parenchyma cells and, although similar spheres are produced in other Cucurbitaceae, genus and often species level distinction is possible (Piperno, Andres, Stothert 2000). A single Cucurbita sphere was identified in the archaeological sediments. Its size, $82.5 \mu$ thick by $70 \mu$ long, and shape conform to diagnostic characteristics of domesticated squash.

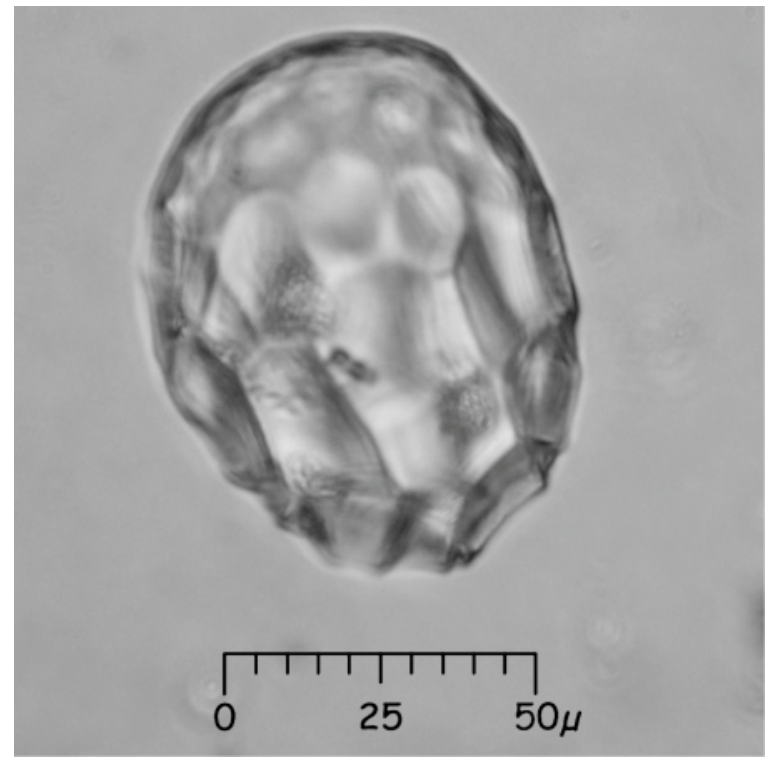

Figure 7.3 Faceted sphere diagnostic to Cucurbita sp. recovered from archaeological sediments in Unit B-10, Level 200/250, Feature 1.

Spheres with stellate projections

Sphere of this type, $80 \mathrm{IKb}$, are produced in leaf and inflorescence tissue of Calathea allouia in Marantaceae (Figure 7.4). Phytoliths of a similar type are produced in the leaves of Costaceae, e.g. Costus scaber and C. guanaiensis, Type 80IKa, but these can be easily 
distinguished from Calathea in that the Calathea type is smaller, ranging from 7.5 to $25 \mu$, has smaller and more abundant projections (see Figure 4.4).
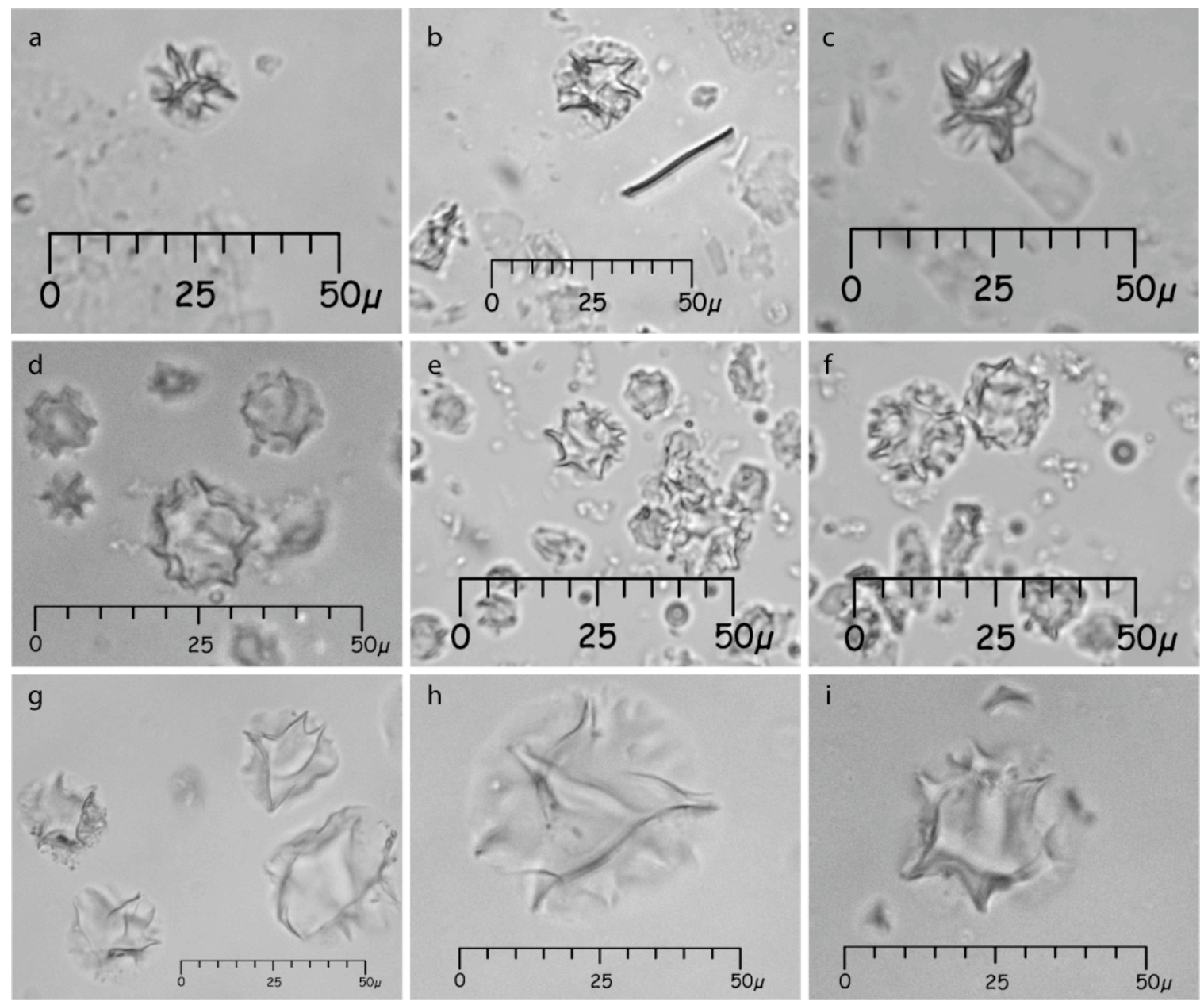

Figure 7.4 Spherical phytoliths with stellate projections, Type 80IK. Top row (a-c) archaeological phytoliths from Buena Vista sediments, Type $80 \mathrm{IKb}$. Middle row (d-f) comparative phytoliths from Calathea allouia Type 80IKb. Bottom row (g-i): comparative phytoliths from Costus guanaiensis, Type 80IKa. Note size of phytoliths and abundance and size of projections among archaeological and comparative specimens of Calathea in comparison to $C$. guanaiensis. Comparative specimens from MU type collection. 
Large $(>10 \mu)$ rugulose spheres

These spherical phytoliths are produced in the leaves and rhizomes of herbaceous monocot plants in the Marantaceae, Cannaceae, and Costaceae ${ }^{6}$ in the MU comparative collection (Figure 7.5). Similar rugulose phytoliths are produced by eudicot shrubs and trees, but can be distinguished on the basis of size, generally between 3 to $9 \mu$ (Piperno 2006b:39).
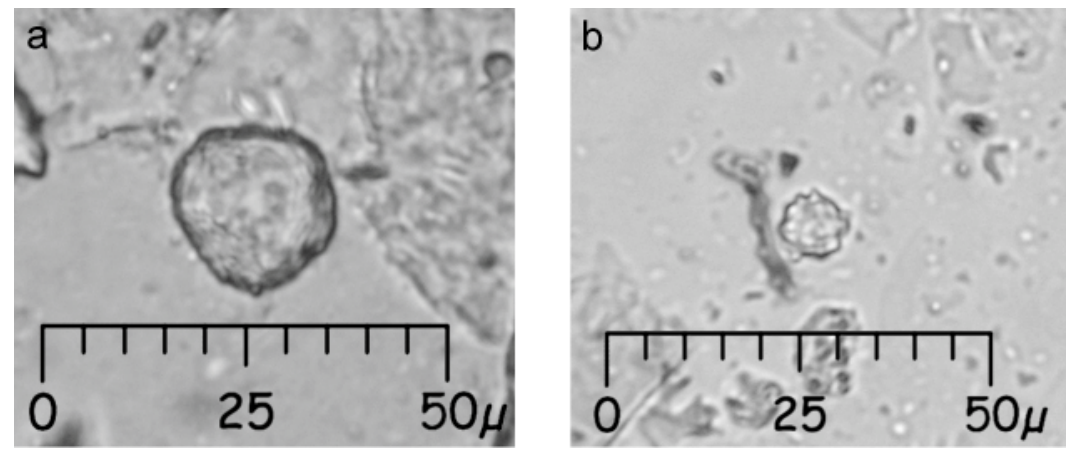

Figure 7.5 Large rugulose sphere produced in Marantaceae and Cannaceae (a) and a nodular sphere (b) produced in Marantaceae and Bombacoideae from archaeological sediments, B-10, Level 200/250 and C-6 Level 250.

Spheres with nodular surfaces, Type 80Ica

These spherical phytoliths are produced in plants of Marantaceae and

Bombacoideae (Malvaceae) (Figure 7.5 b).

Spheres with nodules and ruminate surfaces, Type 80ICc

Spherical phytoliths having both nodules and ruminate surfaces are produced in Costaceae and Bombacoideae.

\footnotetext{
${ }^{6}$ In MU system, phytoliths of this type were identified in Costus, formerly classified in the Zingiberaceae.
} 
Conical phytoliths with nodular surfaces, Type 80IIIB

Conical, or hat-shaped, phytoliths with nodular surfaces are diagnostic of

\section{Marantaceae.}

These five phytolith types, stellate spheres, large rugulose spheres, nodular spheres, ruminate-nodular spheres, and conical bodies with nodular surfaces, are all produced in herbaceous monocot taxa in the order Zingiberales. The nodular sphere and ruminatenodular sphere type, however, overlap with those phytoliths produced by eudicot plants in the Bombacoideae subfamily of Malvaceae ${ }^{7}$. In the Bombacoideae, two species appear to be native to the central coast of Perú, Eriotheca discolor (punga) and Ochroma pyramidale (balsa) (Brako and Zarucchi 1993:214-215). In the MU collection, Eriotheca spp. have not been studied, but of the ten species of Bombacoideae that have been studied, nodular spheres were produced in only four (MU Paleoethnotany Lab documents). Of those four, only in one case did nodular spheres occur in abundance, Pseudobombax milliei. They were very rare in Ochroma sp. and other species. Both Eriotheca sp. and Ochroma sp. may have contributed phytoliths to this assemblage, but it is unlikely because they are very soft woods and would not have been a first choice for use as fuel. Species of the Marantaceae, Cannaceae, and Costaceae do not occur naturally on the central coast or western flanks of the Andes in this region of Perú. The use of plants in the Costaceae is not documented archaeologically in Perú. However, a species of Cannaceae, Canna indica (=C. edulis), achira, is well documented archaeologically and occurs in sites contemporary with Buena Vista such as Aspero (Feldman 1980), Chilca I (Jones 1988), La Galgada (Grieder et al. 1988; Smith

\footnotetext{
${ }^{7}$ Classified as Bombacaceae in the MU system. Bombacaceae now classified as subfamily Bombacoideae in Malvaceae (Stephens 2010)
} 
1988), Huaca Prieta (Bird, Hyslop, and Skinner 1985), and Los Gavilanes (Bonavia 1982; Popper 1982).

In the Marantaceae, there is limited archaeological evidence for Maranta arundinacea (arrowroot) and no other evidence for Calathea allouia (leren). Both arrowroot and leren were domesticated in the New World, but other species in both genera produce several edible tubers that could have once held great significance in agricultural systems of the New World (Pearsall n.d). The area of origin for these domesticated Marantaceae is not fully understood, but they do grow wild in northern South America, Brazil, and in Central America (Piperno and Pearsall 1998:115). Both domesticates are noted archaeologically in South America as early as 9000 cal B.P. in Colombia (Piperno and Pearsall 1998) and Ecuador (Piperno and Pearsall 1998; Piperno and Stother 2003; Piperno 2009). In central Perú, investigators have found evidence for Maranta at only one other site, Waynuna in the southern highlands dating to 4000-3600 B.P. Thus far, the phytolith evidence for arrowroot in the sediments is based on the presence of phytoliths diagnostic of Marantaceae and supported by the identification of arrowroot starch from artifacts. For leren, phytoliths diagnostic to Calathea allouia confirms the presence of a second species of Marantaceae being utilized at Buena Vista.

\section{Troughed-body phytoliths}

These phytoliths are diagnostic of Heliconia sp. in Heliconiaceae (Figure 7.6). Heliconia is represented by over 30 species in Perú, however its natural distribution is primarily limited to the eastern slopes of the Andes and lowlands (Brako and Zaruchhi 1993). On the western side of the Andes, Heliconia occurs in the northernmost 
departments of Perú (Weberbauer 1945:155) as an understory plant in cloud forests (Llatas and López 2005) and in lowland and cloud forests on the coast of Ecuador (Svenson 1946:418). In archaeological material from Ancón near the lower Chillón Valley, de Rochebrune (1879) identified what may have been Heliconia as "Musa paradisiaca". Musa is a modern introduced cultigen, bananas and plantains, but has large green leaves similar to some species of Heliconia. Phytoliths produced by Musa and Heliconia are easily discernable and not likely to be confused (Mbida et al. 2006). Those species of Heliconia with large leaves are used as wrapping in cooking, such as steaming fish or in modern humitas and tamales, and several species have edible rhizomes (Soukoup 1970:149; Brack Egg 1999:238241).
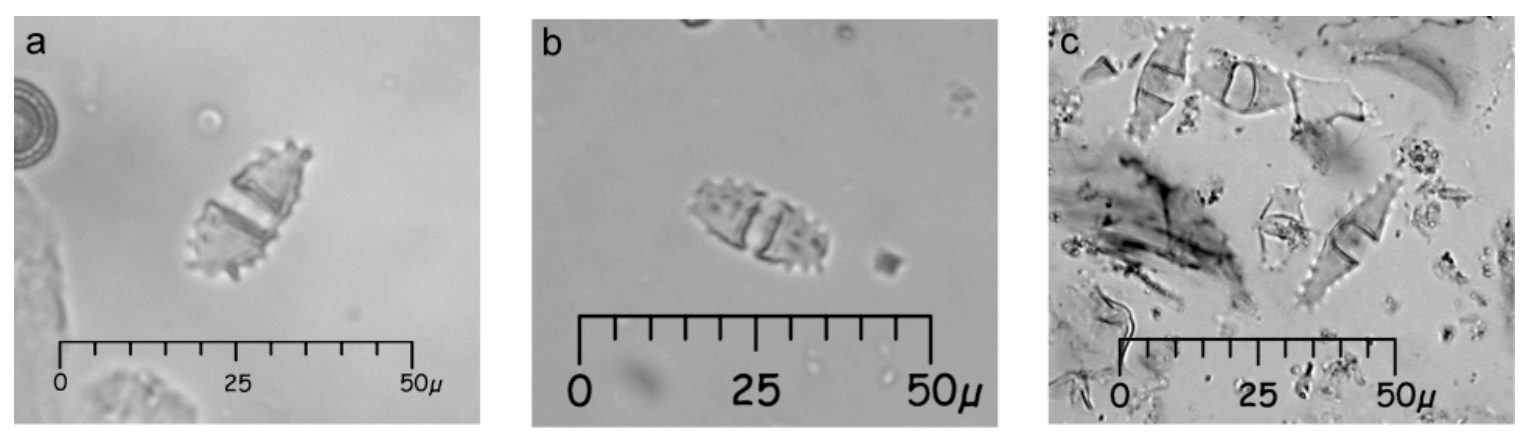

Figure 7.6 Heliconia sp. trough-bodied phytoliths. (a-b) Heliconia phytoliths from archaeological sediments, Unit B10, Level 350. (b) comparative troughed-body from Heliconia cf. curtispatha. in the MU type collection.

Other herbaceous or woody phytolith indicator types

Other phytolith types indicate herbaceous plants, such as cystoliths, which form in leafy foliage, and silicified hair cells produced in the epidermis of eudicot plants. Many of these hair cells cannot be identified to taxa. Schlerids (silicified schlerenchyma cells), serve as general indicators of woody plants. 
Poaceae phytolith types

Phytoliths from grasses (Poaceae) are well represented in the assemblage. There is significant overlap of phytolith types produced in Poaceae, denoted in Table 7.3 as "Redundant Poaceae indicators", but sub-family contributions to a phytolith assemblage can be identified by the relative abundance of particular phytolith types and, in some cases, genus and species level identifications can be made on the basis of individual types (Piperno and Pearsall 1998). Grasses of the subfamily Chloridoideae are common in the assemblage as represented by characteristic saddle-shaped short cell phytoliths. Panicoideae phytoliths are also common, including bilobate types, crosses, and complex rondels. Maize (Zea mays), a Panicoid grass not native to South America can be identified by several kind of phytoliths, including complex "ruffle-top" rondels produced in the cupules of maize cobs (Pearsall et al. 2003) and "narrow elongate" rondels that occur in Andean maize and probably other maize types (Logan 2006; see also Thompson and Mulholland 1994; Bozarth 1996). Other indicators of maize include large cross-shaped phytoliths produced in the leaves of maize and a few other Panicoid grasses. Maize produces a higher percentage of large cross-shaped phytoliths (measured as the length of the smallest side being greater than $16 \mu)$ and has been used to distinguish maize from other grasses and identify maize in archaeological samples (Pearsall 1976, 1978, 1979, 1982). Subsequently, Piperno (1984) classified three-dimensional morphology of cross shapes to indentify maize crosses from other grasses. Piperno's criteria established eight morphological cross variants and showed that cross morphology, in addition to cross size, could securely identify maize in archaeological sediments where there are high percentages of large crosses, high numbers of Variant 1 crosses, low numbers of Variant 6 crosses, and large and extra large Variant 1 
crosses. The technique was bolstered by the application of discriminate function analysis that formalized these criteria (Piperno and Starczak 1985) as a method of separating maize from wild grasses. The cross body method was successfully tested with archaeological materials from Ecuador (Pearsall and Piperno 1990) and a previously unexplored region of southern Uruguay (Iriarte 2003).

In the Buena Vista assemblage, maize was not identified by phytoliths in any of the undisturbed contexts. Cross-shaped phytoliths were present in a number of such contexts (Table 7.4). Variant 1 crosses occur in subsurface contexts $(n=6)$, but only one cross is larger than $16 \mu$. Therefore the low proportion of Variant 1 crosses to Variant 5/6 crosses $(\mathrm{n}=16)$ in subsurface deposits is more likely indicative of other panicoid grasses. As shown in Table 7.3, panicoid grasses were present at the site. Because the number of large Variant 1 crosses is so low, the application of statistical analysis is not warranted in this case. Maize is indentified by phytoliths in two surface samples, however: in Unit B-4b by the presence of a "ruffle-top" rondel and very large (>21 $\mu)$ variant 1 crosses produced only in maize, and in Unit C-6 by two large Variant 1 crosses and twelve rondel phytoliths of the type described by Logan (2006) in her study of Andean maize.

Table 7.4 Cross-shaped phytoliths and Variant 1 size determinations identified in sediments. ${ }^{*}$ indicates large, ${ }^{* *}$ indicates extra large Variant 1 crosses.

\begin{tabular}{|c|c|c|c|c|c|c|c|c|}
\hline Phytosoil & Unit & Level & Feature & $\begin{array}{l}\text { Variant } 1 \\
\text { Count }\end{array}$ & & $\begin{array}{c}\text { Variant } 1 \\
\text { Size }\end{array}$ & & $\begin{array}{l}\text { Count } \\
\text { Variant 5/6 }\end{array}$ \\
\hline 2423 & B-10 & 300 & F-1 & 1 & $10 \times 10$ & & & 2 \\
\hline 2424 & B-10 & 425 & F-1 & 2 & $15 \times 15$ & $18 \times 18^{*}$ & & 1 \\
\hline 2427 & C-6 & Surface & & 2 & $18 \times 18^{*}$ & $18 \times 18^{*}$ & & 3 \\
\hline 3314 & C-6 & 100 & & 2 & $10 \times 15$ & $13 \times 13$ & & 4 \\
\hline 2429 & C-6 & 250 & & 1 & $13 \times 15$ & & & 3 \\
\hline 3412 & C-6E & 300 & & 1 & $13 \times 13$ & & & 3 \\
\hline 3411 & C-10 & 300 & & 2 & $15 \times 20$ & $13 \times 16$ & & 7 \\
\hline 3404 & C-1 & 100 & & 1 & $13 \times 18$ & & & 4 \\
\hline 3414 & B- 4 B & Surface & & 3 & $20 \times 30 * *$ & $18 \times 20$ & $35 \times 35^{* *}$ & 3 \\
\hline 3415 & B-5a & Surface & & 3 & $15 x 15 x$ & $15 \times 15$ & $17 \times 22^{*}$ & 5 \\
\hline
\end{tabular}




\section{INTERPRETATION OF PHYTOLITH DATA}

As discussed in Chapter 3 and again in Chapter 6, the ecology at the site and surrounding area helps to shape our interpretation of the plant remains, and in this case the phytolith assemblage recovered from soils sampled from the archaeological contexts at the site. Depositional processes for phytolith assemblages in natural environments can be complex even without factoring in the influence of human activities that transport plant materials across a landscape. However, as phytoliths are part of the soil components, if soils move so go the phytoliths (Pearsall 2000:939). For many natural environments, phytolith deposition appears to be the result of a plant's 'decay in place' (Dimbleby 1978; Mulholland 1989: Piperno 1988) and phytoliths tend not to move in stable soils due to the chemical and electrical bonds between phytoliths and soil components such as silts and clays (Pearsall 2000:393). However, phytolith dispersal may be influenced by several processes other than 'decay in place' (Fredlund and Tiezen 1994), such as eolian processes (see Twiss et al. 1969) and through lofting of ashed plant materials in fires, actions of herbivory that transport phytoliths in the plants consumed in one location to deposition in another, and fluvial and colluvial processes that move soils and sediments in swamp or lake settings (Piperno 1993) or freshwater runoff into coastal mangroves (Neff et al. 2006a, 2006b). In archaeological contexts at Buena Vista, the deposition of phytoliths into the soils should be considered in light of these processes, but one should also consider other factors, such as the ecology of the area and the source of the plant material, the arid climate that lends to the high degree of preservation of plant source material, as well as the 
human-built architectural spaces from which the sediment samples were taken in order to interpret accurately the phytolith assemblage.

In Chapter 5, the case was made that the plant macroremains recovered from the architectural contexts of the site, particularly the pit feature in B-10, were not representative of plants that would have grown wild on the hillside surrounding the site, rather, most plants were selected by people and brought into these contexts. Likewise, humans also brought most of the plants that contributed phytoliths to this assemblage into these contexts. In the Buena Vista phytolith assemblage, one might predict similar taxonomic identifications to the macroremain assemblage from the same contexts. There is some overlap, for instance, grasses, squash rinds, bean pods, Cyperaceae seeds, and Asteraceae identified in the macroremains are phytolith producers, but these are not abundant in the phytolith assemblage, with the exception of the grasses. Small fragments of rhizome peels were also identified in the macroremains as Canna/Maranta rhizomes. These macroremains correspond to phytoliths produced in Marantaceae and Cannaceae, such as large rugulose spheres that are abundant in both rhizomes and leaves of Maranta but are only produced in the leaves of Canna (MU lab documents). Marantaceae also produces nodular spheres abundantly in the leaves and less abundantly in the rhizomes. However, three other plants not identified in the macroremains occur in the phytolith assemblage, Calathea allouia, Heliconia sp., and palms. Given the high degree of preservation that was observed in the macroremains, it is not likely that these plants decayed in place; rather, phytoliths of these plants were introduced through other taphonomic means. 
One likely source is with the abundant ash produced in cooking fires and the burning of other materials. If, for example, leaves of Heliconia or palms were used for wrapping food for cooking, they may be burned in the process or disposed of in the fire. This may also explain the high numbers of large rugulose spheres present that are produced in abundance in the leaves of Maranta and Calathea, which can be used in a similar way to cook food. Palm phytoliths may also represent palm fruits that may have been charred as well. If these plants parts were burned, phytoliths would have been released from their organic matrix and deposited into the sediments with the ash and other carbonized remains. Burning may also explain the high numbers of grass phytoliths in the assemblage, since grass, too, was not likely decaying in place at such a high degree. Dry grass makes convenient tinder and also could be used in cooking for steaming foods, especially shellfish. Grasses used as temper material for plaster floors and walls, as observed at Buena Vista, would be a source for phytolith deposition as well. In the descriptions of the phytolith assemblage by archaeological contexts, the preceding issues will be considered.

Sector B, Unit 10, Feature 1 - The Sunken Pit

In the macroremains analysis, the stratigraphic levels of plant remains in the sunken pit in the center of the Gran Sala of Sector B follow a deliberate sequence of deposition corresponding to the refuse of remains produced by activities involving food. Changes in botanical density and in richness and diversity of food remains show a greater contribution of food plants discarded in the upper levels of the pit. Because phytoliths of food plants other than Maranta and Calathea are limited, such as squash and beans, in the 
assemblage, it is difficult to compare directly the phytoliths to the macroremains. However, the overall patterning of phytoliths in the pit by stratigraphic level can be compared to the results of the macroremains and some preliminary conclusions can be made.

The phytolith assemblage for the B-10, Feature 1, is overwhelmingly dominated by phytoliths produced in various grasses (Figures 7.7 and 7.8). Beginning with Level 425, taken from the floor of the pit, the phytolith assemblage is nearly $98 \%$ dominated by grasses as would be predicted by the archaeological observation of the level being a layer of grass leaves and culms placed atop the plaster floor. Specifically, phytoliths from Chloridoid grasses are most abundant and probably represent the grass types placed at the bottom of the pit. Several stellate shaped spheres produced by Calathea allouia and a single large rugulose sphere produced in Marantaceae and Cannaceae were identified. Above, in Level 400 , grasses compose nearly $65 \%$ of the assemblage, but stellate spheres of Calathea are well represented here $(\mathrm{n}=55)$, as well as several large rugulose spheres from Marantaceae/Cannaceae, and one unexpected phytolith type from Heliconia.

Richness of herbaceous and woody phytolith types increases in Level 350, with the presence of mixed-type phytoliths, nodular spheres, produced in Marantaceae and Bombacaceae, another Heliconia phytolith, and a single phytolith produced in Cordia lutea. Darkened/smooth sphere cystoliths, general herbaceous indicators, are most abundant in this level. A silicified transport element produced in fruits was also identified. This archaeological level was noted to be a layer of round river cobbles and gravel, but macroremains showed a relatively high density of plant remains and a marked increase in food diversity. The greater richness of phytolith types produced by herbaceous plants 
reflects the increase in diversity of macroremains at this level of the pit compared to levels below.

In Level 300, grass phytoliths contribute over $92 \%$ percent of the assemblage and only a few herbaceous/woody phytolith types are represented. Phytoliths of Asteraceae are present only in this level, as well as large rugulose spheres and darkened smooth sphere cystoliths. The number of stellate shaped spheres of Calathea is reduced to one. This level has the highest overall richness and diversity of food taxa in the macroremain assemblage, but this is not directly reflected in the phytolith assemblage.

Above, in Level 200/250, the percentage of grass phytoliths drops to only $61.5 \%$ and herbaceous and woody phytolith types show greatest richness. In addition to types occurring in lower levels of the pit, Arecaceae spinulose spheres possibly from palm fruits, small rugulose spheres from woody eudicots, and two hair cell bases from a eudicot are present. In this level, macroremains show the highest density of charred wood and overall high diversity of food remains. A single phytolith from squash, Cucubita sp. was also noted in this level.

Although different in composition with regard to the abundant food plants recovered in the macroremains, the phytolith assemblage from the sunken pit in Unit B-10 supports the conclusion that an intensification of food-related discard occurred in the upper levels of the pit, but only if we can correctly hypothesize the function for several of the taxa that are represented by phytoliths. For instance, two phytolith types are present that are produced in the Marantaceae: large rugulose spheres also produced in Cannaceae, and nodular spheres, also produced in Bombacoideae. It is likely that wood from 
Bombacoideae trees would have contributed phytoliths if these plants were utilized as fuel or otherwise were burned, but the presence of large rugulose spheres in the wood of this family has not been studied, and these soft woods do not make good fuel. However, the large rugulose spheres produced in Marantaceae and Cannaceae possibly represent the cultivated Maranta arundinacea (arrowroot). An arrowroot starch grain recovered from gourd artifacts from the sunken pit corroborates this conclusion. 


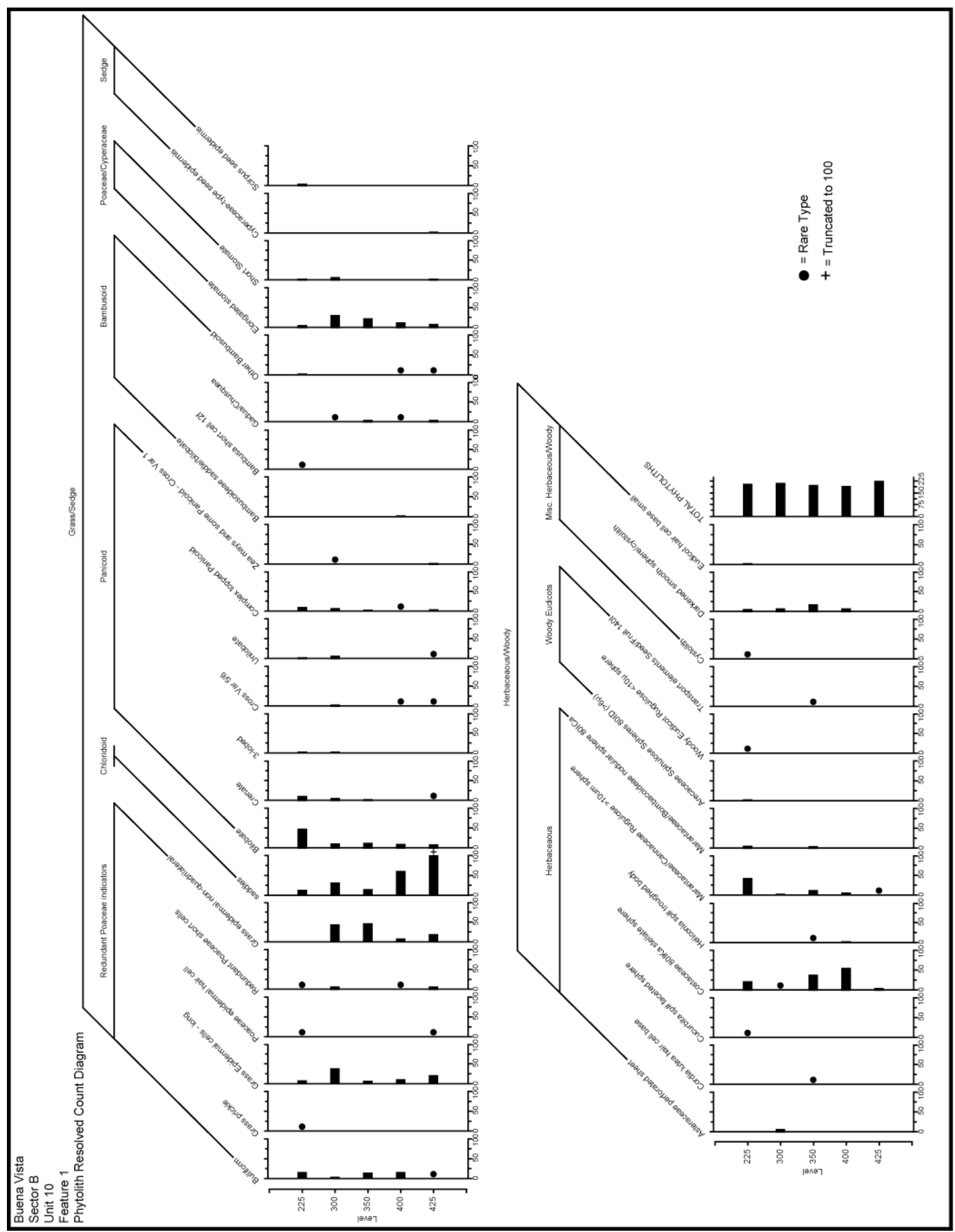

Figure 7.7 Phytolith resolved count diagram for Unit B-10, Feature 1. 


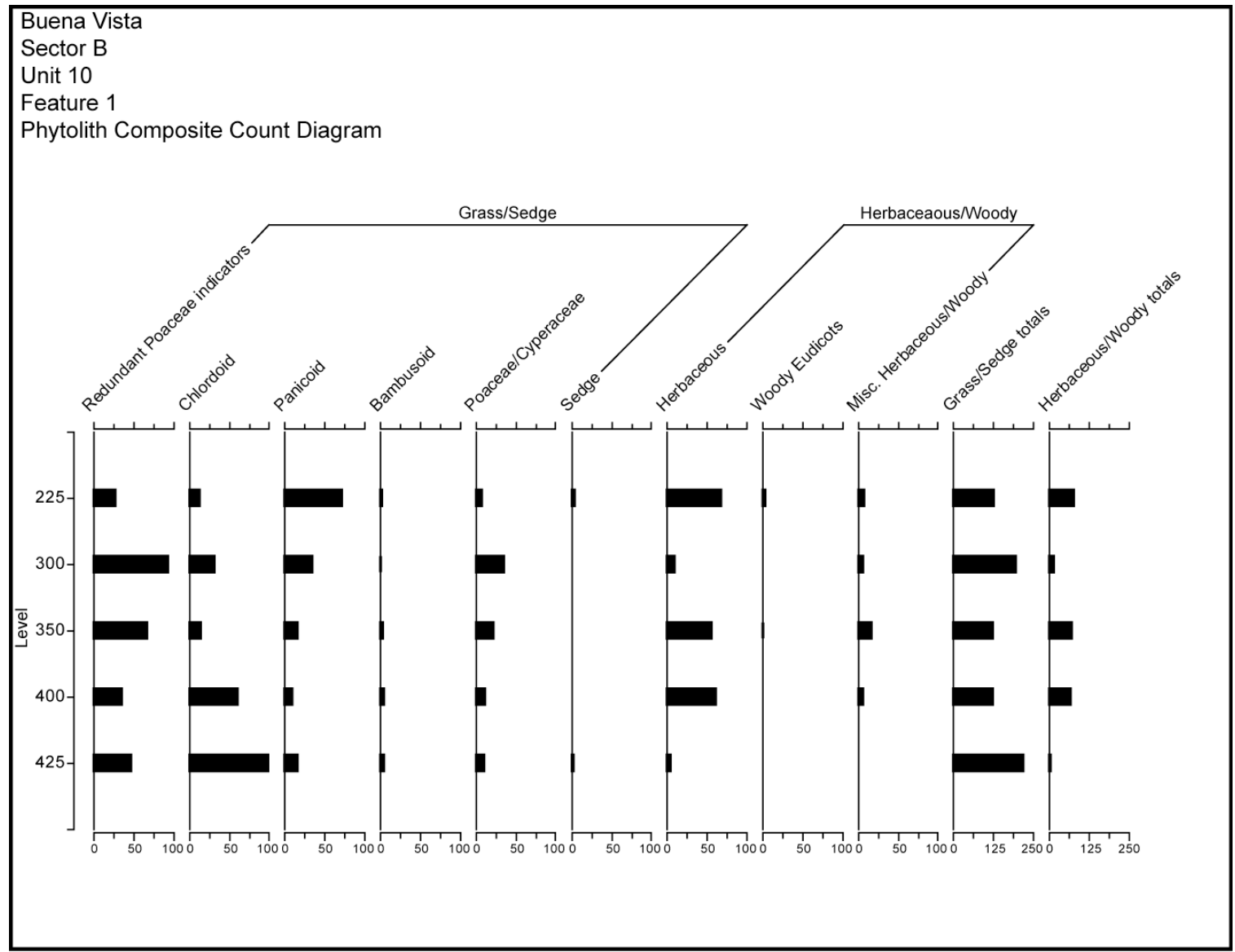

Figure 7.8 Pytolith composite count diagram for Unit B-10, Feature 1

Because the extra-local taxa, such as Heliconia, Calathea, and palms were identified in the phytoliths and not the macroremains in the sunken pit presents an interesting taphonomical question as to how those phytoliths ended up in the sediments of the pit. One hypothesis predicts that if these plants were used in the preparation of food, the phytoliths were released through ashing of the plant tissue during cooking. Unfortunately, we know very little about culinary techniques of the distant past, but modern analogs may apply here. Leaves of plants in the Zingiberales, including Marantaceae and Heliconiaceae, are commonly used throughout the Neotropics as wrappings for steaming, or as in modern 
Perú, in making humitas prepared in a pachamanca, an earth oven. It is possible that these taxa were cultivated on the coast during this time, but an alternative, though not exclusive, hypothesis is that these taxa arrived as wrappings of materials brought from long distances and nevertheless discarded in to the firepits. Another alternative is that the tubers of these plants were used in a liquid drink, although phytoliths diagnostic of the tubers of these plants are absent and would be expected if used in such a way. The presence of phytoliths in liquid brews, however, has not been studied. These scenarios are discussed in more detail below.

Sector C, Unit 1

In Unit C-1 and its adjacent extension, C-2, excavation uncovered a raised plastered floor with a canal-like feature running parallel to it (See Chapter 5, Figure 5.18). Sediment samples for phytolith analysis were taken from Level 100, a layer of looter's mixed backfill and from Level 200, a thin layer of fine silty soil that topped the plastered trench (Figure 7.9). From Level 100, grass phytoliths are dominant, but phytoliths from Phaseolus, Marantaceae/Bombacoideae, and Costaceae/Bombacoideae, represent cultivated and or plants used in food preparation. Due to the highly disturbed nature of the fill, little can be said of their provenience. In the silty layer that topped the plastered trench, Level 200, no economic plants are indicated in the scant phytolith assemblage, only abundant grasses and several eudicot indicators. Unfortunately, phytolith analysis does not help us determine a function for this unique architectural feature. I suspect, however, because the phytolith count is so low in this context, unlike most of the other architectural contexts sampled, this plastered trough was swept clean prior to its burial under architectural fill. 


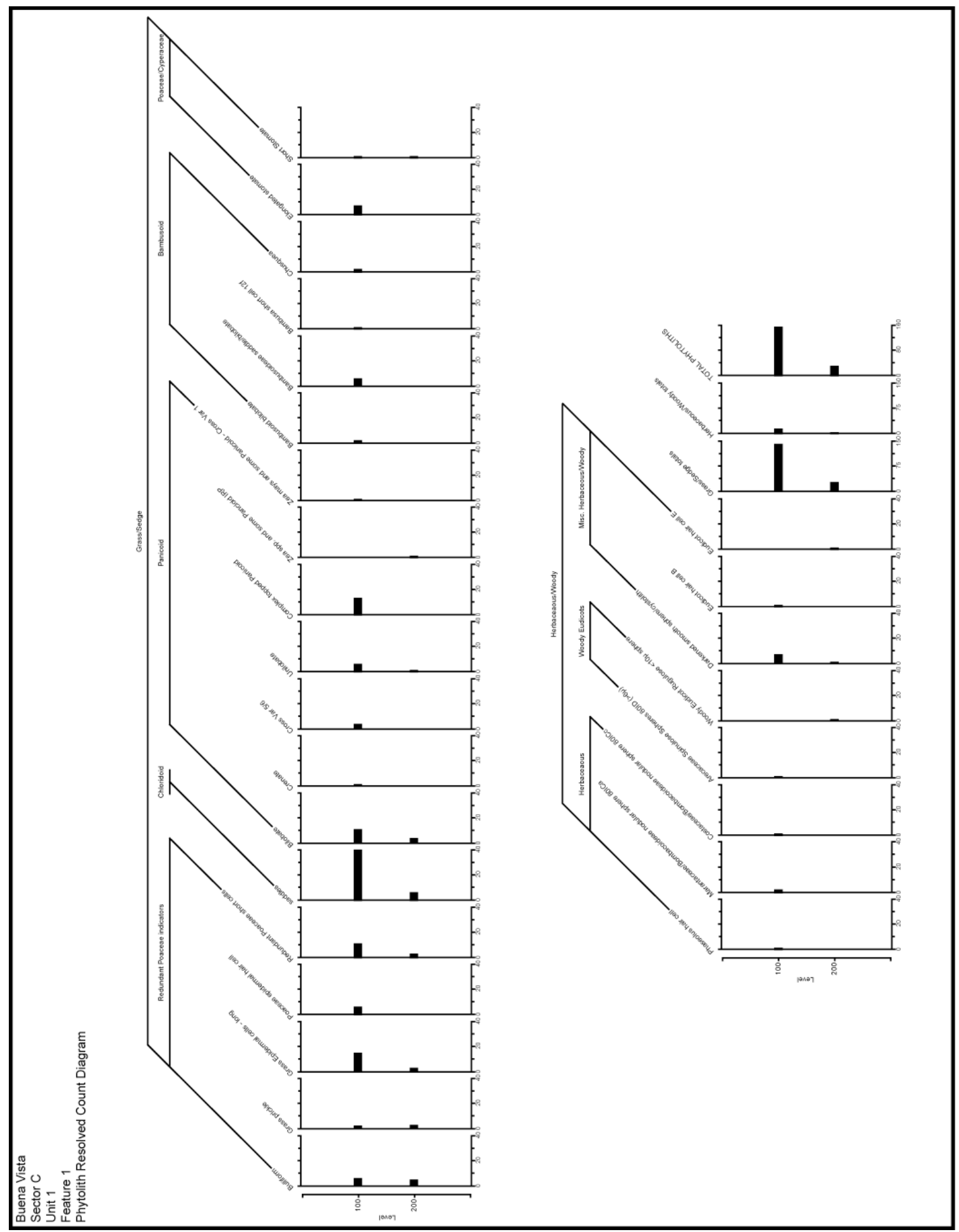

Figure 7.9 Phytolith resolved count diagram for Unit C-1, Feature 1 
Sector C, Unit 6

As described in previous chapters, Unit 6 in Sector C is comprised of two excavation units, Unit 6 and Unit 6E, excavated in separate field seasons. In the table, Table 7.3, the level numbers have been edited to denote continuous stratigraphic levels across both of the units. Soil samples were taken for microfossil analysis from the surface of the unit prior to excavation, the badly looter-disturbed Level 100, the hearth contents labeled Level 250 in the center of the unit, and the surrounding ashy matrix, Level 200 atop the plastered floor, and from the sediments beneath the floor, Level 300 (Figure 7.10). Phytoliths counts for two levels are relatively low, a total of 111 in Level 200 and just 53 in Level 300, but for all samples, grass phytoliths dominate the assemblage. The composition of the assemblage is somewhat similar among levels. Maize phytolith types, two extra large Variant 1 maize crosses and abundant narrow elongate rondels, indicate maize in the disturbed surface sample but maize does not appear in the undisturbed contexts below.

There does not appear to be a correlation of the plant macroremains to phytolith identifications in Unit C-6. Also, macroremain density does not appear to have an effect on phytolith preservation. For example, in Level 100, which consisted of disturbed fill and looter's backdirt, the phytolith assemblage compares favorably in composition to other levels in Unit C-6, however the macroremain component was found to be the least dense in terms of preservation. However, in the hearth context, F-1 as Level 250, the phytolith assemblage is roughly similar in composition to that of the surrounding ashy matrix of Level 200, but the deposition of phytoliths differs dramatically from inside and outside the hearth; phytolith counts being high in the hearth contexts and low in the surrounding 


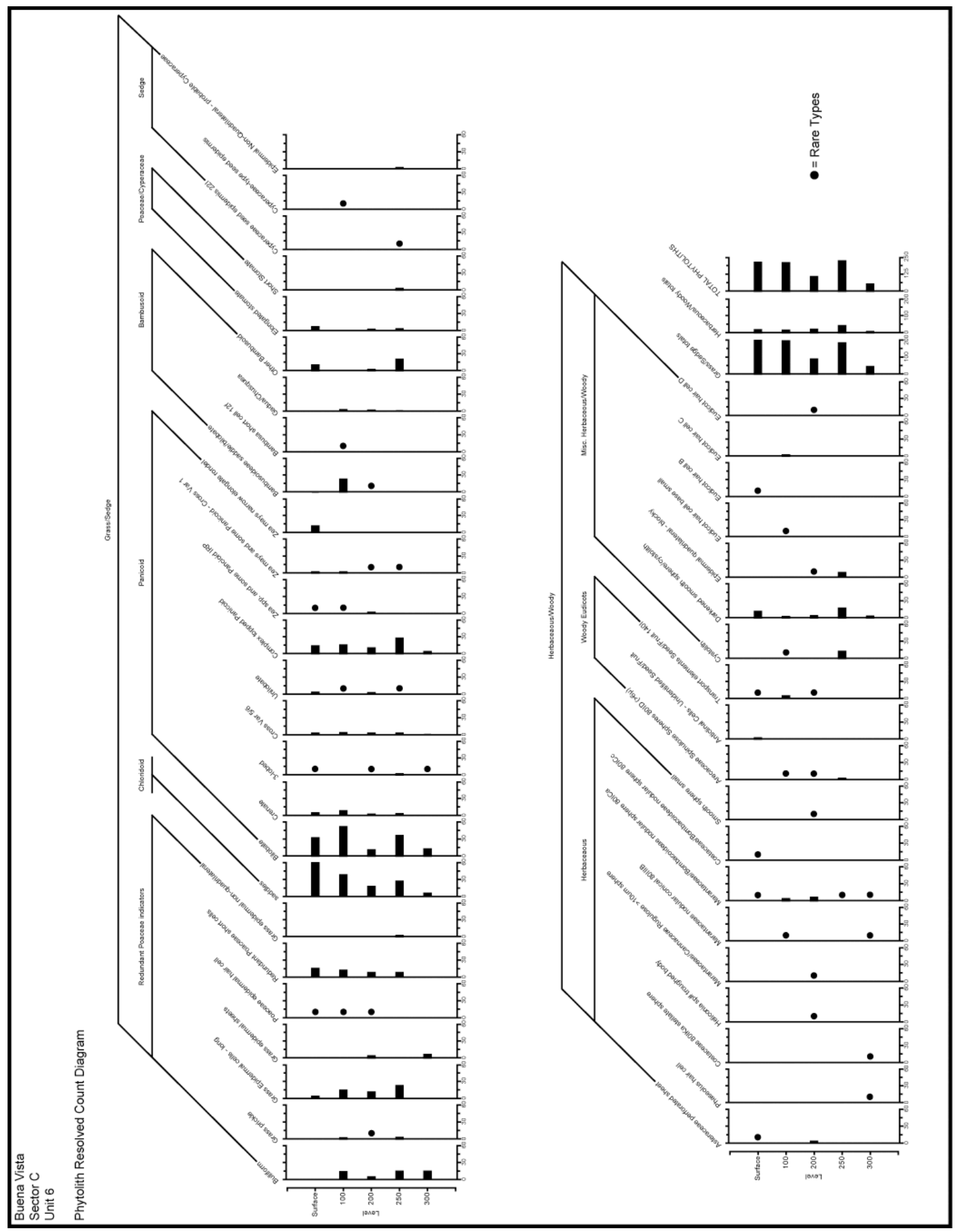

Figure 7.10 Phytolith resolved count diagram for Unit C-6 
matrix. Inside the hearth, the greater deposition of phytoliths may be the direct result of burning materials in a concentrated area. The ashy matrix that surrounds the hearth contained similar kinds of macroremains found inside the hearth context, but the lower counts for phytoliths may be due in part to the dispersal of the ash over a wider area atop the plaster floor.

The phytolith types, differing in quantity between the hearth and surrounding matrix, also differ somewhat in richness of herbaceous and woody taxa. The hearth contexts are less rich, containing a nodular sphere of Marantaceae/Bombacoideae, palm spinulose spheres, and relatively high numbers of cystoliths. These phytoliths likely represent charred food remains, of arrowroot and palm fruits, and for cystoliths, woody taxa used as fuel. In the Level 200 outside the hearth, herbaceous types are richer and include Asteraceae, a Heliconia troughed body, large rugulose spheres from Marantaceae/Cannaceae, and several nodular spheres of Marantaceae/Bombacoideae. Beneath the floor, in a layer of coarse gravel, Level 300, phytolith recovery was much lower, but this may be explained by the nature of the matrix. Coarse gravel or sandy contexts are not conducive deposition of phytoliths, which are silt-sized particles. However, despite the low numbers of phytoliths, several identifications are significant; a hair cell produced in Phaseolus representing cultivated bean, Calathea allouia stellate spheres, nodular surfaced conical bodies diagnostic to Marantaceae and Marantaceae/Bombacoideae nodular spheres most likely from Maranta arundinacea.

The results of the phytolith analysis from Unit C-6 present an interesting comparison to the macroremain study. In the macroremains, there was a high density of 
similar botanical materials both within and outside the contexts of the hearth, and I hypothesized that the hearth had been emptied several times and its contents discarded onto the floor surrounding it. However, the phytoliths show a higher density of microfossils within the hearth contents than without. But outside the hearth, in Level 200, the richness of phytolith types is higher overall, particularly for herbaceous and woody taxa. I suggest that phytolith concentration is greater within the hearth because not all ash was carefully removed from it during cleaning, and less dense in the surrounding matrix because the ash would have been dispersed over a much larger area. The greater richness of herbaceous taxa in the matrix surrounding the hearth atop the plastered floor may be due to culinary practices. If food wrappings made from Heliconia and Marantaceae/Cannaceae were removed from the cooking fire before complete charring occurred, phytoliths from these taxa would have been deposited outside the hearth.

Sector C, Unit 10

Upon excavation, this unit exposed an architectural wall that split the unit into two halves, each excavated separately. As described in Chapters 5 and 6, the area within and surrounding this excavation unit was badly disturbed by looter activity. Also, the excavated levels were not sampled adequately for macroremains, but complete finescreen sets were taken from two levels, Level 200W and 300E, each from either side of the architectural wall. Corresponding phytoliths samples were taken from each of these levels as well (Figure 7.11). Level 200W was a badly disturbed level containing mixed, loose fill, abundant charcoal, and frequent mollusk shells. Though disturbed, this may have been the original fill that topped the architectural wall that bisected the unit. Food plants were present in 
the macroremains, but these and other plants were not abundant. Likewise, phytolith recovery was low here, just 45 individual phytoliths. Grass phytoliths $(n=35)$ are most abundant, but several herbaceous/woody phytolith types are present: a small rugulose sphere and darkened smooth sphere/cystoliths.

Level 300E consisted of a $12 \mathrm{~cm}$ layer of compact soil atop a hard packed gravel floor on the eastern side of the architectural wall. Again, food remains were present in the macroremains and also wood and charcoal. Phytolith recovery from atop the gravel floor is good, 226 phytoliths, and contains a much more mixed assemblage than from Level 200W. Herbaceous plants are represented by Asteraceae perforated sheets and several Marantaceae/Bombacoideae nodular spheres. Woody plant indicators are represented by a faceted phytolith from Annonaceae and silicified anticlinal cells and transport elements from seed or fruit. Hair cells from as yet unidentified eudicot plants are also present.

Unfortunately, the phytolith assemblage does not add significantly to our understanding of the function of either of these rooms in C-10. It is possible these rooms were part of a domestic complex in Sector C, given the presence of a few food items. On the other hand, the excavation of a polished stone of no apparent utilitarian function at the base of Level 300E and the presence of food remains, guava and lucuma, and possible fruits from Annonaceae, loosely suggest that rituals involving food took place here. 


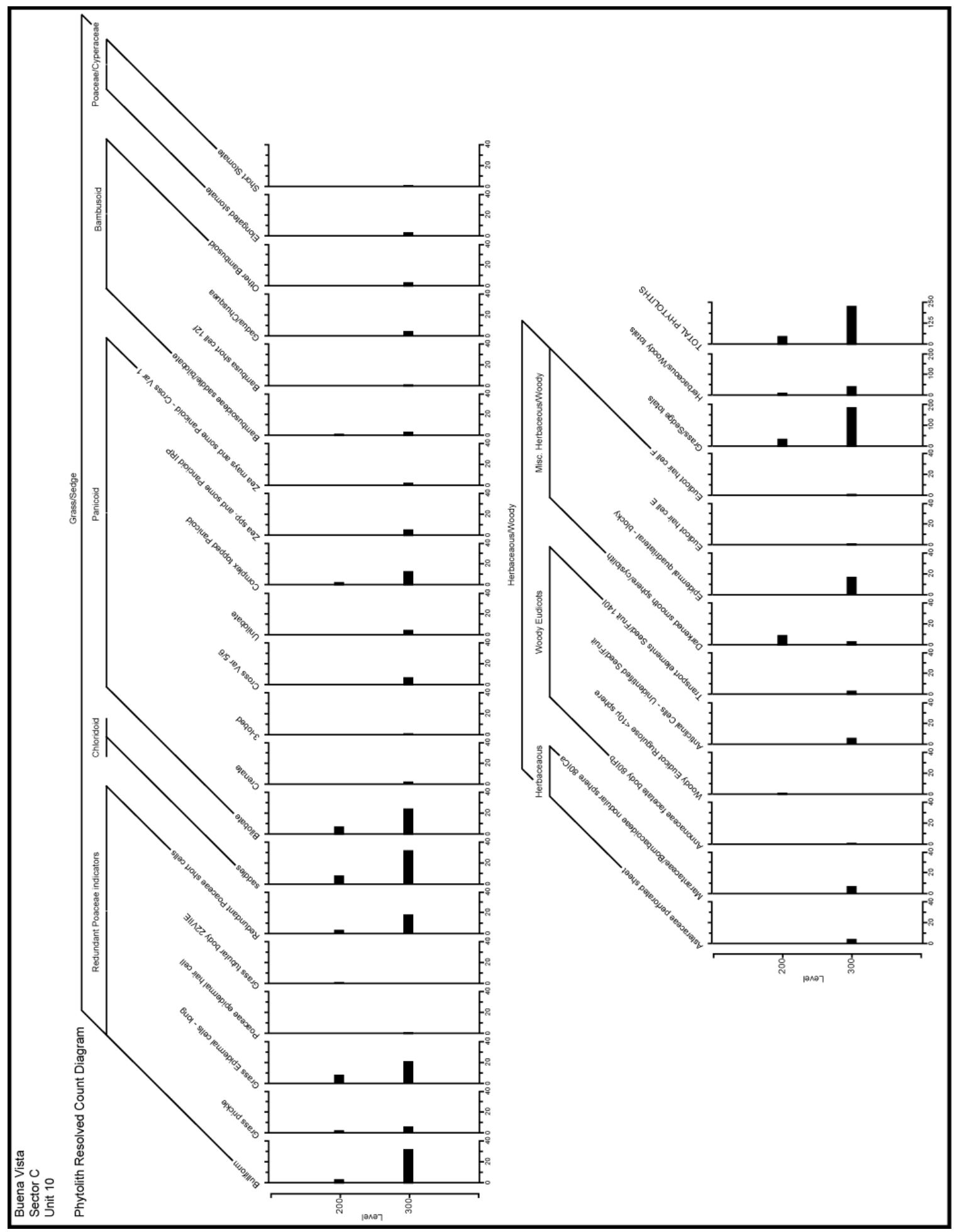

Figure 7.11 Phytolith resolved count diagram for Unit C-10 


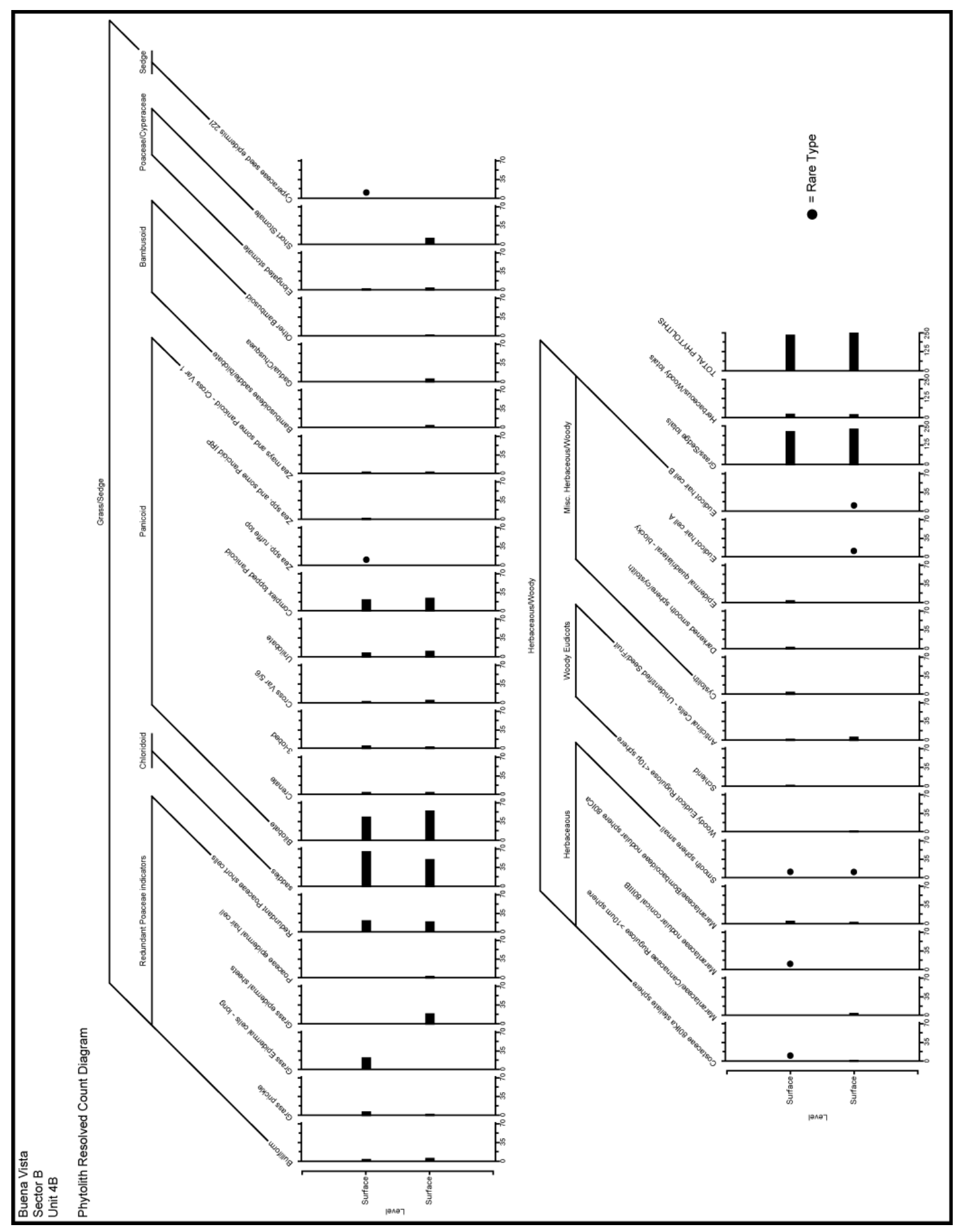

Figure 7.12 Phytolith resolved diagram for surface samples at Unit B-4b 
Sector B, Units 4B, 5A, Surface Samples

Two sediment samples were taken from the surfaces of excavation units for the purpose of comparison, one at Unit 4B to the southeast of the Gran Sala, and another from Unit 5A near the extreme southern end of the preceramic architecture. Phytoliths recovered from these surfaces are not necessarily representative of the natural environment, given that they were taken from surfaces of an archaeological site where there has been a large amount of pedoturbation due to looting activities and other disturbances. As an indication of disturbance, I suggest that the presence of several extra-local taxa identified in the archaeological contexts, such as Calathea allouia spheres, large rugulose Marantaceae/Cannaceae, Marantaceae/Bombacoideae nodular spheres, and the nodular sphere diagnostic of Marantaceae, does not represent the local flora growing on the surface of the site, rather, these are present due to sub-surface archaeological deposits being mixed with surface materials. Grass phytoliths, ubiquitous and abundant, probably represent at least some actual surface material, in particular the indicators of maize, such as the extra large Variant 1 crosses and ruffle-top rondel diagnostic to maize. Surface samples from offsite contexts on the hillside above the archaeological site are not available for study at this time.

\section{SumMaRY AND Discussion OF STARCH AND PHYTOLITHS FROM SEDIMENTS}

The starch and phytolith components in this paleoethnobotanical investigation of Buena Vista site sediments, provide an increased and more nuanced understanding of plant taxa used by people at Buena Vista. This is particularly so in regard to the phytolith assemblage, which provides additional identifications of taxa not found in the 
macroremains. Unfortunately, starch was not recovered from the sediments as successfully, and only tentative identifications could be made for those grains that were recovered. Phytoliths recovered from the archaeological contexts do not, however, directly reflect the identifications of taxa in the macroremain component, with the exception of abundant and ubiquitous grasses and presence of Maranta/Canna rhizome fragments. Grasses are particularly well represented in the both macro and micro components and their phytoliths are likely to be major components of the assemblage given the sheer abundance of grass in the archaeological contexts. For instance, grass used as temper in wall and floor plaster undoubtedly contributed to the assemblage as it dries and breaks apart, falls to the floor, and is trod upon. The presence of Canna/Maranta rhizome fragments in the macroremains only partly explains the abundance of phytoliths produced by Marantaceae and Cannaceae, it is likely the leaves of these plants were used as well. An alternate pathway of deposition for other plants not occurring in the macroremains must be considered to explain the presence of those phytoliths.

One explanation for this macro/micro discrepancy is that the extremely high degree of preservation of desiccated botanical remains diminishes the potential for these remains to decay in place, thus silica bodies in the plant tissues were not deposited into the surrounding sediments as they decayed. Alternatively, human activities brought about the release of silica from these plants through burning as fuels or through cooking, and this is a more likely explanation of plant silica in the archaeological contexts, particularly the buried sunken pit. Evidence in support of this explanation comes from the identification of these taxa themselves and how people at Buena Vista may have used them. The herbaceous 
monocot taxa identified from Heliconia, Marantaceae, and Cannaceae, all produce edible rhizomes, such as Calathea allouia (leren), Maranta arundinacea (arrowroot), and Canna indica (achira), in some cases edible flowers. Also, each have species with broad flexible leaves used in preparing food, particularly for wrapping foods for cooking, but also for transport. Each of these plants may have served a dual purpose as food and utility; in fact, several Peruvian species of Heliconia have edible rhizomes and their broad leaves are used to wrap foods for steaming (Soukoup 1970:149; Brack Egg 1999:238-241). It is reasonable to presume that culinary techniques of wrapping foods for cooking were developed very early in human prehistory. These plant taxa produce phytoliths in abundance, and if the leaves or tubers were burnt in cooking or as waste, they would very likely release silica into the ash. ${ }^{8}$

In Units C-6 and C-10, where deposits undisturbed (by looting) were sampled, the presence of the herbaceous taxa above can be explained as entering the sediments as part of the ash matrix from nearby hearths; one hearth was excavated in C-6, but only abundant ash, likely to be from a nearby hearth, was noted in C-10. For the sunken pit in B-10, these phytoliths were deposited in the pit with the ash and charcoal from other areas that were cleaned prior to the temple's burial. This would also explain the higher concentration of these plants in the sunken pit context than in others if multiple locations were cleaned and the refuse collected was deposited in the pit, as inferred from the macroremain analysis.

Considering the natural distribution of Heliconia, Marantaceae, Cannaceae, and Arecaceae, is it reasonable to assume that some or all were cultivated on the coast of Perú

${ }^{8}$ I should note that grasses, too, if used as tinder would also deposit phytoliths in the ash. 262 
during the Preceramic? Microfossil evidence of Maranta arundinaceae at Waynuna (Perry et al. 2006) and macroremains of Canna indica at several preceramic sites in Central Perú, including the nearby Aspero (Feldman 1980), provide corroborating evidence for these two lowland tropical plants being cultivated well outside their natural range. It is certainly possible that Heliconia and species of Calathea allouia were cultivated near Buena Vista as well. If not cultivated, these extra-local plants may have arrived as wrappings of materials brought to the site from long distances. The evidence for palms is much less known and limited to a single palm seed reported at La Galgada (Smith 1988). Palms are not native to the coast of Perú, despite being cultivated there today. Well outside their natural distribution (Weberbauer 1945:146-7; Milan 2006; Llatas and Lopez 2005), palm phytoliths present in the Buena Vista assemblage suggest that palm materials were utilized; perhaps the fibrous leaves were used in baskets to carry foodstuffs. Because of the great distance one would need to travel from Buena Vista to harvest palm leaves, it is less likely the leaves were used in thatch roofing here. If not cultivated, these plants represent great effort in regard to their acquisition and provide evidence to exotic or luxury items brought in from great distances for ritual or elite consumption or use in a feasting context. In the following chapter, I present the results of microfossils identified from the residues of gourd and squash artifacts recovered from the sunken pit. Together, the macroremains, microfossils, and artifact residues will provide a multi-component analysis of the use of food in a ritual context at Buena Vista. 


\section{Chapter Eight - Starch and Phytoliths from Cucurbit Artifacts Recovered from Sector B, Unit 10, Feature 1}

In this chapter, I present the results of an experimental technique aimed at isolating and identifying starch grains and phytoliths from gourd and squash artifact residues?. Fragments of gourd and squash rinds were selected from contexts within the buried sunken pit, Unit B-10, with the hopes of identifying evidence of foods or other residues that would provide an indication of how the rinds were used. Because gourd and squash rinds can and were used as food containers in the past, an enhanced understanding of the use of bottle gourds in aceramic cultures provides us with a potential pathway to understanding behavioral, symbolic, and ritual contexts in which these artifacts are found. However, the myriad uses for bottle gourd (Lagenaria siceraria) shells in the archaeological record complicates precise use determination of gourd artifacts without direct contextual information, such as gourd fishing floats attached to nets (Whitaker and Bird 1949) or encountering whole or partial gourd artifacts from which one can infer their use through ethnographic analogy by their shape or modification (Speck 1941). The results of this experiment show that a function of gourd and squash artifacts as food containers can be identified through microfossil analysis of residues. This research has important implications in the study of prehistoric non-ceramic using cultures. In the sections to

\footnotetext{
${ }^{9}$ The research presented in this chapter was previously published in Duncan, Pearsall, and Benfer (2009) but a more detailed description is given in this chapter. 
follow, I will describe the cultural significance of squash and gourds in prehistory and their origins and domestication, as well as techniques used in the identification of macro and micro remains, the methodology used in microfossil extraction and the results of the experiment.

\section{Gourd AND SQUash Uses AND Origins In ANDEAN Prehistory}

One cannot underestimate the cultural significance of squash and bottle gourds in human prehistory. From seed to fruit, squash and gourds have been important sources of food and raw materials. Early foragers were likely attracted first to the edible, protein rich seeds, given the bitter cucurbitacins in the flesh of wild cucurbit fruits (Cutler and Whitaker 1961; Nee 1990). The wild fruits of both Cucurbita and Lagenaria are edible, particularly young fruits if boiled and rinsed to remove bitterness (Nee 1990). However, there are few accounts in the Americas in which bottle gourd flesh is prepared as food (Cutler and Whitaker 1961). In modern contexts, the gourd fruit is a more common ingredient in cuisines in Asia, with one variety, trompette, eaten in Europe (Sturtevant 1919). For Cucurbita, foragers may have intentionally selected for nonbitter mutations leading to a rapid domestication (Heiser 1990). However, the cultivation and diffusion of one species, Cucurbita pepo, may have been driven initially by their use as fishing floats and tools and only later for cultivation of non-bitter fruits for food (Fritz 1999). The fruits of Cucurbita pepo also can be made into useful containers or rattles once dried (Speck 1941; Cutler and Whitaker 1961) and these artifacts are found in sites in North America.

The overwhelming importance of Lagenaria siceraria is its utility; the thick exocarp of the fruit allows it to be transformed into an array of durable utensils, rattles, musical 
instruments, and any variety of storage and serving containers for foods or other sundry items (Speck 1941; Heiser 1979). On the coast of Perú, bottle gourds are common in Preceramic contexts as utensils and are closely associated with maritime subsistence for use as floats in fishing (Whitaker and Bird 1949). Because of the extensive utility of bottle gourds, one cannot assume that fragments of gourds in an archaeological context represent a singular function. Likewise, for Cucurbita squashes, fruits of most domesticated species are used as foods, but medicinal uses in northern Perú are known for leaves and stems in the treatment of inflammation (Bussman and Sharon 2007:236-7). In North America, the dried rinds of squashes, like gourds, also have been used as containers (Asche 1994:30) and probably net floats (Cutler 1975; Gilliland 1975; Fritz 1999; Hart et al. 2004). No ethnographic or archaeological reports for the use of squash species in Perú as containers or net floats are known to this researcher, but microfossil evidence, discussed below, suggests squash rinds were used as containers for serving or preparing food.

Bottle gourds and squashes are among the first cultivated plants in the Americas, appearing together in the archaeological record as early as 10,000 B.P. (Erickson et al. 2005) and are well represented in Preceramic, and later, Peruvian sites (for a review see Pearsall 2003a). Unlike Cucurbita squashes, no wild progenitors of Lagenaria bottle gourds are known in the Americas. Until recently, scholars attributed the dispersion of bottle gourd into the Americas via an oceanic route from Asia or Africa independent of people (Whitaker 1971; Heiser 1973,1985,1989,1990), possibly with people from Africa (Lathrap 1977), or as independent domestication of a pan-tropical species (Richardson 1971). Morphological and DNA evidence now indicates that bottle gourd in the Americas most 
likely was domesticated in Asia as early as 13,000 B.P. and brought to the Americas as a domesticated species (Decker-Walters et al. 2004; Erickson et al. 2005). Based on genetic comparisons between a population of wild Lagenaria siceraria in Zimbabwe and domesticated African, Asian, and American Lagenaria siceraria, Decker-Walters et al. (2004) hypothesized that Lagenaria siceraria could have been dispersed into the Americas already as a domesticate. This hypothesis is supported by comparing DNA sequences of modern Asian and African landraces, then comparing those sequences to the DNA sequences of archaeological gourd fragments from sites in the Americas (Erickson et al. 2005). Erickson et al. concluded that pre-contact archaeological gourd specimens are identical to modern Asian landraces and also that only post-contact bottle gourds were of African origin. The DNA evidence thus far rules out the possibility that bottle gourds were domesticated independently in the Americas from African gourds, however they may have arrived on the continents.

The genus Cucurbita includes at least five species domesticated prehistorically in the Americas (Nee 1990). Molecular systematics on the genus has been difficult due to close genetic relationships of some of the cucurbit species (H. Wilson et al. 1992; Decker 1988; Decker-Walters 1993). Mitochondrial DNA comparisons have helped separate some of the closely related cucurbit species and led to confirmation of species ancestral to some of the domesticated Cucurbita (Sanjur et al. 2002) (Table 8.1).

Four squashes are suspected to have originated in South America and are found regularly in prehispanic archaeological contexts: C. ficifolia, C. moschata, C. maxima, and C. ecuadorensis. Of the four, C. ecuadorensis has the most limited distribution, archaeologically 
and botanically, occurring only in western Ecuador. Phytolith evidence for its semi-

domesticated form appears as early as 11000 years ago at the Vegas period site OGSE-80 in southwestern Ecuador (Piperno, Andres, and Stothert 2000; Piperno and Stothert 2003).

Through time, C. ecuadorensis may have fallen out of favor as a cultivated crop and reverted to a semi-domesticated species (Nee 1990). The other three species are reported from many Late Archaic sites on the coast of Perú and at Vegas in western Ecuador; all three squashes are cultivated today.

Table 8.1 Domesticated Cucurbita spp. in the Americas discussed in the text.

\begin{tabular}{llll}
\hline Domesticated & Wild Progenitor & Likely Origin & Reference \\
\hline $\begin{array}{lll}\text { C. maxima } \\
\text { C. moschata }\end{array}$ & C. andreana & Bolivia/Argentina & Nee 1990 \\
& Colombia (?) & Nee 1990; Sanjur et al. \\
C. ecuadorensis (semi- & C. ecuardorensis & Ecuador & Nee 1990; Piperno \& \\
$\begin{array}{l}\text { domesticated) } \\
\text { C. ficifolia }\end{array}$ & Unknown & South America & Stothert 2003 \\
$\begin{array}{l}\text { C. } \text { argyrosperma } \\
\text { C. pepo subsp. pepo }\end{array}$ & C. sororia & Mexico 2002 \\
& C. pepo subsp pepo/ C. pepo & Mexico & Sanjur et al. 2002 \\
C. pepo subsp. ovifera & subsp. fraterna (?) & & Sanjur et al. 2002 \\
& C. pepo subsp. ovifera/ C. pepo & North America & Decker-Walters 1993; \\
\hline
\end{tabular}

The earliest reported evidence of squash macrobotanical remains comes from late Paijan and Las Pircas sites in the Zaña Valley of northern Perú at 10,000 to 9,000 B.P.; the seeds are identified as C. moschata (Dillehay et al. 2007). This supports the postulate that C. moschata is also represented by phytoliths at site OGSE-80 in Ecuador slightly earlier (Piperno, Andres, and Stothert 2000; Piperno and Stothert 2003). Seeds of this species are also present at Paloma by 7800 B.P. (Dering and Weir 1979) and in Late Preceramic contexts at Huaca Prieta as early as 4600 B.P. (Whitaker and Bird 1949), sites in the 
Ancón-Chillón region (Cohen 1978) and at Buena Vista in contexts dating to around 4000 B.P. By the Late Preceramic, C. moschata is a well-established cultivar whose range extends from South America to Mexico, and by 900 A.D.has spread into North America (Cutler and Whitaker 1961). The ancestor species of C. moschata is still unknown, but a high diversity of forms in Colombia, including those with small seeds and a bitter fruit, point to a lowland South American origin (Nee 1990; Sanjur et al. 2002; Piperno, Andres, and Stothert 2000). In Perú, a variety C. moschata, loche or zapallo loche, is grown today that exhibits traits of advanced domestication, including a reduced seed cavity and number of seeds, no lignification of the rind, and very sweet flesh (Andres, Ugas and Bustamente 2006).

Cucurbita maxima likewise was domesticated early in South America. Seeds of C. maxima are reported at Late Preceramic ( 4000 B.P.) sites in the Casma Valley of northern Perú (Whitaker 1983; Ugent et al. 1984, 1986), at Huaca Prieta (Whitaker and Bird 1949), and slightly later at El Paraíso in the Chillón Valley (Quilter et al. 1991). The distribution of C. maxima was limited to South America, particularly Perú, Bolivia, Chile, and Argentina, until historic times (Cutler and Whitaker 1961). C. maxima is very closely related to the wild C. andreana (Sanjur et al. 2002), which supports the hypothesis that C. maxima was domesticated from C. andreana in temperate Argentina (Nee 1990) or Bolivia (Sanjur et al. 2002).

Along with C. maxima, C. ficifolia is reported at Preceramic sites such as Huaca Prieta (Whitaker and Bird 1949), sites in the Casma Valley of Perú (Whitaker 1983; Ugent et al. 1984), and at sites in the Ancón-Chillón region (Cohen 1978) and slightly later at El 
Paraiso (Quilter et al. 1991). It is likely that this species is misidentified in archaeological assemblages and therefore underestimated (T. Andres 2008, personal communication; Andres 1990). For example, seeds are usually a distinctive dark brown to black, but do occur a dingy white. Immature seeds of this species may also be pale yellow or buff colored, such as in comparative material grown by D. Pearsall in Missouri. Therefore, in archaeological samples, one should not rely on seed color alone. There does not seem to be a correlation of the color of the seeds to the color of the fruit (Cardenas 1969:161). The distribution of C. ficifolia extends into higher altitudes than other Cucurbita (Andres 1990; Nee 1992), despite most archaeological specimens being found on the coast. A wild progenitor to C. ficifolia may be found in Andean South America (Andres 1990:113; Nee 1992). Despite linguistic clues that the common names used in South America for C. ficifolia, lacayote, lacahuite, cayote, etc., are derived from the Nahuatl chilacayote in Mexico, no wild ancestor was found after an intensive search in Mexico (Andres 1990). In the Yungas of Bolivia, Martín Cardenas (1969:161) reported wild or spontaneously growing specimens hanging from the mountainous slopes. The sun-hardened fruit was opened and inside he found germinated seeds and well formed cotelydons, suggesting the plant could grow outside of cultivation. Genetic studies have not yet been successful matching C. ficifolia to any wild species; it is probably basal to other native species of Cucurbita (Sanjur et al. 2002). Presently, this species is still under cultivation in South America, but is more popularly grown and consumed in Southeast Asia.

As discussed in Chapter 6, the evidence for domesticated species of gourd and squash is well documented by the Late Preceramic in Perú. Along with Lagenaria siceraria, 
squashes identified in the macroremain assemblage at Buena Vista include those reported from other contemporary sites: C. moschata, C. maxima, and C. ficifolia. In the following section, I will describe how identification of gourds and squashes in the macroremains at Buena Vista were done before selecting for residue analysis.

\section{SQUASH AND GOURD MACROREMAINS FROM BUENA VISTA}

Correct identification of cucurbit materials in the macroremain assemblage at

Buena Vista is important for documenting the distribution of these cultivated plants and helps to explain the agricultural economy of the Chillón Valley during the Late Preceramic. Utilizing standard analytical techniques, seeds and rinds from gourds and squashes are distinguishable to taxon. The cucurbits recovered in the macroremain assemblage are limited to two excavation units: the sunken pit of Unit B-10 and the architectural structure in Unit C-6 (Table 8.2). The majority of cucurbit items occurred in the upper levels of the sunken pit, levels 250 and 300 . Other parts of the plants, such as peduncles or leaves and stems, were not identified in the macroremains.

Table 8.2 Cucurbit material recovered from macroremain samples at Buena Vista

\begin{tabular}{|c|c|c|c|c|c|c|c|c|}
\hline \multicolumn{2}{|l|}{ Unit } & \multicolumn{4}{|l|}{ B-10 } & & \multicolumn{2}{|l|}{ C-6 } \\
\hline Level & & $200 / 250$ & 300 & 350 & 400 & 425 & 250 & $300 E$ \\
\hline \multirow[t]{2}{*}{ Rind/Peel } & Cucurbita sp. & & & & 1 & & & \\
\hline & L. siceraria & 8 & 20 & 2 & 1 & 7 & & \\
\hline \multirow[t]{5}{*}{ Seed } & C. ficifolia & 65 & 65 & & & & & \\
\hline & C. Maxima & 16 & 15 & & & & & \\
\hline & C. moschata & 3 & 4 & & & & & 1 \\
\hline & Cucurbita sp. & 3 & 8 & & & 1 & 1 & 2 \\
\hline & L. siceraria & & 1 & & 2 & & 1 & \\
\hline
\end{tabular}



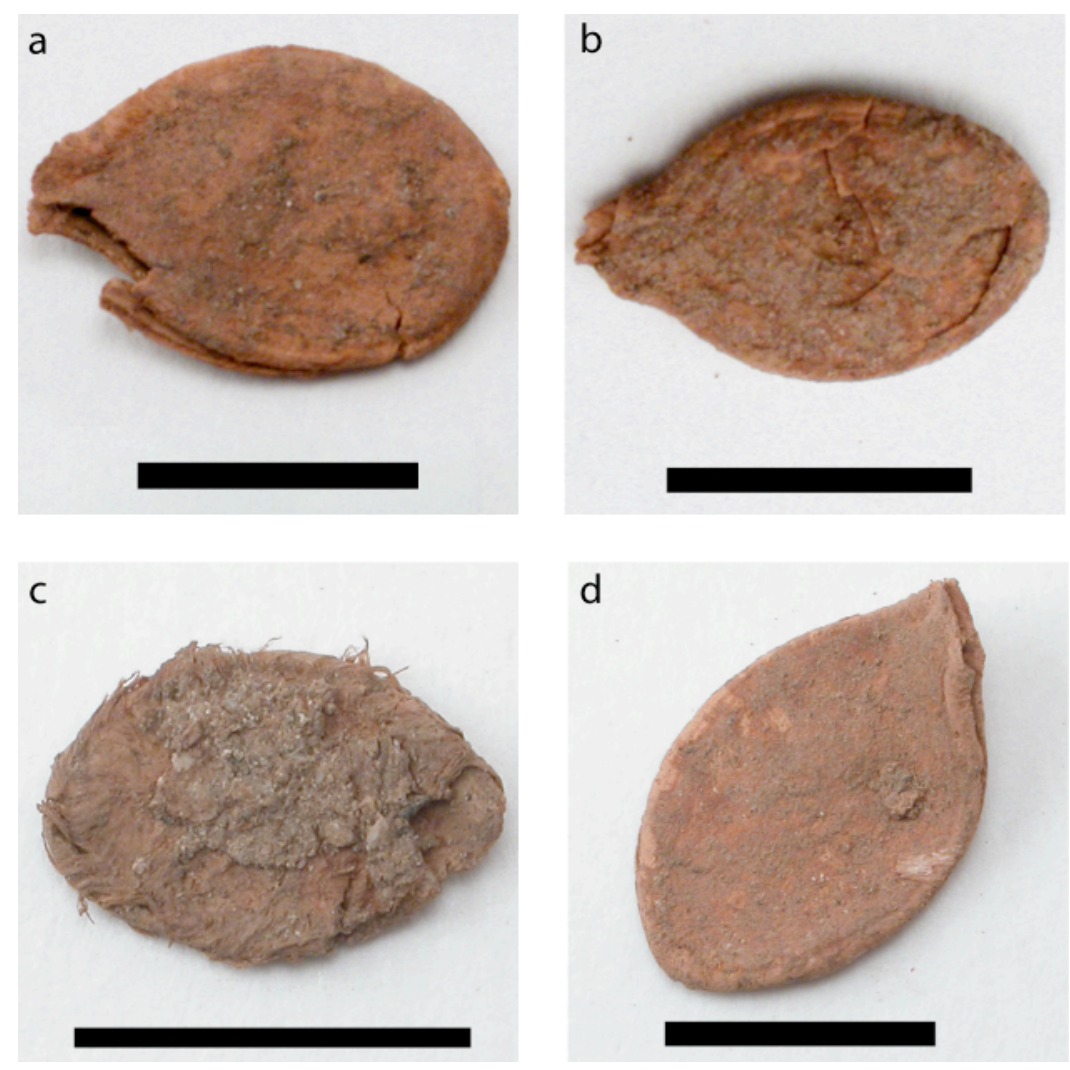

Figure 8.1 Archaeological squash seeds from Unit B-10, Feature 1, Level 300. (a-b) Cucurbita ficifolia, (c) C. moschata, and (d) C. maxima. Scale bar equals $2 \mathrm{~cm}$.

Seeds

The identification of seeds to taxon was made with the aid of comparative materials in the MU collection, locally grown C. ficifolia, modern cucurbit specimens collected in northern Perú, and published sources of comparative descriptions (Whitaker and Bird 1949; Cutler and Whitaker 1961; Whitaker and Cutler 1986; Whitaker 1971, 1983; Andres 1990). In addition, Thomas Andres of the Cucurbit Network provided valuable guidance in identifications of squash seeds. Cucurbita (squash) and Lagenaria (gourd) are 
easily distinguishable by simple seed morphology. However, distinguishing squash taxa requires careful observation and this is especially important with regard to archaeological material where seed color, often used as an identifier of C. ficifolia, may be masked or changed due to the soil chemistry or taphonomic properties. In general, seeds of C. ficifolia are usually dark in color, but this was not the case for any of the C. ficifolia seeds in the Buena Vista assemblage (Figure 8.1). These were identified on the basis of having relatively broad bodies with smooth, rounded margins.

Rinds

Lagenaria siceraria rind fragments can be distinguished easily from Cucurbita spp. by microscopic examination of their cross sections (Whitaker 1948; Cutler and Whitaker 1961). This method has proven much more successful in separating Lagenaria from Cucurbita (Ford 1986:15) than using simple measurements of thickness alone, however cross section morphollogy is not sufficient for separating species of Cucurbita. The arrangement of the cells of the mesocarp is the most obvious difference between the two genera. In Cucurbita, the cells of the mesocarp are large, thin-walled and isodiametric (round) arranged in a relatively regular pattern. The mesocarp cells of Lagenaria siceraria are somewhat large, elongated cells in an irregular arrangement (Figure 8.2). To identify the rinds, a clean portion of the cross-section was exposed using a razor blade. Specimens were examined using a Zeiss Standard reflected light microscope at 160x magnification. To avoid contamination, this procedure was carried out in a laboratory where no comparative starch is sampled nor processed and care was taken to clean all tools between samples using a small butane torch to clean tweezers, probes, and razor blades. 


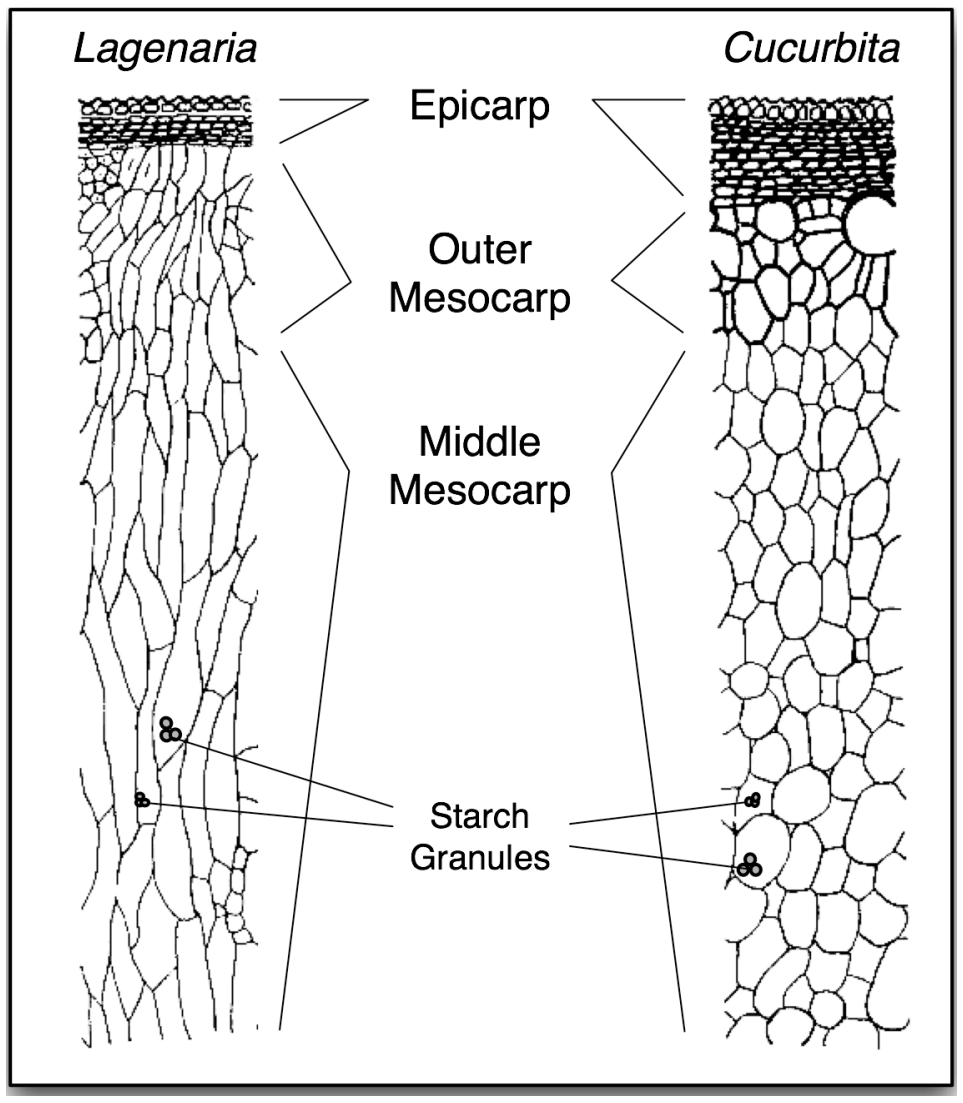

Figure 8.2 Cross sectional morphology of gourd and squash rinds. Adapted from Cutler and Whitaker (1961:479)

Ten rind fragments, one of which is Cucurbita, were selected for microfossil analysis. Most are small fragments averaging around three centimeters in diameter (Figure 8.3). Two of these fragments show evidence of modification; one with a linear design and another is perforated along one edge with four holes, in two of which cotton thread fragments remain. Sewing is a widespread method for repairing gourd artifacts (Heiser 1979; see also Hayashida 2008, Figure 5); the gourd from which this fragment comes may have been subject to such repair. 

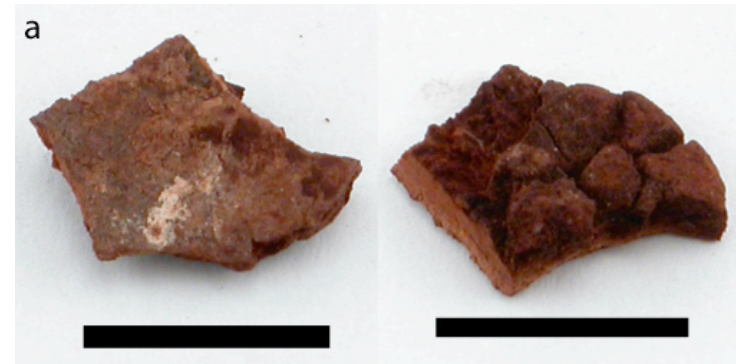

c
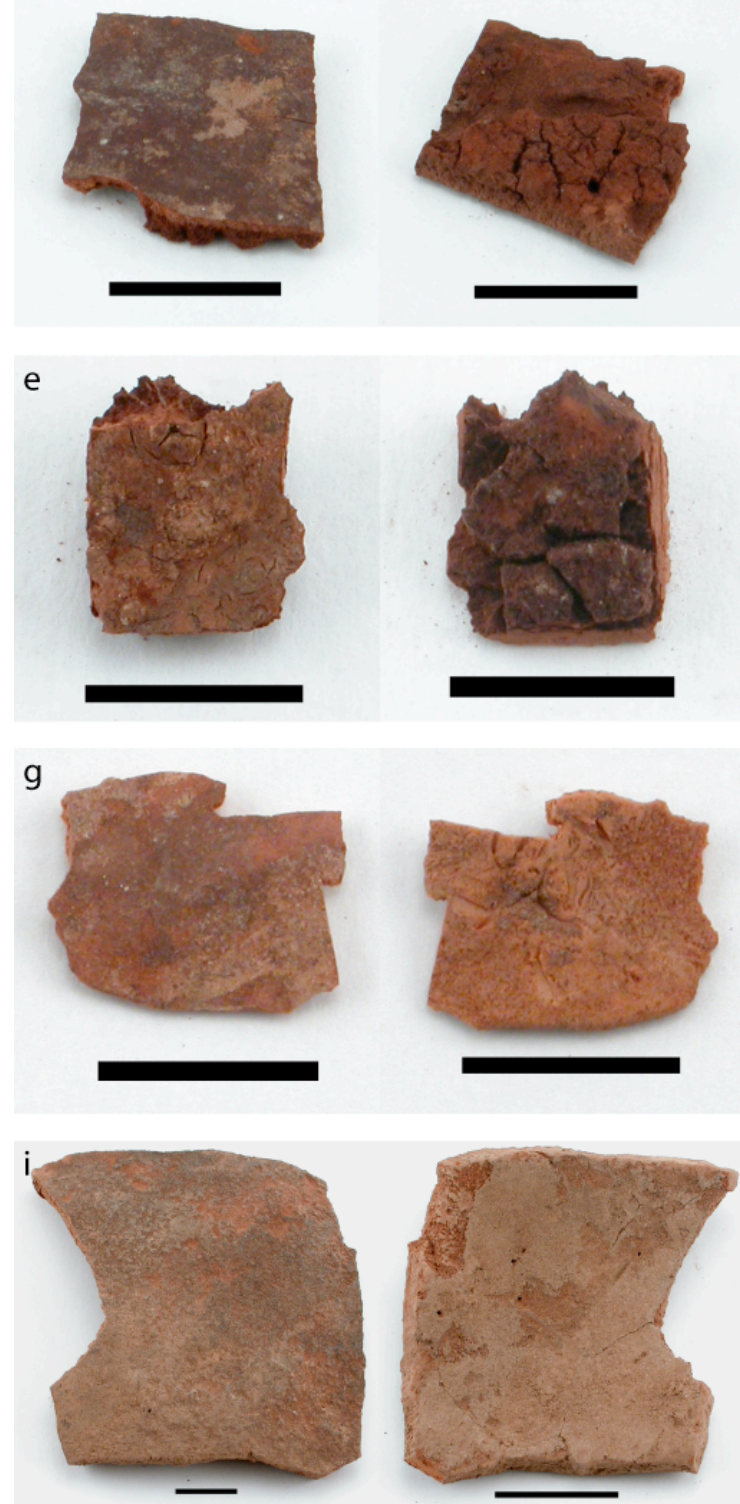

b

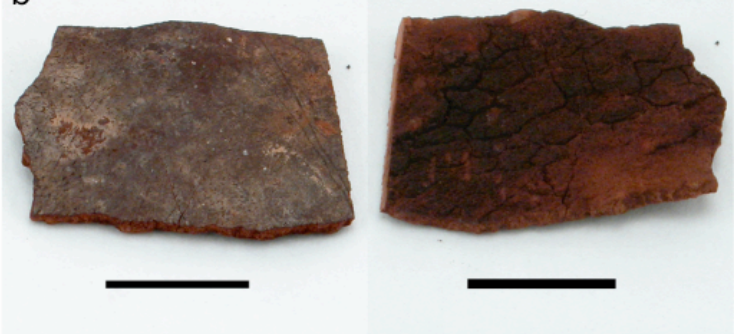

d

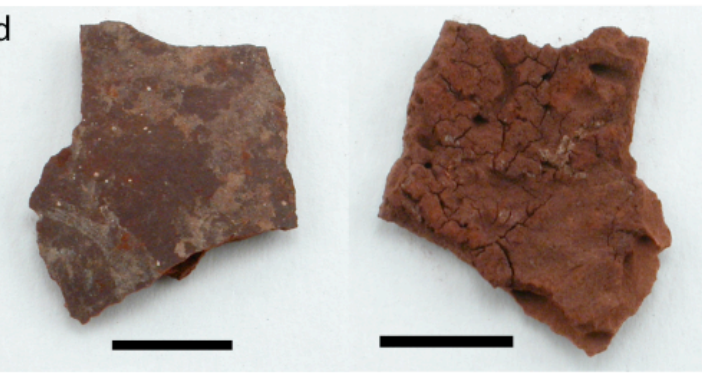

$f$
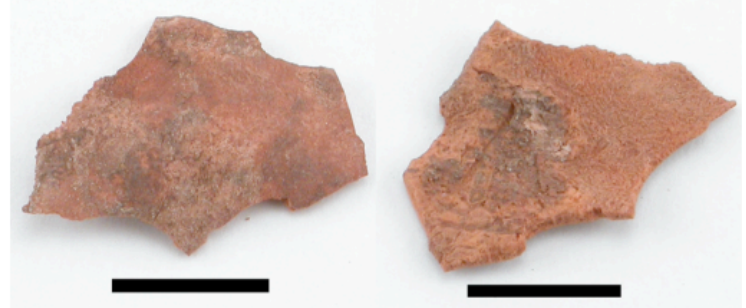

h
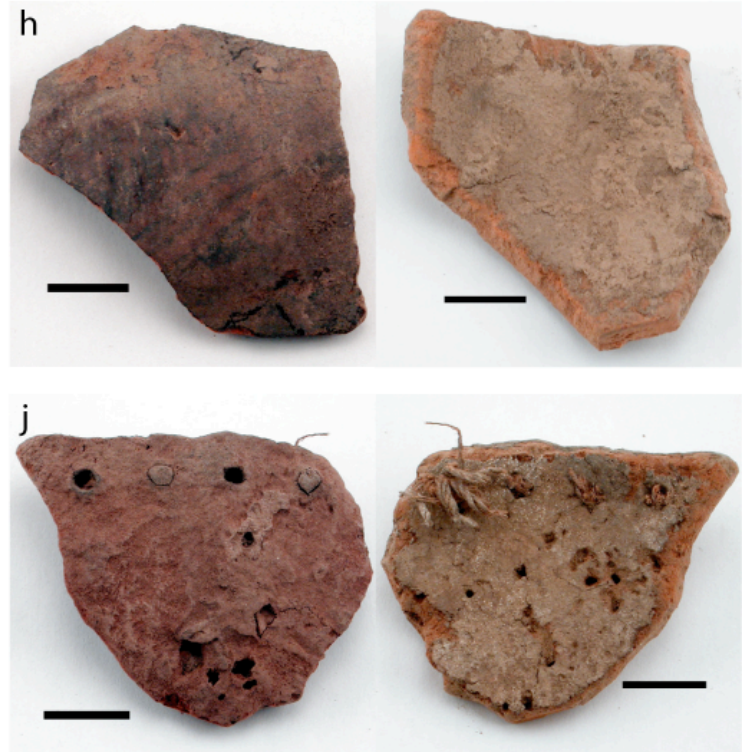

Figure 8.3 Cucurbit rind fragments sampled for microfossils. (b) a single squash rind from Cucurbita sp. 


\section{COMPARATIVE GOURD AND SQUASH Phytoliths AND STARCH}

Comparative material for phytolith production in Cucurbitaceae in the MU collection was consulted in addition to published diagnostics (Piperno, Andres, and Stothert 2000; Piperno and Stothert 2003). In order to differentiate starch grains of gourds (Lagenaria siceraria) and squashes (Cucurbita spp.) from those of other producers, I studied comparative samples of modern dried gourds and market-purchased C. maxima from Chiclayo, Perú, C. pepo (acorn squash) purchased in Columbia, MO, and C. ficifolia (chilacayote) grown by Deborah Pearsall in Missouri. There is considerable overlap in starch morphotypes in Cucurbitaceae. However, some of the South American squash starches are distinguishable on the basis of diagnostic morphology of certain grain types (Piperno and Dillehay 2008).

In sampling dried comparative specimens of Lagenaria siceraria, I found abundant starch granules in the dried mesocarp tissue, but relatively fewer starch granules in the exocarp. In the archaeological samples, only the exocarp portion, consisting of the epicarp and outer mesocarp, of the bottle gourd rind survives. This may explain the relatively few numbers of Lagenaria starch granules in the archaeological residues discussed below.

Generally, this pattern holds for Cucurbita as well; starch grains are found in the fruits within the thick-walled cells of the middle mesocarp (Barber 1909:280). The outer layers of cells, the exocarp, which includes the epicarp and outer mesocarp, contain low numbers of grains relative to the middle mesocarp of the fruit. 

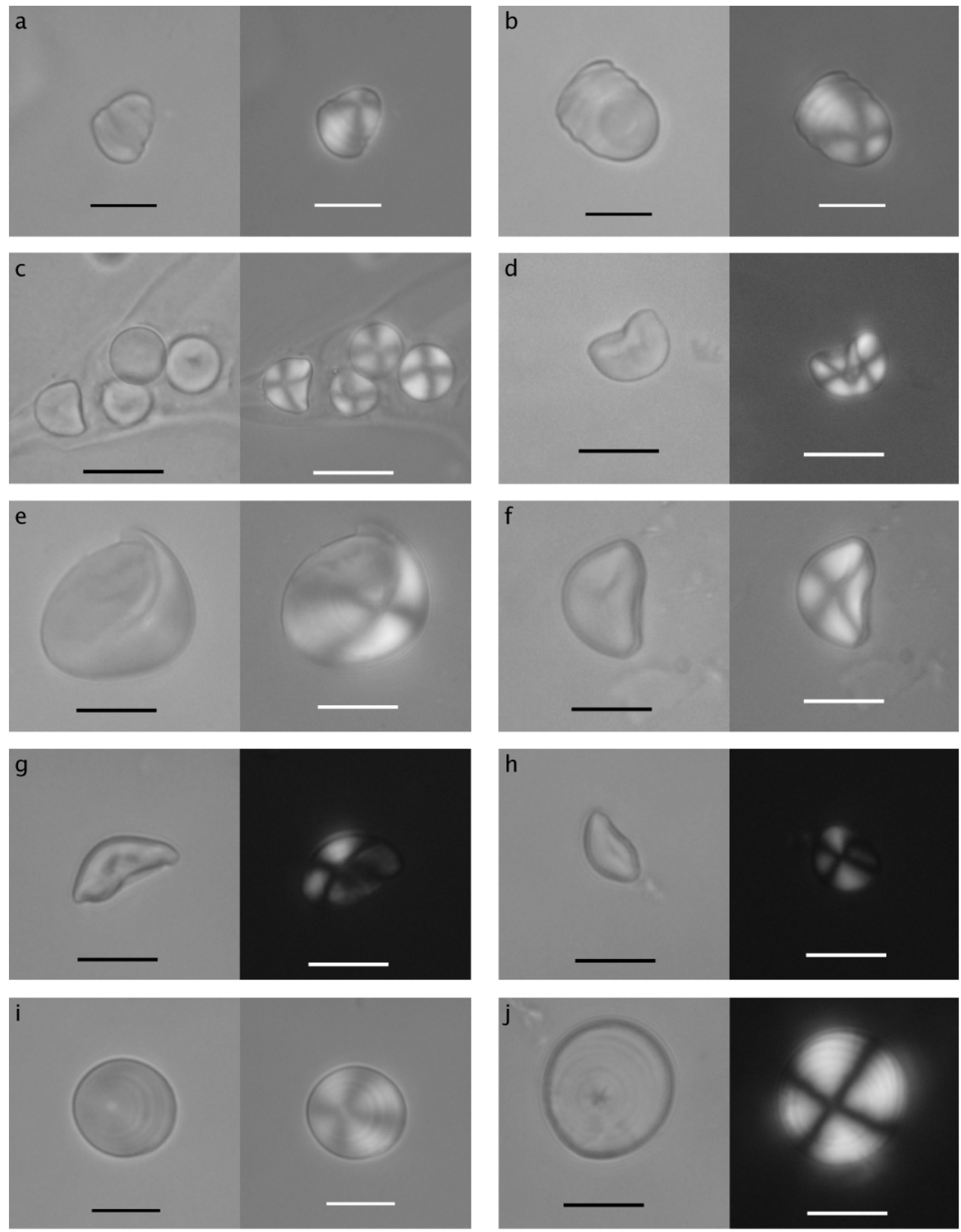

Figure 8.4 Comparative starch grains from Lagenaria siceraria. See text for descriptions. 
Lagenaria siceraria Comparative Starch

In Lagenaria siceraria, starch grains vary in shape from spherical to hemispherical, to oblong hemispheres (bell-shaped). The oblong hemispheres (Figure $8.4 \mathrm{a}, \mathrm{b}$ ) may have pronounced, thick lamellae in distinct concentric rings perpendicular to the long axis of the grain. In profile, the sides of the grain appear crenate. Hila are usually open and eccentric, but always are locatedin the dome of the hemisphere. Grain size in our comparative specimens ranges from 8 to $15 \mu$ in length. These grains are diagnostic to Lagenaria siceraria. Bell-shaped grains with pleated lamellae are present in C. moschata (Piperno and Dillehay 2008), C. ficifolia, and Cyclanthera pedata, however these taxa can be distinguished based on differences in bell-shape grain morphology individual to each taxon, as discussed below. For example, bell-shaped grains with pleated lamellae produced in Cyclanthera pedata are smaller than in squashes, averaging around $6 \mu$, more narrow and lightly pleated with three or four lamellae and nearly smooth sides that are not as distinctly crenate as L. siceraria or C. ficifolia.

Spherical grains in Lagenaria siceraria are generally round in outline with smooth surfaces (Figure $8.4 \mathrm{i}, \mathrm{j}$ ). The centric to slightly eccentric hilum is usually open and may be subject to tearing (Figure $8.4 \mathrm{j}$ ). Note that unlike spheres in manioc, for example, lamellae are present and pronounced in larger gourd grains. Spherical gourd grains range in size from 8 to $25 \mu$ in our samples. The unique lamellae occurring on these spheres likely make the grain an additional diagnostic morphotype produced only by L. siceraria.

Hemispherical gourd starch grains have smooth surfaces and usually closed centric to slightly eccentric hila (Figure $8.4 \mathrm{c}, \mathrm{e}$ ). Small hemispheres, less than 10 microns, are 
common (Figure $8.4 \mathrm{c}$ ) but larger grains, up to 20 microns, are more distinctive, usually having visible lamellae (Figure $8.4 \mathrm{e}$ ). The base of the hemisphere is concave or deeply indented. This type, a hemisphere with a deeply indented base, is also found in the Cucurbita studied here as well as in Sicana odorifera and Cyclanthera pedata. This type may be a family-level diagnostic. Less abundant gourd starch morphotypes include small compound and double faceted hemispheres with smooth margins (Figure $8.4 \mathrm{~d}$ ) and compound granules consisting of two to three individual grains, each of which will exhibit individual extinction crosses under cross-polarized light.

Flattened hemispherical grains with deeply indented bases (Figure $8.4 \mathrm{f}, \mathrm{h}$ ) are also present in gourd. When viewed from the top of the dome, these grains are longer than wide. From the side, the grains have a distinctive bump on the bottom edge of the long axis. The hilum is located on the side of the grain along a surface feature that resembles a small ridge running parallel or in a ' $v$ ' perpendicular to the long axis of the grain. Lamellae are generally absent. This grain type overlaps types in C. ficifolia, but may be a useful indicator of Lagenaria siceraria.

\section{Cucurbita ficifolia Comparative Starch}

Starch grains in C. ficifolia, grown in Missouri by Pearsall, include oblong hemispherical grains from 10 to $16 \mu$ in length having faint pleat-like lamellae with slightly crenate sides and a deeply indented basal facet, often with a lipped edge (Figure 8.5 a,b). The pleated lamellae are much less pronounced and narrower than in oblong hemispherical grains produced in L. siceraria. These grains also differ from bell-shaped 

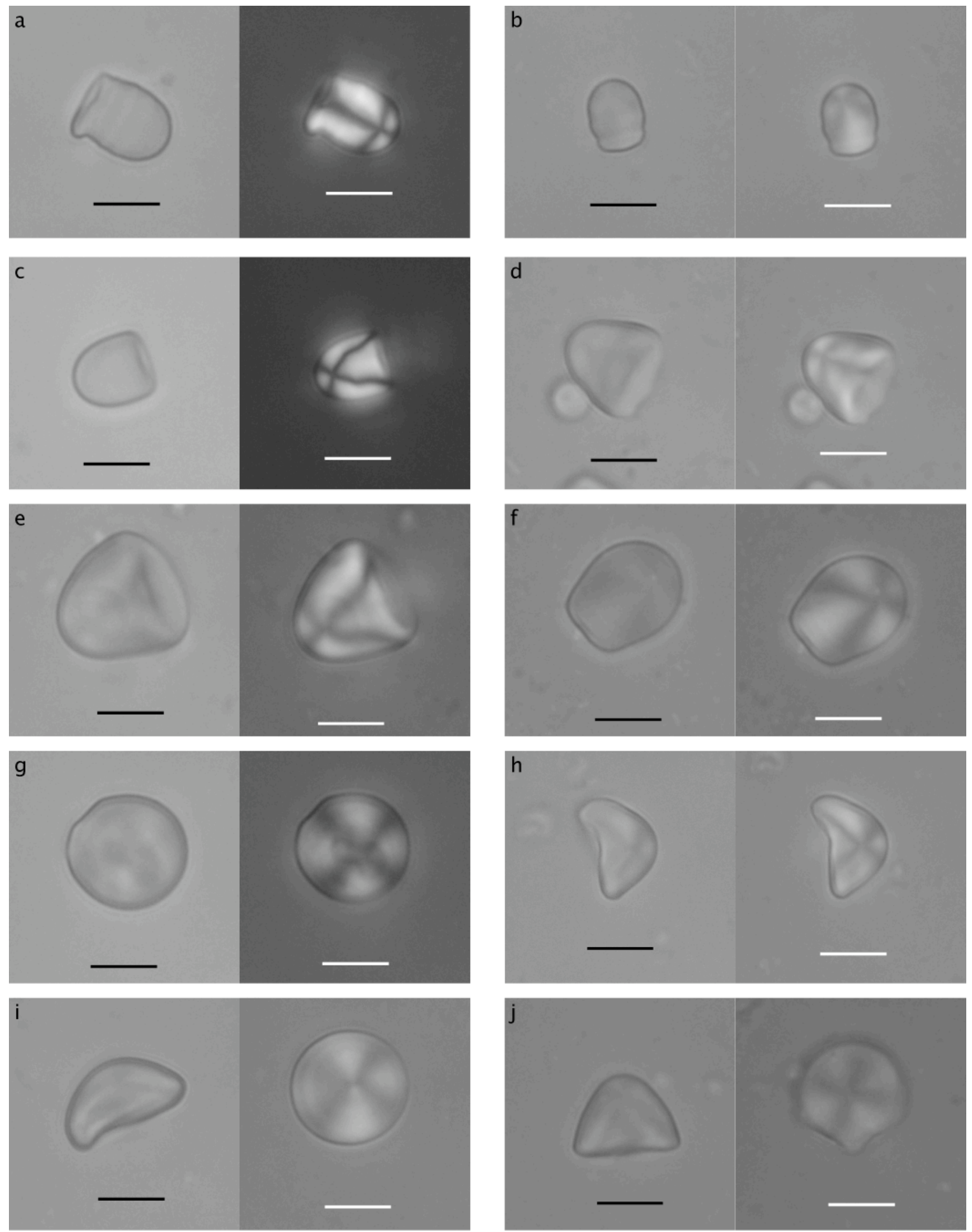

Figure 8.5 Comparative starch grains from Cucurbita ficifolia. See text for descriptions. 
grains with pleated lamellae produced in the modern butternut variety of C. moschata, which tend to be smaller and have more pronounced lamellae and an irregular base. The oblong hemispheres produced by C. ficifolia differ from traditional varieties of C. moschata as well, in that the latter produces oblong hemispheres with pleat-like lamellae lacking crenate sides (Piperno and Dillehay 2008).

Other bell-shaped hemispheres with smooth sides are present in C. ficifolia and these, too, typically have a deeply indented basal facet (Figure $8.5 \mathrm{c}-\mathrm{e}$ ). These grains range in size from 10 to $22 \mu$ in length. Spherical grains with smooth surfaces, lamellae and an open hilum are also present, from 10 to $20 \mu$ in diameter. There is considerable variation in starch produced in C. ficifolia and C. maxima (see below) and both produce significant numbers of potentially diagnostic types (Dolores Piperno, personal communication 2009). For example, flattened hemispheres (Figure 8.5 h,i) having a deeply indented base and a bump along the bottom edge of the long axis overlap types in Lagenaria siceraria, however certain flattened hemispherical grains in C. ficifolia are distinctively round when viewed from the top of the dome (Figure $8.5 \mathrm{i}$ ) and diagnostic to this species. These grains are typically 15 to $20 \mu$ in diameter.

\section{Cucurbita maxima Comparative Starch}

Starches in C. maxima, obtained from a comparative specimen from Chiclayo, Perú and locally purchased buttercup squash, contained hemispherical starch grains with a deeply indented basal facet and compound hemispheres with double basal facets (Figure $8.6 \mathrm{a}, \mathrm{c})$, types frequently found in other Cucurbitaceae. Irregularly shaped spheres are 

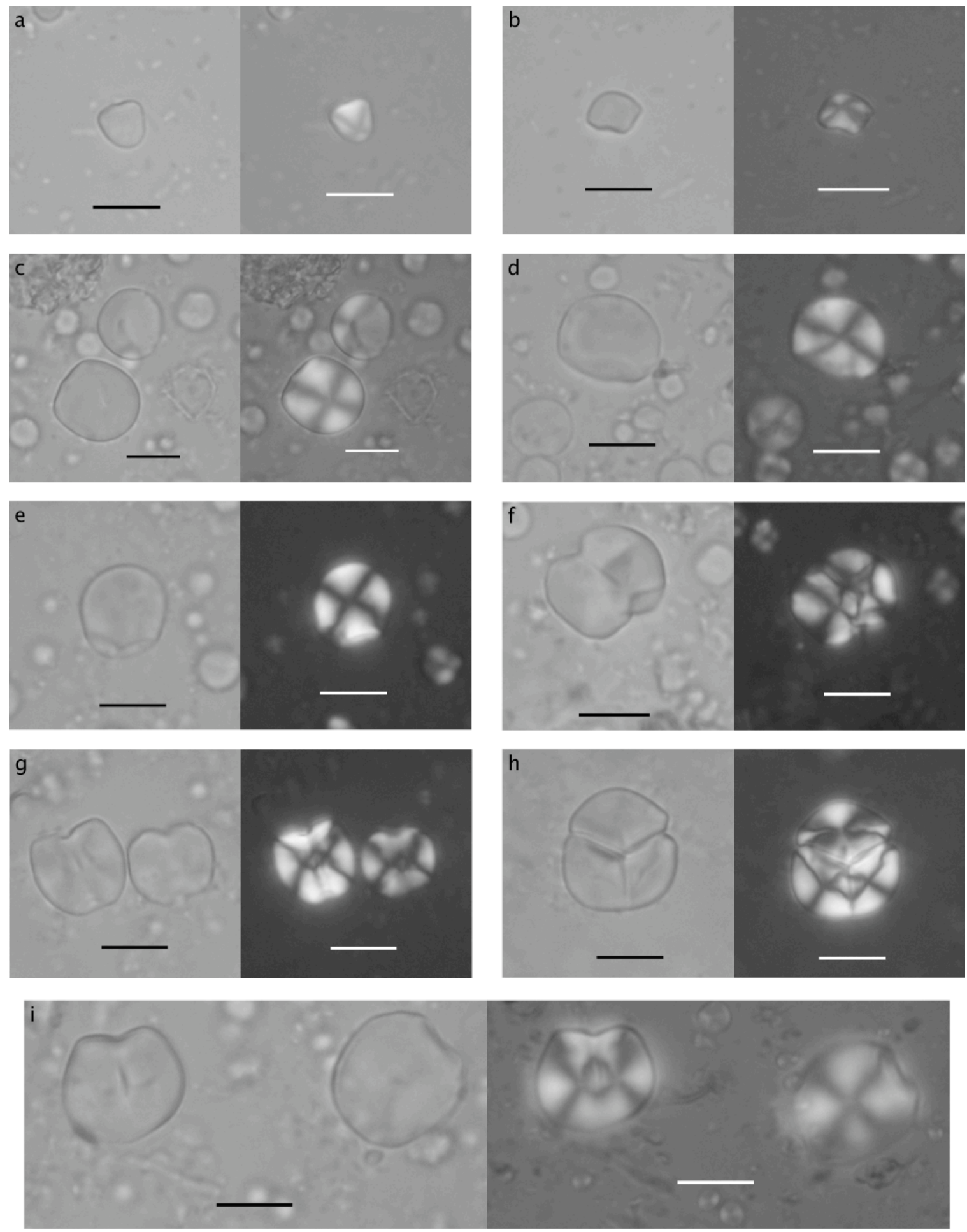

Figure 8.6 Comparative starch from Cucurbita maxima. See text for descriptions. 
common (ranging from 5 to $20 \mu$ ) with centric, open hila and weak lamellae, and often with one or more pressure facets (Figure $8.6 \mathrm{c}-\mathrm{e}$ ). This species also produces distinctive double or triple compound starch (Figure $8.6 \mathrm{f}-\mathrm{i}$ ). The compound granules may exhibit only a small fissure under transmitted light, but under polarized light, one can see individual extinction crosses in each grain. These compound granules range in size from 10 to $20 \mu$ in diameter.

\section{Cucurbita moschata Comparative Starch}

Cucurbita moschata, locally purchased butternut squash, contains oblong hemispherical grains with crenate sides and a deeply indented basal facet (Figure 8.7 a-d). The lamellae are more pronounced than in bell-shaped grains of C. ficifolia, but also differ from L. siceraria in that the lamellae on the modern C. moschata grains occur over twothirds the length of the grain (Figure $8.7 \mathrm{c}$ ). Other bell-shaped grains with pleated lamellae in C. moschata are distinct in having a smaller base than dome. In our comparative samples, these grains range in size from 8 to $12 \mu$ in length. Other starch granules in C. moschata include spheres and hemispheres ranging in size from 5 to $15 \mu$ with shallow lamellae and open hila (Figure 8.7 e-f). The hemispheres typically have an indented base characteristic of other Cucurbitaceae.

Although the oblong hemispherical grains produced in our comparative butternut squash can be distinguished from other Cucurbitaceae, these grains with thickly pleated lamellae and crenate sides do not occur in traditional varieties of C. moschata (Dolores Piperno, personal communication 2009). Therefore it is very important to note that starch 
grains from modern butternut squash do not represent traditional South American

varieties of C. moschata that produce diagnostic bell-shaped hemispheres with thin pleat-like lamellae and lacking crenate sides (Piperno and Dillehay 2008). Thus, these modern types of C. moschata starch are not expected archaeologically.
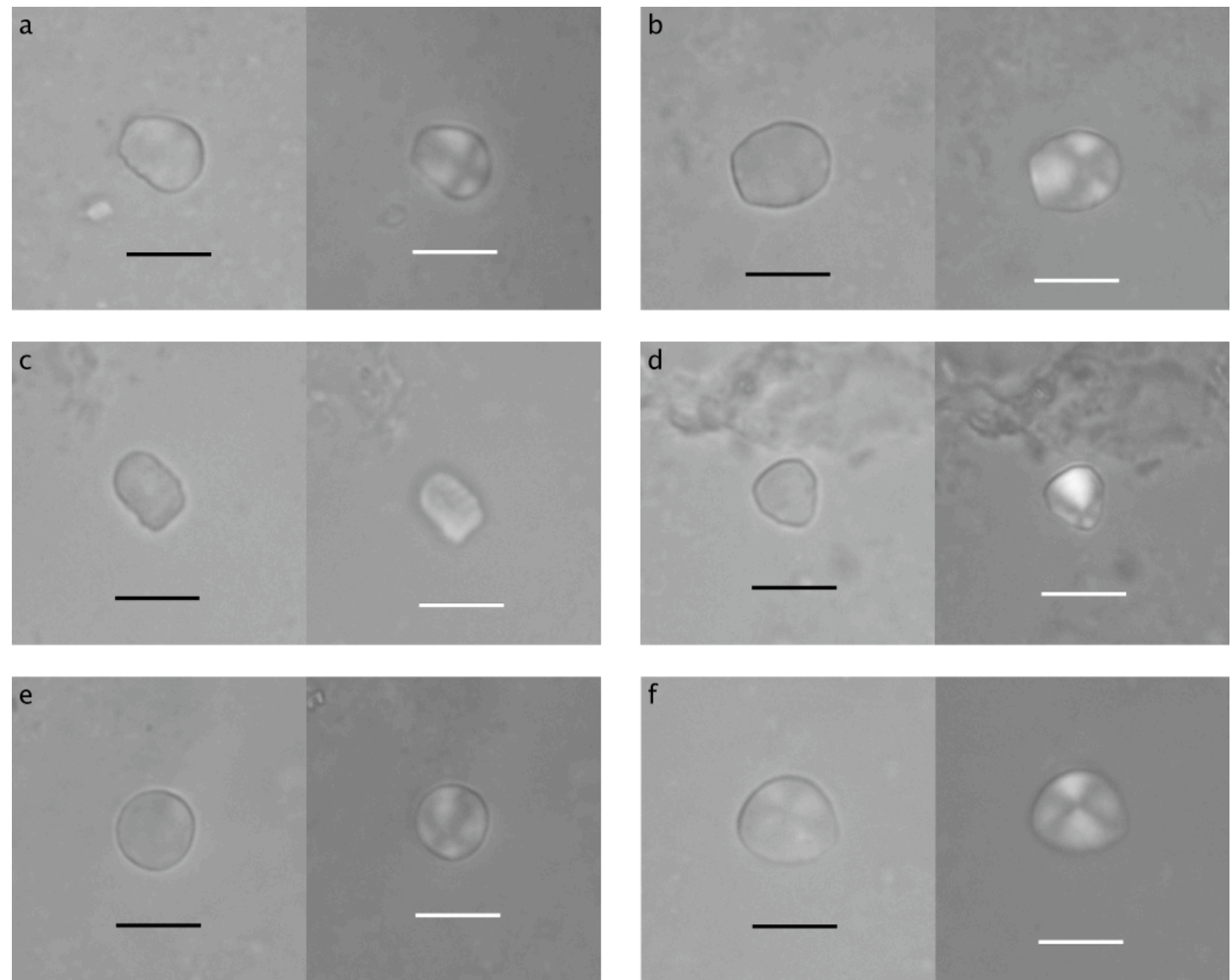

Figure 8.7 Comparative starch grains from modern Cucurbita moschata. See text for descriptions.

Other Cucurbitaceae Comparative Starch

To distinguish squash and gourd starch granules from other South American economic taxa in the Cucurbitaceae family, I studied starch grains from Cyclanthera pedata (caygua) and Sicana odorifera (sicana) both purchased in Chiclayo, Perú. Cyclanthera pedata 
starch grains include hemispheres with indented bases common to other Cucurbitaceae (Figure $8.8 \mathrm{a}, \mathrm{b}$ ) and spheres with open hila and lamellae (Figure $8.8 \mathrm{~d}$ ). This species also produces an oblong hemisphere with crenate sides and an indented base (Figure $8.8 \mathrm{c}$ ), however the size of these granules, 6 to $8 \mu$, is much smaller than those in C. moschata, C. ficifolia, or L. siceraria. Based on size, this type may be diagnostic to Cyclanthera sp.
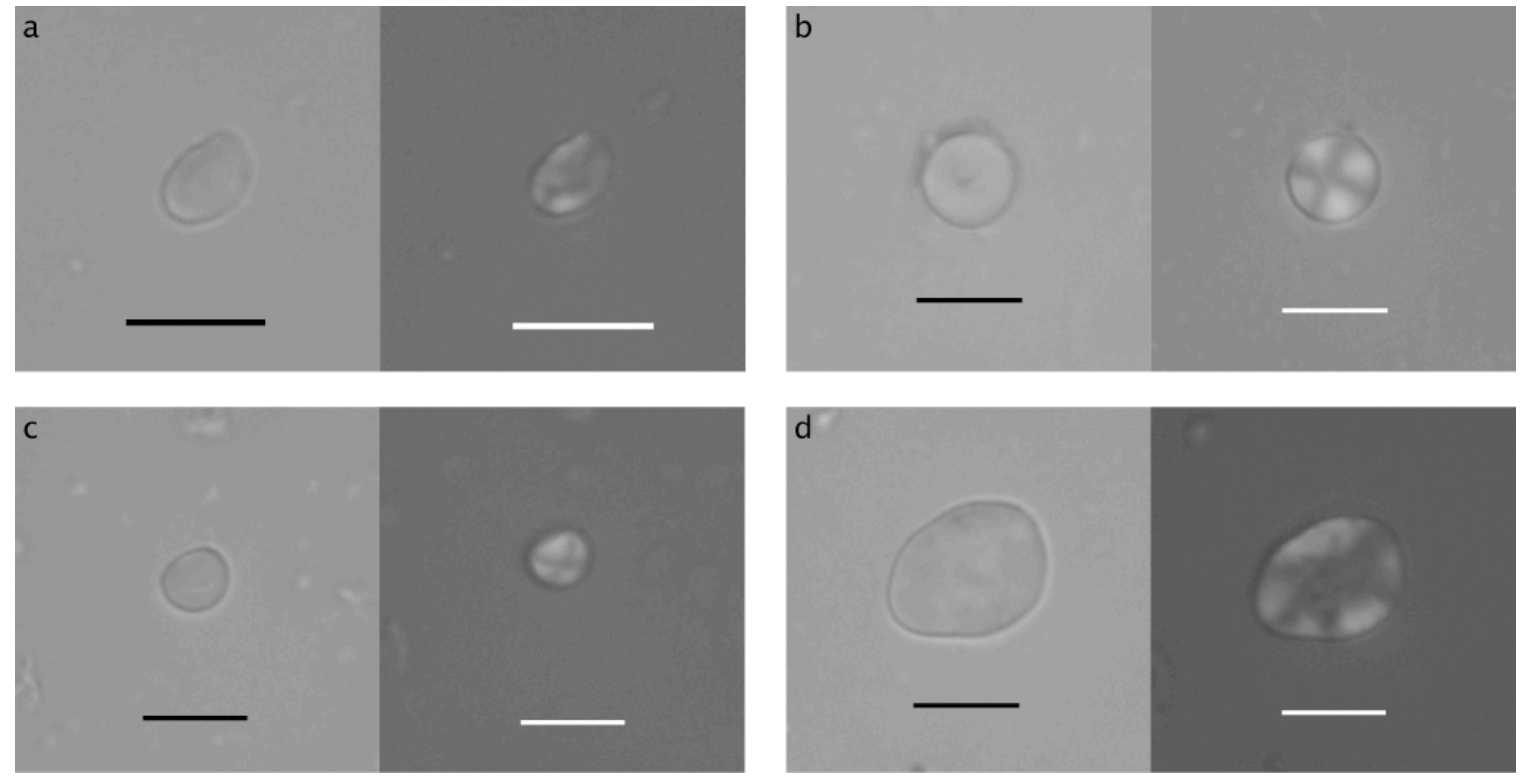

Figure 8.8 Comparative starch grains from Cyclanthera pedata.

As in other Cucurbitaceae, Sicana odorifera starches include hemispheres with indented bases (Figure 8.9 a-d). These hemispheres lack lamellae, have closed and eccentric hila, and range in size from 6 to $20 \mu$. Sicana odorifera also produces irregularly spherical grains with multiple facets that under polarized light appear creased along the axes of the extinction cross (Figure $8.9 \mathrm{e}-\mathrm{h}$ ). They range in size from 8 to $16 \mu$. This type is probably diagnostic to Sicana sp. 

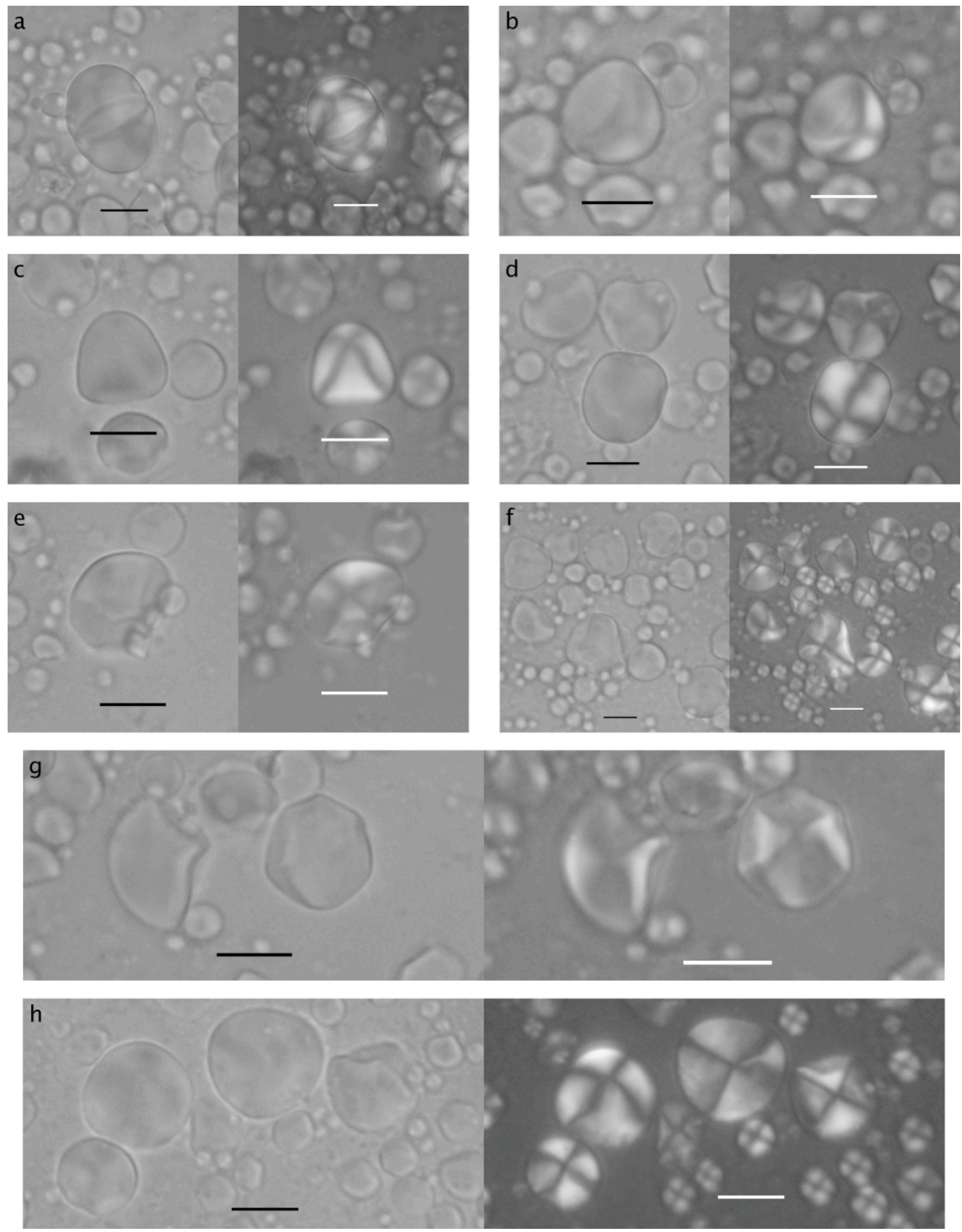

Figure 8.9 Comparative starch grains from Sicana odorifera. See text for descriptions. 


\section{Methods For Starch and Phytolith EXtraction from CUCURbit ARtiFacts}

Ten fragments were analyzed (nine identified as Lagenaria siceraria, one identified as Cucurbita sp.) from the sunken pit in Unit B-1 in contexts dating to 4200 calB.P. (see

Chapter 6, Table 6.2). The artifacts in this study were pulled in the laboratory from bulk or fine-screen samples collected in the field. It is also important to note that all of the sampled gourd and squash artifacts in this study were removed from the macroremain finescreen or bulk samples before those samples underwent flotation. Three of the artifacts were recovered from Level 300, four from Level 400, and two from the disturbed upper material in Level 100.

Table 8.3 Gourd and squash artifacts and radiocarbon dated contexts at Buena Vista

\begin{tabular}{llll}
\hline Artifact \# & Context & Radiocarbon Age B.P. & Date in Years B.P. ${ }^{*}$ \\
\hline 02, 05, 07 & Sunken Pit: Unit 10, Feature 1, Level 300 & $3770 \pm 80$ B.P. (GX-31276) & 3928-4412 Cal \\
01, 03, 04, 08 & Sunken Pit: Unit 10, Feature 1, Level 400 & $3790 \pm 80$ B.P. (GX-32177) & 3973-4417 Cal \\
09, 10 & Unit 10, Cuad 3, level 100 & Not dated \\
Standard radiocarbon date from associated charcoal, 2 $\sigma$ calibrated result. & \\
\hline
\end{tabular}

Sampling Artifacts for Starch and Phytolith Residue

I adapted published procedures for extracting microfossil residues from stone tools and ceramics (Loy 1994; Chandler-Ezell and Pearsall 2003; Perry 2004; Zarrillo and Kooyman 2006). The artifacts in this study are very well preserved, desiccated specimens recovered under conditions of exceptional preservation. In developing a technique to sample the gourd artifacts, one should weigh the costs and benefits of microfossil recovery to the preservation of the artifact itself. These artifacts survived this processing with no visible adverse affects, however, for organic artifacts in more fragile condition, alternative 
sampling methods, such as in situ sampling (Loy et al. 1992; Chandler-Ezell and Pearsall 2003) should be considered to avoid damage to the artifact.

In working with these artifacts, only new, unused plastic bags, test tubes, bottles, and plastic weigh-boats were used for this procedure. Also, any tools, such as metal tweezers and probes were 'sterilized' with concentrated steam and a small butane torch to eliminate starch contamination. In addition, only high quality unpowdered latex gloves were worn, as powdered gloves are often coated in cornstarch. The procedure used is as follows:

Sonication

First, an artifact was placed in a new, curation quality, re-sealable polyvinyl bag sized $5 \times 7$ inches, with approximately $25 \mathrm{ml}$ of distilled water, or enough to completely submerge the artifact. Before sealing, the top of the bag was folded over, just above the waterline, and the seam held down with a binder clip. This removed the air from the bag and helped keep the artifact fully submerged in the distilled water. This also helped keep the bags from floating in the sonicator. The bag containing the artifact was then placed into an ultrasonic cleaner filled with water and sonicated for five minutes to dislodge gently the residue from the artifact. After five minutes, the bag containing the artifact was removed from the sonicator. While being careful not to spill the water in the bag, the artifact was removed with sterile tweezers and placed in a new plastic container and reserved. The water and all sediment from the bag were then transferred and the bag rinsed into a new $50 \mathrm{ml}$ test tube. The sediment dislodged from the sonication was labeled Sediment 1 . The $50 \mathrm{ml}$ tube containing the sediment dislodged from the artifact by sonication was topped off with distilled water and placed in a centrifuge for five minutes at 
$2500 \mathrm{rpm}$ to concentrate the sample at the bottom of the tube. The supernatant was then carefully decanted or pipetted off leaving the sample undisturbed at the bottom of the tube. This tube containing Sediment 1was reserved.

\section{Sediment 2}

The artifact was removed from the plastic container and the interior surface of the artifact was then gently rinsed with distilled water from a squirt bottle. The rinse water was collected in the plastic container. To increase recovery of starch, the interior surface of the artifact was gently brushed with a soft bristled toothbrush. Then, the artifact and the brush were rinsed again into the same container. To avoid cross-contamination, only a new, unused disposable toothbrush was used for each artifact. The artifact was then removed and allowed to dry thoroughly before being returning to curation. The water was transferred and the container rinsed into a new $50 \mathrm{ml}$ centrifuge tube or a new $250 \mathrm{ml}$ bottle if the quantity of water was over $50 \mathrm{ml}$. Then, the tube was centrifuged for five minutes at $2500 \mathrm{rpm}$ to concentrate the sample at the bottom of the tube. The supernatant was then carefully decanted leaving the sample undisturbed at the bottom of the tube. This tube containing Sediment 2 was reserved.

\section{Dispersion}

To neutralize chemical and electrical bonds in the sediments and help release the starch grains, $10 \mathrm{ml}$ of $0.1 \%$ disodium salt $\left(\mathrm{Na}_{2} \mathrm{H}_{2}\right.$ EDTA) solution was added to the Sediment 1 and Sediment 2 tubes and the tubes were placed in a reciprocating shaker for two hours to disperse the sediments. After removing from the shaker, the tubes were topped off with distilled water and centrifuged for 3 minutes at $2500 \mathrm{rpm}$ and the 
supernatant carefully decanted. The water rinse was repeated two more times to remove any remaining chemical.

\section{Oxidation}

If the sediment at the bottom of the tubes and the remaining water appeared clear, oxidation was skipped. Otherwise, gentle oxidation, sufficient to remove superfluous organic matter, but gentle enough not to damage the starch, was carried out. To each tube was added $10 \mathrm{ml}$ of $5.75 \%$ solution of hydrogen peroxide $\left(\mathrm{H}_{2} \mathrm{O}_{2}\right)$ and the reactions were monitored for a maximum of ten minutes. The tubes were then topped off with distilled water and centrifuged for 3 minutes at $2500 \mathrm{rpm}$. The supernatant was then carefully decanted leaving the sample undisturbed at the bottom of the tube. The rinse was repeated two more times to remove any remaining hydrogen peroxide.

\section{Flotation}

To recover starch from the remaining sediments, flotation was performed for those sediments with visible residue following oxidation. Cesium chloride $(\mathrm{CsCl})$ was dissolved in distilled water to a specific gravity of 1.6 . Then, $5 \mathrm{ml}$ of the $\mathrm{CsCl}$ solution was added to the samples and gently mixed. The tubes were then centrifuged for 5 minutes at $2000 \mathrm{rpm}$. The supernatant containing the suspended starch sample was then decanted into a fresh 50 $\mathrm{ml}$ tube and reserved. The flotation was repeated, decanting the suspended starch solution to the starch sample. To rinse, the starch samples were topped off with distilled water to reduce the specific gravity and centrifuged for 5 minutes at $2000 \mathrm{rpm}$ to concentrate the starch at the bottom of the tube. The supernatant was very carefully decanted leaving approximately $15 \mathrm{ml}$ of water and the starch sample undisturbed at the bottom of the tube. 
The rinse was repeated two more times to completely remove remaining $\mathrm{CsCl}$ and the starch sample reserved. The remainder sediment sample was topped off with distilled water and centrifuged for 5 minutes at $2000 \mathrm{rpm}$ and the rinse was repeated two more times. The sediment was reserved for phytolith extraction.

Starch Slide Mounts and Microscope Scanning

$22.5 \mu \mathrm{l}$ of concentrated starch sample was placed on a clean glass slide with two drops of $100 \%$ glycerol. A cover slip was placed on top and the edges were sealed with nail polish. Slides were scanned on a Zeiss Standard transmitted light microscope equipped with polarizing light filters at $375 x$ and photographed at 400x. Polarized light is necessary to observe birefringent properties of starch.

Phytolith Extraction

Chemical extraction and flotation for phytoliths were only conducted on those samples that underwent flotation for starch removal. For other samples, I made slides using the method described above for starch mounts, and scanned these as dual phytolith/starch extract slides. For sediments from which starch was floated, I continued with a chemical extraction of phytoliths following published procedures (Chandler-Ezell and Pearsall 2003). The sediments were exposed to a strong acid, hydrochloric acid $(\mathrm{HCl})$ and nitric acid (HNO3), solution for approximately one hour to remove carbonate material and oxidize organics. Further oxidation followed using hydrogen peroxide in a $27^{\%}$ solution. Finally, phytoliths were chemically floated out using lithium metatungstate (LMT) ${ }^{10}$. Slide mounts

\footnotetext{
${ }^{10}$ The MU lab switched from $\mathrm{ZnI}_{2}$ to LMT during the time this research was done.
} 
were made using immersion oil and scanned on a Zeiss Standard transmitted light microscope at 400x.

\section{RESUlTS}

Starch and phytoliths were recovered from gourd and squash artifacts. Evidence for food plants was found in the starch fraction, however, phytolith recovery was not successful in identifying economic plants. The results for each microfossil extraction are discussed below.

Phytolith Results

Extractions for phytoliths from the residues of the gourd and squash artifacts were not quite as successful as those for starch (Table 8.4). Only two fragments of the ten sampled yielded phytoliths and these fragments, both gourd, were found in the fill material above the pit, artifact 9 and artifact 10 from Level 100. Also, in both cases the phytoliths were only recovered from Sediment 2, the brushed fraction. No diagnostic Cucurbitaceae phytoliths were seen. Four extracts contained non-silicified parenchyma cells and vascular tissue from the artifacts themselves. From the two artifacts providing phytoliths, grass silica bodies were common in one (artifact 10), including epidermal cells and short-cell phytoliths. From artifact 9, phytoliths of irregularly folded and angled spheres were present. This type is produced in several families of the Zingiberales, including economic plants achira (or Canna edulis), lleren (Calathea sp) and also arrowroot (Figure 8.10). This phytolith type does not occur in the sediments (see previous chapter). 
Table 8.4 Phytolith and non-silicified tissues from gourd and squash artifacts per sediment sample. Non-silicified tissues are indicated as present $(p)$.

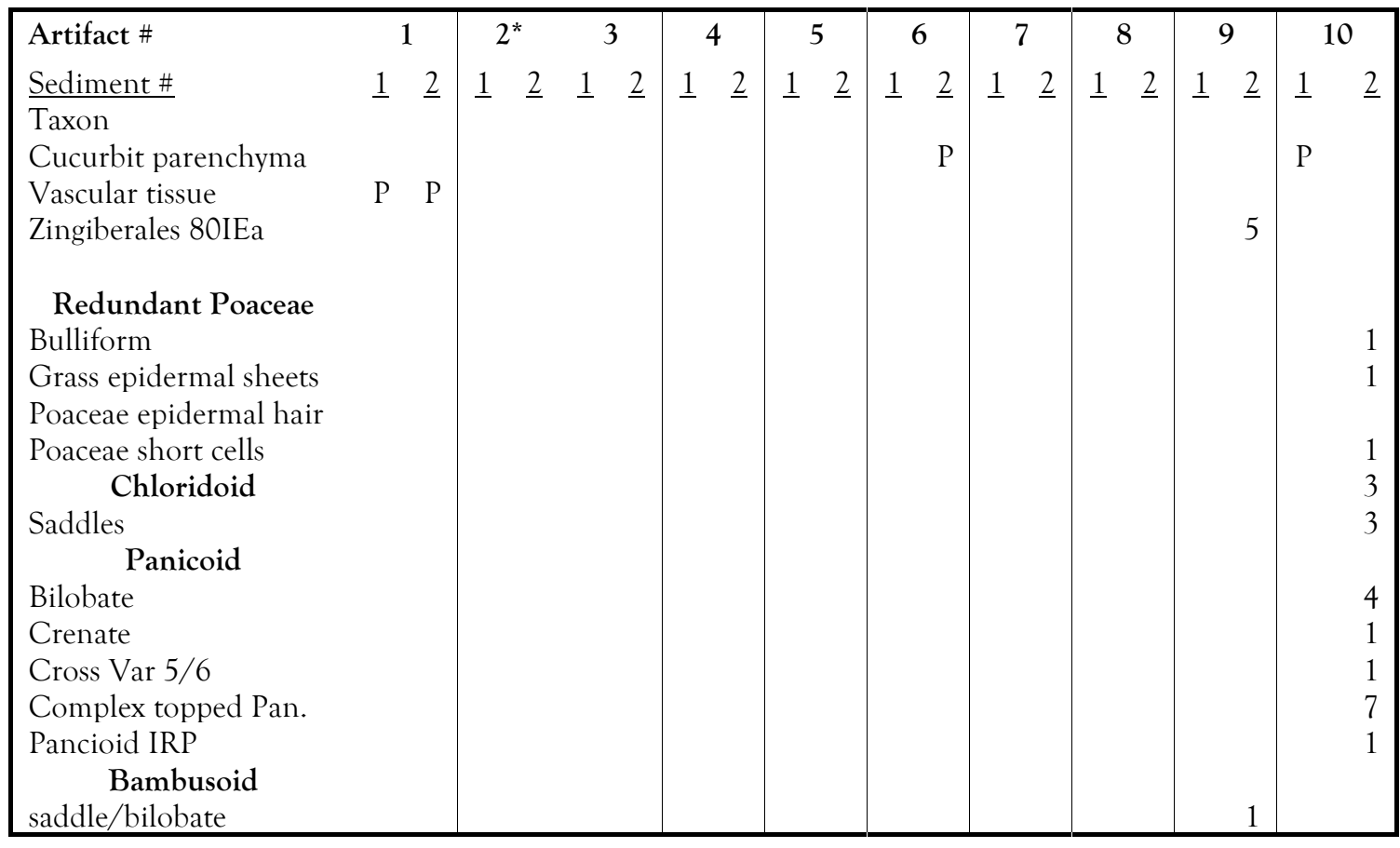

${ }^{*}$ Cucurbita sp. artifact. All others identified as Lagenaria siceraria 

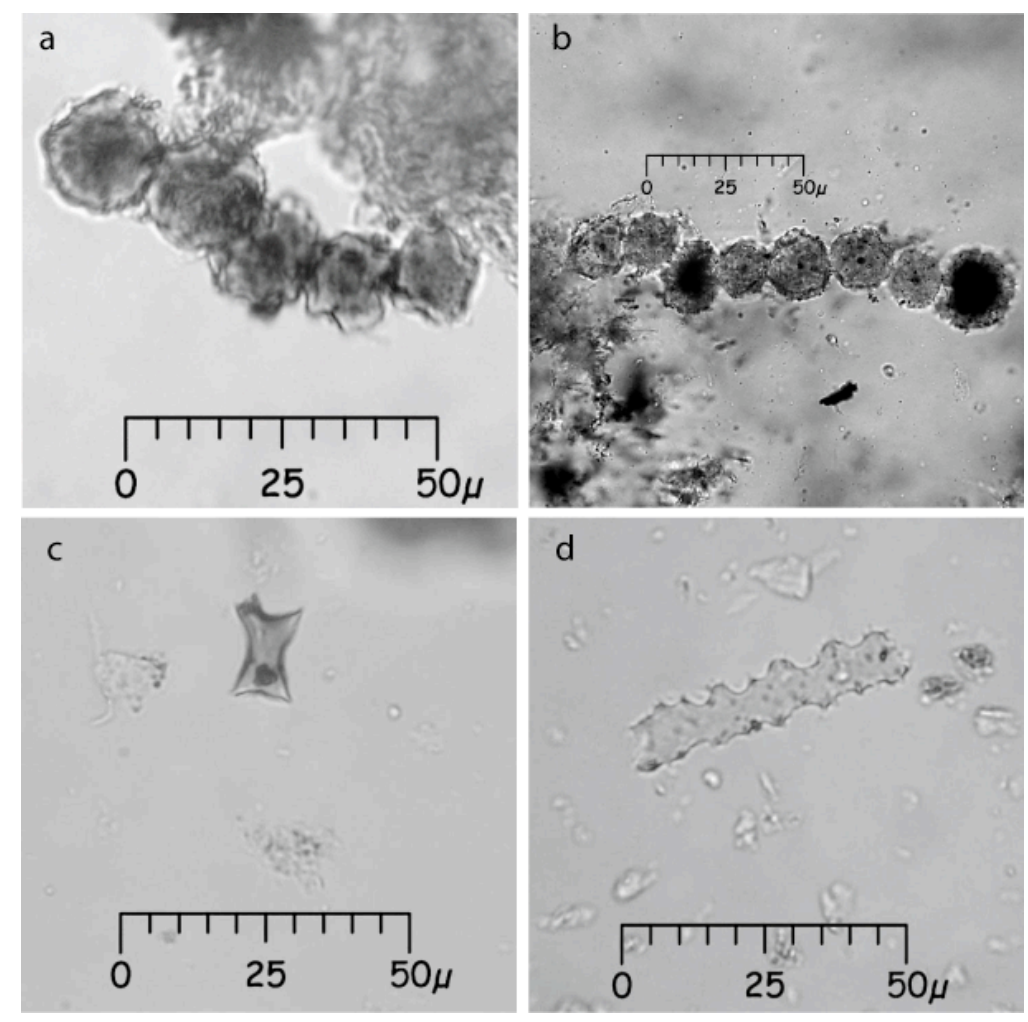

Figure 8.10 Phytoliths recovered from residue of gourd artifacts. (A) Zingiberales spheres, archaeological, Type 80IEa. (B) MU Comparative 80IEa from Canna edulis. (C) Bambusoid saddle type, archaeological. (D) Panicoid grass rectangular IRP type, archaeological.

Starch Results

Starch recovery was successful from seven of the ten artifacts sampled, with three gourd artifacts producing no starch using this sampling method (Table 8.5). However, as expected, in all seven of the artifacts that yielded starch, I identified grains that ostensibly represent starch from the mesocarp of the artifact itself. As described earlier, the method for extracting starch residues from the artifacts involves two procedures, sonication, Sediment 1, and brushing and rinsing, Sediment 2. There is no significant difference in the number of Cucurbitaceae grains between Sediment 1 and Sediment 2 samples, and starch from other taxa is associated with the Cucurbitaceae starch in both sediments. As 
discussed in Chapter 7, only a few starch grains, most of which appear to be transitory, were recovered from site sediments. One starch grain from site sediments was tentatively identified as cf. Manihot and three grains are consistent with Cucurbitaceae starch. A strong case, then, can be made that the economic starch grains recovered with Cucurbitaceae starch from the artifacts represent contact residue from tool-use and not transfer of starch to the aritifacts from site sediments (see Haslam 2004).

Table 8.5 Starch grain data from gourd and squash artifacts per sediment sample.

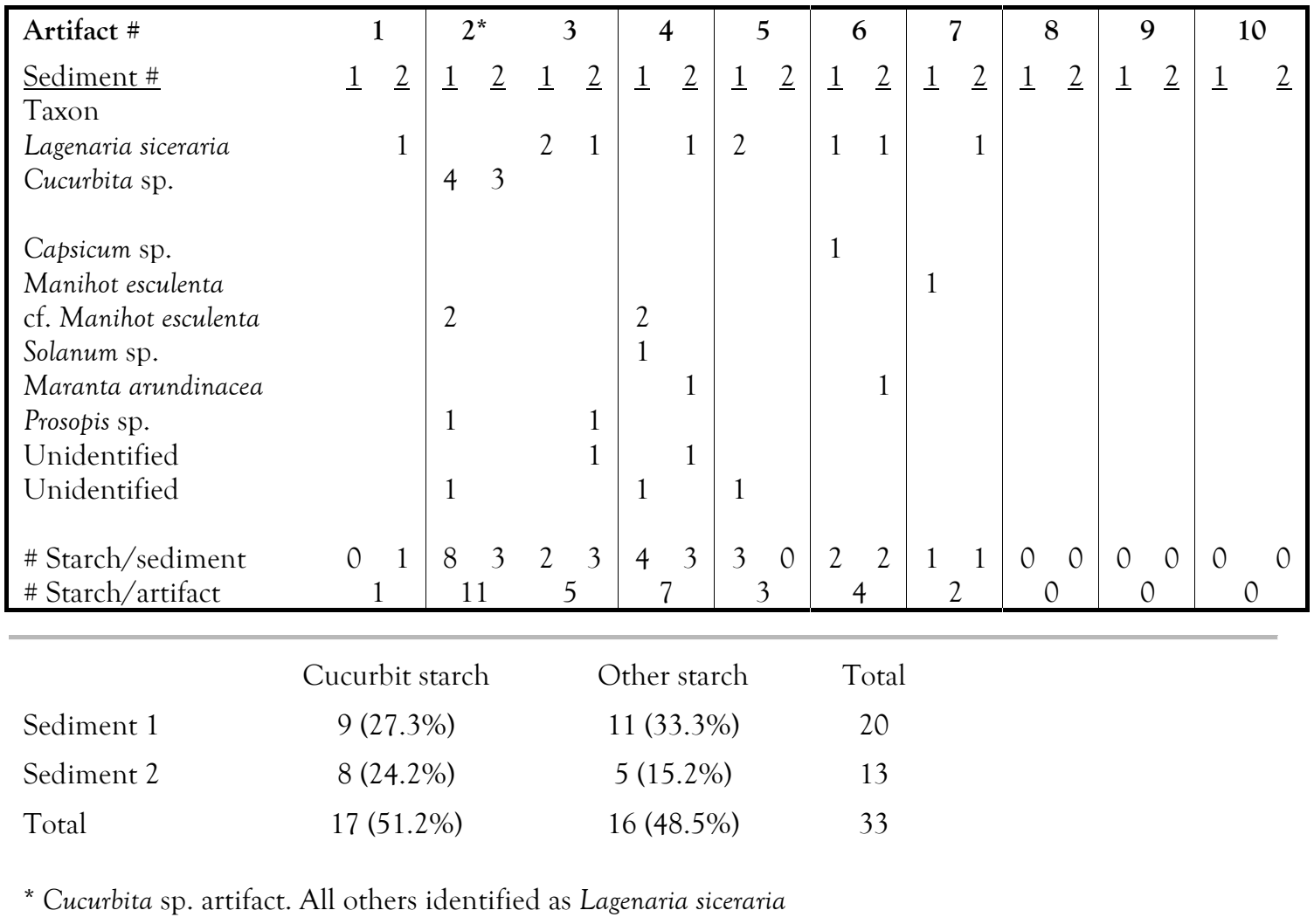


Beyond the comparative material studied for this experiment, starch identifications were aided by a collection of over 250 comparative starch specimens from wild and economic Neotropical taxa in Pearsall's laboratory at MU and published reports and keys to starch types germane to the region (including Piperno and Holst 1998; Pearsall et al. 2004; Perry 2002; Pagán Jimenez 2007; Reichert 1913; Ugent et al. 1982, 1984,1986; Chandler-Ezell et al. 2006). Several additional taxa were also studied at MU and are presented in Appendix B. Given the potential for variation in starch grain morphology of a particular taxon, e.g. Lagenaria and Cucurbita, multiple criteria must be used to identify an individual grain and this is especially important when, as in this case, the population of starch grains is small. Following Piperno (2006c:51), the criteria for starch identification include three-dimensional shape of the grain and its surface features, the position (centric or eccentric) of the hilum and any distinct characteristics it might have, the presence of pressure facets and their characteristics, any fissures or internal cracks in the grain, the presence or absence of lamellae, and lastly, the nature of the extinction cross when the grain is viewed under cross-polarized light. Individual grains that represent all of the diagnostic criteria of a particular taxon may be rare among the population of grains produced in the taxon. One should expect those diagnostic grains to be less common in archaeological contexts. Therefore, it is important to note that identifying grains in an archaeological context may also involve inference from other grains in the population and the archaeological context.

The identifications are conservative, especially for grains that may not exhibit all criteria needed for a solid determination of taxon. Not including cucurbit grains, I securely 
identified five taxa, Manihot esculenta (manioc), Solanum (potato), Maranta arundinacea (arrowroot), Prosopis (algarrobo) and Capsicum (chili pepper).
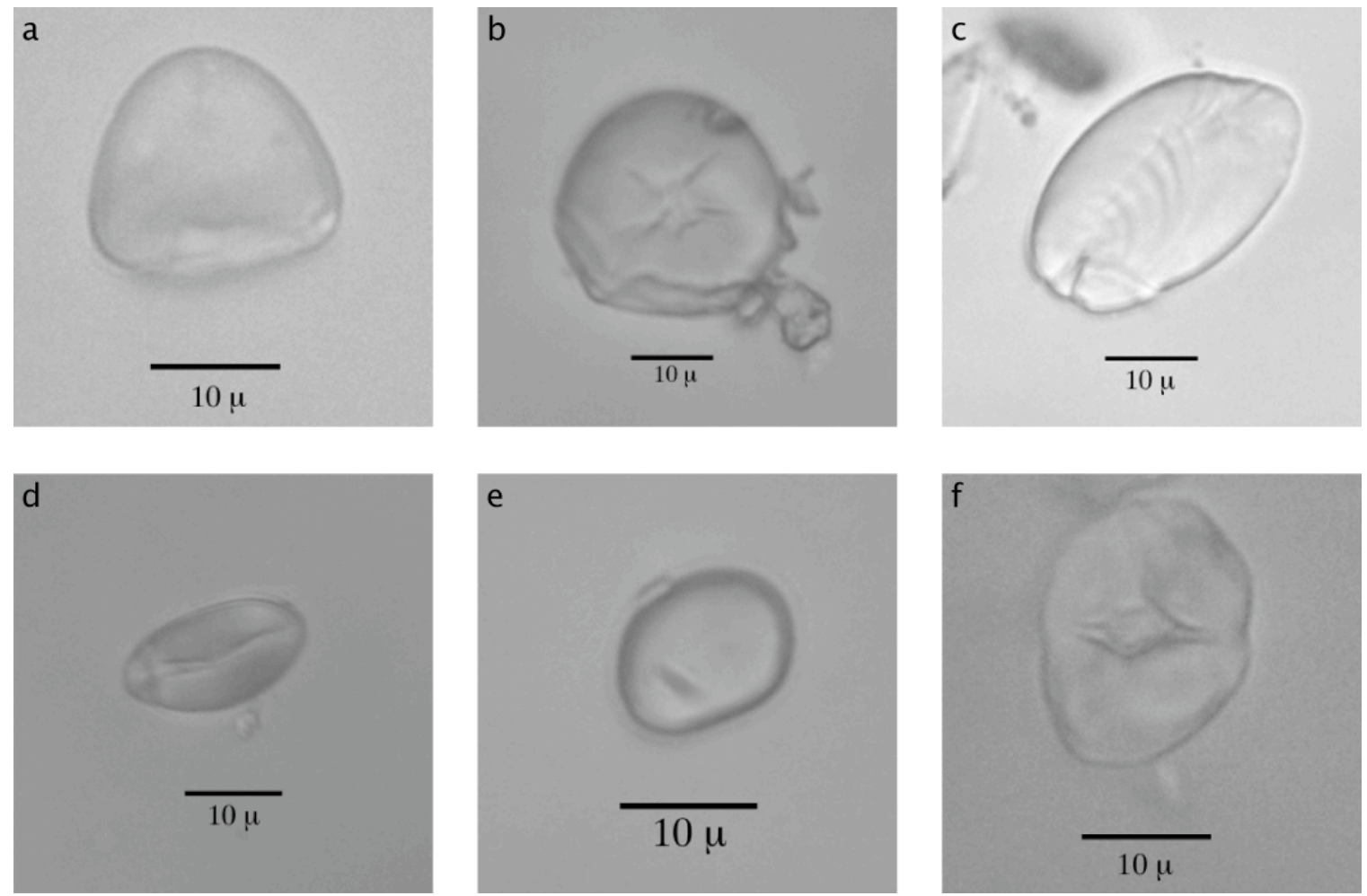

Figure 8.11 Starch grains recovered from gourd and squash artifacts. (a) cucurbit starch, (b) Manihot esculenta tuber starch grain, (c) Solanum sp. tuber starch grain, (d) Capsicum sp. fruit starch, (e) Maranta arundinacea rhizome starch, and (d) Prosopis sp. pod starch.

Manioc starch occurs on three artifacts. One grain (Figure $8.11 \mathrm{~b}$ ), on gourd artifact 7 , is a relatively large $(28 \mu)$ sphere with two basal facets and a large stellate-shaped fissure.

Grain size is in the upper range of domesticated manioc starch and likely too large to be wild (Piperno et al. 2000). Grains consistent with Manihot esculenta starch grains were found on artifact 2, a fragment of Cucurbita, and one more grain on artifact 4, a Lagenaria fragment. Three of these grains are hemisphere-shaped with two basal facets, a form characteristic of manioc, but not necessarily diagnostic on their own. Grains of this type, 
hemispheres with basal facets, are more angular than the faceted hemispheres noted in Cucurbitaceae, but less angular and lacking the distinct facet margins of grains produced by Ipomoea batatas. The last grain, identified as cf. Manihot esculenta is a spherical grain with a depressed linear fissure at the hilum and a regular extinction cross. This grain lacks basal facets or a stellate fissure diagnostic to the species, however the type does appear along with diagnostic grains and faceted hemispheres in our comparative samples of manioc.

Manioc macroremains are widespread at coastal Peruvian sites. In Preceramic contexts, macroremains of manioc tubers are reported as early as 8000 B.P. at Quebrada de Las Pircas (Rossen et al. 1996), later at Los Gavilanes around 4500 B.P. (Bonavia 1982; Popper 1982), and a number of Initial Period sites in the Casma Valley (Ugent et al. 1986). The early archaeological data led some to propose that Manihot esculenta may have had multi-local domestications and hybridizations, including on the central coast region of Perú (Ugent et al. 1986; Rogers and Appan 1973). More likely, as others have argued, the origin of domesticated manioc lies in northern South America and Central Brazil (Sauer 1952; Piperno and Pearsall 1998) and this conclusion is supported by phylogenetic analyses which point to a single wild progenitor M. esculenta ssp. flabellifolia most likely in the southern Amazon basin (Olsen and Schaal 1999, 2001; Olsen 2004). In Perry's (2002) study, starch grains from Initial Period and late pre-contact archaeological manioc specimens from coastal Perú lacked the distinguishing stellate fissure (Piperno and Holst 1998) characteristic of Amazonian manioc starch. However, one manioc grain recovered from a gourd artifact at Buena Vista contains a large stellate fissure consistent with the Amazonian morphotype. It is possible that this single starch grain represents an earlier 
imported lowland variety of manioc on the coast of Perú that over time was subject to selection eventually resulting in the morphotypes seen in coastal assemblages. Alternatively, this starch grain represents an early variety from the lowlands that ceased to be cultivated on the coast or is not directly related to the later coastal forms. Additional starch microfossils from early coastal contexts would help clarify these issues.

A starch grain from Solanum sp. (potato) tuber was identified on a gourd fragment, artifact 4 (Figure $8.11 \mathrm{c}$ ). The grain is large, $30 \mu$ in length, ovate-shaped, and round if viewed in transverse cross-section. Lamellae are coarse and plainly visible and the hilum is eccentric. The shape of the grain, the position of the hilum and the well-pronounced lamellae are characteristics of tuber starch in this genus (Reichert 1913). The rugged lamellae differentiate it from starch with otherwise similar features, such as arrowroot (Maranta arundinacea). The proximal and distal ends of the grain appear damaged. Near the hilum, there is an angled fissure visible in transmitted light, but it only slightly affects the shape of the extinction cross under cross-polarized light. The distal end shows some roughening of the edge, but not enough to compromise the structures of the grain. Several potato species and their varieties are cultivated today and in the past, and a great many wild forms of potato exist (Hawkes 1990). At this time, we cannot identify this starch grain to species.

Potato has great significance to modern and ancient populations of the Andean region. Archaeologically, the starch grain identified in this study is consistent with the presence of macroremains and microfossils of potato recovered from a number of contemporaneous sites throughout Perú, such as Waynuna in the southern highlands 
(Perry et al. 2006), sites in the Casma Valley (Ugent et al. 1982), and Buena Vista's largest neighbor, El Paraíso (Quilter et al. 1991), among others. The potato's normal range of cultivation is between 2500-4300 masl, but can be cultivated in coastal lowland fog oases or otherwise with sufficient irrigation (Ugent and Ochoa 2006).

Capsicum (chili pepper) is represented by a single flattened lenticular starch grain with an indented base and a linear feature visible in side-view recovered from artifact 6 (Figure 8.11 d). The grain is consistent with Capsicum sp. (Perry et al. 2007), especially its central linear feature diagnostic of the starches in this genus. Capsicum is widely reported from Cotton Preceramic sites on the coast of Perú (Pearsall 2003) and was cultivated at the same time in the highlands at Waynuna (Perry et al. 2007).

Two grains identified as root starch from Maranta arundinacea (arrowroot) in Marantaceae were found on artifacts 4 and 6, bottle gourd fragments (Figure 8.11 e). These grains are relatively small, around $13-15 \mu$, ovoid spheres with very fine lamellae. Both grains present another diagnostic feature of root starch from Maranta, an eccentric hilum associated with a small fissure (Piperno and Holst 1998). Despite its widespread and long record of use in the Neotropics (Piperno and Pearsall 1998; Zarillo et al. 2008; ChandlerEzell et al. 2006; Pearsall et al. 2004, Pearsall n.d.), arrowroot is underrepresented in Peruvian archaeological contexts. Thus far, the only other evidence for arrowroot in Central Andes comes from microfossils at Waynuna in the southern highlands in contexts dating to 4000-3600 B.P. (Perry et al. 2006). At several thousand meters above its natural range, the arrowroot at Waynuna certainly represents a cultivated variety, which Perry et al. (2006) suggested may have been imported from the eastern lowlands. Identification of 
microfossils of arrowroot at Buena Vista suggests an alternative source, on the coast as early as the Late Preceramic. Wild Maranta is not known to grow on the coast of Perú (see Chapter 6 for discussion), therefore it is highly unlikely the starch grains identified in this study represent a wild form. Also, arrowroot requires rainfall of 1500-2000 mm per year (Piperno and Pearsall 1998), far more than occurs on the desert coast of Perú, but its need for water could easily be mitigated through floodplain irrigation. Thus, a parsimonious explanation for the presence of arrowroot starch on these gourd artifacts is that it was cultivated near Buena Vista. However, that arrowroot may have been imported from the lowlands should also be considered.

Two starch grains identified to the pods of Prosopis (algarrobo) in the Fabaceae family were found on gourd fragments, Artifacts 2 and 3 (Figure $8.11 \mathrm{f}$ ). These granules have a very unique appearance, lobed shape protuberances and a deeply depressed area at the hilum, along with a very irregular extinction cross. A valuable systematic study of starch from Prosopis was done by Giovannetti et al. (2008). From the starch types they identified from P. chilensis and P. flexuosa, one, Type B2-totally irregular with more than two protuberances and/or facets irregularly disposed (see also Fig 4, 13-18 ibid.), corresponds well to the archaeological types in this study. Further comparative work is needed, but this starch type appears to be a generic indicator of starch produced in the pods of Prosopis.

The genus Prosopis consists of several closely related and morphologically similar species, thus, there is considerable confusion in the botanical (Pasiecznik et al. 2001:22) and archaeological (Towle 1961) literature regarding its identification. To further complicate matters, inter-specific hybridization is common enough that many individual 
specimens cannot be assigned a single species by morphology alone (Pasiecznik et al. 2001). Currently, the dominant Prosopis on the coast of Perú is P. pallida, with P. chilensis in higher elevations of the south, and P. juliflora in the northwest (Díaz Celis 1995 in Pasiecznik et al. 2001:22). Each of these species produces similarly sweet edible pods. The similarity between species is likely to be reflected in the starch grains from the pods, as well. For example, Giovannetti et al. (2008) found no differences in starch morphology between Argentinean P. chilensis and P. flexuosa. The starch grains they describe are likely to be characteristic of other algarrobos with sweet pods. Algarrobo seeds do not contain starch.

Algarrobo is ubiquitous in archaeological contexts in Perú, most often as a fuel wood or construction material (Quilter et al. 1991; Goldstein 2007), or more rarely its seeds and edible pods (Towle 1961). A much deeper history of algarrobo use occurs in archaeological contexts in Argentina dating back as early as 10,000 B.P. (Giovannetti et al. 2008). In Perú, much less is understood regarding the prehistoric consumption of algarroba pods which can be ground into flour to make a syrup, algorrobina, or for drinks, such as the fermented beverage, chicha de algarrobo, produced today at a household level in northern Perú. At this time, this study presents the earliest indirect evidence of algarrobo consumption in central Perú.

Among the unidentified starch grains are those that have features inconsistent with the Cucurbitaceae material studied, are not currently represented in our comparative collection, or are starch grains that have been damaged in some way as to make their identifications problematic. In Artifact 2 Sediment 1, grain E is large sphere showing center damage to the hilum consistent with milling or grinding (Pilar Babot 2003; Henry et 
al. 2009) (Figure 8.12 a). A granule with similar morphology and damage was found on Artifact 4 Sediment 1 (Grain B) (Figure 8.12 b). Both of these grains are relatively large and the stellate structures at the hilum suggest Manihot esculenta or another species of root or tuber. Another damaged grain was found on Artifact 5 Sediment 1 (Figure 8.12 c).

Structural tearing is present at the distal end of the grain, however the damage did not negatively affect its birefringent properties. The grain is classified as unidentified at this time.

Other unidentified grains at this time include a hemisphere, or bell-shaped grain, with a roughened basal facet on Artifact 3 Sediment 2 (grain E) (Figure $8.11 \mathrm{~d}$ ). Another grain on Artifact 4 (Grain F) has some peculiar and unusual features: a single indentation or facet at one end and a ridged area at the closed hilum (Figure 8.11e).
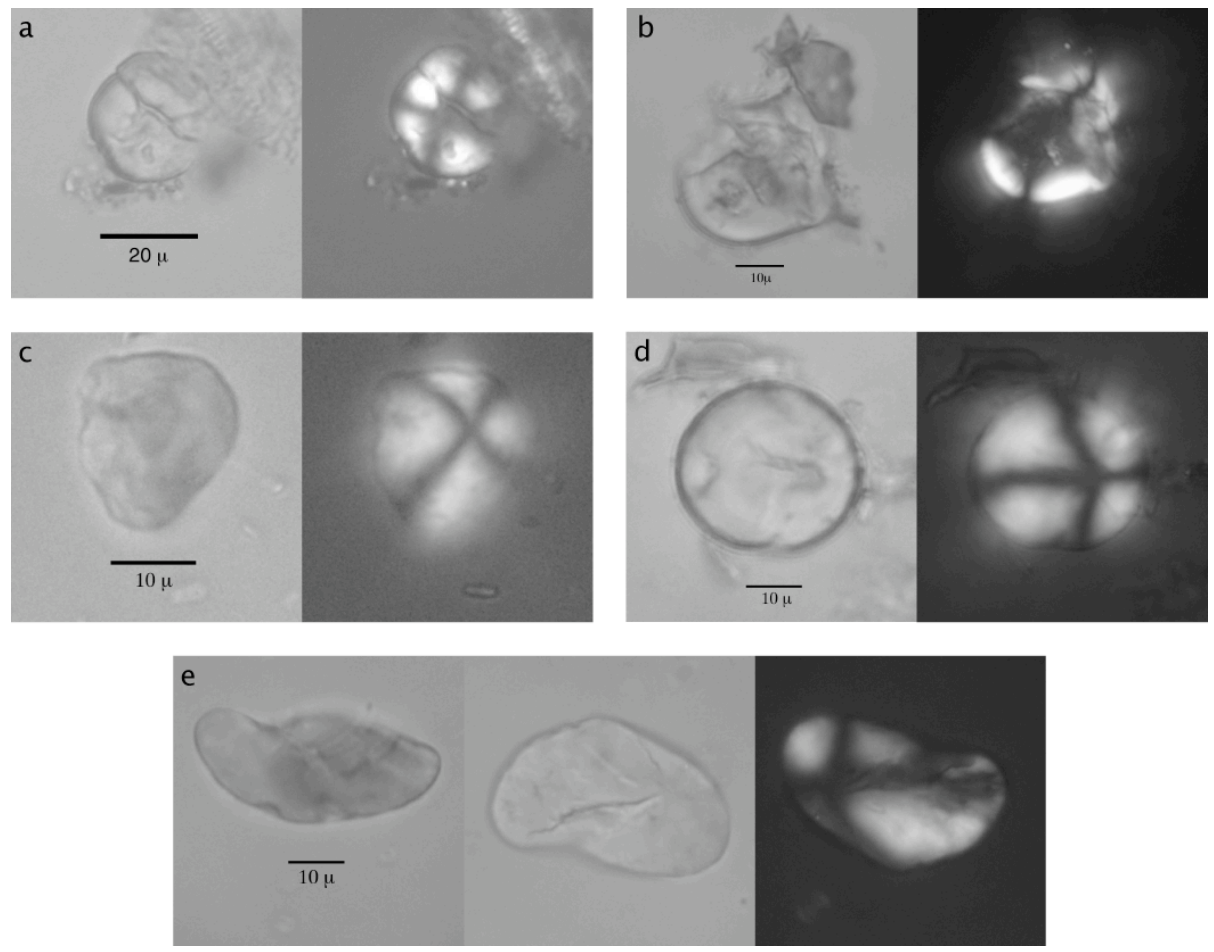

Figure 8.12 Unidentified starch grains from cucurbit artifacts. See text for descriptions. 


\section{DISCUSSION}

This experimental method for extracting microfossils from the residues of gourd, and squash artifacts provides a new approach to identifying the function of these fruits in archaeological contexts. It will be a particularly important method for understanding cuisine and consumption in archaeological contexts in which these artifacts are preserved. This study shows that starch and phytoliths of food residues can be extracted and analyzed from gourd vessels that were used in food production or consumption. In addition, the presence of foods, algarrobo and possibly manioc, in the residue from a squash rind fragment documents the similar use of squash fruits as vessels for other foods in South America. This study was also successful in documenting the earliest evidence for arrowroot in Perú and the earliest direct evidence of the utilization of algarrobo pods for food. The presence of arrowroot starch on the artifacts also supports an interpretation of arrowroot presence based on the phytolith data from sediment samples at the site. Other foods identified include manioc, potato, and chili pepper, all of which were known cultigens on the coast of Perú, however, particularly for the root/tuber remains, they are not always well represented in macroremain assemblages. At Buena Vista, the presence of manioc, arrowroot, and potato, and possibly achira, (Canna indica), in phytoliths, brings to fore direct evidence for the use of these taxa as foods. Being far from their natural wild distribution, the most likely scenario is that these roots and tubers were cultivated in the valley floor.

In regard to the archaeology at Buena Vista, the fact that these artifacts of serving vessels or food preparation containers were recovered from the upper levels of the sunken 
pit in Unit B-10, is consistent with the interpretation of discard generated in food-related activities, most likely a feasting event or events just prior to the interment of the temple.. The unique architectural feature from which the artifacts were recovered suggests a special ritual use of food in a feasting context. The social and ritual use of food in emergent complex society is not well understood, especially in Perú, and this research enhances our potential for understanding these issues. In addition, we should consider how these plants were consumed. I suggest that fermented beverages were prepared from manioc and algarrobo, both of which are known libations in later periods. Manioc and algarrobo are fermentable in preparing alcoholic beverages (Denevan 1974; Pasiecznik et al. 2001; and see Chapter 9) and this practice likely has great antiquity despite a lack of archaeological evidence of alcohol production during the Preceramic. The possibility that these plants could have been used in the production of alcohol at Buena Vista should not be overlooked. 


\section{Chapter Nine - Discussion and Concluding Remarks}

The objective of this dissertation has been the analysis of paleoethnobotanical materials recovered from special archaeological contexts at Buena Vista with a goal towards evaluating the evidence for feasting at a Late Preceramic site. The analysis of plant macroremains, phytoliths, and starch grains sampled from multiple contexts at Buena Vista consequentially provides significant clues to subsistence at an inland monumental center and provides further evidence for interregional exchange during the Late Preceramic. As discussed in Chapter 2, the identification of feasting in the archaeological record is an inductive process that compares archaeological observations to criteria of feasting compiled from the ethnographic and ethnohistoric record. Feasting as a communal sharing of food and drink in a special social context or for special purpose, may be seen as a form of public ritual activity, having condensed symbolic representation of social relations (Dietler 2001:71). Feasts may also have very practical functions in generating and maintaining social difference for those who organize and host them (Hayden 2001). Practically, feasts can mobilize labor, while simultaneously creating and maintaining cooperative and reciprocal relationships among their participants. Without making an a priori assumption that feasting occurred at Buena Vista, it is worthwhile reiterating some of the criteria used to interpret feasting from the material record. Following Hayden (2001), there are a 
number of material correlates of feasting that apply to the Buena Vista materials. First, the architecture of Buena Vista's temple mound provides the ritualized spatial context within which a feast could occur. Second, the remains of consumed food are disposed of in a special location, in this case the sunken pit in the Gran Sala. Third, the material remains of foods are the remains of foods consumed by people, not those given as offerings. Fourth, serving vessels are disposed of with the consumed foods, in this case the gourd and squash fragments from which starches and phytoliths show they were used in the serving and preparation of foods. The fifth criteria is the presence of food preparation areas, here the room in Unit C-6 serves this purpose. Finally, rare items or foods, such as heliconia, arrowroot or leren in this example, may indicate the presence of special rare foods with high symbolic meaning. In the following section, I will review the archaeological contexts that were studied, then discuss the criteria of feasting in a broader ritual and social context.

\section{Archaeological Contexts of Macroremains, Phytoliths, AND Starch}

Using data from macroremains, phytoliths, and starch provides a strong basis for comparison to other sites, but also for the comparison of contexts within Buena Vista to identify the function of those sampled contexts: the sunken pit in the center of the Gran Sala and the architectural complex of rooms sampled in Units C-6 and C-10. By far, the sunken pit provided the most robust dataset, in terms of abundance, diversity, and richness of the plant materials, but also revealed the presence of new foods from residues on gourd and squash artifacts buried in the pit.

For the sunken pit in the Gran Sala, the pattern of deposition is indicative of a deliberate and sequential burial of the pit; each level was possibly associated with a 
sequence of ritual events that filled the pit just before the entire room was filled in with large boulders and bags of shicra. A layer of round river cobbles and gravel horizontally divides the contents of the pit. Beneath the cobbles were discarded food remains and other plants, such as cotton seeds atop a layer of grass lining the floor. In the upper levels of the pit above the round cobbles and gravel, the overall density of plant remains increases dramatically and food remains increase in abundance, richness and diversity suggesting and even greater contribution of remains associated with activities involving food. Patterns of phytolith deposition seem to correspond to the macroremain sequence; a general increase in richness of phytolith types produced by herbaceous plants occurs, probably reflecting the increase in diversity of macroremains above Level 350. Phytoliths from the sediments also provide some evidence of foods, including some not occurring in the macroremain assemblage. These plants are discussed in more detail below. Starches from the sediments in the pit, and elsewhere at the site, only provided tentative identifications.

In comparison to the Gran Sala, activities involving the use of food are also evident in other areas of the site. In Unit B-7, a small assemblage of plant remains was found on the floor, including seeds from squash and guava and a gourd fragment. In Unit C-6, a room with a central hearth, ulluco, sweet potato, lucuma, guava, bean pods, chili and squash were found in the floor matrix and in the hearth. Charcoal, ash, and wood fragments, too, were scattered throughout the floor. The scattered refuse throughout the room and the ephemeral, impermanent nature of the hearth construction suggest that this room was used as a food preparation area and not as a residence or for the burning of ritual offerings. House floors are usually swept clean and the burning of ritual offerings 
would more likely be confined to the hearth area rather than scattered on the floor. The deposition pattern in Unit C-6 contrasts sharply with that of the Gran Sala and the sunken pit, where materials were apparently gathered to be deposited in the pit, leaving the room almost perfectly clean. These contrasting depositional patterns reflect different activities that occurred in these two areas and, as discussed below, might represent different symbolic meaning associated with each.

In addition to macroremains and microfossils from sediments, this study also provides a novel method for extracting microfossils from residues of gourd and squash artifacts. Gourds and squashes were not only sources of food - seeds and the fruits of squashes - but provided valuable and durable tools for containers especially before the adoption of ceramics. This new method adds to the interpretation of gourd and squash artifacts as containers for serving and preparing food. The artifacts in this study were collected from the macroremain assemblage in the sunken pit and provide further evidence for food use in feasting, such as starch grains from manioc, potato, and chili pepper, and phytoliths possibly from achira. The study also provides the earliest evidence thus far for arrowroot use in South America and the first direct evidence for the use of algarrobo pods for food or drink. The gourd and squash artifacts recovered from the sunken pit were used as vessels for the serving and the preparation of foods, consistent with the interpretation of discard generated by activities involving food. 


\section{Buena Vista in Ritual CONTEXT}

The special architecture at Buena Vista provides the ritual setting for feasting and other ritualized activities to occur. Multiple lines of evidence converge in support for the interpretation of Buena Vista as ritual architecture, as discussed earlier in Chapter 2. The architecture of the site contains features that are similar to those of other Late Preceramic ritual constructions, identified as the Kotosh Religious Tradition or the Mito Tradition, in the form of the niche-walled sunken pit in the Gran Sala of the temple (Unit 10, Feature 1). There are also significant differences that make Buena Vista a unique example of Late Preceramic monuments, notably the menacing disk and its attendant foxes excavated in 2005 (see Chapter 1, Figure 1.3). Buena Vista is also unlike other coastal monumental sites of the Late Preceramic, such as Caral and others in the Supe Valley region, all of which contain sunken circular courts. No such feature appears to be associated with the temple architecture at Buena Vista. However, a theme common to both Buena Vista and other Late Preceramic sites appears to be the division of ritual space from public to private. At Buena Vista, overlapping stairways for ritual procession, and observance by those below, to the top of the temple mound where the ritual participants descended into an exclusive and mysterious place where their activities would not have been observable by those outside or at the base of the stairs.

The contents of the sunken pit in the Gran Sala provided a rare opportunity to explore plant use associated with ritual architecture from a much different perspective than has been done before with materials of this time period. The remains of consumed foods were sequestered and disposed of in the pit. During excavation, many of us thought that 
these plant remains, particularly the food remains, were offerings put in the pit during ritual, a logical assumption given that offerings are commonly found associated with monumental architecture. However, upon analysis, the plant remains of foods were found to consist entirely of post-processed waste such as seeds, rinds, and peels. Given the excellent preservation and near pristine condition of plant remains recovered from the pit, it is very unlikely the plant remains suffered much taphonomical degradation that would make them falsely appear to be byproducts of food preparation. Together with large amounts of charcoal, wood fragments, and leaves, it is more likely the plant remains were disposed of in the pit in nearly the same condition they were recovered. Given that these plant remains are refuse, the symbolic value of the remains in the pit takes on a very different connotation than if they were whole or in the form of prepared foods, as would be expected if the remains were offerings. Perhaps this point should be made more explicitly.

There are significant symbolic differences between offerings and refuse. An offering is like a gift in that what is given is something which is personal to the giver, has some value to both the giver and the recipient, and it is given voluntarily with a sentiment of respect toward the recipient (Firth 1963). Offerings have any number of functions as human-divine transactions, to placate, to please, or to praise a divine power, or have reciprocal function, such as an offering made in exchange for divine favor (Bell 1997:108). The presence of refuse in a context one might expect to contain offerings is vexing and very much unlike sites of the Kotosh Religious Tradition, where burnt offerings were made. Both burnt offerings and feasts involve the consumption of food and the generation of refuse. For 
burnt offerings, the refuse is of a divine meal in which the gods consume the food (and goods) through fire (see Bolin 1998:42 for a modern Andean example). For feasts, people eat the foods. For both, the act of consumption destroys that which is being consumed; therefore the consumed food cannot be recirculated or reinvested in the exchange. In the context of reciprocal exchange (Mauss 1966), Dietler (2001:73) points out that commensal consumption is the literal 'embodiment' or 'incorporation' of the gift and the social debt it engenders; thus, a symbolic distinction between burnt offerings and the refuse of human meals is an important element of meaning for refuse in the pit. If an offering, the refuse of human consumption would hold no value for the divine. Moreover, if offerings invoke a complex interplay or reciprocal relationship between the human and the divine (Bell 1997:109), that interplay implies an asymmetrical status relationship between the giver, humans, and the recipient, the divine (Firth 1963:12). The presence of refuse in the pit inverts this asymmetrical relationship. The refuse in the pit severs the reciprocal relationship, perhaps ritually cancelling the pit just before entombment.

In contrast, the room surrounding the raised platform and the pit, the Gran Sala, was found in virtually pristine condition, without refuse on the floor. Just prior to the construction process and burial of this room and the pit, the room was apparently cleaned. All that remained was a single large tree trunk. This pattern of clean and non-clean suggests a deliberate sequestration of refuse into the sunken pit; the refuse probably came from the surrounding room, but may have come from adjacent areas as well. In contrast, there is very different pattern of cleanliness in the rooms of Sector $\mathrm{C}$ where ritual meals might have been prepared. In the room of Unit C-6, fairly large amounts of debris, similar in 
composition of materials in the hearth at the room's center, were found throughout the matrix of the floor. Apparently, this room, unlike the Gran Sala, was not cleaned prior to its burial. From a structuralist point of view, following Mary Douglas (1966), this pattern of cleanliness in the Gran Sala where rituals were performed in contrast to unclean areas where meals were prepared, suggests there were strict rules for cleanliness, perhaps symbolic purity that needed to be maintained for the Gran Sala, a maintenance of sacred space. The deposition of refuse into the pit suggests an attempt to desacralize the pit by subjecting it to unclean waste.

\section{Ritual cleaning prior to entombment is known from other Late Preceramic} monumental sites such as those in the Kotosh tradition. For example, Burger and SalazarBurger (1985) noted the scarcity of artifacts or refuse in areas where rituals occurred; material remains were confined primarily to the central hearths of the ritual chambers. As discussed above, the hearth contents of burnt offerings likely held very different significance than the refuse in the pit at Buena Vista.

The symbolic cancellation of the pit followed other rituals. Robert Benfer (et al. 2007; n.d.) suggests the pattern of fill, in particular the layer of round river cobbles, is consistent with the concept of ushnu, where liquids, e.g. chicha in later times, were poured as offerings into rectangular structures. Microfossil evidence from starch or phytoliths from the soils in the pit is inconclusive of liquid offerings, but if the pit was used in such a way, it was likely coordinated with other rituals, including feasting, and timed to occur just before the room was interred; the radiocarbon date from Level 300, above the layer of round stones in Level 350, and the date from the lowest level, Level 425 at the base of the 
pit both return the same date of $2200 \mathrm{cal}$ B.C. In the macroremains, there is an increase in abundance, richness, and diversity of the discarded materials, especially food remains in the upper levels above the round cobbles. One can only speculate why the pit was filled in with discard immediately after being used as a receptacle for liquid offerings. Perhaps the timing of these events coincided with the end of a ritual cycle that negated the ceremonial usefulness of the pit. Or, perhaps the rituals conducted did not have the desired outcome of divine intervention.

We may never know why the pit, perhaps used first as an ushnu, was filled in such a way, but the remains themselves, the consumed foods, cotton seeds, and other refuse, provide material evidence for activities, such as feasting, ongoing up to the time the room was buried. At this point, we might infer the function of feasting that generated the food materials in the pit. One function of feasting is in the mobilization of labor. Excavations of the temple mound revealed multiple building episodes and repeated sequences of fill, a process that has been called "temple entombment" (Izumi and Matsuzawa 1967) or "temple renovation" to distinguish renovations from entombment related to abandonment (Onuki 1993). Here, I do not make such a distinction and for practicality use both terms synonymously. Renovations at Buena Vista probably occurred over several generations, although radiocarbon dates are still needed to confirm the earliest constructions. The extended time over which renovations occurred and the generally small-scale renovations to the temple mound did not require massive mobilizations of labor. Perhaps small work parties could be mobilized through the hosting of feasts. 
A contemporary example appears at Cerro Lampay. Vega-Centeno's $(2005,2007)$ excavations revealed a similar entombment process, although his scale of analysis of the architectural sequence is much greater than this study of the Buena Vista materials. At Cerro Lampay, like Buena Vista, construction processes consisted of temple entombment, whereby an existing architectural space was filled in and a new architectural space was constructed on top. Vega-Centeno was the first to identify feasting associated with this process. At Cerro Lampay, food preparation, consumption, and cleaning all occurred within architectural spaces just prior to their entombment. Burned areas on prepared floors, that previously were not cooking areas (lacking hearths), and trash deposits over floors in the lower levels of fill, that entombed the rooms, suggest that activities involving food preparation and consumption occurred immediately before construction events. VegaCenteno reasons that those who participated in the feasting were the same as those who participated in the construction.

At Buena Vista, because the timing of the burial of the Gran Sala containing the pit coincides with the final rituals and feasting that occurred there, those who participated in the constructions were likely the same who participated in the rituals and feasting. At Buena Vista, as at Cerro Lampay, feasting was likely part of a labor motivation strategy invoked by an individual or group of some higher sociopolitical influence. The highly repetitive nature of construction processes over time at Cerro Lampay reflects for VegaCenteno a weak authority not capable of mobilizing large amounts of labor for significant construction events. A similar scenario probably existed at Buena Vista as well, given the small-scale renovations over time. 
Labor probably came from the entire community that was involved in the production of the rituals and the preparation of meals. Some of the other contents in the pit fill at Buena Vista provide clues to those who participated in the rituals, specifically, the large amount of cotton seeds in the macroremain assemblage. One explanation is that the processing of raw cotton bolls for their fiber resulted in an abundance of cotton seeds. I propose that the presence of cotton seeds in such abundance is due to the participation of women and men in either the production of ritual and/or the preparation of meals. This would be a very worthwhile topic to pursue but requires more rigorous testing than this dissertation can accomplish. Therefore, I will just provide only a brief discussion in support of this interpretation.

Cotton was a very valuable resource by the Late Preceramic as it was associated with subsistence in the production of nets for fishing (Moseley 1975, 2001), but also in the production of textiles (Moseley and Barrett 1969). Various aspects of textile production may have gendered domains and many examples exist of gender divisions associated with planting and harvesting that can be referenced cross culturally. It is difficult to identify gendered divisions of labor, given a lack of other material evidence from Late Preceramic sites. For the Andean region, however, there is significant evidence for gendered domains of agriculture and the production of textiles in the ethnographic and ethnohistoric record. It is a tenuous thread that links the ethnographic present to the Late Preceramic past, but I suggest that it may be possible to identify and test hypotheses of gender divisions even in the Preceramic. Examples from the present provide clues. In the Andes, the Inka, and later colonial, demands for labor no doubt influenced contemporary divisions of labor (Howard- 
Malverde 1997:102-3; Kellogg 2005:50). Today, weaving in the Andes is often considered a quintessentially female task (Kellogg 205:50), but the divisions are never sharp. Both men and women weave and spin wool, but women tend to be responsible for finer textiles and embroidery (Bolin 1998:119; Allen 2002:57-58; see also Bourque and Warren 1991:192). In the lowland Amazon, gender divisions for weaving may be much more strict. For example, Shipibo women are responsible for the entire production of textiles: from planting and harvesting of cotton, to spinning, to weaving (Eakin, Lauriault and Boonstra 1986:17).

Did gender divisions, particularly the domain of weaving and spinning, exist in the past? There is limited evidence, for example, spindle whorls and cotton are found associated with Moche female burials (Strong and Evans 1952; Donnan Machey 1978; see also Gero 1992). At Buena Vista, cotton textile and net production may have been gendered in that, based on modern and archaeological examples from later contexts, the spinning and weaving of cotton were part of a domain of work primarily done by women. But this alone does not explain the abundance of cotton seeds in the refuse. The seeds were not likely offerings because of their association with other refuse. One explanation is that cleaning of cotton seeds, spinning thread, and possibly weaving were being conducted during idle periods, such as in between ritual events or while cooking. This activity could have a ritualized aspect to it, possibly with the participation of men and women, or simply cleaning cotton was just something to do. For example, Allen (2002:57) notes that women, much less so men, are nearly always spinning wool when other tasks do not demand their attention. Goldstein and Shimada (2010), in archaeological contexts, interpreted spinning, 
along with coca chewing, as "waiting" activities during long-term cooking or ceramic firing. Whether ritualized or more mundane, the cleaning of cotton at Buena Vista probably indicates the participation of an entire community, both men and women, in ritual and in the preparation of feasts.

\section{BuENA VisTa In SOcial CONTEXT}

Buena Vista is the only documented Late Preceramic site in the inland Chillón Valley. Only two sites in the lower Chillón region are known containing monumental architecture (Lanning 1967; Moseley 1975). Punta Grande consists of a series of artificial terraces, probably living surfaces, at the base of a hill (Moseley 1975:25), now nearly destroyed under the urban expansion of Lima. The other, El Paraíso, is one of the largest sites of its kind in this period (Patterson and Lanning 1964; Engel 1966; Moseley 1975; Quilter et al. 1991). In the Chillón, only this Late Preceramic site rivals Buena Vista in terms of architectural grandeur and intricacy of design. El Paraíso and Buena Vista differ significantly in terms of scale, the former being much larger, laid out in a possible U-shape on the valley floor, while the latter is more of an accretional construction on a hillside.

Buena Vista and its sprawling coastal neighbor beg comparison chiefly because El Paraíso features prominently in several models of social organization and emerging complexity during the Late Preceramic based explicitly on data from the Chillón region (Patterson 1971; Cohen 1977; Moseley 1975). Subsistence is key to these models of social change; therefore the paleoethnobotanical dataset from Buena Vista, El Paraíso's inland contemporary, provides a vital comparison. As discussed in more detail in Chapter 4, Michael Moseley (1968, 1975, 1985; Sandweiss and Moseley 2001) put forth one of the 
most widely argued explanations of the development of complex society on the coast of Perú. In the Maritime Foundations of Andean Society (MFAC), Moseley hypothesized that complex society developed on the coast of Perú without an agricultural base for subsistence. Rather, the marine resources supplied enough food and surplus to allow for sedentary populations to develop complex social and political structures. At the MFAC's conception, very little was known about inland sites, like Buena Vista, though others, particularly Thomas Patterson (1971), hypothesized that these yet to be found inland sites were integrated into an agriculturally centered economy with sites on the coast. Others critiqued the model for what was perceived as an over reliance on unstable marine resources (Wilson 1981; 1999; see also Raymond 1981), but these critiques were somewhat flawed as discussed in Chapter 3.

Some criticisms of the MFAC, however, were valid, such as Raymond's (1981) points that El Paraíso and other Late Preceramic monumental sites are located in areas of very arable land and that the contribution of root crops as significant staples is highly underestimated. It is also significant that the appearance of monumental architecture coincides with a dramatic increase in the richness of cultivated foods (Pearsall 2003). At this time, our knowledge of inland sites is growing rapidly due to new data from the Supe Valley region (Shady 1999; Shady et al. 2001) where marine products are found with cultivated and managed plants. Moseley (2001:112; Sandweiss and Moseley 2001) has since proposed a "fishing-farming symbiosis" that allows for a greater contribution of agriculture in subsistence of early complex society. 
Cultivated plants are found at all of the Late Preceramic monumental sites. However, quantifying the contribution of agriculture is difficult because of uneven preservation of important cultigens, such as root crops. For coastal sites, a superabundance of marine foods in the remains biases the archaeological record and this, combined with a not-so-careful sampling for plant remains until recently, has given us a somewhat skewed perspective on subsistence during the Late Preceramic. Clearly the primary source of protein at coastal sites came from marine resources, but evidence that precocious inland sites with monumental architecture appeared simultaneously with new cultivated plants not native to the western slopes of the Andes indicates strongly that agriculture must be taken seriously as a significant contributor to subsistence in the Late Preceramic.

Determining how inland sites were integrated with coastal sites is beyond the scope of this dissertation. But a comparison of paleoethnobotanical findings from Buena Vista to El Paraíso and other Late Preceramic sites is insightful because it provides additional clues to subsistence, adds to evidence of far-reaching interregional interaction, and provides possible evidence for special use of foods in feasting and ritual. In Table 9.1, I present a comparison of the presence of domesticated or managed plant resources at Buena Vista, El Paraíso, and several other examples of Late Preceramic sites: coastal Aspero, inland Cerro Lampay and Caral, and highland sites La Galgada, Waynuna, and sites in the Zaña Valley region. At Buena Vista, more so than any other Late Preceramic site, there is a rich assemblage of root crops, several of which are not well represented at other sites. For example, manioc, sweet potato, arrowroot, ulluco, and potato are not well represented or 
rare at other Late Preceramic sites, but all are present at Buena Vista. Interestingly, one of the most ubiquitous root/tuber cultigens, achira, is not positively identified in the Buena Vista macroremain assemblage, but may be indicated by phytoliths of a mixed Marantaceae/Cannaceae type and by phytoliths in the residue of a gourd artifact.

\begin{tabular}{|c|c|c|c|c|c|c|c|c|c|}
\hline & & $\begin{array}{l}\text { Buena } \\
\text { Vista }\end{array}$ & $\begin{array}{c}\text { El } \\
\text { Paraíso }\end{array}$ & Aspero & $\begin{array}{c}\text { Cerro } \\
\text { Lampay }\end{array}$ & Caral & $\begin{array}{c}\text { La } \\
\text { Galgada }\end{array}$ & Waynuna & $\begin{array}{l}\text { Zaña } \\
\text { sites }\end{array}$ \\
\hline & & 2200 & 1800 & 2410 & 2400 & 2627 & 2662 & 2050 & 7290 \\
\hline & Years BC & & & & & & & & \\
\hline & Common & & & & & & & & \\
\hline Genus species & Name & & & & & & & & \\
\hline \multicolumn{10}{|l|}{ Bunchosia } \\
\hline Canavalia sp. & jack bean & $\mathrm{m}$ & & & & & $\mathrm{m}$ & & \\
\hline Canna indica & achira & ps & $\mathrm{m}$ & $\mathrm{m}$ & $\mathrm{m}$ & $\mathrm{m}$ & $\mathrm{m}$ & & \\
\hline Capsicum spp. & chili & $\mathrm{m} \mathrm{s}$ & $\mathrm{m}$ & $\mathrm{m}$ & $\mathrm{m}$ & & $\mathrm{m}$ & & \\
\hline Crescentia cujete & totumo & & & & $\mathrm{m}$ & $\mathrm{m}$ & & & \\
\hline Cucurbita spp. & squash & $\mathrm{mp}$ & $\mathrm{m}$ & $\mathrm{m}$ & $\mathrm{m}$ & $\mathrm{m}$ & $\mathrm{m}$ & & $\mathrm{m}$ \\
\hline $\begin{array}{l}\text { Gossypium } \\
\text { barbadense }\end{array}$ & cotton & $\mathrm{m}$ & $\mathrm{m}$ & $\mathrm{m}$ & $\mathrm{m}$ & $\mathrm{m}$ & $\mathrm{m}$ & & $\mathrm{m} \mathrm{s}$ \\
\hline \multirow[t]{2}{*}{ Inga feuilleei } & pacae & $\mathrm{m}$ & & $\mathrm{m}$ & $\mathrm{m}$ & $\mathrm{m}$ & $\mathrm{m}$ & & s \\
\hline & sweet & & & & & & & & \\
\hline Ipomoea batatas & potato & $\mathrm{m}$ & & & & $\mathrm{m}$ & & & \\
\hline Lagenaria siceraria & gourd & $\mathrm{m}$ & $\mathrm{m}$ & $\mathrm{m}$ & $\mathrm{m}$ & $\mathrm{m}$ & $\mathrm{m}$ & & \\
\hline Manihot esculenta & manioc & $\mathrm{m}$ & & & $\mathrm{m}$ & & & & $\mathrm{m}$ \\
\hline $\begin{array}{l}\text { Maranta } \\
\text { arundinaceae }\end{array}$ & arrowroot & $\mathrm{m} \mathrm{s}$ & & & & & & $\mathrm{ps}$ & \\
\hline Pachyrrhizus sp. & jikima & $\mathrm{m}$ & $\mathrm{m}$ & & & & & & \\
\hline Persea americana & avocado & & & & & & $\mathrm{m}$ & & \\
\hline Phaseolus spp. & beans & $\mathrm{m} \mathrm{p}$ & $\mathrm{m}$ & $\mathrm{m}$ & $\mathrm{m}$ & $\mathrm{m}$ & $\mathrm{m}$ & & $\mathrm{s}$ \\
\hline Pouteria lucuma & lucuma & $\mathrm{m}$ & $\mathrm{m}$ & & $\mathrm{m}$ & $\mathrm{m}$ & $\mathrm{m}$ & & \\
\hline Psidium guayaba & guava & $\mathrm{m}$ & $\mathrm{m}$ & $\mathrm{m}$ & $\mathrm{m}$ & $\mathrm{m}$ & $\mathrm{m}$ & & \\
\hline Solanum & & & & & & & & & \\
\hline tuberosum & potato & $\mathrm{m} \mathrm{s}$ & & & & & & $\mathrm{s}$ & \\
\hline Ullucus tuberosus & ulluco & $\mathrm{m}$ & & & & & $\mathrm{m}$ & & \\
\hline Zea mays & maize & & & & $\mathrm{m}$ & $\mathrm{m}$ & & p s & \\
\hline Arachis hypogea & peanut & & & & & & & & $\mathrm{m} \mathrm{s}$ \\
\hline Chenopodium & & & & & & & & & \\
\hline quinoa & quinoa & & & & & & & & $\mathrm{m}$ \\
\hline Heliconia sp. & heliconia & $\mathrm{p}$ & & & & & & & \\
\hline Calathea allouia & leren & $\mathrm{p}$ & & & & & & & \\
\hline
\end{tabular}

Table 9.1 Cultivated plants from selected Preceramic sites in Perú. $\mathrm{m}=$ macroremains, $\mathrm{s}=\mathrm{starch}, \mathrm{p}=$ phytoliths represented. Sources: El Paraíso (Quilter et al. 1991; Pearsall lab documents), Aspero (Feldman 1980), Cerro Lampay (Vega-Centeno 2005), Caral (Shady 1999, 2006), La Galgada (Grieder et al. 1988; Smith 1988), Waynuna (Perry et al. 2006), Zaña sites Rossen et al.1996; Dillehay et al. 2007; Piperno and Dillehay 2008) 
A direct comparison of Buena Vista's botanical assemblage to El Paraíso's reveals that all cultivated taxa identified at El Paraíso also appear at Buena Vista. In comparing other sites, too, most cultivated plants that appear at Late Preceramic sites also appear at Buena Vista. The few exceptions are: ciruela de fraile, avocado, totumo (Crescentia cujete; a managed lowland tree), peanuts, quinoa, and maize, all of which are lacking at Buena Vista. Of these plants, several become ubiquitous at later sites in the Initial Period: ciruela, avocado, peanuts, quinoa and maize (Pearsall 2003). Present at Buena Vista are two possibly cultivated plants that are not found in other sites of this time period, heliconia and leren (Calathea allouia), and one, arrowroot, that is only known from one other Peruvian site in the Andes, Waynuna. In general, both the coastal and inland sites share similar suites of cultigens. The highland sites Waynuna in the south and those in the Zaña Valley in the north appear to have somewhat less diversity, due in part to poor macroremain preservation. Nevertheless, these highland sites provide evidence for the early cultivation of introduced plants, such as peanuts, squash, and manioc at Zaña sites and arrowroot and maize at Waynuna.

For archaeologists, one of the most difficult aspects of agriculture in the Late Preceramic of Perú is in understanding early interregional interactions; many cultivated plants arrived as already domesticated plants from the northern or eastern selva. These cultigens begin to appear in the Late Preceramic simultaneously with monumental sites on the coast. They include: cotton domesticated in northern Perú or Ecuador (Westengen et al. 2005), chili peppers from eastern slopes of the Andes or lowland Bolivia (Perry et al 2007), manioc from the southern Amazon basin (Olsen and Schaal 2001), avocado from 
the northern Andes (Piperno and Pearsall 1998), and sweet potato possibly domesticated in northern South America (Austin 1988). At Buena Vista, phytolith evidence of leren (Calathea allouia), heliconia (Heliconia sp.), and arrowroot (Maranta arundinacea) show even further evidence for early interregional interaction. The areas of origin for leren and arrowroot, both cultivated plants common throughout the Neotropics, are not yet fully understood (Pearsall n.d.) but they are most likely native to northern South America. Heliconia, likewise is not native to the coast of Perú, but grows in coastal Ecuador and on the eastern slopes of the Andes and lowland Amazon. The presence of these plants most likely reflects ancient interconnectedness between the lowlands, the eastern Andes and the sierra that eventually included the coast (Spinden 1917; Lathrap 1973, 1977; Pearsall 2003, 2008; Perry et a. 2006).

The paleoethnobotanical data from Buena Vista generate several questions. For instance, are heliconia, leren, and arrowroot early introductions grown on the coast, or are they evidence of exchange networks of plant products linking the coast to the north and the selva? Are they early coastal cultigens, like sweet potato, achira, manioc, and chili peppers? Because each of these plants could have been cultivated in the floodplain of the Chillón Valley, perhaps arrowroot, heliconia, and leren, too, were part of the suite of plants that arrived on the coast of Perú, were grown initially, but eventually ceased to be cultivated over time. The utility of heliconia and Marantaceae species for their broad pliable leaves used as wrappings in cooking food was perhaps supplanted by ceramics and thus these plants were no longer cultivated. Some species of heliconia also have edible tubers like leren and arrowroot, but perhaps these three foods were abandoned in favor of 
other root/tuber plants, manioc, potato and sweet potato, as culinary tastes changed over time. Evidence for heliconia, leren and arrowroot is absent or rare at other sites, but as discussed below, microfossil studies could reveal their presence.

An alternative hypothesis to local production is that plants such as heliconia, leren, and arrowroot represent continued interzonal interaction at Buena Vista, possibly coming into Buena Vista as part of trade or with visitors. For instance, goods or foods wrapped in bundles of leaves from heliconia and Marantaceae could have been transported long distances. This idea is not new, for example, Donald Lathrap (1973) proposed that there was substantial interchange between people in southwestern Ecuador and coastal Perú. Early settlements on the north coast likely had interactions with peoples to the north and the Amazon. In northern Perú, the Huancabamba Depression (Sagastegui et al. 1999), between $4^{\circ}$ and $6^{\circ}$ degrees South latitude provides one of the easiest passes from the coast to the headwaters of the Marañon River that flows eastward into the Amazon. At many Preceramic monumental sites, items having northern or eastern origins have been found. For northern interactions, evidence comes from Spondylus shell, native to the warm tropical waters off the Ecuadorian coast, found at El Paraíso (Quilter 1985), La Galgada (Grieder et al. 1988), Aspero (Feldman 1985), and small fragments in fill material at Buena Vista, although, spondylus does appear rarely as far south as the Ancón-Chillón coast during strong ENSO events (Arntz 1986). Shell from a related Ecuadorian mollusk, Strombus, has also been found in the highlands at Telermarchay cave (Lavalée et al. 1984). Also, gourds with Ecuadorian Valdivia designs were recovered at Huaca Prieta on the north coast of Perú (Lanning 1967; Lathrap 1973). Evidence of connections to the selva include a piranha 
bone at Kotosh (Wing 1972: Table 3) and feathers of parrots or macaws found at La

Galgada (Grieder et al. 1988) and El Paraíso (Quilter 1985) that may have come from the eastern lowlands. Also at La Galgada, a single fragment of a palm seed was recovered from a fire pit (Smith 1988:127). Palm leaf phytoliths were also recovered at Buena Vista, suggesting their use on the coast as well. Palms are not native on the western slopes of the Andes.

Other plant-based evidence for coastal-selva interaction is found at Caral. Shady (1999) reports the presence of lowland plants Bixa orellana (annatto), Campomanesia lineatifolia (Myrtaceae) ${ }^{11}$, and Ormosia sp. (Fabaceae; chocho beans used as beads). Wood from the highland tree Kageneckia lanceolata (Rosaceae) at Caral hints of exchange between coastal and highland populations, too. Highland interaction at Buena Vista is also suggested by the presence of mid-and high-elevation cultigens ulluco and potato. Arrowroot starch at Waynuna in the southern highlands and at Buena Vista provides evidence of the breadth of these interregional connections. Even if some of the tropical plants, such as arrowroot, leren, and Heliconia, were early cultigens at coastal Preceramic sites, the presence of other items acquired from great distances suggests that these interactions were ongoing and continued through time. For example, Spondylus shell is also found at highland Chavín in later contexts (Burger 1995) and crushed Spondylus shell was ritually served as "food" for the dead at the Huari site of Cheqo Wasi (Hastorf 2003a,b).

\footnotetext{
${ }^{11}$ Campomanesia lineatifolia may have been cultivated on the coast of Perú. Seeds are reported from Ancón, Chiquitanta near El Paraíso, Pachacamac, and Cahuachi (Towle 1961:72)
} 
Unfortunately, we understand little about the nature of Late Preceramic interregional exchange for which we have significant evidence. But I think it is interesting that phytoliths from Buena Vista show evidence for northern and eastern plants, including palms, that do not appear in other Late Preceramic plant assemblages, with the exception of arrowroot at only one other site. Very few microfossil studies have been done in Perú (see Chapter 7), therefore it is too early to infer that Buena Vista represents a unique case in which the richness of plants is enhanced by special exchange networks. I suspect that if phytolith and starch analyses are carried out for other Late Preceramic sites, a similar assemblage of plants would be noted and probably other exotic species would be found as well. The physical preservation of plant specimens, and other materials, on the dry desert coast is remarkable indeed. But as the Buena Vista example shows, microfossils from sediments can reveal 'hidden' plants that are not identified in macroremain assemblages. In Chapter 7, I pointed out that several plants identified in the phytolith assemblage do not appear in the macroremains, including palms, heliconia, and leren. Although phytolith-producing parts of several plants are identified in the macroremains, phytoliths representing these plants are not abundant in the phytolith assemblage, such as squash, beans, and Asteraceae, with the exception of Marantaceae/Cannaceae types and those from grasses and sedges. These exceptions are abundant phytolith producers, but the other plants, squashes and beans, generally produce low numbers of phytoliths. Therefore one would not expect them to be well represented. These results show the importance of utilizing multiple approaches, macroremains and microfossils, but may reveal important taphonomical processes that result in what actually gets preserved in the macroremain 
assemblage. I hypothesized that phytoliths of plants not represented in the macroremains entered the assemblage through other mechanisms, possibly with the ash of cooking fires that was collected and deposited in the pit. Those phytolith-producing plants would have been ashed and not observable as macroremains.

If heliconia, leren, and arrowroot are eventually found to be widely represented at other sites, perhaps all three were part of the suite of root crops cultivated in the Late Preceramic. It would be very useful to have other contemporary sites to test for the presence of phytoliths from these and other rare taxa. If these plants are indeed rare, it is also possible that they, and others yet unknown, have special symbolic importance as items of exchange. It is possible that these represent luxury foods that were difficult to procure, reserved for special ritual events, or restricted and used only by elders or higher status individuals (Hastorf 2003b). Because macroremains of these plants are scarce or absent, maybe these plants, having symbolic importance, were burned in ritual. One might imagine bundles of food wrapped in heliconia leaves burned as offerings in ritual fires, while people gathered to feast on other foods.

In considering a special role for the exotic plants present at Buena Vista, it would also be interesting to consider evidence for the special preparation of cultivated plants as alcoholic beverages in a feasting context at Buena Vista. At the risk of over-interpretation, I think it is worthy to consider the possibility that feasting at Buena Vista involved the use of fermented beverages. Prior to Spanish colonial pressures in the Andes, the consumption of alcoholic beverages, chicha, was widespread and highly ritualized (Morris 1979). A number of different plants including maize, quinoa (Chenopodium quinoa), oca tubers (Oxalis spp.), 
and molle (Schinus molle) berries were used to produce chicha (Rowe 1946:292). Chicha varieties described in historical documents were also made from manioc and peanuts (Jennings and Bowser 2009:6). The most widely known chicha in the Andes was made from maize, and its use is well documented in the more recent prehistoric and historic past (Morris 1979; Jennings 2005; see also Hayashida 2008, 2009; Jennings and Bowser 2009). For the Preceramic in Perú, we can only speculate at this point that the use of alcoholic beverages was not uncommon, at least given that very early material evidence of alcohol production appears in Asia by 8000 B.C. (McGovern et al. 2004) and given the near universal use of alcoholic beverages (McGovern 2009:276-7). It may be significant that the most ubiquitous food plants in the macroremain assemblage at Buena Vista are from fruits, the super abundant seeds from guava and lucuma, which could have been fermented into drinks or mashes along with root and tubers, such as manioc, arrowroot, achira, and sweet potato.

Most fruits, including guava, have enough fermentable sugars that, to prepare a fermented drink, all that is required is just smashing the fruit in a container, adding water, and leaving it to the action of wild yeasts in the air. For guava, only a handful of ethnographic and ethnohistoric accounts suggest that this fruit was used as an alcoholic beverage. Pulque de guajava was reportedly being produced near Mexico City in the $18^{\text {th }}$ century (Wilson and Pineda 1963). In South America, where guava was widespread in the past, I could find no direct ethnographic evidence of its use in alcohol production, but fruits from a close relative of guava, Campomanesia sp., are sometimes used by Guaraní (Reed 1995) in the southern Amazon as a sugar additive when making maize-based chicha. 
Guava, Psidium guajava, like most fruits, ferments naturally as it turns from ripe to overripe (Jain et al. 2001; Neelima et al. 2005) and there are numerous reports of birds becoming intoxicated on guava fruits. Guava could have been used in a similar way as an added sugar source, especially when fully ripe, but also as a catalyst to start fermentation if added to the mash when the fruits were ripe and fermenting. Perhaps lucuma could be used in the same way, but no ethnographic analogue was found.

Starch grains of guava or lucuma, however, were not recovered in the residues of the gourd and squash fragments of serving vessels recovered from the pit or in the sediments. This fact does not disprove the hypothesis that guava and lucuma could have been used to make chicha or as chicha additives, but residues on the artifacts provide other clues of possibly fermented beverages: algarroba, manioc, and arrowroot.

Although native on the coast of Perú, most information on the use of algarroba (Prosopis spp.) pods in the production of chicha comes from the Gran Chaco region of Argentina and Bolivia (Alvarsson 1988; Pasiecznik et al. 2001). The most valuable tree to the people in the region is Prosopis for its richly sugary pods (Karsten 1932:2). Chicha, by the Mataco name aloja, made from algarroba was considered the best, even preferable to that made from honey (Karsten 1913 in Alvarsson 1988:211). Feasts featuring the production and consumption of aloja were held in honor of initiation ceremonies, weddings, or before undertaking dangerous acts, such as raids or conflicts. To make the aloja (Alvarsson 1988:211), women gather the fruits and pound them in mortars, then boil one part of the pounded pods while another part was chewed and spat into the brew. The 
enzymes in saliva help to speed up the fermentation process. Then, the mash is poured into a large container, a hollowed log, large calabash, or ceramic pot, where it is left to ferment.

One of the most widespread bases for chicha in South America is manioc where it remains the most common chicha type in the Amazon (Uzendoski 2004; Weismantel 2009) and lowland Ecuador (Bowser and Patton 2004). Manioc chicha is made from both bitter and sweet varieties, although the process of fermentation ameliorates the deadly cyanogenic glucosides that can be fatal if ingested (Battcock and Azam-Ali 1998:10). A strong version of manioc chicha was reportedly made by modern Guarauno (Warao) in the northern Amazon from the water collected as the bitter manioc is pressed. The water is then boiled and strained to produce an "extremely strong drink" (Turrado 1945:115) but apparently without deadly side effects. Other manioc chichas (Harner 1973:51) are made by first peeling the tuber, then boiling the cut pieces of flesh. When cooled, the flesh is mashed by hand or with a paddle, while pieces of the cooked manioc are chewed and returned to the pot. The manioc mash is then allowed to ferment, up to five days for full alcoholic effect, then strained to remove fibers, thinned with a little water, and consumed. Additives to manioc chicha, such as sweet potatoes (Turrado 1945:115; Eakin et al. 1986:10) may be made to enhance the color. Other starchy tubers, such as arrowroot, or sugars, such as maize or palm fruits, may be added (Hugh-Jones 1979:179) to enhance the texture or flavor of the finished product.

Manioc and algarroba starch grains occur on gourd artifacts from the sunken pit at Buena Vista and several manioc rind peels were found in the macroremains, but was chicha being consumed at Buena Vista? I think so. In the starch fraction of the residues from 
gourd artifacts, manioc starch was found on three separate fragments (see Chapter 8: Table 8.5). On one artifact, manioc co-occurs with arrowroot, on another, manioc appears with arrowroot and potato, and on another, manioc occurs with algarroba. If a fermented brew was being prepared and consumed, this dataset suggests that perhaps manioc served as the base of the mash to be fermented. Arrowroot may have been an additive to enhance the texture and algarrobo, guava or lucuma may have added fermentable sugars and flavors to the brew. Perhaps chili peppers were also used to spice the brew. This is an area for future research; molecular and chemical analyses of gourd containers may confirm the presence of alcohol (McGovern et al. 2004) and a larger data set may reveal starch grains with damage consistent with fermentation (Pilar Babot 2003). If these plants were being used as sources for alcohol, it is also likely they would have been used in feasting. Alcohol would have provided both symbolic and physical transformation through ritual.

The identification of feasting and importantly of alcohol associated with feasting as early as the Late Preceramic is significant. For example, the early link between alcohol and feasting suggests that the underlying structure for feasting, its social and political function, was present in emergent complexity long before later hierarchical societies, such as the Moche, Tiwanaku, Wari, and Inka, institutionalized and formalized the production of feasting foods, like maize for chicha, and the performance of feasting rituals in large-scale, asymmetrical, and reciprocal relationships for the purpose of labor and tribute.

Feasting associated with alcohol also may have important implications for subsistence. For example, the use of manioc in the production of alcohol as early as the Preceramic would have implications for its domestication and spread over such a large area 
of South America. The spread of manioc is due, in part, to its high nutritive value and low cultivation cost (Piperno and Pearsall 1998:120-126), but perhaps its appeal is enhanced by the social importance of its fermentation capabilities. Smalley and Blake (2003) formulated a similar hypothesis to explain the spread of maize; the "sugar-stalk" hypothesis that maize spread rapidly due to demand for easily fermentable sugary stalks before maize developed as a staple food source. But, the social dimensions of food in ritual and alcohol production likely were already in place in South America, especially where manioc beer was made. Manioc remains the most dominant staple in much of the eastern lowlands and, as a food, it is inextricable from its use as a fermented beverage. The Jívaro, for example, turn to manioc beer as a clean source of drinking water, but also because it is considered be far superior to plain water (Harner 1973:51). On the coast of Perú, where manioc was being cultivated at Late Preceramic sites, the archaeological record for the appearance of maize is discontinuous and erratic until the late Initial Period/Early Horizon, and then most closely associated with highland cultures living above the altitudinal constraints for growing manioc. Interestingly, unlike Mesoamerica, maize never came to be a staple crop for consumption in the Andes; rather its production was closely associated with chicha. It would appear that if manioc beer held a primary focus of social and ritual dimensions on the coast, it was only supplanted by maize beer after highland societies began intensive cultivation of maize for chicha. This would explain the limited and isolated appearance of maize in only several Late Preceramic contexts on the coast of Perú. Perhaps, too, the very early, but sparse presence of maize in Coastal Ecuador is more of a confirmation of interregional interaction than it is a change in subsistence. 


\section{CONCLUDING REMARKS}

In this paleoethnobotanical study of remains recovered from a unique archaeological context at Buena Vista, my goal has been to evaluate the evidence of feasting at a Late Preceramic site. In the preceding discussion, I have attempted to situate the evidence for feasting as it relates to the archaeological, ritual, and social contexts. The architecture of Buena Vista provides the ritual space within which feasts and other rituals take on a greater symbolic value. The nature of the deposits, specifically the remains in the sunken pit of the Gran Sala, are indicative of activities associated with food and ritual, but also more mundane activities that probably included the participants of those rituals. The material remains of feasting provide valuable comparisons to other Late Preceramic sites and give some insight into subsistence, interregional interactions, and the social significance of plant use in the production and consumption of foods and beverages in a feasting context. This study provides just a glimpse of a moment in time before the interment of the temple mound at Buena Vista, but these results raise significant questions for future research into the Late Preceramic that have not been emphasized before. What roles does gender play in Late Preceramic societies? What is the nature of local interactions among coastal and inland sites and, more broadly, interregional interactions connecting the coast of Perú to Ecuador and the selva? How do these interactions relate to crop dispersal, ritual, feasting, and emergent complexity? None of these questions are answered satisfactorily in this research, but this study shows the potential advantages in-depth paleoethnobotanical research offers for the Late Preceramic. Using multiple indicators, 
paying close attention to archaeological contexts, and employing systematic sampling will enhance future research on the Late Preceramic.

In conclusion, this study was successful in finding strong evidence for feasting at Buena Vista. Feasting, as a social event, provides us some insight into how emergent leaders could have mobilized small communities for labor projects, but feasts also served to provide community solidarity and communitas through participation of the feast and other rituals that occurred simultaneously. Feasts were probably an essential practice for emergent leaders to garner sociopolitical and symbolic power. In the Buena Vista example, it appears that leaders here did not possess the absolute authority to mobilize a large labor force for the purpose of large-scale renovations. It is more likely that those who participated in the rituals and feasting were those who participated in the renovation process, an entire community. 


\section{Appendix A: Botanical and Ethnobotanical Profiles of Plant Taxa}

\section{Identified at Buena Vista}

AgavaceAe

Known as the agave family, the Agavaceae are monocotyledonous plants, usually perennial shrubs, trees, or sometimes herbs (Simpson 2006). Several species have fibrous leaves useful for basketry and cordage. For some species, uses are well known. Agave sp. in Mexico is used in the production of pulque and tequila. On the coast of Perú, a related genus, Furcraea, is known archeologically. Fibers are utilized in the making of slings, belts, and cordage and have been found in Late Preceramic burials in the Chillón (Yacovleff and Herrera 1934) and at El Paraíso (Quilter et al. 1991).

In the Buena Vista assemblage, Furcraea occidentalis Trel. leaves were identified. This species is native to the area, but may also have been cultivated (Brack Egg 1999). Another closely related species, Furcraea andina, has similar leaves and fibers. These species appear to have slight differences in distribution. Both can be found up to 2500 masl, but F. occidentalis occurs more frequently at lower altitudes, less than 1500 masl (Brako and Zarucchi 1993). There is some ambiguity in the archaeological identification of Furcraea 
species in Perú (Ugent and Ochoa 2006:42), but given the natural distribution of the plants, the coastal examples identified in the macroremains may be F. occidentalis.

\section{ANNONACEAE}

The Annonaceae are best known for their fruiting trees, but this family also produces shrubs and lianas. Mainly tropical plants, the custard-apple family has economic importance for their fruits, scented woods, and timber (Simpson 2006). In Perú, species of Annona are important cultivated and managed fruit trees. A. muricata (guanábano, anonas) and A. cherimola (cherimoya) are cultivated on the coast of Perú, although A. cherimola is more commonly found archaeologically. In the Late Preceramic, A. cherimola is identified at Huarmey (Bonavia 1996) and A. muricata was found at the Initial Period site of Mina Perdida (Chevalier 2002). In the Buena Vista assemblage, Annonaceae is identified by a faceted phytolith, type 80IFb3 in the MU system.

\section{APIACEAE}

Apiaceae, the carrot family, are usually herbaceous plants, but rarely may occur as shrubs or small trees (Simpson 2006). A large number of species occurs in Perú, 88, and over two dozen are endemic (Brako and Zarucchi 1993). A number of species are native to the coast of Perú and western slopes of the Andes. Medicinal uses are reported for several species, including Browlesia sp. (Ugent and Ochoa 2006:52), that also occur on the coast. Of particular economic importance, however, is Arracacia xanthorrhiza Bancroft., known commonly as arracacha, a mid-elevation herb with edible roots and leaves that is cultivated 
today as well as in the past. In this assemblage, a seed in the macroremains only was identified as cf. Apiaceae, although it is not Arracacia.

\section{ARECACEAE}

The palm-family, Arecaceae, is a monocotyledonous plant family producing perennial trees, large rhizomatous herbs, and occasionally lianas (Simpson 2006). The family has a natural distribution throughout the tropics and sub-tropics; however, palms in Perú have a natural distribution limited to the eastern slopes of the Andes and generally north of $7^{\circ}$ South latitude in inter-Andean areas on the western slopes (Weberbauer 1945:146-7; Milan 2006; Llatas and Lopez 2005). This is well north of the Chillón Valley. Palms are widely used by humans: fibrous leaves are used for roofing and weaving, palm wood is durable, and the fruits are edible (Heiser 1990). A fragment of a palm seed was reported at the highland site of La Galgada (Smith 1988) and Rochebrune (1879) reported leaves in graves at Ancón. At Buena Vista, palm phytoliths, which are produced in the leaves, stems, petioles, and fruits of Arecaceae, were identified in the sediments, but no macroremains were recovered.

\section{Asteraceae}

Asteraceae, or sunflower family, is a large group of eudicotyledonous plants containing over 1500 genera and over 22,000 species (Simpson 2006:326). In Perú, some 222 genera and 1432 species occur (Brako and Zarucchi 1993). This family consists of herbs, shrubs, trees, and sometimes vines. A number of herby examples of this family are native to the coast and western slopes of the central Andes. Although of little economic 
importance, many species of Asteraceae in Perú are used medicinally, including several introduced from Europe and Asia (see Ugent and Ochoa 2006: Tables 2-3). In the Buena Vista assemblage, this family is not well represented and only family-level identifications could be made for a seed in the macroremains and phytoliths from the sediments.

\section{BASELLACEAE}

The Basellaceae is a relatively small family of herbs or vines. In Perú, just three genera and eight species are known (Brako and Zarucchi 1993). Several species grow within a wide range of elevation and some can grow at fairly high altitudes. Species of Anredera inhabit coastal and disturbed areas, but may also occur as high as 4000 masl. Of particular economic importance, one mid-elevation low growing herb, Ullucus tuberosus Caldas, ulluco, is cultivated for its edible root.

Ulluco probably was domesticated very early. It appears in assemblages from Tres Ventanas cave in deposits dating from 8000 to 6000 B.C. (Engel 1973) and it was also found at Guitarerro Cave in deposits dating between 8500 and 5500 B.C. (Smith 1980), but these early dates from cave sites are difficult to interpret due to human or animal disturbance of cave sediments (Pearsall 1992). Ulluco is not commonly found archaeologically, a symptom shared by other root/tuber species, since the tubers are often eaten in their entirety. Nevertheless, ulluco is reported from a presumably Late Preceramic midden at Chiquitanta near El Paraíso (Harms 1922). Fragments of ulluco tubers are fairly well represented in the Buena Vista assemblage.

Ulluco is considered a completely domesticated crop (NRC1989) and like potato, another Andean tuber, there are many, many varieties grown in the Andes. The tuber can 
be grown in temperate and tropical highland environments, is resistant to frost and heat, tolerant of a wide range of soil conditions, and is high yielding, although it does require a day length of 10-14 hours for tuber production (Ibid.,113). Propagating is done by planting small tubers in soil, which will sprout in temperatures above $18^{\circ} \mathrm{C}$. The growing cycle may take as long as nine months at higher attitudes, but may be as short as five months in warmer conditions. It is possible that ulluco could be cultivated in the coastal valleys, provided there is sufficient sunlight and water. Its modern cultivation zone, however, is mid-elevation up to around 4000 masl

\section{BEGONIACEAE}

The Begoniaceae is a family of eudicotyledonous herbaceous, sometimes viney plants (Simpson 2006). In Perú, only one genus, Begonia, is known. Seventy-six species is occur in Perú, but only two species are native to the coastal region, Begonia geraniifolia Hook, and B. octopetala L'Héritier subsp. octopetala (Brako and Zarucchi 1993). Archaeologically, only B. geraniifolia is reported regularly. Tubers of begonia are found at middle Preceramic sites, such as Paloma, and may represent an early-domesticated species (Dering and Weir 1979, 1981; Benfer 1982; Weir and Dering 1986) or cultivated plant. Begonia geraniifolia is not used as a food plant today, but may have been managed for its purportedly edible rhizome. Rhizomes were common at Paloma, thus and Weir and Dering (1986) hypothesized the plant may have been subject to early management. Begonia epidermal tissue was tentatively identified in a human coprolite from the Preceramic site of Asia (Jones 1988:81). Experimenting with various cooking methods, Weir and Dering (1986) were not successful in overcoming the rhizome's acrid taste. Possibly, the rhizome 
was used as a flavoring agent or even as a medicinal. Ethnographically, the rhizome is consumed medicinally in an infusion, ground, or eaten fresh as a purgative (Ruiz 1952 in Soukoup 1970:41). In the Buena Vista materials, Begonia geraniifolia Hook. rhizome tissue was identified in the macroremains.

\section{BORAGINACEAE}

Boraginaceae, the borage family, is composed of mostly herbs (Simpson 2006:298). In Perú, 16 genera are known, but only three are native to the coastal environs: Cordia, Cryptantha, and Heliotropium (Brako and Zarucchi 1993). At Buena Vista, a phytolith hair cell base identifies Cordia lutea Lam. in the sediments. Known as flor de overo, this shrub or small tree produces fine yellow flowers that, apart from ornamental use, are used in northern Perú in medicinal mixtures to treat inflammation (Bussman and Sharon 2007:185). This plant commonly grows in disturbed areas and rocky slopes with sufficient water.

\section{BROMELIACEAE}

The Bromeliaceae is a family of terrestrial and epiphytic perennial herbs and small rosette trees (Simpson 206:203). Of the 17 genera and 420 species of Bromeliaceae in Perú, only two general are native to the coastal region, Puya and Tillandsia, the vast majority of species being in the eastern lowlands (Brako and Zarucchi 1993). In the Chillón Valley, Tillandsia L. is a common epiphyte growing on the rocky hillsides of the valley, where it is 
often the only plant visible. Remains of this genus were identified in the macroremains at Buena Vista.

\section{CACTACEAe}

The cactus family, Cactaceae, is represented by a single cactus spine recovered in the macroremains at Buena Vista, identified only at the family level. In Perú, several cacti have economic importance for food and fiber, such as Opuntia spp., the prickly pear cactus. The San Pedro cactus, Echniopsis pachanoi, is used today medicinally and ritually for its hallucinogenic properties (Bussman and Sharon 2007:200). It is likely it was used in a similar way in the past. Cactus spines of San Pedro are represented in iconography at Garagay (Burger 1995:64) and the cactus is represented in the hand of the "Staff God" at Chavín (Burger 1992).

\section{CANNACEAE}

Cannaceae consists of only one genus, Canna, of which there are from 10 to 25 species (Simpson 2006:198). These monocotyledonous, herbaceous plants are native to the Neotropics. In Perú, there are eight species, seven that can be found on the eastern slopes and lowlands and one, Canna indica L. (=C. edulis Ker-Gawler), that grows on the western slopes up to around 2000 masl (Brako and Zarucchi 1993:326). Canna indica, or achira, was an early cultigen and may have been domesticated by peoples on the coast and inland valleys of northern Andes (Sauer 1952; Gade 1966), but is likely to be part of a large group of big-leafed herbs with edible rhizomes and tubers that were domesticated by lowland 
peoples (Piperno and Pearsall 1998:118). C. indica's modern range in the western Andes attests to its adaptability as a wild plant to a wide variety of climates and broad tolerance of a wide range of soil types (NRC 1989:31).

The rhizome, or corm, of C. indica are unique among other root/tuber crops in that it can be eaten raw, but more often it is baked (NRC 1998:31). Achira contains abundant, easily digested starch, with a sweet, sticky texture when baked. Also, the leaves and shoots are edible and nutritious, containing at least 10\% protein (Ibid.). Achira, like ulluco, and potato, is propagated by planting the cut rhizome tips or even whole rhizomes in soil, usually just before the rainy season (Piperno and Pearsall 1989:118). The plant can grow rapidly and under the right conditions can be harvested as early as six months after planting, but usually after eight to ten months (NRC 1989:33). Once mature, the rhizomes can be left in the ground for up to two years (Gade 1966).

Archaeologically, achira is one of the earliest crops known on the coast of Perú, and is well documented archaeologically in sites contemporary with Buena Vista, such as Aspero (Feldman 1980), Chilca I (Jones 1988), La Galgada (Grieder et al. 1988; Smith 1988), Huaca Prieta (Bird, Hyslop, and Skinner 1985), and Los Gavilanes (Bonavia 1982; Popper 1982). In the Buena Vista macroremain assemblage, rhizome fragments indistinguishable from another edible rhizome, arrowroot, only tentatively identify achira. Phytoliths produced by both Cannaceae and Marantaceae were present in the sediments sampled; phytoliths consistent with those produced by C. indica are identified in the residue of a gourd artifact. 


\section{Convolvulaceae}

The Convolvulaceae, the morning glory or bindweed family, consists of herbaceous and woody vines, sometimes herbs, shrubs, and rarely trees (Simpson 2006:319). In Perú, eighteen genera are present, but less than six herbs and vines are thought to be native to the western coast (Brako and Zarucchi 1993). One non-native plant produces large edible tubers. These tubers of Ipomoea batatas (L) Lam., sweet potato, are an early domesticated crop.

Sweet potatoes prefer well-drained soil and sufficient water and sunlight. Sweet potatoes require from 750 to $1250 \mathrm{~mm}$ of rainfall throughout the year (Piperno and Pearsall 1989:128), therefore to be cultivated in the lower Chillón Valley, sweet potato would require sufficient irrigation. The plants are propagated, like manioc, by burying stem cuttings in mounds or ridges of soil. Tubers are then harvested from three to six months after planting, but store poorly.

The origin of this domesticated form of Ipomoea is unclear, but probably lies in Northern South America or Central America (Piperno and Pearsall 1998:127). Sweet potato remains are found, but rarely, in archaeological contexts in coastal Perú as early as the Late Preceramic at Los Gavilanes (Bonavia 1982), Huaynuna (Pozorski and Pozorski 1987) and in the highlands at Tres Ventanas (Engel 1970). At Buena Vista, tuber and rind fragments were identified in the macroremains and were confirmed by starch examination. Seeds identified as Ipomoea sp. were also identified and another seed was identified only to family. 


\section{COSTACEAE (AND Bombacoideae)}

The Costaceae is a tropical monocot family closely related to Zingiberaceae, the ginger family. In Perú, species of Costaceae are known only in the eastern and far northern departments, not on the coast or western slopes of the Andes. In the Buena Vista phytolith assemblage, nodular spheres, a phytolith type produced in Costaceae and also in the Bombacoideae, only tentatively indicate the presence of this family. More likely, the phytolith type identifies Bombacoideae in this context (see discussion of this phytolith type in Chapter 7).

\section{CucurbitaceAE}

Cucurbitaceae, the squash family, consists almost entirely of vine-like plants (Simpson 2006). This family contains gourds and squashes, as well as melons and luffa, a species that, when dried, can be used like a sponge. The origins and archaeology of cucurbits is discussed in more detail in Chapter 8. In the Buena Vista assemblage, gourds and squashes were identified to species by seeds and to genus by rinds. One phytolith from Cucurbita sp. was identified from the sediments. Species identified include Cucurbita moschata Duchesne, also known as loche, zapallo, calabaza; Cucurbita ficifolia Bouche, zambo, zapallo loche; Cucurbita maxima Duchesne ex Lam., zapallo macre; and the gourd Lagenaria siceraria (Molina) Standl.

The squashes identified in the Buena Vista assemblage are all winter-type squashes that store well after harvesting. C. ficifolia, in particular, is known to keep very well for up to two years if kept dry; the flesh remains fresh and actually gets sweeter with age (NRC 1989:206). While each of these squashes can be grown in the lower Chillón region, some 
have different degrees of tolerance. C. moschata is more tolerant of high temperature and humidity, whereas C. ficifolia is more tolerant of cooler temperatures, but neither are frost resistant.

In the Supe region, modern farmers plant crops of C. ficifolia twice per year, but many recall planting only in the winter months (Zechenter 1988). Propagated from seed, squashes and gourd require little care and could have been cultivated year round in the lower Chillón Valley.

\section{CYPERACEAE}

The Cyperaceae, or sedge family, consists of monocotyledonous plants that can be perennial or annual herbs. This family has a worldwide distribution of around 104 genera and some 5000 species (Simpson 2006:206). Several of these species would have grown in riparian areas or low areas with sufficient water. They were identified to family or genus level in the phytoliths and several seeds were identified in the macroremains. These include: Scirpus L., from seed and phytolith; cf. Cladium P. Browne, identified from seed; and cf. Eleocharis R. Br., also identified from seed.

\section{EUPHORBIACEAE}

Euphorbiaceae, or spurge family, consists of herbs, shrubs, vines, and occasionally trees (Simpson 2006). Only one species was identified at Buena Vista, Manihot esculenta Crantz, from tuber fragments in the macroremains and starch grains on gourd artifacts. A seed was identified as cf. Euphorbiaceae, having characteristics similar to other species in 
the family. The origins and archaeology of Manihot esculenta, manioc or yuca, is discussed in Chapter 8.

Manioc is highly tolerant of a wide range of soils if given proper drainage and depth (Purseglove 1968) and requires only a minimum of $750 \mathrm{~mm}$ of rain per yer (Sauer 1993). Like sweet potato, planting cuttings in soil, not from seed, propagates manioc. Both the tubers and leaves are edible. Information collected by Zechenter (1988) from farmers in the Supe Valley is applicable to the Chillón, where tubers mature and are harvested eight to nine months after planting, but can be left in the ground for up to three years, making it a crop available for harvest in any season. Manioc can be planted in the same field for up to nine years.

\section{FABACEAE}

Fabaceae, or bean family, is a very large family of eudicot plants consisting of shrubs, herbs, vines, and trees of up to 643 genera and 18,000 species. In the Buena Vista assemblage the family is represented by five species.

In the macroremain assemblage, root tissue identified as cf. Pachyrrhizus sp., known as jicama or ahipa, was identified. Two species of Pachyrrhizus in South America are valued for their edible tuber-like roots. One, P. ahipa is thought to be native to the Andes of Perú and Bolivia, but has not been recorded in its wild state (NRC 1989:44). The other species is cultivated in the Amazon, P. tuberosus, and may have been domesticated in the upper Amazon basin. At this time, it is not possible to identify the macroremains at Buena Vista to species, but other examples of Pachyrrhizus are known archaeologically in the Late 
Preceramic at Los Gavilanes (Bonavia 1982; Las Haldas (Cohen 1978), and El Paraíso (Engel 1963; Quilter et al. 1991).

Canavalia DC., known as jack bean, pod fragments were identified in the macroremains. C. plagiosperma is considered native to South America, is closely related related to C. ensiformis in Central America. (Piperno and Pearsall 1989:132-3). Jack beans are present in Late Preceramic assemblages at La Galgada (Smith 1988) and Huaca Prieta (Bird et al. 1985).

Phaseolus L., pod and seed fragments, as well as a phytolith hair cell from the sediments, identifies common and/or lima beans in the assemblage, but these cannot be distinguished to species at this time. These beans were probably domesticated from wild beans on the slopes of the Andes (Piperno and Pearsall 1989:134). Despite early dates for the presence of beans in the Preceramic at only a few sites, beans become much more common in assemblages in the later ceramic period. Piperno and Pearsall (1989:139) propose that in early contexts, beans were used in their green form, rather than dried, because of limited cooking technology, e.g. lacking of ceramics to boil dried beans. This too, explains their limited occurrence at early sites, since both pods and beans may have been eaten.

Inga feuilleei DC., known as pacae or pachay, pod fragments and seed were also found in the macroremains. A common tree in the coastal lowlands of Perú and Ecuador, this tree is also widely grown in the Andean highland valleys. It is known as the 'ice cream bean' because of its sweet pulp produced in its large pods. This species also contributes forage, lumber, fuel, and fixes nitrogen in the soil (NRC 1989:280-1). Fruit production is 
generally continuous throughout the year, but may be limited on the central coast;

Zechenter (1988:439) reports that fruiting of pacae trees in the Supe Valley begins around March and April and continues through June. These fruits are commonly found in Late Preceramic assemblages.

Prosopis L., algarroba, was identified in the macroremains, a seed fragment, and by starch from algarroba pods in the residues from gourd artifacts. The archaeology of Prosopis is discussed in more detail in Chapter 8 .

\section{HELICONIACEAE}

The group known as the bird-of-paradise family, Heliconiaceae consists of just one genus, Heliconia, and about 35 species occurring in Perú (Brako and Zarucchi 1993).

Heliconia is a big-leafed monocot herb with a habit similar to Canna, having a rhizomatous stem with sheathing leaves, although there is considerable variation among Heliconia species. In certain species, the leaves can grow to nearly ten feet in length. Heliconia is sometimes classified in Musaceae, the banana family, and also shares similar leaf habits with some Musa. Musa is a modern introduced cultigen, bananas and plantains. However, based on genetic analysis, Heliconiaceae is recognized as a distinct family (Stephens 2010).

Heliconia L. is identified in phytoliths from sediments at Buena Vista. The natural distribution is primarily limited to the eastern slopes of the Andes and lowlands (Brako and Zaruchhi 1993). On the western side of the Andes, Heliconia occurs in the northernmost departments of Perú (Weberbauer 1945:155) as an understory plant in cloud forests (Llatas and López 2005) and in lowland and cloud forests on the coast of Ecuador (Svenson 1946:418). In archaeological material from Ancón, near the lower Chillón Valley, 
de Rochebrune (1879) identified what may have been Heliconia as "Musa paradisiaca". Phytoliths produced by Musa and Heliconia are easily discernable and not likely to be confused (Mbida et al. 2006). Those species of Heliconia with large leaves are used as wrapping in cooking, such as steaming fish or in making humitas and tamales, and several species have edible rhizomes (Soukoup 1970:149; Brack Egg 1999:238-241). It is possible that Heliconia was cultivated in the Lower Chillón, but it may also have arrived there through trade.

\section{Malvaceae}

Malvaceae, or mallow family, is a large family of trees and shrubs in which many have distinct stellate trichomes, hair-like structures, on the leaves (Simpson 2006:286). With recent genetic analyses (Ibid.), this family now includes several other families often classified separately: Bombacaceae, Sterculiaceae, and Tiliaceae. In Perú, the most economically important genus is Gossypium, cotton. G. barbadense was domesticated in the dry tropics of northern South America, probably the coastal plain of southern Ecuador or northern Perú (Piperno and Pearsall 1989:150). By the Late Preceramic, domesticated cotton was introduced into the coastal and inland valleys of central Perú. Cotton cultivation for nets and textiles appears to have been very important economically and is commonly found at Late Preceramic sites, thus this period of time is often referred to as the Cotton Preceramic (Engel 1957; Moseley 1975). Gossypium barbadense L. seeds and fibers were abundant in the macroremains at Buena Vista. The significance of cotton is discussed in more detail in Chapter 6 and Chapter 9. 


\section{MARANTACEAE}

Like Heliconiaceae and Cannaceae, Marantaceae is a family of rhizomatous, herbaceous plants in the Zingiberales. In Perú, around ten genera and ninety species are known (Brako and Zarucchi 1993), all of which are naturally distributed on the eastern slopes of the Andes and in the Amazon, or the northern region near Ecuador. Two plants in this family were identified at Buena Vista. Maranta arundinacea (L.), arrowroot, was identified to species by starch grains in gourd residues and possibly by phytoliths of Marantaceae. Rhizome fragments in the macroremains are indistinguishable from Canna or Maranta. Calathea allouia (Aubl.) Lindl., or leren, was identified by phytoliths in sediments. Archaeologically, there is only limited evidence for the presence of Marantaceae in the central Andes. This is discussed in more detail in Chapter 7 and Chapter 9. Both arrowroot and leren are cultivated for their starchy rhizomes.

Arrowroot can be cultivated from sea level to about 900 masl in suitable soils with good drainage and regular watering (Kay 1973). In the east and lowlands of Perú, planting of rhizomes is done between August and October, then harvested approximately ten months later (Brack Egg 1999:312). If portions are left in fallow, the plants will regenerate spontaneously. Leren, like arrowroot, requires similar well-drained loamy soils to grow well. Parts of the rhizomes are usually planted near the beginning of the rainy season and harvested eight to twelve months later, but the rhizomes can be left in the soil after the plant dies back to provide a subsequent crop the following year (Martin and Cabanillas 1976). Both of these rhizomes, once established in fields, could provide, like manioc, a year round food resource. 


\section{MYRTACEAE}

Myrtaceae is a family of woody, fruit bearing trees and shrubs. Some twenty genera and 160 species are represented in Perú (Brako and Zarucchi 1993). On the coast of Perú, one species, Psidium guajava L., guava, is of particular economic importance for its fruits. The remains of guava, usually the plentiful pips, commonly are found at Late Preceramic sites on the coast of Perú. Guava may occur naturally on the coast of Perú, but was probably managed and cultivated. Guava seeds can be planted directly in a wide variety of soils and the trees even tolerate poorly drained conditions where other fruit trees would suffer (Morton 1987). Guava trees grow rapidly and begin fruiting between the second and fourth year after planting and continue to fruit for 30 to 40 years more. Modern guava cultivators in Puerto Rico collect two crops of fruits per year (Ibid.). In the Supe region, the valley just north of the Chillón in Perú, guava trees were observed to fruit in March for up to four months, but fruits may appear as early as February (Zechenter 1988).

\section{POACEAE}

The grass family Poaceae is well represented in the Buena Vista assemblage, however, only a few genera or species could be identified by seed morphology or phytolith type. Grasses identified include: cf. Eleusine indica (L.) Gaertn., Gynerium sagittatum (Aubl.) P. Beauv., Panicum L., Paspalum L., and Setaria P. Beauv. It is likely that these grasses were growing locally in the area adjacent to Buena Vista. 


\section{SAPOTACEAE}

Sapotaceae is a family of trees and shrubs. In Perú, ten genera and 84 species are known (Brako and Zarucchi 1993). Most species occur in the eastern lowlands. The family includes many important fruit trees in the selva, but only one coastal species, Pouteria lucuma (Ruiz \& Pav.) Kuntze (=Lucuma bifera Molina), is known. Otherwise known as lucuma, seeds of this fruit commonly are found archaeologically on the coast of Perú. It is though to be native to the inter-Andean valleys from Chile to Ecuador. Lucuma is propagated by seed and the tree will mature and fruit four to five years after planting (Brack Egg 2003). It is harvested from November thorough March (Calzada Benza (1980:141) but harvesting may begin as early as October and last through May on the coast (Zechenter 1988:440). In addition to being immediate food sources after harvesting, the ripe fruits can also be dried and milled into coarse flour for long-term storage (NRC 1989:263). The seeds of lucuma fruits are well represented in the Buena Vista macroremains.

\section{SOLANACEAE}

Solanaceae is a family of herbs, shrubs, trees, and sometimes lianas (Simpson 2006:319). Around 94 genera and 2,950 species are currently recognized. Most genera have a worldwide distribution, but are concentrated in South America. Economically important species are early domesticates, including Capsicum (chili peppers), Lycopersicon (tomatoes), Physalis (tomatillo, aguaymanto or capuli), Solanum tuberosum (potatoes), and Nicotiana (tobacco). A number of other plants in the Solanaceae are well known for their medicinal 
or pharmacological uses, such as Datura (Jimpson weed), Atropa belladonna, and species of Solanum. In the Buena Vista assemblage, chili peppers, tomatillo, and potato were identified. For chili peppers, the history of domestication is a complicated issue, only somewhat resolved by genetic data (see Piperno and Pearsall 1989:152-154 for a discussion). The areas of origin for different species of chili peppers may overlap, but generally, C. baccatum appears to have been domesticated in the southern Amazon lowlands, and C. pubescens may have originated in the mid-elevation Bolivia, while C. annuum was domesticated in Central America or eastern Mexico. In the Buena Vista assemblage, a starch grain in the gourd artifact residues and seeds of Capsicum sp. and C. pubescens Ruiz \& Pav identify chili peppers. C. pubescens seeds can be distinguished from other chili seeds their dark brown to black color. In Table A:1, size measurements are reported for seeds identified to this genus.

Table App. A.1: Seed sizes in mm. for identified Capsicum in the macroremains from Buena Vista.

\begin{tabular}{lrrr}
\hline Determination & \multicolumn{1}{c}{ length } & \multicolumn{1}{l}{ width } & \multicolumn{1}{c}{ thickness } \\
\hline C. pubescens & 3.2 & 3 & 0.4 \\
C. pubescens & 3 & 2.6 & 0.4 \\
Capsicum sp. & 3.5 & 3.5 & 1.5 \\
Capsicum sp. & 3.5 & 3 & 1.5 \\
Capsicum sp. & 3 & 3 & 1 \\
Capsicum sp. & 3 & 2.5 & 0.4 \\
Capsicum sp. & 3.5 & 3 & 0.5 \\
Capsicum sp. & 3.7 & 3.4 & 0.4 \\
Capsicum sp. & 3.5 & 3.2 & 0.4 \\
Capsicum sp. & 3 & 3 & 0.4 \\
Capsicum sp. & 3 & 2.5 & 0.4 \\
Capsicum sp. & 3.3 & 3.1 & 0.4 \\
Capsicum sp. & 3.8 & 2.9 & 0.8 \\
Capsicum sp. & 3.5 & 3 & 0.7 \\
Capsicum sp. & 2.5 & 2.3 & 0.3 \\
Capsicum sp. & 3.4 & 2.5 & 0.5 \\
Capsicum sp. & 3 & 2.1 & 0.5 \\
Capsicum sp. & 3.1 & 3 & 1 \\
cf. Capsicum & 2 & 2 & - \\
\hline
\end{tabular}


Modern cultivation of chili peppers in the Supe region, as reported by Zechenter (1988) is probably comparable to methods in the past. Planting of peppers can occur anytime, but may give the best yields in the summer months on the coast. Plants will continue to produce fruit until the end of the plants life.

Physalis L. was identified by seeds in the macroremains at Buena Vista. The habit of these plants resembles chili plants, but the fruits are small round tomato-like fruits with a papery husk. The natural distribution of these plants is usually to the eastern Andes from 600 to 2000 masl, extending from Venezuela to Chile (Calzada Benza 1980:149). However, P. angulata and P. peruviana may occur rarely in coastal lomas formations (Dillon 2005). The fruits are juiced or made into jams and jellies. These fruits may have been cultivated during the Late Preceramic in the Chillón Valley; seeds identified as Physalis were also found at El Paraíso (Quilter et al. 1991).

Solanum L., potato, was identified in starch from the residue of a gourd artifact. Several potato species and their varieties are cultivated today and in the past, and a great many wild forms of potato exist (Hawkes 1990). Archaeologically, potato macroremains and microfossils are recovered from a number of contemporaneous sites throughout Perú, such as Waynuna in the southern highlands (Perry et al. 2006), sites in the Casma Valley (Ugent et al. 1982), and at El Paraíso (Quilter et al. 1991), among others. The potato's normal range of cultivation is between $2500-4300$ masl, but can be cultivated in coastal lowland fog oases or otherwise with sufficient irrigation (Ugent and Ochoa 2006). 


\section{Appendix B: Additional Comparative Starch}

Pouteria lucuma (Ruiz \& Pav.) Kuntze (Sapotaceae)

Fruits of P. lucuma were collected at markets in Chiclayo, Perú. In these samples, starch grains were found in abundance, even from fully ripened fruits. Compound and single grains were noted. Compound grains (Figure App.B.1:a) may be made up of 2 or more granules, but compound grains of up to eight granules were noted. The morphology of individual grains is highly variable; they can be spherical to hemispherical with faceted sides, sometimes polygonal, sometimes elongated hemispheres with single facets. Size range also is variable for individual grains, ranging from $2 \mu$ to $12 \mu$. On larger individual grains, stellate-shaped fissures may be seen at the location of the hilum (Figure App. B.1:b-d). Birefringence for starches in lucuma is generally strong with well-defined extinction crosses. The larger individual grains produced in P. lucuma may be distinguishable from starches of other taxa with similar features on the basis of size, particularly Manihot esculenta in which starches with stellate-shaped fissures and faceted sides are common. M. esculenta produces starch grains from $6 \mu$ to $20 \mu$, but grains sized $16 \mu$ to $20 \mu$ are common (Pearsall, lab documents). The upper range in M. esculenta is significantly larger than that of P. lucuma, but the smaller M. esculenta grains may be confused with larger P. lucuma grains if both species are encountered archaeologically. Therefore, special attention to size and other morphology should be taken. 


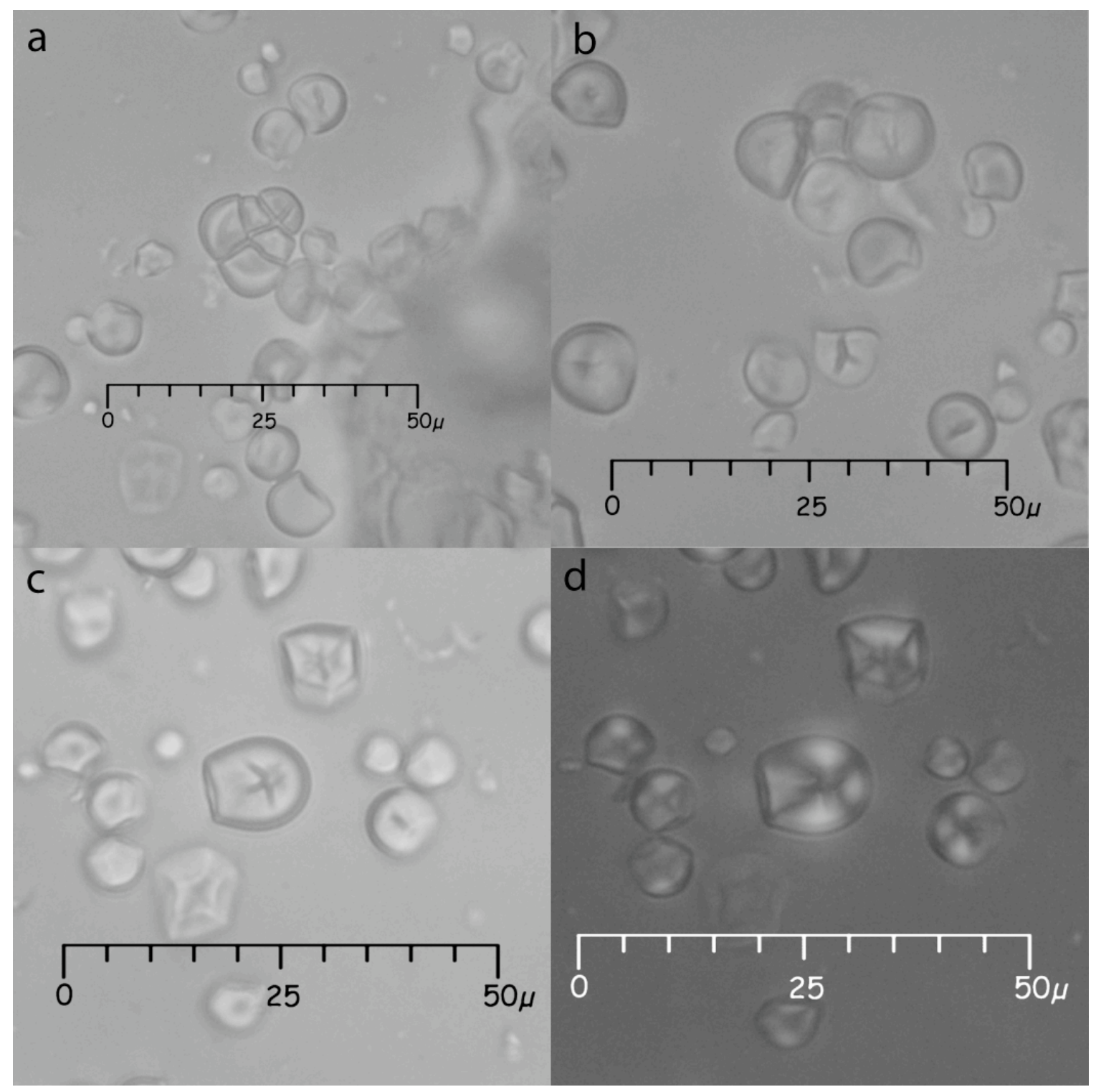

Figure App. B.1 Starch from the fruit of Pouteria lucuma. A compound grain in the center of the photo in transmitted light (a) and individual granules in transmitted light (b). A single granule in the center of the photo in transmitted light $(\mathrm{c})$ and in polarized light $(\mathrm{d})$. Note polygonal starch granules in $\mathrm{c}$ and $\mathrm{d}$. 


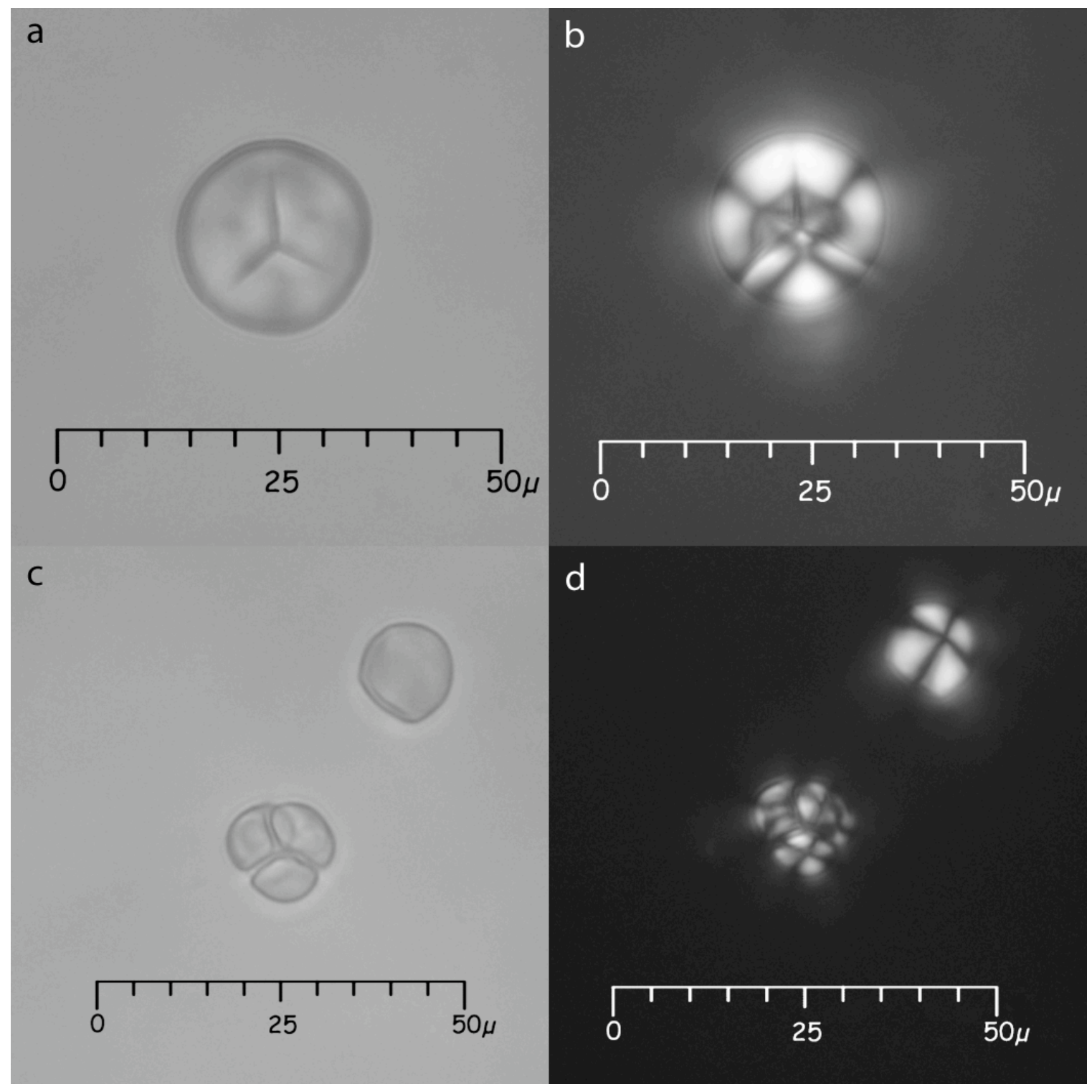

Figure App. B.2 Starch from the fruit of Cyphomandra betacea. Compound grains shown under transmitted light (a, c) and under polarized light (b, d). A single granule is visible in upper right corner of frames $\mathrm{c}$ and $\mathrm{d}$. 
Cyphomandra betacea (Cav.) Sendtn. (=Solanum betaceum Cav.) (Solanaceae)

Fruits of C. betacea, tree tomato or tamarillo, were sampled for starch. The fruits were purchased in Chiclayo, Perú. Compound and singular grains are produced in this fruit. Compound grains ranged in size from $15 \mu$ to $20 \mu$ and were observed to have two to six individual granules (Figure App. B.2:a-d). Individual granules were hemispherical to spherical with one or more facets. Size of individual granules were usually between $5 \mu$ and $8 \mu$, but occasional individual granules of up to $16 \mu$ were noted (Figure App. B.2:c-d). Starches in C. betacea tend to exhibit a high degree of birefringence with well-defined extinction crosses with straight "arms".

\section{Solanum muricatum Aiton}

Starch from S. muricatum, known commonly as pepino, was extracted from fruits purchased in Columbia, Mo. These fruits produce compound and singular starch grains. The compound grains are usually composed of two hemispherical granules (Figure App. B. $3 \mathrm{a}, \mathrm{b})$ and range in size from $10 \mu$ to $20 \mu$ along their longest axis. Occasional compound grains consisting of three granules were noted and resemble compound grains produced in C. betacea. Singular grains produced in S. muricatum consist of hemispheres (Figure App. B. 3 c,d) and spheres ranging in size from $5 \mu$ to $10 \mu$. In general, the singular grains are featureless, smooth and lacking lamellae. In Figure App. B.3, frames (c) and (d) show a hemisphere with a damaged edge that probably occurred in the slurrying for extraction. Starch from S. muricatum is strongly birefringent under polarized light showing a well-defined extinction cross with straight to slightly curved arms. 


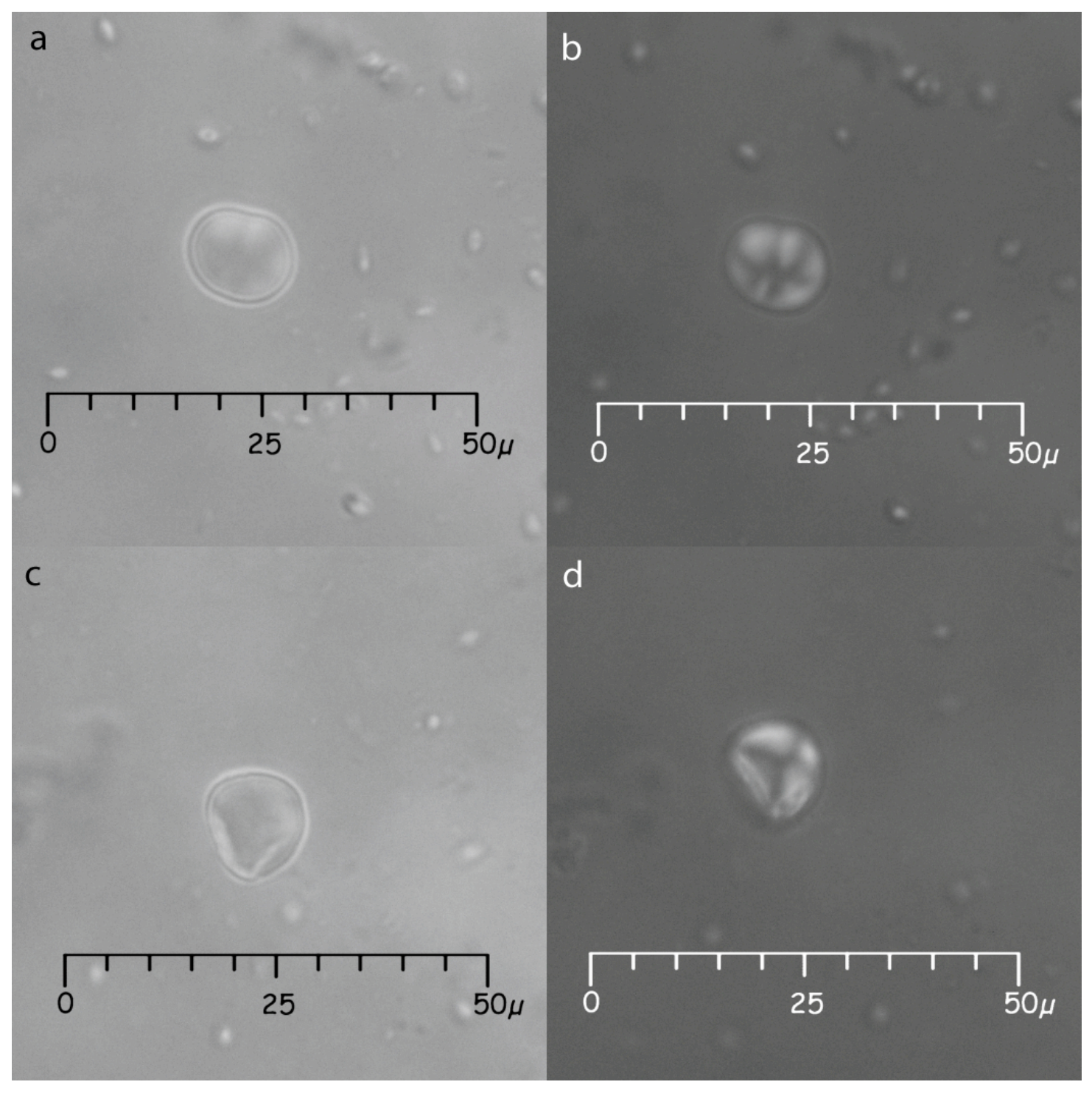

Figure App. B.3 Starch from the fruit of Solanum muricatum. A compound grain in transmitted light (a) and in polarized light (b). A single granule with edge damage in transmitted light (c) and in polarized light (d).

Opuntia ficus-indica (L.) Mill.

Fruits of O. ficus-indica, commonly known as tuna or pupa, were collected in Chiclayo, Perú. Starch grains were extracted from the fruit flesh. Starch granules were found to be spherical or hemispherical. Granule size ranges from $7 \mu$ to $14 \mu$, though grains as large as $20 \mu$ were found rarely. Spheroidal granules may be oblong or irregularly 
shaped (Figure App. B.4 a-d) or round in outline with a very gently irregular surface (Figure App. B.4 c,d). Lamellae may be visible on larger grains. A distinctive linear feature is common in granules from O. ficus-indica, and when viewed under polarized light, this feature causes an eccentric and/or irregular extinction cross. Often, the hilum appears enlarged and open on granules with this linear feature when viewed under polarized light (Figure App. B.4 b).

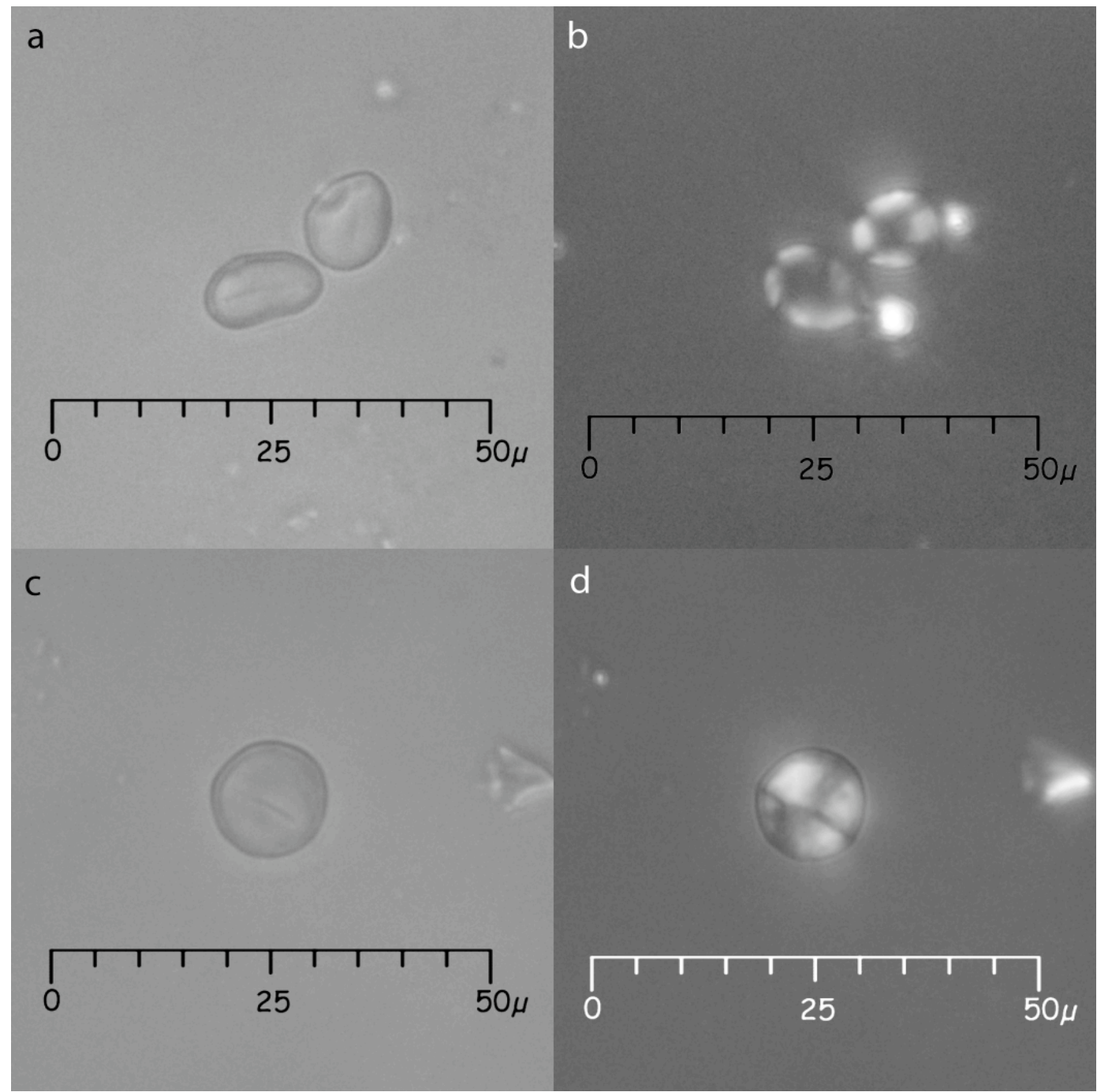

Figure App. B.4 Starch from the fruit of Opuntia ficus-indica. Two granules (a) in transmitted light and in polarized light (b). A single granule in transmitted light (c) and in polarized light (d). Note linear feature. 


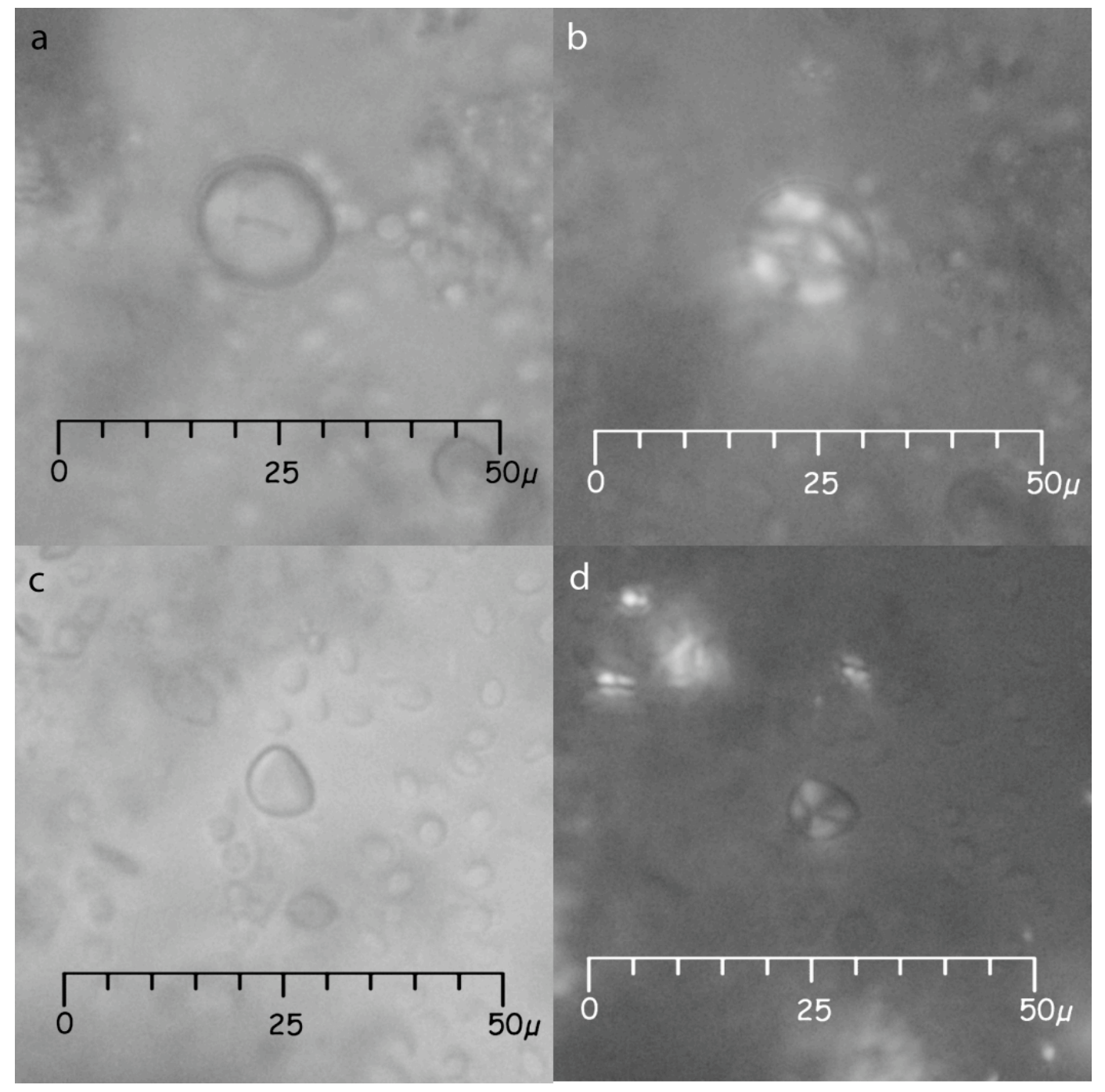

Figure App. B.5 Starch from the stem of Echinopsis pachanoi. A compound grain in transmitted light (a) and in polarized light (b). A single granule in transmitted light (c) and in polarized light (d).

Echinopsis pachanoi (Britton \& Rose) Friedrich \& G.D.

Samples of E. pachanoi, also known as San Pedro cactus, were purchased in

Chiclayo, Perú. Starch was sampled from the flesh of the succulent stem. Compound and singular grains were observed. Compound grains consist of two individual granules (Figure App. B.5 a, b) and range in size from $10 \mu$ to $20 \mu$ along the longest axis. In compound 
grains, a short linear fissure may be visible under transmitted light. The fissure separates the two individual granules and is fully visible under polarized light. Individual granules were also observed and include small simple spheres and hemispheres ranging in size from $3 \mu$ to $10 \mu$ across their longest axis. These individual grains are generally unremarkable. Starch grains in E. pachanoi are strongly birefringent with eccentric extinction crosses with curved to wavy "arms".

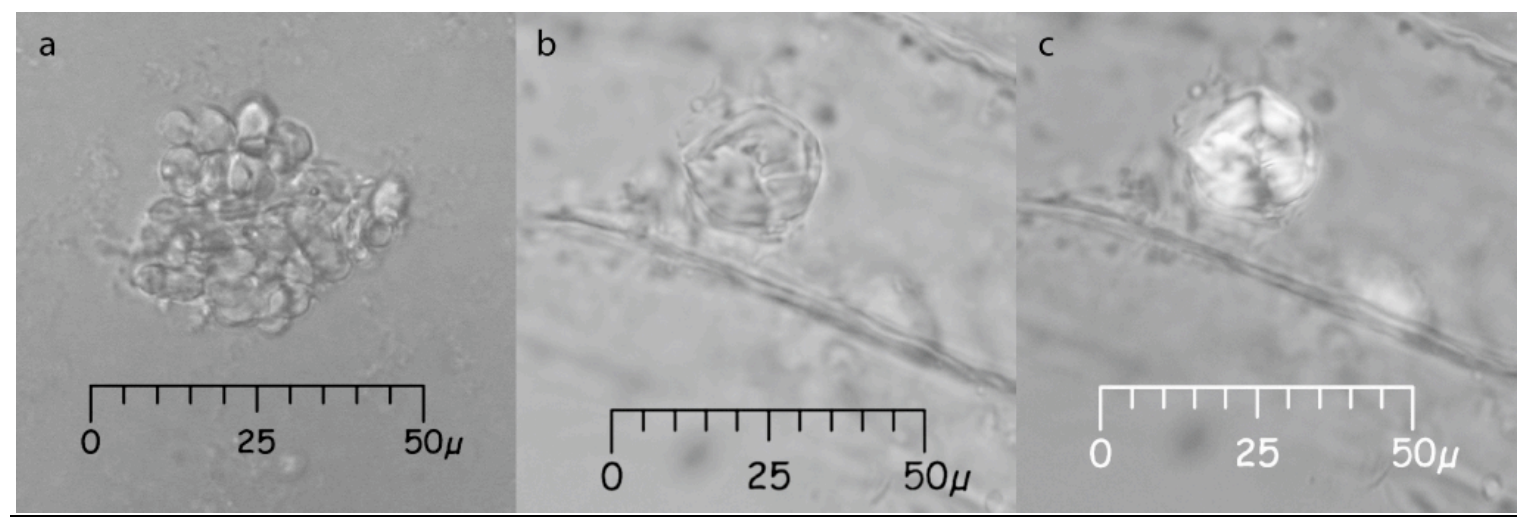

Figure App. B.6 Stone cells in Prosopis juliflora (a) and a starch grain (a-transmitted light, b-polarized light) from Prosopis pallida.

\section{Prosopis L.}

Prosopis, or algarrobo, pods were sampled for starch following techniques outlined in Giovannetti et al. (2008). Pod fragments from three Peruvian species P. juliflora, P. pallida, and P. chilensis were studied. Starch extractions were taken from the mesocarp of the pods; the seeds do not contain starch. Starch grains were not abundant in any of the samples, occurring only rarely in $P$. pallida, but further sampling is needed. Pods contain various other structures, such as stone cells from sclerenchymatous tissue in the endocarp (Figure App. B.6 a). Starch from Prosopis is irregularly shaped and highly variable, having 
lobed protuberances and a deeply depressed area at the hilum, along with a very irregular extinction cross (Figure App. B.6 b,c). Further comparative work with Peruvian Prosopis material is still needed, but the starch grains observed here are consistent with those described for Argentinean P. chilensis and P. flexuosa (Giovannetti et al. 2008).

\section{Psidium guajava L., (Myrtaceae)}

Guava fruits were purchased from supermarkets in Atlanta, Ga. and Columbia, Mo. Unfortunately, starch extraction was not successful from the fruits available. Multiple techniques were tried to acquire starch from fruit flesh, such as simple tissue scrapings and slurrying and sieving. Starch grains from guava were not characterized in this study. Guava fruits do contain starch, around $3.4 \%$ of the unripe fruit's weight, but as the fruits quickly ripen, starch content decreases to less than $1 \%$ of the fruit's weight (Jain et al. 2003). Future attempts to extract starch from guava fruits will be made with unripe fruit and a higher concentration of the sample. 


\section{Bibliography}

Adkins, L. R. and R. A. Benfer 2009 Lunar Standstill Markers at Preceramic Temples at the Buena Vista Site in Peru. Astronomical Society of the Pacific Conference Series 409:267-278.

Aldenderfer, M.

1999 The Pleistocene/Holocene Transition in Perú and Its Effects Upon Human Use of the Landscape. Quaternary International 53-54(1):11-19.

2008 High Elevation Foraging Societies. In Handbook of South American Archaeology, edited by H. Silverman and W. H. Isbell, pp. 131-144. Springer, New York.

Almendinger, J. C. and D. S. Hanson 1998 Identification, Description, and Ecology of Forested, Native Plant Communities : Draft Ecological Land Classification Handbook for the Northern Minnesota Drift $\mathbb{E}$ Lake Plains and the Chippewa National Forest. Minnesota Dept. of Natural Resources, Division of Forestry, St. Paul, Minnesota

Alvarsson, J.-Å.

1988 The Mataco of the Gran Chaco: An Ethnographic Account of Change and Continuity in Mataco Socio-Economic Organization. Academiae Upsaliensis, Uppsala, Sweden.

Andres, T. C., R. Ugás and F. Bustamante 2006 Loche: A Unique Pre-Columbian Squash Locally Grown in North Coastal Perú. In Proceedings of Cucurbitaceae, edited by G. J. Holmes. Universal Press, Raleigh.

Andrus, C. F. T., D. E. Crowe, D. H. Sandweiss, E. J. Reitz and C. S. Romanek 2003 Otolith Delta O-18 Record of Mid-Holocene Sea Surface Temperatures in Peru. Science 295(5559):1508-1511.

Arnold, D. E.

1985 Ceramic Theory and Cultural Process. Cambridge University Press, Cambridge. 
Arntz, W. E.

1986 The Two Faces of El Niño 1982-3. Meeresforschung / Reports on Marine Research 31(1):1-46.

Asch, D. L.

1994 Aboriginal Specialty-Plant Cultivation in Eastern North America. In Illinois Prehistory and a Post-Contact Perspective, edited by W. Green, pp. 25-86 Office of the State Archaeologist, Report 19, Iowa City, Iowa.

Asch, N. B. and D. L. Asch

1975 Plant Remains from the Zimmerman Site - Grid A: A Quantitative Approach. In The Zimmerman Site: Further Excavations at the Grand Village of Kaskakia, edited by M. K. Brown, pp. 116-120. Reports of Investigations, No. 32. Illinois State Museum, Springfield.

Austin, D. F.

1988 The Taxonomy, Evolution and Genetic Diversity of Sweet Potatoes and Related Wild Species. In Exploration, Maintenance, and Utilization of Sweet Potato Genetic Resources, edited by P. Gregory, pp. 27-60. International Potato Center Lima.

Baehni, C. and L. Bernardi

1970 Flora of Perú. Field Museum of Natural History, Botany, 13(5/A,3):135-177.

Balme, J. and W. E. Beck

2002 Starch and Charcoal: Useful Measures of Activity Areas in Archaeological

Rockshelters. Journal of Archaeological Science 29:157-166.

Barber, K. G.

1909 Comparative Histology of Fruits and Seeds of Certain Species of Cucurbitaceae. Botanical Gazette 47(4):263-310.

Barnett, W. K. and J. W. Hoopes

1995 The Emergence of Pottery: Technology and Innovation in Ancient Societies.

Smithsonian Institution Press, Washington D.C.

Barton, $\mathrm{H}$.

2007 Starch Residues on Museum Artefacts: Implications for Determining Tool Use. Journal of Archaeological Science 34(10):1752-1762.

Battcock, M. and S. Azam-Ali

1998 Fermented Fruits and Vegetables: A Global Perspective. FAO Agricultural Services Bulletin 134. FAO, Rome. 
Bell, C.

1997 Ritual: Perspectives and Dimensions. Oxford University Press, Oxford.

Benfer, R. A.

1982 El Proyecto Paloma de La Universidad de Missouri y El Centro de Investigaciones de Zonas Áridas. Zonas Aridas 2(33-73).

1984 The Challenges and Rewards of Sedentism: The Preceramic Village of Paloma, Perú. In Paleopathology at the Origins of Agriculture, edited by M. N. Cohan and G. J. Armelagos, pp. 531-558. Academic Press, New York.

1990 The Preceramic Period Site of Paloma, Perú: Bioindications of Improving Adaptations to Sedentism. Latin American Antiquity 1(4):284-318.

1999 Proyecto de Excavaciones en Paloma: el Valle de Chilca, Perú. Boletín de Arqueología PUCP, El Período Arcaico en el Perú. Hacia una Definición de los Orígenes 3:213-237. 3:213-237.

2008 Early Villages. In Encyclopedia of Archaeology, edited by D. M. Pearsall, pp. 368-380. Academic Press, Oxford.

Benfer, R. A. and L. R. Adkins

2007 The Americas' Oldest Observatory. Astronomy Magazine 35:40-43.

Benfer, R. A., L. Furbee and H. Ludeña R.

n.d. Four-Thousand Years of Myth of the Fox in South American Cosmology Journal of Cosmology, in press.

Benfer, R. A., Hugo Ludeña, Miriam Vallejos 2004 Proyecto de Investigación Arqueológica: Pozos de Prueba en Los Sitios Arqueológicas de Buena Vista y La Quipa, Primera Etapa. Informe Preliminar Presentado al Instituto Nacional de Cultura del Perú el 7 de junio de 2004.

Benfer, R. A., B. Ojeda and G. H. Weir 1987 Early Water Management Strategies on the Coast of Perú. In Risk Management and Arid Land Use Strategies in the Andes, edited by D. Browman, pp. 195-206. Westview Press, Boulder, CO.

Benfer, J., R. A., B. Ojeda, N. A. Duncan, L. R. Adkins, H. Ludeña, M. Vallejos, V. Rojas, A. Ocas, O. Ventocilla and G. Villarreal 2007 La Tradición Religioso-Astronómica en Buena Vista. Boletín de Arqueología Pontificia Universidad Católica del Perú 11:53-102. 
Berryman, C. A.

2010 Food, Feasts, and the Construction of Identity and Power in Ancient Tiwanaku: A Bioarchaeological Perspective. Ph.D. Dissertation, Department of Anthropology, Vanderbilt University.

Bird, J. B.

1948 Preceramic Cultures in Chicama and Virú. Memoirs of the Society for American Archaeology, No. 4. A Reappriasal of Peruvian Archaeology: 21-28.

Bird, J. B., J. Hyslop and M. D. Skinner

1985 The Preceramic Excavations at Huaca Prieta, Chicama Valley, Perú.

Anthropological Papers 62, Part 1. American Museum of Natural History, New York.

Bird, R. M.

1990 What Are the Chances of Finding Maize in Perú Dating before 1000 B.C.?: Reply to Bonavia and Grobman. American Antiquity 55(4):828-840.

Bolin, I.

1998 Rituals of Respect: The Secret of Survival in the High Peruvian Andes. University of Texas Press, Austin.

Bonavia, D.

1982 Precerámico Peruano. Los Gavilanes. Mar, Desierto, y Oasis en la Historia del Hombre. Oficina de Asuntos Culturales, Instituto Arqueológico Alemán, Comissión de Arqueología General y Comparada. Editorial Ausonia-Talleres Gráficos, Lima.

Bonavia, D. and A. Grobman

1989 Preceramic Maize in the Central Andes: A Necessary Clarification. American Antiquity 54(4):836-840.

Bonavia, D.

1996 De la Caza-Recolección a la Agricultura: una Perspectiva Local. Bulletin Institut Francais d'Etudes Andines25(2):169-186.

Bonnier, E.

1997 Preceramic Architecture in the Andes: The Mito Tradition. In Archaeologica Peruana 2 - Prehispanic Architecture and Civilization in the Andes, edited by E. Bonnier and Henning Bischof, pp. 120-144. Reiss-Museum, Mannheim.

Bonnier, E. and C. Rozenberg

1988 Del Santuario al Caserío: Acerca de la Neolitización en la Cordillera de los Andes Centrales. Bulletin - Institut Francais d'Etudes Andines XVII(2):23-40. 
Bonzani, R. M.

1997 Plant Diversity in the Archaeological Record: A Means toward Defining

Hunter-Gatherer Mobility Strategies. Journal of Archaeological Science 24:1129-1139.

Bourque, S. C. and K. B. Warren

1991 Women of the Andes: Patriarchy and Social Change in Two Peruvian Towns. University of Michigan Press, Ann Arbor.

Bowser, B. J. and J. Q. Patton

2004 Domestic Spaces as Public Places: An Ethnoarchaeological Case Study of Houses, Gender, and Politics in the Ecuadorian Amazon. Journal of Archaeological Method and Theory 11(2):157-181.

Boyadjian, C. H. C., S. Eggers and K. Reinhard 2007 Dental Wash: A Problematic Method for Extracting Microfossils from Teeth. Journal of Archaeological Science 34(10):1622-1628.

Bozarth, S. R.

1996 Pollen and Opal Phytolith Evidence of Prehistoric Agriculture and Wild Plant Utilization in the Lower Verde River Valley, Arizona. Ph.D. Dissertation, Department of Geography, University of Kansas, Lawrence.

Brack Egg, A.

1999 Diccionario Enciclopédico de Plantas Utiles del Perú. Centro de Estudios Regionales Andinos, Cuzco.

2003 Frutas del Perú. Universidad San Martin de Porres, Lima.

Brako, L. and J. L. Zarucchi

1993 Catalogue of the Flowering Plants and Gymnosperms of Peru. Monographs in Systematic Botany from the Missouri Botanical Garden, 45. Missouri Botanical Garden, St. Louis.

Bray, T. L.

2003a The Archaeology and Politics of Food and Feasting in Early States and Empires. Kluwer Academic/Plenum, New York.

2003b Inca Pottery as Culinary Equipment: Food, Feasting, and Gender in Imperial State Design. Latin American Antiquity 14:3-28.

Bressani, R.

1965 The Use of Cottonseed Protein in Human Foods. Food Technology 19(11):5151. 
Brose, U., N. D. Martinez and R. J. Williams

2003 Estimating Species Richness: Sensitivity to Sample Coverage and Insensitivity to Spatial Patterns. Ecology 84(9):2364-2377.

Browman, D. L.

1974 Pastoral Nomadism in the Andes. Current Anthropology 15(2):188-196.

Bryant, V. M.

1974 Prehistoric Diet in Southwest Texas: The Coprolite Evidence. American Antiquity 39(3):407-420.

Bueno Mendoza, A. and T. Grieder

1979 Arquitectura Precerámica De La Sierra Norte. Espacio (1):5.

Burger, R. L.

1981 The Radiocarbon Evidence for the Temporal Priority of Chavín de Huantar. American Antiquity 46(3):592-602.

1988 Unity and Heterogeneity within the Chavín Horizon. In Peruvian Prehistory, edited by R. W. Keatinge, pp. 99-144. Cambridge University Press, Cambridge.

1995 Chavin and the Origins of Andean Civilization. Second ed. Thames and Hudson, New York.

Burger, R. L. and Michael D. Glascock

2000 The Puzolana Obsidian Source: Locating the Geologic Source of Ayacucho Type Obsidian. Andean Past 6:289-307.

Burger, R. L. and N. J. Van Der Merwe

1990 Maize and the Origin of Highland Chavin Civilization: An Isotopic

Perspective. American Anthropologist 92(1):85-95.

Burger, R. L. and L. Salazar-Burger

1980 Ritual and Religion at Huaricoto. Archaeology 33:26-32.

1985 The Early Ceremonial Center of Huaricoto. In Early Ceremonial Architecture in the Andes, edited by C. B. Donnan, pp. 111-138. Dumbarton Oaks, Washington, D.C.

1986 Early Organizational Diversity in the Peruvian Highlands: Huaricoto and Kotosh. In Andean Archaeology, edited by R. Matos and S. Turpin, pp. 65-82. UCLA Institute of Archaeology, Los Angeles. 
Bussmann, R. and D. Sharon

2007 Plants of the Four Winds: The Magic and Medicinal Flora of Perú. Graficart, Trujillo, Peru.

Calzada Benza, J.

1980143 Frutales Nativos. Universidad Nacional Agraria La Molina, Lima.

Cárdenas, $\mathrm{M}$.

1969 Manual de Plantas Económicas De Bolivia. Impressa Icthus, Cochabamba.

Cardich, A.

1958 Los Yacimientos de Lauricocha: Nuevas Interpretaciones de la Prehistória Peruana. Studia Praehistorica 1, Centro Argentino de Estudios Prehistoricos, Buenos Aires.

1964 Lauricocha: Fundamentos para una Prehistoria de los Andes Centrales. Studia Praehistorica 3. Centro Argentino de Estudios Prehistoricos, Buenos Aires.

Caviedes, C. N.

1984 El Nino 1982-83. Geographical Review 74(3):267-290.

Chandler-Ezell, K. and D. M. Pearsall 2003 "Piggy-Back" Microfossil Processing: Joint Starch and Phytolith Sampling from Stone Tools. Phytolitharian Newsletter 15(3):2-7.

Chandler-Ezell, K., D. M. Pearsall and J. A. Zeidler 2006 Root and Tuber Phytoliths and Starch Grains Document Manioc (Manihot Esculenta), Arrowroot (Maranta Arundinacea), and Llerén (Calathea sp.) at the Real Alto Site, Ecuador. Economic Botany 60(2):103-120.

Chauchat, C. 1988 Early Hunter-Gatherers on the Peruvian Coast. In Peruvian Prehistory, edited by R. W. Keatinge, pp. 41-66. Cambridge University Press, Cambridge.

Chauchat, C., E. Wing, J.-P. Lacombe, P.-Y. Demars, S. Uceda and C. Dexa 1992 Préhistoire de la Côte Nord du Pérou: Le Paijanien de Cupisnique. Cahiers Du Quaternaire 18. Centre National de la Recherche Scientifique, Paris.

Chevalier, A. L.

2002 L'exploitation des Plantes Sur la Côte Péruvienne en Contexte Formatif. Doctoral Dissertation, University of Geneva, Geneva. 
2008 Early Holocene Adaptation in the Central Andes: What the Phytoliths Can Tell Us. In Matices Interdisciplinários en Estúdios Fitolíticos y de Otros Microfósiles, edited by M. A. Korstanje and M. D. Pilar Babot. BAR International Series 1870, Oxford, UK.

Childe, V. G.

1950 The Urban Revolution. Town Planning Review 21:3-17.

Clark, J. E. and M. Blake

1993 The Power of Prestige: Competitive Generosity and the Emergence of Rank Societies in Lowland Mesoamerica. In Factional Competition and Political Development in the New World, edited by E. Brumfiel and J. W. Fox, pp. 17-30. Cambridge University Press, New York.

Cohen, M.

1978 Archaeological Plant Remains from the Central Coast of Peru. Nawpa Pacha 16:23-51.

Cohen, M. N.

1977 Population Pressure and the Origins of Agriculture: An Archaeological Example from the Coast of Peru. In Origins of Agriculture, edited by C. A. Reed, pp. 135-177. Mouton Publishers, The Hague.

Conlan, R. and R. Service

2000 El Niño and La Niña: Tracing the Dance of Ocean and Atmosphere. National Academy of Sciences Office on Public Understanding of Science, Washington D. C.

Correll, D. S.

1967 Flora of Peru. Solanaceae. Field Museum of Natural History, Botany 13 (5/B, 2):271-458.

Cortella, A. R. and M. L. Pochettino 1994 Starch Grain Analysis as a Microscopic Diagnostic Feature in the Identification of Plant Material. Economic Botany 48(2):171-181.

Crowther, A.

2005 Starch Residues on Undecorated Lapita Pottery from Amir, New Ireland. Archaeology in Oceana 40:62-66. 
Cutler, H. C.

1975 Two Kinds of Gourds from Key Marco. In The Material Culture of Key Marco, Florida, edited by M. S. Gilliland, pp. 255-256. University of Florida Press, Gainesville.

Cutler, H. C. and T. W. Whitaker 1961 History and Distribution of the Cultivated Cucurbits in the Americas. American Antiquity 26(4):469-585.

Czaja, A. T.

1978 Structure of Starch Grains and the Classification of Vascular Plant Families. Taxon 27(5/6):463-470.

Decker, D. S.

1988 Origin(s), Evolution, and Systematics of Cucurbita pepo (Cucurbitaceae). Economic Botany 42(1):4-15.

Decker-Walters, D. S.

1993 New Methods for Studying the Origins of New World Domesticates: The Squash Example. In Foraging and Farming in the Eastern Woodlands, edited by C. M. Scarry, pp. 91-97. University Press of Florida, Gainesville.

Decker-Walters, D. S., M. Wilkins-Ellert, S. M. Chung and J. E. Staub 2004 Discovery and Genetic Assessment of Wild Bottle Gourd [Lagenaria siceraria (Mol.) Standley; Cucurbitaceae] from Zimbabwe. Economic Botany 58(4):501-508.

deFrance, S. D., D. K. Keefer, J. Richardson III, and A. Umire 2001 Late Paleo-Indian Coastal Foragers: Specialized Extractive Behavior at Quebrada Tacahuay. Latin American Antiquity 12:413-426.

deFrance, S. D. and A. Umire 2004 Quebrada Tacahuay: un Sitio Marítimo del Pleistocene Tardío en la Costa Sur del Perú. Chungará 36(257-278).

Denevan, W. M. 2001 Cultivated Landscapes of Native Amazonia and the Andes. Oxford University Press, Oxford.

Dering, P. and G. H. Weir 1979 Analysis of Plant Remains from the Preceramic Site of Paloma, Chilca Valley, Peru. Manuscript on file, University of Missouri, Columbia. 
Dickau, R., A. J. Ranere, and R. G. Cooke 2007 Starch Grain Evidence for the Preceramic Dispersals of Maize and Root Crops into Tropical Dry and Humid Forests of Panama. Proceedings of the National Academy of Sciences of the United States of America 104(9):3651-3658.

Dietler, M.

2001 Theorizing the Feast: Rituals of Consumption, Commensal Politics, and Power in African Contexts. In Feasts: Archaeological and Ethnographic Perspectives on Food, Politics, and Power, edited by B. Hayden and M. Dietler, pp. 65-113. Smithsonian Institution Press, Washington D.C.

Dillehay, T. D.

1977 Tawantinsuyu Integration of the Chillon Valley: A Case of Inca Geopolitical Mastery. Journal of Field Archaeology 5:456-473.

1979 Prehispanic Resource Sharing in the Central Andes. Science 204:24-31.

1997 Monte Verde: A Late Pleistocene Settlement in Chile, Vol. 2: The Archaeological Context and Interpretation. Smithsonian Institution Press, Washington D.C.

2000 The Settlement of the Americas: A New Prehistory. Basic Books, New York.

Dillehay, T. D., D. Bonavia and P. Kaulicke 2004 The First Settlers. In Andean Archaeology - Blackwell Studies in Global Archaeology, edited by H. Silverman, pp. 16-34. Blackwell Publishing Ltd, Malden, MA.

Dillehay, T. D., C. Ramírez, M. Pino, M. B. Collins, J. Rossen and J. D. Pino-Navarro 2008 Monte Verde: Seaweed, Food, Medicine, and the Peopling of South America: Supplementary Materials. Science 320:784-786.

Dillehay, T. D., J. Rossen, T. C. Andres and D. E. Williams 2007 Preceramic Adoption of Peanut, Squash, and Cotton in Northern Perú. Science 316:1890-1892.

Dillon, M. O. 2005 The Solanaceae of the Lomas Formations of Coastal Peru and Chile. In A Festschrift for William G. D'arcy: The Legacy of a Taxonomist. Monographs in Systematic Botany from the Missouri Botanical Garden, edited by W. G. D'arcy, R. Keating, V. C. Hollowell and T. B. Croat, pp. 131-156. Missouri Botanical Garden, St. Louis. 
Dillon, M. O., M. Nakazawa and S. L. Gonzáles 2003 The Lomas Formations of Coastal Peru: Composition and Biogeographic History. Fieldiana Botany 43:1-9.

Dillon, M. O. and P. W. Rundel 1990 The Botanical Response of the Atacama and Peruvian Desert Floras to the 1982-83 El Niño Event. In Global Eclogical Consequences of the 1982-83 El NiñoSouthern Oscillation, edited by P. W. Glynn, pp. 487-504. Elsevier, New York.

Dimbleby, G. W. 1978 Plants and Archaeology, Second Edition (1967). Humanities Press, Atlantic Highlands, New Jersey.

Dollfus, M. O.

1960 Note Sur Une Crise Climatique Récente Dans le Désert Péruvien a Partir De L'analyse D'ossements Humains Au C.14. Bulletin de L'Association de Géographes Français (294-295):187-192.

Donnan, C. B. and C. Mackey 1978 Ancient Burial Patterns of the Moche Valley, Peru. University of Texas Press, Austin.

Douglas, M.

1966 Purity and Danger: An Analysis of the Concepts of Pollution and Taboo. Routledge and Keegan Paul, London.

Doyle, M. A.

1988 Religion and Social Evolution in the Seventeenth and Eighteenth Century, Central Peru. PhD Dissertation, Department of Anthropology, University of Michigan, Ann Arbor.

Druc, I. C., R. L. Burger, R. Zamojska, and P. Magny 2001 Ancón and Garagay Ceramic Production at the Time of Chavín de Huantar. Journal of Archaeological Science 28(1):29-43.

Duncan, N. A. 2003 At the Edge of the Puna: Archaeological Test Excavation and Sampling for Phytolith Signatures of Ancient Corrals at Antibal, Perú. MA Thesis, Department of Anthropology, University of Missouri, Columbia.

Duncan, N. A., R. Benfer, H. Ludeña and M. Vallejos 2008 Investigaciones Arqueológicas en el Sítio de la Quipa, Chilca. In Arqueología De La Costa Centro Sur Peruana, edited by O. Pinedo and H. Tantaleán, pp. 63-74. Avqi Ediciones, Lima, Perú. 
Duncan, N. A., D. M. Pearsall and R. A. Benfer

2009 Gourd and Squash Artifacts Yield Starch Grains of Feasting Foods from

Preceramic Perú. Proceedings of the National Academy of Sciences of the United States of America 106(32):13202-13206.

Durkheim, E.

1995 [1912] The Elementary Forms of Religious Life, edited by K. Fields. The Free Press, New York.

Eakin, L., E. Lauriault and H. Boonstra

1986 People of the Ucayali, the Shipibo and Conibo of Perú. International Museum of Cultures Publication, 12. Dallas, TX.

Earle, T. K., T. N. D'Altroy, C. J. Leblanc, C. A. Hastorf and T. Y. Levine

1980 Changing Settlement Patterns in the Upper Mantaro Valley, Perú. Journal of New World Archaeology 4(1):1-49.

Edwin, G.

1971 Flora of Perú. Field Museum of Natural History, Botany 8 (5/B, 3):461-717.

Ellenberg, $\mathrm{H}$.

1959 Über den Wasserhaushalt Tropischer Nebeolasen in der Küstenwüste

Perús. Berichte des Geobotanischen Institutes der Eidg. Technischen Hochschule, Stiftung

Rübel. 1958:47-74.

Engel, F. A.

1957 Sites et Etablissements sans Céramique de la Côte Péruvienne. Journal de la Société des Américanistes 44:43-95.

1958 Algunos Datos con Referencia a los Sitios Precerámicos de la Costa Peruana.

Museo Nacional de Antropología y Arquelogía, Lima, Peru.

1962 Elementos de Prehistoria Peruana. Stylo, Lima, Peru.

1963 A Preceramic Settlement on the Central Coast of Peru: Asia, Unit I. American Philosophical Society, Philadelphia.

1964 El Precerámico sin Algodón en la Costa del Perú. XXXV Congreso Internacional de Americanístas 3, México. 
1966 Geografía Humana Prehistórica y Agricultura Precolombina de la Quebrada de Chilca. Universidad Nacional Agraria la Molina. Centro de Investigaciones de Zonas Áridas, Lima, Perú.

1967 Le Complexe Précéramique D'el Paraiso (Perou). Journal de la Sociéte des Américanistes 55:43-96.

1973 New Facts About Pre-Columbian Life in the Andean Lomas. Current Anthropology 14:271-280.

1976 An Ancient World Preserved: Relics and Records of Prehistory in the Andes. Crown Publishers, New York.

1980 Prehistoric Andean Ecology: Man, Settlement, and Environment in the Andes, 1, Paloma. Distributed by Humanities Press for the Department of Anthropology, Hunter College, City University of New York, [Atlantic Highlands, N.J.].

1984 Prehistoric Andean Ecology: Man, Settlement, and Environment in the Andes, 4, Chilca. Distributed by Humanities Press for the Department of Anthropology Hunter College City University of New York, [Atlantic Highlands, N.J.].

1987 De las Begónias al Maiz: Vida y Producción en el Perú Antiguo. Universidad Nacional Agraria La Molina. Centro de Investigaciones de Zonas Aridas, Lima, Perú.

Erickson, D. L., B. D. Smith, A. C. Clark, D. H. Sandweiss, and N. Tuross 2005 An Asian Origin for a 10,000-Year-Old Domesticated Plant in the Americas. Proceedings of the National Academy of Sciences of the United States of America 102(51):18315-18320.

Feldman, R. A.

1980 Aspero, Peru: Architecture, Subsistence Economy and Other Artifacts of a Preceramic Maritime Chiefdom. Ph.D. Dissertation, Department of Anthropology, Harvard University.

1985 Preceramic Corporate Architecture: Evidence for the Development of NonEgalitarian Social Systems in Peru. In Early Ceremonial Architecture in the Andes, edited by C. B. Donnan, pp. 71-92. Dumbarton Oaks, Washington D.C.

Ferreyra, R.

1982 Flora Del Perú: Dicotiledoneas. Universidad Nacional Mayor de San Marcos, Lima, Peru. 
Firth, R.

1963 Offering and Sacrifice: Problems of Organization. Journal of the Royal Anthropological Institute of Great Britain and Ireland 93(1):12-24.

Flores Palomino, M.

1985 El Niño Phenomena and its Socio-Economic Consequences. PESCA 46(34):12-16.

Fogelin, L.

2007a The Archaeology of Religious Ritual. In Annual Review of Anthropology, Vol. 36, pp. 55-71.

2007b History, Ethnography, and Essentialism: The Archaeology of Religion and Ritual in South Asia. In The Archaeology of Ritual, edited by E. Kyriakidis, pp. 23-42. Cotsen Institute of Archaeology, Los Angeles.

Ford, R. I.

1986 Reanalysis of Cucurbits in the Ethnobotanical Laboratory, University of Michigan. Missouri Archaeologist 47:13-31.

Franquemont, C., E. Franquemont, W. Davis, T. Plowman, S. R. King, C. R. Sperling and C. Niezgoda

1990 The Ethnobotany of Chinchero, an Andean Community in Southern Perú. Fieldiana Botany 24:1-126.

Fredlund, G. G. and L. T. Tieszen 1994 Modern Phytolith Assemblages from the North American Great Plains. Journal of Biogeography 21:321-335.

Fritz, G. J.

1999 Gender and the Early Cultivation of Gourds in Eastern North America. American Antiquity 64(3):417-429.

Fullagar, R., J. Field, T. Denham and C. Lentfer 2006 Early and Mid Holocene Tool-Use and Processing of Taro (Colocasia esculenta), Yam (Dioscorea sp.) and Other Plants at Kuk Swamp in the Highlands of Papua New Guinea. Journal of Archaeological Science 33(5):595-614.

Fung Pineda, R.

1988 The Late Preceramic and Initial Period. In Peruvian Prehistory: An Overview of Pre-Inca and Inca Society, edited by R. W. Keatinge, pp. 67-98. Cambridge University Press, Cambridge. 
Gade, D. W.

1966 Achira, the Edible Canna: Its Cultivation and Uses in the Peruvian Andes. Economic Botany 20(4):407-415.

Galán de Mera, A., S. Baldeón, H. Beltrán, M. Benavente and J. Gómez Carrión 2004 Datos Sobre la Vegetación del Centro del Perú. Acta Botanica Malacitana 29:89-115.

Galán de Mera, A., J. A. Vincente Orellana and J. Gómez Carrión 1998 El Significado Biogeográfico de la Vegetación en el Centro del Perú. Arnaldoa 5(2):265-272.

Galán De Mera, A., M. V. Rosa and C. Cáceres 2002 Una Aproximación Sintaxonómica Sobre la Vegetación del Perú. Clases, Órdenes y Alianzas. Acta Botanica Malacitana 27:75-103.

Gentry, A. H.

1996 A Field Guide to the Families and Genera of Woody Plants of Northwest South America (Colombia, Ecuador, Peru), with Supplementary Notes on Herbaceous Taxa. University of Chicago Press, Chicago.

Gentry, A. H., M. O. Dillon, S. B. Jones and J. F. Macbride 1980 Flora of Peru. Compositae. Fieldiana Botany New Series 5.

Gero, J.

1992 Feasts and Females: Gender Ideology and Political Meals in the Andes. Norwegian Archaeological Review 25:1-16.

Ghezzi, I. and C. Ruggles 2007 Chankillo: A 2300-Year-Old Solar Observatory in Coastal Perú. Science 315(5816):1239-1243.

Gilliland, M. S.

1975 The Material Culture of Key Marco Florida. University of Florida Press, Gainseville.

Giovannetti, M. A., V. S. Lema, C. G. Bartoli and A. Capparelli 2008 Starch Grain Characterization of Prosopis chilensis (Mol.) Stuntz and P. flexuosa DC, and the Analysis of their Archaeological Remains in Andean South America. Journal of Archaeological Science 35(11):2973-2985. 
Goldstein, D. J.

2007 Forests and Fires: A Paleoethnobotanical Assessment of the Impact of Middle Sicán Pyrotechnology on the Dry Tropical Forests of the La Leche River Valley, Lambayeque, Perú. PhD Dissertation, Department of Anthropology, Southern Illinois University, Carbondale.

Goldstein, D. J. and I. Shimada 2010 Feeding the Fire: Food and Craft Production in the Middle Sicán Period (AD 950-1050). In Inside Ancient Kitchens: New Directions in the Study of Daily Meals and Feasts, edited by E. Klarich, pp. 161-190. University Press of Colorado, Boulder.

Grayson, D. K. 1984 Quantitative Zooarchaeology. Academic Press, Orlando.

Grieder, T.

1975 A Dated Sequence of Building and Pottery at Las Haldas. Nawpa Pacha 13:99-112.

Grieder, T. and A. Bueno Mendoza 1985 Ceremonial Architecture at La Galgada. In Early Ceremonial Architecture in the Andes, edited by C. B. Donnan, pp. 93-110. Dumbarton Oaks, Washington D.C.

1988 The History of La Galgada Architecture. In La Galgada, Perú: A Preceramic Culture in Transition, by T. Grieder, A. Bueno Mendoza, C. E. Smith and R. M. Malina, pp. 19-67. University of Texas Press, Austin.

Grieder, T., A. Bueno Mendoza, C. E. Smith, and R. Malina 1988 La Galgada, Perú: A Preceramic Culture in Transition. University of Texas Press, Austin.

Gumerman, G. and B. S. Umemoto 1987 The Siphon Technique: An Addition to the Flotation Process. American Antiquity 52(2):330-336.

Gutierrez, F., T. Piechota and J. Dracup 1998 Conexiones entre Caudales de Algunos Ríos de La Costa Norte y Central Del Perú Y El Niño. Bulletin de l'Institut Français d'Études Andines 27(3):829-838.

Haas, J. and W. Creamer

2004 Cultural Transformations in the Central Andean Late Archaic. In Andean Archaeology, edited by H. Silverman, pp. 35-50. Blackwell, Malden, MA. 
2006 Crucible of Andean Civilization: The Peruvian Coast from 3000 to 1800 B.C. Current Anthropology 47(5):745-775.

Haas, J., W. Creamer and A. Ruiz 2004 Dating the Late Archaic Occupation of the Norte Chico Region in Perú. Nature 432(7020): 1020-1023.

Hardy, K., T. Blakeney, L. Copeland, J. Kirkham, R. Wrangham and M. Collins 2009 Starch Granules, Dental Calculus and New Perspectives on Ancient Diet. Journal of Archaeological Science 36(2):248-255.

Harms, H. V. 1922 Übersicht der Bisher in AltPeruanishen Graben Gefundenen Pflanzenreste. In Festschrift Eduard Seler, pp. 157-186. Stuttgart.

Harner, M.

1973 The Jivaro: People of the Sacred Waterfalls. Anchor Press, Garden City, NY.

Harry, K. and L. Frink

2009 The Arctic Cooking Pot: Why Was It Adopted? American Anthropologist 111(3):330-343.

Hart, J. P., R. A. Daniels and C. J. Sheviak 2004 Do Cucurbita pepo Gourds Float Fishnets? American Antiquity 69(1):141-148.

Haslam, M.

2004 The Decomposition of Starch Grains in Soils: Implications for Archaeological Residue Analyses. Journal of Archaeological Science 31:1715-1734.

Hastorf, C. A. 2003a Community with the Ancestors: Ceremonies and Social Memory in the Middle Formative at Chiripa, Bolivia. Journal of Anthropological Archaeology 22(4):305-332.

2003b Andean Luxury Foods: Special Food for the Ancestors, Deities and the Elite. Antiquity 77(297):545-554.

2007 Archaeological Andean Rituals: Performance, Liturgy, and Meaning. In The Archaeology of Ritual, edited by E. Kyriakidis, pp. 77-108. Cotsen Institute of Archaeology, Los Angeles. 
Hastorf, C. A. and T. K. Earle

1985 Intensive Agriculture and the Geography of Political Change in the Upper Mantaro Region of Central Peru. In British Archaeological Reports International Series, edited by I. Farrington, pp. 569-595. vol. 232.

Hastorf, C. A. and S. Johannessen

1993 Prehispanic Political Change and the Role of Maize in the Central Andes of Peru. American Anthropologist 95(1):115-138.

Hawkes, C.

1954 Wenner-Gren Foundation Supper Conference: Archeological Theory and Method: Some Suggestions from the Old World. American Anthropologist 56(2):155168.

Hawkes, J. G.

1990 The Potato: Evolution, Biodiversity and Genetic Resources. Smithsonian Institution Press, Washington, D.C.

Hayashida, F. M.

2008 Ancient Beer and Modern Brewers: Ethnoarchaeological Observations of Chicha Production in Two Regions of the North Coast of Perú. Journal of Anthropological Archaeology 27(2):161-174.

2009 Chicha Histories: Pre-Hispanic Brewing in the Andes and the Use of Ethnographic and Historical Analogues. In Drink, Power, and Society in the Andes, edited by J. Jennings and B. J. Bowser, pp. 232-256. University of Florida Press, Gainesville.

Hayden, B.

1995a The Emergence of Prestige Technologies and Pottery. In The Emergence of

Pottery: Technology and Innovation in Ancient Societies, edited by W. K. Barnett and J. W. Hoopes, pp. 257-265. Smithsonian Institution Press, Washington, D.C.

1995b Pathways to Power: Principles for Creating Socioeconomic Inequalities. In Foundations of Social Inequality, edited by T. D. Price and G. Feinman, pp. 15-85.

Plenum, New York.

2001 Fabulous Feasts: A Prolegomenon to the Importance of Feasting. In Feasts: Archaeological and Ethnographic Perspectives on Food, Politics, and Power, edited by M. Dietler and B. Hayden, pp. 23-64. Smithsonian Institution Press, Washington D.C.

Hayden, B. and A. Cannon

1983 Where the Garbage Goes: Refuse Disposal in the Maya Highlands. Journal of Anthropological Archaeology 2:117-163. 
Heiser, C. B.

1973 Variation in the Bottle Gourd. In Tropical Forest Ecosystems in Africa and South America: A Comparative Review, edited by B. J. Meggers, E. S. Ayensu and W. D. Duckworth, pp. 121-128. Smithsonian Institution Press, Washington, D.C.

1979 The Gourd Book. University of Oklahoma Press, Norman.

1985 Of Plants and People. University of Oklahoma Press, Norman.

1990 Seed to Civilization. The Story of Food. Harvard University Press, Cambridge, MA.

Henry, A. G., H. F. Hudson and D. R. Piperno 2009 Changes in Starch Grain Morphologies from Cooking. Journal of Archaeological Science 36:915-922.

Henry, A. G. and D. R. Piperno 2008 Using Plant Microfossils from Dental Calculus to Recover Human Diet: A Case Study from Tell Al-Raqā'i, Syria. Journal of Archaeological Science 35(7):19431950.

Hodder, I.

1992 Theory and Practice in Archaeology. Routledge, London.

Holdridge, L. R.

1967 Life Zone Ecology. Revised ed. Tropical Science Center, San Jose, Costa Rica.

Hoopes, J. W.

1994 Ford Revisited: A Critical Review of the Chronology and Relationships of the Earliest Ceramic Complexes in the New World, 6000-1500 B.C. Journal of World Prehistory 8(1):1-49.

Horrocks, M.

2005 A Combined Procedure for Recovering Phytoliths and Starch Residues from Soils, Sedimentary Deposits and Similar Materials. Journal of Archaeological Science 2005(32):1169-1175.

Hubbard, R. N. L. B. and A. Clapham 1992 Quantifying Macroscopic Plant Remains. Review of Palaeobotany and Palynology 73:117-132.

Huston, M. A.

1994 Biological Diversity: The Coexistence of Species on Changing Landscapes Cambridge University Press. Cambridge. 
INRENA-Instituto Nacional De Recursos Naturales (Perú)

1996 Diagnóstico de la Calidad del Agua de la Vertiente del Pacífico. 2 vols. INRENA, Lima, Perú.

Iriarte, J.

2003 Assessing the Feasibility of Identifying Maize through the Analysis of CrossShaped Size and Three-Dimensional Morphology of Phytoliths in the Grasslands of Southeastern South America. Journal of Archaeological Science 30(9):1085-1094.

Iriarte, J. and E. A. Paz

2009 Phytolith Analysis of Selected Native Plants and Modern Soils from

Southeastern Uruguay and Its Implications for Paleoenvironmental and

Archeological Reconstruction. Quaternary International 193(1-2):99-123.

Izumi, S. and T. Matsuzawa

1967 Early Pre-Ceramic Cultist Culture of the Central Andes: On the Kotosh

Mito Phase. Latin American Studies 8:39-69.

Izumi, S. and K. Terada

1972 Andes 4: Excavations at Kotosh, Peru, 1963 and 1966. University of Tokyo Press, Tokyo.

Jain, N., K. Dhawan, S. P. Malhotra, S. Siddiqui and R. Singh

2001 Compositional and Enzymatic Changes in Guava (Psidium guajava L.) Fruits During Ripening. Acta Physiologiae Plantarum 23(3):357-362.

Jain, N., K. Dhawan, S. P. Malhotra and R. Singh

2003 Biochemistry of Fruit Ripening of Guava (Psidium guajava L.):

Compositional and Enzymatic Changes. Plant Foods for Human Nutrition 58(309315).

Jennings, J.

2005 La Chichera y el Patrón: Chicha and the Energetics of Feasting in the

Prehistoric Andes. In Foundations of Power in the Prehispanic Andes, edited by C. A. Conlee, D. Ogburn and K. Vaughn, pp. 241-259. Archaeological Publications of the AAA, vol. 14. American Anthropological Association, Washington, D.C.

Jennings, J. and B. J. Bowser 2009 Drink, Power, and Society in the Andes. University Press of Florida, Gainesville.

Johannessen, S.

1984 Paleoethnobotany. In American Bottom Archaeology, edited by C. J. Bareis and J. W. Porter, pp. 197-214. University of Illinois Press, Urbana. 
Jones, G. E. M.

1991 Numerical Analysis in Archaeobotany. In Progress in Old World

Palaeoethnobotany, edited by W. V. Zeist, K. Wasylikowa and K.-E. Behre, pp. 63-78, Balkema, Rotterdam.

Jones, J. G.

1988 Middle to Late Preceramic (6000-3000 B.P.) Subsistence Patterns on the Central Coast of Peru: The Coprolite Evidence. MA Thesis, Department of Anthropology, Texas A\&M University, College Station.

1993 Analysis of Pollen and Phytoliths in Residue from a Colonial Period Ceramic Vessel. In Current Research in Phytolith Analysis: Applications in Archaeology and Paleoecology, edited by D. M. Pearsall and D. R. Piperno, pp. 31-35. MASCA Research Papers in Science and Archaeology, Vol. 10, K. Ryan, general editor. MASCA, The University Museum of Archaeology and Anthropology, University of Pennsylvania, Philadelphia.

Kaplan, L.

1985 Phytolith Studies of Archaeological Sediments from the Peruvian Andes, 3800 Meters above Sea Level. Proceedings of the Second Phytolith Conference April 27. 28. University of Minnesota, Duluth.

Karsten, R.

1932 Indian Tribes of the Argentine and Bolivian Chaco: Ethnological Studies. Akademische Buchhandlung, Helsingfors, Finland.

Kaulicke, P.

1975 Pandanche: Un Caso Formativo en los Andes de Cajamarca. Seminario de Historia Rural Andina. Universidad Nacional Mayor de San Marcos, Lima.

1981 Keramik der Fruhen Initialperiode aus Pandanche, Departamento. Cajamarca, Perú. Beitrage zur allgemeinen und bergleichenden Archaologie 3:363-389.

Kay, D. E.

1973 Root Crops. Crop and Product Digest 2. Tropical Products Institute, London.

Keatinge, R. W.

1981 The Nature and Role of Religious Diffusion in the Early Stages of State Formation: And Example of Peruvian Prehistory. In The Transition to Statehood in the New World, edited by G. D. Jones and R. R. Kauts, pp. 172-187. 
Keefer, D. K., S. D. deFrance, M. E. Mosely, J. B. Richardson III, D. R. Satterlee, and A. Day-Lewis

1998 Early Maritime Economy and El Nino Events at Quebrada Tacahuay. Science 281:1833-1835.

Kosok, P.

1965 Life, Land, and Water in Ancient Peru: An Account of the Discovery, Exploration, and Mapping of Ancient Pyramids, Canals, Roads, Towns, Walls, and Fortresses of Coastal Peru with Observations of Various Aspects of Peruvian Life, Both Ancient and Modern. Long Island University Press, New York.

Krebs, C. J.

1989 Ecological Methodology. Harper \& Row, New York.

Lamotta, V. M. and M. B. Schiffer 1999 Formation Processes of House Floor Assemblages. In The Archaeology of Household Activities, edited by P. M. Allison, pp. 19-29. Routledge, New York.

Lanning, E. P.

1963 A Pre-Agricultural Occupation on the Central Coast of Peru. American Antiquity 28(3):360-371.

1967 Peru Before the Incas. Prentice-Hall, Englewood Cliffs, N.J.

1974 Western South America. In Prehispanic America, edited by S. Gorenstien, pp. 65-86. St. Martin's Press, New York.

Lathrap, D.

1973 The Antiquity and Importance of Long-Distance Trade Relationships in the Moist Tropics of Pre-Columbian South America. World Archaeology 5(2):170-186.

1977 Our Father the Cayman, Our Mother the Gourd: Spinden Revisited, or a Unitary Model for the Emergence of Agriculture in the New World. In Origins of Agriculture, edited by C. Reed, pp. 713-751. Mouton, The Hague, Netherlands.

Lau, G. F.

2002 Feasting and Ancestor Veneration at Chinchawas, North Highlands of Ancash, Peru. Latin American Antiquity 13(3):279-304.

Lavallée, D., M. Julien and J. Wheeler 1984 Telarmachay: Niveles Precerámicos de Ocupación. Revista del Museo Nacional (Lima) 46 (1982):55-133. 
Lawn, B.

1974 University of Pennsylvania Radiocarbon Dates XVII. Radiocarbon 16(2):219237.

Leach, E. R.

1979 [1966] Ritualization in Man in Relation to Conceptual and Social

Development. In Reader in Comparative Religion. Fourth Edition, edited by W. A. Lessa and E. Z. Vogt. pp. 229-233. Harper Collins, New York.

Lennstrom, H. A. and C. A. Hastorf

1995 Interpretation in Context: Sampling and Analysis in Paleoethnobotany. American Antiquity 60(4):701-721.

Lentfer, C. J. and W. E. Boyd

1999 An Assessment of Techniques for the Deflocculation and Removal of Clays from Sediments Used in Phytolith Analysis. Journal of Archaeological Science 26:3134.

Lentz, D. L.

1991 Maya Diets of the Rich and Poor: Paleoethnobotanical Evidence from Copan. Latin American Antiquity 2(3):269-287.

Lentz, D. L. and R. Dickau

2005 Seeds of Central America and Southern Mexico: The Economic Species. Memoirs of the New York Botanical Garden V. 91. New York Botanical Garden Press, Bronx.

León, B. and C. Monsalve

2006 Anacardiaceae Endémicas del Perú. Revista Peruana de Biología 13(2):33-34.

Lepofsky, D. and K. Lertzman

2005 More on Sampling for Richness and Diversity in Archaeobiological Assemblages. Journal of Ethnobiology 25(2):175-188.

Lepofsky, D. and N. Lyons 2003 Modeling Ancient Plant Use on the Northwest Coast: Towards an Understanding of Mobility and Sedentism. Journal of Archaeological Science 30:13571371 .

Llagostera, A., R. Weisner, G. Castillo, M. Cervellino G. and M. A. Costa-Junqueira 2000 El Complejo Huentelauquén Bajo una Perspectiva Macroespacial y Multidisciplinaria. Contribución Aarqueológica 5(1):461-482. 
Llatas-Quiroz, S. and M. López-Mesones

2005 Bosques Montaños-Relictos en Kañaris (Lambayeque, Perú). Revista Peruana de Biología 12(3):299-308.

Logan, A. L.

2006 The Application of Phytolith and Starch Grain Analysis to Understanding Formative Subsistence, Ritual, and Trade on the Taraco Peninsula, Highland Bolivia. M.A. Thesis, Department of Anthropology, University of Missouri, Columbia.

Loy, T. H. 1994 Methods in the Analysis of Starch Residues on Prehistoric Stone Tools. In Tropical Archaeobotany: Applications and New Developments, edited by J. G. Hather, pp. 86-114. Routledge, London.

Loy, T. H., M. Spriggs and S. Wickler 1992 Direct Evidence for Human Use of Plants 28,000 Years Ago: Starch Residues on Stone Artefacts from the Northern Solomon Islands. Antiquity 66:898912.

Ludeña, $\mathrm{H}$.

1970 San Humberto: Un Sitio Formativo en El Valle Del Chillón. Informe Preliminar. Arqueología y Sociedad 2. Museo de Arqueología y Etnología, Universidad Nacional Mayor de San Marcos, Lima, Peru.

1975 Secuencia Cronología y Cultural del Valle De Chillón, PhD Dissertation, Universidad Nacional Mayor San Marcos, Lima, Peru.

Lumbreras, L. G.

1974 The Peoples and Cultures of Ancient Peru. Smithsonian Institution Press, Washington, D. C.

Lusas, E. W. and G. M. Jividen

1987 Glandless Cottonseed: A Review of the First 25 Years of Processing and Utilization Research. Journal of the American Oil Chemists' Society 64(6):839-854.

Lyman, R. L. and K. M. Ames 2004 Sampling to Redundancy in Zooarchaeology: Lessons from the Portland Basin, Northwestern Oregon and Southwestern Washington. Journal of Ethnobiology 24:329-346. 
Lynch, T. F.

1983 Camelid Pastoralism and the Emergence of Tiwanaku Civilization in the South-Central Andes. World Archaeology 15(1):1-14.

1990 Glacial-Age Man in South America? A Critical Review. American Antiquity 55(1):12-36.

Macbride, J. F.

1936 Marantaceae. Flora of Perú. Fieldiana Botany 13, Part 1(1-3):741-767.

Macneish, R. S., A. Nelken-Terner, R. K.Vierra and C. J. Phagen

1980 The Prehistory of the Ayacucho Basin, Perú 3, Nonceramic Artifacts. University of Michigan Press, Ann Arbor.

Magurran, A. E.

2004 Measuring Biological Diversity. Blackwell Publishers, Malden, Ma.

Margalef, R.

1958 Information Theory in Ecology. General Systems 3:36-71.

Martin, A. C. and W. D. Barkley

1961 Seed Identification Manual. University of California Press, Berkeley.

Martin, F. W. and E. Cabanillas

1976 Leren (Calathea allouia), a Little Known Tuberous Root Crop of the Caribbean. Economic Botany 30:249-256.

Martins, R.

1976 New Archaeological Techniques for the Study of Ancient Root Crops in

Peru. PhD Dissertation, University of Birmingham, Birmingham, UK.

Martins, T. R. and T. J. Barkman

2005 Reconstruction of Solanaceae Phylogeny Using the Nuclear Gene SAMT. Systematic Botany 30(2):435-447.

Matsutani, A.

1972 Spodographic Analysis of Ash from the Kotosh Site. In Andes 4: Excavations at Kotosh, Peru, 1963 and 1966, edited by S. Izumi and K. Terada, pp. 319-326. University of Tokyo Press, Tokyo.

Matsuzawa, T.

1978 The Formative Site of Las Haldas, Perú: Architecture, Chronology, and Economy. American Antiquity 43:652-673. 
Mauss, M.

1966 The Gift: Forms and Functions of Exchange in Archaic Societies. Routledge, London.

Mbida, C. H., E. D. Langhe, L. Vrydaghs, H. Doutrelepont, R. O. Swennen, W. Vanneer and P. Demaret 2006 Phytolith Evidence for the Early Presence of Domesticated Banana (Musa) in Africa. In Documenting Domestication: New Genetic and Archaeological Paradigms, edited by M. A. Zeder, pp. 68-81. University of California Press, Berkeley, Calif.

McCormac, F. G., P.J. Reimer, A.G. Hogg, T.F.G. Higham, M.G.L. Baillie, J. Palmer, M. Stuiver

2002 Calibration of the Radiocarbon Time Scale for the Southern Hemisphere Ad 1850 - 950. Radiocarbon 44(3):641-651.

McGovern, P. E.

2009 Uncorking the Past: The Quest for Wine, Beer, and Other Alcoholic Beverages. University of California Press, Berkeley.

McGovern, P. E., J. Zhang, J. Tang, Z. Zhang, G. R. Hall, R. A. Moreau, A. Nuñez, E. D. Butrym, M. P. Richards, C. S. Wang, G. Cheng, Z. Zhao and C. Wang 2004 Fermented Beverages of Pre- and Proto-Historic China. Proceedings of the National Academy of Sciences of the United States of America 101(51):17593-17598.

McKey, D., S. Rostain, J. Iriarte, B. Glaser, J. J. Birk, I. Holst and D. Renarda 2010 Pre-Columbian Agricultural Landscapes, Ecosystem Engineers, and SelfOrganized Patchiness in Amazonia. Proceedings of the National Academy of Sciences of the United States of America 107(17):7823-7828.

Meddens, F. M., N. P. Branch, C. V. Pomacanchari, N. Riddiford and R. A. Kemp 2008 High Altitude Ushnu Platforms in the Department of Ayacucho Peru, Structure, Ancestors and Animating Essence. In Pre-Columbian Landscapes of Creation and Origin, edited by J. E. Staller, pp. 315-355. Springer, New York.

Meggers, B. J.

1994 Archaeological Evidence for the Impact of Mega-Niño Events on Amazonia During the Past Two Millennia. Climatic Change 28:231-338.

Mejía Xesspe, T.

1978 Importancia Prehistórica de La Huaca Florida en El Valle de Lima. In III Congreso Peruano El Hombre y La Cultura Andina. Actas y Trabajos, edited by R. M. Mendieta, pp. 493-520. vol. 2, Lima, Peru. 
Menzel, D.

1977 The Archaeology of Ancient Peru and the Work of Max Uhle. R. H. Lowie Museum of Anthropology, University of California, Berkeley.

Miksecik, C. H.

1987 Formation Processes of the Archaeobotanical Record. Advances in Archaeological Method and Theory 10:211-247.

Miller, N. F.

1988 Ratios in Paleoethnobotanical Analysis. In Current Paeleoethnobotany, edited by C. A. Hastorf and V. S. Popper, pp. 72-85. University of Chicago Press, Chicago.

Minnis, P. E.

1981 Seeds in Archaeological Sites: Sources and Some Interpretive Problems. American Antiquity 46(1):143-152.

Montoya Vera, M.

2007 Arquitectura de La Tradición Mito en El Valle Medio del Santa: Sitio El Silencio. Bulletin - Institut Francais d'Etudes Andines36(2):199-220.

Moore, J. D.

1996 Architecture and Power in the Ancient Andes: The Archaeology of Public Buildings. New Studies in Archaeology. Cambridge University Press, Cambridge.

Moore, K. M.

1989 Hunting and the Origins Herding in Peru. PhD Dissertation, Department of Anthropology, University of Michigan, Ann Arbor.

Morris, C.

1979 Maize Beer in the Economics, Politics, and Religion of the Inca Empire. In Fermented Beverages in Nutrition, edited by C. F. Gastineau, W. J. Darby and T. B. Turner, pp. 21-34. Academic Press, New York.

Morton, J. F.

1987 Fruits of Warm Climates. Creative Resource Systems, Winterville, NC.

Moseley, M. E.

1968 Changing Subsistence Patterns: Late Preceramic Archaeology of the Central Peruvian Coast, PhD Dissertation, Department of Anthropology, Harvard University, Cambridge.

1975 The Maritime Foundations of Andean Civilization. Cummings Publishing, Menlo Park, CA. 
1985 The Exploration and Explanation of Early Monumental Architecture in the Andes. In Early Ceremonial Architecture in the Andes. A Conference at Dumbarton Oaks, edited by C. B. Donnan, pp. 26-58. Dumbarton Oaks Research Library and Collection, Washington, DC.

1992 Maritime Foundations and Multilinear Evolution: Retrospect and Prospect. In Andean Past 3:5-42

1992 The Incas and Their Ancestors: The Archaeology of Peru. Thames and Hudson, New York.

2001 The Incas and Their Ancestors: The Archaeology of Peru, Second Edition. Thames \& Hudson, New York.

Moseley, M. E. and L. K. Barrett

1969 Change in Preceramic Twined Textiles from the Central Peruvian Coast. American Antiquity 34(2):162-165.

Mulholland, S.

1989 Phytolith Shape Frequencies in North Dakota Grasses: A Comparison to General Patterns. Journal of Archaeological Science 16:489-511.

Murra, J. V.

1967 La Visita de Los Chupachu como Fuente Etnológica. In Visita de La Provincia de León De Huánuco en 1562, Tomo I, edited by J. Murra, pp. 381-406. Universidad Nacional Herilio Valdizán, Huánuco, Peru.

1972 El "Control Vertical" de un Máximo de Pisos Ecológicos en la Economía de las Sociedades Andinas. Universidad Hermilio Valdiza, Huánuco, Perú.

1980 The Economic Organization of the Inka State. Research in Economic Anthropology, Supplement 1. Jai Press, Greenwich, CT.

Murray, P.

1980 Discard Location: The Ethnographic Data. American Antiquity:490-502.

Nagendra, $\mathrm{H}$.

2002 Opposite Trends in Response for the Shannon and Simpson Indices of Landscape Diversity. Applied Geography 22:175-186.

NRC - National Research Council

1989 Lost Crops of the Incas: Little-Known Plants of the Andes with Promise for Worldwide Cultivation. National Research Council (USA) Advisory Committee on Technology Innovation. National Academy Press, Washington, D.C. 
Nee, M.

1990 The Domestication of Cucurbita (Cucurbitaceae). Economic Botany 3:56-68.

Neelima Garg, N., P. Yadav, N. Goel, A. K. Bhattacharjee, S. Rajan and R. Kumar 2005 Screening of Acidic Guava Accessions for Cider Preparation. Proceedings of the First International Guava Symposium 735:647-650.

Neff, H., D. M. Pearsall, J. G. Jones, B. Arroyo, S. K. Collins and D. E. Friedel 2006a Early Maya Adaptive Patterns: Mid-Late Holocene Paleoenvironmental Evidence from Pacific Guatemala. Latin American Antiquity 17(3):287-315.

2006b Climate Change and Population History in the Pacific Coastal Lowlands of Southern America. Quarternary Research 65:390-400.

Netherly, P.

1988 From Event to Process: The Recovery of Late Andean Organizational Structure by Means of Spanish Colonial Records. In Peruvian Prehistory, edited by R. W. Keatinge, pp. 257-278. Cambridge University Press, Cambridge.

Olsen, K. M.

2004 SNPs, SSRs and Inferences on Cassava's Origin. Plant Molecular Biology 56(4):517-526.

Olsen, K. M. and B. A. Schaal

1999 Evidence on the Origin of Cassava: Phylogeography of Manihot esculenta.

Proceedings of the National Academy of Sciences of the United States of America 96(10):5586-5591.

2001 Microsatellite Variation in Cassava (Manihot esculenta, Euphorbiaceae) and its Wild Relatives: Further Evidence for a Southern Amazonian Origin of Domestication. American Journal of Botany 88(1):131-142.

ONERN - Oficina Nacional de Evaluación de Recursos Naturales, Perú 1975 Inventario y Evaluación de Los Recursos Naturales de La Zona del Proyecto Marcapomacocha. Estudios Onern 37. 2 vols. República del Perú, Presidencia de La República, Oficina Nacional de Evaluación de Recursos Naturales, Lima, Perú.

1976 Oficina Nacional de Evaluación de Recursos Naturales, Perú. Mapa Ecologico del Perú: Guia Explicativa. República del Perú, Presidencia de La República, Oficina Nacional de Evaluación de Recursos Naturales, Lima, Perú. 
Onuki, Y.

1993 Las Actividades Ceremoniales Tempranas en La Cuenca del Alto Huallaga y Algunos Problemas Generales. Senri Ethnological Studies 37(2):69-96.

Orme, A. R.

2007a The Tectonic Framework of South America. In The Physical Geography of South America, edited by T. T. Veblen, K. R. Young and A. R. Orme, pp. 3-22. Oxford University Press, Oxford.

2007b Tectonism, Climate, and Landscape Change. In The Physical Geography of South America, edited by T. T. Veblen, K. R. Young and A. R. Orme, pp. 23-44. Oxford University Press, Oxford.

Ortloff, C. R. and A. L. Kolata

1994 Climate and Collapse: Agro-Ecological Perspectives on the Decline of the Tiwanaku State. Journal of Archaeological Science 20:195-221.

Pagán Jiménez, J. R.

2007 De Antiguos Pueblos y Culturas Botánicas en El Puerto Rico Indígena. El Archipiélago Borincano y La Llegada de Los Primeros Pobladores Agroceramistas. BAR International Series 1687. Oxford, UK.

Parr, J. F. and M. Carter

2003 Phytolith and Starch Analysis of Sediment Samples from Two Archaeological Sites on Dauar Island, Torres Strait, Northeastern Australia. Vegetative History and Archaeobotany 12:131-141.

Parsons, J. J. and N. Psuty

1975 Sunken Fields and Prehispanic Subsistence on the Peruvian Coast. American Antiquity 40:259-282.

Pasiecznik, N. M., P. Felker, P., J. C. Harris, L. N. Harsh, G. Cruz, J. C. Tewari, K. Cadoret and L. J. Maldonado 2001 The Prosopis juliflora-Prosopis pallida Complex: A Monograph. Henry Doubleday Research Association, Coventry, UK.

Patterson, T. C.

1971 Central Peru: Its Population and Economy. Archaeology 24(4):316-321.

1971 The Emergence of Food Production in Central Peru. In Prehistoric Agriculture, edited by S. Struever, pp. 181-207. American Museum of Natural History, Garden City, NY. 
1985 The Huaca La Florida. In Early Ceremonial Architecture in the Central Andes, edited by C. B. Donnan, pp. 59-70. Dumbarton Oaks, Washington, D.C.

Patterson, T. C. and E. P. Lanning

1964 Peru before the Incas. Nawpa Pacha 2:113-123.

Patterson, T. C. and M. E. Moseley

1968 Late Preceramic and Early Ceramic Cultures of the Central Coast. Nawpa Pacha 6:115-133.

Pavlu, I.

1997 Pottery Origins: Initial Forms, Cultural Behavior, and Decorative Styles. Karlovy University Press, Prague.

Pearsall, D. M.

1976 Evidence of Maize from Real Alto, Ecuador: Preliminary Results of Opal Phytolith Analysis. Paper presented at the 41st Annual Meeting of the Society for American Archaeology, St. Louis.

1978 Phytolith Analysis of Archeological Soils: Evidence for Maize Cultivation in Formative Ecuador. Science 199:177-178.

1979 The Application of Ethnobotanical Techniques to the Problem of Subsistence in the Ecuadorian Formative. PhD Dissertation, Department of Anthropology, University of Michigan, Ann Arbor.

1980 Analysis of an Archaeological Maize Kernel Cache from Manabí Province, Ecuador. Economic Botany 34(4):344-351.

1983 Evaluating the Stability of Subsistence Strategies by Use of Paleoethnobotanical Data. Journal of Ethnobiology 3:121-137.

1992 The Origins of Plant Cultivation in South America. In The Origins of Agriculture: An International Perspective, edited by C. W. Cowan and P. J. Watson, pp. 173-206. Smithsonian Institution Press, Washington.

1999 The Impact of Maize on Subsistence Systems in South America: An Example from the Jama River Valley, Coastal Ecuador. In The Prehistory of Food, edited by C. Gosden and J. Hather, pp. 419-437. Routledge, New York.

2000 Paleoethnobotany: A Handbook of Procedures. 2 ed. Academic Press, San Diego. 
2003a Plant Food Resources of the Ecuadorian Formative: An Overview and Comparison to the Central Andes. In Archaeology of Formative Ecuador, edited by J. S. Raymond, R. L. Burger, pp. 213-257, J. Quilter, general editor. Dumbarton Oaks, Washington D. C.

2003b Integrating Biological Data: Phytoliths and Starch Grains, Health and Diet, at Real Alto, Ecuador. In Phytolith and Starch Research in the Austalian-Pacific-Asian Regions: The State of the Art, edited by D. M. Hart and L. A. Wallis, pp. 187-200. Pandanus Books, Terra Australis 19, Canberra.

2008 Plant Domestication and the Shift to Agriculture in the Andes. In Handbook of South American Archaeology, edited by W. H. Isbell and H. Silverman, pp. 105-120. Springer, New York.

n.d. Arrowroot (Maranta arundinaceae) and Leren (Calathea latifolia), Marantaceae. Ms. on file, Department of Anthropology, University of Missouri.

Pearsall, D. M., K. Chandler-Ezell and A. Chandler-Ezell 2003 Identifying Maize in Neotropical Sediments and Soils Using Cob Phytoliths. Journal of Archaeological Science 30:611-627.

Pearsall, D. M., K. Chandler-Ezell and J. A. Zeidler 2004 Maize in Ancient Ecuador: Results of Residue Analysis of Stone Tools from the Real Alto Site. Journal of Archaeological Science 31:423-442.

Pearsall, D. M. and D. R. Piperno 1990 Antiquity of Maize Cultivation in Ecuador: Summary and Reevaluation of the Evidence. American Antiquity 55(2):324-337.

Peilou, E. C.

1977 Mathematical Ecology. Wiley and Sons, New York.

Perry, L.

2001 Prehispanic Subsistence in the Middle Orinoco Basin: Starch Analyses Yield New Evidence. PhD Dissertation, Department of Anthropology, Southern Illinois University at Carbondale.

2002 Starch Granule Size and the Domestication of Manioc (Manihot esculenta) and Sweet Potato (Ipomoea batatas). Economic Botany 56(4):335-349.

2004 Starch Analyses Reveal the Relationship between Tool Type and Function: An Example from the Orinoco Valley of Venezuela. Journal of Archaeological Science 31:1069-1081. 
Perry, L., R. Dickau, S. Zarrillo, I. Holst, D. M. Pearsall, D. R. Piperno, M. J. Berman, R. G. Cooke, K. Rademaker, A. J. Ranere, J. S. Raymond, D. H. Sandweiss, F. Scaramelli, K. Tarble and J. A. Zeidler 2007 Starch Fossils and the Domestication and Dispersal of Chili Peppers (Capsicum spp. L.) in the Americas. Science 315(5814):986-988.

Perry, L. and K. V. Flannery 2007 Precolumbian Use of Chili Peppers in the Valley of Oaxaca, Mexico. Proceedings of the National Academy of Sciences of the United States of America 104(29):11905-11909.

Perry, L., D. H. Sandweiss, D. R. Piperno, K. Rademaker and M. A. Malpass 2006 Early Maize Agriculture and Interzonal Interaction in Southern Peru. Nature 440(2):76-79.

Pilar Babot, M.

2003 Starch Grain Damage as an Indicator of Food Processing. In Phytolith and Starch Research in the Australian-Pacific-Asian Regions: The State of the Art, edited by L. A. Wallis and D. M. Hart, pp. 69-81. Pandanus Books, Canberra.

Pino Matos, J. L. 2004 El Ushnu Inka y La Organización del Espacio en Los Principales Tampus de Los Wamani de La Sierra Central del Chinchaysuyu. Chungara, Revista de Antropología Chilena 36(2):303-311.

2005 El Ushnu y La Organización Espacial Astronómica en La Sierra Central Del Chinchaysuyu. Estudios atacameños 29:143-161.

Piperno, D. R.

1984 A Comparison and Differentiation of Phytoliths from Maize and Wild Grasses: Use of Morphological Criteria. American Antiquity 49:361-383.

1988 Phytolith Analysis: An Archaeological and Geological Perspective. Academic Press, New York.

1991 The Status of Phytolith Analysis in the American Tropics. Journal of World Prehistory 5(2):155-191.

1993 Phytolith and Charcoal Records from Deep Lake Cores in the American Tropics. In Current Research in Phytolith Analysis: Applications in Archaeology and Paleoecology, edited by D. M. Pearsall and D. R. Piperno, pp. 58-71. MASCA Research Papers in Science and Archaeology. vol. 10, K. Ryan, general editor. MASCA, The University Museum of Archaeology and Anthropology, University of Pennsylvania, Philadelphia. 
2006a The Origins of Plant Cultivation and Domestication in the Neotropics: A Behavioral Ecological Perspective. In Behavioral Ecology and the Transition to Agriculture, edited by D. J. Kennett and B. Winterhalder, pp. 137-166. University of California Press, Berkeley.

2006b Phytoliths: A Comprehensive Guide for Archaeologists and Paleoecologists. AltaMira Press, Oxford.

2006c Identifying Manioc (Manihot esculenta Crantz) and Other Crops in PreColumbian Tropical America through Starch Grain Analysis: A Case Study from Central Panama. In Documenting Domestication: New Genetic and Archaeological Paradigms, edited by M. A. Zeder, D. G. Bradley, E. Emshwiller and B. D. Smith, pp. 46-67. University of California Press, Berkeley.

2008 Identifying Crop Plants with Phytoliths (and Starch Grains) in Central and South America: A Review and an Update of the Evidence. Quaternary International 193(1-2):146-159.

Piperno, D. R., T. C. Andres and K. E. Stothert 2000 Phytoliths in Cucurbita and Other Neotropical Cucurbitaceae and Their Occurrence in Early Archaeological Sites from the Lowland American Tropics. Journal of Archaeological Science 27(3):193-208.

Piperno, D. R. and T. D. Dillehay 2008 Starch Grains on Human Teeth Reveal Early Broad Crop Diet in Northern Peru. Proceedings of the National Academy of Sciences of the United States of America 105(50):19622-19627.

Piperno, D. R. and I. Holst 1998 The Presence of Starch Grains on Prehistoric Stone Tools from the Humid Neotropics: Indications of Early Tuber Use and Agriculture in Panama. Journal of Archaeological Science 25:765-776.

Piperno, D. R., I. Holst, L. Wessel-Beaver and T. C. Andres 2002 Evidence for the Control of Phytolith Formation in Cucurbita Fruits by the Hard Rind ( $\mathrm{Hr}$ ) Genetic Locus: Archaeological and Ecological Implications. Proceedings of the National Academy of Sciences of the United States of America 99(16):10923-10928. 
Piperno, D. R., J. E. Moreno, J. Iriarte, I. Holst, M. Lachniet, J. G. Jones, A. J. Ranere and R. Castanzo

2007 Late Pleistocene and Holocene Environmental History of the Iguala Valley, Central Balsas Watershed of Mexico. Proceedings of the National Academy of Sciences of the United States of America 104(29):11874-11881.

Piperno, D. R. and D. M. Pearsall

1993 Phytoliths in the Reproductive Structures of Maize and Teosinte: Implications for the Study of Maize Evolution. Journal of Archaeological Science 20:337-362.

1998 The Silica Bodies of Tropical American Grasses: Morphology, Taxonomy, and Implications for Grass Systematics and Fossil Phytolith Identification. Smithsonian Contributions to Botany 85.

1998 The Origins of Agriculture in the Lowland Neotropics. Academic Press, San Diego.

Piperno, D. R., A. J. Ranere, I. Holst and P. Hansell 2000 Starch Grains Reveal Early Root Crop Horticulture in the Panamanian Tropical Forest. Nature 407(6806):894-897.

Piperno, D. R. and V. Starczak

1985 Numerical Analysis of Maize and Wild Grass Phytoliths Using Multivariate Techniques. Paper presented at the 2nd Phytolith Research Workshop, Duluth, MN.

Piperno, D. R. and K. E. Stothert

2003 Phytolith Evidence for Early Holocene Cucurbita Domestication in Southwest Ecuador. Science 299:1054-1057.

Popper, V.

1988 Selecting Quantitative Measurements in Paleoethnobotany. In Current Paleoethnobotany: Analytical Methods and Cultural Interpretations of Archaeological Plant Remains, edited by C. A. Hastorf and V. S. Popper, pp. 53-71. Chicago University Press, Chicago.

Popper, V. S.

1982 Análisis General de Las Muestras. In Preceramico Peruano: Los Gavilanes, Mar. Desierto y Oasis en La Historia del Hombre, edited by D. Bonavia, pp. 148-156. Corporacion Financiera de Desarrollo S. A. (Cofide). Oficina de Asuntos Culturales: Instituto Arqueologico Aleman, Comision de Arqueologia General y Comparada. Editorial Ausonia-Talleres Graficos S. A., Lima. 
Pozorski, S. and T. Pozorski

1987 Early Settlement and Subsistence in the Casma Valley, Peru. University of Iowa Press, Iowa City.

1990 Reexamining the Critical Preceramic/Ceramic Period Transition: New Data from Coastal Peru. American Anthropologist 92:481-491.

2008 Early Cultural Complexity on the Coast of Peru. In Handbook of South American Archaeology, edited by H. Silverman and W. H. Isbell, pp. 607-632. Springer, New York.

Pozorski, T. and S. Pozorski 1990 Huaynuna, a Late Cotton Preceramic Site on the North Coast of Peru. Journal of Field Archaeology 17(1):17-26.

1996 Ventilated Hearth Structures in the Casma Valley, Peru. American Antiquity 7(4):341-353.

Pulgar Vidal, J.

1996 Geografía del Perú: Las Ocho Regiones Naturales, La Regionalización Transversal, La Sabiduría Ecológica Tradicional. 10. ed. Ediciones Peisa, Lima, Perú.

Purseglove, J. W.

1968 Tropical Crops. Dicotyledons. Wiley, New York.

Quilter, J.

1985 Architecture and Chronology at El Paraíso. Journal of Field Archaeology 12(3):279-297.

1986 Cerro De Media Luna: An Early Intermediate Period Site in the Chillón Valley, Peru. Nawpa Pacha 24:73-98.

1989 Life and Death at Paloma: Society and Mortuary Practices in a Preceramic Peruvian Village. University of Iowa Press, Iowa City.

1991 Late Preceramic Peru. Journal of World Prehistory 5:387-483.

Quilter, J., B. Ojeda E., D. M. Pearsall, D. H. Sandweiss, J. G. Jones, and E. S. Wing 1991 Subsistence Economy of El Paraíso, an Early Peruvian Site. Science 251(4991):277-283.

Quilter, J. and T. Stocker

1983 Subsistence Economies and the Origins of Andean Complex Societies. American Anthropologist 85(3):545-562. 
Ramenofsky, A. F., L. C. Standfifer, A. M. Whitmer and M. S. Standfifer

1986 A New Technique for Separating Flotation Samples. American Antiquity 51(1):66-72.

Rappaport, R. A.

1968 Pigs for The Ancestors. Ritual in the Ecology of a New Guinea People. Yale University Press, New Haven.

1999 Ritual and Religion in the Making of Humanity. Cambridge University Press, Cambridge.

Ravines, R. and J. Alvarez

1975 Fechas Radiocarbónicas Para El Perú. Arqueológicas 11:21. Museo Nacional de Antropologia y Arqueologia Pueblo Libre, Lima.

Raymond, J. S.

1981 The Maritime Foundations of Andean Civilization: A Reconsideration of the Evidence. American Antiquity 46:806-821.

Reed, R. K.

1995 Prophets of Agroforestry: Guarani Communities and Commercial Gathering. University of Texas Press, Austin.

Reichert, E. T.

1913 The Differentiation and Specificity of Starches in Relation to Genera, Species, Etc. Chapman, London.

Reitz, E. J.

1988 Preceramic Animal Use on the Central Coast. In Economic Prehistory of the Central Andes, edited by E. S. Wing and J. C. Wheeler, pp. 31-55. Bar International Series 427, Oxford, UK.

2003 Resource Use through Time at Paloma, Peru. Bulletin of the Florida Museum of Natural History 44(1):65-80.

Renfrew, C.

1985 The Archaeology of Cult: The Sanctuary at Phylakopi. The British School of Archaeology at Athens, London.

2007 The Archaeology of Ritual, of Cult, and of Religion. In The Archaeology of Ritual, edited by E. Kyriakidis, pp. 109-122. Cotsen Institute of Archaeology, Los Angeles. 
Reycraft, R. M.

2001 Long-Term Human Response to El Niño in South Coastal Peru, Circa AD 1400. In Environmental Disaster and the Archaeology of Human Response, edited by G. Bawden and R. M. Reycraft, pp. 99-120. Maxwell Museum of Anthropology, Albuquerque.

Rice, P. M.

1999 On the Origins of Pottery. Journal of Archaeological Method and Theory 6(1):154.

Richardson III, J. B.

1978 Early Man on the Peruvian North Coast: Early Maritime Exploitation and the Pleistocene and Holocene Environment. In Early Man in America from a CircumPacific Perspective, edited by A. L. Bryan, pp. 274-289. Archaeological Research International, Edmonton.

1981 Modeling the Development of Sedentary Maritime Economies of the Coast of Peru: A Preliminary Statement. Annals of the Carnegie Museum 50(5):139-150.

1994 People of the Andes. 1st ed. Exploring the Ancient World. St. Remy Press; Smithsonian Books, Washington, D.C.

1998 Looking in the Right Places: Pre-5,000 B.P. Maritime Adaptations in Peru and the Changing Environment. Revista de Arqueología Americana (15):33-56.

Rick, J. W.

1980 Prehistoric Hunters of the High Andes. Academic Press, New York.

Rick, J. W., S. Rodriguez R, R. Mendoza R. and J. A. Kembel

1998 La Arquitectura del Complejo Ceremonial de Chavín de Huántar: Documentación Tridimensional y sus Implicancias. Boletín de Arqueología Pontificia Universidad Católica del Perú 2:181-214.

Risco, C. A. and C. C. Chase

1997 Gossypol. In Handbook of Plant and Fungal Toxicants, edited by J. P. F. D'mello, pp. 87-98. CRC Press, Boca Raton, FL.

Robb, J. E.

1998 The Archaeology of Symbols. Annual Review of Anthropology 27:329-346.

Rocek, T. R.

1995 Sedentarization and Agricultural Dependence: Perspectives from the Pithouse-to-Pueblo Transition in the American Southwest. American Antiquity 60(2):218-239. 
Rochebrune, A. T., de

1879 Recherches D'ethnographie Botanique sur La Flore des Sepultures Péruviennes D'ancón. Actes de la Société Linnéenne de Bordeaux 3:343-358.

Rogers, D. J. and S. G. Appan

1973 Manihot Manihotoides (Euphorbiaceae). Flora Neotropica 13(Jun. 22, 1973):1-272.

Rossen, J. and T. D. Dillehay

1996 Ancient Cultigens or Modern Intrusions? Evaluating Plant Remains in an Andean Case Study. Journal of Archaeological Science 23:391-407.

1997 Modeling Ancient Plant Procurement and Use at Monte Verde. In Monte Verde: A Late Pleistocene Settlement in Chile, edited by T. D. Dillehay, pp. 331-350. vol. 2: The Archaeological Context and Interpretation. Smithsonian Institution Press, Washington D. C.

Rostworowski de Diez Canseco, M.

1972 Las Etnias del Valle de Chillón. Revista del Mueseo Nacional (Lima), Tomo XXXVIII:250-314.

1988 Conflicts over Coca Fields in XVIth-Century Perú. Studies in Latin American Ethnohistory and Archaeology, vol 4. Museum of Anthropology, University of Michigan, Ann Arbor.

1989 Costa Peruana Prehispanica. Instituto de Estudios Peruanos, Lima, Perú.

Rowe, J. H.

1946 Inca Culture at the Time of Spanish Conquest. In Handbook of South American Indians, vol. 2, The Andean Civilizations, edited by J. Steward. Smithsonian Institution, Bureau of American Ethnology, Bulletin 143:210-233. US Government Printing Office, Washington, D.C.

1962 Stages and Periods in Archaeological Interpretation. Southwest Journal of Anthropology 18(1):40-54.

1967 Form and Meaning in Chavín Art. In Peruvian Archaeology. Selected Readings, edited by J. H. Rowe and D. Menzel, pp. 72-103. Peek Publications, Palo Alto, CA.

Rundel, P. W., M. O. Dillon, B. Palma, H. A. Mooney, S. L. Gulmon and J. R. Ehleringer 1991 The Phytogeography and Ecology of the Coastal Atacama and Peruvian Deserts. Aliso 13(1):1-49. 
Rundel, P. W., P. E. Villagra, M. O. Dillon, S. Roig-Juñent and G. Debandi 2007 Arid and Semi-Arid Ecosystems. In The Physical Geography of South America, edited by T. T. Veblen, K. R. Young and A. R. Orme, pp. 158-183. Oxford University Press, Oxford.

Sagastegui-Alva, A., M. O. Dillon, I. Sánchez-Vega, S. Leiva-González and P. LezamaAsencio

1999 Diversidad Floristica Del Norte De Perú, Tomo I. World Wildlife Fund, Lima, Perú.

Sandweiss, D. H. 2008 Early Fishing Societies in Western South America. In Handbook of South American Archaeology, edited by H. Silverman and W. H. Isbell, pp. 145-156. Springer, New York.

Sandweiss, D. H., K. A. Maasch and D. C. Anderson 1999 Transitions in the Mid-Holocene. Science 283(5401):499-500.

Sandweiss, D. H., K. A. Maasch, R. L. Burger, J. B. Richardson Iii, H. B. Rollins and A. Clement

2001 Variation in Holocene El Niño Frequencies: Climate Records and Cultural Consequences in Ancient Perú. Geology 29(7):603-606.

Sandweiss, D. H. and M. E. Moseley

2001 Amplifying Importance of New Research in Peru. Science 294(5547):1651. 1653.

Sandweiss, D. H., R. Shady Solís, M. E. Moseley, D. K. Keefer and C. R. Ortloff 2009 Environmental Change and Economic Development in Coastal Peru between 5,800 and 3,600 Years Ago. Proceedings of the National Academy of Sciences of the United States of America 106:1359-1363.

Sandweiss, D. H., H. McInnis, R. L. Burger, A. Cano, B. Ojeda, R. Paredes, M. del Carmen, M. Sandweiss, and M. D. Glascock

1998 Quebrada Jaguay: Early South American Maritime Adaptations. Science 281(5384):1830-1832.

Sandweiss, D. H., J. B. Richardson III, E. J. Reitz, H. B. Rollins and K. A. Maasch 1996 Geoarchaeological Evidence from Peru for a 5000 Years B.P. Onset of El Niño. Science 273:1531-1533. 
Sandweiss, D. H., J. B. Richardson III, E. J. Reitz, J. T. Hsu and R. A. Feldman 1989 Early Maritime Adaptations in the Andes: Preliminary Studies at the Ring Site, Peru. In Ecology, Settlement and History in the Osmore Drainage, Peru, edited by D. S. Rice, C. Stanish and P. R. Scarr, pp. 35-84. BAR International Series 545 (ii), Oxford, UK.

Sanjur, O. I., D. R. Piperno, T. C. Andres and L. Wessel-Beaver 2002 Phylogenetic Relationships among Domesticated and Wild Species of Cucurbita (Cucurbitaceae) Inferred from a Mitochondrial Gene: Implications for Crop Plant Evolution and Areas of Origin. Proceedings of the National Academy of Sciences of the United States of America 99(1):535-540.

Sauer, C. O.

1952 Agricultural Origins and Dispersals. Bowman Memorial Lectures Series, American Geographical Society. New York.

Sauer, J. D.

1993 Historical Geography of Crop Plants. A Select Roster. CRC Press, Boca Raton, FL.

Scheele, $\mathrm{H}$.

1970 The Chavín Occupation of the Central Coast of Perú. PhD Dissertation, Department of Anthropology, Harvard University, Cambridge.

Schiffer, M. B.

1976 Behavioral Archaeology. Academic Press, New York.

Shady Solís, R.

1999 El Sustento Económico del Surgimiento de La Civilzación en El Perú.

Boletín del Museo Arqueología y Antropología 2(11):2-4.

2006 Caral-Supe and the North-Central Area of Peru: The History of Maize in the Land Where Civilization Began. In Histories of Maize, edited by J. Staller, R. H. Tykot and B. F. Benz, pp. 381-402. Academic Press, New York.

2005 Caral-Supe y su Entorno Natural y Social en los Orígenes de la Civilización. Investigaciones Sociales Año IX(14):89-120.

Shady Solís, R., J. Haas and W. Creamer

2001 Dating Caral, a Preceramic Site in the Supe Valley on the Central Coast of Peru. Science 292(27):723-726. 
Shady Solís, R. and M. Machacuay

2003 El Altar del Fuego Sagrado del Templo Mayor de La Ciudad Sagrada de Caral-Supe. In La Ciudad Sagrada de Caral-Supe: Los Origines de la Civilizacion Andina y la Formacion del Estado Pristino en el Antiguo Perú, edited by R. Shady Solís and C. Leyva, pp. 169-185. Instituto Nacional de Cultura, Lima, Peru.

Shimada, I.

1986 Batan Grande and Cosmological Unity in the Prehistoric Central Andes. In Andean Archaeology - Papers in Memory of Clifford Evans, edited by Ramiro Matos, Solveig A. Turpin and J. Herbert H. Eling, pp. 163-188. UCLA Institute of Archaeology, Los Angeles.

Siegel, P. E. and P. G. Roe

1986 Shipibo Archaeo-Ethnography: Site Formation Processes and Archaeological Interpretation. World Archaeology:96-115.

Silva, J.

1996 Prehistoric Settlement in the Chillón River Valley, Perú. PhD Dissertation, Department of Anthropology, University of Michigan.

Silva, J., D. Morales, R. García and E. Bragayrac

1988 Cerro Culebra: Un Asentamiento de La Época Lima en El Valle Del Chillon. Boletín de Lima 56:23-33.

Simpson, M. G. 2006 Plant Systematics. Elsevier/Academic Press, Boston.

Smalley, J. and M. Blake 2003 Sweet Beginnings: Stalk Sugar and the Domestication of Maize. Current Anthropology 44:675-703.

Smith, C. E., Jr. 1980 Plant Remains from Guitarrero Cave. In Guitarrero Cave. Early Man in the Andes, edited by T. F. Lynch, pp. 87-119. Academic Press, New York.

1988 Floral Remains. In La Galgada, Perú: A Preceramic Culture in Transition, by T. Grieder, A. Bueno Mendoza, C. E. Smith and R. M. Malina, pp. 125-151. University of Texas Press, Ausitn.

Soukup, J.

1970 Vocabulario de Los Nombres Vulgares de La Flora Peruana. Colegio Salesiana, Lima, Peru. 
Speck, F. G.

1941 Gourds of the Southeastern Indians; a Prolegomenon on the Lagenaria Gourd in the Culture of the Southeastern Indians. The New England Gourd Society, Boston, MA.

Spinden, H. J.

1917 The Origin and Distribution of Agriculture in America. Proceedings of the XIX International Congress of Americanists, 1915:269-276. Washington, D.C.

Stahl, P.

2008 Animal Domestication in South America. In Handbook of South American Archaeology, edited by H. Silverman and W. H. Isbell, pp. 121-130. Springer, New York.

Stanish, C. 2001 The Origin of State Societies in South America. Annual Review of Anthropology 30:41-64.

Steele, A. R.

1964 Flowers for the King; the Expedition of Ruiz and Pavon and the Flora of Peru. Duke Historical Publications. Duke University Press, Durham, N.C.

Stephens, S. G. and M. E. Moseley 1974 Early Domesticated Cottons from Archaeological Sites in Central Coastal Peru. American Antiquity 39(1):109-122.

Stevens, P. F.

2010 Angiosperm Phylogeny Website. Version 9, June 2008. http://www.Mobot.org/Mobot/Research/Apweb/.

Stothert, K. E. 1980 The Villa El Salvador Site and the Beginning of the Early Intermediate Period in the Lurín Valley, Peru. Journal of Field Archaeology 7(3):279-295.

1985 The Preceramic Las Vegas Culture of Coastal Ecuador. American Antiquity 50:613-637.

Strong, W. D. and C. Evans

1952 Cultural Stratigraphy in the Viru Valley, Northern Peru. In Columbia Studies in Archaeology and Ethnology 4. Columbia University Press, New York.

Sturtevant, W. C.

1969 History and Ethnography of Some West Indian Starches. In The

Domestication and Exploitation of Plants and Animals, edited by P. J. Ucko and G. W. Dimbleby, pp. 177-199. Aldine Publishing Company, Chicago. 
Svenson, H. K.

1946 Vegetation of the Coast of Ecuador and Perú and its Relation to the Galapagos Islands. I. Geographical Relations of the Flora. American Journal of Botany 33(5):394-426.

Therin, M., R. Fullagar and R. Torrence 1999 Starch in Sediments: A New Approach to the Study of Subsistence and Land Use in Papua New Guinea. In The Prehistory of Food: Appetites for Change, edited by C. Gosden and J. Hather, pp. 438-462. One World Archaeology, P. J. Ucko, general editor. Routledge, London.

Titiev, M.

1971 Old Oraibi: A Study of the Hopi Indians of Third Mesa. University of New Mexico Press, Albuquerque.

Towle, M. A.

1961 The Ethnobotany of Pre-Columbian Peru. Aldine, Chicago.

Turrado Moreno, A.

1945 Ethnography of the Guarauno Indians. Vargas, Caracas, Venezuela.

Twiss, P., E. Suess and R. Smith

1969 Morphological Classification of Grass Phytoliths. Soil Science Society of America Proceedings 33:109-115.

Ugent, D. and C. M. Ochoa

2006 La Etnobotánica del Perú: Desde La Prehistoria al Presente. 1. ed. Consejo Nacional de Ciencia,Tecnología e Innovación Tecnológica, CONCYTEC, Lima, Perú.

Ugent, D. and L. W. Peterson 1988 Archaeological Remains of Potato and Sweet Potato in Peru. Circular of the International Potato Center 16(3):1-10.

Ugent, D., S. Pozorski and T. Pozorksi 1981 Prehistoric Remains of the Sweet Potato from the Casma Valley of Peru. Phytologia 49(5):401-415.

1982 Archaeological Potato Tuber Remains from the Casma Valley of Peru. Economic Botany 36(2):182-192.

1984 New Evidence for Ancient Cultivation of Canna edulis in Peru. Economic Botany 38(4):417-432. 
1986 Archaeological Manioc (Manihot) from Coastal Peru. Economic Botany 40:78102.

Umlauf, M. L.

1988 Paleoethnobotanical Investigations at the Initial Period Site of Cardal, Peru. MA

Thesis, Department of Anthropology, University of Missouri.

Uzendoski, M. A.

2004 Manioc Beer and Meat: Value, Reproduction and Cosmic Substance among the Napo Runa of the Ecuadorian Amazon. Journal of the Royal Anthropological Institute 10:883-902.

Van Der Veen, M.

2007 Formation Processes of Desiccated and Carbonized Plant Remains: The Identification of Routine Practice. Journal of Archaeological Science 34:968-990.

Vaughn, K. J.

2004 Households, Crafts, and Feasting in the Ancient Andes: The Village

Context of Early Nasca Craft Consumption. Latin American Antiquity 15(1):61-88.

Vega-Centeno Sara-Lafosse, R.

2005 Ritual and Architecture in a Context of Emergent Complexity: A

Perspective from Cerro Lampay, a Late Archaic Site in the Central Andes. PhD

Dissertation, Department of Anthropology, University of Arizona.

2007 Construction, Labor Organization, and Feasting During the Late Archaic

Period in the Central Andes. Journal of Anthropological Archaeology 26(2):150-171.

2010 Cerro Lampay: Architectural Design and Human Interaction in the North Central Coast of Perú. Latin American Antiquity 21 (2):115-146.

Wallace, A. F. C.

1966 Religion: An Anthropological View. Random House, New York.

Watson, P. J.

1976 In Pursuit of Prehistoric Subsistence: A Comparative Account of Some Contemporary Flotation Systems. Mid-Continental Journal of Archaeology 1:77-100.

Weber, H. E., J. Moravec and J. P. Theurillat 2000 International Code of Phytosociological Nomenclature. 3rd Edition. Journal of Vegetation Science 11(5):739-768. 
Weberbauer, A.

1945 El Mundo Vegetal De Los Andes Peruanos: Estudio Fitogeográfico. Ministerio de Agricultura, Lima.

Weir, G. H., R. A. Benfer, and J. G. Jones

1988 Preceramic to Early Formative Subsistence on the Central Coast. In Economic Prehistory of the Central Andes, edited by J. C. Wheeler and E. S. Wing, pp. 56-94. BAR International Series 427, Oxford, UK.

Weir, G. H. and D. Bonavia 1985 Coprolitos y Dieta del Precerámico Tardío de La Costa Peruana. Bulletin Institut Francais d'Etudes Andines 14(1-2):85-140.

Weir, G. and P. Dering

1986 The Lomas of Paloma: Human-Environmental Relationships in a Central Peruvian Fog Oasis-Archaeobotany and Palynology. In Andean Archaeology, edited by R. M. Matos, S. A. Turpin and J. Herbert H. Eling, pp. 18-44. Monographs of the Institute of Archaeology, University of California, Los Angeles.

Weismantel, M. J. 2009 Have a Drink: Chicha, Performance, and Politics. In Drink, Power, and Society in the Andes, edited by D. L. Jennings and B. J. Bowser, pp. 257-277. University of Florida Press, Gainesville.

Wells, L. E. and J. S. Noller 1999 Holocene Coevolution of the Physical Landscape and Human Settlement in Northern Coastal Peru. Geoarchaeology 14(8):755-789.

Wendel, J. F. and V. A. Albert 1992 Phylogenetics of the Cotton Genus (Gossypium): Character State Weighted Parsimony Analysis of Chloroplast-DNA Restriction Site Data and its Systematic and Biogeographic Implications. Systematic Botany 17:115-143.

Westengen, O. T., Z. Huamán and M. Heun 2005 Genetic Diversity and Geographic Pattern in Early South American Cotton Domestication. Theoretical and Applied Genetics 110:392-402.

Whitaker, T. W. 1948 Lagenaria: A Pre-Columbian Cultivated Plant in the Americas. Southwestern Journal of Anthropology 4(1):49-68.

1983 Cucurbits in Andean Prehistory. American Antiquity 43(3):576-585. 
Whitaker, T. W. and J. B. Bird

1949 Identification and Significance of the Cucurbit Materials Form Huaca

Prieta, Peru. American Museum Novitates: American Museum of Natural History

(1426): $1-15$.

Whitaker, T. W. and H. C. Cutler

1971 Pre-Historic Cucurbits from the Valley of Oaxaca. Economic Botany 25(2):123-127.

1986 Cucurbits from Preceramic Levels at Guilá Naquitz. In Guilá Naquitz.

Archaic Foraging and Early Agriculture in Oaxaca, Mexico, edited by K. V. Flannery, pp. 275-279. Academic Press, Orlando, Florida.

WHO - World Health Organization

2000 El Niño and Its Health Impacts. World Health Organiztion Fact Sheet No. 192, Revised March 2000

http://www.who.int/mediacentre/factsheets/fs192/en/index.html.

Willey, G. R.

1945 Horizon Styles and Pottery Traditions in Peruvian Archaeology. American Antiquity 11(1):49-56.

Willey, G. R. and P. Phillips

1958 Method and Theory in American Archaeology. University of Chicago Press, Chicago.

Williams, C.

1980 Complejos de Pirámides con Plana en "U”, Patrón Arquitectónico de La Costa Central. Revista del Museo Nacional (Lima) 44:95-110.

1985 A Scheme for the Early Monumental Architecture of the Central Coast of Peru. In Early Ceremonial Architecture in the Andes, edited by C. B. Donnan, pp. $227-$ 240. Dumbarton Oaks, Washington, D.C.

Wilson, D. J.

1981 Of Maize and Men: A Critique of the Maritime Hypothesis of State Origins on the Coast of Peru. American Anthropologist 93(1):93-120.

1999 Indigenous South Americans of the Past and Present: An Ecological Perspective. Westview Press, Boulder.

Wilson, H. D., J. Doebley and M. Duvall 1992 Chloroplast DNA Diversity among Wild and Cultivated Members of Cucurbita (Cucurbitaceae). Theoretical and Applied Genetics 84:859-865. 
Wilson, I. H. and A. Pineda

1963 Pineda's Report on the Beverages of New Spain. Journal of the Southwest 5(1):79-90.

Wing, E. S.

1986 Domestication of Andean Mammals. In High Altitude Tropical Biogeography, edited by F. Vuilleumier and M. Monasterio, pp. 246-264. Oxford University Press, New York.

1972 Utilization of Animal Resources in the Peruvian Andes. In Andes 4:

Excavation at Kotosh, Peru, 1963 and 1964, edited by I. Seiichi and K. Terada, pp. 327-351. University of Tokyo Press, Tokyo.

Wing, E. S. and J. C. Wheeler

1988 Economic Prehistory of the Central Andes. BAR International Series 427, Oxford, UK.

Wittmack, L. 1880-1887 Plants and Fruits. Necropolis of Ancón in Perú, vol. 3, Part 13, edited by W. Reiss and A. Stübel, Berlin.

Yacovleff, E. and F. L. Herrera 1934 El Mundo Vegetal De Los Antiguos Peruanos. Revista del Museo Nacional (Lima) 3:241-322.

Yamasaki, F., T. Hamada and C. Fujiyama

1966 Riken Natural Radiocarbon Measurements II. Radiocarbon 8:324-339.

Zarrillo, S. and B. Kooyman

2006 Evidence for Berry and Maize Processing on the Canadian Plains from Starch Grain Analysis. American Antiquity 71(3):473-499.

Zarrillo, S., D. M. Pearsall, J. S. Raymond, M. A. Tisdale and D. J. Quon 2008 Directly Dated Starch Residues Document Early Formative Maize (Zea mays L.) in Tropical Ecuador. Proceedings of the National Academy of Sciences of the United States of America 105(13):5006-5011. 


\section{Zechenter, E.}

1988 Subsistence Strategies in the Supe Valley of the Peruvian Central Coast During the Complex Preceramic and Initial Periods. PhD Dissertation, Department of Anthropolgy, University of California, Los Angeles.

Zhao, Z. and D. M. Pearsall

1998 Experiments for Improving Phytolith Extraction from Soils. Journal of Archaeological Science 25:587-598. 


\section{VITA}

Neil Duncan was born in Chicago, Illinois and has lived in Toledo, Ohio, Atlanta, Georgia and Columbia, Missouri. In 1994, he received a B.A. in anthropology with honors at Georgia State University in Atlanta. At the University of Missouri - Columbia, he received an M.A. in 2004 and a Ph.D. in 2010, both in anthropology. His archaeological fieldwork experience includes cultural resource management work in the Southeastern U.S. and academic work in Peru and Ecuador. He is married to Eliana Duncan and they have a daughter, Leyla, born in 2010. 